DEPARTMENT OF THE INTERIOR

U.S. GEOLOGICAL SURVEY

United States Earthquakes, 1979

By

Car1 W. Stover

and

Car1 A. von Hake

Open-File report $84-979$

Prepared in cooperation with National Oceanic and Atmospheric Administration. This report has not been reviewed for conformity with U.S. Geological Survey editorial standards. 



\section{Contributors}

Contributors to this publication are 1isted below according to the information furnished or service performed:

Hypocenters and magnitudes:

W. LeRoy Irby, U.S. Geological Survey Reino Kangas, U.S. Geological Survey John H. MInsch, U.S. Geological Survey Russ Needham, U.S. Geological Survey Waverly J. Person, U.S. Geological Survey Bruce W. Presgrave, U.S. Geological Survey Robert Y. Koyanag1, Hawalian Volcano Observatory, U.S. Geological Survey Intensities :

Car1 W. Stover, U.S. Geological Survey

Robert Y. Koyanag1, Hawallan Volcano Observatory, U.S. Geological Survey Network Operations (by institution):

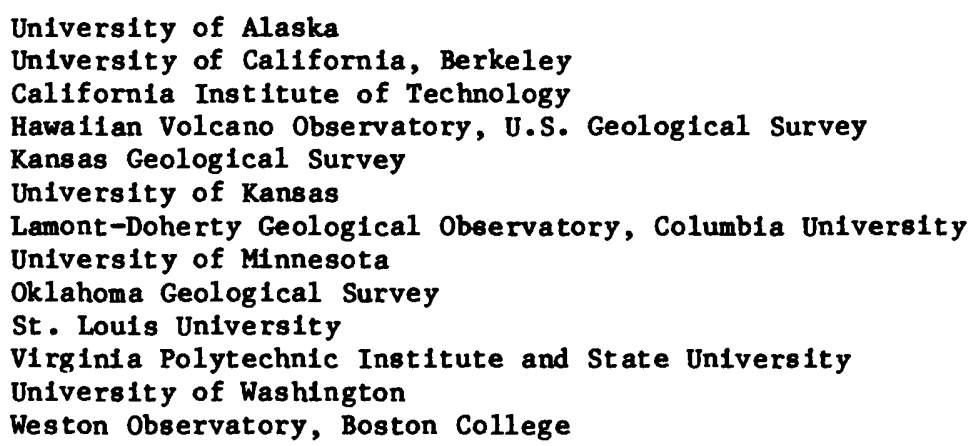

Sandford R. Holdahl, NOAA, NOS, National Geodetic Survey Richard A. Snay, NOAA, NOS, National Geodetic Survey

Tsunamis :

Mark G. Spaeth, NOAA, National Weather Service

Strong-motion selsmograph data:

Ronald L. Porcella, U.S. Geological Survey

Editorial assistance and manuscript preparations:

Paula K. Smith, U.S. Geological Survey 



\section{Contents}

Contributors .............................................111

Introduction $\ldots \ldots \ldots \ldots \ldots \ldots \ldots \ldots \ldots \ldots \ldots \ldots \ldots \ldots \ldots \ldots \ldots \ldots \ldots \ldots \ldots \ldots \ldots \ldots \ldots$

Discussion of Tables.................................... 1

Eplcenter and Isoselsmal Maps.............................. 1

Earthquake Information Services........................... 3

Magnitude and Intensity Ratings ............................ 3

Modifled Mercalli Intensity Scale............................. 5

Collaborators....................................... 7

Earthquake Descriptions.................................... 8

Alaska............................................ 8

Artzona $\ldots \ldots \ldots \ldots \ldots \ldots \ldots \ldots \ldots \ldots \ldots \ldots \ldots \ldots \ldots \ldots \ldots \ldots \ldots \ldots \ldots \ldots \ldots \ldots \ldots \ldots \ldots$

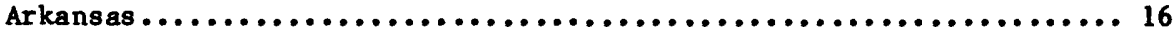

California......................................... 17

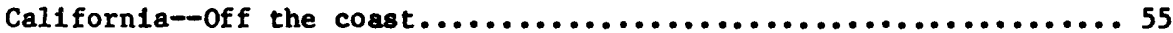

Colorado.............................................. 56

Connect1cut ........................................... 57

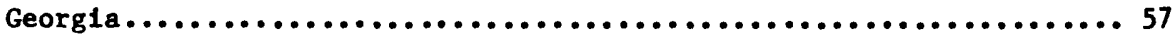

Hawa11............................................ 57

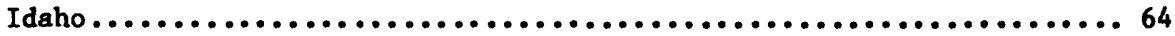

Kans as ............................................... 64

Kentucky ............................................ 64

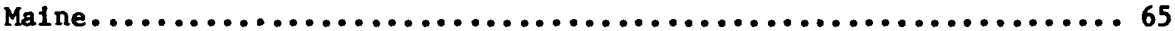

Massachusetts........................................ 68

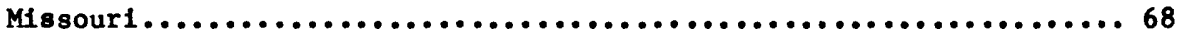

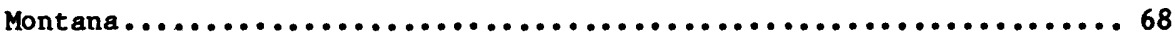

Nebraska..............................................69

Nevada .............................................. 69

New Hampsh1re......................................... 71

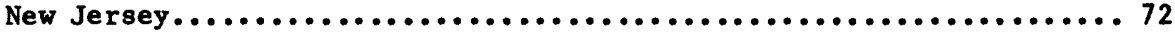

New York................................................ 73

North Carolina......................................73

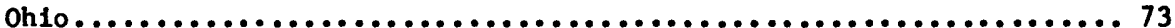

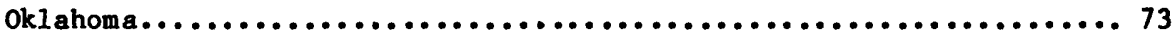

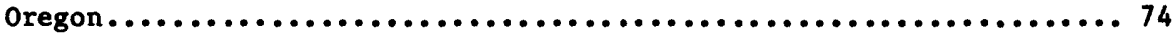

Pennsylvania ........................................... 74

Puerto Rico.......................................... 74

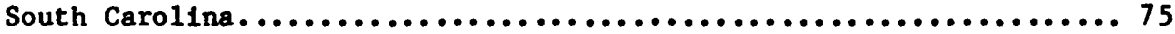

Tennessee............................................. 76

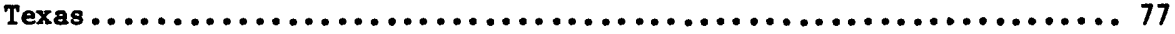

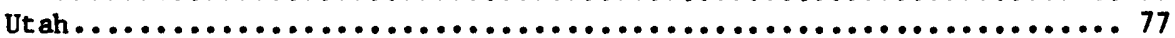

Vermont ........................................... 77

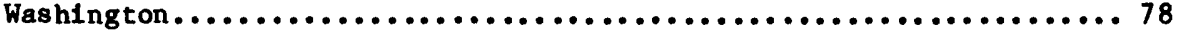

West Virginia........................................ 79

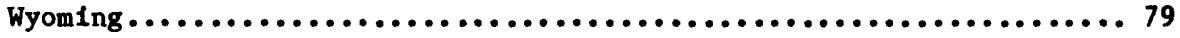




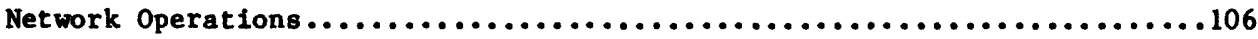

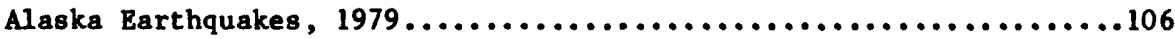

Northern and Central California Earthquakes, $1979 \ldots \ldots \ldots \ldots \ldots \ldots \ldots \ldots 106$

Southern California Earthquakes, 1979.........................108

Hawali Earthquakes, $1979 \ldots \ldots \ldots \ldots \ldots \ldots \ldots \ldots \ldots \ldots \ldots \ldots \ldots \ldots \ldots \ldots \ldots \ldots \ldots \ldots \ldots 109$

Kansas Earthquakes, $1979 \ldots \ldots \ldots \ldots \ldots \ldots \ldots \ldots \ldots \ldots \ldots \ldots \ldots \ldots \ldots \ldots \ldots \ldots \ldots 114$

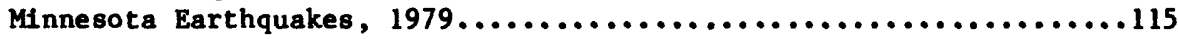

Central Mississipp1 Valley Earthquakes, 1979...................116

Nebraska Earthquakes, $1979 \ldots \ldots \ldots \ldots \ldots \ldots \ldots \ldots \ldots \ldots \ldots \ldots \ldots \ldots \ldots \ldots \ldots \ldots \ldots \ldots 117$

New England Earthquakes, $1979 . \ldots \ldots \ldots \ldots \ldots \ldots \ldots \ldots \ldots \ldots \ldots \ldots \ldots \ldots \ldots \ldots \ldots$

Earthquakes in New York State and Adjacent Areas, 1979.............121

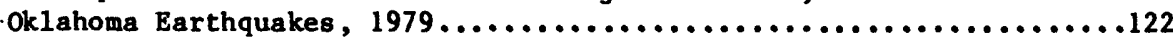

Southeastern United States Earthquakes, $1979 \ldots \ldots \ldots \ldots \ldots \ldots \ldots \ldots \ldots \ldots \ldots 124$

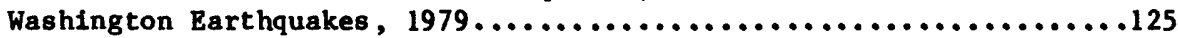

M1scellaneous Activities...................................127

Crustal Movement Studies..................................127

Tsunam1s............................................... 28

Princlpal Earthquakes of the World..........................129

Strong-Motion Seismograph Data...............................134

Introduction. .........................................134

Accelerograph Data..................................... 135

References $\ldots \ldots \ldots \ldots \ldots \ldots \ldots \ldots \ldots \ldots \ldots \ldots \ldots \ldots \ldots \ldots \ldots \ldots \ldots \ldots \ldots \ldots \ldots \ldots \ldots \ldots \ldots$

\section{LIST OF TABLES}

Table

1 Summary of U.S. earthquakes for $1979 \ldots \ldots \ldots \ldots \ldots \ldots \ldots \ldots \ldots \ldots \ldots \ldots \ldots . \ldots 1$

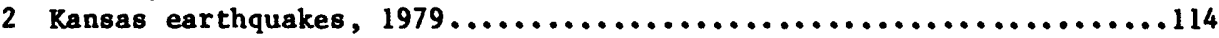

3 Station locations for the Central Minnesota Seismic Array...........115

41979 Minnesota earthquakes recorded by the Central Minnesota Seismic Array.................................................115

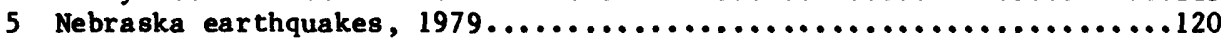

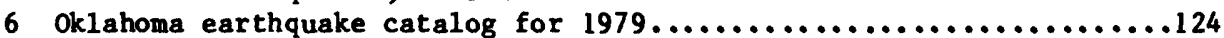

7 Southeastern United States earthquakes, $1979 \ldots \ldots \ldots \ldots \ldots \ldots \ldots \ldots \ldots \ldots \ldots$

8 Principal earthquakes of the world during $1979 \ldots \ldots \ldots \ldots \ldots \ldots \ldots \ldots \ldots 130$

9 Summary of U.S. accelerograph records recovered during $1979 \ldots \ldots \ldots \ldots 1$

\section{LIST OF ILLUSTRATIONS}

1 Earthquake epicenters in the conterminous United States for 1979.... 2

2 Earthquake epicenters in Alaska for $1979 \ldots \ldots \ldots \ldots \ldots \ldots \ldots \ldots \ldots \ldots \ldots \ldots \ldots 2$

3 Barthquake epicenters in Hawail for $1979 \ldots \ldots \ldots \ldots \ldots \ldots \ldots \ldots \ldots \ldots \ldots$

4 Plot of earthquakes in the conterminous United States that were felt or caused damage in $1979 \ldots \ldots \ldots \ldots \ldots \ldots \ldots \ldots \ldots \ldots \ldots \ldots \ldots \ldots \ldots \ldots \ldots \ldots . \ldots$

5 Plot of earthquakes in Alaska that were felt or caused damage in $1979 . \ldots \ldots \ldots \ldots \ldots \ldots \ldots \ldots \ldots \ldots \ldots \ldots \ldots \ldots \ldots \ldots \ldots \ldots \ldots \ldots \ldots \ldots \ldots \ldots \ldots \ldots \ldots . \ldots 4$

6 Plot of earthquakes in Hawail that were felt or caused damage in $1979 . \ldots \ldots \ldots \ldots \ldots \ldots \ldots \ldots \ldots \ldots \ldots \ldots \ldots \ldots \ldots \ldots \ldots \ldots \ldots \ldots \ldots \ldots \ldots \ldots \ldots . \ldots \ldots$ 
7 Isoseismal map for the St. El1as earthquake of 28 February 1979.... 11

8 Isoseismal map for the southern Callfornia earthquake of 1 January

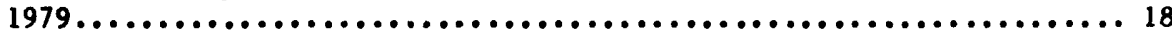

9 Isoseismal map for the southern Callfornia earthquake of 12 February

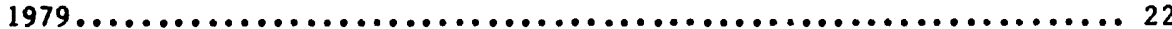

10 Isoseismal map for the northern Callfornla earthquake of 22 February

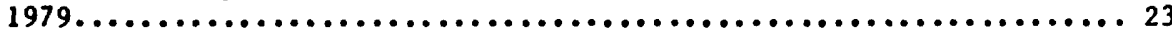

11 Isoselsmal map for the southern Callfornla earthquake of 15 March

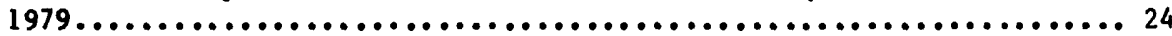

12 Isose1smal map for the central Cal1fornia earthquake of 28 April

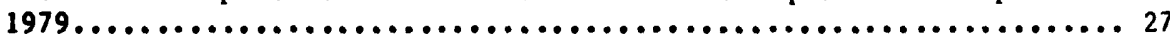

13 Isoselsmal map for the central Callfornia earthquake of 8 May 1979.. 28

14 Isosel smal map for the southern Californla earthquake of 29 June

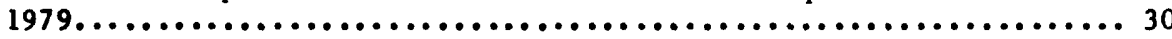

15 Isoseismal map for the southern California earthquake of 30 June

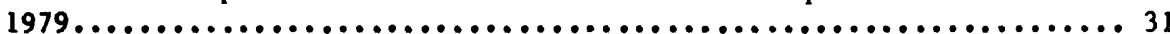

16 Isoselsmal map for the central California earthquake of 6 August

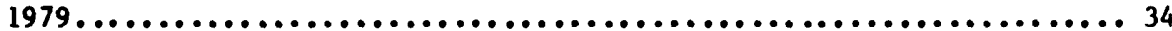

17 Isoselsmal map for the Imperial valley, California earthquake of 15 October 1979...................................... 42

18 Photograph of damage to the Imperial County Services Bullding in Imper1al, Calff......................................45

19 Support p1llar fallure at the east end of the Imperial County Services. Bullding in El Centro, California caused by the earthquake

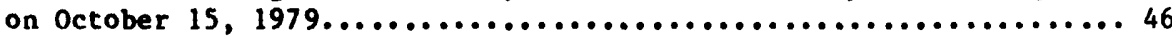

20 Damage to a wall of the McMahn's Furniture Store In Calexico, Cal1f. 47

21 Damage to the cornlce of the Deluxe Cleaners bullding in F,1 Centro, Cal1f .............................................. 48

22 Isoselsmal wap for the southern Callfornta earthquake of 17 October

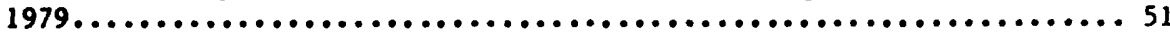

23 Isose1smal map for the northern Callfornta earthquake of 3 February

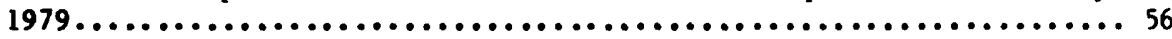

24 Isoselsmal map for the southern Malne earthquake of 18 Apri1 1979... 66

25 Isose 1smal map for the central New Jersey earthquake of 30 January

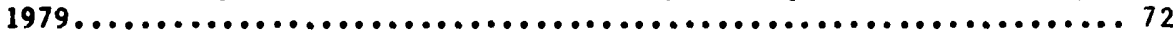

26 Isoseismal map for the northwestern South Carolina earthquake of

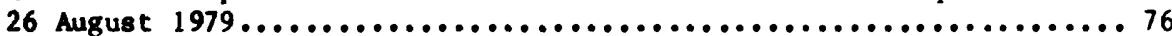

27 Locations of the 1977 Falrbanks earthquake swarm...................107

28 Plot of distance versus depth for the 1977 earthquake swarm........108

29 Locations of the 1979 Falrbanks earthquake swarm................109

30 Plot of distance versus depth for the 1979 earthquake swarm........110

31 University of Alaska selsmograph1c stations operated in 1979.......110

32 Northern and central Cal1fornla earthquakes during 1979..........111

33 Plot of the cumulative number of earthquakes versus local Richter

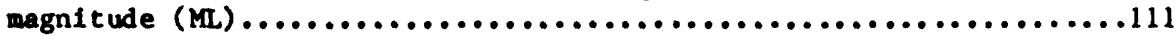

34 Displacement selsmograms of the Coyote Lake mainshock............111

35 Southern California earthquakes of magnitude $3.0 \mathrm{ML}$ or greater

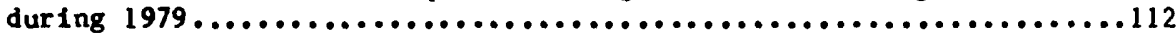

36 The Homestead Valley, California earthquake sequence of 15 March

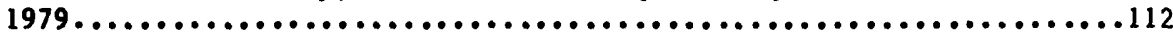

37 The Imperial Valley, California earthquake of 15 October 1979 and

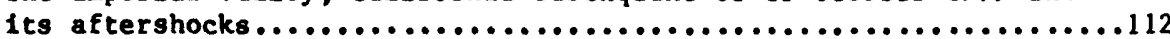

381979 eplcenter map of Kilauea-Mauna Loa showling all located earthquakes .............................................113

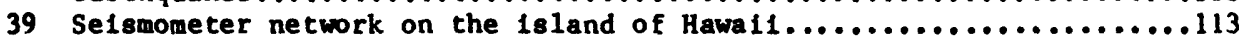

40 Microearthquake activity in Kansas from December 1, 1977 to

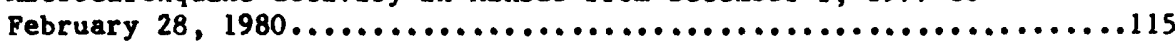

41 Microearthquake and Bouguer Gravity Map of northeastern Kansas......116 
42 Kansas Geological Survey selsmograph network in 1979............117

43 Central Minnesota Seismic Array, quarry blasts, and ear thquakes

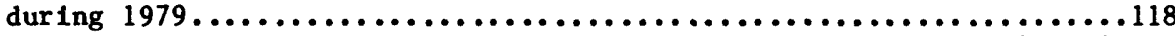

44 Central Mississippi Valley earthquakes during 1979 within $4^{\circ} \times 4^{\circ}$

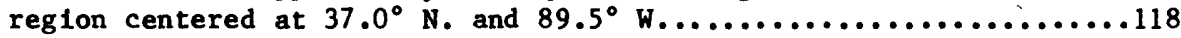

45 Central Mississippi Valley earthquakes during 1979 within a $1.5^{\circ} \mathrm{x}$ $1.5^{\circ}$ region centered at $36.25^{\circ} \mathrm{N}$. and $89.75^{\circ} \mathrm{W} \ldots \ldots \ldots \ldots \ldots \ldots \ldots \ldots 118$

46 Map of the Nebraska Geological Survey seismic network and earthquake epicenters in Nebraska during 1979.........................119

47 Selsmicity for 1979 in the area of the Sleepy Hollow 011 Field, Nebraska............................................119

48 New England earthquake epicenters during $1979 \ldots \ldots \ldots \ldots \ldots \ldots \ldots \ldots \ldots \ldots$

49 Distribution of short-period seismic stations operated by the Lamont-Doherty Geological Observatory in New York State and adjacent

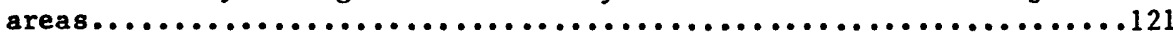

50 All earthquakes recorded by the Lamont-Doherty network in New York State and adjacent areas during $1979 \ldots \ldots \ldots \ldots \ldots \ldots \ldots \ldots \ldots \ldots \ldots \ldots 121$

51 Distribution of earthquakes ( $\mathrm{mb} \geq 2$ ) recorded by the Lamont-Doherty network in New York State and adjacent areas from 1970 through 1980.122

52 Active seismograph stations in oklahoma.......................123

53 Distribution of 0klahoma earthquakes during $1979 \ldots \ldots \ldots \ldots \ldots \ldots \ldots \ldots$

54 Earthquake epicentral locations for 1979 in Canadian County and nearby Grady and Caddo Counties, Oklahoma......................124

55 Southeastern United States earthquake epicenters during 1979.......125

56 Southeastern United States seismic stations operating at the close

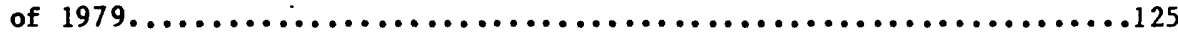

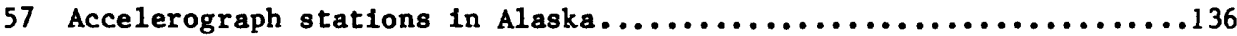

58 Icy Bay and Yakutat accelerograms from St. Elias, Alaska earthquake

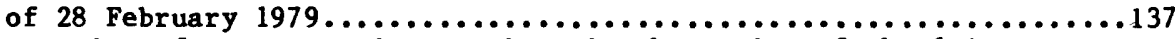

59 Location of strong-motion stations in the region of the 6 August

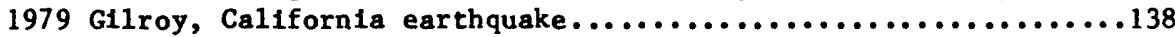

60 Gilroy array accelerograms from the earthquake of 6 August $1979 \ldots \ldots 139$

61 Strong-motion stations in the greater Imperial Valley region that are known to have been operational at the time of the 15 October

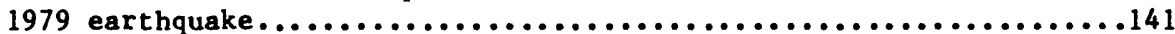

62 Close-in strong-motion stations that operated during the 15 October 1979 Imperial Valley earthquake...........................142

63 Selection of USGS accelerograms from the Imperial Valley earthquake

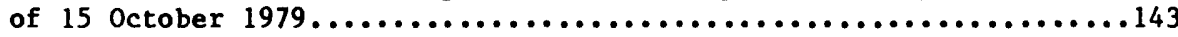

64 Accelerograms from E1 Centro array station 9, Imperial Valley earthquakes of 15 October 1979 and 18 May $1940 \ldots \ldots \ldots \ldots \ldots \ldots \ldots \ldots \ldots$ 


\title{
United States Earthquakes, 1979
}

\author{
Carl W. Stover, U.S. Geological Survey \\ Carl A. von Hake, NOAA, Environmental Data and Information Service
}

\section{Introduction}

This publication describes all earthquakes that were reported felt in the United States and nearby territories in 1979. It has been compiled by the U.S. Geological Survey (USGS) and published jointly with NOAA, Environmental Data and Information Service (EDIS). Its purpose is to provide a continuous history of U.S. earthquakes for studying seismic risk, evaluating nuclear powerplant sites, designing earthquakeresistive structures, and answering inquiries from the scientific and general public.

The publication is composed of four major chapters: "Earthquake Descriptions," which includes a summary of macroseismic data reported for each earthquake and a chronological list of earthquakes by State (table 1); "Network Operations," which summarizes the results from local seismic networks; "Miscellaneous Activities," which contains information on crustal movement studies, tsunamis, and principal earthquakes of the world (table 8 ), and "Strong-Motion Seismograph Data" (table 9). The intensity and macroseismic data in "Earthquake Descriptions" are compiled from questionnalre canvasses (see next paragraph), newspaper articles, and reports prepared by other government organizations, State institutions, local organizations, and individuals. Each description includes date, origin time, hypocenter, and the source of the hypocenter computation, maximum intensity (Modified Mercalli), and macroseismic effects reported in the area.

The USGS collects intensity information primarily by mailing questionnaires, "Earthquake Report" forms, to postmasters in the earthquake area. Postmasters complete the forms and return them to the USGS, where they are evaluated and intensities are assigned. For damaging earthquakes, the questionnaires are supplemented by USGS field investigations. The USGS publishes preliminary intensity data in its quarterly circular, Earthquakes in the United States. The final information is pubished in the United States Earthquakes series, issued annually since 1928 .

\section{DISCUSSION OF TABLES}

The earthquake parameters in tables 1 and 8 include date, origin time, hypocenter (epicenter and focal depth), and magnitude. Table 1 also contains the maximum observed Modified Mercalli (MM) intensity. The origin time and date are 1isted in Universal Coordinated Time (UTC). The epicenters were taken principally from the USGS Preliminary Determination of Epicenters, Month1y Listings or Earthquakes in the United States 2 . The accuracy of the epicenters is that claimed by the institution supplying the hypocenter and is not necessarily the accuracy indicated by the number of decimals 1 isted. The epicenters located by the USGS have a varying degree of accuracy, usually two-tenths of a degree or less, depending on their continental or oceanic location. The oceanic hypocenters are less accurate than those on the continent, even though both are listed to two decimals. Depths are listed to the nearest kilometer.

Magnitudes listed in the tables were furnished by cooperating institutions or determined by the USGS. The computational sources are indicated by letter codes identified in headnotes to the tables.

\section{EPICENTER AND ISOSEISMAL MAPS}

Figures 1-3 are computer plots of all earthquake epicenters in the conterminous United States, Alaska, and Hawail 11sted in table 1. Each earthquake epicenter is indicated by a small circle or square.

Figures 4-6 are computer plots of 1979 earthquake epicenters in the conterminous United States, Alaska, and Hawail by Modified Mercalli (MM) intensity. Maximum intensities are represented by Arabic numerals at the epicentral locations. Earthquakes of intensity I-IV are represented by solid circles.

${ }^{1}$ For sale by the Superintendent of Documents, U.S. Government Printing office, Washington, D.C. 20402 .

${ }^{2}$ Copies of these reports are available free on application to Branch of Distribution, U.S. Geological Survey, 1200 South Eads Street, Arlington, Va. 22202 . 


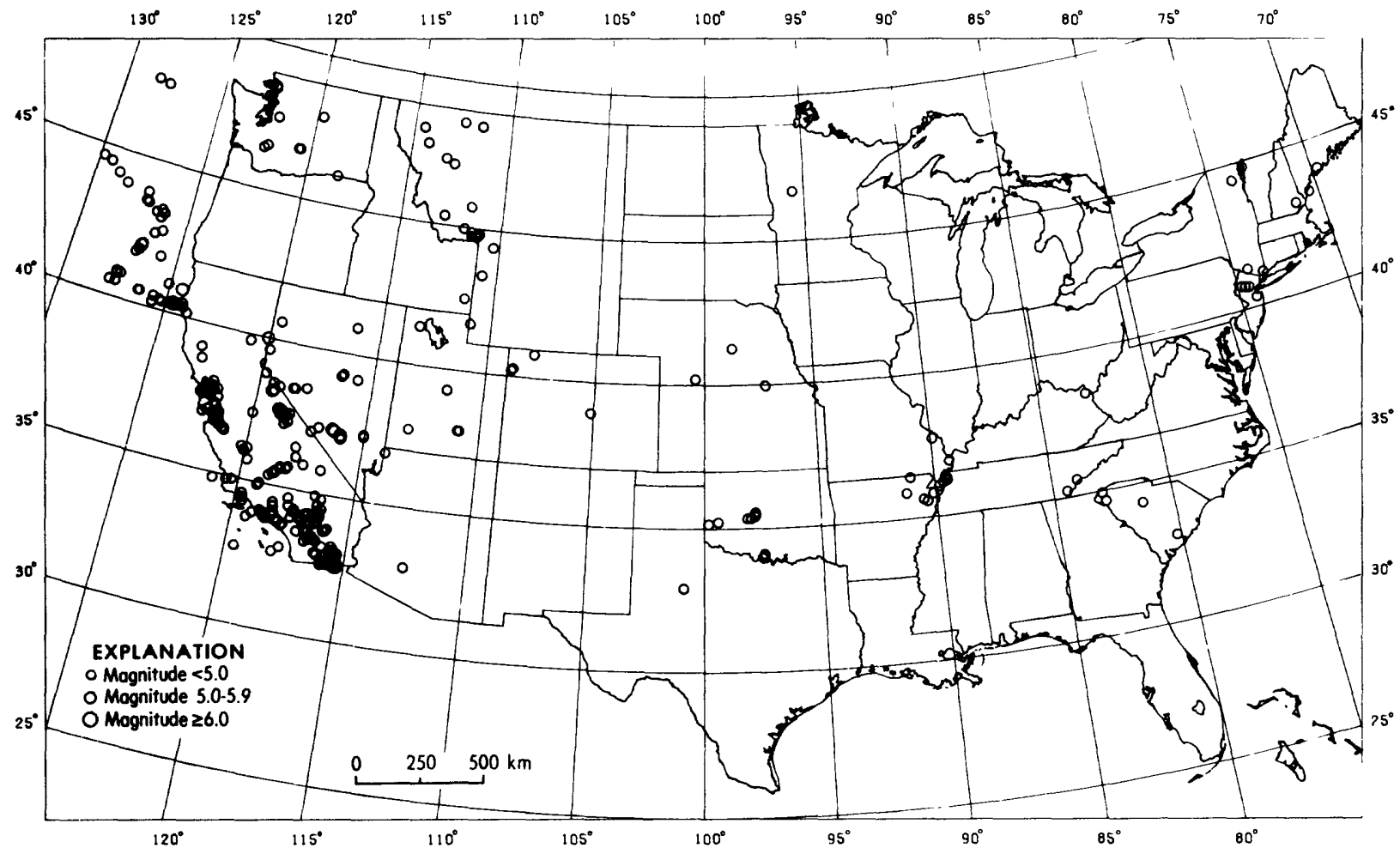

FIGURE 1.--Earthquake epicenters in the conterminous United States for 1979.

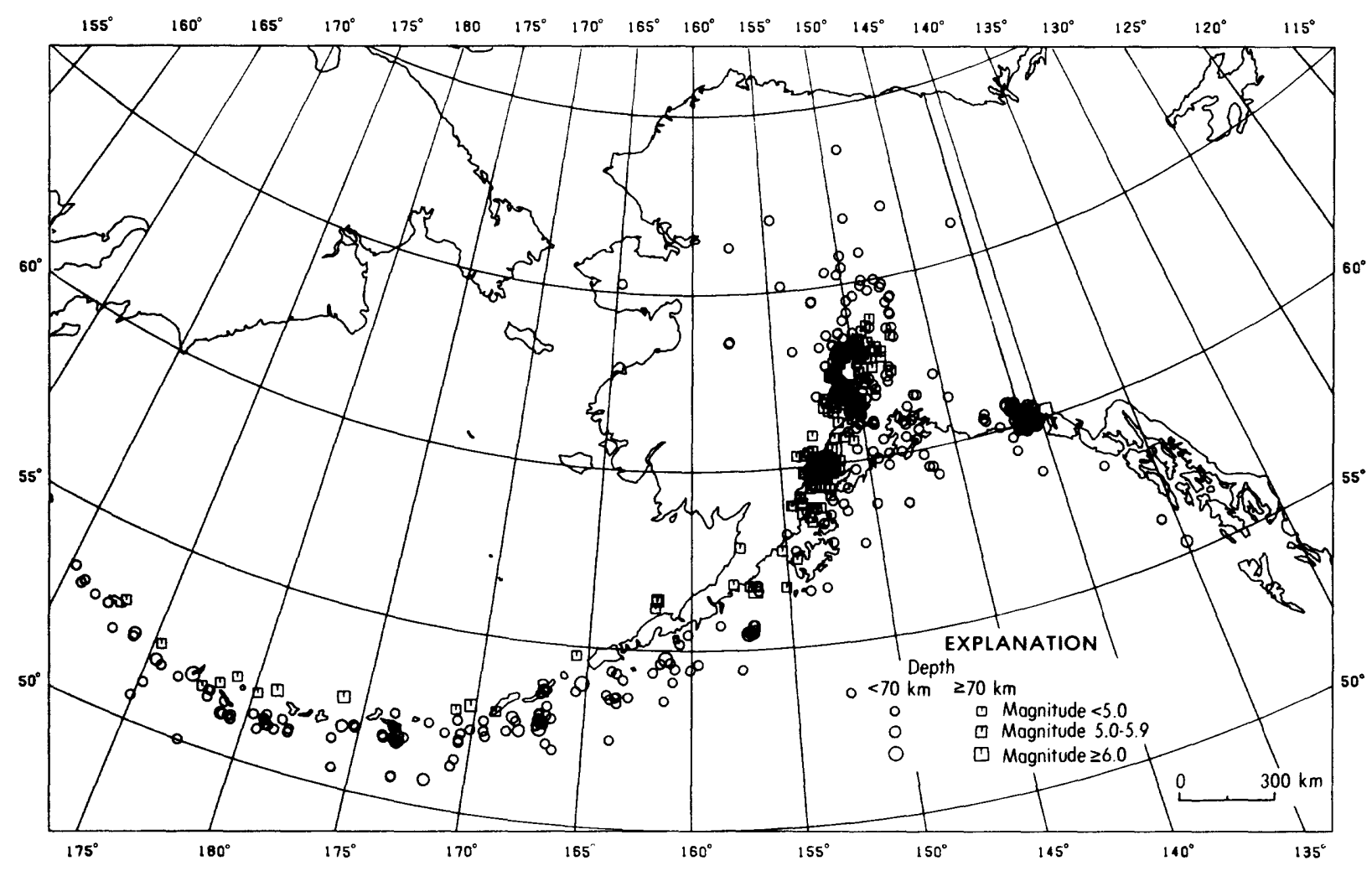

FIGURE 2.--Earthquake epicenters in Alaska for 1979. 


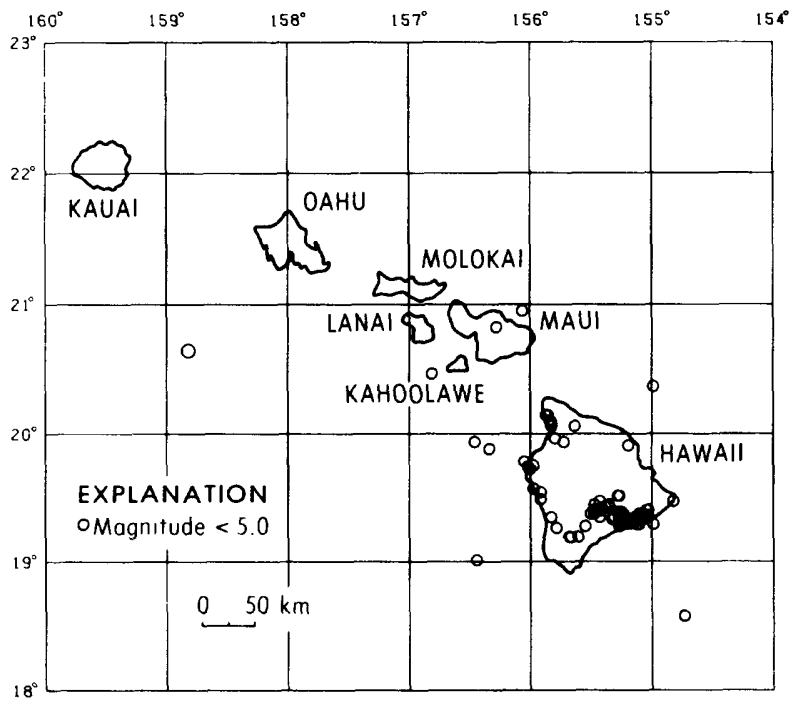

FIGURE 3.--Earthquake epicenters in Hawaii for 1979.

The USGS coordinates the collection of all types of earthquake information, with the special objective of correlating instrumentally determined earthquake locations with noninstrumental locations indicated by intensity data. This correlation is achieved through regional investigations of earthquakes by local organizations and the USGS. Primary data are gathered by a canvass of the epicentral area using questionnaire cards. When returned and analyzed, this information is used to prepare isoseismal maps which show the areal pattern of intensity associated with individual earthquakes.

The selection of intensity or isoseismal maps shown in the Earthquake Descriptions is governed largely by the size of the area affected. This means that sharp, localized shocks of intensity VI (which often occur in California) may not be represented by these maps, whereas more widely felt earthquakes of intensity $V$ and $V I$ (which are characteristic of the Eastern and Central states) often will be illustrated because of the larger felt areas. Arabic numerals on these computer-plotted maps represent the maximum MM intensities at sampled localities. Isoseismal contours are a generalization of intensity data and are extrapolated in regions that have few observations. The contours do not include each intensity observation.

\section{EARTHQUAKE INFORMATION SERVICES}

The National Geophysical and SolarTerrestrial Data Center (NGSDC), one of the flve major facilities of NOAA's Environmental Data and Information Service, is responsible for data activities in seismology. Its services include preparing local and regional seismic histories for engineers, actuaries, and other scientists and answering direct inquiries from the public on all aspects of historical earthquakes. Additional services and products include publishing annual earthquake summaries and revised historical earthquake reports; and making available copies of seismograms, accelerograms, displacement meter records, digitized strong-motion seismograms, and epicenter 1 ists in several formats. Many of these products and services are based on seisnic records or other data that have originated with USGS recording networks or with USGS data-reduction facilities. Information concerning services and products of NGSDC may be obtained from the National Geophysical and Solar-Terrestrial Data Center, NOAA/EDIS, Boulder, CO 80303 .

\section{MAGNITUDE AND INTENSITY RATINGS}

Magnitude, a measure of the "size" of an earthquake, is roughly related to the energy release at the focus of an earthquake. Although the magnitude scale has neither "top" nor "bottom" values the highest ever recorded was magnitude 8.9 and the lowest about -3 . On this logarithmic scale, a magnitude 6 shal low-focus earthquake represents elastic-wave energy about 30 times greater than that generated by a magnitude 5 earthquake, 900 times greater than that of a magnitude 4 shock, and so forth. Many factors enter into the determination of earthquake magnitude, including earthquake focal depth, frequency content of the sampled energy, and the earthquake radiation pattern. Magnitude values calculated by the USGS are based on the following formulas:

$$
M S=\log (A / T)+1.66 \log D+3.3,
$$

as adopted by the International Association of Seismology and Physics of the Earth's Interior (IASPEI; Bath, 1966, p. 153), where A is the maximum vertical surface-wave ground amplitude, in micrometers; $T$ is the period, in seconds, and $18 \leq \mathrm{T} \leq 22$; and $\mathrm{D}$ is the distance in geocentric degrees (station to epicenter), and $20^{\circ}<D<160^{\circ}$. No depth correction is made for depth less than $50 \mathrm{~km}$, and no MS magnitudes are computed for depths greater than $50 \mathrm{~km}$.

$$
m b=\log (A / T)+Q(D, h),
$$

as defined by Gutenberg and Richter (1956), except that $T$, the period in seconds, is restricted to $0.1 \leq \mathrm{T} \leq 3.0$, and $A$, the ground amplitude in micrometers, is not necessarily the maximum of the $P$-wave group. $Q$ is a function of distance $D$ and depth $h$, where $D \geq 5^{\circ}$.

$$
M L=\log A-\log A_{0} \text {, }
$$

as defined by Richter (1958, p. 340), where A is the maximum trace amplitude in millimeters, written by a Wood-Anderson torsion seismometer, 


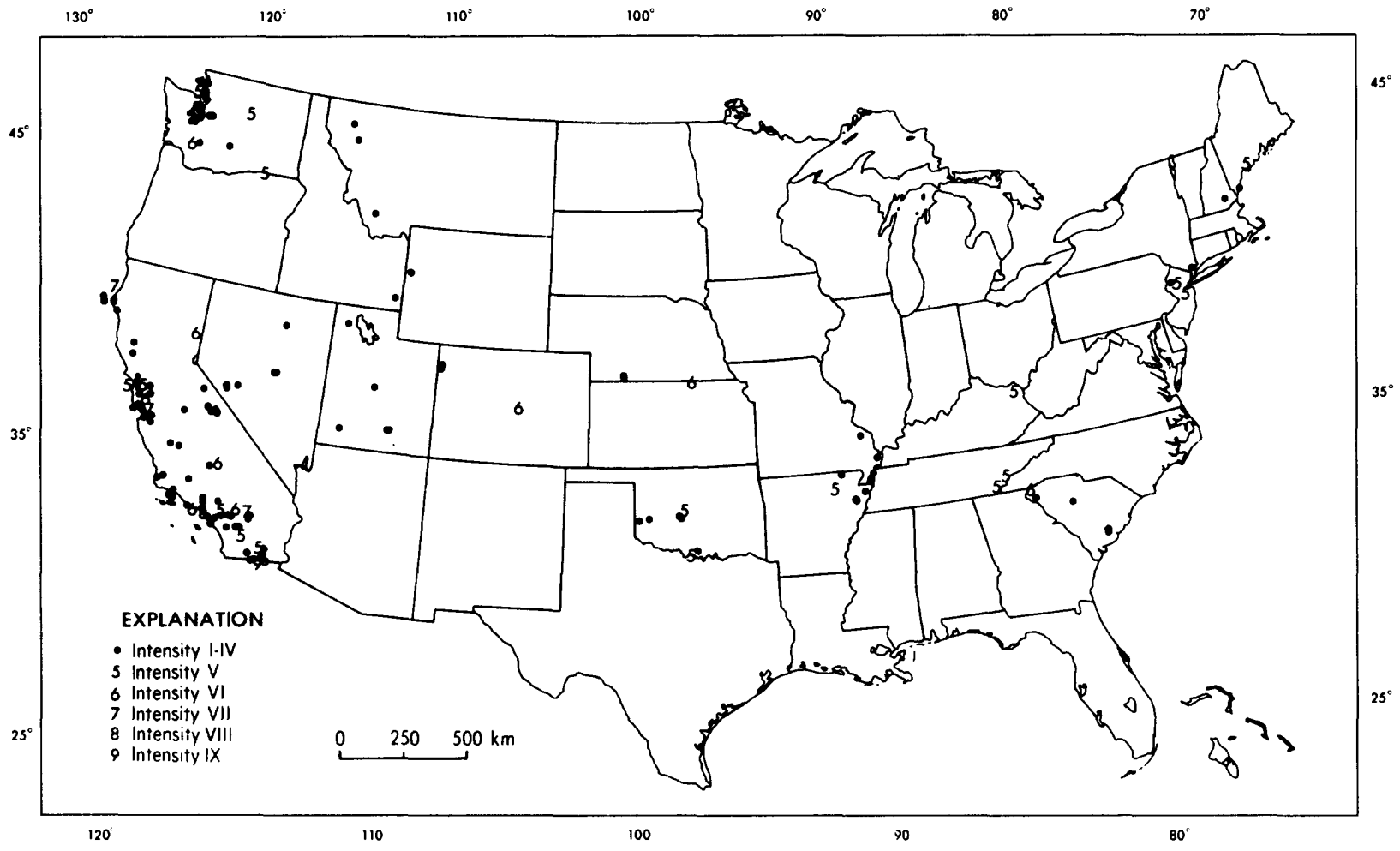

FIriURE 4.--P1ot of earthquakes in the conterminous United States that were felt or caused damage in 1979.

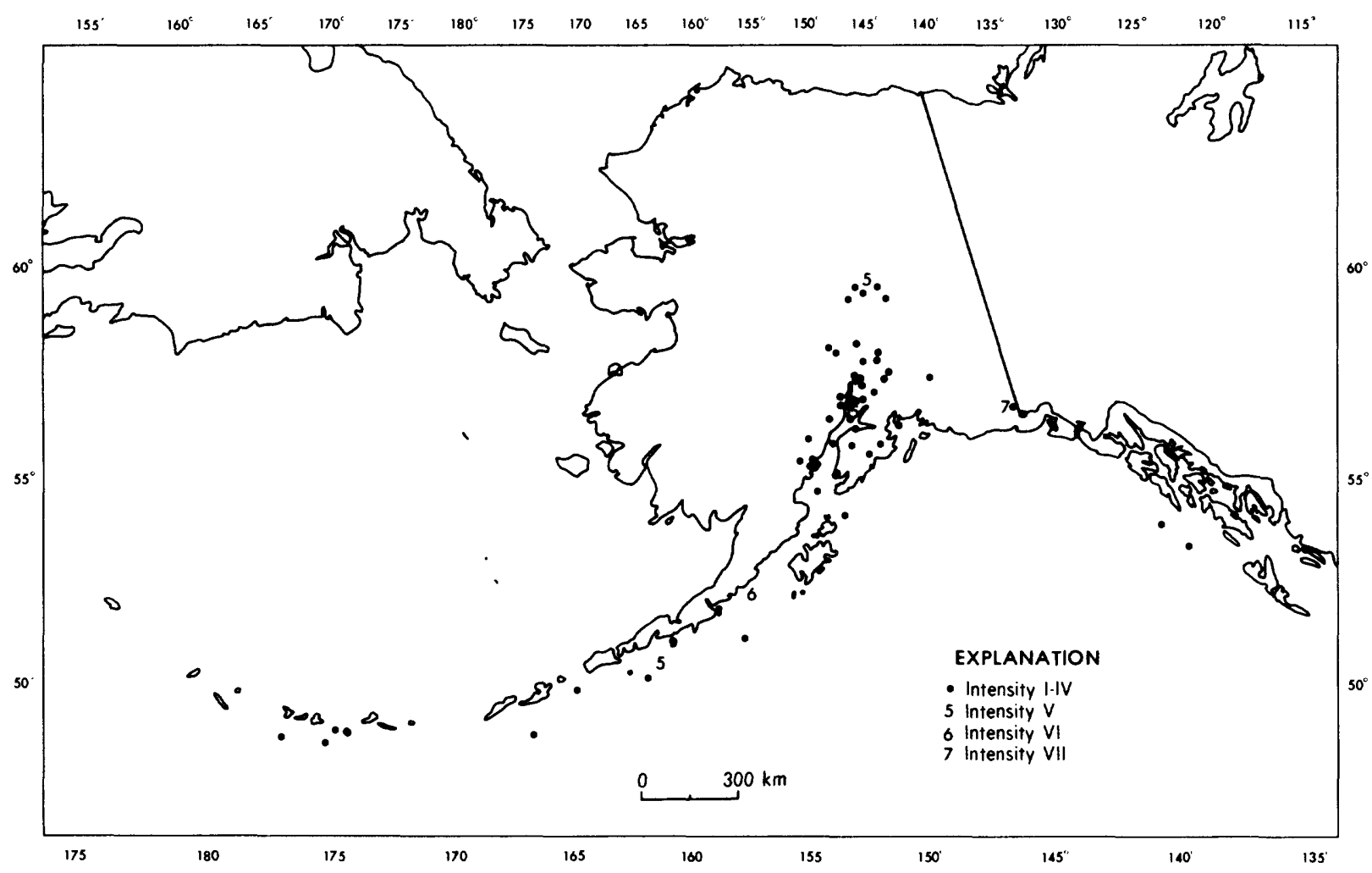

FIGURE 5.--Plot of earthquakes in Alaska that were felt or caused damage in 1979. 


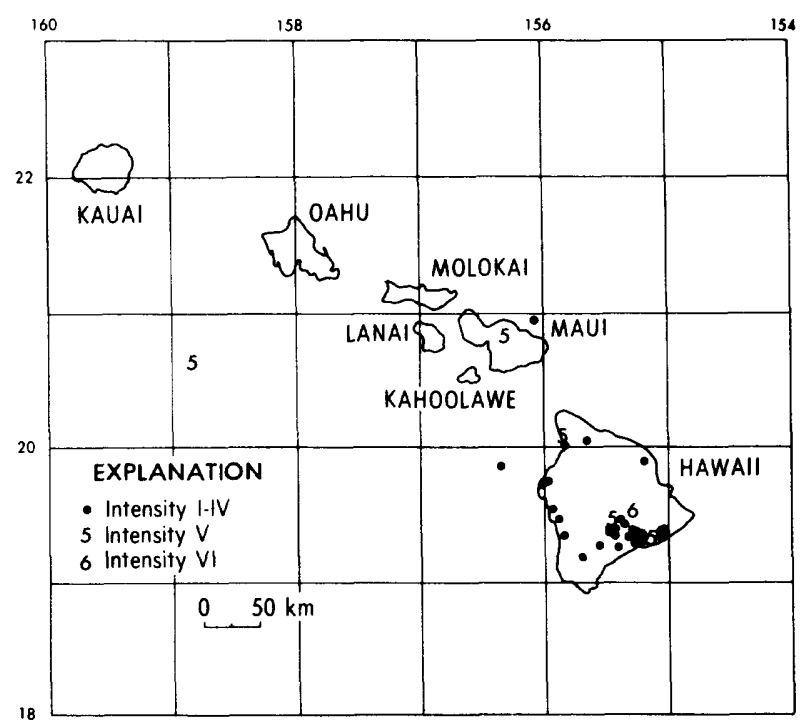

FIGURE 6.--Plot of earthquakes in Hawa ii

that were felt or caused damage in 1979.

and $\log A_{0}$ is a standard value as a function of distance, where the distance is $<600 \mathrm{~km}$. ML values are also calculated from other seismometers by conversion of recorded ground intion to the expected response of the torsion selsmometer:

$$
\begin{gathered}
\mathrm{mbLg}=3.75+0.90(\log \mathrm{D}) \\
+\log (\mathrm{A} / \mathrm{T}) 0.5^{\circ} \leq \mathrm{D} \leq 4^{\circ}, \\
\mathrm{mbLg}=3.30+1.66(\log \mathrm{D}) \\
+\log (\mathrm{A} / \mathrm{T}) 4^{\circ} \leq \mathrm{D} \leq 30^{\circ},
\end{gathered}
$$

as proposed by Nutrli (1973), where A/T is expressed in micrometers per second, calculated from the vertical-component 1 -second $\mathrm{Lg}$ waves, and $D$ is the distance in geocentric degrees.

MD is used in this publication for the duration or coda length magnitude. MD is usually computed from the difference, in seconds, between $P n$ or Pg-wave arrival time and the time the final coda amplitude decreases to the background-noise amplitude. These magnitudes are normally correlated with ML or mbLg so that resulting magnitudes are compatible. Thus the formulas vary for different geographic regions and seismograph systems.

Intensity, as applied to earthquakes, represents a quantity determined from the effects on people, manmade objects, and the earth's surface (landslides, ground fissures). Intensities are assigned according to the descriptions listed in the Modified Mercalli Intensity Scale of 1931 (Wood and Neumann, 1931). There are 12 discrete steps in the MM scale (see next section). An earthquake in a populated area will have different intensities at different localities, owing to the distance from the focus of the earthquake, type of focal mechanIsm, local seological conditions, structural design of buildings, and the earthquake magnitude.

The text of this publication gives the intensity at locations where the earthquake was reported felt and summaries of the strongest effects. Each earthquake is further characterized by its maximum intensity, which is given in the text and in table 1 .

Although the Modified Mercalli Intensity Scale is in many instances inadequate for present-day requirements, the scale has been the guide used by the USGS and NOAA and will continue to be so used until a new scale has been devised and has acceptance in the engineering and seismological communities. Questions concerning the interpretation of historical earthquake intensities should be referred to the USGS.

\section{MODIFIED MERCALLI INTENSITY SCALE OF 1931}

Adapted from Sieberg's Mercalli-Cancani scale, modified and condensed.

I. Not felt - or, except rarely under especially favorable circumstances. Under certain conditions, at and outside the boundary of the area in which a great shock is felt: sometimes birds, animals, reported uneasy or disturbed; sometimes dizziness or nausea experienced; sometimes trees, structures, liquids, bodies of water, may sway--doors may swing, very slowly.

II. Felt indoors by few, especially on upper floors, or by sensitive, or nervous persons. Also, as in grade $I$, but of ten more noticeably: sometimes hanging objects may swing, especially when delicately suspended; sometimes trees, structures, liquids, bodles of water, may sway, doors may swing, very slowly; sometimes birds, animals, reported uneasy or disturbed; sometimes dizziness or nausea experienced.

III. Felt indoors by several, motion usually rapid vibration. Sometimes not recognized to be an earthquake at first. Duration estimated in some cases. Vibration like that due to passing of light, or lightly loaded trucks, or heavy trucks some distance away. Hang ing objects may swing slightly. Movements may be appreciable on upper levels of tall structures. Rocked standing motor cars slightly.

IV. Felt indoors by many, outdoors by few. Awakened few, especlally light sleepers. 
Frightened no one, unless apprehensive from previous experience. Vibration like that due to passing of heavy or heavily loaded trucks. Sensatinn like heavy body striking bullding or falling of heavy objects inside. Rattling of dishes, windows, doors; glassware and crockery clink and clash. Creaking of walls, frame, especially in the upper range of this grade. Hanging objects swung, in numerous instances. Disturbed liquids in open vessels slightly. Rocked standing motor cars noticeably.

V. Felt indoors by practically all, outdoors by many or most: outdoors direction estimated. Awakened many, or most. Frightened few--slight excitement, a few ran outdoors. Builitings trembled throughout. Broke dishes, glassware, to some extent. Cracked windows--in some cases, but not generally. Overturned vases, small or unstable objects, in many instances, with occasional fall. Hanging objects, doors, swing generally or considerably. Knocked pictures against walls, nr swung them out of place. opened, or closed, doors, shutters, abruptly. Pendulum clocks stopped, started or ran fast, or slow. Moved small objects, furnishings, the latter to slight extent. Spilled liquids in small amounts from well-filled open containers. Trees, bushes, shaken slightly.

VI. Felt by all, indoors and outdoors. Frightened many, excitement general, some alarm, many $r$ an outdoors. Awakened all. Persons made to move unsteadily. Trees, bushes, shaken slightly to moderately. Liquid set in strong motion. Small belis rang--church, chape1, school, etc. Danage slight in poorly built buildings. Fa11 of plaster in small amount. Cracked plaster somewhat, especially fine cracks chimneys in some instances. Broke dishes, glassware, in considerable quantity, also some windows. Fall of knickknacks, books, pictures. Overturned furniture in many instances. Moved furnishings of moderately heavy kind.

VII. Frightened all--general alarm, all ran outdoors. Some, or many, found it difficult to stand. Noticed by persons driving motor cars. Trees and bushes shaken moderately to strongly. Waves on ponds, lakes, and running water. Water turbid from mud stirred up. Incaving to some extent of sand or gravel stream banks. Rang large church bells, etc. Suspended objects made to quiver. Damage negligible in buildings of good design and construction, slight to moderate in wel1built ordinary buildings, considerable in poorly built or badly designed buildings, adobe houses, old walls (especially where laid up without mortar), spires, etc. Cracked chimneys to considerable extent, wal. Is to some extent. Fall of plaster in considerable to large amount, also some stucco. Broke numerous windows, furniture to some extent. shook down loosened brickwork and tiles. Broke weak chimneys at the roof-line (sometimes damaging roofs). Fall of cornices from towers and high buildings. Dislodged bricks and stones. Overturned heavy furniture, with damage from breaking. Damage considerable to concrete irrigation ditches.

VIII. Fright general--alarm approaches panic. Disturbed persons driving motor cars. Trees shaken strongly-branches, trunks, broken off, especially palm trees. Ejected sand and mud in small amounts. Changes: temporary, permanent; in flow of springs and wells; dry wells renewed flow; in temperature of spring and well waters. Damage slight in structures (brick) built especially to withstand earthquakes. Considerable in ordinary substantial buildings, partial collapse: racked, tumbled down, wooden houses in some cases; threw out pane1 walls in frame structures, broke of $f$ decayed piling. Fall of walls. Cracked, broke, solld stone walls seriously. Wet ground to some extent, also ground on steep slopes. Twisting, fall, of chimneys, columns, monuments, also factory stacks, towers. Moved conspicuously, overturned, very heavy furniture.

IX. Panic general. Cracked ground conspicuously. Damage considerable in (masonry) structures built especially to withstand earthquakes: Threw out of plumb some wood-frame houses built especially to withstand earthquakes; great in substantial (masonry) buildings, some collapse in large part; or wholly shifted frame buildings off foundations, racked frames; serious to reservoirs; underground pipes sometimes broken.

X. Cracked ground, especially when loose and wet, up to widths of several inches; $f$ issures up to a yard in width ran parallel to canal and stream banks. Landslides considerable from river banks and steep coasts. Shifted sand and mud horizontally on beaches and flat land. Changed level of water in wells. Threw water on banks of canals, lakes, rivers, etc. Damage serious to dams, dikes, embankments. Severe to well-built wooden structures and bridges, some destroyed. Developed dangerous cracks in excellent brick walls. Destroyed most masonry and frame structures, also their foundations. Bent railroad rails slightly. Tore 
apart, or crushed endwise, pipe lines buried in earth. Open cracks and broad wavy folds in cement pavements and asphalt road surfaces.

$X I$. Disturbances in ground many and widespread, varying with ground material. Broad fissures, earth slumps, and 1 and slips in soft, wet ground. Ejected water in large amounts charged with sand and mud. Caused sea-waves ("tidal" waves) of significant magnitude. Damage severe to wood-frame structures, especially near shock centers. Great to dams, dikes, embankments of ten for long distances. Few, if any (masonry) structures remained standing. Destroyed large well-built bridges by the wrecking of supporting piers, or pillars. Affected yielding wooden bridges less. Bent railroad rails greatly, and thrust them endwise. Put pipe lines buried in earth completely out of service.

XII. Damage total-practically all works of construction damaged greatly or destroyed. Disturbances in ground great and varied, numerous shearing cracks. Landslides, falls of rock of significant character, slumping of river banks, etc., numerous and extensive. Wrenched loose, tore off, large rock masses. Fault slips in firm rock, with notable horizontal and vertical offset displacements. Water channels, surface and underground, disturbed and modified greatly. Dammed lakes, produced waterfalls, deflected rivers, etc. Waves seen on ground surfaces (actually seen, probably, in some cases). Distorted lines of sight and level. Threw objects upward into the air.

\section{COLLABORATORS}

Active cooperation in earthquake investigations in the United States is provided by several seismological collaborators. The following served as collaborators to the USGS and NOAA during 1979.

Alabama.-L. J. Eisele, Spring Hill College, Mobile.

Alaska.--Staf $\mathrm{f}$ of NOAA-Alaska Tsunami Warning Center, Palmer.

Arizona.--Marc Sbar, University of Arizona, Tucson.

Callfornia (northern).--Bruce A. Bolt, University of Callfornia, Berkeley.

California (southern).--Clarence R. Allen, Cal1fornia Institute of Technology, Pasadena.
Connecticut.--Robert Miller, University of Connecticut, Groton.

Delaware.--Kenneth $D$. Woodruff, University of Delaware, Newark.

Florida and Georg1a.--Leland T. Long, Georgia Institute of Technology, Atlanta.

Hawa i1.--Robert Koyanag1, USGS, Hawailan Volcano Observatory, Hawail National Park.

Idaho.--James K. Applegate, Boise State University, Boise.

Indiana.--Robert F. Blakely, Department of Natural Resources, Geological Survey, Bloomington.

Iowa.--J. P. Kopp, Loras College, Dubuque.

Kansas.--Henry V. Beck, Kansas State University, Manhattan, and Don W. Steeples, Kans as Geological Survey, Lawrence.

Kentucky.--Ronald L. Street, University of Kentucky, Lexing ton.

Michigan.--F. Mauk, University of Michigan, Ann Arbor.

Minnesota.--Harold Mooney, University of Minnesota, Minneapolis.

Missouri, Illinois, Arkansas area.--0tto Nuttli and Robert B. Herrmann, Saint Louis University, Saint Louis.

Montana.--Anthony Qamar, University of Montana, Missoula.

New England.--John F. Ebe1, Boston College, Weston, Mass.

New York.--Lynn R. Sykes and Yash P. Aggarwal, Lamont-Doherty Geological Observatory, Palisades.

Ohio.--Edward J. Walter, John Carroll University, Cleveland.

Oklahoma.--James E. Lawson, Jr., Oklahoma Geological Survey, Leonard.

oregon.--Richard W. Couch, Oregon State University, Corvallis.

Pennsylvania.--Benjamin F. Howe11, Jr., Pennsy1vania State University, University Park.

South Carolina.--Pradeep Talwani, University of South Carolina, Columbia, and Joyce Bagwe11, Baptist College at Charleston, Charleston.

Tennessee.--Berlen C. Moneymaker, Knoxville, and Arch C. Johnston, Tennessee Earthquake Information Center, Memphis.

Texas.--G. R. Keller, University of Texas, El Paso.

Utah.--Kenneth Cook, University of Utah, Salt Lake City.

Virginia.--G. A. Bollinger, Virginia Polytechnic Institute and State University, Blacksburg.

Washington.--Robert S. Crosson, University of Washington, Seattle.

West Virginia.--R. W. Laird, West Virgina University, Morgantown.

Wisconsin.--David E. Willis, University of Wisconsin, Milwaukee.

Wyoming--R. A. Hutchinson, National Park Service, Yellowstone National Park. 


\section{Earthquake Descriptions}

This section 1 ists all earthquakes alphabetically by State. The origin time of earthquake occurrences is given in Universal Coordinated Time (UTC). Times are expressed continuously from midnight to midnight, or 0 to 24 hours.

Sources of noninstrumental information (macroseismic data) in this publication include questionnaire canvasses conducted by the USGS; newspaper articles; bulletins of the Seismological Society of America; and special earthquake reports of other organizations. Instrumental data are provided by the USGS, National Earthquake Information Service.

Roman numera1s in the earthquake descriptions refer to the Modified Mercalli Intensity Scale of 1931 (see page 2), which gives about equal weight to the disturbance of inanimate objects and to personal reactions. When more than one degree of intensity is reported from a town, the town is assigned the highest intensity reported. All earthquake reports or press reports that contain only minimal information which preludes the assignment of an intensity are listed as "Felt."

The following symbols are used to indicate authority for arrival or origin times, epicenters, and/or magnitudes: (B) Iniversicv of california, Berkeley; (D) Universitv of Montand, Missoula; (E) l'.S. Department of linergy, Las Vegas, Nevada; (F) Bollinger and Nathend, 1980); (C) I... cocolngical Survey, National Earthquake Inforination service, Colden, Coln.: (H) U.S. Geological Survev, Hawalian Loleano Ohservators, Hawai i National Park; (J) Weston Observatorv, Weston, Mass, ; (K) Kansits lieological Survey, Lawrence; (L) Lamont-Dohertv ceolugical ubservatorv, Palisades i $Y$, (N) NOAA, Alaska Tsunami Warning (enter, Palmer; (C) tarth

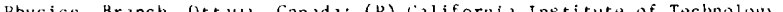

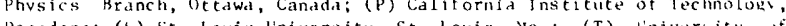

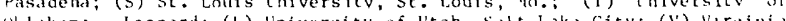

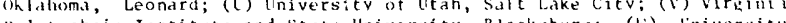
of Watshington, Seattle; $(Y)$ l'niversity ot kentuchv, Lexingtum; $(C)$ stephens and others, 1980

\section{Alaska}

4 January (G) Southern Alaska Origin time: 153504.0 Epicenter: $\quad 61.73 \mathrm{~N} ., 150.04 \mathrm{~W}$. Depth: $\quad 34 \mathrm{~km}$

Magnitude: $\quad 3.4 \mathrm{ML}(\mathrm{M})$

Felt at Eagle River and Willow.

8 January (G) Southe $\mathrm{Cn}$ Alaskal Origin time: $\quad 10 \quad 1100.8$ Epicenter: $\quad 61.77$ N., $150.08 \mathrm{~W}$. Depth: $\quad 45 \mathrm{~km}$
Alaska--Cont inued

Magnitude: $\quad 2.5 \mathrm{ML}(\mathrm{M})$

Intensity II: Palmer.

10 January ( $\left.C_{s}\right)$ Southern Alaska

Origin time: 003448.1

Epicenter: $\quad 61.58 \mathrm{~N} ., 150.06 \mathrm{~W}$.

Depth: $\quad 42 \mathrm{~km}$

Magnitude: $\quad 3.0$ ML (Mi)

Intensity II: Palmer.

25 January (G) Central Alaska

Origin time: 024903.5

Epicenter: $\quad 63.32 \mathrm{N.}, 151.16 \mathrm{~W}$.

Depth: Normal.

Magnitude: $\quad 3.5$ MI.(M)

Intensity III: Fairbanks (II).

25 January (G) Southern Alaska

Origin time: $\quad 193006.1$

Epicenter: $\quad 60.13 \mathrm{Ne}, 153.12 \mathrm{~W}$.

Depth: $\quad 105 \mathrm{~km}$

Magnitude: $\quad 5.5 \mathrm{mh}(G)$

Felt from Kodiak Island to Fairbanks (it).

Intensity IV: Anchorage, Clam Gulch, Cooper Landing, liomer, Kenai, Larsen Bav, Seldovia, Seward, Soldotna, Sterling, Tyonek.

Intensity III: Karluk, Nikishka, Olga Bay, Pedro Bay.

Felt: $\quad$ Kodiak, Palmer, Talkeetna

(press reports).

27 January $\left(C_{1}\right)$ southern Alaska

Origin time: $\quad 164811.5$

Epicenter: $\quad 60.96 \mathrm{N.}, 149.38 \mathrm{li}$.

Depth: $\quad 49 \mathrm{~km}$

Magnitude: $\quad 3.6 \mathrm{mh}(\mathrm{i}), 3.2 \mathrm{Mll}(\mathrm{Y})$

Intensity IV: Anchorage, Chugiak, Clam

Gulch, Sutton, Talkectna.

Inteusity III: Skwentna.

Intensity II: Kenai.

27 January (G) Alaska Peninsula

Origin time: $\quad$ J8 5755.0

Epicenter: $\quad 54.77 \mathrm{~N} .161 .25 \mathrm{~K}$.

bellit: $17 \mathrm{~km}$

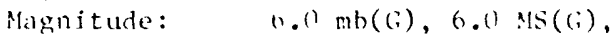

Intensity $V^{\prime}$ :

$$
5.8 \mathrm{MS}(\mathrm{b}), 5.8 \mathrm{MS}(\mathrm{L})
$$

Cold Bay (hairline cracks in exterior walls; unconfirmed report of a building 
moved on its foundation; light furniture shifted, small objects fell and overturned; windows, doors, and dishes rattled; felt by many).

Sand Point (small objects fell; buildings creaked and shook; wi ndows, doors, and dishes rattled; felt by many).

Intensity IV: King Cove, Perryville. Intensity III: False Pass.

31 January (G) Andreanof Islands, Aleutian Is lands

Origin time: 030732.0

Epicenter: $\quad 51.72 \mathrm{~N} ., 175.81 \mathrm{~W}$.

Depth: $\quad 64 \mathrm{~km}$

Magnitude: $\quad 5.0 \mathrm{mb}(\mathrm{G})$

Intensity III: Adak (M).

1 February (G) Southern Alaska

Origin time: $\quad 122905.4$

Epicenter: $\quad 60.24$ N., $152.84 \mathrm{~W}$.

Depth: $\quad 109 \mathrm{~km}$

Magnitude: $\quad 4.8 \mathrm{mb}(\mathrm{G})$

Intensity IV: Kenai (M), Seward (M), Soldotna (M).

Intensity III: Homer (M), Anchorage (M).

6 February (G) Kenai Peninsula

Origin time: 225200.6

Epicenter: $\quad 60.72 \mathrm{~N} ., 151.77 \mathrm{~W}$.

Depth: $\quad 87 \mathrm{~km}$

Magnitude: None computed.

Felt at Kenai and Soldotna (M).

7 February (G) Southern Alaska

Origin time: 133329.1

Epicenter: $\quad 61.03 \mathrm{~N} ., 150.15 \mathrm{~W}$.

Depth: $\quad 32 \mathrm{~km}$

Magnitude: $\quad 3.0 \mathrm{ML}(\mathrm{M})$

Felt at Anchorage (M).

9 February (G) Southern Alaska

Origin time: 184925.1

Epicenter: $\quad 60.06 \mathrm{~N} ., 152.59 \mathrm{~W}$.

Depth: $\quad 88 \mathrm{~km}$

Magnitude: $\quad 4.8 \mathrm{mb}(\mathrm{G})$

Felt at Anchorage and on the Kenai Peninsula (M).

13 February (G) Alaska Peninsula region Origin time: 053425.9

Epicenter: $\quad 55.45$ N., 157.16 W.

Depth:

Normal.

Magnitude: $\quad 5.9 \mathrm{mb}(G), 6.7 \mathrm{MS}(G)$, $6.6 \mathrm{MS}(\mathrm{B}), 6.8 \mathrm{mb}(\mathrm{P})$, $6.5 \mathrm{MS}(\mathrm{P})$

Intensity IV: Chignik, Perryville, Pilot Point, Port Heiden.
Intensity III: Egegik, King Salmon, Sand Point.

Intensity II: Naknek.

17 February (G) Southern Alaska

Origin time: 080124.6

Epicenter: $\quad 62.80 \mathrm{~N} ., 148.28 \mathrm{~W}$.

Depth: $\quad 95 \mathrm{~km}$

Magnitude: None computed.

Intensity II: Palmer (M).

17 February (G) Southern Alaska

Origin time: $\quad 104808.7$

Epicenter: $\quad 62.31 \mathrm{~N} ., 149.50 \mathrm{~W}$.

Depth: $\quad 54 \mathrm{~km}$

Magnitude: $\quad 4.9 \mathrm{mb}(\mathrm{G})$

Felt from Talkeetna to Anchorage and at Val$\operatorname{dez}(M)$.

Intensity IV: Palmer (M). Intensity III : Talkeetna.

23 February (G) Central Alaska

Origin time: 094203.6

Epicenter: $\quad 64.98$ N., $147.85 \mathrm{~W}$.

Depth: $\quad 24 \mathrm{~km}$

Magnitude: $\quad 4.3 \mathrm{mb}(\mathrm{G}), 4.2 \mathrm{ML}(\mathrm{M})$

Intensity $\mathrm{V}$ : Fairbanks (small objects fell).

23 February (G) Central Alaska

origin time: 1814

Epicenter: Not located.

Depth: None computed.

Magnitude: None computed.

Intensity III: Fairbanks.

27 February (G) Southern Alaska

Origin time: $\quad 144245.2$

Epicenter: $\quad 62.29 \mathrm{~N} ., 149.81 \mathrm{~W}$.

Depth: $\quad 34 \mathrm{~km}$

Magnitude: $\quad 2.7 \mathrm{ML}(\mathrm{M})$

Felt at Talkeetna.

28 February (G) Fox Islands, Aleutian Islands Origin time: 024710.4

Epicenter: $\quad 52.94 \mathrm{~N} ., 169.06 \mathrm{~W}$.

Depth: $\quad 79 \mathrm{~km}$

Magnitude: $\quad 4.5 \mathrm{mb}(\mathrm{G})$

Felt at Nikolski.

28 February (G) Southeastern Alaska Origin time: $\quad 212706.1$

Epicenter: $\quad 60.64$ N., 141.59 W. Depth: $\quad 15 \mathrm{~km}$

Magnitude: $\quad 6.4 \mathrm{mb}(G), 7.1 \mathrm{MS}(\mathrm{G})$

$7.4 \operatorname{MS}(P), 7.3 \mathrm{MS}(\mathrm{B})$,

$6.9 \mathrm{ML}(\mathrm{M})$ 
The information on the effects of this earthquake was collected by the U.S. Geological Survey and Lamont-Doherty Geological Observatory in the United States, and by the Earth Physics Branch in Canada. The descriptions listed below were taken from Stover and others (1980). This earthquake was felt over an area of approximately $500,000 \mathrm{sq} \mathrm{km}$ of Alaska and western Canada ( $\mathrm{fig} \cdot 7$ ). The lack of major damage was due to the epicenter being in an unpopulated area of ice fields near the eastern end of the Chugach Mountains and in the vicinity of Mt. St. Elias. It is the first major earthquake since 1899 to occur between Yakutat Bay and Prince William Sound. Lahr and others (1980) determined 102 aftershocks with magnitudes greater than 2.5 within 6 days following this event, and Stephens and others (1980) located 308 aftershocks that occurred between 28 February and 31 March 1979.

Porcella (1979) reported ground accelerations recorded on strong motion accelerographs at Icy Bay (73 km distant), Munday Creek (92 km distant), and Yakutat (16l km distant), were $0.16 \mathrm{~g}, 0.06 \mathrm{~g}$, and $0.09 \mathrm{~g}$ respectively.

\section{Intensity VII:}

\section{United States--}

Alaska--

Icy Bay Lumber Camp (A heavy logging truck on the road just west of the camp had just stopped when the earthquake was first felt. The motion bounced the truck sideways across the road so strongly that the driver was unable to descend from the truck. The reports from the camp described books shaken from shelves to the floor, minor cracking in a concrete slab floor, people had difficulty in standing, trees and bushes shaken strongly, overhead electric lines whipped back and forth.)

Intensity VI:

United States--

Alaska--

Border City (building foundation cracked, plaster cracked, a wooden building on permafrost moved on its foundation).

Cape Yakataga (drywall cracked, a few windows cracked, small objects broken, hanging objects swung violently, some hanging pictures fell, trees and bushes shaken strongly, felt by all).
Haines (plaster cracked, heavy furniture and appliances shifted, cracks in the exterior concrete wall near the roof of the office of the Thunderbird Motel, small exterior cracks in the exterior wall of the bank).

Juneau Airport (deplaning passengers had difficulty standing and needed support to remain upright; in the terminal building a heavy desk was bounced away from a wall and back again; heavy fire extinguishers hanging on a wall swung about 15 $\mathrm{cm}$ ).

Mendenhal 1 subdivision--north of Juneau (many instances of cracked plaster, furniture shifted, and a double-width mobile home separated at the joint).

Valdez Airport $--5 \mathrm{~km}$ east of Valdez (The terminal, which is an earthquake-resistant building, suffered no damage to exterior walls. There were many instances of cracked wallboard on the inside walls at corners, doorways, and windows. People in the terminal had difficulty standing and described the motion as long, slow, and rolling.).

Yakutat (The city hall on Monti Bay was shaken strongly enough to cause people to be nauseous and leave the building. Outside they had difficulty standing alone and had to hang onto each other to remain upright. Trucks near the building were rocked back and forth and open truck doors swung. There were many reports of parked cars being moved back and forth. Electric power lines were whipped back and forth. The concrete slab floor of a restaurant was cracked in two separate areas across its length.).

\section{Canada--}

Yukon Territory--

Beaver Creek (cracked plaster in the upper floor of a two-story house, hanging lamps swung violently, school teachers evacuated the school, cracks widened in the wall of the school along the base with numerous vertical cracks appearing, one well went dry for a day and a half).

Burwash Landing (people had difficulty in standing, dishes broken, liquid spilled, fresh cracks in the exterior walls of the Aeradio station building).

Destruction Bay (residents at the Talbot Arm Lodge reported that water 


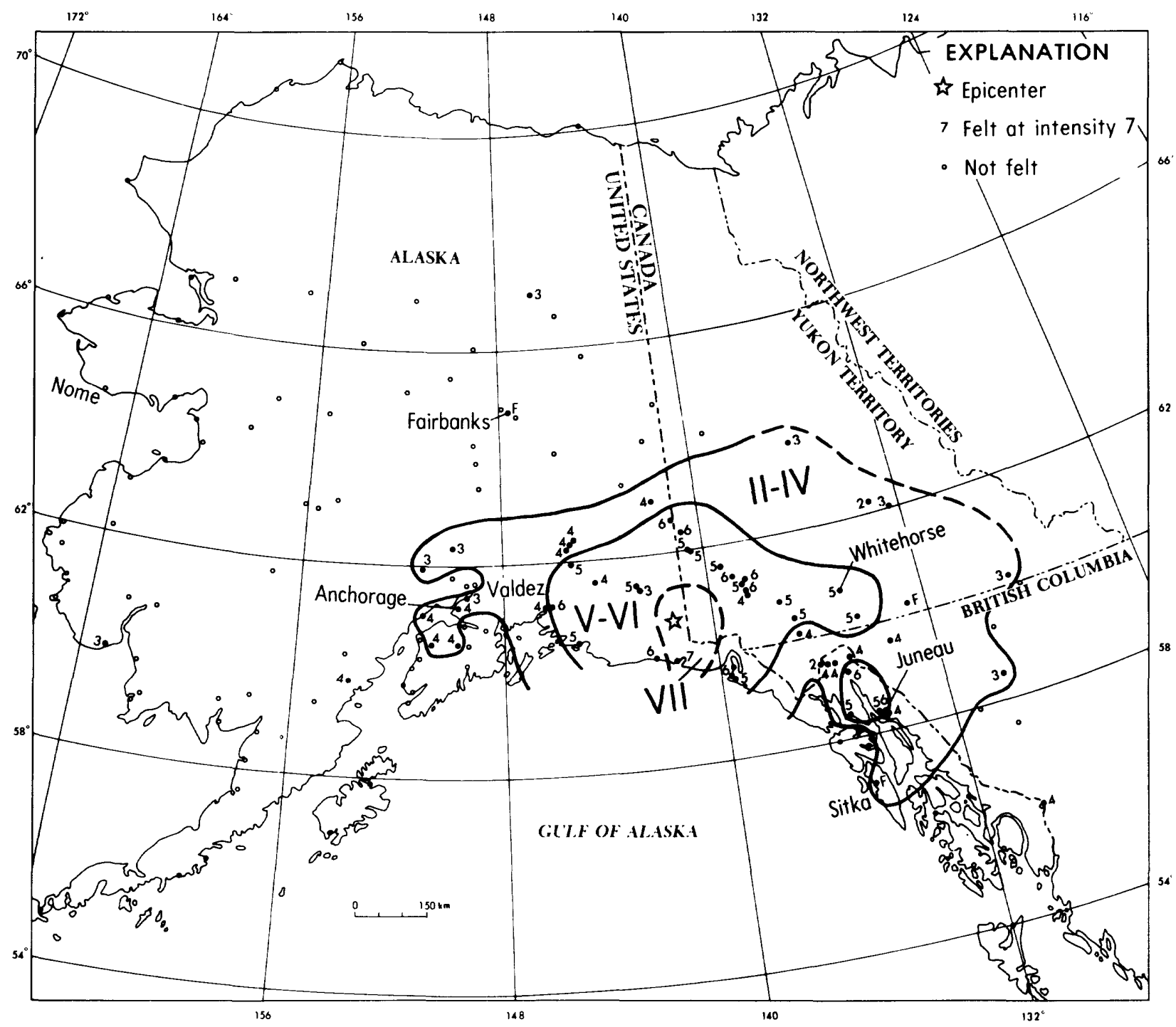

FIGURE 7.--Isoseismal map for the St. Elias earthquake of 28 February $1979,212706.1$ UTC. Roman numerals represent Modified Mercalli intensities between isoseismals; Arabic nume rals are used to represent these intensities at specific sites.

\section{Alaska--Continued}

splashed out of the kitchen sink, the canopy over the grill moved, cracks appeared in the plaster walls, and pictures swung).

Kluane Lake Fishing Camp (The owners noticed vertical motion of trees and vehicles and the log cabin walls whipped violently up and down. They left their cabin in a panic and were afraid that their truck would be overturned by the tremor. In the cabin, taxidermic displays fell and water splashed out of a large kettle on the stove.).

\section{Alaska--Continued}

Intensity $\mathrm{V}$ :

United States--

Alaska--Auke Bay, Cordova, Gustavus, McCarthy, Yakutat Airport. Canada--

Yukon Territory--Bayshore Esso, Carcross, Dezadeash, Haines Junction, Kluane Wilderness Village, Koidern, Whitehorse, White River.

Intensity IV:

United States--

Alaska--Anchorage, Chitina, Cooper Landing, Copper Center, Gakona, Glennallen, Gulkana (FAA Airport), Juneau, 
Klukwan, Northway, Pedro Bay, Skagway, Sterling, Tyonek, Valdez, 33 Mile Cafe.

Canada--

British Columbia--Atlin, Stewart.

Yukon Territory--Arctic Institute, DPW. Intensity III:

United States--

Alaska--Chugiak, Kontiginak, May Creek, Skwentna, Talkeetna, Venetie.

Canada--

British Columbia-Dease Lake.

Yukon Territory--Mayo, Ross River, Watson Lake.

\section{Intensity II:}

Canada--

Yukon Territory--Customs, Faro.

Felt, but not enough data to evaluate the intensity:

United States--

Alaska--Fairbanks, Sitka.

Canada--

Yukon Territory--Teslin.

1 March ( $Z$ ) Southeastern Alaska

Origin time: 070853.7

Epicenter: $\quad 60.63 \mathrm{~N} ., 141.24 \mathrm{~W}$.

Depth:

$11 \mathrm{~km}$

Magnitude:

$5.4 \mathrm{mb}(\mathrm{G}), 4.7 \mathrm{MS}(\mathrm{G})$

$4.9 \mathrm{ML}(\mathrm{Z}), 5.3 \mathrm{ML}(\mathrm{M})$

Felt at Cape Yakataga (M).

2 March (Z) Southeastern Alaska

Origin time: 093445.4

Epicenter: $\quad 60.38 \mathrm{~N} ., 140.69 \mathrm{~W}$.

Depth: $\quad 1 \mathrm{~km}$

Magnitude: $\quad 5.4 \mathrm{mb}(\mathrm{G}), 5.2 \mathrm{ML}(\mathrm{M})$,

$5.0 \mathrm{ML}(\mathrm{Z})$

Felt at Cape Yakataga and Icy Bay Lumber Camp (M).

14 March (G) Cook Inlet

$\begin{array}{ll}\text { Origin time: } & 075631.4 \\ \text { Epicenter: } & 59.79 \mathrm{~N} ., 151.92 \mathrm{~W} . \\ \text { Depth: } & 87 \mathrm{~km} \\ \text { Magnitude: } & 3.4 \mathrm{mb}(\mathrm{G})\end{array}$

Felt at Anchor Point and Homer (M).

14 March (G) Kenai Peninsula

Origin time: 133134.5

Epicenter: $\quad 60.98 \mathrm{~N} ., 149.39 \mathrm{~W}$.

Depth: $\quad 41 \mathrm{~km}$

Magnitude: $\quad 4.0 \mathrm{mb}(G), 3.8 \mathrm{ML}(\mathrm{M})$

Intensity IV: Anchorage (M), Hope (M), Palmer (M).

24 March (G) Southern Alaska

Origin time: $\quad 183741.8$

Epicenter: $\quad 61.53 \mathrm{~N} ., 149.93 \mathrm{~W}$.
Depth: $\quad 52 \mathrm{~km}$

Magnitude: None computed.

Felt in the Anchorage area (M).

26 March Southern Alaska

Origin time: 2311

Epicenter: Not located.

Depth: None computed.

Magnitude: None computed.

Intensity III: Fish Lake (M), Talke€ $n$ (M).

27 March (G) Andreanof Islands, Aleutian Islands origin time: 113909.0

Epicenter: $\quad 51.82 \mathrm{~N} ., 175.33 \mathrm{~W}$.

Depth: $\quad 43 \mathrm{~km}$

Magnitude: $\quad 5.0 \mathrm{mb}(G), 4.4 \mathrm{MS}(G)$

Intensity IV: Adak (M).

27 March (G) Southern Alaska

origin time: $\quad 183842.2$

Epicenter: $\quad 60.49 \mathrm{~N} ., 148.98 \mathrm{~W}$.

Depth: $26 \mathrm{~km}$

Magnitude: $\quad 2.9 \mathrm{ML}(\mathrm{M})$

Felt at Girdwood and Portage. A snowslide was reported at Alyeska resort (M).

2 April (G) Central Alaska

Origin time: 021531.4

Epicenter: $\quad 64.81 \mathrm{~N} ., 147.43 \mathrm{~W}$.

Depth:

$10 \mathrm{~km}$

Magnitude:

$3.1 \mathrm{ML}(\mathrm{M})$

Felt at Fairbanks (M).

4 April (G) Southern Alaska

Origin time: $08 \quad 16 \quad 15.3$

Epicenter: $\quad 60.32$ N., $153.59 \mathrm{~W}$.

Depth: $\quad 174 \mathrm{~km}$

Magnitude: $\quad 4.5 \mathrm{mb}(G)$

Felt at Chugiak (M).

17 April (G) Southern Alaska

Origin time: 025920.3

Epicenter: $\quad 61.68$ N., $150.12 \mathrm{~W}$.

Depth:

Magnitude: $\quad 2.7 \mathrm{ML}(\mathrm{M})$

Intensity II: Palmer (M).

18 April (G) Southern Alaaka

origin time: $\quad 170619.5$

Epicenter: $\quad 62.16 \mathrm{~N} ., 149.52 \mathrm{~W}$.

Depth:

Magnitude: None computed.

Intensity II: Palmer (M).

20 April (G) Southeastern Alaska

Origin time: $\quad 124906.5$

Epicenter: $\quad 60.28$ N., $140.78 \mathrm{~W}$. 
Depth:

$8 \mathrm{~km}$

Magnitude: $\quad 5.3 \mathrm{mb}(G), 4.9 \mathrm{MS}(G)$,

$$
5.0 \mathrm{ML}(\mathrm{Z})
$$

Intensity IV: Cape Yakataga, Icy Bay, Yakutat.

25 April (G) Central Alaska

Origin time: 002757.6

Epicenter: $\quad 63.35$ N., $149.50 \mathrm{~W}$.

Depth:

$119 \mathrm{~km}$

Magnitude:

$3.9 \mathrm{mb}(\mathrm{G})$

Felt at Curry and Gold Creek (M).

25 April (G) Central Alaska

Origin time: 093900.0

Epicenter: $\quad 64.88 \mathrm{~N} ., 148.83 \mathrm{~W}$.

Depth: $\quad 11 \mathrm{~km}$

Magnitude: $\quad 3.3 \mathrm{ML}(\mathrm{M})$

Intensity III: Fairbanks.

28 April (G) Central Alaska

Origin time: 073306.0

Epicenter: $\quad 64.61 \mathrm{~N} ., 149.46 \mathrm{~W}$.

Depth:

$28 \mathrm{~km}$

Magnitude:

$3.0 \mathrm{ML}(\mathrm{M})$

Felt at Fairbanks and Nenana (M).

5 May (G) Southern Alaska

Origin time: $\quad 065038.8$

Epicenter: $\quad 62.97 \mathrm{~N} ., 148.23 \mathrm{~W}$.

Depth:

$77 \mathrm{~km}$

Magnitude:

$4.6 \mathrm{mb}(\mathrm{G})$

Felt at Anchorage and Palmer (M).

9 May (G) Southern Alaska

Origin time: $\quad 142221.0$

Epicenter: $\quad 61.93 \mathrm{~N} ., 148.92 \mathrm{~W}$.

Depth:

Magnitude: $\quad 2.9 \mathrm{ML}(\mathrm{M})$

Intensity III: Palmer (M).

13 May Andreanof Islands, Aleutian Islands Origin time: 1851

Epicenter: Not located.

Depth:

None computed.

Magnitude :

None computed.

Felt on Adak.

14 May (G) Southern Alaska

Origin time: 201436.0

Epicenter: $\quad 61.73 \mathrm{~N} ., 150.89 \mathrm{~W}$.

Depth: $\quad 45 \mathrm{~km}$

Intensity II: Palmer (M).

18 May (G) Central Alaska

Origin time: 053522.6

Epicenter: $\quad 64.41 \mathrm{~N} ., 147.08 \mathrm{~W}$.

Depth:

$28 \mathrm{~km}$
Magnitude: $\quad 3.2 \mathrm{ML}(\mathrm{M})$

Intensity III: Fairbanks, Harding lake, and Salcha River areas (M).

20 May (G) Alaska Peninsula a rea

Origin time: 081400.1

Epicenter: $\quad 56.65 \mathrm{~N} ., 156.73 \mathrm{~W}$.

Depth:

$71 \mathrm{~km}$

Magnitude: $\quad 6.4 \mathrm{mb}(G), 6.5 \mathrm{mb}(P)$, $6.1 \mathrm{MS}(P), 6.2 \mathrm{mb}(\mathrm{B})$

Felt strongly at Dillingham (press report).

Intensity VI: Larsen Bay ( $p l a s t e r$ and dry wall cracked; hairline cracks in exterior walls, small objects shifted and fell, hanging pictures fell, felt by all, awakened many).

Intensity $\mathrm{V}$ :

Chignik (small objects fell, hanging objects swung violently, hanging pictures swung, water splashed onto sides of lakes and ponds, vehicles rocked strongly, felt by and awakened many).

Ivanof Bay (light furniture shifted, small objects fell, water spilled from containers, felt by all).

Kodiak (light and heavy furniture shifted, water spilled from small containers, hanging pictures fell, small landslides, standing vehicles rocked moderately).

Perryville (water spilled from small containers, many awakened, felt by all).

Intensity IV: Akhiok, Egegik, King Salmon, Pilot Point, Port Heiden, Port Lions, Sand Point.

20 May (G) Southern Alaska

Origin time: 222838.1

Epicenter: $\quad 62.83 \mathrm{~N} ., 149.17 \mathrm{~W}$.

Depth:

$95 \mathrm{~km}$

Magnitude: None computed.

Felt along the Alaska Railroad at Gold Creek and Chulitna (M).

21 May (G) Central Alaska

origin time: $\quad 100511.6$

Epicenter: $\quad 64.7 \mathrm{i}$ N., $148.43 \mathrm{~W}$.

Depth: Normal.

Magnitude: $\quad 3.0 \mathrm{ML}(\mathrm{M})$

Intensity II: Fairbanks (M).

25 May (G) Fox Islands, Aleutian Islands origin time: $\quad 164527.3$

Epicenter: $\quad 52.61 \mathrm{~N} ., 167.02 \mathrm{~W}$.

Depth:

$23 \mathrm{~km}$

Magnitude: $\quad 6.0 \mathrm{mb}(G), 6.2 \mathrm{MS}(G)$, $6.0 \mathrm{MS}(\mathrm{B})$,

Intensity IV: Nikolski (M). 
28 May (G) Southern Alaska

Origin time: 175014.3

Epicenter: $\quad 61.64$ N., 150.02 W.

Depth :

$45 \mathrm{~km}$

Magnitude:

None computed.

Intensity II: Anchorage, Palmer, Wasilla (M).

31 May (G) Southern Alaska

Origin time: 042254.3

Epicenter: $\quad 61.74 \mathrm{~N} ., 149.88 \mathrm{~W}$.

Depth: $\quad 55 \mathrm{~km}$

Magnitude: $\quad 3.4 \mathrm{mb}(\mathrm{G})$

Felt in the Anchorage area (M).

20 June (G) Southern Alaska

Origin time: 081830.8

Epicenter: $\quad 60.88 \mathrm{~N} ., 147.69 \mathrm{~W}$.

Depth: Normal.

Magnitude: $\quad 3.3 \mathrm{ML}(\mathrm{M})$

Felt at mile 2 of Parks Highway and at Goat Creek (M).

23 June (G) Southern Alaska

Origin time: $\quad 104658.6$

Epicenter: $\quad 61.87$ N., $150.28 \mathrm{~W}$.

Depth:

Normal.

Magnitude: $\quad 3.1 \mathrm{mb}(\mathrm{G}), 3.1 \mathrm{ML}(\mathrm{M})$

Intensity IV: Willow (M).

23 June (G) Southern Alaska

Origin time: $\quad 183932.2$

Epicenter: $\quad 58.03 \mathrm{~N} ., 134.91 \mathrm{~W}$.

Depth: $\quad 15 \mathrm{~km}$

Magnitude: $\quad 3.8 \mathrm{mb}(G)$

Intensity IV: Juneau-Douglas area (M)

26 June (G) Southern Alaska

Origin time: 190821.3

Epicenter: $\quad 62.36$ N., $147.83 \mathrm{~W}$.

Depth: $\quad 86 \mathrm{~km}$

Magnitude: $\quad 3.8 \mathrm{mb}(G)$

Intensity IV: Palmer-Talkeetna area (M).

10 July (G) Southern Alaska

origin time: $\quad 040420.5$

Epicenter: $\quad 63.20 \mathrm{~N} ., 150.72 \mathrm{~W}$.

Depth: $\quad 130 \mathrm{~km}$

Magnitude: $\quad 4.9 \mathrm{mb}(\mathrm{G})$

Intensity II: Anchorage (M).

11 July (G) Southeastern Alaska

Origin time: $\quad 122802.9$

Epicenter: $\quad 55.32 \mathrm{~N} ., 134.97 \mathrm{~W}$.

Depth:

$10 \mathrm{~km}$

Magnitude:

$5.1 \mathrm{mb}(G), 5.1 \mathrm{MS}(\mathrm{G})$,

$5.1 \mathrm{MS}(\mathrm{B}), 5.8 \mathrm{ML}(\mathrm{M})$

Intensity IV: Craig, Hydaburg, Klawock (M), Metlakatla, Petersburg, Port Alexander.

Intensity II: Ketchikan, Sitka.
16 July (G) Southern Alaska

Origin time: 234558.5

Epicenter: $\quad 60.86 \mathrm{~N} ., 153.02 \mathrm{~W}$.

Depth: $\quad 141 \mathrm{~km}$

Magnitude: $\quad 4.6 \mathrm{mb}(\mathrm{G})$

Felt at Anchorage (M).

17 July (G) Southern Alaska

Origin time: 204429.5

Epicenter: $\quad 62.27$ N., 148.14 W.

Depth: $\quad 58 \mathrm{~km}$

Magnitude: $\quad 5.3 \mathrm{mb}(\mathrm{G}), 5.0 \mathrm{mb}(\mathrm{B})$

Intensity IV: Anchorage, Chickaloon (telegraphic report), Chugiak, Girdwood, Moose Pass, Sutton, Whittier.

Intensity III: Palmer, Skwentna, Willow.

Intensity II: Fairbanks (telegraphic report).

Felt:

Glennallen, Talkeetna, Valdez.

23 July (G) Southern Alaska

Origin time: 083813.0

Epicenter: $\quad 58.63 \mathrm{~N} ., 151.51 \mathrm{~W}$.

Depth: Normal.

Magnitude: $\quad 4.4 \mathrm{mb}(\mathrm{G}), 4.6 \mathrm{ML}(\mathrm{M})$

Intensity II: Kodiak.

23 July (G) Southern Alaska

Origin time: 090707.7

Epicenter: $\quad 61.64 \mathrm{~N} ., 150.51 \mathrm{~W}$.

Depth: $\quad 49 \mathrm{~km}$

Magnitude: $\quad 2.9 \mathrm{ML}(\mathrm{M})$

Intensity II: Palmer area.

30 July (G) Southern Alaska

Origin time: 022404.6

Epicenter: $\quad 62.04$ N., $145.44 \mathrm{~W}$.

Depth: $\quad 14 \mathrm{~km}$

Magnitude: $\quad 3.5 \mathrm{ML}(\mathrm{M})$

Intensity II: Glennallen (M).

4 August (G) Southern Alaska

Origin time: 201210.6

Epicenter: $\quad 62.49$ N., 149.77 W.

Depth: $\quad 99 \mathrm{~km}$

Magnitude: $\quad 4.1 \mathrm{mb}(\mathrm{G})$

Intensity III: Gold Creek (M), Talkeetna (M).

Intensity II: Palmer (M).

7 August (G) Andreanof Islands, Aleutian Islands

Origin time: $\quad 181509.5$

Epicenter: $\quad 51.32$ N., 176.11 W.

Depth: Normal.

Magnitude: $\quad 4.6 \mathrm{mb}, 4.0 \mathrm{ML}(\mathrm{M})$

Intensity III: Adak (M).

10 August (G) Southern Alaska

Origin time: 000225.4

Epicenter: $\quad 61.97$ N., $150.94 \mathrm{~W}$. 
Alaska--Cont inued

Depth: $\quad 81 \mathrm{~km}$

Magnitude: $\quad 4.3 \mathrm{mb}(\mathrm{G})$

Intensity III: Talkeetna.

27 August Andreanof Islands,

Aleutian Islands

Origin time: 1815

Epicenter: Not located.

Depth: None computed.

Magnitude: $\quad 4.0 \mathrm{ML}(\mathrm{M})$

Intensity III: Adak (M).

29 August (G) Southern Alaska

Origin time: $\quad 193811.4$

Epicenter: $\quad 61.91 \mathrm{~N} ., 150.80 \mathrm{~W}$.

Depth: $\quad 88 \mathrm{~km}$

Magnitude: $\quad 3.9 \mathrm{mb}(G)$

Intensity III: Hatcher Pass (M), Wasilla (M).

31 August (G) Alaska Peninsula

Origin time: 204227.4

Epicenter: $\quad 54.39 \mathrm{~N} ., 161.84 \mathrm{~W}$.

Depth: $\quad 20 \mathrm{~km}$

Magnitude: $\quad 5.1 \mathrm{mb}(\mathrm{G}), 4.3 \mathrm{MS}(\mathrm{G})$

Intensity III: Cold Bay (M).

1 September (G) Fox Islands, Aleutian Islands

Origin time: 052717.6

Epicenter: $\quad 53.98$ N., $165.20 \mathrm{~W}$.

Depth: $\quad 69 \mathrm{~km}$

Magnitude: $\quad 5.8 \mathrm{mb}(\mathrm{G}), 6.4 \mathrm{mb}(\mathrm{B})$, $6.3 \mathrm{mb}(\mathrm{P})$

Intensity IV: Dutch Harbor (M).

14 September Near Islands, Aleut ian

Islands

Origin time: 0729

Epicenter: Not located.

Depth: None computed.

Magnitude: None computed.

Intensity III: Shemya Island (M).

23 September (G) Near Islands, Aleutian

Islands

Origin time: $\quad 101720.8$

Epicenter: $\quad 52.29 \mathrm{~N} ., 174.03 \mathrm{E}$.

Depth: $\quad 43 \mathrm{~km}$

Magnitude: $\quad 5.8 \mathrm{mb}(\mathrm{G}), 5.6 \mathrm{MS}(\mathrm{G})$

Intensity IV: Shemya (M).

24 September (G) Near Islands, Aleutian

Is lands

Origin time: 031956.7

Epicenter: $\quad 52.19$ N., 174.02 E.

Depth: Normal.

Magnitude: $\quad 4.8 \mathrm{mb}$

Intensity IV: Shemya (M).
Alaska--Continued

26 September Andreanof Islands, Aleutian Islands

Origin time: 0718

Epicenter: Not located.

Depth: None computed.

Magnitude: None computed.

Intensity III: Adak (M).

27 September Andreanof Islands,

Origin time: Aleutian Islands

Epicenter: Not located.

Depth: None computed.

Magnitude: None computed.

Intensity III: Adak (M).

7 October (G) Southern Alaska

Origin time: 055921.8

Epicenter: $\quad 61.22 \mathrm{~N} ., 150.43 \mathrm{~W}$.

Depth:

$9 \mathrm{~km}$

Magnitude: $\quad 3.1 \mathrm{ML}(\mathrm{M})$

Felt at Anchorage (M).

10 October (G) Southeastern Alaska

Origin time: 233645.1

Epicenter: $\quad 56.15 \mathrm{~N} ., 135.75 \mathrm{~W}$.

Depth: Normal

Magnitude: $\quad 4.4 \mathrm{mb}(G)$

Felt at Sitka (M).

15 October (G) Andreanof Islands,

Aleutian Islands

$\begin{array}{ll}\text { Epicenter: } & 562401.2 \\ & 51.77 \mathrm{~N} ., 175.24 \mathrm{~W} .\end{array}$

Depth: $\quad 54 \mathrm{~km}$

Magnitude: $\quad 4.8 \mathrm{mb}(G)$

Intensity IV: Adak (M).

16 October (G) Rat Islands, Aleutian Island s

Origin time: 211605.2

Epicenter: $\quad 51.85$ N., 175.36 E.

Depth: $\quad 34 \mathrm{~km}$

Magnitude: $\quad 5.3 \mathrm{mb}(\mathrm{G}), 5.2 \mathrm{MS}(\mathrm{G})$

Intensity II: Shemya (M).

18 October (G) Rat Islands, Aleutian

$$
\text { Islands }
$$

Origin time: 033526.9

Epicenter: $\quad 51.86 \mathrm{~N} ., 177.13 \mathrm{E}$.

Depth:

Magnitude: $\quad 6.0 \mathrm{mb}(\mathrm{G})$

Intensity III: Shemya (M).

27 October (G) Southern Alaska

Origin time: 063202.3

Epicenter: $\quad 61.70$ N., 149.58 W. 


\section{Alaska--Cont inued}

Depth: $\quad 44 \mathrm{~km}$

Magnitude: $\quad 3.0 \mathrm{ML}(\mathrm{M})$

Intensity II: Palmer (M).

27 October (G) Southern Alaska

Origin time: 221659.2

Epicenter: $\quad 59.38 \mathrm{~N} ., 152.90 \mathrm{~W}$.

Depth: $\quad 77 \mathrm{~km}$

Magnitude: $\quad 4.1 \mathrm{mb}(\mathrm{G})$

Felt in the Homer area (M).

28 October (G) Southern Alaska

Origin time: 062409.8

Epicenter: $\quad 59.86 \mathrm{~N} ., 151.67 \mathrm{~W}$.

Depth:

$82 \mathrm{~km}$

Magnitude: None computed.

Fe1t in the Homer area (M).

2 November (G) Andreanof Islands, Aleutian Islands

Origin time: 032104.1

Epicenter: $\quad 51.16$ N., 178.05 W.

Depth: Normal.

Magnitude: $\quad 4.8 \mathrm{mb}(\mathrm{G}), 4.6 \mathrm{MS}(\mathrm{G})$

$$
\text { 4.3 ML(M) }
$$

Intensity III: Adak (M).

7 November (G) Southern Alaska

origin time: 031436.1

Epicenter: $\quad 60.59$ N., $150.68 \mathrm{~W}$.

Depth: $\quad 90 \mathrm{~km}$

Magnitude: None computed.

Intensity III: Naptown (M).

Intensity II: Soldotna (M), Sterling (M).

14 November (G) Southern Alaska

origin time: 230042.8

Epicenter: $\quad 61.38 \mathrm{~N} ., 150.09 \mathrm{~W}$.

Depth: $\quad 57 \mathrm{~km}$

Magnitude: $\quad 5.1 \mathrm{mb}(G)$

Intensity $V$ :

Spenard (1ight furniture and smal1 objects moved; hanging pictures swung; buildings shook strongly; windows, doors and dishes rattled; felt by several).

Wasilla (light furniture and small objects moved, hanging pictures knocked out of place; buildings creaked and shook, felt by severa1).

Intensity IV: Anchorage, Chugiak, Skwenta, Sutton, Whittier.

Intensity III: Anchorage--Mountain View, Big Lake Area, Kenai, North Kenai, Palmer (M).

Intensity II: Willow.

15 November (G) Southern Alaska

Origin time: 020834.8

Epicenter: $\quad 61.26 \mathrm{~N} ., 150.00 \mathrm{~W}$.

Depth:
Alaska--Continued

Magnitude: $\quad 3.8 \mathrm{ML}(\mathrm{M})$

Intensity IV: Anchorage.

15 November (G) Kenai Peninsula

Origin time: 071513.2

Epicenter: $\quad 60.18 \mathrm{~N} ., 149.68 \mathrm{~W}$.

Depth:

Magnitude: None computed.

Intensity IV: Seward.

26 December (G) Southern Alaska

Origin time: $\quad 131216.7$

Epicenter: $\quad 61.42 \mathrm{~N} ., 151.62 \mathrm{~W}$.

Depth: $\quad 111 \mathrm{~km}$

Magnitude: $\quad 4.1 \mathrm{mb}(\mathrm{G})$

Intensity II: Anchorage (M).

\section{Arizona}

$15 \operatorname{March}(P)$ Southern California

origin time: 210716.5

See California listing.

15 October (P) Imperial Valley a rea Origin time: 231654.5

See California listing.

11 December Central Arizona

Origin time: 2030

Epicenter: Not located.

Depth: None computed.

Magnitude: None computed.

Felt by many in the Theodore Roosevelt Lake area.

Intensity IV: Roosevelt (press report).

21 December ( $P$ ) Imperial Valley area

Origin time: 204025.3

See California listing.

\section{Arkansas}

5 February (S) Northeastern Arkansas Origin time: 053109.3

Epicenter: $\quad 35.84 \mathrm{~N}$., $90.08 \mathrm{~W}$.

Depth: $\quad 14 \mathrm{~km}$

Magnitude: $\quad 3.2 \mathrm{mbLg}(\mathrm{T})$

Intensity IV:

Arkansas--Blytheville, Manila.

Missouri--Whiteoak.

Intensity III :

Arkansas--De 11 . 
Intensity II:

Arkansas--Burdette.

Missouri--Arbyrd.

Tennessee--Tipton.

27 February Southeastern Arkansas

Origin time: 0825

Epicenter: Not located.

Depth: None computed.

Magnitude: None computed.

Intensity IV: Pine Bluff (two windows (racked), Moscow.

27 February (S) Northeastern Arkansas

Origin time: 225454.0

Epicenter: $\quad 35.92 \mathrm{~N} ., 91.24 \mathrm{~W}$.

Depth:

$9 \mathrm{~km}$

Magnitude: $\quad 3.1 \mathrm{mbLg}(\mathrm{S}), 3.4 \mathrm{mbLg}(\mathrm{T})$

Intensity $\mathrm{V}$ :

Ravenden Springs (unconfirmed reports of slightly cracked streets, sidewalks, and brick fences; light furniture and small objects shifted).

Tuckerman (1ight furniture and small objects shifted).

Intensity IV: Alicia, Calamine, Cash, Cave City, Newark, o'Kean, Portia (telephone report), Poughkeepsie, Powhatan, Ravenden, Saffe1l, Smithville, Strawberry, Swifton. Intensity III: Imboden.

Intensity II: Sulphur Rock, Walnut Ridge (telephone report), Weiner.

27 February (S) Northeastern Arkansas

Origin time: 225512.0

Epicenter: $\quad 35.93 \mathrm{~N} ., 91.24 \mathrm{~W}$.

Depth:

Magnitude: None computed.

Intensity IV: Powhatan (S).

11 June (S) New Madrid region

origin time: 041216.9

See Missouri 1isting.

25 June (S) Northeastern Arkansas

origin time: $\quad 171113.4$

Epicenter: $\quad 35.53 \mathrm{~N} ., 90.43 \mathrm{~W}$.

Depth: $\quad 11 \mathrm{~km}$

Magnitude: $\quad 3.0 \mathrm{mbLg}(\mathrm{T}), 3.2 \mathrm{mbLg}(\mathrm{S})$

Felt throughout Poinsett County (press report).

Intensity IV: Lepanto, Marked Tree, Payneway, Tyronza.

Intensity III: Gilmore.

26 August Northern Arkansas

Origin time: 1128

Epicenter: Not located.

Depth: None computed.

Magnitude: None computed.

Intensity IV: Hardy (two windows were broken and the earthquake noise was described as similar to a sonic boom--press report). Intensity III: Salem (press report).

5 November (S) Northern Arkansas

Origin time: $\quad 163526.0$

Epicenter: $\quad 36.44 \mathrm{~N} ., 91.01 \mathrm{~W}$.

Depth: $\quad 8 \mathrm{~km}$

Magnitude: $\quad 2.9 \mathrm{mbLg}(\mathrm{S})$

Intensity IV: Biggers, Dalton (S), May-

nard.

Intensity III: Reyno, Success.

\section{California}

1 January (P) Southern California

Drigin time: $\quad 231438.9$

Epicenter: $\quad 33.95$ N., $118.68 \mathrm{~W}$.

Depth:

Magnitude: $\quad 5.1 \mathrm{mb}(G), 4.7 \mathrm{MS}(\mathrm{G})$,

$5.0 \mathrm{ML}(\mathrm{P}), 4.9 \mathrm{ML}(\mathrm{B})$

The press reported a few broken store windows in the Malibu area, shattered store windows in Culver City at Exposition and Sepulveda Boulevard, one broken store window in Santa Monica, and cracked store windows in Buena Park and Seal Beach. The press also reported slight damage in North Hollywood and Toluca Lake areas. The CaIIfornia Highway Patrol reported a number of boulders fell onto Pacific Coast Highway in the Malibu area, closing one lane of the highway. Mud and boulders also fell across other roads in Malibu. The Los Angeles sheriff's office reported no injuries or damage except for objects falling from shelves and windows broken. California Institute of Technology recorded about 50 aftershocks by $5: 30 \mathrm{p} \cdot \mathrm{m}$. local time. The earthquake was felt over an area of approximately $21,500 \mathrm{sq} \mathrm{km}$ (fig. 8).

Porcella (1979) reported that 23 accelerograms were recovered for this earthquake in the Los Angeles and San Fernando Valley areas; 8 of these recorded peak accelerations greater than $5 \% \mathrm{~g}$. Topanga Fire Station recorded the peak horizontal acceleration at $0.09 \mathrm{~g}$ at a distance of $20 \mathrm{~km}$ from the epicenter. Eleven add1tional accelerograms were recovered by the State of California.

Intensity VI:

Culver City (shattered store windows-press report).

La Mirada (plaster cracked; small objects 


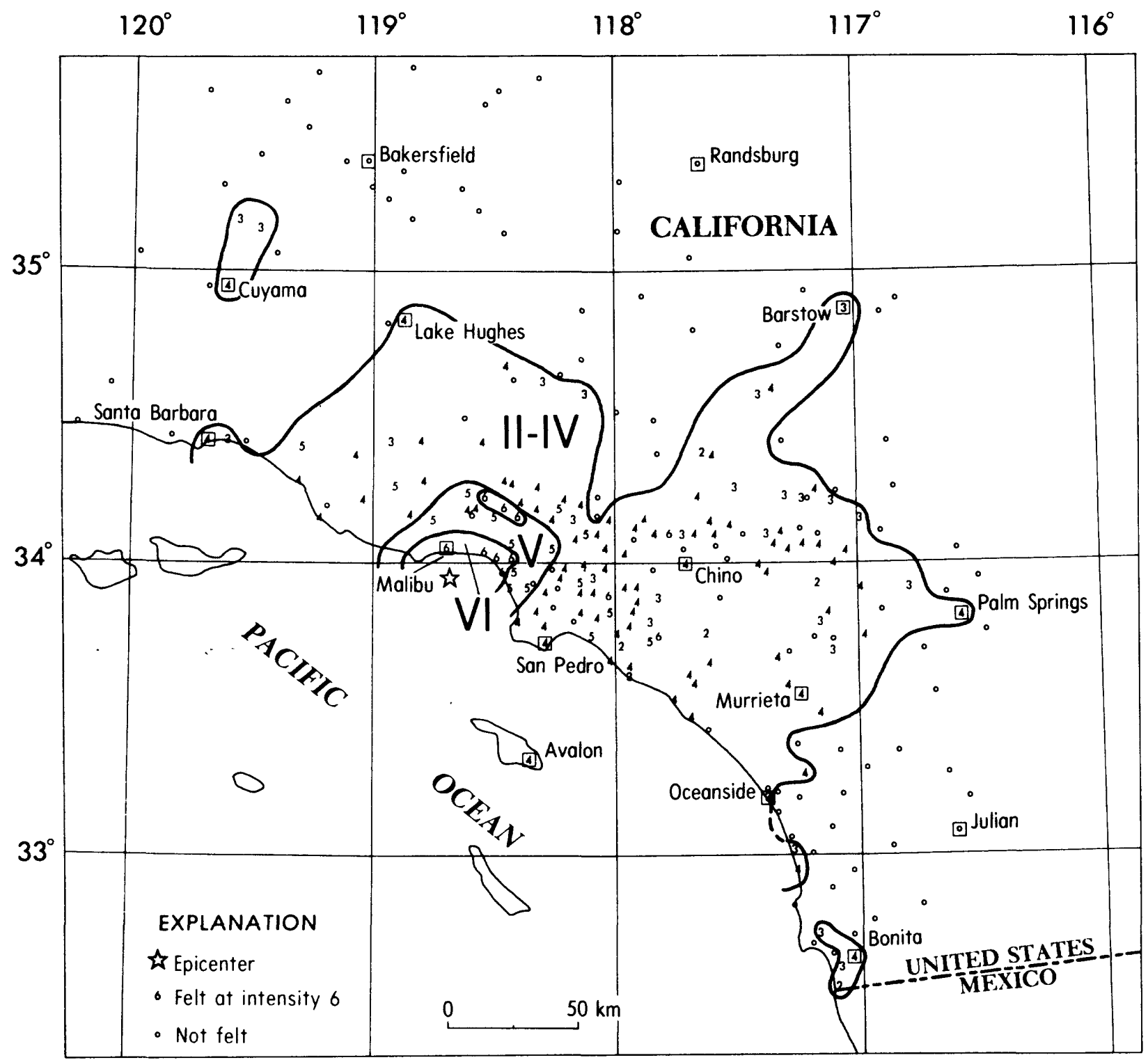

FIGURE 8.--Isoseismal map for the southern California earthquake of 1 January 1979,2314 38.9 UTC. Roman numerals represent Modified Mercalli intensities between isoseismals; Arabic numerals are used to represent these intensities at specific sites.

\section{California--Continued}

and light furniture shifted; windows, doors, and dishes rattled; hanging pictures and lamps swung; felt by many).

La Verne (plaster cracked; windows, doors, and dishes rattled; hanging pictures swung; felt by many).

Malibu (few broken windows; boulders fell onto highway; mud and rock slides--press report).

Northridge (plaster cracked in interior walls; hairline cracks in exterior
California--Cont inued

walls; light furniture and small objects shifted; hanging pictures swung; windows, doors, and dishes rattled; small landslides; felt by all).

Pacific Palisades ( $f$ loor of home cracked; resident held a television on the stand to keep it from falling).

Santa Monica (one broken store windowpress report).

Sherman Oaks (plaster cracked and broken; small objects shifted; hanging objects 
swung moderately; windows, doors, and dishes rattled; felt by many).

Studio City (interior walls cracked and split; hairline cracks in exterior walls; light furniture and small nbjects shifted; hanging objects swung moderately; windows, doors, and dishes rattled; felt by all).

Tustin (some windows broken; small objects shifted; hanging pictures swung; windows, doors, and dishes rattled; small landslides; cracks in wet ground; felt by many).

Venice (some windows broken; small objects bruken; hanging pictures swung out of place; windows, doors, and dishes rattled; felt by many).

Woodland Hills (three-year-old post office showed cracks and chips of concrete broken off, felt by many).

Intensity $V$ :

Agoura (light furniture shifted, small objects fell).

Beverly Hills (Near Beverly Boulevard and Santa Monica Boulevard, a man sitting in a chair experienced movenent of the chair in an east-west direction; at the same residence the metal shelf holders for the lower three shelves of the refrigerator were broken of $f$.).

Buena Park (store windows cracked--press report).

Chatsworth (few windows cracked, felt by a11).

Cypress (report of a resident holding his television so that it would not be shaken from 1 ts stand, small objects fel1).

Downey (small objects fell and broke, felt by al1).

El Segundo (hairline cracks in exterior. walls, felt by all).

Encino (light furniture and small objects shifted, felt by all).

Hawthorne (small objects fell, small mudslides, felt by all).

Los Angeles (small objects fell, small landslides, felt by many).

Marina Del Rey (small objects fell, felt by many).

Montrose (light furniture shifted, felt by many).

Moorpark (light furniture shifted).

Oak View (light and heavy furniture shifted, felt by many).

San Gabriel (less than ten 1 tems fell from shelves in a grocery store, light furniture shifted, felt by many).

Santa Ana (few cracked windows, felt by al1).

Seal Beach (store windows cracked, felt by many).
Intensity IV: Alhambra, AJta Loma, Altadena, Anaheim, Arcadia, Avalon, Azusa, Beaumont, Bellflower, Bonita, Bonsall, Brea, Bryn llawr, Burbank, Calimesa, Camarillo, Canoga Park, Capistrano Beach, Carson, Chino, Colton, Costa Mesa, Cucamonga, Cuyama, Del lar, Duarte, El Toro, Etiwanda, Fullerton, Carden Grov", Gardena, Glendale, Glendora, Crinada Hills, Harbor City, Hemet, Hunt ingt on Beach, La Canada, La Habra, La Puente. Laguna Beach, Lake Arrowhead, Lake Elsinore, Lake Hughes, Lakeview, Lakewisod, Lebec, Loma Linda, Lomita, Long Btach, Long Beach Veterans Hospital, Los Alamitos, Manhattan Beach, Mar Vista, Maywood, Mentone, Midway City, Mission Vieju, Monrovia, Montebello, Montecito, Mt. Baldy, Murrieta, Norwalk, Uro Grande, Pacoima, Palm Springs, Palos Verdes Estates, Panorama City, Phelan, Piru, Placentia, Port Hueneme, Redlands, Reseda, Riverside, Rosemead, Rossmoor, Rubiduux, San Bernardino, San Dimas, San Jacinto, San Pedro, Santa Barbara, Santa Paula, Saugus, Simi Valley, Skyforest, Solana Beach, South El Monte, South Gate, South Whittier, Sun Valley, Sunland, Sunset Beach, Surfside, Sylmar, Temecula, Temple City, Thousand Oaks, Torrance, Trabuco Canyon, Upland, Ventura, Whittier, Wildomar, Wilmington, Yucaipa.

Intensity III: Adelanto, Angelus Oaks, Barstow, Cabazon, Cardiff by the Sea, Chula Vista, Claremont, Crestline, Etiwanda (Rancho Cucamonga), Fellows, Fillmore, Laguna Hills, Leona Valley, Los Nietos, Los Serranos, Lytle Creek, Newport Beach, Nuevo, Oceanside, Orange, Palmdale, Pasadena, Rialto, Running Springs, San Diego, San Diego Navy Amphibious Base, Santa Fe Springs, Summerland, Taft, Twin Peaks, West Hollywood, Winchester, Yorba Linda.

Intensity II: Fountain Valley, Moreno, Nestor, Silve rado, Wrightwood.

1 January (P) Southern California

Origin time: 232214.3

Epicenter: $\quad 33.93 \mathrm{~N} ., 118.70 \mathrm{w}$.

Depth:

$12 \mathrm{~km}$

Magnitude: $\quad 3.4 \mathrm{ML}(\mathrm{P})$

Felt at Malibu (P).

1 January (P) Southern California

Origin time: 232925.0

Epicenter: $\quad 33.95 \mathrm{~N} ., 118.67 \mathrm{~W}$.

Depth:

$2 \mathrm{~km}$

Magnitude: $\quad 4.1 \mathrm{mb}(G), 3.9 \mathrm{ML}(P)$

Felt at Downey, Malibu, Monrovia, and Pasadena $(P)$. 


\section{California--Continued}

1 January ( $P$ ) Southern California

Origin time: 234958.8

Epicenter: $\quad 33.93 \mathrm{~N} ., 118.67 \mathrm{~W}$.

Depth: $\quad 6 \mathrm{~km}$

Magni tude: $\quad 3.7 \mathrm{ML}(\mathrm{P})$

Felt at Malibu (P).

2 January (P) Southern California

Origin time: 074114.1

Epicenter: $\quad 33.95 \mathrm{~N}, 118.70 \mathrm{~W}$.

Depth: $\quad 6 \mathrm{~km}$

Magnitude: $\quad 3.7 \mathrm{ML}(\mathrm{P})$

Felt at Downey, Malibu, and the San Fernando Valley (P).

2 January (P) Southern California

Origin time: 181631.4

Epicenter: $\quad 33.95$ N., $118.70 \mathrm{~W}$.

Depth: $\quad 15 \mathrm{~km}$

Magnitude: $\quad 3.4 \mathrm{ML}(\mathrm{P})$

Felt at Malibu (P).

2 January (P) Southern California

Origin time: 222957.9

Epicenter: $\quad 33.93 \mathrm{~N} ., 118.68 \mathrm{~W}$.

Depth: $\quad 6 \mathrm{~km}$

Magnitude: $\quad 2.5^{\circ} \mathrm{ML}(\mathrm{P})$

Felt at Malibu (P).

2 January (P) Southern California

origin time: 224327.1

Epicenter: $\quad 33.95 \mathrm{~N} ., 118.68 \mathrm{~W}$.

Depth: $\quad 11 \mathrm{~km}$

Magnitude: $\quad 2.6 \mathrm{ML}(\mathrm{P})$

Felt at Malibu (P).

3 Janaury (P) Southern California

Origin time: 002052.4

Epicenter: $\quad 33.90$ N., 118.68 W.

Depth: $\quad 6 \mathrm{~km}$

Magnitude: $\quad 2.8 \mathrm{ML}(\mathrm{P})$

Feit at Mailibu (P).

3 January (P) Southern California

Origin time: $\quad 165416.5$

Epicenter: $\quad 33.95$ N., $118.70 \mathrm{~W}$.

Depth: $\quad 11 \mathrm{~km}$

Magnitude: $\quad 3.0 \mathrm{ML}(\mathrm{P})$

Felt at Malibu (P).

3 January (P) Southern California

Origin time: $\quad 200043.0$

Epicenter: $\quad 35.02 \mathrm{~N} ., 119.13 \mathrm{~W}$.

Depth: $\quad 5 \mathrm{~km}$

Magnitude: $\quad 3.4 \mathrm{ML}(\mathrm{P})$

\section{Cal1 fornia--Continued}

Intensity IV: Santa Barbara.

Intensity III: Bakersfield.

7 January (B) Central California

Origin time: $\quad 113732.3$

Epicenter: $\quad 36.10 \mathrm{~N} ., 120.21 \mathrm{~W}$.

Depth: $\quad 4 \mathrm{~km}$

Magnitude: $\quad 3.9 \mathrm{mb}(G), 3.8 \mathrm{ML}(B)$, $3.9 \mathrm{ML}(\mathrm{P})$

Intensity IV: Avenal, Coalinga.

Intensity II: San Joaquin.

11 January (B) Central California

Origin time: $\quad 195726.6$

Epicenter: $\quad 37.00 \mathrm{~N} ., 121.72 \mathrm{~W}$.

Depth: $\quad 9 \mathrm{~km}$

Magnitude: $\quad 3.1 \mathrm{ML}(\mathrm{B})$

Felt at Morgan Hill and Watsonville (B).

11 January (B) Central California

Origin time: 203923.8

Epicenter: $\quad 37.39 \mathrm{~N} ., 121.75 \mathrm{~W}$.

Depth: $\quad 1 \mathrm{~km}$

Magnitude: $\quad 3.6 \mathrm{ML}(\mathrm{B})$

Felt at San Jose and in the Santa Clara Valley (B).

Intensity IV: Blossom Hi11, Cupertino.

Intensity III: Mount Hamilton.

Intensity II: Mission.

13 January (P) Southern California

Origin time: $\quad 110729.4$

Epicenter: $\quad 33.95$ N., $118.68 \mathrm{~W}$.

Depth: $\quad 13 \mathrm{~km}$

Magnitude: $\quad 2.8 \mathrm{ML}(\mathrm{P})$

Felt at Malibu (P).

15 January (P) Southern California

Origin time: $\quad 124118.7$

Epicenter: $\quad 33.97 \mathrm{~N} ., 118.72 \mathrm{~W}$.

Depth: $\quad 10 \mathrm{~km}$

Magnitude: $\quad 3.7 \mathrm{ML}(\mathrm{P})$

Intensity IV: Rancho Park.

Felt: Canoga Park (P), Malibu (P), North Hollywood (P), Pasadena ( $P$ ), Santa Monica (P), Temple City (P), Woodland H11ls ( $P$ ).

19 January (B) Central California

Origin time: 135955.4

Epicenter: $\quad 37.34 \mathrm{~N} ., 121.72 \mathrm{~W}$.

Depth: $\quad 8 \mathrm{~km}$

Magnitude: $\quad 3.1 \mathrm{ML}(\mathrm{B})$

Felt in east San Jose (B).

19 January (B) Owens Valley area Origin time: $\quad 181042.0$ 
Epicenter:

37.55 N., $118.53 \mathrm{~W}$.

Depth:

$9 \mathrm{~km}$

Magni tude:

4.1 ML(B), 4.2 ML(P)

Intensity IV: Benton, Big Creek, Bishop,

Crowley Lake, Crowley Lake Dam, Tom's Place.

Intensity III: Grant Grove.

24 January (B) Owens Valley area

Origin time: 211427.2

Epicenter: $\quad 37.52 \mathrm{~N} ., 118.60 \mathrm{~W}$.

Depth: $\quad 10 \mathrm{~km}$

Nagnitude: $\quad 4.6 \mathrm{ML}(\mathrm{B}), 4.4 \mathrm{ML}(\mathrm{P})$

Intensity IV:

California--Big Pine, Bishop Airport, Crowley Lake, Crowley Lake Dam, E1 Portal, Fresno (Ashlan Park), Groveland, Lake Shore, Lemoncove, Long Barn, Mammoth Lakes, Murphys, Yosemite Lodge. Intensity III:

California-Bass Lake, June Lake, Sultana. Intensity II:

Califurnia--Fresno.

Nevada--Tonopah.

29 January (P) Southern California

Origin time: $\quad 045922.7$

Epicenter: $\quad 33.95 \mathrm{~N} ., 118.67 \mathrm{~W}$.

Depth: $\quad 6 \mathrm{~km}$

Magnitude: $\quad 3.1 \mathrm{ML}(\mathrm{P})$

Felt at Malibu (P).

5 February (B) Northern California

Origin time: 020819.6

Epicenter: $\quad 37.77$ N., 122.17 W.

Depth: $\quad 8 \mathrm{~km}$

Magnitude: $\quad 2.7 \mathrm{ML}(\mathrm{B})$

Felt widely in the East Bay.

Intensity v: East 0akland (few windows broken--press report).

Intensity III: Oakland, San Leandro (press report).

5 February (B) Northern California

Origin time: 072241.3

Epicenter: $\quad 37.32 \mathrm{~N} ., 121.67 \mathrm{~W}$.

Depth: $\quad 8 \mathrm{~km}$

Magni tude : $\quad 3.4 \mathrm{ML}(\mathrm{B})$

Felt at San Jose (B).

12 February (P) Southern California

Origin time: 044842.3

Epicenter: $\quad 33.45$ N., $116.43 \mathrm{~W}$.

Depth: $\quad 4 \mathrm{~km}$

Magnitude: $\quad 4.2 \mathrm{ML}(\mathrm{P})$

This earthquake was felt over an area of approximately $12,300 \mathrm{sq} \mathrm{km}$ of Imperial,
Orange, Riverside, San Bernardino, and San Diego Counties ( $f$ ig. 9).

Intensity $\mathrm{V}$ :

Agua Caliente Springs (small objects fell; hanging objects swung moderately; windows, doors, and dishes rattled).

Palm Desert (report of cracked drywall; hanging pictures swung; windows, doors, and dishes rattled).

Intensity IV: Aguanga, Anza, Boulevard, Desert Hot Springs, E1 Cajon, Fallbrook, Idyllwild, Indio, Jamul, Julian, Luce rne Valley, Mecca, Mount Laguna, Mountain Center, Nestor, Palm Springs, Potrero, Ranchita, Salton City, Santa Ysabel, Santee, Thermal, Valley Center, Warner Springs, Winchester.

Intensity III: Cathedral City, Chula Vista, Coachella, Cuyamaca, Laguna Beach, Lincoln Acres, Lytle Creek, Nuevo, Rancho Del Rey, Riverside.

Intensity II: Escondido, San Diego (P), Santa Ana.

12 February (B) Central California Origin time: 202622.1

Epicenter: $\quad 36.66 \mathrm{~N} ., 121.34 \mathrm{~W}$.

Depth: $\quad 7 \mathrm{~km}$

Magnitude: $\quad 3.6 \mathrm{ML}(\mathrm{B})$

Intensity IV: Hollister, Paicines.

15 February (P) Santa Barbara Channel

Origin time: 030516.6

Epicenter: $\quad 34.27 \mathrm{~N}$., $119.72 \mathrm{~W}$.

Depth:

Magnitude: $\quad 3.5 \mathrm{ML}(\mathrm{P})$

Intensity 1II: Goleta-Santa Barbara area (press report).

15 February (P) Santa Barbara Channel Origin time: $\quad 031932.9$

Epicenter: $\quad 34.27 \mathrm{~N} ., 119.70 \mathrm{~W}$.

Depth: $5 \mathrm{~km}$

Magnitude: $\quad 3.4 \mathrm{ML}(\mathrm{P})$

Intensity III: Goleta-Santa Barbara area (press report).

21 February (B) Central California

Origin time: $\quad 125647.9$

Epicenter: $\quad 37.83 \mathrm{~N} ., 121.77 \mathrm{~W}$.

Depth: $\quad 12 \mathrm{~km}$

Magnitude: $\quad 3.5 \mathrm{ML}(\mathrm{B})$

Intensity IV: Brentwood (Marsh Creek Trailer Park), Clayton, Livermore.

22 February (B) Northern Calffornia Origin time: $\quad 155728.8$

Epicenter: $\quad 40.00 \mathrm{~N} ., 120.09 \mathrm{~W}$.

Depth:

$5 \mathrm{~km}$

Magnitude: $\quad 5.0 \mathrm{mb}(\mathrm{G}), 4.6 \mathrm{MS}(\mathrm{G})$,

$5.3 \mathrm{ML}(\mathrm{B})$ 


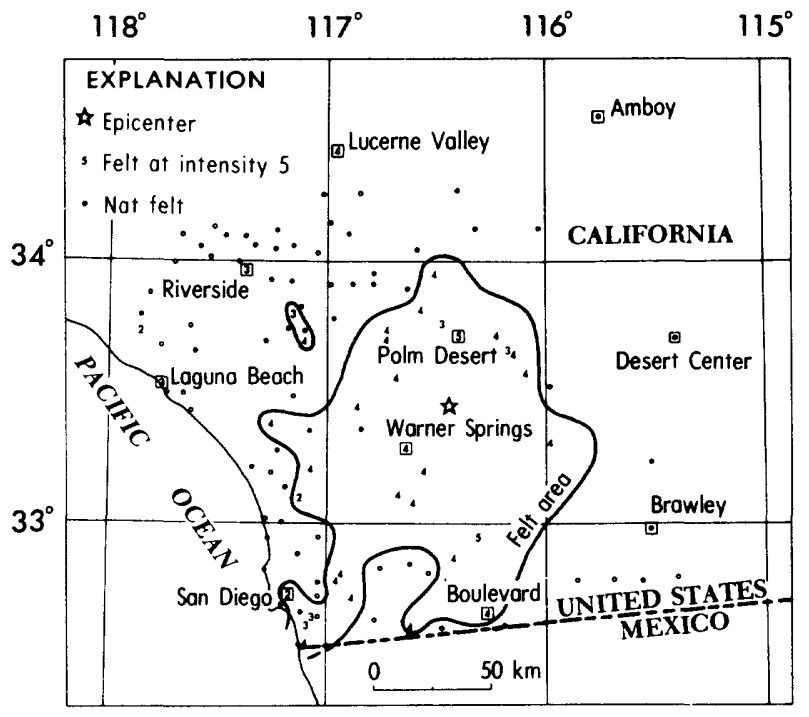

FIGURE 9.--Isoseismal map for the southern California earthquake of 12 February 1979, 044842.3 UTC. Roman numerals represent Modified Mercalli intensities between isoseismals; Arabic numerals are used to represent these intensities at specific sites.

\section{California--Cont inued}

The epicenter was located in the southeast portion of Honey Lake Valley of Lassen County. It was preceded by a foreshock at 071656.1 UTC and followed by aftershocks that lasted until February 23. The largest aftershock occurred on the 23 rd at 03 4052.2 UTC. Bryant (1979) indicates that this region has a history of earthquakes of this magnitude extending back to 1875 . This earthquake caused only minor damage in the epicentral area and disrupted telephone service. It was felt over an area of approximately $46,000 \mathrm{sq} \mathrm{km}$ of California and Nevada (fig. 10).

Intensity VI:

California-Doyle (drywall cracked; desks moved; small objects shifted; hanging pictures swung out of place; windows, doors, and dishes rattled; felt by all). Intensity $\mathrm{V}$ :

Each place listed below reported one or more effects such as small objects or pictures fell, light or heavy furniture moved, hairline cracks in exterior walls:

California--Chilcoot, Clio, Cromberg, Portola, Sattley, Sierraville, Vinton.

Intensity IV:

California--Alleghany, Alta, Arnold,
California--Cont inued

Baxter, Beale AFB, Beckworth, Berry Creek, Blairsden, Calpine, Camino, Camptonville, Chicago Park, Crescent Hills, Dobbins, Downieville, Dutch Flat, Emigrant Gap, Fiddletown, Forbestown, Foresthill, Glencoe, Gold Run, Goodyears Bar, Graeagle, Greenville, Grimes, Grizzly Flats, Herlong, Iowa Hill, Janesville, Keddie, Kyburz, La Porte, Loyalton, Milford, Nevada City, Norden, Oroville, Pollock Pines, $10 \mathrm{~km}$ east of Sheridan, Sierra City, Smithflat, Soda Springs, Spring Garden, Standish, Strawberry Valley, Washington, Weimar, Wendel, Westwood.

Nevada--Carson City, Fernley, Genoa, Gerlach, Incline Village, Nixon, Reno, Silver City, Silver Springs, Sparks, Verdi.

Intensity III:

California--Clipper Mills, Quincy, Robbins, Sacramento, Sheep Ranch, Storrie, Taylorsville, Twin Bridges.

Nevada--French Gulch.

Intensity II:

California-Murphys, Pacific House.

Nevada--Empire, Minden, Wadsworth.

27 February (P) Southern California

Origin time: 070738.6

Epicenter: $\quad 33.95$ N., $118.32 \mathrm{~W}$.

Depth :

Magnitude: $\quad 3.0 \mathrm{ML}(\mathrm{P})$

Intensity IV: El Segundo, Los Angeles.

Intensity III: Southgate.

Felt: Inglewood ( $P$ ), Hawt horne

$(P)$, Lawndale $(P)$, downtown Los Angeles

(P).

27 February (P) Central California Origin time: $\quad 153632.4$

Epicenter: $\quad 36.08 \mathrm{~N} ., 119.95 \mathrm{~W}$.

Depth: $\quad 5 \mathrm{~km}$

Magnitude: $\quad 3.3 \mathrm{ML}(\mathrm{P})$

Intensity IV: Avenal.

1 March (P) Southern California

Origin time: 122603.4

Epicenter: $\quad 34.32$ N., 118.35 W.

Depth: $\quad 5 \mathrm{~km}$

Magnitude: $\quad 2.3 \mathrm{ML}(\mathrm{P})$

Felt at Woodland Hills (P).

5 March (P) Southern California

Origin time: $\quad 104931.0$

Epicenter: $\quad 33.95$ N., 118.70 w.

Depth: $\quad 13 \mathrm{~km}$

Magnitude: $\quad 3.7 \mathrm{ML}(\mathrm{P})$

Felt in the Los Angeles Bas in and at Pasadena (P). Also felt at Malibu and 


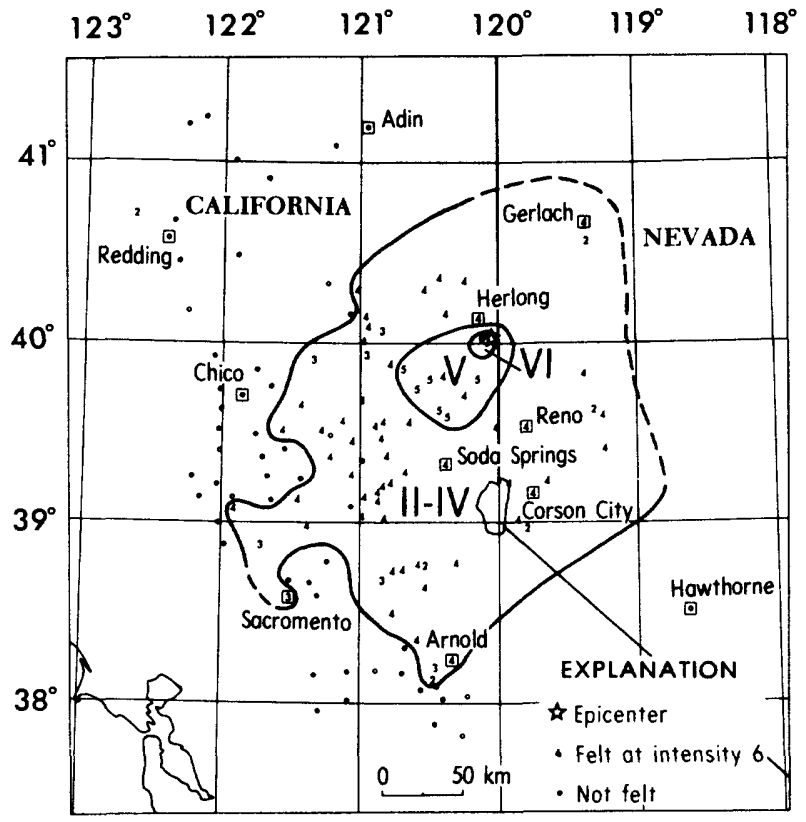

FIGURE 10.--Isoseismal map for the northern California earthquake of 22 February 1979 , 155728.8 UTC. Roman numerals represent Modified Mercalli intensities between isoseismals; Arabic numerals are used to represent these intensities at specific sites.

California--Cont inued

part of the San Fernando Valley (press report).

Intensity IV: Los Angeles.

5 March (P) Southern California

origin time: 121153.0

Epicenter: $\quad 34.37$ N., 119.75 W.

Depth: $\quad 5 \mathrm{~km}$

Magnitude: $\quad 2.8 \mathrm{ML}(\mathrm{P})$

Felt at Santa Barbara (P).

8 March (P) Southern California

Origin time: $\quad 182137.8$

Epicenter: $\quad 34.12 \mathrm{~N} ., 118.33 \mathrm{~W}$.

Depth:

$4 \mathrm{~km}$

Magnitude :

$2.0 \mathrm{ML}(\mathrm{P})$

Felt in the downtown area of Los Angeles (P).

11 March (P) Southern California

Origin time: $\quad 105431.9$

Epicenter: $\quad 33.70$ N., $116.77 \mathrm{~W}$.

Depth: $\quad 5 \mathrm{~km}$

Magnitude: $\quad 3.0 \mathrm{ML}(\mathrm{P})$

Felt at Idy11wild (P).
California--Continued

12 March (B) Central California

origin time: $\quad 120609.6$

Epicenter: $\quad 37.57 \mathrm{~N} ., 121.69 \mathrm{~K}$.

Depth: $\quad 7 \mathrm{~km}$

Magnitude: $\quad 3.2 \mathrm{ML}(\mathrm{B})$

Felt near Pleasanton (B).

15 March (P) Southern California

Origin time: $\quad 201749.8$

Epicenter: $\quad 34.30 \mathrm{~N} ., 116.43 \mathrm{~W}$.

Depth: $\quad 1 \mathrm{~km}$

Magnitude: $\quad 5.0 \mathrm{mb}(\mathrm{G}), 4.9 \mathrm{MS}(\mathrm{G})$,

$5.3 \mathrm{ML}(\mathrm{B}), 4.9 \mathrm{ML}(\mathrm{P})$

This is the first earthquake of a series in this area. It was followed 50 minutes later by a larger event at 210716.5 . The damage and felt data could not be differentiated between the two earthquakes therefore, the data were combined and are 1isted below with the largest magnitude event. The third largest event at 2307 58.4 was felt nearly as strongly as the two earlier earthquakes. Many of the aftershocks were felt in the epicentral area.

Felt in Los Angeles, Orange, Riverside, San Bernardino, and San Diego Counties (P).

15 March (P) Southern California

Origin time: 210716.5

Epicenter: $\quad 34.32$ N., 116.45 W.

Depth:

$1 \mathrm{~km}$

Magnitude: $\quad 5.5 \mathrm{mb}(\mathrm{G}), 5.6 \mathrm{MS}(\mathrm{G})$, $5.7 \mathrm{ML}(\mathrm{B}), 5.2 \mathrm{ML}(\dot{\mathrm{P}})$

This is the largest of a series of earthquakes in this area, the two largest occurring on this date. A surface rupture occurred in the Homestead Valley area (Hawkins and McNey, 1979) along the east bank of Pipes Wash and in three locations west of Pipes Wash fault. The maximum intensity of VII was observed at Landers where electric and telephone services were disrupted for several hours and moderate damage to buildings and their contents was reported (press report). This earthquake was felt over an area of approximately $76,800 \mathrm{sq} \mathrm{km}$ of California, Arizona, and Nevada (fig. 11).

Intensity VII:

\section{California-}

Landers (a chimney was knocked down, walls cracked, many windows broken, dishes and merchandise broken and strewn about throughout the area. The Halliday Liquor Store reported $\$ 1000$ damage to merchandise (press report). Hawkins and McNey (1979) reported that 


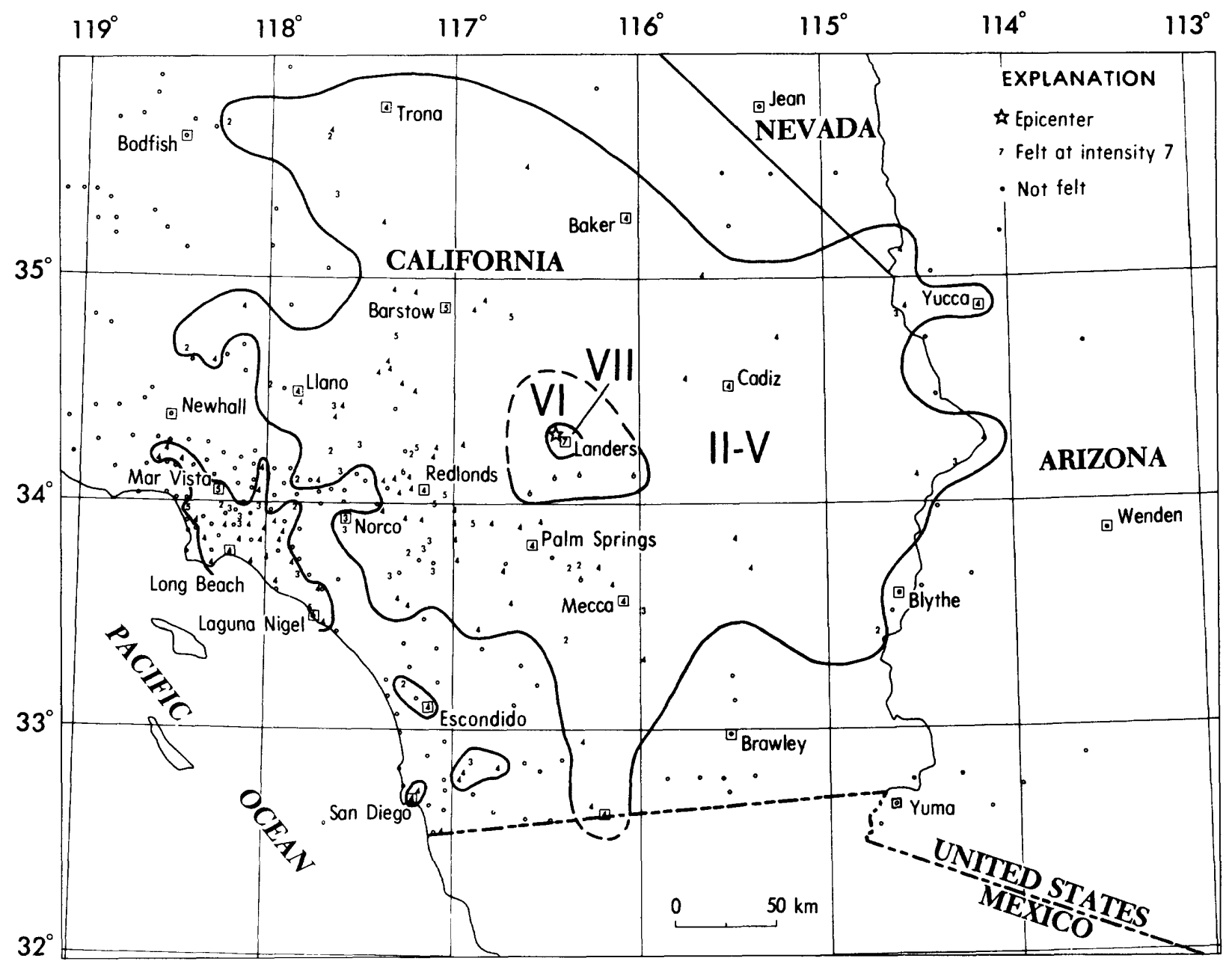

FIGURE 11.--Isoseismal map for the southern Calffornia earthquake of 15 March $1979,210716.5$ UTC. Roman numerals represent Modified Mercalli intensities between isoseismals; Arabic numerals are used to represent these intensities at specific sites.

California--Continued

a Franklin stove moved about $15 \mathrm{~cm}$ southwest and telephone poles moved about $7 \mathrm{~cm}$ northwest. In homes, items were thrown from shelves and cabinets to the floor and were broken.).

Intensity VI:

California--

Del Rosa (plaster cracked in interior walls and hairline cracks in exterior walls, light furniture and small objects shifted, a few windows cracked, water splashed onto sides of pools, felt by many).

Joshua Tree (plaster cracked in interior walls and hairline cracks in exterior walls, small objects shifted, water splashed out of the Joshua Tree Inn's swimming pool, felt by all).

\section{California--Cont inued}

La Quinta (plaster cracked in interior walls, foundation cracked, hairline cracks in exterior walls, felt by many).

Laguna Niguel (plaster cracked and fell on the first and fourth floors of the Laguna Federal Building and a cinder block wall cracked on the first floor, felt by all).

Morongo Valley (plaster cracked in interior walls, hairline cracks in exterior brick walls, small objects shifted, felt by many).

Twentynine Palms (There were several reports of fallen plaster and overturned furniture. At the Marine Corps Station a beam cracked in a building and it was evacuated--press report.). 
Yucca Valley (The press reported the Flamingo Grocery store lost a considerable amount of wine, soft drinks, and various glass items, and Von's Market had $\$ 500$ damage due to broken bottles and jars.).

Intensity $\mathrm{V}$ :

California--Banning, Barstow, Calimesa, Helendale, Laguna Beach, Lake Arrowhead (one report of plaster walls cracked), Mar Vista, Marina Del Rey, Newberry Springs, Yucaipa.

Intensity IV:

Arizona--Bullhead City, Dolan Springs, Mohave Valley, Riviera.

California-Adelanto, Agua Caliente Springs, Aguanga, Alpine, Amboy, Anaheim, Angelus Oaks, Anza, Apple Valley, Arcadia, Argus, Baker, Beaumont, Boulevard, Bryn Mawr, Buena Park, Cabazon, Cadiz, Capistrano Beach, Cherry Valley, China Lake, Claremont, Compton, Costa Mesa, Cypress, Daggett, De1 Rosa (San Bernardino), Desert Center, Eagle Mountain, E1 Cajon, E1 Monte, Escondido (press report), Essex, Fawnskin, Fort Irwin, George AFB, Gilman Hot Springs, Green Valley Lake, Hemet, Highland, Hinkley, Hollywood, Indio, Jacumba, Kelso, La Habra, Laguna Hills, Lakewood, Leona Valley, Lindbergh Field (San Diego), Llano, Loma Linda, Long Beach, Lost Lake, March AFB, Mecca, Mentone, Midway City, Moreno, Morongo Valley, Mountain Center, Murrieta, North Inglewood, North Palm Springs, Northridge, Norton AFB, Norwalk, Oro Grande, Palm Springs, Parker Dam, Phelan, Placentia, Redlands, Reseda, Rialto, Rimforest, Riverside, Rosamond, Running Springs, Salton City, San Bernardino (Downtown, Base Line, Westside), San Diego, San Diego (Naval Hospital), San Jacinto, San Pedro, San Ysidro, Santa Ana, Santee, Sherman Oaks, Sunnymead, Sunset Beach, Surfside, Thermal, Torrance, Trona, University City, Valyermo, Victorville (press report), Vidal, White Water, Wildomar, Wrightwood, Yermo.

Intensity III:

Arizona--Parker.

California--Alta Loma, Bailey, Bell, Bellflower, Corona, Earp, Encanto, Irvine, Johannesburg, Lake Elsinore, Lakeside, Lakeview, Lytle Creek, Maywood, Needles, Norco, North Shore, Nuevo, Oak View, Pinon Hills, Seal Beach, South Downey, Winchester. Nevada--Las Vegas.

Intensity Ir:

California--Arlington, Diamond Bar, Indian Wells, Lake Hughes, Littlerock, Los Angeles, Mt. Baldy, Onyx, Palm City,
Palm Desert, Palo Verde, Perris, Randsburg, Ridgecrest, San Dimas, Twin Peaks, Vista, Whittier.

15 March (P) Southern California

Origin time: 213425.5

Epicenter: $\quad 34.35 \mathrm{~N} ., 116.45 \mathrm{~W}$.

Depth: $\quad 1 \mathrm{~km}$

Magnitude: $\quad 4.5 \mathrm{ML}(\mathrm{P}), 4.3 \mathrm{ML}(\mathrm{B})$

Felt in Los Angeles and San Bernardino Counties.

15 March (P) Southern California

Origin time: 230758.4

Epicenter: $\quad 34.33 \mathrm{~N} ., 116.43 \mathrm{~W}$.

Depth: $\quad 5 \mathrm{~km}$

Magnitude: $\quad 4.5 \mathrm{mb}(G), 4.4 \mathrm{MS}(\mathrm{G})$,

$4.8 \mathrm{ML}(\mathrm{P}), 5.0 \mathrm{ML}(\mathrm{B})$

Felt in Los Angeles, Orange, Riverside, and San Bernardino Counties.

15 March (P) Southern California

Origin time: 231638.1

Eplcenter: $\quad 34.30 \mathrm{~N} ., 116.43 \mathrm{~W}$.

Depth: $\quad 1 \mathrm{~km}$

Magnitude: $\quad 3.9 \mathrm{ML}(\mathrm{P})$

Felt in Los Angeles and San Bernardino Counties.

16 March (P) Southern California

Origin time: 055400.5

Epicenter: $\quad 34.30 \mathrm{~N} ., 116.43 \mathrm{~W}$.

Depth: $\quad 2 \mathrm{~km}$

Magnitude: $\quad 3.7 \mathrm{ML}(\mathrm{P})$

Felt at Landers (P).

16 March (P) Southern California

origin time: 062203.1

Epicenter: $\quad 34.32 \mathrm{~N} ., 116.42 \mathrm{~W}$.

Depth: $\quad 1 \mathrm{~km}$

Magnitude: $\quad 2.4 \mathrm{ML}(\mathrm{P})$

Felt at Landers ( $P$ ).

16 March (P) Southern California

origin time: 064018.8

Epicenter: $\quad 34.32 \mathrm{~N}, 116.42 \mathrm{~W}$.

Depth: $\quad 3 \mathrm{~km}$

Magnitude: $\quad 2.7 \mathrm{ML}(\mathrm{P})$

Felt at Landers ( $P$ ).

16 March (P) Southern California

Origin time: 064246.2

Epicenter: $\quad 34.30$ N., $116.43 \mathrm{~W}$.

Depth: $\quad 2 \mathrm{~km}$

Magnitude: $\quad 3.0 \mathrm{ML}(\mathrm{P})$

Felt at Landers (P). 
Cali fornia--Cont inued

16 March (P) Southern California

Origin time: 070633.0

Epicenter: $\quad 34.30 \mathrm{~N}$., $116.43 \mathrm{~W}$.

Depth: $\quad 1 \mathrm{~km}$

Magnitude: $\quad 2.5 \mathrm{ML}(\mathrm{P})$

Felt at Landers (P).

16 March (P) Southern California

Origin time: $\quad 075209.1$

Epicenter: $\quad 34.32 \mathrm{~N} ., 116.43 \mathrm{~W}$.

Depth: $2 \mathrm{~km}$

Magnitude: $\quad 3.5 \mathrm{ML}(\mathrm{P})$

Felt at Landers and Pasadena (P).

16 March (P) Southern California

Origin time: 093349.6

Epicenter: $\quad 34.32 \mathrm{~N} ., 116.43 \mathrm{~W}$.

Depth: $\quad 1 \mathrm{~km}$

Magnitude: $\quad 2.6 \mathrm{MI}(\mathrm{P})$

Felt at Landers (P).

16 March (P) Southern California

Origin time: 134120.5

Epicenter: $\quad 34.32 \mathrm{~N} ., 116.42 \mathrm{~W}$.

Depth: $\quad 1 \mathrm{~km}$

Magnitude: $\quad 2.8 \mathrm{ML}(\mathrm{P})$

Felt at Landers (P).

16 March (P) Southern California

Origin time: $\quad 141057.5$

Epicenter: $\quad 34.33 \mathrm{~N} ., 116.40 \mathrm{~W}$.

Depth: $\quad 1 \mathrm{~km}$

Magnitude: $\quad 3.2 \mathrm{ML}(\mathrm{P})$

Felt at Landers (P).

16 March (P) Southern California

Origin time: 173659.1

Epicenter: $\quad 34.33 \mathrm{~N} ., 116.40 \mathrm{~W}$.

Depth: $\quad 5 \mathrm{~km}$

Magnitude: $\quad 4.0 \mathrm{ML}(\mathrm{P}), 4.1 \mathrm{ML}(\mathrm{B})$

Felt at Landers (P).

18 March (P) Southern California

Origin time: 225302.6

Epicenter: $\quad 34.22$ N., 116.35 W.

Depth: $\quad 5 \mathrm{~km}$

Magnitude: $\quad 4.2 \mathrm{ML}(\mathrm{P}), 4.1 \mathrm{ML}(\mathrm{B})$

Intensity III: Morongo Valley.

Fe1t: Landers (P), Joshua Tree (P).

26 March (P) Southern California

Origin time: $\quad 150429.0$

Epicenter: $\quad 34.87 \mathrm{~N}$., $120.50 \mathrm{~W}$.

Depth: $\quad 5 \mathrm{~km}$
California--Continued

Magnitude: $\quad 2.8 \mathrm{ML}(\mathrm{P})$

Felt at Santa Maria (press report).

26 March (P) Southern California

Origin time: $\quad 152223.5$

Epicenter: $\quad 34.87 \mathrm{~N} ., 120.50 \mathrm{~W}$.

Depth: $\quad 10 \mathrm{~km}$

Magnitude: $\quad 3.6 \mathrm{ML}(\mathrm{P})$

Intensity IV: Halcyon, Orcutt, Santa María.

31 March (P) Off the Coast of Baja California

Origin time: 213657.0

Epicenter: $\quad 31.80 \mathrm{~N} ., 117.42 \mathrm{~W}$.

Depth: $\quad 5 \mathrm{~km}$

Magnitude: $\quad 4.3 \mathrm{mb}(G), 4.7 \mathrm{ML}(\mathrm{P})$

Intensity IV: Ocean Beach.

Intensity III: San Diego (Lindbergh Field). Intensity II: Escondido, San Diego Naval Air Station, University City.

19 April (P) Southern California

Origin time: 142247.3

Epicenter: $\quad 34.10 \mathrm{~N} ., 118.33 \mathrm{~W}$.

Depth: $\quad 7 \mathrm{~km}$

Magnitude: $\quad 2.5 \mathrm{ML}(\mathrm{P})$

Felt at Alhambra (P).

19 April (P) Southern California

Origin time: 223956.8

Epicenter: $\quad 34.37$ N., $119.73 \mathrm{~W}$.

Depth: $\quad 4 \mathrm{~km}$

Magnitude: $\quad 3.3 \mathrm{ML}(\mathrm{P})$

Intensity III: Santa Barbara (press report).

21 April (P) Southern Caliiornia

Origin time: 060038.3

Epicenter: $\quad 33.78 \mathrm{~N} ., 118.07 \mathrm{~W}$.

Depth: $\quad 5 \mathrm{~km}$

Magnitude: $\quad 3.1 \mathrm{ML}(\mathrm{P})$

Intensity IV: Long Beach.

22 April (B) Central California

Origin time: 062325.2

Epicenter: $\quad 36.83 \mathrm{~N} ., 121.40 \mathrm{~W}$.

Depth: $\quad 10 \mathrm{~km}$

Magnitude: $\quad 3.1 \mathrm{ML}(\mathrm{B})$

Felt at Hollister (B).

28 April (B) Central California

Origin time: $\quad 004444.8$

Epicenter: $\quad 37.65$ N., $122.46 \mathrm{~W}$.

Depth: $\quad 13 \mathrm{~km}$

Magnitude: $\quad 4.4 \mathrm{ML}(\mathrm{B})$

This earthquake knocked out traffic signals 
in western San Francisco and disrupted telephone service. A power pole fell on Market Street. The BART underground transportation system was halted 10 minutes for emergency checks. The press reported cans and boxes tumbled from shelves in some markets in the San Francisco area. It was felt over an area of approximately $6,300 \mathrm{sq} \mathrm{km}$ in the San Francisco Bay area of Central California (fig. 12).

Intensity V:

Daly City (felt strongly in the Westlake District, one person ran out of a restaurant without finishing his food, buildings shook strongly--press report).

Petaluma (few windows cracked, light furniture and small objects moved, hanging pictures swung).

South San Francisco (smal1 objects overturned and broken, hanging pictures fel1, felt by many).

Intensity IV: Alameda (press report), Berkeley (press report), Bolinas, Burlingame (press report), E1 Granada, Emeryville, Fairfax, Forest Knol1s, Half Moon Bay, La Honda, Millbrae, Montara, Novato, Pacifica, Redwood City, Ross, San Anselmo, San Francisco (Embarcadero Center, Mission District), San Francisco International Airport, Sausalito, Woodacre.

Intensity III: Alamo, Albany (press report), Belmont, Benicia, Concord (press report), Danville, El Cerrito, Inverness, Larkspur, Livermore, Marsha11, Mill Va1ley, Moraga, Moss Beach, Nicasio, Dakland, Orinda, Palo Alto, Point Reyes Station, Port Costa, Richmond, San Bruno, San Carlos, San Leandro, San Lorenzo, San Mateo, Stinson Beach, Union City, Vallejo.

Intensity II: San Jose (press report), Santa Rosa (press report).

2 May (P) Imperial Valley

Origin time: 222252.7

Epicenter: $\quad 33.00 \mathrm{~N} ., 115.57 \mathrm{~W}$.

Depth:

$5 \mathrm{~km}$

Magni tude:

$2.9 \mathrm{ML}(\mathrm{P})$

Felt at Brawley (P).

8 May (B) Central California

Origin time: 051107.7

Epicenter: $\quad 37.30 \mathrm{~N} ., 121.68 \mathrm{~W}$.

Depth:

$6 \mathrm{~km}$

Magnitude:

$4.3 \mathrm{mb}(\mathrm{G}), 4.0 \mathrm{MS}(\mathrm{G})$, 4.8 $\mathrm{ML}(\mathrm{B})$

The press reported this earthquake was felt most strongly in east San Jose where pictures fell from walls, one refrigerator

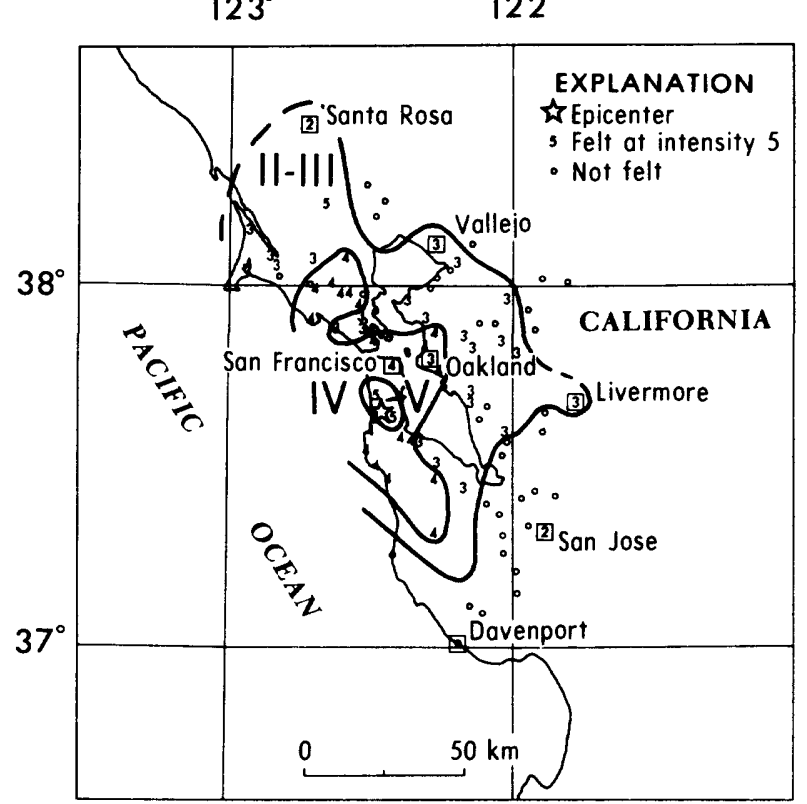

FICURE 12.--Isoseismal map for the central California earthquake of 28 April 1979, 00 4444.8 UTC. Roman numerals represent Modified Mercalli intensities between isoseismals; Arabic numerals are used to represent these intensities at specific sites.

\section{California--Cont inued}

fell over, and objects fell from table tops. It was felt over an area of approximately $9,800 \mathrm{sq} \mathrm{km}$ of the coastal area around San Francisco Bay (fig. 13).

Intensity VI:

East San Jose (cracked plaster on walls, windows broken, hanging pictures fell, one refrigerator fell over, felt by many).

Intensity $\mathrm{V}$ :

Alviso (light and heavy furniture moved; small objects moved; hanging pictures out of place; windows, doors, and dishes rattled).

Larkspur (light furniture and small appliances moved; liquid spilled from small containers; windows, doors, and dishes rattled; felt by many).

Los Gatos (windows broken; small objects moved; hanging pictures out of place; windows, doors, and dishes rattled; felt by many).

Pescadero (light furniture and snall objects moved; hanging pictures out of place; windows, doors, and dishes rattled; felt by many). 


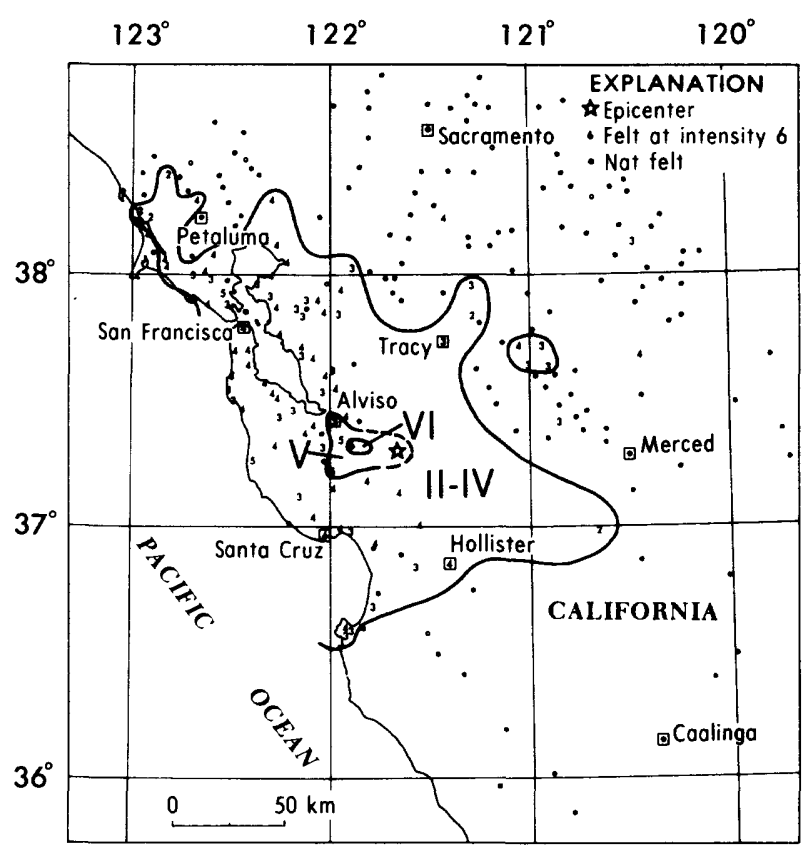

FIGURE 13.--Isoseismal map for the central California earthquake of 8 May 1979, 0511 07.7 UTC. Roman numerals represent Modified Mercalli intensities between isoseismals; Arabic numerals are used to represent these intensities at specific sites.

\section{California--Continued}

Santa Clara (light and heavy furniture or appliances moved; small objects moved; buildings shook strongly; windows, doors, and dishes rattled; felt by many).

Intensity IV: Alameda, Alamo, Belmont, Berkeley, Brisbane, Capitola, Clayton, Crockett, Daly City, El Sobrante, Felton, Freedom, Fremont, Gilroy $(12.8 \mathrm{~km}$ northeast), Half Moon Bay, Hayward, Hollister, Holy City, La Grange, La Honda, Los Altos, Los Osos, Milpitas, Morgan Hill (press report), Mountain View, Mount Hermon, Napa, New Almaden, Novato, Olema, Pacific Grove, Penngrove, Point Reyes Station, Redwood Estates, Ross, Salida, San Carlos, San Francisco, San Jose, San Leandro, San Mateo, Santa Cruz, Sausalito, Soque1, South San Francisco, Stinson Beach, Thornton, Union City, Vallejo, Walnut Creek, Woodacre.

Intensity III: Aptos, Boulder Creek, Cupertino (press report), Diablo, Dillon Beach, El Cerrito, El Granada, Empire, Fairfax, Forest Knolls, Hilmar, Lafayette, Marina, Menlo Park, Mill Valley, Modesto (press report), Montara, Monterey (press report),

\section{California--Cont inued}

Moraga, Murphys, Newark, Orinda, Pacifica, Palo Alto, Pebble Beach, Pittsburg, Redwood City, Richmond, Riverbank, San Juan Bautista, San Lorenzo, Stockton, Tracy. Intensity II: Albany, Dos Palos, Lathrop, Sebastopol, Tomales.

16 May (P) Southern California

Origin time: 032523.6

Epicenter: $\quad 33.85$ N., $118.55 \mathrm{~W}$.

Depth: $\quad 5 \mathrm{~km}$

Magnitude: $\quad 2.7 \mathrm{ML}(\mathrm{P})$

Felt at Redondo Beach (P).

20 May (P) Southern California

Origin time: $\quad 120447.9$

Epicenter: $\quad 34.07$ N., 116.37 W.

Depth: $\quad 5 \mathrm{~km}$

Magnitude: $\quad 3.7 \mathrm{ML}(\mathrm{P})$

Intensity III: Morongo Valley. Felt:

Yucca Valley $(\mathrm{P})$.

21 May (P) Southern California

Origin time: 051904.0

Epicenter: $\quad 34.10 \mathrm{~N} ., 116.37 \mathrm{~W}$.

Depth: $\quad 8 \mathrm{~km}$

Magnitude: $\quad 3.0 \mathrm{ML}(\mathrm{P})$

Intensity III: Morongo Valley.

Felt: Yucca Valley (P).

1 June (B) Central California

Origin time: 235826.3

Epicenter: $\quad 37.87 \mathrm{~N} ., 122.21 \mathrm{~W}$.

Depth: $\quad 10 \mathrm{~km}$

Magnitude: $\quad 2.6 \mathrm{ML}(\mathrm{B})$

Felt on the University of CaliforniaBerkeley campus and in the ConcordPittsburg area (B).

3 June (B) Northern California

Origin time: $\quad 040729.4$

Epicenter: $\quad 40.34 \mathrm{~N}$., $124.23 \mathrm{~W}$.

Depth: $\quad 12 \mathrm{~km}$

Magnitude: $\quad 3.2 \mathrm{ML}(\mathrm{B})$

Intensity III: Rio Dell.

11 June (B) Central California

Origin time: 115156.8

Epicenter: $\quad 37.97$ N., $122.05 \mathrm{~W}$.

Depth:

$12 \mathrm{~km}$

Magnitude: $\quad 2.8 \mathrm{ML}(\mathrm{B})$

Intensity IV: Clayton, Concord, Martinez, Orinda, Walnut Creek.

Intensity III: Pittsburg (press report), Port Costa.

Fe1t:

Berkeley (B), Oakland (B).

13 June (P) Imperial Valley

Origin time: $\quad 070958.1$

Epicenter: $\quad 33.08$ N., $115.62 \mathrm{~W}$. 
Depth: $\quad 6 \mathrm{~km}$

Magnitude: $\quad 3.7 \mathrm{ML}(\mathrm{P})$

Felt at Brawley (P).

13 June (P) Imperial Valley

Origin time: $\quad 194645.9$

Epicenter: $\quad 33.10 \mathrm{~N} ., 115.65 \mathrm{~W}$.

Depth: $\quad 6 \mathrm{~km}$

Magnitude: $\quad 4.1(\mathrm{P})$

This is the largest of a swarm of earthquakes in the Imperial Valley.

Intensity V: Brawley (concrete-slab porch floor cracked, small objects overturned, felt by all).

Intensity IV: Westmorland (felt by all).

Intensity III: Auga Caliente Springs (Canebrake Canyon), Palo Verde.

Intensity II: Aguanga.

13 June (P) Imperial Valley

Origin time: 202111.3

Epicenter: $\quad 33.12 \mathrm{~N} ., 115.62 \mathrm{~W}$.

Depth: $\quad 6 \mathrm{~km}$

Magnitude: $\quad 3.3 \mathrm{ML}(\mathrm{P})$

Felt at Brawley (P).

14 June (P) Central California

Origin time: 073927.9

Epicenter: $\quad 35.72 \mathrm{~N} ., 118.02 \mathrm{~W}$.

Depth: $\quad 5 \mathrm{~km}$

Magnitude: $\quad 4.2 \mathrm{mb}(\mathrm{G}), 4.4 \mathrm{ML}(\mathrm{B})$,

$$
4.6 \mathrm{ML}(\mathrm{P})
$$

Intensity VI: Onyx (large cracks in plaster walls, open cracks in brick fences and walks, small objects moved, a few people awakened, felt by many).

Intensity IV: Inyokern, Lake Isabella, Ridgecrest, Weldon, Wof ford Heights.

Intensity III: Randsburg.

Fe1t: $\quad$ Kernville (P).

16 June (B) Californa-Nevada border region

Origin time:

$2244 \quad 59.5$

Epicenter: $\quad 37.58$ N., $118.92 \mathrm{~W}$.

Depth:

$13 \mathrm{~km}$

Magnitude: $\quad 4.2 \mathrm{ML}(\mathrm{P}), \quad 4.3 \mathrm{ML}(\mathrm{B})$

Intensity IV: Benton, Mammoth Lakes.

Intensity III: Crowley Lake, Mono Hot springs.

17 June (B) Central California

Origin time: 035945.8

Epicenter: $\quad 37.97 \mathrm{~N} ., 122.04 \mathrm{~W}$.

Depth: $\quad 18 \mathrm{~km}$

Magnitude: $\quad 2.7 \mathrm{ML}(\mathrm{B})$

Felt at Concord and Walnut Creek (B).
17 June (B) Central California

Origin time: 040134.9

Epicenter: $\quad 38.10 \mathrm{~N} ., 122.04 \mathrm{~W}$.

Depth: $\quad 16 \mathrm{~km}$

Magnitude: $\quad 2.9 \mathrm{ML}(\mathrm{B}), 3.7 \mathrm{ML}(\mathrm{P})$

Felt at Concord and Walnut Creek (B).

17 June (B) Central California

Origin time: $\quad 180637.7$

Epicenter: $\quad 37.34 \mathrm{~N} ., 119.98 \mathrm{~W}$.

Depth: $\quad 5 \mathrm{~km}$

Magnitude: $\quad 3.1 \mathrm{ML}(\mathrm{B})$

Intensity IV: Mariposa.

20 June (P) Southern California

Origin time: 053035.8

Epicenter: $\quad 34.03 \mathrm{~N} ., 118.35 \mathrm{~W}$.

Depth:

$5 \mathrm{~km}$

Magnitude: $\quad 3.0 \mathrm{ML}(\mathrm{P})$

Felt at Beverly Hills, Compton, and Culver City $(P)$.

Intensity III: Los Angeles area.

22 June (P) Central California Origin time: 065458.4

Epicenter: $\quad 34.95$ N., $120.27 \mathrm{~W}$.

Depth: $\quad 4 \mathrm{~km}$

Magnitude: $\quad 2.5 \mathrm{ML}(\mathrm{P})$

Felt at Santa Maria (P).

26 June (B) Owens Valley

Origin time: $\quad 142855.6$

Epicenter: $\quad 37.52 \mathrm{~N} ., 118.58 \mathrm{~W}$.

Depth: $\quad 10 \mathrm{~km}$

Magnitude: $\quad 3.7 \mathrm{ML}(\mathrm{B}), 3.3 \mathrm{ML}(\mathrm{P})$

Felt north of Bishop (P).

26 June (B) Owens Valley

Origin time: 151358.2

Epicenter: $\quad 37.53 \mathrm{~N} ., 118.58 \mathrm{~W}$.

Depth: $\quad 10 \mathrm{~km}$

Magnitude: $\quad 3.4 \mathrm{ML}(\mathrm{B}), 3.3 \mathrm{ML}(\mathrm{P})$

Felt north of Bishop (P).

29 June (P) Southern California

Origin time: 055320.5

Epicenter: $\quad 34.25 \mathrm{~N} ., 116.90 \mathrm{~W}$.

Depth: $\quad 6 \mathrm{~km}$

Magnitude: $\quad 4.1 \mathrm{mb}(G), 4.5 \mathrm{ML}(\mathrm{P})$

Felt strongly in the Big Bear Lake recreation area. Also felt in the Los Angeles Basin and as far away as Sacramento and San Diego. It was felt over an area of approximately $13,000 \mathrm{sq} \mathrm{km}$ of southern California ( $\mathrm{fig} \cdot 14$ ). 


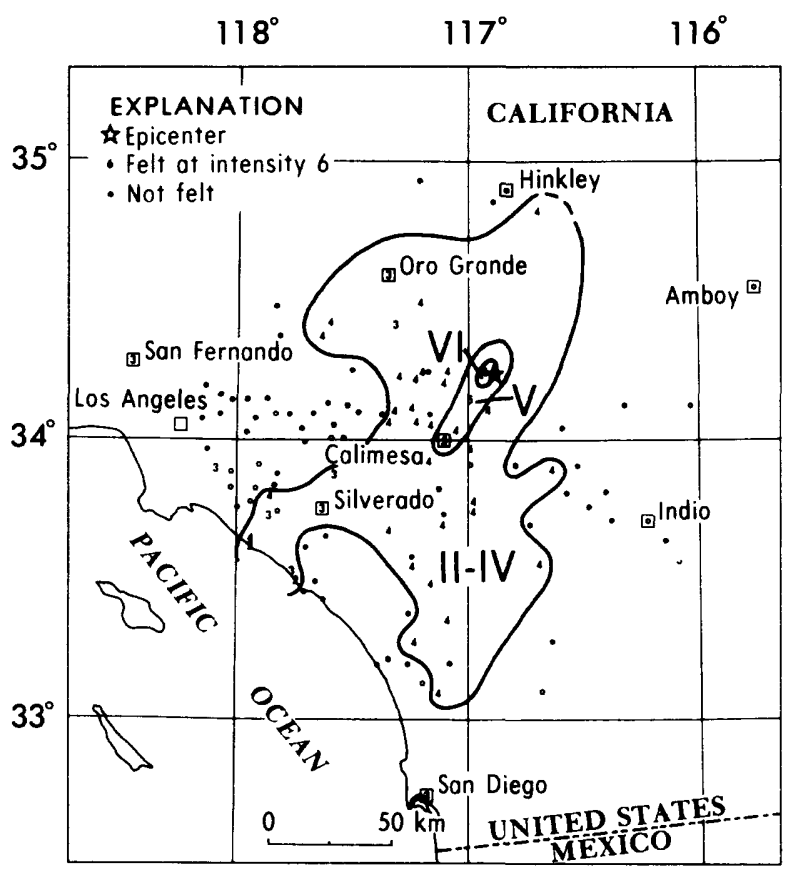

FIGURE 14.--Isoseismal map for the southern California earthquake of 29 June 1979, 05 5320.5 UTC. Roman numerals represent Modified Mercalli intensitles between isoseismals; Arabic numerals are used to represent these intensities at specific sites.

\section{California--Continued}

Intensity VI: Big Bear Lake (several burglar alarms triggered, a plate glass window shattered in a bank--press report, large cracks in plaster, foundation cracked, few windows cracked, liquid spilled from small containers, several awakened, felt by many).

Intensity $\mathrm{V}$ :

Angelus Oaks (light furniture and small objects moved; hanging pictures swung; windows, doors, and dishes rattled; awakened and felt by many).

Calimesa (bricks in chimney loosened, light furniture and small objects moved, few windows cracked, liquid spilled from small containers, awakened and felt by many).

Intensity IV: Anza, Apple Valley, Bonsall, Cherry Valley, Colton, Costa Mesa, Crestline, Escondido, Fawnskin, Forest Falls, Green Valley Lake, Hemet (press report), Highland, Lake Arrowhead, Lake Elsinore, Mentone, Moreno, Murrieta, Newberry Springs, Orange, Pala, Perris, Phelan, Redlands, Running Springs, San Bernardino, San Jacinto, Temecula, Twin Peaks, White Water, Winchester, Wrightwood, Yucaipa.

\section{Calif ornia--Cont inued}

Intensity III: Corona Del Mar, Crest Park, Hesperia, Laguna Beach ( $P)$, Norwalk (P), Oro Grande, Sacramento (press report), San Diego (press report), San Fernando (press report), Santa Ana ( $P)$, Silverado.

Intensity II: Laguna Niguel, Newport Beach.

30 June ( $P$ ) Southern California

Origin time: 003411.6

Epicenter: $\quad 34.25 \mathrm{~N} ., 116.90 \mathrm{~W}$.

Depth: $\quad 10 \mathrm{~km}$

Magnitude: $\quad 4.6 \mathrm{mb}(\mathrm{G}), 4.8 \mathrm{ML}(\mathrm{B})$, $4.9 \mathrm{ML}(\mathrm{P})$

This is the largest of a series of earthquakes in the Big Bear Lake area. It caused minor damage on the south shore of the lake and was felt over an area of approximately $20,300 \mathrm{sq} \mathrm{km}$ of southern California (fig. 15).

Intensity VI:

Big Bear City (walls were cracked, several windows broken, mirrors fell from walls and broke, large section of acoustictile ceiling in the sheriff's station shook down).

Sugarloaf (bricks loosened on chimneys, ceiling tile cracked, foundation cracked, light and heavy furniture moved, small objects overturned and broken, few windows cracked, felt by all).

Intensity $\mathrm{V}$ :

Angelus Oaks (small landslides, standing vehicles rocked moderately, light furniture and small objects moved, few windows cracked, liquid spilled from small containers, felt by many).

Calimesa (few windows cracked, small objects moved, hanging pictures swung, felt by many).

Fawnskin (light furniture or small appliances moved, small objects overturned or broken, few windows cracked, liquid spilled from small containers, felt by many).

Forest Falls (small landslides, light furniture and small objects moved, standing and moving vehicles rocked slightly, hanging pictures out of place, felt by a11).

Westside, San Bernardino (bricks loosened in chimney, few windows cracked, hanging pictures swung, felt by many).

Intensity IV: Adelanto, Anza, Beaumont, Cabazon, Colton, Crest Park, Crestline, Cucamonga, E1 Cajon, Esc ondido, Fallbrook, Green Valley Lake, Hesperia, Highland, Indio, Lake Arrowhead, Lakeside, Loma Linda, Long Beach, Lytle Creek, Mead Valley, Murrieta, Norco, North Palm Springs, 


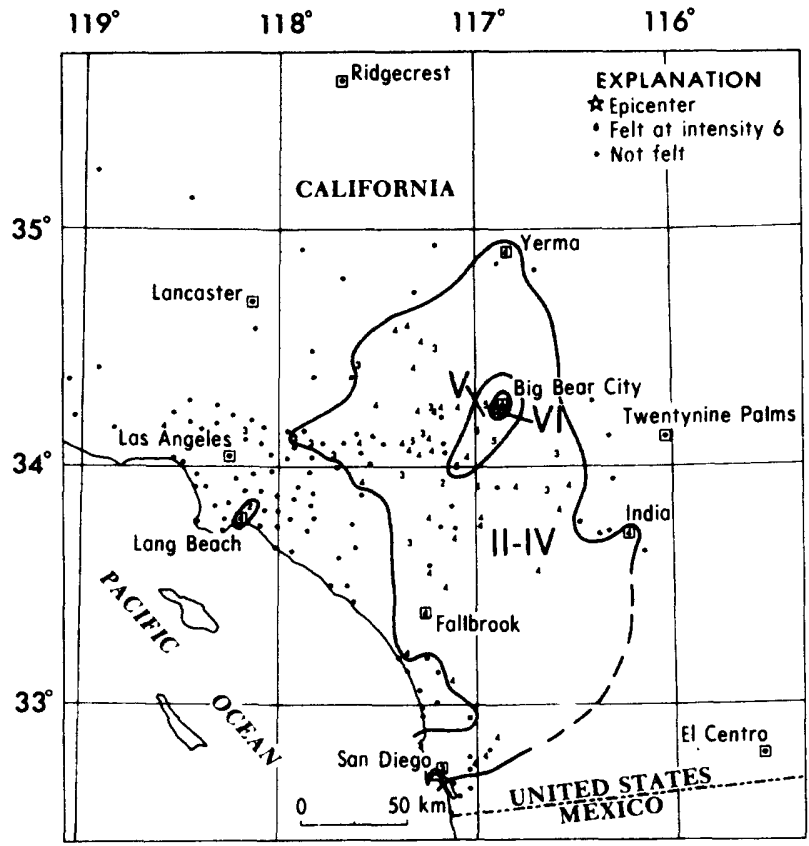

FIGURE 15.--Isoseismal map for the southern California earthquake of 30 June 1979, 00 $34 \quad 11.6$ UTC. Roman numerals represent Modified Mercalli intensities between isoseismals; Arabic numerals are used to represent these intensities at specific sites.

\section{California-Cont inued}

Oro Grande, Palm Springs, Palm Springs (Smoke Tree), Perris, Redlands, Rialto, San Bernardino, San Jacinto, San Luis Rey, Skyforest, Spring Valley, Temecula, Twin Peaks, Victorville (press report), Winchester, Woodland Hills, Yale, Yermo, Yucaipa.

Intensity III: Apple Valley, Azusa (P), Blue Jay, Cedar Glen, Del Rosa, La Jolla (press report), Lake Elsinore, Morongo Valley, Norton AFB, Pasadena (P), Patton, Phelan, Pomona, San Diego (press report), San Dimas, White Water, Riverside (Magnolia Center).

Intensity II: Lakewood, Moreno.

30 June (P) Southern California

Origin time: 070352.9

Epicenter: $\quad 34.25 \mathrm{~N} ., 116.90 \mathrm{~W}$.

Depth:

$10 \mathrm{~km}$

Magnitude: $\quad 4.0 \mathrm{mb}(G), 4.4 \mathrm{ML}(\mathrm{P})$

This earthquake is one of a series in the Big Bear Lake area beginning on June 29.

Felt at Redlands, San Bernardino, and Pasadena ( $P$ ).

\section{California--Cont inued}

1 July (P) Southern California

Origin time: 092928.0

Epicenter: $\quad 34.22 \mathrm{~N} ., 116.92 \mathrm{~W}$.

Depth: $\quad 6 \mathrm{~km}$

Magnitude: $\quad 3.2 \mathrm{ML}(\mathrm{P})$

Felt at Big Bear (P).

2 July (P) Southern California

Origin time: 065140.7

Epicenter: $\quad 34.05 \mathrm{~N} ., 117.55 \mathrm{~W}$.

Depth: $\quad 14 \mathrm{~km}$

Magnitude: $\quad 2.5 \mathrm{ML}(\mathrm{P})$

Felt at Riverside (P).

2 July (P) Southern California

Origin time: 115155.2

Epicenter: $\quad 33.50 \mathrm{~N} ., 116.49 \mathrm{~W}$.

Depth: $\quad 16 \mathrm{~km}$

Magnitude: $\quad 3.7 \mathrm{ML}(\mathrm{P})$

Felt at Anza-Borrego Desert State Park, Borrego Springs, Coachella (P), Indio (P), Palm Springs, San Diego, and other areas of San Diego County. No damage was reported (press report).

2 July (P) Southern California

Origin time: 124237.0

Epicenter: $\quad 33.52 \mathrm{~N} ., 116.49 \mathrm{~W}$.

Depth:

$17 \mathrm{~km}$

Magnitude: $\quad 3.6 \mathrm{ML}(\mathrm{P})$

Felt at Anza-Borrego Desert State Park, Borrego Springs, Coachella (P), Indio (P), San Diego, and other areas of San Diego County. No damage was reported (press report).

3 July (P) Southern California

Origin time: $\quad 130301.3$

Epicenter: $\quad 34.38 \mathrm{~N} ., 119.78 \mathrm{~W}$.

Depth: $\quad 4 \mathrm{~km}$

Magnitude: $\quad 3.0 \mathrm{ML}(\mathrm{P})$

Intensity III: Santa Barbara (press report).

3 July (B) Central California

Origin time: 132545.5

Epicenter: $\quad 37.60 \mathrm{~N} ., 121.98 \mathrm{~W}$.

Depth: $\quad 8 \mathrm{~km}$

Magnitude: $\quad 3.4 \mathrm{ML}(\mathrm{B})$

Intensity IV: Hayward, Mount Eden, Sunol.

Intensity III: Fremont, La Honda, Newark,

San Francisco (press report), San Leandro. Intensity II: San Lorenzo. Felt: Oakland (B).

3 July (P) Southern California Origin time: 133504.3 


\section{California--Cont inued}

Epicenter:

Depth:

Magnitude :

$34.37 \mathrm{~N} ., 119.78 \mathrm{~W}$.

$3.3 \mathrm{ML}(\mathrm{P})$

Intensity III: Goleta, Santa Barbara (press report).

$4 \mathrm{~km}$
10 July (B) Central California

Epicenter: $\quad 37.86 \mathrm{~N} ., 121.98 \mathrm{~W}$.

Depth: $\quad 17 \mathrm{~km}$

Magnitude: $\quad 3.7 \mathrm{ML}(\mathrm{B})$

Intensity V: Diablo (few windows cracked, hanging pictures out of place, and small objects moved), Danville (felt by all, many awakened, sidewalks slightly cracked).

Intensity IV: Alamo, Antioch, Clayton, Martinez, Pittsburg, Pleasant Hill, San Leandro, San Ramon.

Felt: $\quad$ Berkeley (B), Concord (B), Livermore (B), Moraga (B), Oakland (B), Walnut Creek (B).

13 July (P) Southern California

Origin time: 022603.4

Epicenter: $\quad 34.27 \mathrm{~N} ., 116.43 \mathrm{~W}$.

Depth: $\quad 5 \mathrm{~km}$

Magnitude: $\quad 4.0 \mathrm{ML}(\mathrm{P})$

Intensity IV: Morongo Valley, San Bernardino.

Intensity III: Jooshua Tree, Lake Elsinore, Twentynine Palms, Yucca Valley.

Intensity II: Indio.

13 July (P) Southern Californla

Origin time: 035123.5

Epicenter: $\quad 34.27 \mathrm{~N} ., 116.43 \mathrm{~W}$.

Depth: $\quad 5 \mathrm{~km}$

Magnitude: $\quad 4.2 \mathrm{mb}, 3.9 \mathrm{ML}(\mathrm{P})$

Intensity III: Joshua Tree (press report), Twentynine Palms (press report), Yucca Valley (press report).

Felt: San Bernardino (P).

13 July (B) Central California

Origin time: $\quad 105738.2$

Epicenter: $\quad 37.57$ N., 122.39 W.

Depth: $\quad 6 \mathrm{~km}$

Magnitude: $\quad 2.2 \mathrm{ML}(\mathrm{B})$

Felt at Burlingame, Hillsborough, and San Mateo (B).

27 July (B) Owens Valley Area

origin time: 232308.0

Epicenter: $\quad 37.63 \mathrm{~N} ., 118.92 \mathrm{~W}$.

Depth: $\quad 10 \mathrm{~km}$

Magnitude: $\quad 3.2 \mathrm{ML}(\mathrm{B}), 3.4 \mathrm{ML}(\mathrm{P})$

Felt in the Mammoth Lakes area (B).

\section{California--Continued}

31 July (P) Southern California

origin time: 125111.9

Epicenter: $\quad 33.83 \mathrm{~N} ., 118.10 \mathrm{~W}$.

Depth:

$7 \mathrm{~km}$

Magnitude:

$2.7 \mathrm{ML}(\mathrm{P})$

Felt in the Los Angeles area. Thousands of southeast residents were awakened (press report).

Intensity IV: Bellflower, Long Beach.

2 August (G) Northern California

Origin time: 121845.4

Epicenter: $\quad 40.17 \mathrm{~N} ., 123.98 \mathrm{~W}$.

Depth: $\quad 5 \mathrm{~km}$

Magnitude: $\quad 3.5 \mathrm{ML}(\mathrm{B})$

Intensity III: Rio Dell.

2 August (B) Central California

Origin time: 204135.5

Epicenter: $\quad 36.78 \mathrm{~N}, 121.57 \mathrm{~W}$.

Depth: $\quad 3 \mathrm{~km}$

Magnitude: $\quad 3.1 \mathrm{ML}(\mathrm{B})$

Intensity III: Hollister (press report), San Juan Bautista (B).

2 August (B) Central California

Origin time: 214316.3

Epicenter: $\quad 36.78 \mathrm{~N} ., 121.57 \mathrm{~W}$.

Depth: $\quad 3 \mathrm{~km}$

Magnitude: $\quad 3.9 \mathrm{ML}(\mathrm{B})$

In Hollister, the press reported a few boxes of rice fell at the Gonzalez Market and some rolls of tissue fell to the floor at the Nob Hill Market. No damage reported.

Intensity IV: Hollister, San Juan Bautista.

Felt: $\quad$ Carmel (B), Monterey (B), North of Morgan Hill (B), Pacific Grove (B).

6 August (P) Southern California

Origin time: 070315.5

Epicenter: $\quad 33.87 \mathrm{~N} ., 118.08 \mathrm{~W}$.

Depth: $\quad 3 \mathrm{~km}$

Magnitude: $\quad 2.0 \mathrm{ML}(\mathrm{P})$

Felt at Los Angeles.

6 August (B) Central California

Origin time: $\quad 170522.7$

Epicenter: $\quad 37.10 \mathrm{~N} ., 121.50 \mathrm{~W}$.

Depth:

$6 \mathrm{~km}$

Magnitude: $\quad 5.4 \mathrm{mb}(\mathrm{G}), 5.7 \mathrm{MS}(\mathrm{G})$, $5.9 \mathrm{ML}(\mathrm{B})$

This earthquake, the Coyote Lake earthquake, was generally felt over an area of approximately $63,200 \mathrm{sq} \mathrm{km}$ from about $60 \mathrm{~km}$ 
north of Bakersfield, north to Sacramento, east to the Reno-Lake Tahoe area, and westward to the Pacific Ocean (fig. 16). There were no fatalities but 16 injuries were reported by the press in Hollister and Gilroy. Most injuries were caused by flying glass. There were also unconfirmed reports of heart attacks. Damage in Gilroy and Hollister was estimated at $\$ 500,000$ (press report). The damage consisted mainly of broken store windows, broken glassware in grocery and 1 iquor stores, some damaged chimneys, and some structural damage to five buildings in Gilroy. Ground displacement was observed along the Calaveras fault zone from Hollister northward to the area of Anderson Lake, a distance of $39 \mathrm{~km}$ (Armstrong, 1979). The maximum horizontal displacement observed on August 6 was $5-6 \mathrm{~mm}$ located about $10 \mathrm{~km}$ east of Gilroy where the Calaveras fault zone intersects Highway 152. Continued movement along the fault zone was observed in the days following the main shock. Ground lurching, settlement, and slumping as a result of the ground shaking was observed at many locations between Anderson Lake and Hol1ister (Armstrong, 1979).

Uhrhammer (1980) located 31 aftershocks (2.4<ML<4.4) during August 1979, most of which were located south of the main shock with a concentration of epicenters about $10 \mathrm{~km}$ south on the Calaveras fault zone.

A11 accelerographs within a radius of approximately $40 \mathrm{~km}$ from the epicenter were triggered along with some at greater distances (Porcella, 1980). The maximum acceleration of $0.44 \mathrm{~g}$ was recorded on the instrument at the San Ysidro School in Gilroy located about $9 \mathrm{~km}$ south of the main shock. A much lower acceleration of $0.23 \mathrm{~g}$ was recorded near the epicenter on the Coyote Creek accelerograph. The intensities were also lower on the west side of Coyote Lake which is much nearer the epicenter than Gilroy or Hollister. The maximum intensity determined for the Coyote Lake area appears to be about V along the west shore.

Intensity VII:

California=-

Casa de Fruta--At the Shell service station, located about $3.2 \mathrm{~km}$ ( $2 \mathrm{mi}$ ) northeast of the junction of Highways 152 and 156, there was extensive damage to the building's inside and outside walls and roof. Bricks fell from the chimney, exterior walls bulged outward, interior walls separated from the ceiling or floors, ceiling tiles fell, hanging pictures fell, small objects and merchandise overturned and broke.

Gilroy--Five buildings reported some structural damage. Fords Department store, which had damage in the second floor to beams and uprights, was deemed unsafe and closed. Also on the second floor of the Ford building there were numerous cracks in plaster walls and much china and crystal glassware smashed to the floor. There were many reports of cracks in the exterior of office buildings in Gilroy. At the San Martin vineyards wine tasting room, adobe walls cracked and stacks of wine cases came tumbling down. Many chimneys were damaged, mostly in 75-year-old or older homes near the downtown area. A new crack split a wall in the City Hall buildings and a ceiling in a court ruom of the Municipal Courthouse caved in. Most of the damage in stores, bars, and homes came when dishes, bottles, and goods were thrown of $f$ shelves and out of cupboards. Supermarkets especlally, had their shelves virtually emptied in some areas of town. Sparks from three PG\&E gas lines that were snapped started grass fires. Motorists on Highway 101 overpasses reported being tossed from lane to lane as the quake swayed the support pillars (press reports).

Hollister--A runway was reported cracked at Hollister airport. A roof caved in at the Walker and Lee Real Estate office when a $136 \mathrm{~kg}$ ( $3001 \mathrm{~h})$ parapet toppled. The quake knocked a $3 \mathrm{~m}$ (10 $f t)$ hole in the plaster ceiling of the $\mathrm{J}$. C. Penney building and there were extensive cracks in the ceiling throughout the store. The ceiling partly collapsed at the new Employment Development Department building on San Felipe Road. The walls of the Hollister Travel Service were also cracked. At Northern California Savings extremely heavy files of safety deposit boxes were moved several inches. At a Texaco distribution plant an empty 11,360 1iter ( 3000 gallon) gasoline tank was rolled around. A nearly life-size statue toppled inside Sacred Heart Church. The San Benito County Library was closed temporarily after book stacks were tilted dangerously and books were strewn all over the floor. Grocery and liquor stores suffered much damage. The Gonzalez Market (1280 San Juan Highway) had a 


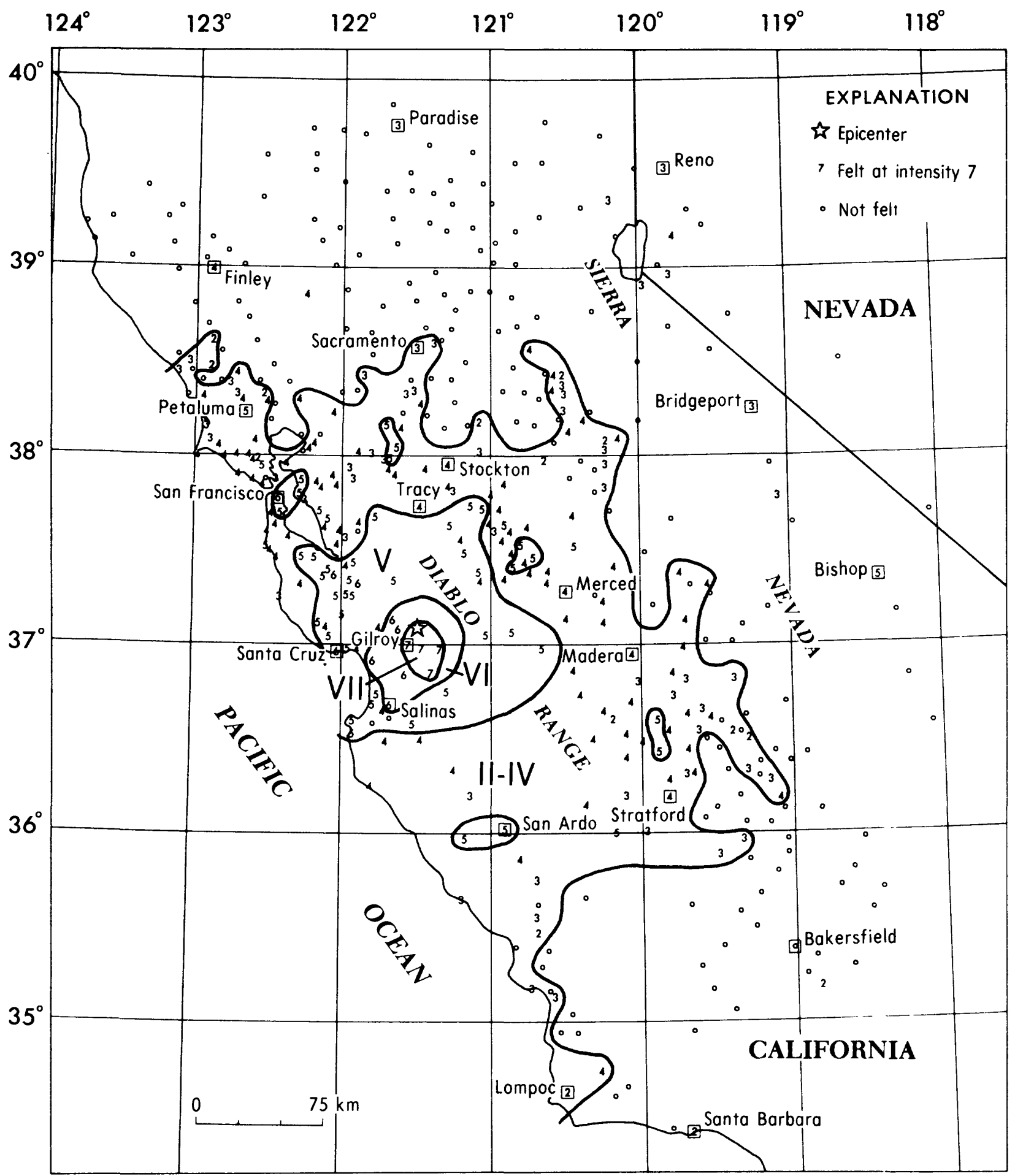

FIGURE 16.--Isoseismal map for the central California earthquake of 6 August $1979,170522.7$ UTC. Roman numerals represent Modified Mercalli intensities between isoseismals; Arabic numerals are used to represent these intensities at specific sites. 
gaping hole in the ceiling where a light fixture had ripped loose and the aisles were filled with toppled bottles, cans, and cartons. Gonzalez Liquors next door estimated $\$ 15,000-$ 20,000 loss due to smashed bottles that filled the aisles with shattered glass. A home located at 1181 South Street reported a hutch filled with dishes was toppled to the floor, paintings were ripped off the walls, and a dresser overturned. There was considerable roof and wall damage at the testing ruom of the Almaden Vineyard on Pacheco Pass Highway and much of its stock of wine crashed to the floor. The power 1 ines were down in the downtown area, and 600 customers were temporarily without electricity. There were also unconfirmed reports of broken water lines in the downtown area. No apparent damage was reported to any of the dams and reservoirs in the area (press reports).

Pacheco Pass--At the state fire station, about $16 \mathrm{~km}$ (10 mi) northeast of Hollister, the lids of the toilet tanks were thrown off and crashed to the floor, pictures fell of $f$ the walls, and a $45 \mathrm{~kg}$ (100 lb) filing cabinet bounced $0.3 \mathrm{~m}$ ( $1 \mathrm{ft}$ ) from the wall. The Pacheco Peak lookout station near the firehouse suffered some structural damage and was vacated. The fire station was reported to have suffered extensive damage (press report).

\section{Intensity VI:}

\section{California--}

Milpitas--large cracks in plaster walls, trees and bushes shook strongly, standing vehicles rocked moderately, buildings shook strongly.

Morgan Hill--cracks in interior walls and dry wall, plaster fell, light and heavy furniture moved, small objects overturned and some fell, buildings shook strongly, felt by all.

Salinas--There were reports of cracked foundations of reinforced concrete, cracks in exterior brick walls, large cracks in interior dry wall and plaster walls, light and heavy furniture moved, some windows cracked and broke, pictures out of place and some fell, felt by all. The press reported that many items were thrown from shelves and there was much broken glassware at the Mid-Town Market.

San Francisco--The press reported two $0.9-\mathrm{m}$ ( $3 \mathrm{ft}$ ) long cracks in the exterior brick work of the Adams Grant Building at 114 Sansome Street. At 40 Westwood Drive the walls were cracked throughout a house, one crack penetrated completely through both sides of the wall. Scores of people ran out of the San Francisco City Hall where plaster was shaken loose from a hallway ceiling on the second floor. Birds were knocked from their roof-top perches, tall buildings were rocked so strongly that people crawled under desks for protection, and cars in the streets were shaken.

San Juan Batista--The north wall of Mission San Juan Bautista cracked and plaster fell. In the mission gift shop, figurines crashed to the floor. At San Juan Bautista State Hjstoric Park walls of several buildings were cracked and plaster fell. In city shops there were reports of objects falling from shelves and plaster falling from ceilings (press reports). Bricks of chimneys were loosened, light and heavy furniture moved, small objects were overturned and some broke, a few windows cracked, hanging pictures out of place, felt by and frightened a11.

San Martin--Some windows and underground pipes broke, heavy furniture moved, light furniture overturned and damaged, small objects overturned and broke, hanging pictures fell, water splashed onto sides of pools, felt by and frightened all.

Santa Cruz-The press reported an apartment building had large cracks and bowed walls, windows were broken throughout Santa Cruz County, and the Santa Cruz County Center had its support beams slightly separated in some rooms.

Sunnyvale--At 1188 Bardeaux Drive a one-story office building of prestressed concrete walls and floor had several cracks in the exterior walls, the doors were put ajar, a $90 \mathrm{~kg}(200$ 1b) drafting table moved, and the suspended ceiling buckled.

Watsonville--There were reports of cracked chimneys, hairline cracks in exterior walls, interior walls separated from the ceiling or floor, light furniture moved, few windows cracked, small objects overturned and broke, felt by many. The police department reported that some older buildings suffered wall and roof cracks (press report).

Intensity $\mathrm{V}$ :

\section{California-}

Avenal--light furniture or small appliances moved, small objects moved, felt by many. 
Ba11ico--1ight and heavy furniture moved, water splashed onto sides of swimming pools, hanging pictures swung, felt by many.

Berkeley--light furniture or small appliances moved, felt by many.

Bethel Island--light furniture or small appliances moved, small objects overturned, hanging pictures out of place, felt by many.

Bishop--few windows cracked, windows, doors, and dishes rattled, felt by many.

Blossom Hill--light and heavy furniture moved, small objects moved, 1 iquid spilled from small containers, hanging pictures out of place, felt by many.

Boulder Creek--light and heavy furniture moved, water splashed onto sides of swimming pools, small objects moved, few windows cracked, hanging pictures fell, felt by many.

Brisbane--light furniture and small objects moved, trees and bushes shook moderately, buildings shook strong1y, felt by many.

Cambrian Park (San Jose)--unconfirmed report of some windows broken, hanging pictures swung, felt by all.

Campbe11--light furniture mover, small objects broke, hanging pictures out of place, buildings shook strongly, felt by many.

Capitola--light furniture and small objects moved, liquid spilled from containers, hangings pictures out of place, building shook strongly, felt by many.

Castroville--small objects overturned, trees and bushes shook moderately, hanging pictures swung, felt by all.

Chular--heavy furniture and small objects moved, hanging objects swung violently, buildings shook strongly, felt by all.

Crows Landing--1ight and heavy furniture moved, small objects moved, hanging objects swung violently, water splashed onto sides of swimming pools, felt by all.

Denair--1ight furniture and small objects moved, water splashed onto sides of swimming pools, felt by many.

Dos Palos--1ight furniture and small objects moved, few windows cracked, liquid spilled from small containers, hanging pictures fell, felt by all.

Empire--1ight furniture moved, few windows cracked, water splashed onto sides of swimming pools, hanging pictures out of place, felt by many.

Gustine--few windows cracked, light furniture and small objects moved, water splashed onto sides of swimming pools, felt by rany.

Hayward--light and heavy furniture moved, small objects moved, hanging pictures swung, buildings shook strongly, trees and bushes shook moderately, felt by many.

Hilmar--light furniture and small objects moved, water splashed onto sides of swimming pools, hanging pictures swung, felt by many.

Jolon--light furniture and small objects moved, hanging pictures swung, felt by many.

Knightson--light furniture and small. objects moved, hanging pictures swung, felt by several.

Laure1--furniture shifted, small objects fell, hanging objects swung moderately.

Livermore--light furniture and small objects moved, few windows cracked, hanging pictures swung, felt by all.

Los Altos--1ight furniture and small objects moved, hanging pictures swung, felt by all.

Los Banos--some goods fell from grocery shelves, few windows cracked, light furniture moved, hanging pictures out of place, felt by many.

Los Gatos--1ight furniture and small objects moved, hanging pictures swung, felt by many.

Marina--1ight furniture and small appliances moved, hanging pictures out of place, standing vehicles rocked moderately, felt by many.

Menlo Park-few windows cracked, buildings creaked, trees and bushes shook moderately, felt by many.

Moss Beach--1ight furniture and small objects moved, hanging pictures swung, felt by many.

Mount Hamilton--1ight furniture and small objects moved, hanging pictures out of place, buildings shook strongly, one report of a cracked foundation, felt by many.

Mount Herman--hanging objects swung violently, trees and bushes shook strongly, water splashed onto sides of swimming pools, buildings shook strongly, felt by many.

Mountain View--1ight furniture damaged, small objects moved, pendulum clocks stopped, felt by many.

Pacific Grove--few windows cracked, hanging pictures out of place, water splashed onto sides of swimming pools, felt by many.

Pebble Beach--1ight furniture and small objects moved, few windows cracked, water splashed onto sides of swimming 
pools, felt by many.

Oakland--furniture moved, ceiling tiles cracked, telephone service interrupted, buildings swayed, felt by many.

Paicines--1ight and heavy furniture moved, small objects moved, trees and bushes shook moderately, felt by all.

Patterson--light furniture and small objects moved, hanging objects swung moderately, felt by many.

Petaluma--few windows cracked, light furniture and small objects moved, water splashed onto sides of swimming pools, felt by many.

Raisin--1ight furniture and small objects moved, hanging pictures swung, felt by several.

Redwood City--few wi ndows cracked, one report of cracked plaster, light furniture and small objects moved, water splashed onto sides of swimming pools, felt by many, people ran into the street.

Redwood Estates--hanging objects swung violently, water splashed onto sides of swimming pools, trees and bushes shook moderately, buildings shook strongly, felt by all.

Rio Vista--1ight furniture and small objects moved, hanging pictures out of place, felt by many.

Ripon--light furniture moved, small objects overturned, few windows cracked, underground pipes broke, hanging objects swung violently, felt by many.

Riverdale-light furniture and small objects moved, trees and bushes shook moderately, hanging pictures swung, felt by many.

Ross--hanging pictures fell, small objects moved, buildings shook strongly, felt by several.

Salida--light furniture and small objects moved, hanging pictures out of place, felt by many.

San Ardo--few windows cracked, small objects moved, hanging pictures swung, felt by many.

San Francisco International Airport--few windows cracked, hanging objects swung violently, buildings shook strongly, felt by all.

San Jose--There were reports of light and heavy furniture moved, small objects moved, buildings shook strongly, and felt by all. The press described the shaking as violent and a police dispatcher said his room moved 4 or $5 \mathrm{in}$. $(10-13 \mathrm{~cm})$ up and down.
San Leandro--small objects broke, hanging objects swung moderately, felt hy many.

Santa Clara--few windows cracked, small objects moved, buildings shook strongly, felt by many.

Saratoga--There were reports of 1 ight furniture moved and hanging pictures swung. The postmaster described it as a "very good shake" that moved the whole Post office building back and forth.

Snelling--light furniture and small objects moved, hanging pictures swung, buildings shook strongly, felt by all.

South Dos Palos--cracks in interior walls, small objects moved, buildings shook strongly, felt by all.

Vernalis--few windows cracked, small objects moved, water splashed onto sides of swimming pools, felt by many. Intensity IV:

California--Ahwanee, Alamo, Alviso, Aptos, Atwater, Bass Lake, Ben Lomond, Benicia, Big Sur, Bolinas, Bradley, Brentwood, Brookdale, Burlingame, Burrel, Byron, Cantua Creek, Carme1, Carmel Valley, Caruthers, Castro Valley, Catheys Valley, Chowchilla, Coalinga, Crockett, Daly City, Danville, Davenport, Delhi, E1 Cranada, E1 Nido, E1 Verano, Escalon, Fairfax, Fairfield, Farmington, Felton, Finley, Firebaugh, Five Points, Forest Knolls, Fort ord, Fowler, Fresno, Friant, Glencoe, Gonzales, Greenfield, Half Moon Bay, Hanford, Hathaway Pines, Helm, Hernandez, Hickman, Holt, Holy City, llughson, Isleton, Keyes, La Grange, La Honda, Lagunitas, Layton, Le Grand, Lemoore NAS, Limington, Lindsay, Livingston, Long Barn, Los Alamos, Madera, Mendota, Merced, Modesto, Monte Sereno, Monterey, Moraga, Mt. Aukum, Mount Eden, Murphys, Myers Flat, New Almaden, Newa rk, Newman, Novato, Olema, O'Neals, Orinda, Pacific Grove, Pacifica, Parlier, Penngrove, Petrolia, Pinedale, Pioneer, Pittsburg, Pleasanton, Oakland International Airport, Point Reyes Station, Port Costa, Richmond, River Pines, Riverbank, San Bruno, Santa Rosa, Sequoia National Park, South San Francisco, Stevinson, Stinson Beach, Stockton, Stratford, Tracy, Tranquillity, Turlock, Union City, Valley Ford, Valley Home, Walnut Creek, Walnut Grove, Westley, Winton, Woodacre.

Nevada--Carson City.

Intensity III:

California--Alameda, Alpaugh, Antioch, Armona, Arroyo Grande, Avila Beach, 


\section{California--Cont inued}

Belvedere-Tiburon, Biola, Bridgeport, Ceres, Clayton, Clovis, Concord, (press report), Corte Madera, Courtland, Del Ray, Diablo, Dixon, Exeter, Fremont, Fulton, Groveland, Guerneville, Healdsburg (press report), Hood, Huron, Inverness, Jenner, June Lake, Kettleman City, King City, Larkspur, Linden, Manteca, Marshall, Martinez (press report), Mountain Ranch, Napa, Oakley, Paradise, Pescadero, Piedra, Pixley, Rail Road Flat, Rohnert Park, Sacramento, San Lorenzo, San Mateo, San Miguel, San Simeon, Santa Clara, Selma, South Lake Tahoe, Sunnyvale, Templeton, Truckee, Tuolumne, Twain Harte, Visalia, Waterford, Wilseyville.

Nevada--Minden, Reno.

Intensity II:

California--Arvin, Atascadero, Clements, Copperopolis, Cutler, Davis (press report), Dinuba, Eldridge, Forest Knolls, Lompoc, Mi-wuk Village, San Anselmo, San Joaquin, Santa Barbara, West Point.

Felt:

California--Coyote.

Nevada--Lake Tahoe area (press report).

6 August (B) Central California

Origin time: $\quad 171043.3$

Epicenter: $\quad 37.09 \mathrm{~N} ., 121.48 \mathrm{~W}$.

Depth: $\quad 6 \mathrm{~km}$

Magnitude: $\quad 3.8 \mathrm{ML}(\mathrm{B})$

Felt in the epicentral area (B). Aftershock of the August 6, 170522.7 earthquake.

6 August (B) Central California

origin time: $\quad 172247.6$

Epicenter: $\quad 37.04 \mathrm{~N}$., $121.48 \mathrm{~W}$.

Depth: $\quad 7 \mathrm{~km}$

Magnitude: $\quad 3.2 \mathrm{ML}(B)$

Felt in the epicentral area (B). Aftershock of the August 6,17 0522.7 earthquake.

6 August (P) Southern California

Origin time: $\quad 180457.4$

Epicenter: $\quad 34.42 \mathrm{~N} ., 118.40 \mathrm{~W}$.

Depth:

$6 \mathrm{~km}$

Magnitude:

$2.8 \mathrm{ML}(\mathrm{P})$

Felt at San Fernando (P).

6 August (B) Central California

Origin time: 222101.7

Epicenter: $\quad 37.03 \mathrm{~N} ., 121.47 \mathrm{~W}$.

Depth:

$6 \mathrm{~km}$

Magnitude:

\section{California--Cont inued}

Felt in the epicentral area (B). Aftershock of the August 6,1705 22.7 earthquake.

6 August (B) Central California

Ortgin time: 223355.4

Epicenter: $\quad 37.00 \mathrm{~N} ., 121.48 \mathrm{~W}$.

Depth: $\quad 4 \mathrm{~km}$

Magnitude: $\quad 4.4 \mathrm{ML}(\mathrm{B})$

Felt in the eplcentral area (B). Aftershock of the August 6, 170522.7 earthquake.

Intensity_IV: Campbell.

6 August (B) Central California

Origin time: 223557.6

Epicenter: $\quad 36.98 \mathrm{~N} ., 121.49 \mathrm{~W}$.

Depth: $\quad 5 \mathrm{~km}$

Magnitude: $\quad 2.9 \mathrm{ML}(\mathrm{B})$

Felt in the epicentral area (B). Aftershock of the August 6, 170522.7 earthquake.

6 August (B) Central California

Origin time: 223604.9

Epicenter: $\quad 36.99 \mathrm{N.}, 121.48 \mathrm{~W}$.

Depth: $\quad 1 \mathrm{~km}$

Magnitude: $\quad 3.8 \mathrm{ML}(B)$

Felt in the epicentral area (B). Aftershock of the August $6,170522.7$ earthquake.

7 August (B) Central California

Origin time: 055651.6

Epicenter: $\quad 37.06 \mathrm{~N} ., 121.49 \mathrm{~W}$.

Depth:

$4 \mathrm{~km}$

Magnitude: $\quad 3.1 \mathrm{ML}(\mathrm{B})$

Felt in the epicentral area (B). Aftershock of the August $6,170522.7$ earthquake.

7 August (B) Central California

Origin time: $\quad 191125.7$

Epicenter: $\quad 36.98 \mathrm{~N} ., 121.47 \mathrm{~W}$.

Depth: $2 \mathrm{~km}$

Magnitude: $\quad 3.2 \mathrm{ML}(\mathrm{B})$

Felt in the epicentral area (B). Aftershock of the August 6,1705 22.7 earthquake.

8 August (B) Central California

Origin time: 225607.9

Epicenter: $\quad 37.03 \mathrm{~N} ., 121.47 \mathrm{~W}$.

Depth:

$4 \mathrm{~km}$

Magnitude :

$3.4 \mathrm{ML}(\mathrm{B})$

Felt in the epicentral area (B). Aftershock of the August $6,170522.7$ earthquake. 
9 August (B) Central California

Origin time: 070320.2

Epicenter: $\quad 37.01 \mathrm{~N} ., 121.45 \mathrm{~W}$.

Depth: $\quad 6 \mathrm{~km}$

Magnitude: $\quad 4.2 \mathrm{ML}(\mathrm{B})$

The press reported that this earthquake was felt at Alameda, East San Jose, Fremont, Gilroy, Hollister, Monterey, Morgan Hill, Newark, San Francisco, San Leandro, Santa Clara, Tiburon, and Union City. Aftershock of the August 6, 170522.7 earthquake.

9 August (B) Central California

Origin time: $\quad 124927.5$

Epicenter: $\quad 36.98 \mathrm{~N} ., 121.46 \mathrm{~W}$.

Depth: $\quad 3 \mathrm{~km}$

Magnitude: $\quad 3.5 \mathrm{ML}(\mathrm{B})$

Felt in Hollister (press report). Aftershock of the August 6, 170522.7 earthquake.

10 August (B) Central California

Origin time: 002520.8

Epicenter: $\quad 37.02 \mathrm{~N} ., 121.46 \mathrm{~W}$.

Depth: $\quad 5 \mathrm{~km}$

Magnitude: $\quad 3.7 \mathrm{ML}(\mathrm{B})$

Felt in the epicentral area (B). Aftershock of the August 6,1705 22.7 earthquake.

10 August (B) Central California

Origin time: 045040.0

Epicenter: $\quad 36.96 \mathrm{~N} ., 121.48 \mathrm{~W}$.

Depth: $\quad 5 \mathrm{~km}$

Magnitude: $\quad 3.0 \mathrm{ML}(\mathrm{B})$

Felt in the epicentral area (B). Aftershock of the August $6,170522.7$ earthquake.

11 August (B) Central Califonia

Origin time: 202935.2

Epicenter: $\quad 37.14$ N., 121.52 W.

Depth: $\quad 5 \mathrm{~km}$

Magnitude: $\quad 3.4 \mathrm{ML}(\mathrm{B})$

Felt in the epicentral area (B). Aftershock of the August 6,1705 22.7 earthquake.

13 August (B) Central California

$\begin{array}{ll}\text { Origin time: } & 190252.5 \\ \text { Epicenter: } & 37.88 \mathrm{~N} ., 122.21 \mathrm{~W} . \\ \text { Depth: } & 13 \mathrm{~km}\end{array}$

Magnitude: $2.3 \mathrm{ML}(\mathrm{B})$

Felt at Orinda (B).

13 August (B) Central California

Origin time: 191846.8

Epicenter: $\quad 37.86 \mathrm{~N} ., 122.17 \mathrm{~W}$.
Depth: $\quad 9 \mathrm{~km}$

Magnitude: $\quad 3.5 \mathrm{ML}(\mathrm{B})$

Intensity IV: Moraga (press report), Rheem Valley, Walnut Creek.

Intensity III: Alamo, Berkeley, Martinez (press report), San Francisco (press report).

Intensity II: Port Costa.

Fe1t:

Oakland (B), Orinda (B).

14 August (B) Central California

Origin time: 031557.0

Epicenter: $\quad 36.99$ N., $121.47 \mathrm{~W}$.

Depth: $\quad 4 \mathrm{~km}$

Magnitude: $\quad 3.6 \mathrm{ML}(\mathrm{B})$

Felt in the epicentral area (B). Aftershock of the August $6,170522.7$ earthquake.

14 August ( $P$ ) Southern California

Origin time: 042018.6

Epicenter: $\quad 33.80 \mathrm{~N} ., 117.80 \mathrm{~W}$.

Depth: $\quad 6 \mathrm{~km}$

Magnitude: $\quad 2.1 \mathrm{ML}(\mathrm{P})$

Felt at Brea (P).

17 August (B) Central California

Origin time: 154303.3

Epicenter: $\quad 37.84 \mathrm{~N} ., 122.23 \mathrm{~W}$.

Depth: $\quad 8 \mathrm{~km}$

Magnitude: $\quad 2.9 \mathrm{ML}(\mathrm{B})$

Felt in Berkeley Hills (B), in parts of Oakland, and as far east as Moraga (press report).

19 August (P) Southern California

Origin time: 031351.2

Epicenter: $\quad 34.08 \mathrm{~N} ., 117.22 \mathrm{~W}$.

Depth: $\quad 5 \mathrm{~km}$

Magnitude: $\quad 2.7 \mathrm{ML}(\mathrm{P})$

Felt at Redlands (P).

19 August (B) Central California

Origin time: 084550.8

Epicenter: $\quad 36.97 \mathrm{~N} ., 121.46 \mathrm{~W}$.

Depth: $5 \mathrm{~km}$

Magni tude: $\quad 2.3 \mathrm{ML}(\mathrm{B})$

Aftershock of the August 6, 170522.7

earthquake

Intensity IV: San Jose.

21 August (P) Southern California

Origin time: $\quad 131807.0$

Epicenter: $\quad 34.55 \mathrm{~N} ., 119.72 \mathrm{~W}$.

Depth:

$6 \mathrm{~km}$

Magnitude: $\quad 3.1 \mathrm{ML}(\mathrm{P})$ 
Intensity IV: Carpenteria, San Roque, Sant a Barbara.

Intensity III: Goleta.

22 August (P) Southern California

Origin time: 020136.4

Epicenter: $\quad 33.70$ N., 116.85 W.

Depth: $\quad 16 \mathrm{~km}$

Magnitude: $\quad 4.0 \mathrm{ML}(\mathrm{P})$

Intensity IV: Aguanga, Bloomington, Bonsal1, Cabazon, Hemet, Indio, Palm Springs, Vista.

Intensity III: Beaumont, Cedar Glen, Highland, Indio (press report), Lake Elsinore (press report), Lakeview, North Palm Springs, Perris, Sunnymead, Temecula, Thousand Palms, Twin Peaks, White Water. Felt: San Bernardino(P).

24 August (B) Central California

Origin time: 044651.6

Epicenter: $\quad 37.84 \mathrm{~N} ., 122.25 \mathrm{~W}$.

Depth: $\quad 7 \mathrm{~km}$

Magnitude: $\quad 2.9 \mathrm{ML}(\mathrm{B})$

Intensity IV: San Francisco.

Felt: $\quad$ Albany (B), Berkeley (B), E1

Cerrito (B), Emeryville (B), Lafayette

(press report), Oakland (B), Orinda (press report), Richmond (B).

27 August (P) Imperial Valley area

Origin time: 072353.5

Epicenter: $\quad 32.70 \mathrm{~N} ., 115.90 \mathrm{~W}$.

Depth: $\quad 5 \mathrm{~km}$

Magnitude: $\quad 3.5 \mathrm{ML}(\mathrm{P})$

Felt at El Centro (P).

28 August (P) Southern California

Origin time: 085756.3

Epicenter: $\quad 34.42 \mathrm{~N} ., 117.73 \mathrm{~W}$.

Depth: $\quad 9 \mathrm{~km}$

Magnitude: $\quad 3.9 \mathrm{ML}(\mathrm{P})$

Intensity IV: Lytle Creek, Mt. Baldy, Pinon Hilis, Wrightwood.

Intensity III: Blue Jay, Cedar Glen.

Intensity II: Action, Valyermo.

Felt: $\quad$ Los Angeles (P), Palmdale

$(\mathrm{P})$, Pasadena (P).

29 August (P) Southern California

Origin time: $\quad 091924.9$

Epicenter: $\quad 33.97 \mathrm{~N} ., 118.70 \mathrm{~W}$.

Depth: $\quad 7 \mathrm{~km}$

Magnitude: $\quad 2.7 \mathrm{ML}(\mathrm{P})$

Felt at Malibu (P).

31 August (B) Central California

Origin time: 185345.1

Epicenter: $\quad 37.84 \mathrm{~N} ., 122.03 \mathrm{~W}$.
Depth: $\quad 8 \mathrm{~km}$

Magnitude: $\quad 2.7 \mathrm{ML}(\mathrm{B})$

Felt at Danville (press report).

2 September (B) Northern Califonia

Origin time: 073800.1

Epicenter: $\quad 39.20 \mathrm{~N} ., 122.86 \mathrm{~W}$.

Depth: $\quad 22 \mathrm{~km}$

Magnitude: $\quad 2.6 \mathrm{ML}(\mathrm{B})$

Intensity III: Potter Valley, Redwood Valley, Ukiah (press report).

5 September (P) Southern California Origin time: $\quad 171107.1$

Epicenter: $\quad 34.07 \mathrm{~N} ., 118.90 \mathrm{~W}$.

Depth: $\quad 7 \mathrm{~km}$

Magnitude: $\quad 3.4 \mathrm{ML}(\mathrm{P})$

Felt at Chatsworth and Thousand Oaks (P).

7 September (B) Owens Valley area

origin time: 094347.3

Epicenter: $\quad 37.62 \mathrm{~N} ., 118.91 \mathrm{~W}$.

Depth: $\quad 3 \mathrm{~km}$

Magnitude: $\quad 4.2 \mathrm{ML}(\mathrm{B}), 4.2 \mathrm{ML}(\mathrm{P})$

Intensity IV: Big Creek, Bridgeport, Crowley Lake, Lake Shore, Mammoth Lakes, Mono City.

Intensity III: June Lake.

9 September (B) Central California

Origin time: 204830.7

Eplcenter: $\quad 37.84 \mathrm{~N} ., 121.95 \mathrm{~W}$.

Depth: $\quad 1 \mathrm{~km}$

Magnitude: $\quad 2.9 \mathrm{ML}(\mathrm{B})$

Felt in Contra Costa County (press report).

10 September (P) Owens Valley area

origin time: 192652.6

Epicenter: $\quad 37.55$ N., $118.68 \mathrm{~W}$.

Depth: $\quad 5 \mathrm{~km}$

Magnitude: $\quad 2.7 \mathrm{ML}(\mathrm{P})$

Felt at Mammoth Lakes (P).

14 September (B) Central California

Origin time: 010405.0

Epicenter: $\quad 37.11 \mathrm{~N} ., 121.94 \mathrm{~W}$.

Depth: $\quad 15 \mathrm{~km}$

Magnitude: $\quad 3.2 \mathrm{ML}(\mathrm{B})$

Felt at Santa Cruz (B).

20 September (B) Central California

Origin time: 030524.8

Epicenter: $\quad 37.88$ N., 122.30 W.

Depth: $\quad 10 \mathrm{~km}$

Magnitude: $\quad 2.5 \mathrm{ML}(\mathrm{B})$

Felt at Berkeley (B). 
24 September (B) Owens Valley area

Origin time: $\quad 130503.2$

Epicenter: $\quad 37.66 \mathrm{~N} ., 118.94 \mathrm{~W}$.

Depth:

$5 \mathrm{~km}$

Magnitude: $\quad 4.1 \mathrm{ML}(\mathrm{B}), 4.4 \mathrm{ML}(\mathrm{P})$

Intensity IV: Mammoth Lakes, Lake Shore.

24 September (B) Owens Valley area

origin time: 142618.5

Epicenter: $\quad 37.66 \mathrm{~N} ., 118.94 \mathrm{~W}$.

Depth: $\quad 5 \mathrm{~km}$

Magnitude: $\quad 3.6 \mathrm{ML}(\mathrm{B}), 3.9 \mathrm{ML}(\mathrm{P})$

Felt at Mammoth Lakes (P).

27 September (B) Central California

Origin time: 061450.2

Epicenter: $\quad 36.79$ N., $121.59 \mathrm{~W}$.

Depth: $2 \mathrm{~km}$

Magnitude: $\quad 2.9 \mathrm{ML}(\mathrm{B})$

Felt at San Juan Bautista (B).

28 September (P) Southern California Origin time: 200826.2

Epicenter: $\quad 34.02 \mathrm{~N} ., 118.32 \mathrm{~W}$.

Depth: $\quad 6 \mathrm{~km}$

Magnitude: $\quad 2.2 \mathrm{ML}(\mathrm{P})$

Felt at Hollywood (P).

1 October (B) Owens Valley area

Origin time: 115200.7

Epicenter: $\quad 37.60$ N., $118.86 \mathrm{~W}$.

Depth: $\quad 10 \mathrm{~km}$

Magnitude: $\quad 2.9 \mathrm{ML}(\mathrm{B})$

Felt at Mammoth Lakes (B).

1 October (B) Owens Valley area

Origin time: 115220.6

Epicenter: $\quad 37.54 \mathrm{~N}$., $118.82 \mathrm{~W}$.

Depth: $\quad 10 \mathrm{~km}$

Magnitude: $\quad 3.2 \mathrm{ML}(\mathrm{B}), 3.4 \mathrm{ML}(\mathrm{P})$

Felt at Mammoth Lakes (B).

1 October (B) Owens Valley area

Origin time: 123702.3

Epicenter: $\quad 37.60 \mathrm{~N} ., 118.85 \mathrm{~W}$.

Depth: $\quad 12 \mathrm{~km}$

Magnitude: $\quad 3.0 \mathrm{ML}(\mathrm{B}), 3.4 \mathrm{ML}(\mathrm{P})$

Felt at Mammoth Lakes.

3 October ( $B$ ) Owens Valley area

Origin time: 085424.8

Epicenter: $\quad 37.63 \mathrm{~N} ., 118.91 \mathrm{~W}$.

Depth: $\quad 12 \mathrm{~km}$

Magnitude: $\quad 3.0 \mathrm{ML}(\mathrm{B}), 3.3 \mathrm{ML}(\mathrm{P})$

Felt at Mammoth Lakes (B).
3 October ( $B$ ) Owens Valley area

Origin time: 085830.8

Epicenter: $\quad 37.62 \mathrm{~N} ., 118.91 \mathrm{~W}$.

Depth: $\quad 10 \mathrm{~km}$

Magnitude: $\quad 3.1 \mathrm{ML}(\mathrm{B}), 3.3 \mathrm{ML}(\mathrm{P})$

Felt at Mammoth Lakes (B).

4 October (B) Southern California

Origin time: 134417.8

Epicenter: $\quad 33.60 \mathrm{~N} ., 117.23 \mathrm{~W}$.

Depth: $\quad 5 \mathrm{~km}$

Magnitude: $\quad 3.4 \mathrm{ML}(\mathrm{P})$

Intensity III: Lake Elsinore, Lakeland Village, Murrieta, Rancho California, Sedco Hills, Sun City, Temecula, Wildomar (all from press reports).

7 October (B) California-Nevada border region Origin time: 205441.4

Epicenter: $\quad 38.22 \mathrm{~N} ., 119.35 \mathrm{~W}$.

Depth: $\quad 9 \mathrm{~km}$

Magnitude: $\quad 4.1 \mathrm{mb}(\mathrm{G}), 5.0 \mathrm{ML}(\mathrm{B})$

Intensity IV: Bridgeport, Friant, Midpines, Mountain Ranch, Murphys, Sonora, Strawberry, Yosemite National Park Lodge, Wawona.

Intensity IIl: Soulsbyville, Topaz.

Intensity II: El Portal, Pacific House.

7 October (B) California-Nevada border region

Origin time: 212053.0

Epicenter: $\quad 38.23 \mathrm{~N} ., 119.36 \mathrm{~W}$.

Depth: $\quad 11 \mathrm{~km}$

Magnitude: $\quad 4.4 \mathrm{ML}(\mathrm{B})$

Felt at Bridgeport (B).

8 October (B) California-Nevada border region

Origin time: 033424.0

Epicenter: $\quad 38.21 \mathrm{~N} ., 119.32 \mathrm{~W}$.

Depth: $\quad 9 \mathrm{~km}$

Magnitude: $\quad 4.6 \mathrm{ML}(\mathrm{B})$

Felt at Bridgeport (B).

15 October (P) Imperial Valley area

Origin time: 231654.5

Epicenter: $\quad 32.63 \mathrm{~N} ., 115.33 \mathrm{~W}$.

Depth:

Magnitude: $\quad 5.7 \mathrm{mb}(\mathrm{G}), 6.9 \mathrm{MS}(\mathrm{G})$, $6.6 \mathrm{ML}(\mathrm{P}), 7.0 \mathrm{ML}(\mathrm{B})$

The felt area in the United States, covering parts of Arizona, California, and Nevada, was approximately $128,000 \mathrm{sq} \mathrm{km}$ (fig. 17). The total felt area cannot be computed because of lack of intensity data from Mexico and because the western boundary of the limit of perceptibility extends to the 


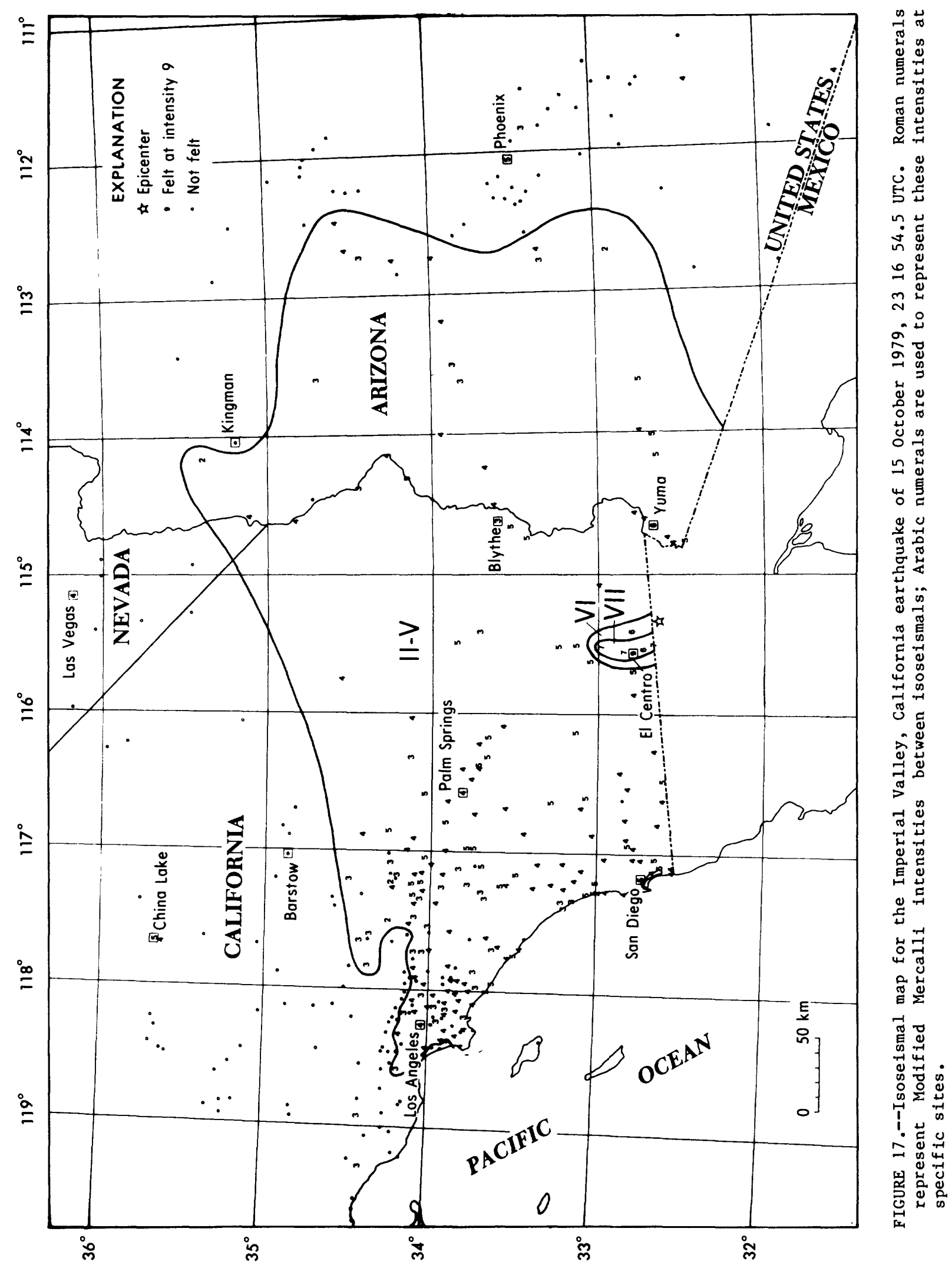


coast line of California. The press reported 91 people injured, mostly cuts from flying glass or bruises from falling objects; two homes destroyed, 1565 homes damaged; 11 businesses destroyed, and 440 businesses damaged; all in the Imperial Valley. There were also numerous bridges with cracked abutments and shifted roadbeds due to slumping or faulting. Extensive lateral slope failure occurred along many irrigation canals, including the All-American Canal.

Neal and others (1979) estimated the damage from the earthquake at $\$ 30$ million with the worst damage occurring in southern Imperial County and northeastern Baja Ca1ifornia. This figure encompasses both buildings and their contents and agricultural losses. The greatest single structure loss was to the Imperial County Services Building in El Centro, a six-story building whose support pillars failed and allowed partial collapse of the east portion of the building ( $f$ ig. 18). Press accounts estimated the preliminary replacement cost at about $\$ 7$ million. The agriculture industry suffered losses due to damage to the irrigation system which included damage to canals and irrigation ditches and damage to subsurface drain tiles which were disturbed by the movement along the Imperial Fault. The worst damage was to the All-American Canal which brings Colorado River water into the Imperial Valley. The earthquake shook down levees on both sides of the canal along a 13-km stretch of the canal east of Calexico. In some places the banks settled by more than $1 \mathrm{~m}$.

Mexicali, Mexico, suffered the same type of damage as the urban centers in California. The press reported about 100 homes, mostly adobe huts, were heavily damaged as was the airport terminal, and several buildings suffered ceiling cave-ins. There were also reports of walls collapsing, bricks falling from fronts of stores, glass breakage, merchandise falling from shelves, debris littered sidewalks, and several breaks in water mains.

Reagor and others (1980) described the damage and effects of this earthquake and its af tershocks in the Imperial Valley as consisting of partially collapsed unreinforced brick walls; isolated instances of cracked or fallen cornices, parapets, and gables; a few chimneys damaged; display windows broken or shattered; plaster cracked and fallen; sections of suspended ceiling tiles with framework displaced or fallen; shelves or counters shifted or overturned with merchandise thrown from shelves in many instances; all types of furniture moved with lighter furniture, bookcases, and table lamps overturned; pictures and mirrors fallen; considerable quantities of glassware, dishes, and other small objects fallen and broken. In the older section of the business districts, porticos were often extensively cracked as were their support columns. Many people found it difficult to stand or to walk and, if sitting, had difficulty arising.

Neal and others (1979) compared the May 18, 1940 and October 15, 1979 Imperial Valley earthquakes as follows: "Although of lesser extent, the October 15, 1979 ground rupture followed the same trace as the 1940 event, and showed many of the same features and characteristics. Both ruptures appeared to have maximum lateral displacements near the International Border, and predominant vertical displacement near the Mesquito Depression east of Imperial. Activity shifted to the north with both events having damaging af tershocks near Brawley. Also, like the 1979 event there is evidence that the Brawley fault under went sympathetic movement in 1940. The similiarities also extend to the distribution and types of damage as described for the 1940 earthquake. In the 1940 event the structural damage was most severe in Brawley, and probably would have been so in the 1979 earthquake if it were not for the failure of the multi-million dollar County Services Building in El Centro."

Nea 1 and others (1979) also described the rupture on the Imperial Fault as extending from about $4 \mathrm{~km}$ north of the International Border to about $4 \mathrm{~km}$ south of Brawley. Maximum lateral displacement was about 55 $\mathrm{cm}$ in Heber Dunes and the maximum vertical displacement was $19 \mathrm{~cm}$ southeast of Brawley. Lateral displacements were characterized by left stepping en echelon cracks and mole tracks. Vertical offsets showed a clean scarp at the base of the preexisting Imperial fault scarps. Secondary features observed by Neal and others (1979) included sand boils and lateral spreading along the southern extent of the fault.

This earthquake triggered all of the USGS accelerographs within about $100 \mathrm{~km}$ of the epicenter and one as far away as $196 \mathrm{~km}$. The maximum acceleration recorded was 1.74 
$g$ on the vertical component of El Centro Station No. 5 located ahout $27 \mathrm{~km}$ from the epicenter and about $1 \mathrm{~km}$ frum the nearest point on the imperial fault trace (Porcella and Matthiesen, 1979).

Many of the aftershocks were felt in the Imperial Valley, especially the one on October 16 at 065843.2 , to which the press attributes additinnai damage in the Brawley area. Table 1 does not list all of the aftershocks of magnitude $\geq 3.0$ that were recorded.

Reagor and others (1980) pointed out that the maximum intensity assigned to this earthquake was VII with the exception of the Imperial County Services Building at El Centro which was assigned intensity IX. This building, a six-story reinforced concrete-frame structure which was designed under the 1967 provisions of the Unjform Building Code, suffered significant structural damage and was torn down after the earthquake.

Most of the damage descriptions for E1 Centro, Brawley, Calexico, and Imperial, California, listed below, were taken from Reagor and others $(1980)$.

Intensity IX:

\section{California-}

E1 Centro--Although the general level of earthquake damage in El Centro is a VII, the Imperial County Services Building (ICSB), located on Main Street between Ninth and Eleventh Streets, has been given an intensity of IX (fig. 18). This six-story reinforced concrete-frame and shear-wall structure, completed in 1971 at a construction cost of $\$ 1.87$ million (Rojahn and Ragsdale, 1980), was designed to be earthquake resistant. Although severely damaged, the building did not collapse. The major damage to the building was the failure of the four reinforced concrete support columns on the east side of the building (fig. 19). The concrete, at the base of the columns along the east side, was shattered and the vertical reinforced bars were severely bent. The partial collapse of these support columns allowed the eastern extremity of the building to sag about $30 \mathrm{~cm}$ ( 1 $\mathrm{ft}$ ) (Rojahn and Ragsdale, 1980). In the upper levels of the building, the south-facing exterior wall was extensively cracked near the window frames. Also, in several instances partial separation occurred between the floors, walls, and ceilings. Fallen suspended ceiling tiles, damage to interior walls, and shifted or overturned office furniture were some of the effects reported to have occurred inside the building.

Intensity VII:

California-

Brawley-Many buildings were damaged in the business district along Main Street between the 500 and 900 blocks. Damage at Brawley was further enhanced by aftershocks, which occurred near midnight on October 15. The af tershocks, according to several people, were responsible for additional building damage, window breakage, and the shaking of large quantities of merchandise from shelves.

'Mahn's Furniture Store (500 block)--An estimated $15-\mathrm{m}(50-\mathrm{ft})$ long crack about $2.5 \mathrm{~cm}$ ( $1 \mathrm{in}$ ) wide occurred in the west wall. Concrete columns which supported the balconies were

moderately cracked at the ceiling connection. Ceiling tiles were dislodged and some fell. The dry wall was split and one section was thrown down from the south-facing wall. The building cornice cracked but did not fall. The east side of the metal sign, which covered the upper level store front, was shaken down.

Newberry Department Store (500 block)-The west brick wall was knocked away from the roof and partially collapsed. Twelve wooden support trusses were broken. Bricks fell from the roof and caused considerable damage to the interior of the store.

National Department Store ( 600 block)-There was some collapse of the roof. Fallen bricks caused dry-wall ceilings to split and fall. The cement floor in the storage area was cracked in a few places. Metal shelves that were bolted to concrete walls were thrown down.

Fire Station ( 800 block)--This building was a reinforced concrete structure with the roof supported by wooden beams. A few of these beams were reported to be cracked along their length. In the firehouse living quarters, a metal support bracket for one of the east-west beams was slightly twisted. A metal hose rack bolted to the west wall was thrown down. Roof tiles were dislodged and some fell. 


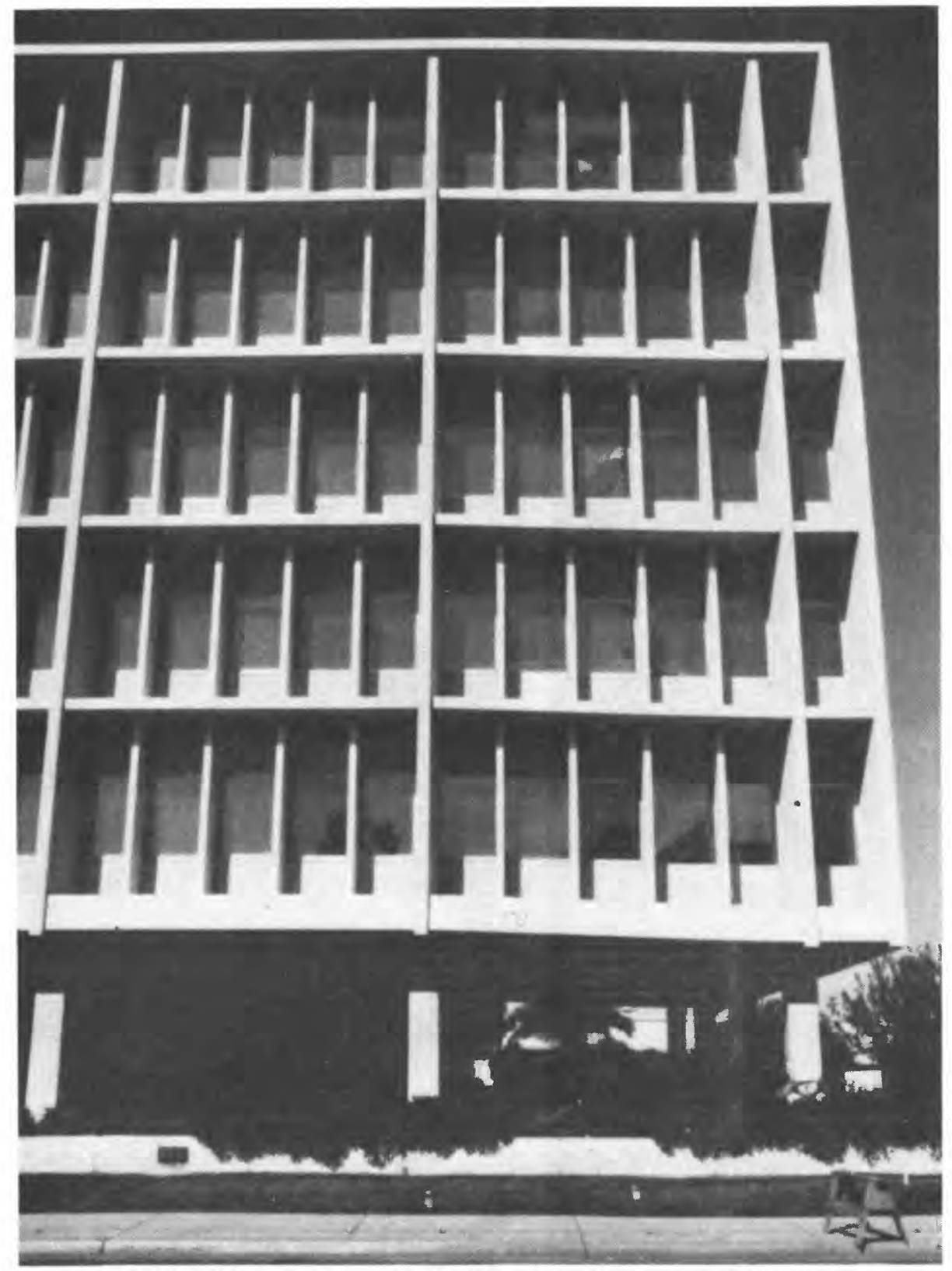

FIGURE 18.--Photograph of damage to the Imperial County Services Building in Imperial, Calif.

During the initial tremor, according to a fireman, "the trucks inside the garage were shaken so strongly they nearly touched each other."

Victory Market (900 block)--The onestory building was a steel-frame and brick structure. The northeast corner of the east facing brick wall partially collapsed. There were 2.5-to5.0-cm (1-to-2-in) open cracks in the west-facing brick wall in several places. In the middle of the 900 block the portico roof partially collapsed. In this area, according to the owner of the Victory Market, some of the buildings were condemned before the earthquake.

Several homes in the 200 block of G Street were damaged. A stucco-covered chimney on the west side of the house shifted about $5 \mathrm{~cm}$ ( 2 in) from the wall. An attached wooden porch roof was shaken down from a wood-frame house across the street to the north. On Third Street, one block south, a few chimneys were either broken at the roof line or the upper tiers of bricks were thrown down to the west.

The press reported extensive damage to Tacos Pancho (201 Main Street) and 


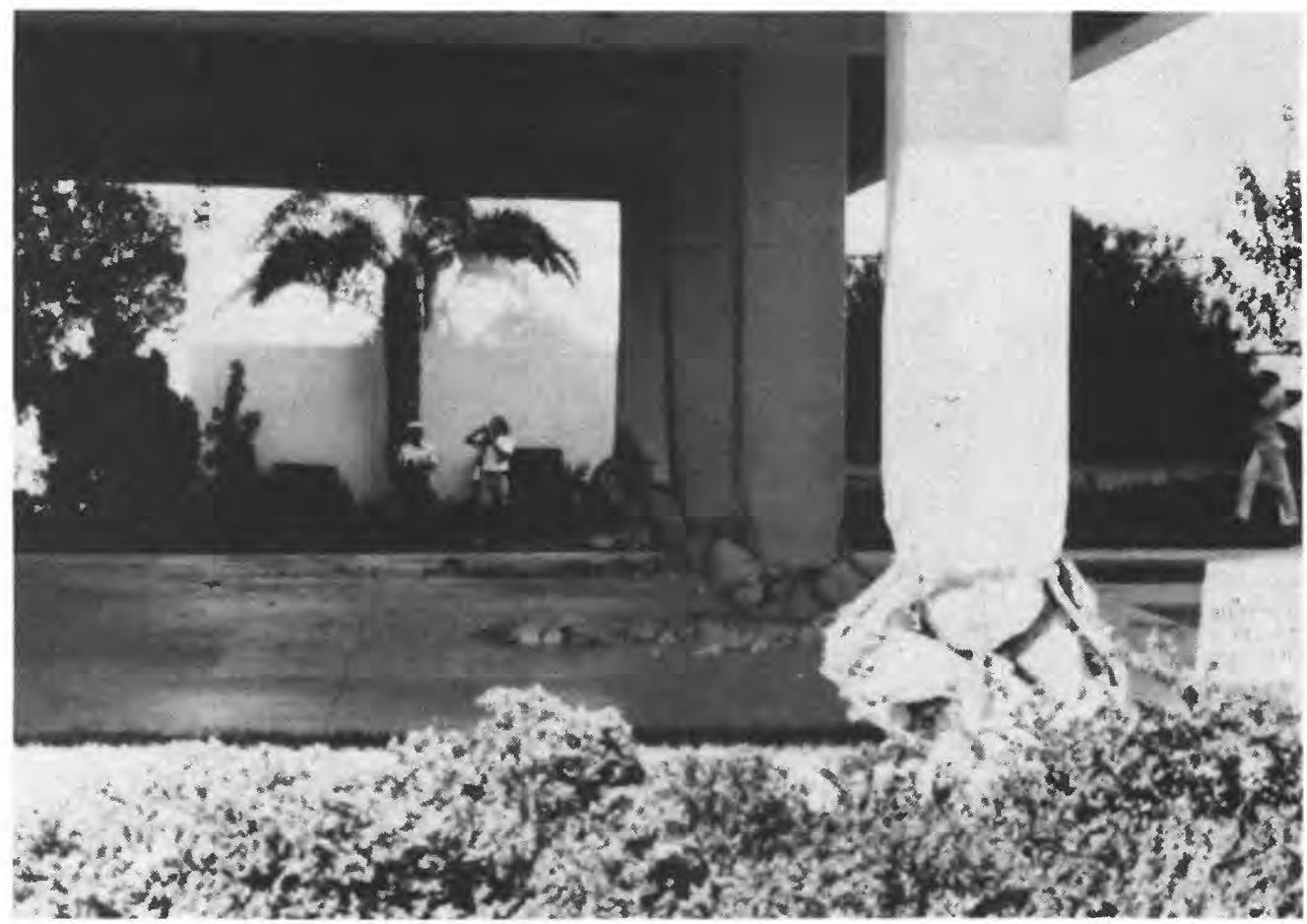

FIGURE 19.--Support pillar failure at the east end of the Imperial County Services Building in El Centro, California caused by the earthquake on October 15, 1979.

\section{California--Continued}

about $\$ 200,000$ damage to the $E 1 k$ 's Lodge (196 State Street). There were also reports of an arcade broken off in front of Desert Shoes Store and a portion of the roof fallen inside E11is' Department Store and lying on shelves.

New River Bridge (on State Highway 86 west of the city)--The abutments at each end of the bridge were cracked and chipped to the extent that the reinforcement bars were exposed at bridge level. Many of the support columns were cracked at the bridge deck connection. The asphalt road had settled about $12.5 \mathrm{~cm}$ ( $5 \mathrm{in}$ ) relative to the bridge.

Two and one-half kilometers south of Main Street on Dogwood Road an elevated water tower collapsed.

Calexico--Damage to several buildings occurred in the business district along Second and Third Streets. Many of the buildings' store fronts along

\section{California--Continued}

Second Street exhibited large vertical and horizontal cracks in the exterior stucco walls.

McMahn's Furniture Store (104 East Second Street)--Partial collapse of the second-story west brick wall and parapet (fig. 20) caused the roof of the portico to cave-in. The upper story was condemned before the earthquake.

International Music Store (Third Street and Paulin Avenue)--The building was damaged by the partial collapse of the east brick fire wall which caved in the roof of the store, damaging merchandise and equipment.

The Port of Entry was damaged when the brick facade tumbled to the floor. It also suffered many plaster cracks (press report).

E1 Camino Real Hotel (Second Street and Paulin Avenue)--The press reported the roof had collapsed.

San Diego State University's main building, which was built in 1915 and lost 


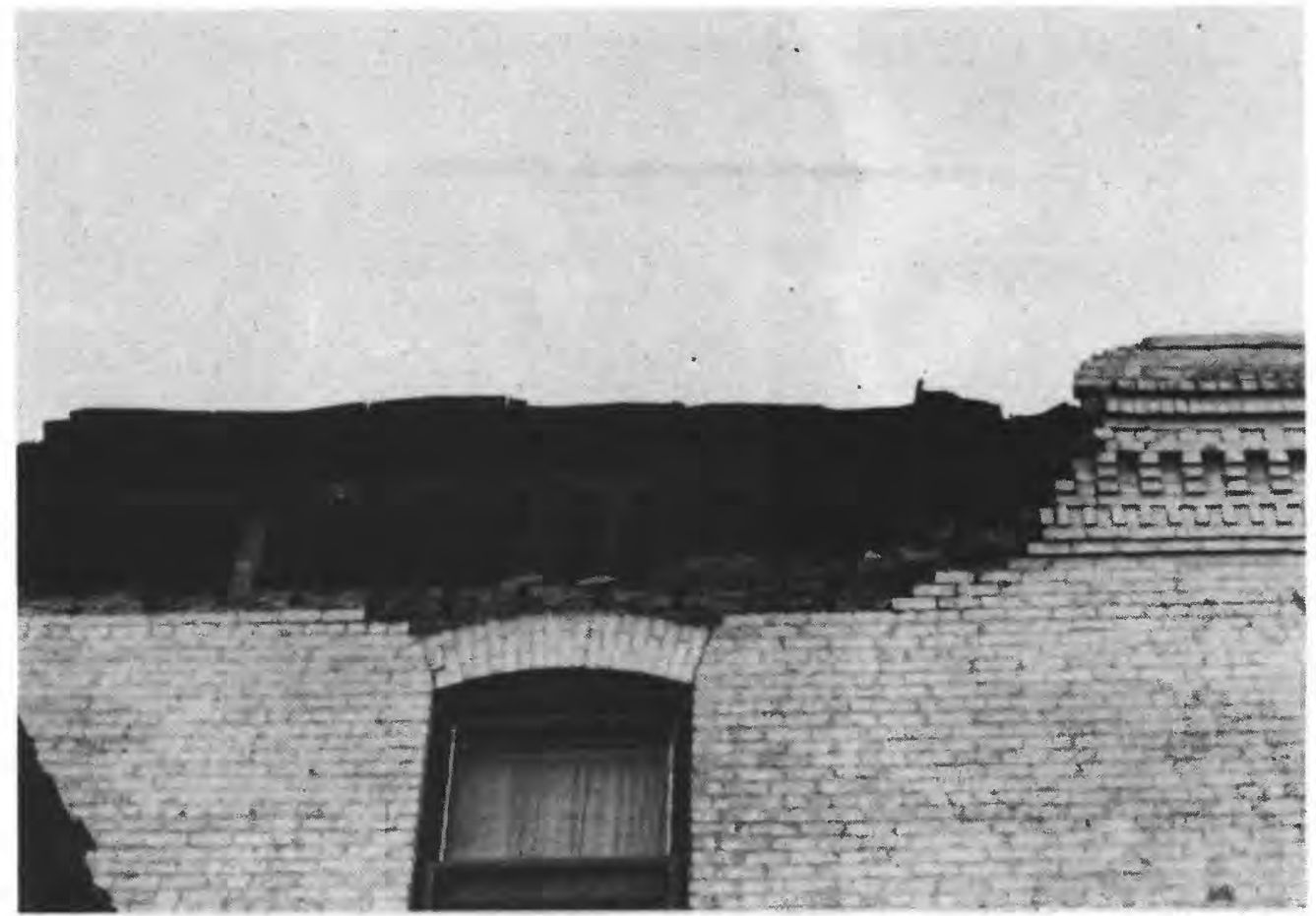

FIGURE 20.--Damage to a wall of the McMahn's Furniture Store In Calexico, Callf.

\section{Cal1fornia--Continued}

the second floor to an earthquake in 1927, suffered severe structural damage and was later condemned. There was no steel in several of the bearing walls which were severely damaged. Also, a basement support was cracked on both sides (press report).

0 ther effects reported by the press were as follows: The Unifled School District buildings suffered damage to walls, fallen 11ght fixtures, broken glass and overturned furniture; several street 1 ights were knocked down; extensive merchandise damage in grocery and drug stores; many bulldIngs sustained cracked and fallen plaster with a few porches damaged; along with broken water malns, leaks in gas lines, and electric lines knocked down.

E1 Centro--In the older business district most of the bullding damage was along Main and State Streets between Fourth and Eighth Streets, and in the 400 and 500 blocks on Broadway.

The newer shopping centers, located along Imperial Avenue and to the west
Cal1fornia--Continued

of the older business district, appeared to have sustalned only minor damage such as small plaster cracks and some fallen plaster, merchandise damage due to fall from shelves, and the displacement and occasional fall of suspended celling tiles with framework slightly bent or hanging down. Hoffman Music Store (534 Main Street)-The brick and stucco veneer 8 tore front over the bullding was extensively fractured.

Deluxe Cleaners (119 North Fif th Street)--The two-story wood-frame and brick building was damaged by the partial collapse of the west facing parapet and by the fall of brick veneer from the second-8tory walls (f1g, 21). The roof over the second story was reported to have collapsed. The upper story had been condemned before the earthquake.

Mayan Hotel (595 State Street)--The two-story steel frame and brick buildIng with stucco veneer was moderately damaged. Along the length of the east wa11, there was about $2.5 \mathrm{~cm}$ ( $1 \mathrm{in}$ ) of separation at the connections of the 


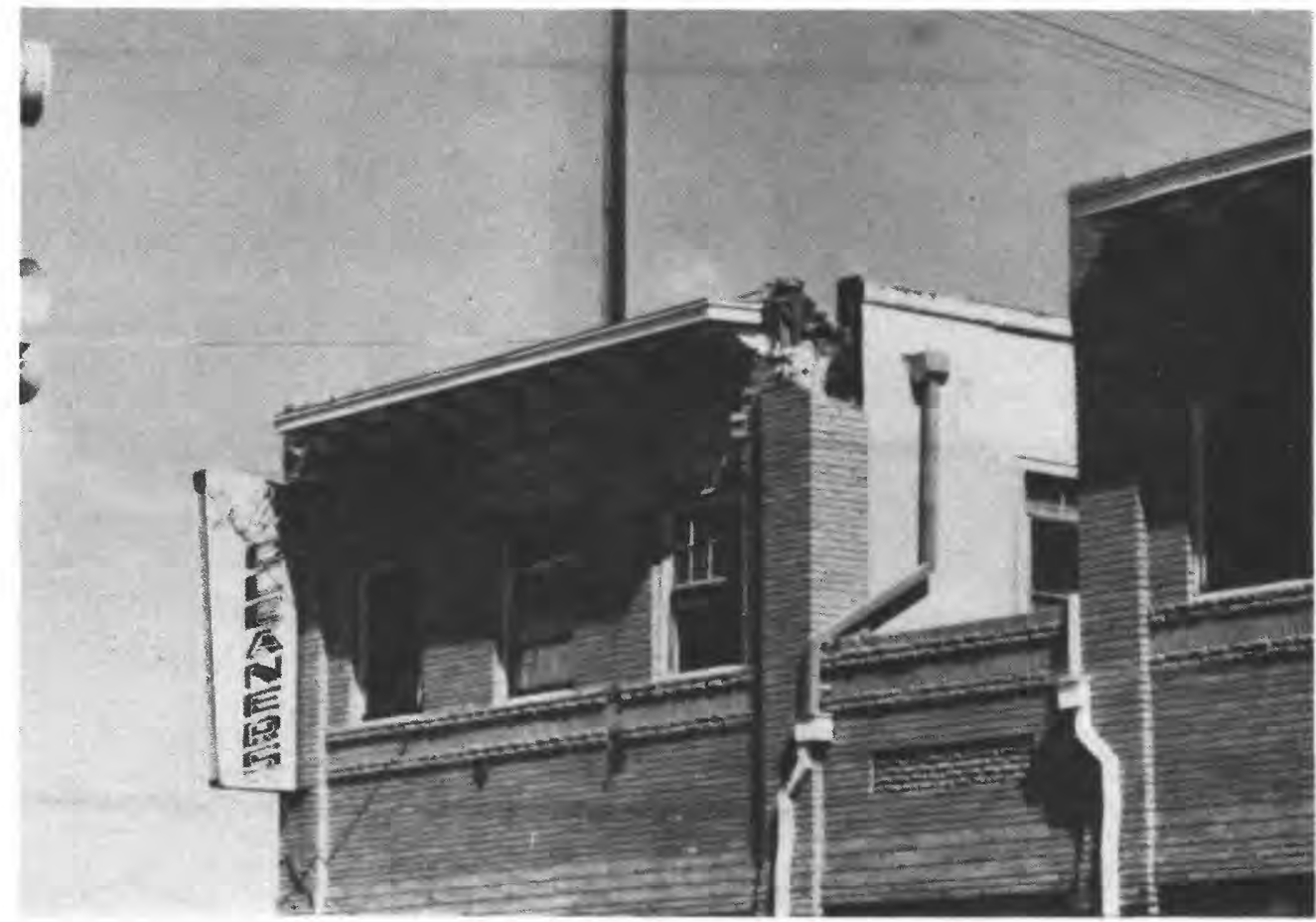

FIGURE 21.--Damage to the cornice of the Deluxe Cleaners building in E1 Centro, Calif.

cellings and floors. There was also considerable fallen and cracked plaster from cellings and walls in all the rooms and in the lobby.

A duplex home (547 Vine Street) was declared structurally unsound accordIng to the press due to a collapsed porch and structural damage to the Interior.

The Firestone Tire bullding (Fourth and Main Streets) sustalned separated walls and damage to the foundation (press report).

The Imperial Valley College (north of E1 Centro) had reported damage of about $\$ 151,000$. There was structural damage to the library bullding, much glass breakage in laboratorles and classrooms, and some kind of damage to nearly all of the bulldings (press report).

The city water storage tower (Third and Commercial Streets) was condemned due to damage to the bracing of the tower and bending of some of the steel support girders (press report).
Green's Custom Jewelry (113 North 5th Street)--Most of the brick facade fell onto the sidewalk (press report).

At Gio's Mobile Home Estates, on Lincoln Avenue, a large number of the nearly 90 mobile homes were damaged when they were shaken from their metal support stands. A concrete-block masonry fence, standing in an east-west direction, was partially thrown down at the south entrance to the mobile home park.

Other effects in and around E1 Centro-North of E1 Centro an oll tank split $15 \mathrm{~cm}$ ( $6 \mathrm{In}$ ) along a seam near the base at the Southern Pacific Plpeline tank farm. Underground water plpes were broken in many places; however, ut1lities were interrupted for only a short period of time. Asphalt roads cracked, buckled, and slumped in many places, especlally where the fault trace crossed the roadway. The San Diego and Arizona Eastern Rallroad tracks were offset about $23 \mathrm{~cm}$ where they crossed the Imperial fault east of E1 Centro near Meloland. 
Imperial--The press reported that more than 80 percent of the buildings in the downtown area had been condemned after sustaining damage estimated at $\$ 1.8 \mathrm{million}$. Most of the damage occurred on the west side of Imperial Avenue. Several sewer pipes were also reported broken.

Lydia's Cafe (133 S. Imperial)--The one-story, wood-frame and brick structure was damaged by the partial collapse of the south wall. Part of the roof was knocked out.

Imperial Hardware Store (125 Imperial) - The rear wall of the brick buflding was severely cracked and the top part of the building was pushed toward the west.

The police chief reported damage to the residential area of Imperial consisted of many stucco homes that moved on their foundations and others that had lateral cracks near their foundations. A masonry fence supporting a carport partially collapsed. Chimney bricks were loosened. At the police station, the plastered wall between the chief's office and the jail area cracked vertically and opened to a width of $2.5 \mathrm{~cm}$ ( 1 in). The police chief said, "I was in a doctor's office at the time of the initial tremor and I could not get up out of the chair due to the building moving in all directions at once. A loud roaring sound preceded the earthquake."

\section{Intensity VI:}

Arizona--

Yuma-The quake was reported felt much more strongly and did more damage in the Yuma Valley than on the Yuma Mesa about 15-30 m above the valley.

The press reported three pencil-wide cracks in the Juvenile Court Center (2849 Avenue B), a masonry building; one water main was broken; the roof of the Stardust Hotel was cracked; and windows cracked and goods were knocked off of shelves at the Yuma Marine Corps Air Station.

Other effects reported were cracks in plaster walls, light and heavy furniture moved, hanging pictures fell, felt by all.

\section{California--}

Heber--cracked foundation and reports of interior walls separated from ceiling to floor, light and heavy furniture moved, few windows cracked, hanging pictures fell, felt by all.
Holtville--Store front windows in occupied building on Fifth and Holt Avenue were broken, a number of buildings sustained cracks in their exterior walls, many homes in the Ralph Simpson subdivision were damaged when brick fireplaces pulled away from the walls, the Barbara Worth Country Club had most of their dishes broken, and one house shifted off its foundation--type of foundation unknown (all from press reports).

Intensity V:

Arizona--Dateland, Parker, Phoenix, San Luis, Tacna, Wellton.

Calffornia--Big Bear City, Bonita, Cabazon, Campo, Cardiff by the Sea, China Lake, Chula Vista, Coachella, Eagle Mountain, Earp, Encinitas, Hemet, Highland, Huntington Beach, Jacumba, Julian, La Quinta, Laguna Niguel, Morongo Valley, Newport Beach, Niland, Ocotillo, Palm Desert, Palo Verde, Rancho Santa Fe, Redlands, Ripley, San Bernardino, San Diego, San Jacinto, Santee, Seeley, Temecula, Warner Springs, Westmorland, Wildomar, Winchester, Yucaipa.

Intensity IV:

Arizona-Aguila, Bouse, Bullhead City, Ehrenberg, Gadsden, Glendale (press report), Palo Verde, Prescott, Quartzsite, Roll, Scottsdale (press report), Silver Bell, Skull Valley, Somerton, Wickenburg, Yarnell.

California--Aguanga, Alhambra, Alpine, Amboy, Anaheim, Angelus Oaks, Anza, Bard, Beaumont, Bonsall, Boulevard, Bryn Mawr, Buena Park, Burbank, Calimesa, Calipatria, Cathedral City, Chino, City of Industry, Corona, Costa Mesa, Covina, Crestline, Culver City, Cypress, Dana Point, Del Mar, Dulzura, East Highlands, E1 Cajon, Escondido, Etiwanda, Fallbrook, Forest Falls, Fullerton, Garden Grove, Glamis, Hawthorne, Idyllewild, Imperial Beach, Indio, La Jolla, La Mesa, La Puente, Laguna Beach, Lakeside, Lakewood, Lemon Grove, Loma Linda, Los Alamitos, Los Angeles, Lucerne Valley, Mecca, Mentone, Midway City, Mission Viejo, Montebello, Moreno, Mount Laguna, Murrieta, National City, Needles, Nestor, North Palm Springs, Norwalk, Pala, Palm Springs, Palos Verdes Peninsula, Parker Dam, Patton, Penasquitos (press report), Pine Valley, Plaster City, Potrero, Poway, Ramona, Rancho Mirage, Redondo Beach, Rialto, Ridgecrest, 
Riverside, Rosemead, San Dimas, San Marcos, Santa Ysabel, Solano Beach, Surfside, Thousand Palms, Torrance, Trabuco Canyon, Twentynine Palms, Valley Center, Vista, Westminster, White Water, Whittier, Wilmington, Winterhaven, Yorba Linda, Yucca Valley (press report). Nevada--Las Vegas.

Intensity III :

Arizona--Arlington, Kirkland, Lake Havasu City, Mesa, Salome, Sasabe, Tucson (press report), Wenden, Wikieup.

California--Apple Valley, Bellflower, B1ythe, Carlsbad, Claremont, Colton, Coronado (press report), Desert Center, E1 Monte, E1 Toro, Fillmore, Fontana, Fountain Valley, Gardena, Green Valley Lake, Joshua Tree, Lake Elsinore, Lakeview, Long Beach, Mira Loma, Oak View, Oceanside, Paramount, Pasadena, Perris, Phelan, Pico Rivera, Pinon Hills, Pomona, Reseda, Running Springs, San Luis Rey, Santa Ana, South Gate, Stanton, Sun City, Sunnymead, Valyermo.

Intensity II:

Arizona--Chloride, Gila Bend.

California-Blue Jay, Lytle Creek.

Fe1t:

Arizona--Kingman (press report).

California--Santee (press report).

16 October (P) Imperial Valley

Origin time: 065843.2

Epicenter: $\quad 33.02 \mathrm{~N} ., 115.58 \mathrm{~W}$.

Depth: $\quad 5 \mathrm{~km}$

Magnitude: $\quad 5.2 \mathrm{mb}(G), 5.7 \mathrm{MS}(G)$,

$$
5.4 \mathrm{ML}(\mathrm{P}), 6.1 \mathrm{ML}(\mathrm{B})
$$

Based on interviews with residents in Imperial and Brawley, Reagor and others (1980) pointed out that aftershocks caused additional damage. The press described one instance in which an aftershock was more strongly felt than the main shock. In the case cited, a home in Imperial (321 Main Street), the main shock caused very little damage but an aftershock that occurred near midnight buckled the floor, caused walls to move so that none were left vertical, steps to the porch to crumple, doors to jam shut, and a 16-year-old gir1 to be thrown out of the top of a bunk bed.

\section{Intensity VI: Brawley, Imperial.}

17 October (P) Imperial Valley

Origin time: 191438.1

Epicenter: $\quad 32.97$ N., $115.60 \mathrm{~W}$.
Depth: $\quad 7 \mathrm{~km}$

Magnitude: $\quad 4.1 \mathrm{ML}(\mathrm{P})$

Fe1t at E1 Centro (press report).

17 October (P) Southern California

Origin time: 205236.8

Epicenter: $\quad 33.90 \mathrm{~N} ., 118.63 \mathrm{~W}$.

Depth:

Magnitude: $\quad 4.5 \mathrm{mb}(G), 4.2 \mathrm{ML}(\mathrm{P})$, 4.0 ML(B)

This earthquake occurred in the same area as the one on January $1,1979,231438.9$ UTC which caused minor damage. The press reports that this shock widened a 2-foot crevice in the Big Rock slide area by about $5 \mathrm{~cm}$ above the Pacific Coast Highway in Malibu. The highway was closed temporarily because rocks had rolled down onto the roadway. Other minor rockslides were reported near a tunnel in Malibu Canyon. It was felt over an area of approximately $5,200 \mathrm{sq} \mathrm{km}$ ( $f i g, 22)$.

Intensity $\mathrm{V}$ :

Compton (few windows cracked; hanging pictures swung; windows, doors, and dishes rattled; felt by many).

La Costa (few windows cracked; small objects moved, buildings creaked; windows, doors, and dishes rattled; felt by many).

Los Angeles--Ladera Heights (small objects were moved and overturned; standing vehtcles rocked moderately; moving vehicles rocked slightly; windows, doors, and dishes rattled; felt by many).

Los Angeles--Rancho Park (small objects fell; buildings trembled and creaked; windows, doors, and dishes rattled; moderate earth noise; felt by many).

Malibu (rock slides on the Pacific Coast Highway, bulldings shook strongly, house under construction almost collapsed-press report, felt by many).

Marina de1 Rey (few windows cracked; hanging pictures knocked out of place; buildings creaked; windows, doors, and dishes rattled; felt by many).

Monrovia (1ight furniture moved; buildings creaked; windows, doors, and dishes rattled; felt by many).

Monterey Park (1ight furniture and small objects moved, water splashed onto sides of swimming pools, hanging pictures knocked out of place, felt by many).

Pacific Palisades (at Palisades Valley School desks were shaken and some books knocked off shelves; in a liquor store bottles rattled and shook; in a drug store a few plastic bottles were shaken 


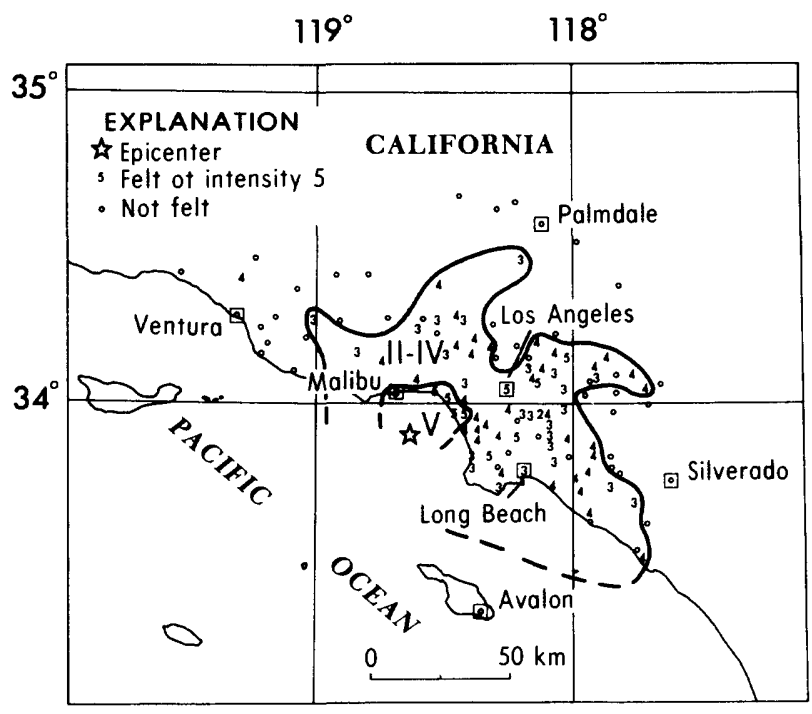

FIGURE 22.--Isoseismal map for the southern California earthquake of 17 October 1979, 205236.8 UTC. Roman numerals represent Modified Mercalli intensities between isoseismals; Arabic numerals are used to represent these intensities at specific sites.

\section{California--Continued}

from shelves--press report).

Santa Monica (light and heavy furniture moved; buildings shook strongly; windows, doors and dishes rattled; felt by few).

Santa Monica--W111 Rogers area (hanging pictures fell; small objects moved; windows, doors, and dishes rattled; felt by severa1).

Venice (one crack reported in the post office ceiling where support pillars join the celling).

Walteria (11ght furniture moved, hanging pictures knocked out of place, felt by many).

Intensity IV: Agoura, Alhambra, Anaheim, Anaheim-Brookhurst Center, Arcadia (press report), Azusa, Barrington, Burbank, Canoga Park, Costa Mesa (press report), Crenshaw, Culver City, East Long Beach, Echo Park (press report), E1 Segundo, Figue roa, Florence, Fountain Valley, Ful1erton, Garden Grove, Gardena, Gateway, Glendora, Hawthorne, Huntington Park, Inglewood, Inglewood--Morningside Park, La Mirada, La Verne, Laguna Nigue1, Lawndale, Lennox, Linco1n Helghts, Los Angeles, Los Angeles--West Adams, Midway City, Newhal1 (press report), North Inglewood, North Ho11ywood, North Hollywood--Victory

\section{California--Continued}

Center, North Torrance, Oakview, Ocean Park, Palms, Playa del Rey, PomonaCentral District, San Marino, Seal Beach, Sierra Madre, Sun Valley, Sunset Beach, Surfside, Sylmar, Topanga, Torrance, Van Nuys, Vernon, Wilmington, Yorba.

Intensity III: Acton, Anaheim-Federal, Bell, Beverly Hills, Buena Park, Cerritos, Chatsworth, Covina, Cudahy, Diamond, East Irvine, E1 Monte, Encino, Granada Hills, Griffith, Huntington Park-State Street area, Kester, Laurel Canyon, Long Beach, Los Alamitos, Los Angeles--Broadway Manchester area, Los Angeles--Farmers Market area, Los Angeles--Veterans Administration area, Maywood, Mission Hills, North Hollywood--Valley Plaza area, North Hollywood--Valley Village area, Norwalk, Norwood Center, Orangehurst, Pacoima, Palos Verdes Peninsula, Panorama City, Perry, Preuss, Redondo Beach, Resada, Rosemead, San Gabriel, Santa Fe Springs, Somis, South E1 Monte, South Pasadena, Studio City, Sunkist, Tarzana, Terminal Island, Thousand Oaks, Westminster, Whittier, Van Nuys--Civil Center.

Intensity II: Pico Rivera, South Whittier.

17 October (P) Imperial Valley

Origin time: 224533.4

Epicenter: $\quad 33.10 \mathrm{~N} ., 115.55 \mathrm{~W}$.

Depth: $\quad 5 \mathrm{~km}$

Magnitude: $\quad 4.8 \mathrm{mb}(\mathrm{G}), 4.5 \mathrm{ML}(\mathrm{P})$, $5.0 \mathrm{ML}(\mathrm{B})$

Felt in the Imperial Valley (press report).

18 October (P) Southern California

Origin time: 042543.2

Epicenter: $\quad 33.93 \mathrm{~N} ., 118.65 \mathrm{~W}$.

Depth: $\quad 16 \mathrm{~km}$

Magnitude: $\quad 3.0 \mathrm{ML}(\mathrm{P})$

Felt at Pacific Palisades and in the San Fernando Valley (press report).

19 October (P) Southern California

Origin time: 122237.7

Epicenter: $\quad 34.20 \mathrm{~N} ., 117.53 \mathrm{~W}$.

Depth: $\quad 7 \mathrm{~km}$

Magnitude: $\quad 4.1 \mathrm{ML}(\mathrm{P}), 4.2 \mathrm{ML}(\mathrm{B})$

Intensity $\mathrm{V}$ :

Lytle Creek (hanging pictures fell, small objects moved, buildings creaked and shook, awakened and felt by all).

Intensity IV: A1ta Loma, Apple Valley, Azusa, Chino, Cla remont, Cucamonga, Devore, Etiwanda, Fawnskin, Fontana, Green Valley Lake, Lake Arrowhead, La Puente, Mt. Baldy, Norco, Ontario, Perris, Phelan, Pinon Hills, Pomona, Rancho Cucamonga 
(press report), Redlands, Rialto, Riverside, San Bernardino, San Dimas, Upland, Wrightwood.

Intensity III: Arcadia, Corona, San Bernardino--West Side, Victorville. Intensity II: Colton. Fe1t: Montclair.

23 October (B) Northern California

Origin time: 105537.9

Epicenter: $\quad 40.43 \mathrm{~N} ., 124.27 \mathrm{~W}$.

Depth: $\quad 19 \mathrm{~km}$

Magnitude: $\quad 4.0 \mathrm{ML}(\mathrm{B})$

Felt in the Scotia area (B).

24 October (P) Southern California

Origin time: 133250.0

Epicenter: $\quad 34.18 \mathrm{~N} ., 116.42 \mathrm{~W}$.

Depth: $\quad 8 \mathrm{~km}$

Magnitude: $\quad 3.4 \mathrm{ML}(\mathrm{P})$

Felt at Yucca Valley (P).

Intensity IV: Morongo Valley.

28 October (P) Owens Valley area

Origin time: 231225.7

Epicenter: $\quad 37.50 \mathrm{~N} ., 118.80 \mathrm{~W}$.

Depth: $\quad 5 \mathrm{~km}$

Magnitude: $\quad 3.0 \mathrm{ML}(\mathrm{P})$

Fe1t at Mammoth Lakes (P).

31 October (P) Imperial Valley

Origin time: 114346.4

Epicenter: $\quad 32.88 \mathrm{~N} ., 115.48 \mathrm{~W}$.

Depth: $\quad 5 \mathrm{~km}$

Magnitude: $\quad 3.4 \mathrm{ML}(\mathrm{P})$

Fe1t at Brawley and E1 Centro (P).

4 November (P) Imperial Valley

Origin time: 171330.8

Epicenter: $\quad 33.08 \mathrm{~N} ., 115.55 \mathrm{~W}$.

Depth: $\quad 5 \mathrm{~km}$

Magnitude: $\quad 3.6 \mathrm{ML}(\mathrm{P})$

Intensity IV: Brawley.

6 November (P) Southern California

Origin time: 043059.0

Epicenter: $\quad 32.92 \mathrm{~N} ., 116.20 \mathrm{~W}$.

Depth: $\quad 7 \mathrm{~km}$

Magnitude: $\quad 3.2 \mathrm{ML}(\mathrm{P})$

Intensity IV: Julian.

7 November (B) Owens Valley area

Origin time: 062724.0

Epicenter: $\quad 37.62$ N., 118.91 W.

Depth: $\quad 11 \mathrm{~km}$

Magnitude: $\quad 3.8 \mathrm{ML}(\mathrm{B}), 3.7 \mathrm{ML}(\mathrm{P})$

Felt at Mammoth Lakes and Lake Crowley (P).
9 November (B) Owens Valley area Origin time: 090052.8 Epicenter: $\quad 37.62 \mathrm{~N} ., 118.89 \mathrm{~W}$. Depth: $\quad 7 \mathrm{~km}$

Magnitude: $\quad 3.3 \mathrm{ML}(\mathrm{B}), 3.3 \mathrm{ML}(\mathrm{P})$

Felt at Mammoth Lakes (B).

9 November (B) Owens Valley area

Origin time: 101253.3

Epicenter: $\quad 37.61$ N., 118.90 W.

Depth: $\quad 5 \mathrm{~km}$

Magnitude: $\quad 4.0 \mathrm{ML}(\mathrm{B}), 4.0 \mathrm{ML}(\mathrm{P})$

Felt at Mammoth Lakes (B).

9 November (B) Owens Valley area

Origin time: 174658.3

Epicenter: $\quad 37.62 \mathrm{~N} ., 118.88 \mathrm{~W}$.

Depth: $\quad 14 \mathrm{~km}$

Magnitude: $\quad 4.0 \mathrm{ML}(\mathrm{B}), \quad 4.1 \mathrm{ML}(\mathrm{P})$

Felt at Mammoth Lakes (B).

9 November (B) Owens Valley area

Origin time: 175415.0

Epicenter: $\quad 37.60$ N., 118.88 W.

Depth: $\quad 3 \mathrm{~km}$

Magnitude: $\quad 4.3 \mathrm{ML}(\mathrm{B}), 4.4 \mathrm{ML}(\mathrm{P})$

Intensity IV: June Lake.

Intensity III: Big Creek.

Felt: Mammoth Lakes.

9 November (B) Owens Valley area

Origin time: $2104 \quad 49.2$

Epicenter: $\quad 37.62 \mathrm{~N} ., 118.90 \mathrm{~W}$.

Depth: $\quad 13 \mathrm{~km}$

Magnitude: $\quad 3.6 \mathrm{ML}(\mathrm{B}), 3.2 \mathrm{ML}(\mathrm{P})$

Felt at Mammoth Lakes (B).

9 November (B) Owens Valley area

Origin time: 222654.4

Epicenter: $\quad 37.62 \mathrm{~N} ., 118.90 \mathrm{~W}$.

Depth: $\quad 14 \mathrm{~km}$

Magnitude: $\quad 3.4 \mathrm{ML}(\mathrm{B}), 3.2 \mathrm{ML}(\mathrm{P})$

Felt at Mammoth Lakes (B).

9 November (B) Owens Valley area

Origin time: 225933.3

Epicenter: $\quad 37.63 \mathrm{~N} ., 118.90 \mathrm{~W}$.

Depth: $\quad 16 \mathrm{~km}$

Magnitude: $\quad 3.6 \mathrm{ML}(\mathrm{B}), 3.6 \mathrm{ML}(\mathrm{P})$

Felt at Mammoth Lakes (B).

10 November (B) Owens Valley area

Origin time: 094508.9

Epicenter: $\quad 37.62$ N., 118.91 W.

Depth: $\quad 17 \mathrm{~km}$

Magnitude: $\quad 4.0 \mathrm{ML}(\mathrm{B}), 4.2 \mathrm{ML}(\mathrm{P})$

Felt at Mammoth Lakes (B). 
14 November (B) Owens Valley area origin time: 010544.7

Epicenter: $\quad 37.61 \mathrm{~N} ., 118.92 \mathrm{~W}$.

Depth: $\quad 10 \mathrm{~km}$

Magnitude: $\quad 3.4 \mathrm{ML}(\mathrm{B}), 3.2 \mathrm{ML}(\mathrm{P})$

Felt at Mammoth Lakes (B).

15 November (B) Owens Valley area

Origin time: 205133.8

Epicenter: $\quad 37.61 \mathrm{~N} ., 118.87 \mathrm{~W}$.

Depth: $\quad 17 \mathrm{~km}$

Magnitude: $\quad 3.3 \mathrm{ML}(\mathrm{B}), 3.5 \mathrm{ML}(\mathrm{P})$

Felt at Mammoth Lakes (B).

16 November (B) Owens Valley a rea

Origin time: 214825.6

Epicenter: $\quad 37.60$ N., $118.87 \mathrm{~W}$.

Depth: $\quad 18 \mathrm{~km}$

Magnitude: $\quad 3.8 \mathrm{ML}(\mathrm{B}), 3.6 \mathrm{ML}(\mathrm{P})$

Felt at Mammoth Lakes (B).

17 November Southern California

Origin time: 0525

Epicenter: Not located.

Depth: None computed.

Magnitude: None computed.

Intensity III: Etiwanda.

20 November (B) Owens Valley area

Origin time: 172359.0

Epicenter: $\quad 37.61$ N., 118.88 W.

Depth: $\quad 14 \mathrm{~km}$

Magnitude: $\quad 4.2 \mathrm{ML}(\mathrm{B}), 4.2 \mathrm{ML}(\mathrm{P})$

Felt at Mammoth Lakes (B).

25 November (B) Owens Valley area

Origin time: 064700.1

Epicenter: $\quad 37.60$ N., 118.86 W.

Depth: $\quad 6 \mathrm{~km}$

Magnitude: $\quad 2.9 \mathrm{ML}(\mathrm{B})$

Felt at Mammoth Lakes (B).

26 November (B) Central California

Origin time: 124008.6

Epicenter: $\quad 37.86 \mathrm{~N} ., 121.99 \mathrm{~W}$.

Depth: $\quad 7 \mathrm{~km}$

Magnitude: $\quad 3.0 \mathrm{ML}(\mathrm{B})$

Felt at Danville (B).

26 November (B) Central California

Origin time: $\quad 124357.6$

Epicenter: $\quad 37.86$ N., 122.00 W.

Depth: $\quad 5 \mathrm{~km}$

Magnitude: $\quad 2.8 \mathrm{ML}(\mathrm{B})$

Felt at Danville (B).
28 November (P) Southern California

Origin time: $1053 \quad 18.0$

Epicenter: $\quad 33.97$ N., $118.65 \mathrm{~W}$.

Depth: $\quad 12 \mathrm{~km}$

Magnitude: $\quad 2.7 \mathrm{ML}(\mathrm{P})$

Felt at Woodland Hills (P).

29 November (P) Central California

Origin time: 150941.0

Epicenter: $\quad 35.63 \mathrm{~N} ., 118.38 \mathrm{~W}$.

Depth: $\quad 3 \mathrm{~km}$

Magnitude: $\quad 2.7 \mathrm{ML}(\mathrm{P})$

Felt at Lake Isabella (P).

2 December ( $P$ ) Southern California

Origin time: 004627.7

Epicenter: $\quad 32.63 \mathrm{~N} ., 116.02 \mathrm{~W}$.

Depth: $\quad 13 \mathrm{~km}$

Magnitude: $\quad 3.9 \mathrm{ML}(\mathrm{P})$

Felt in portions of Imperial and San Diego Counties.

Intensity III: Campo, Julian (Cuyamaca area).

Intensity II: Painted Gorge Valley.

2 December (P) Southern California

Origin time: 180921.1

Epicenter: $\quad 33.93 \mathrm{~N} ., 118.65 \mathrm{~W}$.

Depth: $\quad 7 \mathrm{~km}$

Magnitude: $\quad 2.7 \mathrm{ML}(\mathrm{P})$

Felt in West Los Angeles (P).

6 December (B) Owens Valley area

Origin time: 193238.9

Epicenter: $\quad 37.60 \mathrm{~N} ., 118.87 \mathrm{~W}$.

Depth: $\quad 15 \mathrm{~km}$

Magnitude: $\quad 4.2 \mathrm{ML}(\mathrm{B}), 4.3 \mathrm{ML}(\mathrm{P})$

Felt at Mammoth Lakes (B).

8 December (B) Owens Valley area

Origin time: 213852.4

Epicenter: $\quad 37.60 \mathrm{~N} ., 118.90 \mathrm{~W}$.

Depth: $\quad 16 \mathrm{~km}$

Magnitude: $\quad 4.3 \mathrm{ML}(\mathrm{B}), 4.3 \mathrm{ML}(\mathrm{P})$

Felt at Mammoth Lakes (B).

9 December (B) Owens Valley area

Origin time: 020816.8

Epicenter: $\quad 37.61 \mathrm{~N} ., 118.86 \mathrm{~W}$.

Depth: $\quad 14 \mathrm{~km}$

Magnitude: $\quad 3.5 \mathrm{ML}(\mathrm{B}), 3.5 \mathrm{ML}(\mathrm{P})$

Felt at Mammoth Lakes (B). 
11 December (B) Central California

Origin time: 120502.2

Epicenter: $\quad 37.74$ N., $122.13 \mathrm{~W}$.

Depth: $\quad 6 \mathrm{~km}$

Magnitude: $2.5 \mathrm{ML}(\mathrm{B})$

Felt at Castro Valley and East Oakland (B).

12 December (P) Baja California, Mexico

origin time: 213741.0

Epicenter: $\quad 32.20 \mathrm{~N} ., 116.23 \mathrm{~W}$.

Depth: $\quad 5 \mathrm{~km}$

Magnitude: $\quad 4.0 \mathrm{ML}(\mathrm{P})$

Felt in the Imperial Valley, California.

16 December (P) Southern California

Origin time: 060054.3

Epicenter: $\quad 33.97$ N., $118.67 \mathrm{~W}$.

Depth: $\quad 9 \mathrm{~km}$

Magnitude: $\quad 3.2 \mathrm{ML}(P)$

Felt in West Los Angeles and Pacific Palisades $(P)$.

16 December (B) Owens Valley area

Origin time: 062927.0

Epicenter: $\quad 37.59$ N., 118.86 W.

Depth: $\quad 2 \mathrm{~km}$

Magnitude: $\quad 3.6 \mathrm{ML}(\mathrm{B}), 3.6 \mathrm{ML}(\mathrm{P})$

Felt at Mammoth Lakes (B).

Intensity III: June Lake.

16 December (B) Owens Valley area

Origin time: 104415.8

Epicenter: $\quad 37.60$ N., 118.87 w.

Depth: $13 \mathrm{~km}$

Magnitude: $\quad 3.4 \mathrm{ML}(\mathrm{B}), 3.2 \mathrm{ML}(\mathrm{P})$

Felt at Mammoth Lakes (B).

17 December (B) Central California

Origin time: 065453.1

Epicenter: $\quad 37.06$ N., $121.50 \mathrm{~W}$.

Depth: $\quad 11 \mathrm{~km}$

Magnitude : $\quad 2.9 \mathrm{ML}$ (B)

Intensity IV: Residents awakened near the epicenter (B).

18 December (P) Southern California

Origin time: 115948.5

Epicenter: $\quad 34.07$ N., $117.15 \mathrm{~W}$.

Depth: $\quad 6 \mathrm{~km}$

Magnitude: $\quad 2.7 \mathrm{ML}(\mathrm{P})$

Intensity IV: Redlands

Felt: San Bernardino (P).

18 December ( $P$ ) Southern Californla

Origin time: 120016.5

Epicenter: $\quad 34.07 \mathrm{~N} ., 117.13 \mathrm{~W}$.

Depth: $\quad 2 \mathrm{~km}$

Magnitude: $\quad 2.9 \mathrm{ML}(\mathrm{P})$

Felt at Redlands and San Bernardino (P).

18 December ( $P$ ) Southern California

Origin time: 153713.8

Epicenter: $\quad 34.02 \mathrm{~N} ., 117.12 \mathrm{~W}$.

Depth: $\quad 8 \mathrm{~km}$

Magnitude: $\quad 3.3 \mathrm{ML}(\mathrm{P})$

Felt at Redlands and San Bernardino.

19 December (P) Southern California

Origin time: $\quad 181105.2$

Epicenter: $\quad 34.02$ N., 117.12 W.

Depth: $\quad 5 \mathrm{~km}$

Magnitude: $\quad 2.7 \mathrm{ML}(\mathrm{P})$

Felt at Redlands (P).

20 December (B) Northern California

Origin time: 050219.6

Epicenter: $\quad 38.80 \mathrm{~N} ., 122.80 \mathrm{w}$.

Depth: $\quad 4 \mathrm{~km}$

Magnitude: $\quad 3.0 \mathrm{ML}(\mathrm{B})$

Felt at Cobb (B).

20 December (B) Central California

Origin time: 122956.1

Epicenter: $\quad 37.59$ N., 122.37 W.

Depth: $\quad 15 \mathrm{~km}$

Magnit ude: $2.0 \mathrm{ML}(\mathrm{B})$

Felt at San Jose (B).

21 December (P) Imperial Valley area

Origin time: 204025.3

Epicenter: $\quad 32.78$ N., 115.38 W.

Depth: $\quad 5 \mathrm{~km}$

Magnitude: $\quad 4.5 \mathrm{mb}(G), 4.6 \mathrm{ML}(\mathrm{P})$

Intensity VI:

California-Imperial (large cracks in exterior walls, cracks in stone or brick fences, few windows cracked, light furniture moved, small objects overturned, hanging pictures out of place, felt by many).

Intensity $\mathrm{V}$ :

California--E1 Centro (few windows cracked, light furniture and small objects moved, felt by all).

Intensity IV:

Arizona--Somerton, Wellton, Yuma.

California--Bard, Calexico, Heber.

Intensity III:

Arizona--Gadsden, San Luis, Yuma Marine Corps Air Station.

California--Holtville, Plaster City, Ripley, Seeley. 
Intensity II:

California--Salton City.

Felt:

California--San Diego (P).

24 December (B) Central California

Origin time: 130940.1

Epicenter: $\quad 36.98 \mathrm{~N}$., $122.20 \mathrm{~W}$.

Depth: $\quad 8 \mathrm{~km}$

Magnitude: $\quad 3.8 \mathrm{ML}(\mathrm{B})$

Felt at Bonnie Doon, Boulder Creek, Felton, Monterey Bay, and Santa Cruz (B).

26 December (B) Owens Valley area

Origin time: 080904.4

Epicenter: $\quad 37.53$ N., 118.80 W.

Depth: $\quad 19 \mathrm{~km}$

Magnitude: $\quad 3.9 \mathrm{ML}(\mathrm{B})$

Felt at Mammoth Lakes (B).

28 December (B) Owens Valley area

Origin time: 032949.5

Epicenter: $\quad 37.66 \mathrm{~N} ., 118.87 \mathrm{~W}$.

Depth: $\quad 15 \mathrm{~km}$

Magnitude: $\quad 3.7 \mathrm{ML}(\mathrm{B})$

Felt at Mammoth Lakes (B).

31 December (P) Southern California

Origin time: 060340.3

Epicenter: $\quad 33.65$ N., $117.90 \mathrm{~W}$.

Depth: $\quad 7 \mathrm{~km}$

Magnitude: $\quad 2.7 \mathrm{ML}(\mathrm{P})$

Felt at Costa Mesa (P).

31 December (B) Western Nevada

Origin time: 082751.9

See Nevada listing.

California--0f $f$ the coast

3 February (B) Northern California

Origin time: 095816.0

Epicenter: $\quad 40.92$ N., $124.42 \mathrm{~W}$.

Depth: $22 \mathrm{~km}$

Magnitude: $\quad 5.2 \mathrm{mb}(G), 4.6 \mathrm{MS}(G)$,

$$
5.2 \text { ML(B) }
$$

The press reported numerous store windows broken and merchandise spilled from shelves in the downtown areas of both Arcata and Eureka. Police responded to a number of burglar alarms set off by the quake. There was no damage to bridges reported. The earthquake was felt over an area of approximately $11,200 \mathrm{sq} \mathrm{km}$ of $\mathrm{Del}$

Norte, Humboldt, Mendocino, Siskiyou, and Trinity Counties, California, and in southwestern Oregon near the California border ( $f$ ig. 23).

Intensity VII:

California--

Eureka (windows broken in office supply, furniture, insurance, and variety stores along Fifth street in the downtown area. Many stores had merchandise spilled from shelves. The Safeway store at $930 \mathrm{~W}$. Harris St. had an estimated $\$ 2000$ damage due to broken glassware. Other stores in the area suffered the same type of damage. Ceiling tiles and light fixtures fell in some stores. The county courthouse had some broken windows on the second floor and cracks appeared on freshly painted walls. Three broken water malns were reported and a leak in a 6-inch low-pressure gas line. A city building inspector noted some additional damage to previously damaged masonry buildings on Fourth Street. A chimney on Myrtle Avenue fell with part of it crashing through the roof and part falling on a vehicle parked alongside--press report. There were reports of hairline cracks in exterior walls, cracked plaster and drywall, cracked and broken chimneys, felt by and awakened all, trees and bushes shaken moderately, and standing and moving vehicles rocked slightly.).

Intensity VI:

California--

Arcata (The press reported store windows broke in the downtown plaza and that some stores had shelves nearly emptied by the shaking. Liquor stores had considerable damage due to glassware falling and breaking. Other reports consisted of cracked plaster and drywall, small objects overturned and fell, hanging pictures fell, felt by a11 and many awakened.).

Intensity V:

California--

Fields Landing (furniture shifted, small objects overturned, hanging pictures swung, felt by and awakened many).

Fortuna (small objects fell; windows, doors, and dishes rattled; felt by and awakened many).

Trinidad (small objects fell; windows, doors, and dishes rattled; felt by and awakened many).

Westhaven (light furniture and small objects shifted, hanging pictures swung, felt by and awakened a11). 


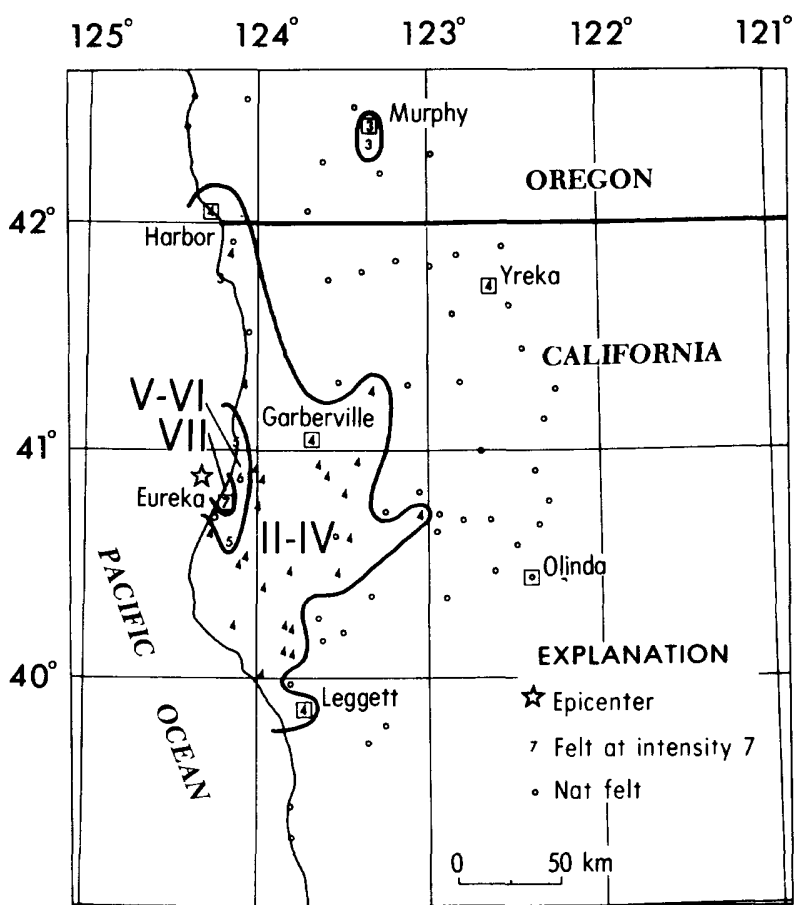

FIGURE 23.--Isoseismal map for the northern California earthquake of 3 February 1979, 095816.0 UTC. Roman numerals represent Modified Mercalli intensities between isoseismals; Arabic numerals are used to represent these intensities at specific sites.

California--of $f$ the coast--Continued

Intensity IV:

California--Blue Lake, Bridgeville, Burnt Ranch, Carlotta, Denny, Forks of Salmon, Fort Dick, Fortuna, Garberville, Honeydew, Hoopa, Hyampon, Junction City, Kneeland, Korbe1, Leggett, Loleta, Mad River, Miranda, Orick, Phillipsville, Redcrest, Redway, Rio Dell, Salyer, Scotia, Whitehorn, Willow Creek, Yreka. Oregon--Brookings, Harbor.

Intensity III:

California--Crescent City.

Oregon--Grants Pass, Murphy.

18 March (B) Northern California

Origin time: 161831.2

Epicenter: $\quad 40.34$ N., 124.71 W.

Depth: $\quad 10 \mathrm{~km}$

Magnitude: $\quad 4.0 \mathrm{mb}(G), 4.1 \mathrm{ML}(\mathrm{B})$

Intensity IV: Ferndale (press report), Rio

Dell, Scotia (press report)

Intensity III: Miranda.
California--off the coast--Continued

8 August (B) Northern California

Origin time: 102457.6

Epicenter: $\quad 40.31$ N., $124.68 \mathrm{~W}$

Depth: $\quad 29 \mathrm{~km}$

Magnitude: $\quad 3.8 \mathrm{mb}(\mathrm{G}), 4.3 \mathrm{ML}(\mathrm{B})$

Intensity IV: Blocksburg, Honey Dew, Leggett, Miranda, Scotia.

Intensity III: Zenia.

24 October (B) Northern California

Origin time: 152350.6

Epicenter: $\quad 40.43 \mathrm{~N} ., 124.70 \mathrm{~W}$.

Depth: $\quad 24 \mathrm{~km}$

Magnitude: $\quad 4.8 \mathrm{mb}(G), 4.5 \mathrm{ML}(\mathrm{B})$

Intensity IV: Arcata, Bayside, Eureka, Fields Landing, Garberville, Loleta, Miranda, Phillipsville, Rio Dell, Weott.

Intensity III: Blue Lake, Hoopa, Hydesville, Korbel, Redway, Scotia.

Intensity II: Car1otta.

Felt: Ferndale, Fortuna.

\section{Color ado}

6 January (G) Central Colorado

Origin time: 015855.3

Epicenter: $\quad 38.96 \mathrm{~N} ., 105.16 \mathrm{~W}$.

Depth: $\quad 5 \mathrm{~km}$

Magnitude: $\quad 2.9 \mathrm{ML}(G), 3.3 \mathrm{mbLg}(\mathrm{T})$

Intensity VI: Cripple Creek (plaster cracked; light furniture shifted; small objects fell; hanging pictures swung; windows, doors and dishes rattled; felt by many).

Intensity V: Florissant (Thirteen reports were received from Florissant and its adjoining rural areas which used the post of fice as a mailing address. Four were evaluated at intensity $V$ and nine at intensity IV. Some of the effects listed were small and heavy furniture shifted, small objects and dishes fell, hanging pictures swung, windows and dishes rattled.

Intensity IV: Cascade, Divide (13 reports), Divide (Broken Wheel Village), Divide (Crescent Ranch), Divide (Highland Lakes), Guffey, Green Mountain Falls (ice cracked on two reservolrs on Pikes Peak Toll Road), Lake George, Royal Gorge, Victor, Woodland Park (six reports). Intensity III: Pine.

Intensity II: Colorado Springs, Hartsel.

19 March (G) Northwestern Colorado

Origin time: 145929.7

Epicenter: $\quad 40.18 \mathrm{~N} ., 108.90 \mathrm{~W}$.

Depth: $2 \mathrm{~km}$

Magnitude: $\quad 3.1 \mathrm{ML}(\mathrm{G}), 3.3 \mathrm{ML}(\mathrm{U})$

Intensity IV: Rangely. 
Colorado--Continued

29 March (G) Northwestern Colorado

origin time: 220713.3

Epicenter: $\quad 40.27 \mathrm{~N} ., 108.81 \mathrm{~W}$.

Depth: $2 \mathrm{~km}$

Magnitude: $\quad 2.6 \mathrm{ML}(\mathrm{G})$

Intensity IV: Rangely (1ight furniture and small objects shifted; windows, doors, and dishes rattled; felt by many).

Connecticut

30 December ( $\mathrm{J}$ ) Southeastern New York

Origin time: 141511.9

See New York listing.

\section{Georg1a}

13 August (G) Southeas tern Tennessee

Origin time: 051856.0

See Tennessee listing.

26 August (G) Northwestern South Carolina

Origin time: 013145.0

See South Carolina listing.

\section{Hawa il}

2 January (H) North of Maui Island

Origin time: 063125.2

Epicenter: $20.95 \mathrm{~N} ., 156.06 \mathrm{~W}$.

Depth: $\quad 12 \mathrm{~km}$

Magnitude: $\quad 3.5 \mathrm{ML}(\mathrm{H})$

Felt on Maui and Oahu Islands.

Intensity III: Haleakala National Park Headquarters, Hana, Kihei Heights, Kula, Maalaea, Makawao, Makena, Maui Meadows, Olinda, Pukalani, Ulupalakua, (all from press reports).

Intensity II: Windward of Oahu Island.

15 January (H) Island of Hawai1

Origin time: 071236.5

Epicenter: $\quad 19.37 \mathrm{~N} ., 155.08 \mathrm{~W}$.

Depth: $\quad 9 \mathrm{~km}$

Magnitude: $\quad 3.1 \mathrm{ML}(\mathrm{H})$

Intensity III: Hilo.

20 January (H) Island of Hawaii

Origin time: 001915.4

Epicenter: $\quad 19.33 \mathrm{~N} ., 155.20 \mathrm{~W}$.
Hawa1i--Cont inued

Depth: $\quad 10 \mathrm{~km}$

Magnitude: $\quad 3.0 \mathrm{ML}(\mathrm{H})$

Intensity III: Pahala, Volcano.

3 February (H) Island of Hawaii

Origin time: 124904.3

Epicenter: $\quad 19.34$ N., $155.20 \mathrm{~W}$.

Depth: $\quad 9 \mathrm{~km}$

Magnitude: $\quad 3.5 \mathrm{ML}(\mathrm{H})$

Intensity III: Mountain View, Volcano.

14 February (H) Island of Hawaii

Origin time: 025251.0

Epicenter: $\quad 19.34 \mathrm{~N} ., 155.07 \mathrm{~W}$.

Depth: $\quad 9 \mathrm{~km}$

Magnitude: $\quad 3.9 \mathrm{ML}(\mathrm{H})$

Intensity IV: Hilo.

Intensity III: Hamakua, Puna, Volcano.

Intensity II: Ninole.

18 February (H) Island of Hawail

Origin time: 144544.1

Epicenter: $\quad 19.45 \mathrm{~N} ., 155.48 \mathrm{~W}$.

Depth: $\quad 11 \mathrm{~km}$

Magnitude: $\quad 3.2 \mathrm{ML}(\mathrm{H})$

Intensity III: Pahala.

2 March (H) Island of Hawail

Origin time: 122718.2

Epicenter: $\quad 19.33 \mathrm{~N} ., 155.11 \mathrm{~W}$.

Depth: $\quad 10 \mathrm{~km}$

Magnitude: $\quad 3.6 \mathrm{ML}(\mathrm{H})$

Intensity III: Hilo, Papaikou, Mountain

view.

Intensity II: Volcano.

6 March (H) Island of Hawaii

Origin time: 064158.6

Epicenter: $\quad 19.35 \mathrm{~N} ., 155.10 \mathrm{~W}$.

Depth: $9 \mathrm{~km}$

Magnitude: $\quad 3.3 \mathrm{ML}(\mathrm{H})$

Intensity III: Hilo, Volcano.

6 March (H) Island of Hawaif

Origin time: 125950.1

Epicenter: $19.33 \mathrm{~N} ., 155.12 \mathrm{~W}$.

Depth: $\quad 10 \mathrm{~km}$

Magnitude: $\quad 3.7 \mathrm{ML}(\mathrm{H})$

Intensity III: Greenwood, Hilo.

Intensity II: Volcano.

6 March (H) Island of Hawail

Origin time: 150758.5

Epicenter: $\quad 19.52 \mathrm{~N} ., 155.27 \mathrm{~W}$.

Depth: $27 \mathrm{~km}$

Magnitude: $\quad 5.0 \mathrm{mb}(G), 4.3 \mathrm{MS}(G)$,

$4.7 \mathrm{ML}(\mathrm{H})$

Felt on the islands of Hawail, Maui, and Oahu (press report).

Intensity VI: Hilo. 
Intensity V: Hamakua, Kona, Puna, Volcano. Intensity IV: Captain Cook, Honokaa, Honomu, Kalaupapa, Kamuela, Kapaau, Kealakekua, Keeau, Kohala, Kualapuu, Kurt is town, Laupahoehoe, Mountain View, Naalehu, Ninole, Ookala, Paauhau, Pahala, Pahoa, Papaaloa, Pepeeko.

10 March (H) Island of Hawaii

Origin time: 135514.6

Epicenter: 19.33 N., 155.11 W.

Depth: $\quad 10 \mathrm{~km}$

Magnitude: $\quad 4.8 \mathrm{mb}(G), 4.5 \mathrm{ML}(\mathrm{H})$

Intensity IV: Hilo, Puna, Volcano.

Intensity III: Hawalian Ocean View Estates, Kona.

10 March (H) Island of Hawail

Origin time: 145449.3

Epicenter: $\quad 19.20$ N., 155.68 W.

Depth: $\quad 7 \mathrm{~km}$

Magnitude: $\quad 3.3 \mathrm{ML}(\mathrm{H})$

Intensity III: Hawailan Ocean View Estates, Kal1.

11 March (H) Island of Hawa11

Origin time: 101456.5

Epicenter: $\quad 19.29$ N., 159.10 W.

Depth: $\quad 11 \mathrm{~km}$

Magnitude: $\quad 3.4 \mathrm{ML}(\mathrm{H})$

Intensity III: Hilo, Keaau.

12 March (H) Island of Hawail

Origin time: 032805.2

Epicenter: $\quad 19.52 \mathrm{~N} ., 155.28 \mathrm{~W}$.

Depth: $\quad 24 \mathrm{Km}$

Magnit ude: $\quad 3.4 \mathrm{ML}(\mathrm{H})$

Intensity III: Volcano.

13 March (H) Island of Hawal1

Origin time: 195708.8

Epicenter: $\quad 19.35 \mathrm{~N} ., 155.43 \mathrm{~W}$.

Depth: $\quad 11 \mathrm{~km}$

Magnitude: $\quad 3.5 \mathrm{ML}(\mathrm{H})$

Intensity III: Hawailan Ocean View Estates, Pahala.

Intensity II: Hilo, Volcano.

15 March (H) Island of Hawali

Origin time: 185501.1

Epicenter: $\quad 19.37$ N., 155.10 W.

Depth: $\quad 1 \mathrm{~km}$

Magnitude: $\quad 3.4 \mathrm{ML}(\mathrm{H})$

Intensity III: Hilo.

15 March (H) Island of Hawail

Origin time: 201014.7

Epicenter: $\quad 19.38$ N., 155.10 W.

Depth: $\quad 0 \mathrm{~km}$

Magnitude: $\quad 3.4 \mathrm{ML}(\mathrm{H})$

Intensity III: Hilo.
20 March (H) Island of Hawaii

Origin time: 230309.9

Epicenter: $\quad 19.35 \mathrm{~N} ., 155.13 \mathrm{~W}$.

Depth: $\quad 9 \mathrm{~km}$

Magnitude: $\quad 3.3 \mathrm{ML}(\mathrm{H})$

Intensity III: Volcano.

22 March (H) Island of Hawali

Origin time: 064659.8

Epicenter: $20.10 \mathrm{~N} ., 155.84 \mathrm{~W}$.

Depth: $\quad 16 \mathrm{~km}$

Magnftude: $\quad 4.5 \mathrm{ML}(\mathrm{H}), 4.6 \mathrm{mb}(\mathrm{G})$

Intensity V: Hawi, Kapaau.

Intensity IV: Honokaa, Honomu, Kamuela,

Kohala, Laupahoehoe, Papaaloa, Ookala. Intensity III: Hilo, Kona, Peepeekeo, Vo1cano.

Intensity II: Hakalau, Ninole.

26 March (H) Island of Hawaii

Origin time: 234125.5

Epicenter: $\quad 19.35$ N., 155.14 W.

Depth: $\quad 7 \mathrm{~km}$

Magnitude: $\quad 3.2 \mathrm{ML}(\mathrm{H})$

Intensity III: Hilo, Hawaii Volcanoes National Park (press report), Volcano.

28 March (H) Island of Hawaii

Origin time: 073009.8

Epicenter: $\quad 20.09$ N., 155.83 W.

Depth: $\quad 12 \mathrm{~km}$

Magnitude: $\quad 4.9 \mathrm{ML}(\mathrm{H})$

Intensity V: Kamuela.

Intensity IV: Holualoa, Honokaa, Kawaihae, Kohala, Kona, Laupahoe hoe

Intensity III: Hilo, Volcano.

28 March (H) Island of Hawaii

Origin time: 073444.9

Epicenter: $\quad 20.07$ N., $155.82 \mathrm{~W}$.

Depth: $\quad 10 \mathrm{~km}$

Magnitude: $\quad 3.1 \mathrm{ML}(\mathrm{H})$

Intensity III: Kamuela.

Intensity II: Honokaa, Kohala.

28 March (H) Island of Hawaii

Origin time: 155450.6

Epicenter: $\quad 19.36 \mathrm{~N} ., 155.08 \mathrm{~W}$.

Depth: $\quad 9 \mathrm{~km}$

Magnitude: $\quad 3.0 \mathrm{ML}(\mathrm{H})$

Intensity III: Hilo.

30 March (G) Southwest of Oahu

Origin time: 090640.7

Eplcenter: $\quad 20.65$ N., 158.82 W.

Depth: $\quad 19 \mathrm{~km}$

Magnitude: $\quad 4.7 \mathrm{mb}(\mathrm{G}), 3.9 \mathrm{MS}(\mathrm{G})$,

Intensity $V$ :

$$
5.5 \mathrm{ML}(\mathrm{H})
$$

Oahu--

Kaimuki (light furniture and small 
objects moved; hanging pictures swung; windows, doors, and dishes rattled; felt by many).

Pearl City (light furniture and small objects moved; few windows cracked; pendulum clocks stopped; liquid spilled from small containers; felt by many).

Intensity IV:

Hawaii--Hawl, Honomu, Papaikou.

Kauai--Kealia, Koloa, Lawai, Lihue.

Maui--Hoolehua, Kualapuu.

Oahu--Alea, Hickman AFB, Honolulu, Hono-

lulu International Airport, Kaaawa,

Kailua, Waimanalo, Waimea, Wainae.

Intensity III:

Kaua1--Kekaha.

Oahu--University of Hawaii, Waikiki.

30 March (H) Island of Hawaif

Origin time: 225621.1

Epicenter: $\quad 20.06 \mathrm{~N} ., 155.83$ W.

Depth: $22 \mathrm{~km}$

Magnitude: $\quad 3.1 \mathrm{ML}(\mathrm{H})$

Intensity III: Spencer Beach Park.

5 April (H) Island of .Hawaii

Origin time: 061458.7

Epicenter: $\quad 19.35$ N., 155.02 W.

Depth: $\quad 7 \mathrm{~km}$

Magnitude: $\quad 3.3 \mathrm{ML}(\mathrm{H})$

Intensity III : H110.

14 April (H) Island of Hawail

Origin time: 133112.7

Epicenter: $\quad 19.40$ N., 155.27 W.

Depth: $\quad 5 \mathrm{~km}$

Magnitude: $\quad 3.4 \mathrm{ML}(\mathrm{H})$

Intensity III: Hawa1i Volcanoes National

Park, Volcano.

17 April (H) Island of Hawaii

Origin time: 062953.9

Epicenter: $\quad 19.26 \mathrm{~N} ., 155.40 \mathrm{~W}$.

Depth: $\quad 47 \mathrm{~km}$

Magnitude: $\quad 3.6 \mathrm{ML}(\mathrm{H})$

Intensity III: Hawaiian Ocean View Estates, Kona, Pahala.

Intensity II: Ainaloa, Mountain View, Volcano.

11 May (H) Island of Hawa11

Origin time: 235937.3

Epicenter: $\quad 19.34$ N., 155.07 W.

Depth: $\quad 9 \mathrm{~km}$

Magni tude: $\quad 3.3 \mathrm{ML}(\mathrm{H})$

Intensity III: Glenwood, Hilo.

17 May (H) Island of Hawai1

origin time: 153052.3

Epicenter: $\quad 19.47$ N., 155.40 W.

Depth:

$10 \mathrm{~km}$
Magnitude: $\quad 3.4 \mathrm{ML}(\mathrm{H})$

Intensity III: Volcano.

22 May (H) Island of Hawa 1i

Origin time: 074226.2

Eplcenter: $\quad 19.33 \mathrm{~N} ., 155.20 \mathrm{~W}$.

Depth: $\quad 9 \mathrm{~km}$

Magnitude: $\quad 3.2 \mathrm{ML}(\mathrm{H})$

Intensity II: Volcano.

25 May (H) Island of Hawaii

Origin time: 022606.1

Epicenter: $\quad 19.38 \mathrm{~N} ., 155.25 \mathrm{~W}$.

Depth: $\quad 3 \mathrm{~km}$

Magnitude: $\quad 3.2 \mathrm{ML}(\mathrm{H})$

Intensity III: Hawaii Volcanoes National Park, Volcano.

29 May (H) Island of Hawa11

Origin time: 045033.8

Epicenter: $\quad 19.37$ N., $155.08 \mathrm{~W}$.

Depth: $\quad 9 \mathrm{~km}$

Magnitude: $\quad 3.0 \mathrm{ML}(\mathrm{H})$

Intensity III: Glenwood.

30 May (H) Island of Hawa11

Origin time: 034355.4

Epicenter: $\quad 19.37 \mathrm{~N} ., 155.21 \mathrm{~W}$.

Depth: $\quad 7 \mathrm{~km}$

Magnitude: $\quad 3.0 \mathrm{ML}(\mathrm{H})$

Intens1ty III: Hawa1i Volcanoes National Park, Volcano.

30 May (H) Island of Hawa11

Origin time: 034455.0

Epicenter: $\quad 19.37$ N., 155.21 W.

Depth: $\quad 5 \mathrm{~km}$

Magnitude: $\quad 3.1 \mathrm{ML}(\mathrm{H})$

Intens 1ty III: Hawa1i Volcanoes National Park, Volcano.

30 May (H) Island of Hawa11

Origin time: 034807.5

Epicenter: $\quad 19.37$ N., 155.22 W.

Depth: $\quad 0 \mathrm{~km}$

Magnitude: $\quad 3.1 \mathrm{ML}(\mathrm{H})$

Intensity III: Hawail Volcanoes National Park, Volcano.

30 May (H) Island of Hawa11

origin time: 035217.0

Epicenter: $\quad 19.36$ N., $155.22 \mathrm{~W}$.

Depth: $\quad 7 \mathrm{~km}$

Magnitude: $\quad 3.2 \mathrm{ML}(\mathrm{H})$

Intensity III: Hawail Volcanoes National Park, Volcano.

5 June (H) Island of Hawa11

Origin time: 221636.5

Epicenter: $\quad 19.36 \mathrm{~N} ., 155.08 \mathrm{~W}$.

Depth: $\quad 9 \mathrm{~km}$

Magnitude: $\quad 3.1 \mathrm{ML}(\mathrm{H})$ 
Intensity III: Kalalua.

Intensity II: Kalapana.

20 June (H) Island of Hawa1t

Origin time: 011738.3

Epicenter: $\quad 19.33 \mathrm{~N} ., 155.18 \mathrm{~W}$.

Depth: $\quad 10 \mathrm{~km}$

Magnitude: $\quad 3.2 \mathrm{ML}(\mathrm{H})$

Intensity III: Hilo, Volcano.

27 June (H) Island of Hawail

Origin time: 074759.8

Epicenter: $\quad 19.48 \mathrm{~N} ., 155.87 \mathrm{~W}$.

Depth: $\quad 10 \mathrm{~km}$

Magnitude: $\quad 3.4 \mathrm{ML}(\mathrm{H})$

Intensity III: Kona.

$3 \mathrm{July}(\mathrm{H})$ Island of Hawa11

0rigin time: 044244.8

Epicenter: $\quad 19.40$ N., 155.45 W.

Depth: $\quad 11 \mathrm{~km}$

Magnitude: $\quad 3.3 \mathrm{ML}(\mathrm{H})$

Intensity IV: Ahualoa

Intens1ty III: Glenwood, Honokaa, Volcano.

5 July (H) Island of Hawa11

Origin time: 032715.9

Epicenter: $\quad 19.35$ N., $155.13 \mathrm{~W}$.

Depth: $\quad 9 \mathrm{~km}$

Magnitude: $\quad 3.4 \mathrm{ML}(\mathrm{H})$

Intensity III: Hawa11 Volcanoes National Park.

$16 \mathrm{July}(\mathrm{H})$ Island of Hawail

origin time: 024207.3

Epicenter: $\quad 19.38 \mathrm{~N} ., 155.09 \mathrm{~W}$.

Depth: $\quad 1 \mathrm{~km}$

Magnitude: $\quad 3.6 \mathrm{ML}(\mathrm{H})$

Intensity IV: Hilo, Puna.

$16 \mathrm{July}$ (H) Island of Hawaif

Origin time: 141315.7

Epicenter: $\quad 19.40$ N., $155.03 \mathrm{~W}$.

Depth: $\quad 9 \mathrm{~km}$

Magnitude: $\quad 3.5 \mathrm{ML}(\mathrm{H})$

Intensity III: Ainaloa, Kurt is town.

$21 \mathrm{July}$ (H) Island of Hawai1

Origin time: 092230.2

Epicenter: $\quad 19.41 \mathrm{~N} ., 135.46 \mathrm{~W}$.

Depth: $\quad 11 \mathrm{~km}$

Magnitude: $\quad 3.6 \mathrm{ML}(\mathrm{H})$

Intensity IV: Pahala.

$25 \mathrm{July}(\mathrm{H})$ Is 1 and of Hawail

Origin time: 040738.3

Epicenter: $\quad 19.33 \mathrm{~N} ., 155.14 \mathrm{~W}$.

Depth: $\quad 10 \mathrm{~km}$

Magnitude: $\quad 3.5 \mathrm{ML}(\mathrm{H})$

Intensity III: Volcano.

26 July (H) Island of Hawali Origin time: 195041.6
Epicenter: $\quad 19.76$ N., 155.97 W.

Depth: $\quad 20 \mathrm{~km}$

Magnitude: $\quad 3.6 \mathrm{ML}(\mathrm{H})$

Intensity III: Holualoa, Kealakekua.

27 July (H) Island of Hawaif

Origin time: 185633.6

Epicenter: $\quad 19.33 \mathrm{~N} ., 155.13 \mathrm{~W}$.

Depth: $\quad 9 \mathrm{~km}$

Magnitude: $\quad 3.5 \mathrm{ML}(\mathrm{H})$

Intensity IV: Hilo.

31 July (H) Island of Hawa11

Origin time: 133051.3

Epicenter: $\quad 19.47$ N., $155.43 \mathrm{~W}$.

Depth: $\quad 12 \mathrm{~km}$

Magnitude: $\quad 4.3 \mathrm{ML}(\mathrm{H}), 4.5 \mathrm{mb}(\mathrm{G})$

Intensity V: Pahala.

Intensity IV: Kona, Puna Areas, Walmea.

Intensity III: Hamakua, Hawa1i Volcanoes

National Park, Hawi, Hilo, Volcano.

1 August (H) Is land of Hawail

Origin time: $16 \quad 14 \quad 11.8$

Epicenter: $\quad 19.39 \mathrm{~N} ., 155.28 \mathrm{~W}$.

Depth: $\quad 3 \mathrm{~km}$

Magnitude: $\quad 3.0 \mathrm{ML}(\mathrm{H})$

Intensity III: Hawa11 Volcanoes National Park, Volcano.

3 August (H) Island of Hawali

Origin time: 133006.3

Epicenter: $\quad 19.33 \mathrm{~N} ., 155.21 \mathrm{~W}$.

Depth: $\quad 10 \mathrm{~km}$

Magnitude: $\quad 3.3 \mathrm{ML}(\mathrm{H})$

Intensity III: Hawa11 Volcanoes National Park, Mountaln Vlew, Volcano.

6 August (H) Island of Hawa11

Origin time: 030334.8

Epicenter: $\quad 19.28 \mathrm{~N} ., 155.54 \mathrm{~W}$.

Depth: $\quad 10 \mathrm{~km}$

Magnitude: $\quad 3.5 \mathrm{ML}(\mathrm{H})$

Intensity IV: Kapapala, Pahala.

Intensity III: Kona, Volcano.

13 August (H) Island of Hawa11

Origin time: 160340.6

Epicenter: $\quad 19.30 \mathrm{~N} ., 155.26 \mathrm{~W}$.

Depth: $\quad 10 \mathrm{~km}$

Magnitude: $\quad 3.4 \mathrm{ML}(\mathrm{H})$

Intensity III: Glenwood, Mountain View, Volcano.

14 August (H) Is land of Mau1

Origin time: 125142.2

Epicenter: $\quad 20.82 \mathrm{~N} ., 156.29 \mathrm{~W}$.

Depth: $\quad 24 \mathrm{~km}$

Magnitude: $\quad 4.5 \mathrm{ML}(\mathrm{H}), 4.1 \mathrm{mb}(\mathrm{G})$

Felt in Kahoolawe, Lanai, Maui, Molokai, and Oahu Islands. Most strongly felt on the eastern half of Maul Island. 
Intensity V:

Maui Island--

Haliimaile--hanging pictures fell; windows, doors, and dishes rattled; felt by and awakened many.

Kahului--shook one house so strongly the owner thought the house would fall down (press report).

Kula.

Makawao-house rattled and shook back and forth (press report).

olinda-house rattled and shook (press report).

Intensity IV:

Hawaif Island--Captain Cook, Honokaa, Pahala, Volcano.

Maui Island--Hoolehua, Kihe1, Kualapuu, Kula, Lahaina, Lanai City, Makawao, Pukalani, Waikapu, Wailuku.

Oahu Island--Aiea.

Intensity III:

Hawa Ii Island-Hamakua District, Kohala District, Papaikou.

Kahoolawe Island (press report).

Lanai Island.

Maui Island--Hana.

Molokai Island.

Oahu Island--Honolulu.

16 August (H) Island of Hawaii

Origin time: 230419.4

Epicenter: $\quad 19.38 \mathrm{~N} ., 155.47 \mathrm{~W}$.

Depth: $\quad 11 \mathrm{~km}$

Magnitude: $\quad 3.9 \mathrm{ML}(\mathrm{H})$

Intensity IV: Kapapala.

Intensity III: Hawaii Volcanoes National

Park, Hawai ian Oce anview Estates, Mauna

Loa Observatory.

Intensity II: Papaikou.

26 August (H) Island of Hawa11

Origin time: $0708 \quad 14.6$

Epicenter: $\quad 19.35$ N., 155.22 W.

Depth: $\quad 10 \mathrm{~km}$

Magnitude: $\quad 3.3 \mathrm{ML}(\mathrm{H})$

Intensity II: Papaikou, Volcano.

28 August (H) Island of Hawaii

Origin time: 152159.1

Epicenter: $\quad 19.31 \mathrm{~N} ., 155.22 \mathrm{~W}$.

Depth: $\quad 11 \mathrm{~km}$

Magnitude: $\quad 3.5 \mathrm{ML}(\mathrm{H})$

Intensity III: Glenwood, Hawail Volcanoes

National Park, Hilo, Mountain View.

28 August (H) Island of Hawail

Origin time: 154724.8

Epicenter: $\quad 19.32 \mathrm{~N} ., 155.22 \mathrm{~W}$.

Depth: $\quad 11 \mathrm{~km}$

Magnitude: $\quad 3.4 \mathrm{ML}(\mathrm{H})$

Intensity III: Glenwood, Hawaif Volcanoes

National Park, Hilo, Mountain View.
28 August (H) Island of Hawaii

Origin time: 165513.2

Epicenter: $\quad 19.31 \mathrm{~N} ., 155.22 \mathrm{~W}$.

Depth: $\quad 11 \mathrm{~km}$

Magnitude: $\quad 3.8 \mathrm{ML}(\mathrm{H})$

Intensity III: Glenwood, Hawaii Volcanoes National Park, Hilo, Mountain View Volcano.

1 September (H) Island of Hawa 11 Origin time: 221633.5

Epicenter: $\quad 19.37$ N., 155.08 W.

Depth: $\quad 10 \mathrm{~km}$

Magnitude: $\quad 3.8 \mathrm{ML}(\mathrm{H})$

Intensity IV: Hilo, Kalapana.

Intensity III: 01aa, Pahoa, Volcano.

4 September (H) Island of Hawafi

Origin time: 113009.2

Epicenter: $\quad 19.74 \mathrm{~N} ., 156.02 \mathrm{~W}$.

Depth: $\quad 9 \mathrm{~km}$

Magnitude: $\quad 3.2 \mathrm{ML}(\mathrm{H})$

Intensity IV: Kailua.

6 September (H) Island of Hawa ii Origin time: 122448.0

Epicenter: $\quad 19.33 \mathrm{~N}, 155.12 \mathrm{~W}$.

Depth: $\quad 10 \mathrm{~km}$

Magnitude: $\quad 3.4 \mathrm{ML}(\mathrm{H})$

Intensity III: Volcano.

Intensity II: Papaikou.

8 September (H) Island of Hawaii

Origin time: 233442.2

Epicenter: $\quad 19.32 \mathrm{~N} ., 155.23 \mathrm{~W}$.

Depth: $\quad 11 \mathrm{~km}$

Magnitude: $\quad 3.4 \mathrm{ML}(\mathrm{H})$

Intensity III: Alnaloa, Volcano.

Intensity II: Pepeekeo.

14 September (H) Island of Hawaii

Origin time: 143217.4

Epicenter: $\quad 19.39 \mathrm{~N} ., 155.28 \mathrm{~W}$.

Depth: $\quad 3 \mathrm{~km}$

Magnitude: $\quad 3.0 \mathrm{ML}(\mathrm{H})$

Intensity III: Hawail Volcanoes National Park, Volcano.

14 September (H) Island of Hawaii

Origin time: 173518.7

Epicenter: $\quad 19.33$ N., 155.20 W.

Depth: $\quad 10 \mathrm{~km}$

Magnitude: $\quad 3.2 \mathrm{ML}(\mathrm{H})$

Intensity III: Hilo, Volcano.

15 September (H) Island of Hawaif

origin time: 013148.0

Epicenter: $\quad 19.35$ N., $155.82 \mathrm{~W}$.

Depth:

$11 \mathrm{~km}$

Magnitude: $\quad 3.8 \mathrm{ML}(\mathrm{H})$

Intensity IV: Honaunau, Kealakekua. 
16 September (H) Island of Hawail

Origin time: 195136.7

Epicenter: $\quad 19.40 \mathrm{~N} ., 155.04 \mathrm{~W}$.

Depth: $\quad 9 \mathrm{~km}$

Magnitude: $\quad 3.2 \mathrm{ML}(\mathrm{H})$

Intensity III: Hilo.

21 September (H) Island of Hawaii

Origin time: 112924.1

Epicenter: $\quad 19.33 \mathrm{~N} ., 155.20 \mathrm{~W}$.

Depth:

$10 \mathrm{~km}$

Magnitude: $\quad 3.4 \mathrm{ML}(\mathrm{H})$

Intensity III: Volcano.

22 September (H) Island of Hawail

Origin time: 075937.6

Epicenter: $\quad 19.35 \mathrm{~N} ., 155.07 \mathrm{~W}$.

Depth: $\quad 9 \mathrm{~km}$

Magnitude: $\quad 5.7 \mathrm{mb}(\mathrm{G}), 4.8 \mathrm{MS}(\mathrm{G})$,

$5.5 \mathrm{ML}(\mathrm{H})$

The press reported this earthquake was felt over the whole island of Hawail and was the most damaging since the November 29 , 1975 shock. According to the press several hundred homes in the Hilo area were damaged and several businesses suffered losses. Damage was reported heaviest in the Ainaka, Wainaku, and Wailuku Drive neighborhoods of Hilo. There were no reports of injuries.

Intensity VI: Hilo area (many windows broke, water lines ruptured, dishes and household effects broke, store merchandise damaged, some foundations damaged--press reports). Reeds Island (foundation and fireplace damage to homes--press report). Intensity V: Glenwood, Hamakua, Honomu, Kurtistown, Laupahoehoe, Mountain View, Papaikou, Volcano.

Intensity IV: Captain Cook, Honokaa, Kau District, Ninole, Keaau, Naalehu, Ookala, Pahala, Waimea.

Intensity III: Holualoa, Papaaloa, Kamuela, Kona District, Kohala District, Paauhau.

22 September (H) Island of Hawa 11

Origin time: 092912.3

Epicenter: $\quad 19.35$ N., $155.03 \mathrm{~W}$.

Depth: $\quad 9 \mathrm{~km}$

Magnitude: $\quad 4.8 \mathrm{mb}(\mathrm{G}), 4.3 \mathrm{ML}(\mathrm{H})$

Intensity IV: Hilo.

Intensity III: Glenwood, Mountain View, Puna District, Volcano.

22 September (H) Island of Hawaif

Origin time: 093617.3

Epicenter: $\quad 19.35$ N., $155.04 \mathrm{~W}$.

Depth: $\quad 8 \mathrm{~km}$

Magnitude: $\quad 3.2 \mathrm{ML}(\mathrm{H})$

Intensity III: Hilo, Puna District, Volcano.
23 September (H) Island of Hawaii

Origin time: 112819.9

Epicenter: $\quad 19.38$ N., 155.07 W.

Depth: $\quad 9 \mathrm{~km}$

Magnitude: $\quad 3.3 \mathrm{ML}(\mathrm{H})$

Intensity III: Hilo, Keaau, Volcano.

25 September (H) Island of Hawai

Origin time: 035023.1

Epicenter: $\quad 19.37$ N., 155.08 w.

Depth: $\quad 9 \mathrm{~km}$

Magnitude: $\quad 3.6 \mathrm{ML}(\mathrm{H})$

Intensity III: Hawaii Volcanoes National Park, Hilo, Honomu, Volcano.

27 September (H) Island of Hawai1

Origin time: 010132.4

Epicenter: $\quad 19.54 \mathrm{~N} ., 155.92 \mathrm{~W}$.

Depth: $\quad 11 \mathrm{~km}$

Magnitude: $\quad 3.2 \mathrm{ML}(\mathrm{H})$

Intensity III: Captain Cook, Kainaliu.

27 September (H) Island of Hawaii

Origin time: 153545.5

Epicenter: $\quad 19.33 \mathrm{~N} ., 155.12 \mathrm{~W}$.

Depth: $\quad 10 \mathrm{~km}$

Magnitude: $\quad 4.7 \mathrm{mb}(G), \quad 4.3 \mathrm{ML}(\mathrm{H})$

Intensity V: Hilo.

Intensity IV: Captain Cook, Honokaa, Kamue la, Kurt is town, Laupahoehoe, Mountain View, Ookala, Pahala, Papaikou, Volcano. Intensity III: Kau District, Kohala District, Kona District, Papaaloa.

27 September (H) Island of Hawail Origin time: 153831.2

Epicenter: $\quad 19.33 \mathrm{~N} ., 155.13 \mathrm{~W}$.

Depth: $\quad 9 \mathrm{~km}$

Magnitude: $\quad 3.2 \mathrm{ML}(\mathrm{H})$

Intensity IV: Hilo.

Intensity III: Glenwood, Kalapana, Volcano.

30 September (H) Island of Hawail

Origin time: 000226.3

Epicenter: $\quad 19.37$ N., 155.11 W.

Depth: $\quad 8 \mathrm{~km}$

Magnitude: $\quad 3.2 \mathrm{ML}(\mathrm{H})$

Intensity II: Hilo.

6 October (H) Island of Hawaii

Origin time: 104612.2

Epicenter: $19.33 \mathrm{~N} ., 155.22 \mathrm{~W}$.

Depth: $\quad 10 \mathrm{~km}$

Magnitude: $\quad 3.9 \mathrm{ML}(\mathrm{H})$

Intensity IV: Keaau.

Intensity III: Hawail Volcanoes National Park, Papaikou, Volcano.

9 October (H) Island of Hawail

Origin time: 024019.8

Epicenter: $\quad 19.33 \mathrm{~N} ., 155.19 \mathrm{~W}$.

Depth: $\quad 10 \mathrm{~km}$ 
Magnitude: $\quad 3.7 \mathrm{ML}(\mathrm{H})$

Intensity III: Hilo.

13 October (H) Island of Hawaii

Origin time: 015925.8

Epicenter: $\quad 19.38 \mathrm{~N} ., 155.25 \mathrm{~W}$.

Depth: $\quad 4 \mathrm{~km}$

Magnitude: $\quad 3.0 \mathrm{ML}(\mathrm{H})$

Intensity II: Hilo.

13 October ( $\mathrm{H}$ ) Island of Hawail

Origin time: 111626.0

Epicenter: $\quad 19.44$ N., $155.35 \mathrm{~W}$.

Depth: $\quad 8 \mathrm{~km}$

Magnitude: $\quad 3.8 \mathrm{ML}(\mathrm{H})$

Intensity III: Hawaii Volcanoes National

Park, Hilo, Keaau, Pohakuloa, Volcano.

13 October (H) Island of Hawaii

Origin time: 125851.0

Epicenter: $\quad 19.45 \mathrm{~N} ., 155.36 \mathrm{~W}$.

Depth: $\quad 7 \mathrm{~km}$

Magnitude: $\quad 3.1 \mathrm{ML}(\mathrm{H})$

Intensity II: Kilauea Military Camp.

14 October (H) Island of Hawaii

Origin time: 173716.9

Epicenter: $\quad 19.91 \mathrm{~N} ., 155.18 \mathrm{~W}$.

Depth: $\quad 41 \mathrm{~km}$

Magnitude: $\quad 4.0 \mathrm{ML}(\mathrm{H})$

Intensity IV: Kohala.

Intensity III: Hawail Volcanoes National

Park, Honomu, Mountainview.

21 October (H) Island of Hawaii

Origin time: 055702.0

Epicenter: $\quad 19.32 \mathrm{~N} ., 155.20 \mathrm{~W}$.

Depth: $\quad 10 \mathrm{~km}$

Magnitude: $\quad 3.5 \mathrm{ML}(\mathrm{H})$

Intensity III: Papaikou, Puna areas, Volcano.

31 October (H) Island of Hawaii

Origin time: 053511.7

Epicenter: $\quad 19.88 \mathrm{~N} ., 156.34 \mathrm{~W}$.

Depth: $\quad 0 \mathrm{~km}$

Magnitude: $\quad 4.2 \mathrm{ML}(\mathrm{H})$

Intensity IV: Holualoa, Kona.

4 November (H) Island of Hawail

Origin time: 040951.6

Epicenter: $\quad 20.06$ N., 155.64 W.

Depth: $\quad 13 \mathrm{~km}$

Magnitude: $\quad 3.0 \mathrm{ML}(\mathrm{H})$

Intensity III: Waimea.

11 November (H) Island of Hawaii

Origin time: 102533.6

Epicenter: $\quad 19.36 \mathrm{~N} ., 155.25 \mathrm{~W}$.

Depth: $\quad 11 \mathrm{~km}$

Magnitude: $\quad 3.5 \mathrm{ML}(\mathrm{H})$

Intensity III: Glenwood, Volcano.
15 November (H) Island of Hawa 11

Origin time: 141300.9

Epicenter: $\quad 19.38$ N., 155.24 W.

Depth: $\quad 4 \mathrm{~km}$

Magnitude: $\quad 3.4 \mathrm{ML}(\mathrm{H})$

Intensity IV: Hawail Volcanoes National Park.

16 November (H) Island of Hawaii

Origin time: 095429.5

Epicenter: $\quad 19.35$ N., 155.23 W.

Depth: $\quad 1 \mathrm{~km}$

Magnitude: $\quad 3.4 \mathrm{ML}(\mathrm{H})$

Intensity III: Hawaii Volcanoes National Park.

17 November (H) Island of Hawaii

Origin time: $\quad 161159.5$

Epicenter: $\quad 19.35$ N., 155.22 W.

Depth: $\quad 10 \mathrm{~km}$

Magnitude: $\quad 3.3 \mathrm{ML}(\mathrm{H})$

Intensity IV: Pauahi Crater.

21 November (H) Island of Hawaii

origin time: 072938.0

Epicenter: $\quad 19.38 \mathrm{~N} ., 155.24 \mathrm{~W}$.

Depth: $\quad 3 \mathrm{~km}$

Magnitude: $\quad 3.2 \mathrm{ML}(\mathrm{H})$

Intensity III: Hawaii Volcanoes National Park, Hawailan Volcano Observatory.

23 November (H) Island of Hawaii

Origin time: 164134.0

Epicenter: $\quad 19.38 \mathrm{~N} ., 155.25 \mathrm{~W}$.

Depth: $\quad 4 \mathrm{~km}$

Magnitude: $\quad 3.4 \mathrm{ML}(\mathrm{H})$

Intensity IV: Hawa1i Volcanoes National

Park, Kilauea Military Camp, Volcano.

Intensity III: Hawaii Ocean View Estates.

23 November (H) Island of Hawail

Origin time: 204538.0

Epicenter: $\quad 19.36$ N., 155.25 W.

Depth: $\quad 1 \mathrm{~km}$

Magnitude: $\quad 3.5 \mathrm{ML}(\mathrm{H})$

Intensity IV: Hawailan Volcano Observatory.

25 November (H) Island of Hawaii

Origin time: 073106.8

Epicenter: $\quad 19.40 \mathrm{~N} ., 155.45 \mathrm{~W}$.

Depth: $\quad 13 \mathrm{~km}$

Magnitude: $\quad 3.5 \mathrm{ML}(\mathrm{H})$

Intensity IV: Volcano.

Intensity III: Hilo.

25 November (H) Island of Hawaii

Origin time: 105001.9

Epicenter: $\quad 19.32$ N., 155.19 W.

Depth: $\quad 9 \mathrm{~km}$

Magnitude: $\quad 3.4 \mathrm{ML}(\mathrm{H})$

Intensity IV: Ainaloa, Hilo. 
30 November (H) Island of Hawail

Origin time: 105547.9

Epicenter: $\quad 19.58$ N., 155.98 W.

Depth: $\quad 11 \mathrm{~km}$

Magnitude: $\quad 3.1 \mathrm{ML}(\mathrm{H})$

Intensity IV: Donkey Mill, Kealakekua.

30 November (H) Island of Hawail

Origin time: 201541.8

Epicenter: $\quad 19.39$ N., 155.25 W.

Depth: $\quad 3 \mathrm{~km}$

Magnitude: $\quad 3.0 \mathrm{ML}(\mathrm{H})$

Intensity IV: Hawaii Volcanoes National

Park, Hawailan Volcano Observatory, Keanakakoi, Volcano.

6 December (H) Island of Hawail

Origin time: 013227.2

Epicenter: $\quad 19.41 \mathrm{~N} ., 155.47 \mathrm{~W}$.

Depth: $\quad 11 \mathrm{~km}$

Magnitude: $\quad 3.8 \mathrm{ML}(\mathrm{H})$

Intensity IV: Hawailan Ocean View Estates, Kona.

Intensity III: Volcano.

14 December (H) Island of Hawait

Origin time: 034403.1

Epicenter: $\quad 19.42 \mathrm{~N} ., 155.41 \mathrm{~W}$.

Depth: $\quad 11 \mathrm{~km}$

Magnitude: $\quad 4.0 \mathrm{ML}(\mathrm{H})$

Intensity IV: Hawailan Ocean View Estates, Kona.

Intensity III: Hilo, Papaikou, Volcano.

16 December (H) Island of Hawail

Origin time: 034513.1

Epicenter: $\quad 19.35 \mathrm{~N} ., 155.31 \mathrm{~W}$.

Depth: $\quad 14 \mathrm{~km}$

Magnitude: $\quad 3.6 \mathrm{ML}(\mathrm{H})$

Intensity IV: Glenwood.

28 December (H) Island of Hawaii

Origin time: 212549.9

Epicenter: $\quad 19.30 \mathrm{~N} ., 155.24 \mathrm{~W}$.

Depth: $\quad 10 \mathrm{~km}$

Magnitude: $\quad 3.1 \mathrm{ML}(\mathrm{H})$

Intensity III: Hilo.

\section{Idaho}

3 June (U) Southeas tern Idaho

Origin time: 045825.4

Epicenter: $\quad 42.51 \mathrm{~N} ., 111.36 \mathrm{~W}$.

Depth: $\quad 5 \mathrm{~km}$

Magnitude: $\quad 3.7 \mathrm{ML}(\mathrm{U})$

Intensity IV: Georgetown.

Intensity III: Montpelier (telephone report).

30 June (K) Northeastern Kansas

Origin time: 204641.3

Epicenter: $\quad 39.94$ N., $97.27 \mathrm{~W}$.

Depth: $\quad 5 \mathrm{~km}$

Magnitude: $\quad 3.3 \mathrm{mbLg}(G)$

Intensity $\mathrm{VI}$ :

Kansas -

Mahaska (foundation of a cinderblock building cracked, plaster cracked and fell in large amounts, small objects broken, felt by many).

Intensity V:

Kansas--

Haddam (few windows cracked, small objects moved, hanging pictures swung, felt by many).

Norka (few windows cracked, standing and moving vehicles rocked slightly, small objects and hanging pictures moved, felt by many).

Morrowville (foundation of wood building cracked, light furniture and small objects moved, felt by several).

Intensity IV:

Kans as--Cuba, Hollenberg, Washington.

Nebraska--Chester, Reynolds.

Intensity III:

Kansas--Munden.

Intensity II:

Kansas-Belleville, Linn.

\section{Kentucky}

9 November (G) Northeastern Kentucky

Origin time: 212959.1

Epicenter: $\quad 38.42$ N., $82.88 \mathrm{~W}$.

Depth: $\quad 10 \mathrm{~km}$

Magnitude: $\quad 3.5 \mathrm{mbLg}(\mathrm{S}), 3.5 \mathrm{mbLg}(\mathrm{V})$

Felt in parts of Kentucky, Ohio, and West Virginia.

Intensity V:

Kentucky--

Flatwoods (few windows cracked; hanging pictures swung; buildings creaked and shook; windows, doors, and dishes rattled; felt by all).

Rush (few windows cracked; buildings shook; windows, doors, and dishes rattled; felt by many).

Intensity IV:

Kentucky-Ashland (Y), Catlettsburg, Grayson, Greenup, Worthington.

Ohio--Franklin, Furnace, Kitts Hill, Haverhil1, Lucasville, South Webster, Whe elersburg. 
West Virginia--0na.

Intensity III:

Kentucky--Hitchins, South Portsmouth, South Shore, West Liberty.

Intensity II:

Ohio-Friendship.

Felt:

Kentucky--Ironville (Y), Louisa $(Y)$, Raceland $(Y)$, Summit $(Y)$.

Ohio--Ironton ( $Y$ ).

\section{Maine}

18 April (J) Southern Maine

Origin time: $0234 \quad 14.4$

Epicenter: $\quad 43.95 \mathrm{~N} ., 69.75 \mathrm{~W}$.

Depth: $\quad 4 \mathrm{~km}$

Magnitude: $\quad 3.8 \mathrm{mbLg}(\mathrm{G}), 4.1 \mathrm{mbLg}(0)$, 4.0 $\mathrm{MD}(\mathrm{J})$

The press reported windows and dishes broken in the epicentral area. Eleven

aftershocks were recorded by Weston

Observatory, ten on Apri1 18 and one on April 19. The magnitudes ranged from 3.0 to less than 1.0. This earthquake was felt over an area of approximately 55,500 sq $\mathrm{km}$ along the coasts of Maine, Massachusetts, and New Hampshire (fig. 24). Some of the data 1 isted below are from a questionnaire canvass made by the Maine Geological Survey and evaluated by the USGS.

\section{Intensity $\mathrm{V}$ : \\ Maine--}

Auburn ( $f e w$ windows cracked; hanging pictures swung; windows, doors, and dishes rattled; felt by many).

Augusta (few windows cracked; hanging pictures swung; windows, doors, and dishes rattled; felt by all).

Belfast (few windows cracked; windows, doors, and dishes rattled; felt by many).

Buckfield (few windows cracked; hanging pictures swung; windows, doors, and dishes rattled; felt by many).

Damariscotta (few windows cracked; hanging pictures out of place; windows, doors, and dishes rattled; felt by many).

Dresden ( $f$ ew windows broken; liquid spilled from small containers; windows, doors, and dishes rattled; people awakened; felt by all).

East Vassalboro (few windows cracked; hanging pictures swung; windows, doors, and dishes rattled; felt by many).
Freedom (few windows cracked; light furnfture or small appliances moved; small objects moved; hanging pictures swung; windows, doors, and dishes rattled; felt by many).

Gray (few windows cracked, light furniture or small appliances moved, small objects moved, chimney bricks loosened, felt by many).

Hallowell (few windows broken; small objects moved; hanging pictures swung; windows, doors, and dishes rattled; several awakened; felt by many).

Lebanon (light furniture or small appliances moved; small objects moved; windows, doors, and dishes rattled; few awakened; felt by many).

Lisbon Falls (few windows cracked; hanging pictures swung; windows, doors, and dishes rattled; few awakened; felt by many).

Livermore Falls (light furniture or small appliances moved; small objects moved; windows, doors, and dishes rattled; felt by all).

Lovell (few windows cracked; small objects moved; hanging pictures out of place; windows, doors, and dishes rattled; few awakened; felt by many).

Mount Vernon (small objects broken; windows, doors, and dishes rattled; few awakened; felt by many).

old Orchard Beach (few windows cracked; small objects moved; hanging pictures out of place; windows, doors, and dishes rattled; several awakened; felt by many).

Scarborough (few windows cracked; small objects moved; windows, doors, and dishes rattled; several awakened).

South Paris (few windows cracked; windows, doors, and dishes rattled; felt by many).

Topsham (few windows cracked; small objects moved; hanging pictures swung; building shook strongly; felt by all).

Troy (few windows cracked; small objects moved; hanging pictures out of place; windows, doors, and dishes rattled; few awakened; felt by many).

West Bowdoin (few windows cracked, light furniture or small appliances moved, small objects moved, hanging pictures out of place, felt by all).

West Peru (few windows cracked; small objects moved; hanging pictures swung; windows, doors, and dishes rattled; felt by many).

Wiscasset (small objects moved and fell; small cracks in house foundation; hanging objects swung moderately; house vibrated; felt by all). 


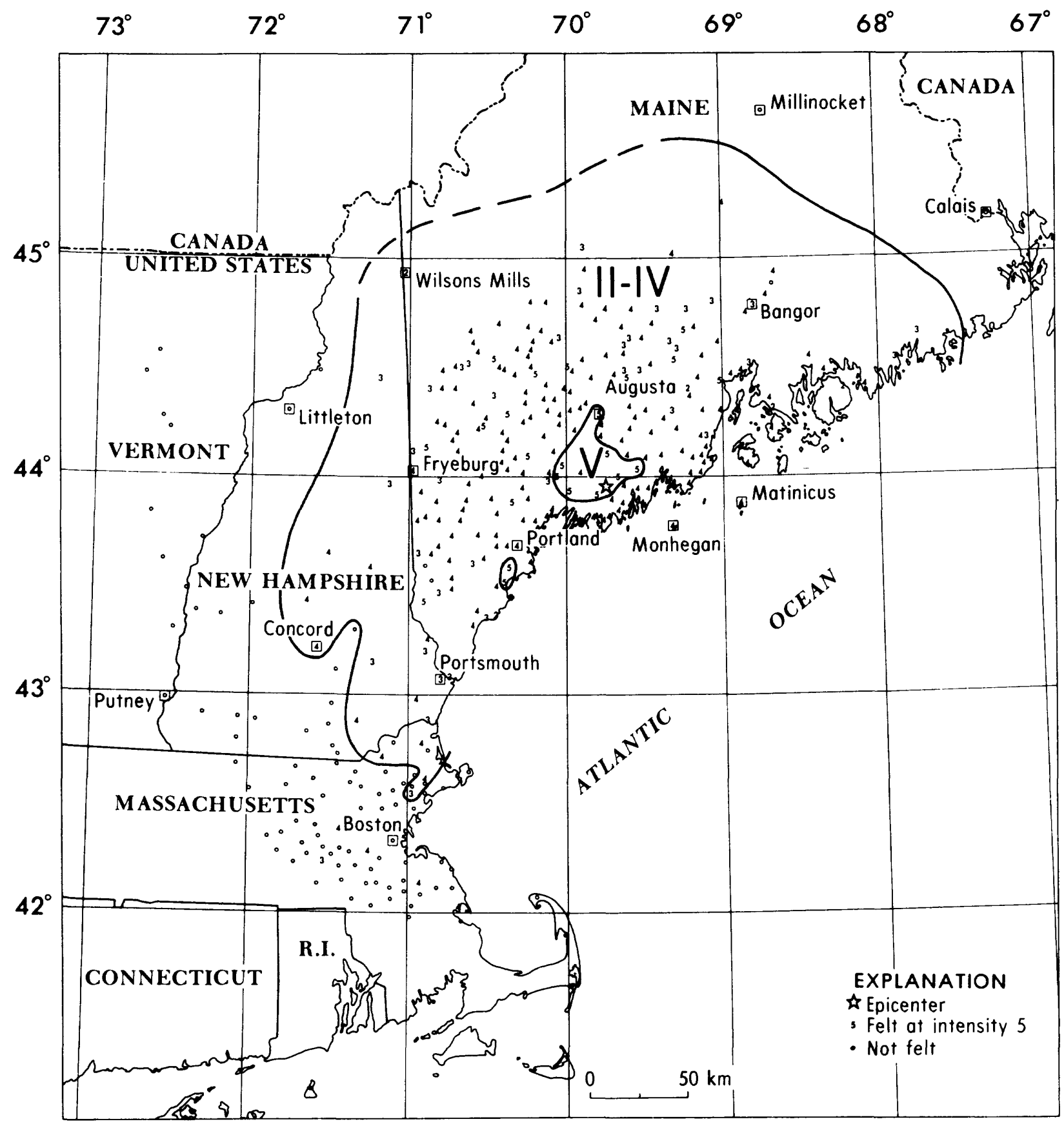

FIGURE 24.--Isoseismal map for the southern Maine earthquake of 18 April $1979,023414.4$ UTC. Roman numerals represent Modified Mercalli intensities between isoseismals; Arabic numerals are used to represent these intensities at specific sites. 
Woolwich (some windows broken; small objects moved; hanging pictures out of place; water splashed onto sides of lakes and ponds; we11 water muddied; buildings shook strongly; windows, doors, and dishes rattled; felt by a11).

Intensity IV:

Maine--Albion, Alfred, A1na, Bath, Be1grade, Belgrade Lakes, Bethel, Boothbay, Boothbay Harbor, Bowdoin, Bowdoinham, Bremen, Bristol, Brooks, Brooksville, Brownfield, Brunswick, Burnham, Buxton, Canaan, Canton, Cape Elizabeth, Casco, Castine, Chebeague Island, Chesterville, Clinton, Coopers Mills, Cornish, Cumberland Center, Cumberland Mills, Cundys Harbor, Danville, Deer Isle, Dexter, Dixmont, Dryden, East Baldwin, East Boothbay, East Dixfield, East Livermore, East Poland, East Peru, East Sebago, East Stoneham, East Waterford, East Wi1ton, East Winthrop, Edgecomb, Ellsworth, Farmington, Farmington Falls, Five Islands, Freeport, Friendship, Frye, Fryeburg, Gardiner, Georgetown, Glen Cove, Gorham, 'Greene, Hampden, Hanover, Harpswe11, Harrison, Hebron, Hinckley, Hiram, Islesboro, Jay, Jefferson, Kennebunk, Kents Hil1, Kezar Falls, Lamoine, Leeds, Lewiston, Liberty, Limerick, Limington, Lincolnville, Lincolnville Center, Lisbon, Lisbon Center, Litchfield, Little Deer Isle, Livermore, Locke Mills, Long Island, Lyman, Madison, Manchester, Matinicus, Mechanic Fal1s, Mexico, Milo, Minot, Monhegan, Monmouth, Monroe, Morri11, Naples, New Gloucester, New Harbor, New Vineyard, Newcastle, Newfield, Newagen, Newry, Nobleboro, Norridgewock, North Edgecomb, North Jay, North Leeds, North Monmouth, North Sebago, North Turner, North Waterboro, North Waterford, North Whitefield, North Windham, Norway, Oakland, 01d Town, Orrs Island, Owls Head, Palermo, Paris, Permaquid Harbor, Peru, Phippsburg, Poland, Poland Spring, Porter, Portland, Pownal, Raymond, Readfield, Richmond, Rockland, Round Pond, Roxbury, Rumford, Sabattus, Saco, Saint George, Salem, Searsmont, Sear sport, Skowhegan, Small Point, Solon, Somerville, South Bristo1, South Freeport, South Gardiner, South Harpswe11, South Hiram, South Portland, South Thomaston, South Waterford, South Windham, Southport, Spruce Head, Standish, Stockton Springs, Stonington, Strong, Sunset, Temple, Tenants Harbor, Thomaston, Turner, Turner Center, Union, Vassa1boro, Veazie, Vienna, Vinalhaven, Waldoboro, Walpole, Warren, Washington,
Waterboro, Waterford, Waterville, Wayne, Weld, Wells, West Baldwin, West Boothbay, West Farmington, West Kennebunk, West Minot, West Paris, West Poland, West Rockport, Westbrook, Westport, Whitefield, Windsor, Winslow, Winter Harbor, Winthrop, Yarmouth.

Massachusetts-Duxbury, Lawrence, Needham, Newburyport, Rockland, South Hamilton, Sudbury.

New Hampshire--Concord, Derry, Exeter, Franklin, Meredith, Somersworth, Wolfeboro.

Intensity III:

Maine--Anson, Bangor, Biddeford, Bingham, Bristol Mills, Brunswick, Burkettville, Carme1, China, Cliff Island, Columbia Falls, Denmark, Dixfield, Durham, Fairfield, Georgetown, Hollis Center, Kennebunkport, Kittery, Maplewood, Milbridge, Milford, New Sharon, North Anson, North Bridgton, North Fryeburg, North Haven, North Vassalboro, North Yarmouth, Parson Field, Pittsfield, Plymouth, Rockport, Rumford Center, Rumford Point, Sandy Point, Sebago Lake, Shawmut, South China, Springuale, Steep Falls, Thorndike, Unity, Wales, Weeks Mills, West Bethe1, West Newfield, West Southport, West Sumner, Wilton.

Massachusetts--Hopkinton, Peabody .

New Hampshire--Berlin, Conway, Deerfield, Dover (press report), Portsmouth (press report), Seabrook (press report).

Intensity II:

Maine--Bar Harbor, Cape Porpolse, North Searsmont, Sargentville, Wilsons Mills.

$28 \mathrm{July}(\mathrm{J})$ Southwestern Maine Origin time: 232912.3 Eplcenter: $\quad 43.29$ N., $70.44 \mathrm{~W}$. Depth: $\quad 11 \mathrm{~km}$

Magnitude: $\quad 3.5 \mathrm{mbLg}(G), 3.5 \mathrm{mbLg}(J)$

The intensities 1 isted below are a combination of USGS and Maine Geological Survey questionnaires which were evaluated by the USGS. The maximum effects reported were small objects moved; windows, doors, and dishes rattled; hanging pictures out of place; loud earth noises; felt by many.

Intensity IV:

Ma1ne--Kennebunkport, Moody, North

Berwick, Onunquit, Saco, Scarborough,

South Berwick, Wells, York, York Harbor. New Hampshire--Mi1ton, Rollinsford.

Intensity III:

Maine--Acton, Bar Mills, Berwick, Bidde-

ford, Cape Elizabeth, East Waterboro,

Hollis Center, Kittery Point, Portland, Springvale.

New Hampshire--New Castle, Somersworth. 
Intensity II:

Maine--Biddeford Pool, Eliot, Kittery. New Hampshire--Greenland.

19 August (0) Southern Quebec, Canada Origin time: 224931.0

Epicenter: $\quad 47.64 \mathrm{~N} ., 69.96 \mathrm{~W}$.

Depth: $\quad 18 \mathrm{~km}$

Magnitude: $\quad 4.6 \mathrm{mb}(\mathrm{G}), 4.5 \mathrm{MS}(\mathrm{G})$, $5.4 \mathrm{mbLg}(0)$

Felt at maximum intensity $V$ in the $S t$. Simeon area in Canada.

Intensity IV: Saint Francis. Intensity III : Lille.

Massachusetts

18 April (J) Southern Maine Origin time: 023414.4

See Maine listing.

23 Apri1 (J) Southern New Hampshire Origin time: 000545.7

See New Hampshire listing.

Missouri

5 February (S) Northeastern Arkansas Origin time: 053109.3

See Arkansas 1isting.

3 June (S) Eastern Mis souri

Origin time: 055024.6

Epicenter: $\quad 38.61 \mathrm{~N} ., 90.52 \mathrm{~W}$.

Depth: $\quad 5 \mathrm{~km}$

Magnitude: $2.1 \mathrm{mbLg}(\mathrm{S})$

Felt in southwest Ladue and at Jennings (S).

11 June (S) New Madrid region

Origin time: 041216.9

Epicenter: $\quad 36.17$ N., 89.65 W.

Depth: $\quad 12 \mathrm{~km}$

Magnitude: $\quad 3.8 \mathrm{mbLg}(\mathrm{S})$

Intensity IV:

Arkansas--Armorel.

Missour1--Cooter, Deering, Marston, Rives.

Tennessee--Bogota, Elbridge, Finley, Hornbeak, Lenox, Ridgely, Samburg.

Intensity III:

Missouri--Car, Gideon, Pascola.

Tennessee--Caruthersville (press report), Dyersburg.

$8 \mathrm{July}$ (S) Southeast Missouri

Origin time: 123515.1

Epicenter: $\quad 36.89 \mathrm{~N} ., 89.29 \mathrm{~W}$.

Depth: $\quad 3 \mathrm{~km}$

Magnitude: $\quad 3.1 \mathrm{mbLg}(\mathrm{S})$

Intensity IV: Wyatt (windows, doors, dishes rattled and small objects moved).

Intensity III: Charleston.

13 July (S) New Madrid region

Origin time: 072939.0

Epicenter: $\quad 36.08$ N., $89.77 \mathrm{~W}$.

Depth: $\quad 11 \mathrm{~km}$

Magnitude: $\quad 2.7 \mathrm{mbLg}(\mathrm{T}), 2.8 \mathrm{mbLg}(\mathrm{S})$

Intensity IV:

Missour1--Campbe11, Clarkton.

Tennessee--Bogota.

Intensity III :

Missouri-Wardell, Whiteoak.

Intensity II:

Missouri-Braggadocio (press report), Marston.

Tennessee--Ridgely.

Felt:

Missouri--Caruthersville.

12 September (S) Eastern Missouri

Origin time: $\quad 105946.2$

Epicenter: $\quad 37.74 \mathrm{~N} ., 89.95 \mathrm{~W}$.

Depth: $\quad 3 \mathrm{~km}$

Magnitude: $2.5 \mathrm{mbLg}(\mathrm{S})$

Felt in the Perryville area (S).

26 November ( $S$ ) New Madrid Region

origin time: 044319.0

Epicenter: $\quad 36.36 \mathrm{~N} ., 89.52 \mathrm{~W}$.

Depth: $\quad 10 \mathrm{~km}$

Magnitude: $\quad 2.7 \mathrm{mbLg}(\mathrm{s})$

Felt in western Kentucky (S).

\section{Montana}

7 May (G) Hebgen Lake region

Origin time: 171543.4

Epicenter: $\quad 44.76 \mathrm{~N} ., 111.14 \mathrm{~W}$.

Depth: $\quad 5 \mathrm{~km}$

Magnitude: $\quad 3.2 \mathrm{ML}(\mathrm{G}), 3.6 \mathrm{ML}(\mathrm{D})$

Intensity III: 01d Faithful, Wyoming.

8 May (G) Hebgen Lake region

Origin time: 005634.1

Epicenter: $\quad 44.77$ N., $111.12 \mathrm{~W}$.

Depth: $\quad 5 \mathrm{~km}$

Magnitude: $\quad 3.3 \mathrm{ML}(\mathrm{G}), 3.5 \mathrm{ML}(\mathrm{D})$

Intensity III: West Yellowstone.

8 May (G) Hebgen Lake region

origin time: 005742.9 
$\begin{array}{ll}\text { Epicenter: } & 44.74 \mathrm{~N} ., 111.20 \mathrm{~W} . \\ \text { Depth: } & 5 \mathrm{~km}\end{array}$

Magnitude: $\quad 3.9 \mathrm{ML}(\mathrm{G}), 4.2 \mathrm{ML}(\mathrm{D})$

Intensity IV:

Mont ana-West Yellows tone.

Wyoming--Madison Junction.

Intensity III:

Wyoming--Mammoth Hot Springs, 01d Faithful.

8 May (G) Hebgen Lake region

Origin time: 005844.8

Epicenter: $\quad 44.75 \mathrm{~N} ., 111.38 \mathrm{~W}$.

Depth: $\quad 5 \mathrm{~km}$

Magnitude: $\quad 4.6 \mathrm{ML}(G), 4.7 \mathrm{ML}(D)$

Intensity IV:

Montana-West Yellowstone (cars rocked noticeably, doors swung, windows rattled, few books fell from shelves, felt by many).

Wyoming--Madison Junction (windows rattled, house plants vibrated).

Intensity III:

Wyoming--Canyon Village, 01d Falthful. Intensity II:

Wyoming--Mammoth Hot Springs.

8 May (G) Hebgen Lake region

Origin time: 012318.3

Epicenter: $\quad 44.78 \mathrm{~N} ., 111.08 \mathrm{~W}$.

Depth: $\quad 5 \mathrm{~km}$

Magnitude: $\quad 3.4 \mathrm{ML}(\mathrm{G}), 3.5 \mathrm{ML}(\mathrm{D})$

Intensity III: West Yellowstone.

10 May Hebgen Lake region

Origin time: 1324

Epicenter: Not located.

Depth: None computed.

Magnitude: None computed.

Intensity III: West Yellowstone.

22 June (G) Southwestern Montana

Origin time: 120226.8

Epicenter: $\quad 45.32 \mathrm{~N} ., 112.83 \mathrm{~W}$.

Depth: $\quad 5 \mathrm{~km}$

Magnitude: $\quad 4.5 \mathrm{ML}(\mathrm{D}), 4.4 \mathrm{ML}(\mathrm{G})$

Intensity IV: Dillon, Polaris.

21 July (G) Northwestern Montana

Origin time: 221847.3

Epicenter: $\quad 47.72 \mathrm{~N} ., 114.15 \mathrm{~W}$.

Depth: $\quad 5 \mathrm{~km}$

Magnitude: $\quad 3.5 \mathrm{ML}(\mathrm{G})$

Felt along the south shore area of Flathead Lake and at Dayton and Ronan (press report).

16 October (G) Northwestern Montana

Origin time: 183344.6

Epicenter: $\quad 48.24 \mathrm{~N} ., 114.54 \mathrm{~W}$.
Depth: $\quad 5 \mathrm{~km}$

Magnitude: $\quad 3.1 \mathrm{ML}(\mathrm{G}), 2.7 \mathrm{ML}(\mathrm{D})$

Felt in the Kalispell Valley (press report).

21 November Northwestern Montana

Origin time: 1900

Epicenter: Not located.

Depth: None computed.

Magnitude: None computed.

Intensity II: Kalispel1.

\section{Nebraska}

6 June (K) Southwestern Nebraska

Origin time: 161622.4

Epicenter: $\quad 40.14 \mathrm{~N} ., 100.41 \mathrm{~W}$.

Depth: $\quad 2 \mathrm{~km}$

Magnitude: $\quad 2.7 \mathrm{mbLg}(G)$

Felt at Bartly and $11 \mathrm{~km}$ south of Bartly (telephone report).

Intensity III: $6.5 \mathrm{~km}$ south of Indianola (K).

30 June (G) Northeastern Kansas

Origin time: 204641.3

See Kansas listing.

16 July (K) Southwestern Nebraska

Origin time: 000347.8

Epicenter: $\quad 40.18 \mathrm{~N} ., 100.35 \mathrm{~W}$.

Depth: $\quad 14 \mathrm{~km}$

Magnitude: $\quad 3.2 \mathrm{mbLg}(\mathrm{T})$

Intensity III: Indianola (telephone report).

2 August (K) Southwestern Nebraska

Origin time: 041622.2

Epicenter: $\quad 40.17$ N., 100.40 W.

Depth: $\quad 1 \mathrm{~km}$

Magnitude: $\quad 2.5 \mathrm{MD}(\mathrm{K})$

Intensity III: $6.5 \mathrm{~km}$ south of Indianola (K).

31 August (K) Southwes tern Nebraska

Origin time: 080011.6

Epicenter: $\quad 40.16 \mathrm{~N} ., 100.33 \mathrm{~W}$.

Depth: $12 \mathrm{~km}$

Magnitude: $\quad 2.2 \mathrm{MD}(\mathrm{K})$

Intensity IV: $6.5 \mathrm{~km}$ south of Indianola

(K).

\section{Nevada}

6 January (G) Central Nevada

Origin time: 012035.1

Epicenter: $\quad 39.24 \mathrm{~N} ., 116.38 \mathrm{~W}$. 
Depth: $\quad 5 \mathrm{~km}$

Magnitude: $\quad 4.2 \mathrm{ML}(\mathrm{B})$

Intensity IV: Austin.

Intensity II: Yerington.

24 January (E) Southern Nevada

Origin time: 180000.099

Epicenter: $\quad 37.10$ N., 116.01 W.

Depth: $\quad 0 \mathrm{~km}$

Magnitude: $\quad 4.5 \mathrm{mb}(\mathrm{G}), 4.5 \mathrm{ML}(\mathrm{B})$

Nevada Test Site explosion "BACCARAT" at $37^{\circ} 06^{\prime} 19.48^{\prime \prime} N^{\prime}, 116^{\circ} 00^{\prime} 42.01^{\prime \prime}$ W. , surface elevation $1338 \mathrm{~m}$, depth of burial $326 \mathrm{~m}$.

24 January (B) Owens Valley Area

Origin time: 211425.9

See California Listing.

8 February (E) Southern Nevada

Origin time: 200000.089

Epicenter: $\quad 37.10 \mathrm{~N} ., 116.06 \mathrm{~W}$.

Depth: $\quad 0 \mathrm{~km}$

Magnitude: $\quad 5.5 \mathrm{mb}(G), 4.1 \mathrm{MS}(G)$,

$$
5.2 \text { ML(B) }
$$

Nevada Test Site explosion "QUINELLA" at $37^{\circ} 06^{\prime} 08.93^{\prime \prime}$ N., $116^{\circ} 03^{\prime} 17.43^{\prime \prime}$ W., surface elevation $1268 \mathrm{~m}$, depth of burial $579 \mathrm{~m}$.

13 February (G) Northern Nevada

Origin time: 155248.5

Epicenter: $\quad 40.93 \mathrm{~N} ., 116.16 \mathrm{~W}$.

Depth: $\quad 5 \mathrm{~km}$

Magnitude: $\quad 4.1 \mathrm{mb}(G), 3.6 \mathrm{ML}(G)$

Intensity IV: Carlin, Carlin Gold Mine.

Intensity III: Tuscarora.

15 February (E) Southern Nevada

Origin time: 180500.164

Epicenter: $\quad 37.15 \mathrm{~N} ., 116.07 \mathrm{~W}$.

Depth: $\quad 0 \mathrm{~km}$

Magnitude: $\quad 4.8 \mathrm{mb}(\mathrm{G}), 4.7 \mathrm{ML}(\mathrm{B})$

Nevada Test Site explosion "KLOSTER" at $37^{\circ} 09^{\prime} 07.24^{\prime \prime}$ N., $116^{\circ} 04^{\prime} 18.61^{\prime \prime}$ W. $_{\text {. , surface }}$ elevation $1324 \mathrm{~m}$, depth of burial $536 \mathrm{~m}$.

22 February (B) Northern California Origin time: 155728.1

See California Listing.

14 March (E) Southern Nevada

Origin time: 183000.095

Epicenter: $\quad 37.03 \mathrm{~N} ., 116.04 \mathrm{~W}$.

Depth: $\quad 0 \mathrm{~km}$

Magnitude: $\quad 4.3 \mathrm{mb}(\mathrm{G}), 4.2 \mathrm{ML}(\mathrm{B})$

Nevada Test Site explosion "MEMORY" at $37^{\circ} 01$ '40.18" N., $116^{\circ} 0223.10^{\prime \prime}$ W., surface elevation $1217 \mathrm{~m}$, depth of burial $366 \mathrm{~m}$.
15 March (P) Southern California Origin time: $2107 \quad 16.5$

See California Listing.

18 March (G) Central Nevada Origin time: 210611.0

Epicenter: $\quad 39.25 \mathrm{~N} ., 116.36 \mathrm{~W}$.

Depth: $\quad 5 \mathrm{~km}$

Magnitude: $\quad 3.5 \mathrm{ML}(\mathrm{G})$

Intensity IV: Austin.

6 June (B) Western Nevada

Origin time: 014956.4

Epicenter: $\quad 38.49$ N., $118.42 \mathrm{~W}$.

Depth: $\quad 12 \mathrm{~km}$

Magnitude: $\quad 4.3 \mathrm{mb}(\mathrm{G}), 4.2 \mathrm{ML}(\mathrm{B})$

Intensity IV: Luning.

Intensity III: Babbitt, Hawthorne, Mina.

8 June (G) Western Nevada

Origin time: 054403.6

Epicenter: $\quad 38.51 \mathrm{~N} ., 117.88 \mathrm{~W}$.

Depth: $\quad 5 \mathrm{~km}$

Magnitude: $\quad 4.0$ ML(G)

Intensity IV: Gabbs, Luning, Mina.

11 June (E) Southern Nevada

Origin time: 140000.170

Epicenter: $\quad 37.29$ N., $116.45 \mathrm{~W}$.

Depth: $\quad 0 \mathrm{~km}$

Magnitude: $\quad 5.5 \mathrm{mb}(\mathrm{G}), 4.4 \mathrm{MS}(\mathrm{G})$, $5.4 \mathrm{ML}(\mathrm{B})$

Nevada test site explosion "PEPATO" at $37^{\circ} 17^{\prime} 22.88^{\prime \prime} N^{\prime}, 116^{\circ} 27^{\prime} 18.91^{\prime \prime}$ W. , surface elevation $1941 \mathrm{~m}$, depth of burial $681 \mathrm{~m}$.

20 June (E) Southern Nevada

Origin time: $\quad 150013.542$

Epicenter: $\quad 37.11$ N., 116.02 W.

Depth: $\quad 0 \mathrm{~km}$

Magnitude: $\quad 4.0 \mathrm{mb}(\mathrm{G}), 4.3 \mathrm{ML}(\mathrm{B})$

Nevada test site explosion "CHESS" at $37^{\circ} 06^{\prime} 27.46^{\prime \prime}$ N., $116^{\circ} 00^{\prime} 54.31^{\prime \prime}$ W. , surface elevation $1336 \mathrm{~m}$, depth of burial $335 \mathrm{~m}$.

28 June (E) Southern Nevada

Origin time: $\quad 144400.168$

Epicenter: $\quad 37.14$ N., 116.09 W.

Depth: $\quad 0 \mathrm{~km}$

Magnitude: $\quad 5.0 \mathrm{mb}(G), 5.0 \mathrm{ML}(\mathrm{B})$

Nevada test site explosion "FAJY" at $37^{\circ} 08^{\prime} 35.39^{\prime \prime}$ N., $116^{\circ} 05^{\prime} 15.06^{\prime \prime}$ W. , surface elevation $1330 \mathrm{~m}$, depth of burial $537 \mathrm{~m}$.

3 August (E) Southern Nevada

Origin time: 150730.163

Epicenter: $\quad 37.08 \mathrm{~N} ., 116.07 \mathrm{~W}$.

Depth: $\quad 0 \mathrm{~km}$

Magnitude: $\quad 4.5 \mathrm{mb}(G), 4.6 \mathrm{ML}(\mathrm{B})$ 
Nevada--Cont inued

Nevada Test Site explosion "BURZET" at $37^{\circ} 05^{\prime} 02.22^{\prime \prime}$ N. $^{\circ} 116^{\circ} 04^{\prime} 11.59^{\prime \prime}$ W. , surface elevation $1262 \mathrm{~m}$, depth of burial $450 \mathrm{~m}$.

6 August (B) Centra1 Callfornia Origin time: 170522.7

See Callfornia 11sting.

8 August (E) Southe rn Nevada

Origin time: 150000.112

Epicenter: $\quad 37.02 \mathrm{~N} ., 116.01 \mathrm{~W}$.

Depth: $\quad 0 \mathrm{~km}$

Magnitude: $\quad 4.8 \mathrm{mb}(\mathrm{G}), 4.6 \mathrm{ML}(\mathrm{B})$

Nevada Test Site explosion "OFFSHORE" at $37^{\circ} 00^{\prime} 53.09^{\prime \prime}$ N., $^{\prime} 116^{\circ} 00^{\prime} 28.82^{\prime \prime}$ W., surface elevation $1209 \mathrm{~m}$, depth of burial $396 \mathrm{~m}$.

29 August (E) Southern Nevada

$\begin{array}{ll}\text { Origin time: } & 150800.171 \\ \text { Epicenter: } & 37.12 \mathrm{~N} ., 116.07 \mathrm{~W} . \\ \text { Depth: } & 0 \mathrm{~km}\end{array}$

Magnitude: $\quad 4.7 \mathrm{mb}(\mathrm{G}), 5.0 \mathrm{ML}(\mathrm{B})$

Nevada Test Site explosion "NESSEL" at $37^{\circ} 07^{\prime} 16.39^{\prime \prime}$ N. $^{\prime} 116^{\circ} 03^{\prime} 59.71^{\prime \prime} \mathrm{W}$, surface elevation $1286 \mathrm{~m}$, depth of burial $464 \mathrm{~m}$.

6 September (E) Southern Nevada

Origin time: 150000.089

Epicenter: $\quad 37.09 \mathrm{~N} ., 116.05 \mathrm{~W}$.

Depth: $\quad 0 \mathrm{~km}$

Magnitude: $\quad 5.8 \mathrm{mb}(G), 4.1 \mathrm{MS}(G)$,

$$
5.5 \mathrm{ML}(\mathrm{B})
$$

Nevada Test Site explosion "HEARTS" at $37^{\circ} 05^{\prime} 17.20^{\prime \prime} \mathrm{N}^{\prime}, 1^{\circ} 16^{\circ} 03^{\prime} 10.02^{\prime \prime} \mathrm{W} .$, surface elevation $1259 \mathrm{~m}$, depth of burial $640 \mathrm{~m}$.

8 September (E) Southern Nevada

Origin time: 170200.090

Epicenter: $\quad 37.15 \mathrm{~N} ., 116.04 \mathrm{~W}$.

Depth: $\quad 0 \mathrm{~km}$

Magnitude: $\quad 3.8 \mathrm{mb}(G), 3.7 \mathrm{ML}(\mathrm{B})$

Nevada Test Site explosion "PERA" at $37^{\circ} 09^{\prime} 17.98^{\prime \prime}$ N., $116^{\circ} 02^{\prime} 17.48^{\prime \prime}$ W., depth of burial $200 \mathrm{~m}$.

26 September (E) Southern Nevada

Origin time: 150000.091

Epicenter: $\quad 37.23 \mathrm{~N} ., 116.36 \mathrm{~W}$.

Depth: $\quad 0 \mathrm{~km}$

Magnitude: $\quad 5.6 \mathrm{mb}(G), 4.1 \mathrm{MS}(G)$,

$5.4 \mathrm{ML}(\mathrm{B})$

Nevada Test Site explosion "SHEEPSHEAD" at $37^{\circ} 13^{\prime} 44.64^{\prime \prime} N^{\prime}, 116^{\circ} 21^{\prime} 50.59^{\prime \prime}$ W. , surface elevation $2060 \mathrm{~m}$, depth of burial $640 \mathrm{~m}$.
Nevada--Cont inued

15 October (P) Imperial Valley area Origin time: 231654.5

See Calffornia listing.

29 November (E) Southern Nevada

Origin time: $\quad 15000.096$

Epicenter: $\quad 36.99 \mathrm{~N} ., 116.02 \mathrm{~W}$.

Depth: $\quad 0 \mathrm{~km}$

Magnitude: $\quad 3.8 \mathrm{mb}(G)$

Nevada Test Site explosion "BACKGAMMON" at $36^{\circ} 59^{\prime} 38.25^{\prime \prime}$ N., $116^{\circ} 01^{\prime} 26.79^{\prime \prime}$ W. , surface elevation $1203 \mathrm{~m}$, depth of burial $229 \mathrm{~m}$.

14 December (E) Southern Nevada

Origin time: 180000.091

Epicenter: $\quad 37.14 \mathrm{~N} ., 116.06 \mathrm{~W}$.

Depth: $\quad 0 \mathrm{~km}$

Magnitude: $\quad 3.6 \mathrm{ML}$ (B)

Nevada Test Site explosion "AZUL" at $37^{\circ} 08^{\prime} 14.54^{\prime \prime}$ N., $116^{\circ} 03^{\prime} 47.06^{\prime \prime}$ W. , surface elevation $1302 \mathrm{~m}$, depth of burial $205 \mathrm{~m}$.

31 December (B) Western Nevada

Origin time: 082751.9

Eplcenter: $\quad 38.40$ N., $118.40 \mathrm{~W}$.

Depth: $\quad 5 \mathrm{~km}$

Magnitude: $\quad 4.2 \mathrm{mb}(G), 4.9 \mathrm{ML}(B)$, 4.8 ML(P)

Intensity IV:

California--Mammoth Lakes, Topaz.

Nevada--Babbitt, Hawthorne, Luning, Mina.

New Hampshire

18 April (J) Southern Maine

Origin time: 023414.4

See Maine listing.

23 Apri1 (J) Southern New Hampshire

Origin time: 000545.7

Epicenter: $\quad 43.04 \mathrm{~N} ., 71.24 \mathrm{~W}$.

Depth: $\quad 0 \mathrm{~km}$

Magnitude: $\quad 3.1 \mathrm{mbLg}(\mathrm{J}), 2.9 \mathrm{mbLg}(\mathrm{L})$

Intensity IV:

Massachusetts--West Boxford, West Newbury. New Hampshire--Candia, Derry, East Candia, East Rochester, Exeter, Gilmanton Iron Works, Greenland, Hampton Falls, Milton, Portsmouth, Rochester, Rye Beach, Salem.

Intensity III:

Massachusetts--Have rhil1.

New Hampshire--Alton Bay, Brentwood (press 
New Hampshire--Cont inued

report), Epping, Gonic, Hooksett (press report), Raymond, Rollinsford.

Intensity II:

Mas sachusetts--Ward Hill.

New Hampshire--East Derry, Farmington, Kingston, Newmarket, Ward Hill.

28 July (J) Southwestern Maine

origin time: 232912.3

See Maine 1isting.

\section{New Jersey}

30 January (L) Centra1 New Jersey

Origin time: 163052.1

Epicenter: $\quad 40.32 \mathrm{~N} ., 74.26 \mathrm{~W}$.

Depth: $\quad 5 \mathrm{~km}$

Magnitude: $\quad 3.0 \mathrm{mbLg}(\mathrm{L}), 3.3 \mathrm{mbLg}(\mathrm{V})$

The press reported the earthquake was felt from southwest of Trenton, New Jersey, to the middle of Fairfield County, Connecticut, a distance of $160 \mathrm{~km}$; and extended over an area of approximately $2,800 \mathrm{sq} \mathrm{km}$ (f1g. 25). In New Jersey, frightened people made thousands of calls to police in Monmouth and Middlesex Counties complaining of shaking walls and rattling dishes. In New York City, the police were flooded with calls from Brooklyn, Manhattan, and Staten Island residents.

Intensity V:

New Jersey--

Cheesequake (a foot-1ong crack in the exterior wall of an elementary school building, objects fell from shelves, shaking described as being so strong that the building seemed as if it would $f a l l$, everyone ran into the streets--press report).

Cranbury (light furniture and small objects shifted, buildings trembled).

Middletown (a few windows cracked; hanging pictures swung out of place; buildings creaked and shook; windows, doors, and dishes rattled; standing and moving vehicles rocked slightly; felt by many).

Milltown (light furniture and small objects shifted; hanging pictures swung; windows, doors, and dishes rattled; standing and moving vehicles rocked slightly).

New York--

Rockville Centre (light furniture and small objects shifted; buildings creaked and shook; windows, doors, and dishes rattled; felt by many).

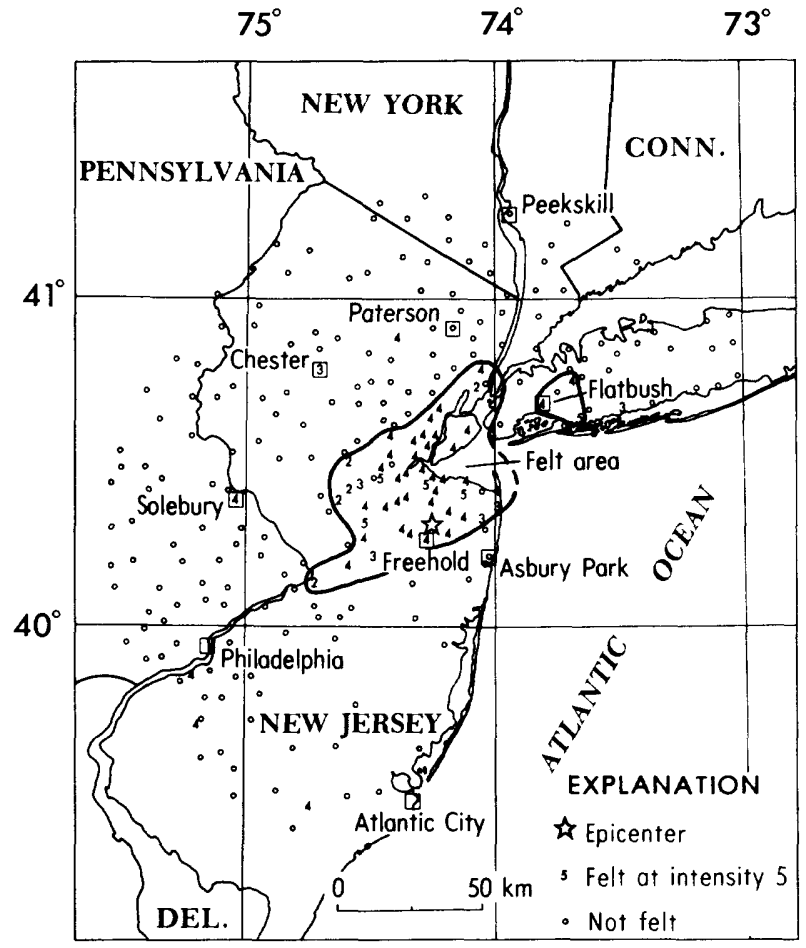

FIGURE 25.--Isoseismal map for the central New Jersey earthquake of 30 January 1979 , 163052.1 UTC. Roman numerals represent Modifled Mercalli intensities between isoseismals; Arabic numerals are used to represent these intensities at specific sites.

\section{Intensity IV:}

New Jersey--Allentown, Avene 1, Browntown, Carteret, Cliffwood, Colts Neck, Dayton, East Keansburg, Edison, Elizabeth, Englishtown, Ewan, Freehold, Helmetta, Hights town, Holmdel, Iselin, Keasbey, Keyport, Lake Hiawa tha (press report), Laurence Harbor, Lincroft, Linden, Mar1boro, Matawan, Mays Landing, Morganville, New Brunswick, North Bergen (press report), Parlin, Perth Amboy, Sayreville, Sewaren, South Amboy, South Plainfield, South River, Spotswood, Tennent, Thorofare, Wickatunk, Woodbridge.

New York--Brooklyn (Bay Ridge--press report), Brooklyn (Bensonhurst--press report), Flatbush (press report), New Dorp (press report), New Hyde Park, Staten Island, Tot tenville.

Pennsylvania--Solebury.

Intensity III:

New Jersey-Belford, Chester, Franklin Park, Hazlet, Little Silver, Rahway, 
New Jersey--Continued

Rooseve1t, Sea Bright, Shrewsbury.

New York--Massapequa.

Intensity II:

New Jersey--Bordentown, East Millstone, Jamesburg, Jersey City, Kendall Park, Kingston.

2 February (L) Northern New Jersey

Origin time: 022613.3

Epicenter: $\quad 40.77 \mathrm{~N} ., 74.66 \mathrm{~W}$.

Depth: $\quad 0 \mathrm{~km}$

Magnitude: $\quad 1.9 \mathrm{mbLg}(\mathrm{L})$

Intensity III: Chester (press report).

23 February (L) Northern New Jersey

Origin time: 102357.2

Epicenter: $\quad 40.80 \mathrm{~N} ., 74.81 \mathrm{~W}$.

Depth: $\quad 13 \mathrm{~km}$

Magnitude: $\quad 2.9 \mathrm{mbLg}(\mathrm{L})$

Intensity IV: Chester, Ironia.

10 March (L) Northern New Jersey

Origin time: 044939.7

Epicenter: $\quad 40.72 \mathrm{~N} ., 74.50 \mathrm{~W}$.

Depth: $3 \mathrm{~km}$

Magnitude: $\quad 2.2 \mathrm{ML}(\mathrm{L})$

Felt in Hunterdon, Middlesex, Morris, Somerset, and Union Counties. At Bernardsville a $1.3 \mathrm{~cm}$ wide crack was observed in a driveway (press report).

Intensity V: Basking Ridge (small objects and hanging pictures fell; windows, doors, and dishes rattled; felt by many).

Intensity IV: Bedminster, Bernardsville (press report), Chester, Far Hills, G11lette, Ironia, Liberty Corner, Middlesex, New Vernon, Peapack.

Intensity III: Bridgewater (press report), East Millstone, Gladstone, Tabor, Warren.

Intensity II: Avenal, Green Village, Rockaway.

Felt: $\quad$ Mendham (L), Morristown (L), New Brunswick (press report).

New York

30 January (L) Central New Jersey

Origin time: 163052.1

See New Jersey Listing.

30 December (L) Southeastern New York

Origin time: 141512.3

Epicenter: $\quad 41.16 \mathrm{~N} ., 73.71 \mathrm{~W}$.

Depth: $\quad 4 \mathrm{~km}$

Magnitude: $\quad 2.0 \mathrm{mbLg}(\mathrm{L})$
New York--Continued

This earthquake was reported heard at New Canaan, Ridgefield, and Welton, Connecticut.

Intensity IV:

Connecticut--Cos Cob, Greenwich.

New York--Armonk, Bedford, Purchase, Valha11a.

Intensity III:

Connecticut-Stamford (press report).

New York-Bedford H1lls, Briarcliff Manor, Marykno11, Pleasantville, Pound Ridge, Thornwood, White Plains.

Felt:

New York--Greenburgh (press report), Ossining (press report).

North Carolina

13 August (G) Southeastern Tennessee Origin time: 051856.0

See Tennessee Listing.

26 August (G) Nort hwes tern South Carolina

Origin time: 013145.0

See South Carolina listing.

12 September (G) Eastern Tennessee Origin time: 062403.6

See Tennessee listing.

\section{Ohio}

9 November (G) Northeastern Kentucky Origin time: 212959.1

See Kentucky 11sting.

\section{Ok1ahoma}

13 March (T) Central Oklahoma

Origin time: 232922.6

Epicenter: $\quad 35.42 \mathrm{~N} .99 .85 \mathrm{~W}$.

Depth: $\quad 5 \mathrm{~km}$

Magnitude: $\quad 1.7 \mathrm{mbLg}(\mathrm{T})$

Intensity II: Southwestern Yukon ( $T$ ).

14 March (T) Central Oklahoma

Origin time: 031056.8

Epicenter: $\quad 35.50$ N., $97.83 \mathrm{~W}$. 
Oklahoma--Cont inued

Depth: $\quad 5 \mathrm{~km}$

Magnitude: $\quad 1.9 \mathrm{mbLg}(\mathrm{T})$

Intensity IV: Mustang ( $T$ ), northern and western Yukon $(T)$.

Intensity III: Union City.

14 March (T) Central Oklahoma

Origin time: 043715.3

Epicenter: $\quad 35.52 \mathrm{~N} ., 97.78 \mathrm{~W}$.

Depth: $\quad 5 \mathrm{~km}$

Magnitude: $2.2 \mathrm{mbLg}(\mathrm{T})$

Intensity V: Northern and western Yukon (T).

Intensity IV: Mustang (T).

Intensity III: Union City (T).

18 March (T) Central Oklahoma

Origin time: 204419.5

Epicenter: $\quad 35.38 \mathrm{~N} ., 98.12 \mathrm{~W}$.

Depth: $\quad 5 \mathrm{~km}$

Magnitude: $\quad 2.9 \mathrm{mbLg}(\mathrm{T})$

Intensity III : $17 \mathrm{~km}$ west of Union City $(\mathrm{T})$.

18 March ( $T$ ) Southern Oklahoma

Origin time: 231901.3

Epicenter: $\quad 34.10 \mathrm{~N}$., $97.45 \mathrm{~W}$.

Depth: $\quad 5 \mathrm{~km}$

Magnitude: $\quad 2.3 \mathrm{mbLg}(\mathrm{T})$

Intensity III: $5 \mathrm{~km}$ south of Wilson.

22 May ( $T$ ) Southern Oklahoma

Origin time: 034923.8

Epicenter: $\quad 34.03 \mathrm{~N} ., 97.47 \mathrm{~W}$.

Depth: $\quad 4 \mathrm{~km}$

Magnitude: $\quad 1.9 \mathrm{mbLg}(\mathrm{T})$

Intensity III: Wilson.

7 June ( $T$ ) Western Oklahoma

Origin time: 073935.6

Epicenter: $\quad 35.19 \mathrm{~N} ., 99.81 \mathrm{~W}$.

Depth: $\quad 5 \mathrm{~km}$

Magnitude: $\quad 3.0 \mathrm{mbLg}(\mathrm{T})$

Intensity IV: Texola.

Intensity III: Sayre (T).

$25 \mathrm{July}(\mathrm{T})$ Southern Oklahoma

Origin time: 031537.3

Epicenter: $\quad 33.97$ N., $97.55 \mathrm{~W}$.

Depth: $\quad 5 \mathrm{~km}$

Magnitude: $\quad 2.7 \mathrm{mbLg}(\mathrm{T})$

Intensity V: Near Wilson (T).

13 September ( $T$ ) Western Oklahoma

Origin time: 004923.0

Epicenter: $\quad 35.22$ N., $99.36 \mathrm{~W}$.

Depth: $\quad 15 \mathrm{~km}$

Magnitude: $\quad 3.4 \mathrm{mbLg}(\mathrm{T})$

Intensity IV: Carter (small objects moved, dishes rattled, buildings shook slightly, felt by many).

Intensity III: Sentinel, Willow.

Fe1t: $\operatorname{Retrop}(\mathrm{T})$.
Oklahoma--Cont inued

16 September ( $T$ ) Central Oklahoma

Origin time: 155720.8

Epicenter: $\quad 35.34 \mathrm{~N} ., 98.00 \mathrm{~W}$.

Depth: $\quad 5 \mathrm{~km}$

Magnitude: $\quad 2.5 \mathrm{mbLg}(\mathrm{T})$

Intensity IV: Minco (T).

17 September ( $T$ ) Central Oklahoma

origin time: 204150.5

Epicenter: $\quad 35.32$ N., $97.97 \mathrm{~W}$.

Depth: $\quad 5 \mathrm{~km}$

Magnitude: $\quad 2.5 \mathrm{mbLg}(\mathrm{T})$

Intensity IV: Minco ( $T$ ).

9 December ( $T$ ) Southern Oklahoma

Origin time: 231258.7

Epicenter: $\quad 33.99$ N., 97.35 W.

Depth: $\quad 5 \mathrm{~km}$

Magnitude: $\quad 2.5 \mathrm{mbLg}(\mathrm{T})$

Intensity III: $20 \mathrm{~km}$ southeast of Wilson (T).

\section{Oregon}

3 February (B) Northern California Origin time: 095816.1

See California--off the coast listing.

11 March (W) Southwestern Washington Origin time: 143933.0

See Washington 1isting.

8 April (W) Oregon-Washington border Origin time: 072937.8

See Washington 11sting.

Pennsylvania

30 January (L) Central New Jersey

Origin time: 163052.1

See New Jersey Listing.

Puerto Rico

23 March (G) Dominican Republic Region

Origin time: 193231.1

Epicenter: $\quad 17.99$ N., 69.04 W.

Depth:

$80 \mathrm{~km}$

Magnitude: $\quad 6.1 \mathrm{mb}(G), 6.4 \mathrm{mb}(P)$

Felt in the Dominican Republic, Puerto Rico, and in parts of Colombia, Haiti, and 
Venezuela. Minor damage was reported in Santo Domingo (press report).

Intensity V: Morovis, Puerto Rico.

Intensity IV: Ponce and San Juan, Puerto Rico (press report).

Fe1t: Mayaguez, Puerto Rico (press report).

3 October (G) Mona Passage

Origin time: 003156.8

Epicenter: $\quad 18.98 \mathrm{~N} ., 67.85 \mathrm{~W}$.

Depth: $\quad 42 \mathrm{~km}$

Magnitude: $\quad 5.0 \mathrm{mb}(\mathrm{G})$

Felt on Puerto Rico.

5 November ( $G$ ) Mona Passage

Origin time: 015112.9

Epicenter: $\quad 17.83 \mathrm{~N} ., 68.62 \mathrm{~W}$.

Depth: $\quad 104 \mathrm{~km}$

Magnitude: $\quad 5.9 \mathrm{mb}(\mathrm{G}), 6.2 \mathrm{mb}(\mathrm{P})$

Felt in eastern Dominican Republic, western Puerto Rico, and nor thern Venezuela.

Intensity V: Ponce and Mayaguez, Puerto Rico (press report).

Intensity IV: San Juan, Puerto Rico (press report).

\section{South Carolina}

19 January (G) Northwestern South Carolina Origin time: 085536.9

Epicenter: $\quad 34.64 \mathrm{~N} ., 82.84 \mathrm{~W}$.

Depth: $\quad 1 \mathrm{~km}$

Magnitude: $\quad 2.8 \mathrm{mbLg}(G), 3.4 \mathrm{mbLg}(\mathrm{V})$

The press reported that the earthquake rattled windows and shook walls in the Lake Keowee area prompting numerous telephone calls to local radio stations and police departments. It was reported felt at Clemson, Salem, Walhalla, and at the Oconee Nuclear Power Station.

Intensity IV: Newry, Seneca, Six Mile.

11 August (F) Eastern South Carolina

Origin time: 021156.6

Epicenter: $\quad 32.99 \mathrm{~N} ., 80.22 \mathrm{~W}$.

Depth: $\quad 10 \mathrm{~km}$

Magnitude: $\quad 2.5 \mathrm{mb}(\mathrm{F})$

Intensity III: Summerville.

26 August (G) Northwestern South Carolina

origin time: 013145.0

Epicenter: $\quad 34.93$ N., 82.97 W.
Depth: $\quad 2 \mathrm{~km}$

Magnitude: $\quad 3.7 \mathrm{mbLg}(\mathrm{V})$

This earthquake was felt over an area of approximately $11,400 \mathrm{sq} \mathrm{km}$ of Georgia, North Carolina, and South Carolina ( $f i g$. 26). The University of South Carolina recorded about 20 aftershocks. The largest aftershock, approximately magnitude 2.2 mbLg, occurred on August 27 at 0507 UTC. Some of the intensities listed below were evaluated by the USGS from a newspaper questionnaire published by the University of South Carolina in the Transylvania Times of Brevard, N.C.; the Seneca Journal of Seneca, S.C.; and the Anderson Independent of Anderson, S.C.

Intensity VI:

South Carolina--

Tamasee--dry wall cracked and fell, concrete basement floor cracked, small objects fell but did not break.

Intensity $\mathrm{V}$ :

North Carolina--

Naples--small objects and 1ight furniture moved; trees and bushes shook moderately; windows, doors, and dishes rattled.

Rosman--small objects and light furniture moved, few windows cracked, hanging pictures swung, felt by several.

Sylva--moved a large business desk and rattled windows (press report).

Zirconia--few windows cracked, small objects moved, water splashed onto sides of lake or swimming pools, hanging pictures swung, felt by several.

South Carolina--

Central--furniture moved; hanging objects swung moderately; windows, doors, and dishes rattled; sounded like an explosion.

Greenville--few windows cracked; hanging pictures swung; windows, doors, and dishes rattled.

Newry--light furniture and small objects moved; hanging pictures swung; windows, doors, and dishes rattled; felt by several.

Intensity IV:

Georgia--Mountain City, Turnerville.

North Carolina--Almond, Arden, Barnardsville, Brevard, Cashiers, Cedar Mountaln, Dillsboro, Hender sonville, Highlands, Horse Shoe, Lake Junaluska, Lake Toxaway, otto, Sapphire, Scaly Mountain, Toxaway Falls (press report), Tuckasegee, Waynesville, Webster. South Carolina--Anderson (press report), Clemson, Cleveland, Easley, Gray Court, 


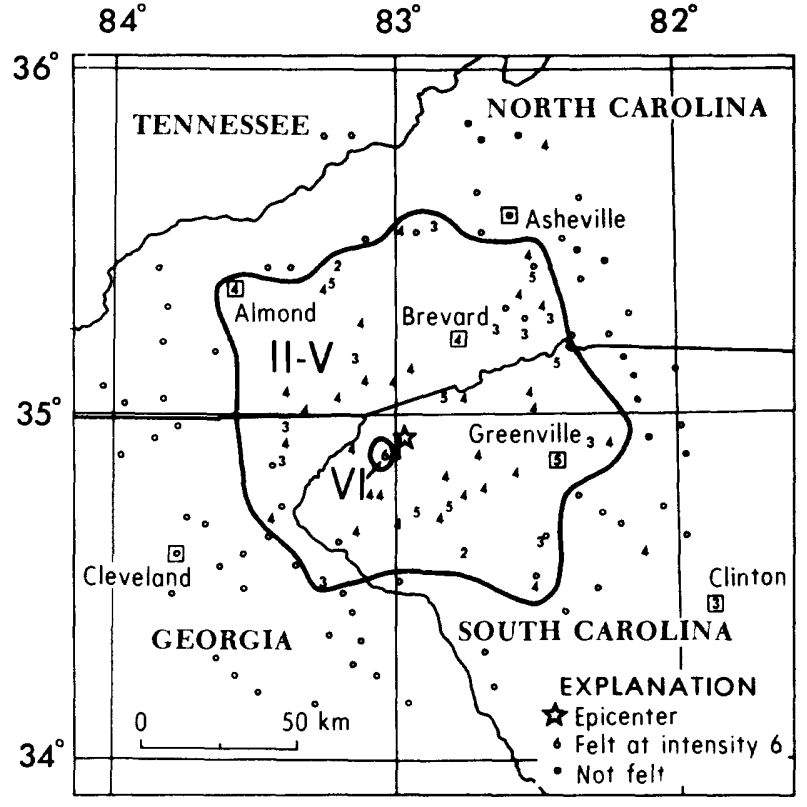

FIGURE 26.--Isoseismal map for the northwestern South Carolina earthquake of 26 August 1979, 013145.0 UTC. Roman numerals represent Modified Mercalli intensities between isoseismals; Arabic numerals are used to represent these intensities at specific sites.

South Carolina--Continued

Greer, Liberty, Marietta, Mountain Rest, Norris, Pickens, Salem, Seneca, Six Mile, Walhalla, West Union, Westminster. Intensity III:

Georgia--Clayton, Eastanollee, Rabun Gap. North Carolina--Canton, Flat Rock, Glenville, Penrose, Tuxedo.

South Carolina--Cinton, Taylors, Williamston.

Intensity II:

Georg1a--Dillard.

North Carolina--Balsam.

South Carolina--Cateechee, Sandy Springs.

8 October (G) Central South Carolina

Origin time: 232010.1

Epicenter: $\quad 34.31 \mathrm{~N} ., 81.36 \mathrm{~W}$.

Depth: $\quad 5 \mathrm{~km}$

Magnitude: $\quad 2.9 \mathrm{mbLg}(G)$

Felt at V. C. Summer Nuclear Power Plant

(telephone report).

7 December (G) Summerville area

origin time: 054335.0

Epicenter: $\quad 33.01 \mathrm{~N} ., 80.17 \mathrm{~W}$.

Depth: $\quad 6 \mathrm{~km}$
South Carolina--Cont inued

Magnitude: $\quad 2.9 \mathrm{mbLg}(\mathrm{G}), 2.8 \mathrm{mbLg}(\mathrm{V})$

Intensity IV: Lincolnville, Summerville (Twin 0aks).

Intensity II: Charleston.

Tennessee

2 February (S) Western Tennessee

Origin time: 111704.9

Epicenter: $\quad 36.27 \mathrm{~N} ., 89.47 \mathrm{~W}$

Depth: $\quad 2 \mathrm{~km}$

Magnitude: $\quad 2.0 \mathrm{mbLg}(\mathrm{S})$

Intensity III: Ridgely (S).

2 February (S) Western Tennessee

Origin time: 184933.0

Epicenter: $\quad 36.26 \mathrm{~N} ., 89.45 \mathrm{~W}$.

Depth: $\quad 3 \mathrm{~km}$

Magnitude: $\quad 1.9 \mathrm{mbLg}(\mathrm{S})$

Intensity II: Ridgely (S).

2 February (S) Western Tennessee

Origin time: 185018.9

Epicenter: $\quad 36.27 \mathrm{~N} ., 89.46 \mathrm{~W}$.

Depth: $\quad 4 \mathrm{~km}$

Magnitude: $\quad 2.0 \mathrm{mbLg}(\mathrm{S})$

Intensity III: Ridgely (S).

3 February (S) Western Tennessee

Origin time: 065642.3

Epicenter: $\quad 36.26 \mathrm{~N} ., 89.47 \mathrm{~W}$.

Depth: $\quad 4 \mathrm{~km}$

Magnitude: $\quad 2.0 \mathrm{mbLg}(\mathrm{S})$

Felt near Ridgely ( $\mathrm{S}$ ).

5 February (S) Northeastern Arkansas Origin time: 053109.3

See Arkansas listing.

11 June (S) New Madrid region Origin time: 041216.9

See Missouri 1isting.

13 July (S) New Madrid Region Origin time: 072939.0

See Missouri listing.

13 August (G) Southeastern Tennessee

Origin time: 051856.0

Epicenter: $\quad 35.24$ N., $84.38 \mathrm{~W}$.

Depth: $\quad 5 \mathrm{~km}$

Magnitude: $\quad 3.7 \mathrm{mbLg}(\mathrm{V})$

Intensity $\mathrm{V}$ :

Georgia--

Cisco--few windows cracked, felt by and 
awakened many.

Varne11--small objects overturned, felt by many and awakened several.

North Carolina--

Murphy-few windows cracked, pendulum clocks stopped, felt by and awakened several.

Tennessee--

Chattanooga-few windows cracked, small objects moved, hanging picture swung, felt by many.

Cleveland--dishes fell (telephone report), hanging pictures out of place, felt by and awakened many.

\section{Intensity IV}

Georgla--Blue Ridge, Cedartown, Chatsworth, Cherrylog, Cohutta, Ellijay, Epworth, Eton, Hiwassee, Marietta, McCaysville, Mineral Bluff, Morganton, Tennga, Tunnel H111 (press report). North Carolina--Andrews, Aquone, Brasstown, Robbinsville, Suit, Topton, Unaka.

Tennessee--Apison, Athens, Benton, Calhoun, Charleston, Coker Creek, Conasauga, Copperhi11, Dafsy, Delano, Ducktown, Etowah, Farner, Harrison, Hixson, Isabella, Madisonville, McDonald, Mount Vernon, Nashville (press report), Niota, Ocoee, Oldfort, Ooltewah, Postelle, Reliance, Riceville, Tellico Plains, Townsend, Turtletown.

Intensity III:

Georgia--Rome, Sandy Springs (press report).

Tennessee--She1byville.

Intensity II:

Georgia--Decatur.

Tennessee--Decatur.

Fe1t:

Georgia--Atlanta (telephone report).

North Carolina--Asheville, Cherokee, Clay.

12 September (G) Eastern Tennessee

Origin time: 062403.6

Epicenter: $\quad 35.59 \mathrm{~N} ., 83.90 \mathrm{~W}$.

Depth: $\quad 5 \mathrm{~km}$

Magnitude: $\quad 3.2 \mathrm{mbLg}(\mathrm{V})$

Intensity V:

Tennessee--Maryville (small objects overturned, windows, doors, and dishes rattled, felt by many).

Intensity IV:

North Carolina--Fontana Dam.

Tennessee--Alcoa, Friendsville, Greenback, Knoxvi1le, Louisville, Madisonville, Tallassee, Townsend, Wa1land.

Texas

5 July (G) West Texas

Jrigin time: 010501.0

Epicenter: $\quad 32.95$ N., 100.90 W.

Depth:

$4 \mathrm{~km}$

Magnitude :

$2.7 \mathrm{mbLg}(\mathrm{T})$

Heard but not felt at Snyder.

\section{Utah}

12 January (U) Southwestern Utah

Origin time: 092900.1

Epicenter: $\quad 37.73$ N., $113.13 \mathrm{~W}$.

Depth: $\quad 0 \mathrm{~km}$

Magnitude: $\quad 3.5 \mathrm{ML}(\mathrm{G})$

Southern Utah State College at Cedar City recorded about 50 af tershocks (press report).

Intensity IV: Cedar City, Parowan.

25 March (U) Northwestern Utah

Origin time: 214155.7

Eplcenter: $\quad 41.34$ N., 113.29 W.

Depth: $\quad 7 \mathrm{~km}$

Magnitude: $\quad 3.2 \mathrm{ML}(\mathrm{U})$

Felt in parts of Davis and Weber Counties.

Intensity III: Ogden (press report). Intensity II: Salt Lake City (press report).

30 Apri1 (U) Southern Utah

Origin time: 020710.3

Epicenter: $\quad 37.88 \mathrm{~N} ., 111.02 \mathrm{~W}$.

Depth: $\quad 7 \mathrm{~km}$

Magnitude: $\quad 3.8 \mathrm{ML}(\mathrm{G})$

Intensity III: Boulder.

6 October (U) Central Utah

Origin time: 101235.2

Epicenter: $\quad 39.29$ N., $111.69 \mathrm{~W}$.

Depth: $\quad 7 \mathrm{~km}$

Magnitude: $\quad 3.2 \mathrm{ML}(\mathrm{U})$

Felt at Ephraim (telephone report).

23 October (U) Southern Utah

Origin time: 041719.9

Epicenter: $\quad 37.89$ N., $110.93 \mathrm{~W}$.

Depth: $\quad 7 \mathrm{~km}$

Magnitude: $\quad 3.5 \mathrm{ML}(\mathrm{U})$

Felt in the epicentral area (telephone report).

Vermont

29 January (L) Northwestern Vermont Origin time: 063546.2

Eptcenter: $\quad 44.82$ N., 73.19 W. 
Depth: $\quad 9 \mathrm{~km}$

Magnitude: $\quad 2.5 \mathrm{mbLg}(\mathrm{L})$

Intensity II: North Hero $(\mathrm{J})$.

Washington

19 January (W) Central Washington

Origin time: 145516.0

Epicenter: $\quad 47.90 \mathrm{~N} ., 119.69 \mathrm{~W}$.

Depth: $\quad 7 \mathrm{~km}$

Magnitude: $\quad 3.6 \mathrm{ML}(\mathrm{G}), 4.0 \mathrm{ML}(\mathrm{W})$

Intensity V: Bridgeport (small objects

fell; hanging pictures swung; windows, doors, and dishes rattled).

Intensity IV: Ardenvoir, Brewster, Chelan, Coulee Dam, Electric City, Grand Coulee, Marlin, Methow, Okanogan, Omak, Pateros, Twisp.

Intensity III: Entiat (press report), Manson.

Intensity II: Mansfield, Orondo.

Felt: Chlef Joseph Dam (W).

21 January Centra1 Washington

Origin time: 2035

Epicenter: Not located.

Depth: None computed.

Magnitude: None computed.

Intensity III: Brewster (press report), Bridgeport, Pateros (press report).

1 February (W) Central Washington

Origin time: 201828.1

Epicenter: $\quad 47.53 \mathrm{~N} ., 121.92 \mathrm{~W}$.

Depth: $\quad 9 \mathrm{~km}$

Magnitude: $\quad 3.6 \mathrm{ML}(\mathrm{G}), 3.4 \mathrm{ML}(\mathrm{W})$

Intensity IV: Fall City, Mercer Island, Ravensdale, Renton, Snoqualmie.

Intensity III: Issaquah, Retsil.

11 March (W) Southwestern Washington

Origin time: 143932.8

Epicenter: $\quad 46.45$ N., $122.40 \mathrm{~W}$.

Depth: $\quad 16 \mathrm{~km}$

Magnitude: $\quad 3.8 \mathrm{mb}(\mathrm{G}), 3.8 \mathrm{ML}(\mathrm{G})$,

Intensity VI:

$$
3.9 \mathrm{ML}(\mathrm{W})
$$

\footnotetext{
Washington--Ariel (hairline cracks in exterior cinderblock wall, slightly cracked sidewalks and brick walls, chimneys cracked).

Intensity $\mathrm{V}$ :

Washington--Castle Rock (few cracked windows--press report).

Intensity IV:

Oregon--Portland.

Washington--Ashford, Chehalis, Cinebar, Cougar, Eatonville, Kelso, La Grande, Lexington (press report), Longview, Morton, Mossyrock, Olympia, Onalaska, Randle, Rochester, Ryderwood, Salkum,
}

Silver Creek, Silverlake, Toledo, Winlock.

Intensity III:

Oregon-Clatskanie (press report).

Washington--Woodland (press report). Felt:

Washington--Rif fe (W).

12 March (W) Northwestern Washington

Origin time: 124137.0

Epicenter: $\quad 48.19$ N., $122.76 \mathrm{~W}$.

Depth: $\quad 24 \mathrm{~km}$

Magnitude: $\quad 3.8 \mathrm{mb}(G), 3.4 \mathrm{ML}(G)$,

$$
3.8 \mathrm{ML}(\mathrm{W})
$$

Intensity $\mathrm{V}$ :

Washington--Oak Harbor ( $f$ ew broken dishes and cracked windows--press report, light furniture and small objects shifted, felt by many).

Intensity IV:

Washington--Chimacum, Clearlake, Clinton, Conway, Coupeville, Edmonds, Freeland, Friday Harbour (press report), Hadlock, Hansville, La Conner, Langley, Lyman, Marysville, Mount Vernon, Port Ludlow, Port Townsend, Poulsbo, Silvana, Stanwood.

Intensity III :

Washington--Gold Bar, Nordland, Sultan.

Canada--Victoria, British Columbia.

Felt:

Washington--Everett (W), Kenmore (W), Mt . Vernon (W), North Seattle (W), Snohomish (W).

8 April (W) Oregon-Washington border Origin time: 072937.8 Epicenter: $\quad 46.00$ N., 118.45 W. Depth: $5 \mathrm{~km}$

Magnitude: $\quad 3.2 \mathrm{ML}(G), 4.1 \mathrm{ML}(\mathrm{W})$

Intensity $\mathrm{V}$ :

Washington--Wa1la Wa1la.

Intensity IV :

Oregon--Mil ton-Freewater. Washington--College Place. Intensity III:

Oregon--Athena, Weston.

7 July (G) Southwestern Washington

Origin time: 205001.5

Epicenter: $\quad 46.52 \mathrm{~N} ., 122.17 \mathrm{~W}$.

Depth: $\quad 5 \mathrm{~km}$

Magnitude: $\quad 3.8 \mathrm{ML}(\mathrm{G})$

Felt in Cowlitz, Lewis, and Pierce Counties.

Intensity IV: Glenoma, Mossyrock.

Intensity III: Ashford, Eatonville (press report), Kelso, Mt. St. Helens area, Morton, Rainier.

Intensity II: Elbe, Randle. 
$28 \mathrm{July}(W)$ Southern Washington Origin time: 021906.9

Epicenter: $\quad 46.67 \mathrm{~N} ., 120.59 \mathrm{~W}$.

Depth: $\quad 0 \mathrm{~km}$

Magnitude: $\quad 3.1 \mathrm{ML}(\mathrm{G}), \quad 3.7 \mathrm{ML}(\mathrm{W})$

Intensity IV: Naches, Selah (W), Selah Firing Center (W), Yakima.

5 September (W) Northwestern Washington

Origin time: 034959.4

Epicenter: $\quad 47.52 \mathrm{~N} ., 122.00 \mathrm{~W}$.

Depth: $\quad 7 \mathrm{~km}$

Magnitude: $\quad 2.1 \mathrm{ML}(\mathrm{W})$

Felt at Issaquah.

15 November ( $Q$ ) British Columbia, Canada Origin time: 161247.6

Epicenter: $\quad 49.24 \mathrm{~N} ., 122.35 \mathrm{~W}$.

Depth: $\quad 15 \mathrm{~km}$

Magnitude: $\quad 3.6 \mathrm{ML}(\mathrm{Q})$

Felt from Hope, B.C. to Langley, B.C.

Intensity III:

Canada--West Vancouver, B.C.

United States--Sumas, Wash.

26 November (W) Northwest Washington

Origin time: 231827.0

Epicenter: $\quad 48.54$ N., 122.41 W.

Depth: $\quad 20 \mathrm{~km}$

Magnitude: $\quad 4.1 \mathrm{mb}(G), 3.9 \mathrm{ML}(G)$

Intensity IV: Acme, Bellingham (press report), Bow, Clearlake, Edison, Seattle, Sedro Woolley.

Intensity III: Anacortes, Clallam Bay, Lopez, Lyman, Sekiu.

Intensity II: Mount Vernon.

Felt: Burlington (W).

27 November (G) Northwestern Washington Origin time: 021346.5

Epicenter: $\quad 48.59 \mathrm{~N} ., 122.41 \mathrm{~W}$.

Depth: $\quad 20 \mathrm{~km}$

Magnitude: $\quad 3.3 \mathrm{ML}(\mathrm{G})$

Intensity III: Acme, Bow.

10 December (W) Central Washington

Origin time: 054007.5

Epicenter: $\quad 46.66$ N., 120.58 W.

Depth: $\quad 5 \mathrm{~km}$

Magnitude: $\quad 3.2 \mathrm{ML}(\mathrm{G}), 3.4 \mathrm{ML}(\mathrm{W})$

Intensity IV: Selah, Yakima.

West Virginia

9 November (G) Northeastern Kentucky

Origin time: 212959.1

See Kentucky listing.
13 March Yellowstone National Park

Origin time: 0244

Epicenter: Not located.

Depth: None computed.

Magnitude: None computed.

Intensity IV: 01d Faithful Ranger Station.

17 March Yellowstone National Park

Origin time: 1147

Epicenter: Not located.

Depth: None computed.

Magnitude: None computed.

Intensity III: Lake.

17 March Yellowstone National Park

Origin time: 2059

Epicenter: Not located.

Depth: None computed.

Magnitude: None computed.

Intensity IV: Lake.

7 May (G) Hebgen Lake region Origin time: $17 \quad 15 \quad 43.4$

See Montana listing.

8 May (G) Hebgen Lake region origin time: 005742.9

See Montana 1isting.

8 May (G) Hebgen Lake region origin time: 005844.8

See Montana listing.

30 June Yellowstone National Park Origin time: 0655

Epicenter: Not located.

Depth: None computed.

Magnitude: None computed.

Intensity II: 01d Faithful.

3 July (G) Northwestern Wyoming

Origin time: 095723.9

Epicenter: $\quad 43.41 \mathrm{~N} ., 110.71 \mathrm{~W}$

Depth: $\quad 5 \mathrm{~km}$

Magnitude: $\quad 3.2 \mathrm{ML}(\mathrm{U})$

Intensity IV: Jackson (awakened some residents--press report).

6 September Yellowstone National

Origin time: 1441

Epicenter: Not located.

Depth: None computed.

Magnitude: None computed.

This is one of a swarm of small earthquakes recorded by the seismograph at the 0ld Falthful Ranger Station.

Intensity III: Norris. 
Wyoming--Continued

5 December Yellowstone National Park

Origin time: Epicenter : Depth:

200034 Not located None computed. None computed.

Intensity III: Grant Village.
Wyoming--Cont inued

11 December Yellowstone National Park

Origin time: 200810

Epicenter: Not located.

Depth: None computed.

Magnitude: None computed.

Intensity III: 01d Faithful. 
Table 1.--Summary of U.S. earthquakes for 1979

[The following symbols are used to indicate authority for arrival or origin times, epicenters, and/or magnitudes: (B) University of California, Berkeley; (C) University of Minnesata, Minneapolis; (D) University of Montana, Missoula; (E) U.S. Department of Energy, Las Vegas, Nevada; (F) Bollinger and Mathena, 1980; (G) U.S. Geological Survey, National Earthquake Information Service, Golden, Colo.; (H) U.S. Geological Survey, Hawaiian Volcano Observatory, Hawaii National Park; ( $J$ ) weston observatory, Weston, Mass.; (K) Kansas Geological Survey, Lawrence; (I)
Lamont-Doherty Geological Observatory, Palisades, N.Y.; (M) NOAA, Alaska Tsunami Warning Center, Palmer; (0) Earth Physics Branch, Ottawa, Canada; (P) California Institute of Technology, Pasadena; (S) St. Louis University, St. Louis, Mo.; (T) University of Oklahoma, Leonard; (L) University of Utah, Salt Lake City; (V) Virginia Polytechnic Institute and State University, Blacksburg; (W) University of Washington, Seat ie: (Z) Stephens and others, 1980, N, Normal depth. Leaders (...) indicate information is not avaliable]

Date
$(1979)$

\section{ALASKA}

\begin{tabular}{|c|c|c|c|c|c|c|c|c|c|c|c|c|c|c|c|c|c|c|c|}
\hline $\begin{array}{l}\text { JAN. } \\
\text { JAN. } \\
\text { JAN. } \\
\text { JAN. } \\
\text { JAN. }\end{array}$ & $\begin{array}{l}2 \\
2 \\
2 \\
2 \\
3\end{array}$ & $\begin{array}{l}10 \\
13 \\
13 \\
15 \\
12\end{array}$ & $\begin{array}{l}58 \\
53 \\
55 \\
26 \\
26\end{array}$ & $\begin{array}{l}05.0 \\
50.8 \\
51.5 \\
26.8 \\
46.2\end{array}$ & $\begin{array}{l}51.59 \\
51.68 \\
51.60 \\
51.79 \\
51.64\end{array}$ & $\begin{array}{l}\mathrm{N} . \\
\mathrm{N} . \\
\mathrm{N} . \\
\mathrm{N} . \\
\mathrm{N} .\end{array}$ & $\begin{array}{l}173.30 \\
173.38 \\
173.31 \\
173.23 \\
173.29\end{array}$ & $\begin{array}{l}W . \\
W \cdot \\
W \cdot \\
W \cdot \\
W \cdot\end{array}$ & $\begin{array}{l}35 \\
31 \\
33 \mathrm{~N} \\
35 \\
33 \mathrm{~N}\end{array}$ & $\begin{array}{l}4.8 \\
5.1 \\
5.2 \\
4.6 \\
4.8\end{array}$ & $\begin{array}{l}4.3 \\
4.8 \\
\ldots \\
\ldots \\
\ldots\end{array}$ & $\begin{array}{l}\cdots \\
\cdots \\
\cdots \\
\cdots\end{array}$ & $\begin{array}{l}\ldots \\
\cdots \\
\cdots \\
\cdots \\
\cdots\end{array}$ & $\begin{array}{l}\mathrm{G} \\
\mathrm{G} \\
\mathrm{G} \\
\mathrm{G}\end{array}$ & $\begin{array}{l}\text { JAN. } \\
\text { JAN. } \\
\text { JAN. } \\
\text { JAN. } \\
\text { JAN. }\end{array}$ & $\begin{array}{l}1 \\
2 \\
2 \\
2 \\
3\end{array}$ & $\begin{array}{l}11 \\
02 \\
02 \\
04 \\
01\end{array}$ & $\begin{array}{l}P . M \text {. } \\
A \cdot M \text {. } \\
A \cdot M \text {. } \\
A \cdot M \text {. } \\
A \cdot M \text {. }\end{array}$ & $\begin{array}{l}\text { BST } \\
\text { BST } \\
\text { BST } \\
\text { BST } \\
\text { BST }\end{array}$ \\
\hline $\begin{array}{l}\text { JAN. } \\
\text { JAN. } \\
\text { JAN. } \\
\text { JAN. } \\
\text { JAN. }\end{array}$ & $\begin{array}{l}4 \\
4 \\
5 \\
6 \\
8\end{array}$ & $\begin{array}{l}02 \\
15 \\
13 \\
08 \\
10\end{array}$ & $\begin{array}{l}17 \\
35 \\
57 \\
56 \\
11\end{array}$ & $\begin{array}{l}42.9 \\
04.0 \\
01.4 \\
29.3 \\
00.8\end{array}$ & $\begin{array}{l}54.63 \\
61.73 \\
60.26 \\
58.55 \\
61.77\end{array}$ & $\begin{array}{l}\mathrm{N} . \\
\mathrm{N} . \\
\mathrm{N} . \\
\mathrm{N} . \\
\mathrm{N} .\end{array}$ & $\begin{array}{l}161.52 \\
150.04 \\
152.27 \\
140.76 \\
150.08\end{array}$ & $\begin{array}{l}\text { W. } \\
W \\
W \\
W \\
W \\
W\end{array}$ & $\begin{array}{c}33 \mathrm{~N} \\
34 \\
116 \\
33 \mathrm{~N} \\
45\end{array}$ & & $\begin{array}{l}\cdots \\
\cdots \\
\cdots\end{array}$ & & $\begin{array}{r}\text { FELT } \\
\ddot{0} \\
\ddot{I I}\end{array}$ & $\begin{array}{l}\mathrm{G} \\
\mathrm{G} \\
\mathrm{G} \\
\mathrm{G}\end{array}$ & $\begin{array}{l}\text { JAN. } \\
\text { JAN. } \\
\text { JAN. } \\
\text { JAN. } \\
\text { JAN. }\end{array}$ & $\begin{array}{l}3 \\
4 \\
5 \\
5 \\
8\end{array}$ & $\begin{array}{l}03 \\
05 \\
03 \\
11 \\
12\end{array}$ & $\begin{array}{l}\mathrm{A} \\
\mathrm{A} \\
\mathrm{P}\end{array}$ & $\begin{array}{l}\text { BST } \\
\text { AST } \\
\text { AST } \\
\text { YST } \\
\text { AST }\end{array}$ \\
\hline $\begin{array}{l}\text { JAN. } \\
\text { JAN. } \\
\text { JAN. } \\
\text { JAN. } \\
\text { JAN. }\end{array}$ & $\begin{array}{r}8 \\
8 \\
8 \\
10 \\
10\end{array}$ & $\begin{array}{l}11 \\
14 \\
16 \\
00 \\
06\end{array}$ & $\begin{array}{l}04 \\
21 \\
01 \\
34 \\
25\end{array}$ & $\begin{array}{l}08.5 \\
41.9 \\
49.5 \\
48.1 \\
50.7\end{array}$ & $\begin{array}{l}56.83 \\
60.70 \\
51.64 \\
61.58 \\
60.33\end{array}$ & $\begin{array}{l}\mathrm{N} . \\
\mathrm{N} . \\
\mathrm{N} . \\
\mathrm{N} . \\
\mathrm{N} .\end{array}$ & $\begin{array}{l}157.86 \\
151.16 \\
173.17 \\
150.06 \\
150.53\end{array}$ & $\begin{array}{l}\text { W. } \\
\text { W. } \\
\text { W. } \\
\text { W. } \\
\text { W. }\end{array}$ & $\begin{array}{r}105 \\
85 \\
43 \\
42 \\
63\end{array}$ & & $\begin{array}{l}\cdots \\
\dot{4} \cdot 6 \\
\cdots \\
\cdots\end{array}$ & $\begin{array}{l}\cdots \\
\ddot{*} \\
\dot{\cdots} \\
\dot{0}\end{array}$ & $\ddot{\cdots}$ & $\begin{array}{l}\mathrm{G} \\
\mathrm{G} \\
\mathrm{G} \\
\mathrm{G}\end{array}$ & $\begin{array}{l}\text { JAN. } \\
\text { JAN. } \\
\text { JAN. } \\
\text { JAN. } \\
\text { JAN. }\end{array}$ & $\begin{array}{l}8 \\
8 \\
8 \\
9 \\
9\end{array}$ & $\begin{array}{l}01 \\
04 \\
05 \\
02 \\
08\end{array}$ & $\begin{array}{l}\mathrm{P} \\
\mathrm{P}\end{array}$ & $\begin{array}{l}\text { AST } \\
\text { AST } \\
\text { BST } \\
\text { AST } \\
\text { AST }\end{array}$ \\
\hline $\begin{array}{l}\text { JAN. } \\
\text { JAN. } \\
\text { JAN: } \\
\text { JAN: } \\
\text { JAN. }\end{array}$ & $\begin{array}{l}10 \\
10 \\
12 \\
12 \\
12\end{array}$ & $\begin{array}{l}09 \\
19 \\
04 \\
12 \\
19\end{array}$ & $\begin{array}{l}16 \\
13 \\
18 \\
06 \\
01\end{array}$ & $\begin{array}{l}25 \cdot 6 \\
19.8 \\
32 \cdot 3 \\
31.9 \\
55.0\end{array}$ & $\begin{array}{l}62.58 \\
63.28 \\
59.95 \\
61.83 \\
63.61\end{array}$ & $\begin{array}{l}N . \\
N . \\
N . \\
N . \\
N .\end{array}$ & $\begin{array}{l}151.28 \\
153.69 \\
141.19 \\
150.80 \\
157.69\end{array}$ & $\begin{array}{l}\mathbf{W} \cdot \\
\mathbf{W} \cdot \\
\mathbf{W} \cdot \\
\mathbf{W} \cdot \\
\mathbf{W} .\end{array}$ & $\begin{array}{l}49 \\
33 \mathrm{~N} \\
59 \\
48 \\
62\end{array}$ & $\begin{array}{l}3.9 \\
3.5\end{array}$ & $\begin{array}{l}\cdots \\
\cdots \\
\cdots \\
\cdots\end{array}$ & $\begin{array}{l}\dot{3} \cdot \mathrm{IM} \\
\cdots \\
\cdots \\
\cdots\end{array}$ & $\begin{array}{l}\cdots \\
\cdots \\
\cdots \\
\cdots\end{array}$ & $\begin{array}{l}\mathrm{G} \\
\mathrm{G} \\
\mathrm{G} \\
\mathrm{G}\end{array}$ & $\begin{array}{l}\text { JAN. } \\
\text { JAN. } \\
\text { JAN. } \\
\text { JAN. } \\
\text { JAN. }\end{array}$ & $\begin{array}{r}9 \\
10 \\
11 \\
12 \\
12\end{array}$ & $\begin{array}{l}11 \\
09 \\
06 \\
02 \\
09\end{array}$ & $\begin{array}{l}\mathrm{A} \\
\mathrm{P} \\
\mathrm{A} \\
\mathrm{A}\end{array}$ & $\begin{array}{l}\text { AST } \\
\text { AST } \\
\text { AST } \\
\text { AST } \\
\text { AST }\end{array}$ \\
\hline $\begin{array}{l}\text { JAN. } \\
\text { JAN. } \\
\text { JAN. } \\
\text { JAN. } \\
\text { JAN. }\end{array}$ & $\begin{array}{l}12 \\
13 \\
13 \\
14 \\
14\end{array}$ & $\begin{array}{l}23 \\
14 \\
19 \\
01 \\
15\end{array}$ & $\begin{array}{l}14 \\
19 \\
21 \\
38 \\
13\end{array}$ & $\begin{array}{l}16.5 \\
46.0 \\
38.0 \\
06.2 \\
08.7\end{array}$ & $\begin{array}{l}61.00 \\
63.33 \\
63.28 \\
54.61 \\
53.30\end{array}$ & $\begin{array}{l}N . \\
N \cdot \\
N \\
N \\
N\end{array}$ & $\begin{array}{l}149.42 \\
151.18 \\
148.93 \\
159.67 \\
170.26\end{array}$ & $\begin{array}{l}\mathrm{W} . \\
\mathrm{W} \cdot \\
\mathrm{W} \cdot \\
\mathrm{W} . \\
\mathrm{E} .\end{array}$ & $\begin{array}{l}34 \\
33 \mathrm{~N} \\
96 \\
34 \\
35\end{array}$ & $\begin{array}{l}\ddot{4} \cdot \dot{4} \\
4.9\end{array}$ & $\ddot{4} \cdot \dot{6}$ & $\begin{array}{l}3.3 \mathrm{~N} \\
3.1 \mathrm{~N} \\
\ldots \\
\ldots \\
\ldots\end{array}$ & $\begin{array}{l}\cdots \\
\cdots \\
\cdots \\
\cdots\end{array}$ & $\begin{array}{l}\mathrm{G} \\
\mathrm{G} \\
\mathrm{G} \\
\mathrm{G}\end{array}$ & $\begin{array}{l}\text { JAN. } \\
\text { JAN. } \\
\text { JAN. } \\
\text { JAN. } \\
\text { JAN. }\end{array}$ & $\begin{array}{l}12 \\
13 \\
13 \\
13 \\
14\end{array}$ & $\begin{array}{l}01 \\
04 \\
09 \\
03 \\
04\end{array}$ & A & $\begin{array}{l}\text { AST } \\
\text { AST } \\
\text { AST } \\
\text { AST } \\
\text { BST }\end{array}$ \\
\hline $\begin{array}{l}\text { JAN. } \\
\text { JAN: } \\
\text { JAN. } \\
\text { JAN. } \\
\text { JAN. }\end{array}$ & $\begin{array}{l}15 \\
15 \\
16 \\
18 \\
22\end{array}$ & $\begin{array}{l}10 \\
20 \\
07 \\
20 \\
17\end{array}$ & $\begin{array}{l}51 \\
09 \\
13 \\
39 \\
51\end{array}$ & $\begin{array}{l}45.5 \\
29.5 \\
31.0 \\
28.2 \\
36.1\end{array}$ & $\begin{array}{l}62.89 \\
66.97 \\
52.50 \\
52.74 \\
51.13\end{array}$ & $\begin{array}{l}\mathrm{N} . \\
\mathrm{N} \cdot \\
\mathrm{N} \cdot \\
\mathrm{N} \cdot \\
\mathrm{N} .\end{array}$ & $\begin{array}{l}149.55 \\
146.41 \\
167.92 \\
168.12 \\
175.18\end{array}$ & $\begin{array}{l}\mathrm{W} . \\
\mathbf{W} \cdot \\
\mathbf{W} \cdot \\
\mathbf{W} \cdot \\
\mathrm{E} .\end{array}$ & $\begin{array}{l}89 \\
60 \\
44 \\
33 N \\
33 N\end{array}$ & & $\begin{array}{l}\because \cdots \\
\dot{5} \cdot \dot{2} \\
\ddot{4} \cdot \dot{5}\end{array}$ & & $\begin{array}{l}\cdots \\
\cdots \\
\cdots \\
\cdots \\
\cdots\end{array}$ & $\begin{array}{l}\mathrm{G} \\
\mathrm{G} \\
\mathrm{G} \\
\mathrm{G}\end{array}$ & $\begin{array}{l}\text { JAN. } \\
\text { JAN. } \\
\text { JAN. } \\
\text { JAN. } \\
\text { JAN. }\end{array}$ & $\begin{array}{l}15 \\
15 \\
15 \\
18 \\
22\end{array}$ & $\begin{array}{l}12 \\
10 \\
08 \\
09 \\
06\end{array}$ & $\begin{array}{l}\mathrm{A} \\
\mathrm{P} \\
\mathrm{A} \\
\mathrm{A}\end{array}$ & $\begin{array}{l}\text { AST } \\
\text { AST } \\
\text { BST } \\
\text { BST } \\
\text { BST }\end{array}$ \\
\hline $\begin{array}{l}\text { JAN. } \\
\text { JAN. } \\
\text { JAN. } \\
\text { JAN. } \\
\text { JAN. }\end{array}$ & $\begin{array}{l}24 \\
25 \\
25 \\
25 \\
25\end{array}$ & $\begin{array}{l}19 \\
02 \\
17 \\
19 \\
20\end{array}$ & $\begin{array}{l}12 \\
49 \\
05 \\
30 \\
54\end{array}$ & $\begin{array}{l}42 \cdot 5 \\
03 \cdot 5 \\
44 \cdot 7 \\
06 \cdot 1 \\
04 \cdot 2\end{array}$ & $\begin{array}{l}63.35 \\
63.32 \\
52.51 \\
60.13 \\
58.60\end{array}$ & $\begin{array}{l}\mathrm{N} . \\
\mathrm{N} \\
\mathrm{N} \\
\mathrm{N} \\
\mathrm{N} .\end{array}$ & $\begin{array}{l}151.18 \\
151.16 \\
176.04 \\
153.12 \\
148.16\end{array}$ & $\begin{array}{l}\mathbf{W} \cdot \\
\mathbf{W} \cdot \\
\mathbf{W} \cdot \\
\mathbf{W} \cdot \\
\mathbf{W} .\end{array}$ & $\begin{array}{r}33 \mathrm{~N} \\
33 \mathrm{~N} \\
156 \\
105 \\
33 \mathrm{~N}\end{array}$ & 5.5 & $\begin{array}{l}\cdots \\
\ldots \\
\cdots \\
\cdots\end{array}$ & $\begin{array}{l}3.1 \mathrm{M} \\
3.5 \mathrm{M} \\
\cdots \\
\ddot{3} \cdot \mathbf{4 M}\end{array}$ & $\begin{array}{l}\dot{I I} \dot{I} \\
\dot{I V} \\
\cdots \cdot\end{array}$ & $\begin{array}{l}\mathrm{G} \\
\mathrm{G} \\
\mathrm{G} \\
\mathrm{G}\end{array}$ & $\begin{array}{l}\text { JAN. } \\
\text { JAN. } \\
\text { JAN. } \\
\text { JAN. } \\
\text { JAN. }\end{array}$ & $\begin{array}{l}24 \\
24 \\
25 \\
25 \\
25\end{array}$ & $\begin{array}{l}09 \\
04 \\
06 \\
09 \\
10\end{array}$ & $\begin{array}{l}\mathrm{A} \\
\mathrm{A} \\
\mathrm{A} \\
\mathrm{A}\end{array}$ & $\begin{array}{l}\text { AST } \\
\text { AST } \\
\text { BST } \\
\text { AST } \\
\text { AST }\end{array}$ \\
\hline $\begin{array}{l}\text { JAN. } \\
\text { JAN. } \\
\text { JAN. } \\
\text { JAN. } \\
\text { JAN. }\end{array}$ & $\begin{array}{l}25 \\
26 \\
26 \\
27 \\
27\end{array}$ & $\begin{array}{l}22 \\
02 \\
08 \\
00 \\
03\end{array}$ & $\begin{array}{l}12 \\
17 \\
25 \\
35 \\
56\end{array}$ & $\begin{array}{l}05.0 \\
40.0 \\
40.6 \\
59 \cdot 3 \\
57 \cdot 2\end{array}$ & $\begin{array}{l}62.48 \\
63.57 \\
59.77 \\
61.96 \\
53.75\end{array}$ & $\begin{array}{l}\mathrm{N} . \\
\mathrm{N} \cdot \\
\mathrm{N} \cdot \\
\mathrm{N} \cdot \\
\mathrm{N} .\end{array}$ & $\begin{array}{l}151.61 \\
147.67 \\
150.80 \\
152.53 \\
165.49\end{array}$ & $\begin{array}{l}\mathbf{W} \cdot \\
\mathbf{W} \cdot \\
\mathbf{W} \cdot \\
\mathbf{W} \cdot \\
\mathbf{W} .\end{array}$ & $\begin{array}{c}113 \\
15 \\
58 \\
33 \mathrm{~N} \\
33 \mathrm{~N}\end{array}$ & & & 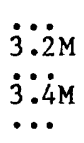 & $\ddot{\cdots}$ & $\begin{array}{l}\mathrm{G} \\
\mathrm{G} \\
\mathrm{G} \\
\mathrm{G}\end{array}$ & $\begin{array}{l}\text { JAN. } \\
\text { JAN. } \\
\text { JAN. } \\
\text { JAN. } \\
\text { JAN. }\end{array}$ & $\begin{array}{l}25 \\
25 \\
25 \\
26 \\
26\end{array}$ & $\begin{array}{l}12 \\
04 \\
10 \\
02 \\
04\end{array}$ & $\begin{array}{l}M \\
P \\
P \\
P \\
P\end{array}$ & $\begin{array}{l}\text { AST } \\
\text { AST } \\
\text { AST } \\
\text { AST } \\
\text { BST }\end{array}$ \\
\hline $\begin{array}{l}\text { JAN. } \\
\text { JAN. } \\
\text { JAN. } \\
\text { JAN. } \\
\text { JAN. }\end{array}$ & $\begin{array}{l}27 \\
27 \\
30 \\
31 \\
31\end{array}$ & $\begin{array}{l}16 \\
18 \\
21 \\
01 \\
03\end{array}$ & $\begin{array}{l}48 \\
57 \\
44 \\
21 \\
07\end{array}$ & $\begin{array}{l}11.5 \\
55.0 \\
10.2 \\
33.9 \\
32.0\end{array}$ & $\begin{array}{l}60.96 \\
54.77 \\
63.05 \\
53.59 \\
51.72\end{array}$ & $\begin{array}{l}\mathrm{N} . \\
\mathrm{N} . \\
\mathrm{N} . \\
\mathrm{N} \cdot \\
\mathrm{N} .\end{array}$ & $\begin{array}{l}149.38 \\
161.25 \\
150.92 \\
163.87 \\
175.81\end{array}$ & $\begin{array}{l}W . \\
W . \\
W . \\
W . \\
W .\end{array}$ & $\begin{array}{r}49 \\
17 \\
147 \\
36 \\
64\end{array}$ & ? & $\begin{array}{l}\dot{6} \\
\ddot{0} \\
\ddot{0}\end{array}$ & $\begin{array}{l}3.2 \mathrm{M} \\
\ldots \\
\cdots \\
\cdots\end{array}$ & $\begin{array}{r}I V \\
V \\
\cdots \\
\dot{I} \dot{I I}\end{array}$ & $\begin{array}{l}\mathrm{G} \\
\mathrm{G} \\
\mathrm{G} \\
\mathrm{G}\end{array}$ & $\begin{array}{l}\text { JAN. } \\
\text { JAN. } \\
\text { JAN. } \\
\text { JAN. } \\
\text { JAN. }\end{array}$ & $\begin{array}{l}27 \\
27 \\
30 \\
30 \\
30\end{array}$ & $\begin{array}{l}06 \\
07 \\
11 \\
02 \\
04\end{array}$ & $\begin{array}{l}A \\
A \\
A \\
P\end{array}$ & $\begin{array}{l}\text { AST } \\
\text { BST } \\
\text { AST } \\
\text { BST } \\
\text { BST }\end{array}$ \\
\hline $\begin{array}{l}\text { JAN. } \\
\text { JAN. } \\
\text { FEB } \\
\text { FEB } \\
\text { FEB. }\end{array}$ & $\begin{array}{r}31 \\
31 \\
1 \\
1 \\
1\end{array}$ & $\begin{array}{l}16 \\
17 \\
04 \\
12 \\
12\end{array}$ & $\begin{array}{l}37 \\
01 \\
29 \\
29 \\
49\end{array}$ & $\begin{array}{l}57.9 \\
40.5 \\
57.1 \\
05.4 \\
55.0\end{array}$ & $\begin{array}{l}51.76 \\
61.15 \\
51.88 \\
60.24 \\
59.99\end{array}$ & $\begin{array}{l}\text { N. } \\
N . \\
N . \\
N . \\
N .\end{array}$ & $\begin{array}{l}175.67 \\
151.43 \\
178.42 \\
152.84 \\
152.19\end{array}$ & $\begin{array}{l}E . \\
W . \\
E . \\
W \\
W\end{array}$ & $\begin{array}{r}42 \\
97 \\
110 \\
109 \\
93\end{array}$ & $\begin{array}{l}4.8 \\
\ldots \\
\dot{4} .8 \\
\ldots\end{array}$ & $\begin{array}{l}3.9 \\
\cdots \\
\cdots \\
\cdots \\
\cdots\end{array}$ & $\begin{array}{l}\ldots \\
\cdots \\
\cdots \\
\cdots\end{array}$ & 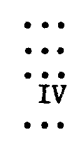 & $\begin{array}{l}\mathrm{G} \\
\mathrm{G} \\
\mathrm{G} \\
\mathrm{G}\end{array}$ & $\begin{array}{l}\text { JAN. } \\
\text { JAN. } \\
\text { JAN. } \\
\text { FEB. } \\
\text { FEB. }\end{array}$ & $\begin{array}{l}31 \\
31 \\
31 \\
1 \\
1\end{array}$ & $\begin{array}{l}05 \\
07 \\
05 \\
02 \\
02\end{array}$ & $\begin{array}{l}\mathrm{A} \\
\mathrm{A} \\
\mathrm{P} \\
\mathrm{A}\end{array}$ & $\begin{array}{l}\text { BST } \\
\text { AST } \\
\text { BST } \\
\text { AST } \\
\text { AST }\end{array}$ \\
\hline $\begin{array}{l}\text { FEB. } \\
\text { FEB } \\
\text { FEB } \\
\text { FEB } \\
\text { FEB. }\end{array}$ & $\begin{array}{l}4 \\
4 \\
4 \\
4 \\
6\end{array}$ & $\begin{array}{l}06 \\
07 \\
20 \\
22 \\
21\end{array}$ & $\begin{array}{l}34 \\
56 \\
26 \\
05 \\
02\end{array}$ & $\begin{array}{l}39.7 \\
24.2 \\
56.6 \\
46.0 \\
11.0\end{array}$ & $\begin{array}{l}51.27 \\
51.15 \\
53.59 \\
62.07 \\
64.52\end{array}$ & $\begin{array}{l}\text { N. } \\
\text { N. } \\
N . \\
N . \\
N \text {. }\end{array}$ & $\begin{array}{l}179.19 \\
179.12 \\
167.08 \\
150.16 \\
149.90\end{array}$ & $\begin{array}{l}W . \\
W . \\
W \cdot \\
W \\
.\end{array}$ & $\begin{array}{l}33 N \\
33 N \\
33 N \\
33 N \\
33 N\end{array}$ & $\begin{array}{l}4 . \\
5 . \\
4\end{array}$ & $\begin{array}{l}\ddot{4} \\
\therefore\end{array}$ & $\begin{array}{l}\cdots \\
\cdots \\
\dot{*} \cdot \dot{8} \\
3.6 \mathrm{r}\end{array}$ & $\begin{array}{l}\cdots \\
\cdots \\
\cdots \\
\cdots\end{array}$ & $\begin{array}{l}\mathrm{G} \\
\mathrm{G} \\
\mathrm{G} \\
\mathrm{G}\end{array}$ & $\begin{array}{l}\text { FEB. } \\
\text { FEB } \\
\text { FEB } \\
\text { FEB. } \\
\text { FEB. }\end{array}$ & $\begin{array}{l}3 \\
3 \\
4 \\
4 \\
6\end{array}$ & $\begin{array}{l}07 \\
08 \\
09 \\
12 \\
11\end{array}$ & • & $\begin{array}{l}\text { BST } \\
\text { BST } \\
\text { BST } \\
\text { AST } \\
\text { AST }\end{array}$ \\
\hline
\end{tabular}


Table 1.--Summary of U.S. earthquakes for 1979-_Continued

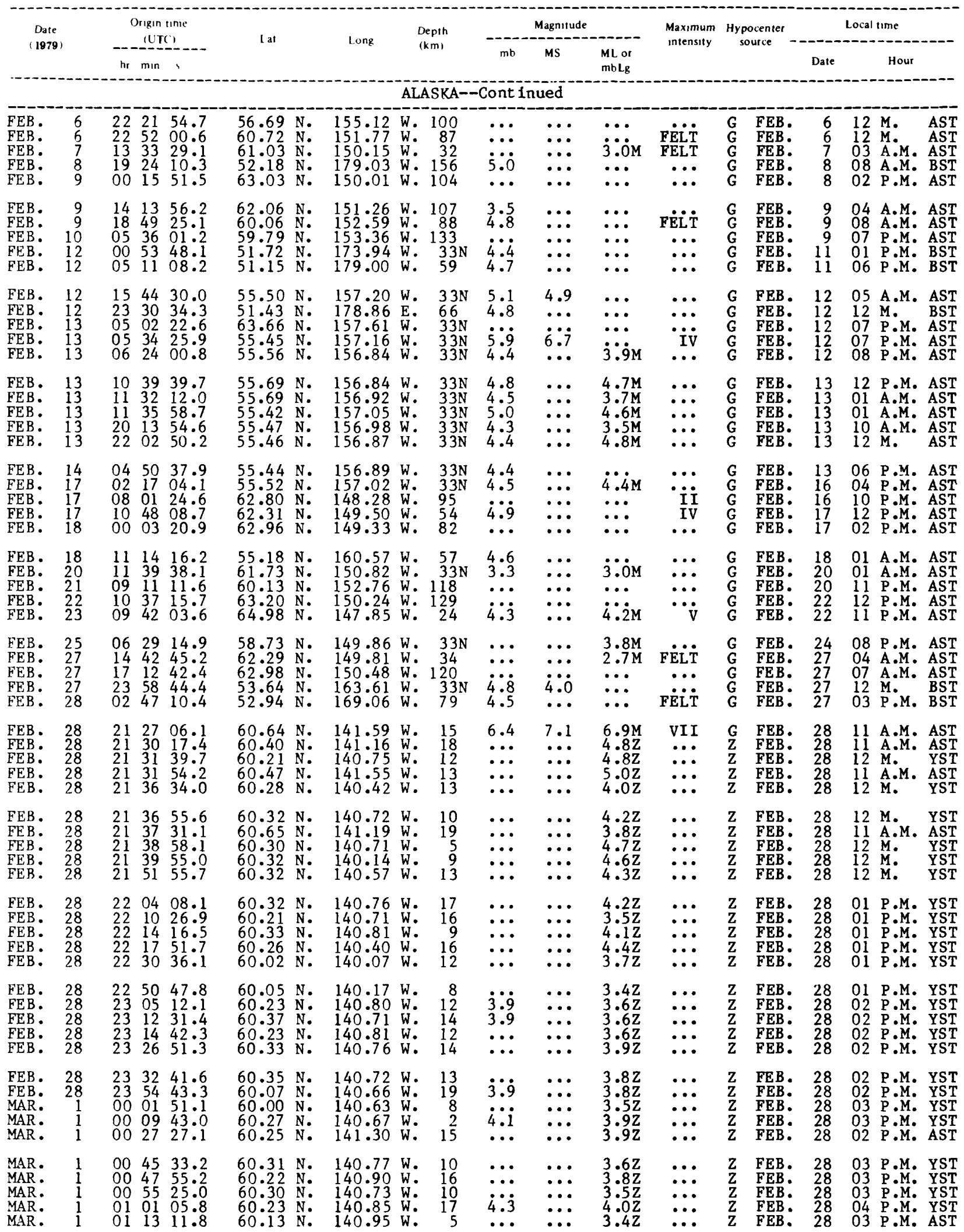


Table 1.--Summary of U.S. earthquakes for 1979--Continued

\begin{tabular}{|c|c|c|c|c|c|c|c|c|c|c|c|}
\hline \multirow{2}{*}{$\begin{array}{l}\text { Date } \\
\text { (1979) }\end{array}$} & $\begin{array}{l}\text { Origin tume } \\
\text { (UT()) }\end{array}$ & \multirow{2}{*}{ Lat } & \multirow{2}{*}{ long } & \multirow{2}{*}{$\begin{array}{l}\text { Depth } \\
(\mathbf{k m})\end{array}$} & \multicolumn{3}{|c|}{ Magnitude } & \multirow{2}{*}{$\begin{array}{l}\text { Maximum } \\
\text { intensity }\end{array}$} & \multirow{2}{*}{$\begin{array}{l}\text { Hypocenter } \\
\text { source }\end{array}$} & \multicolumn{2}{|c|}{ Local time } \\
\hline & he $\min$ & & & & $m b$ & MS & $\begin{array}{l}\text { ML or } \\
\mathrm{mbLg}\end{array}$ & & & Date & Hour \\
\hline
\end{tabular}

ALASKA--Cont Inued

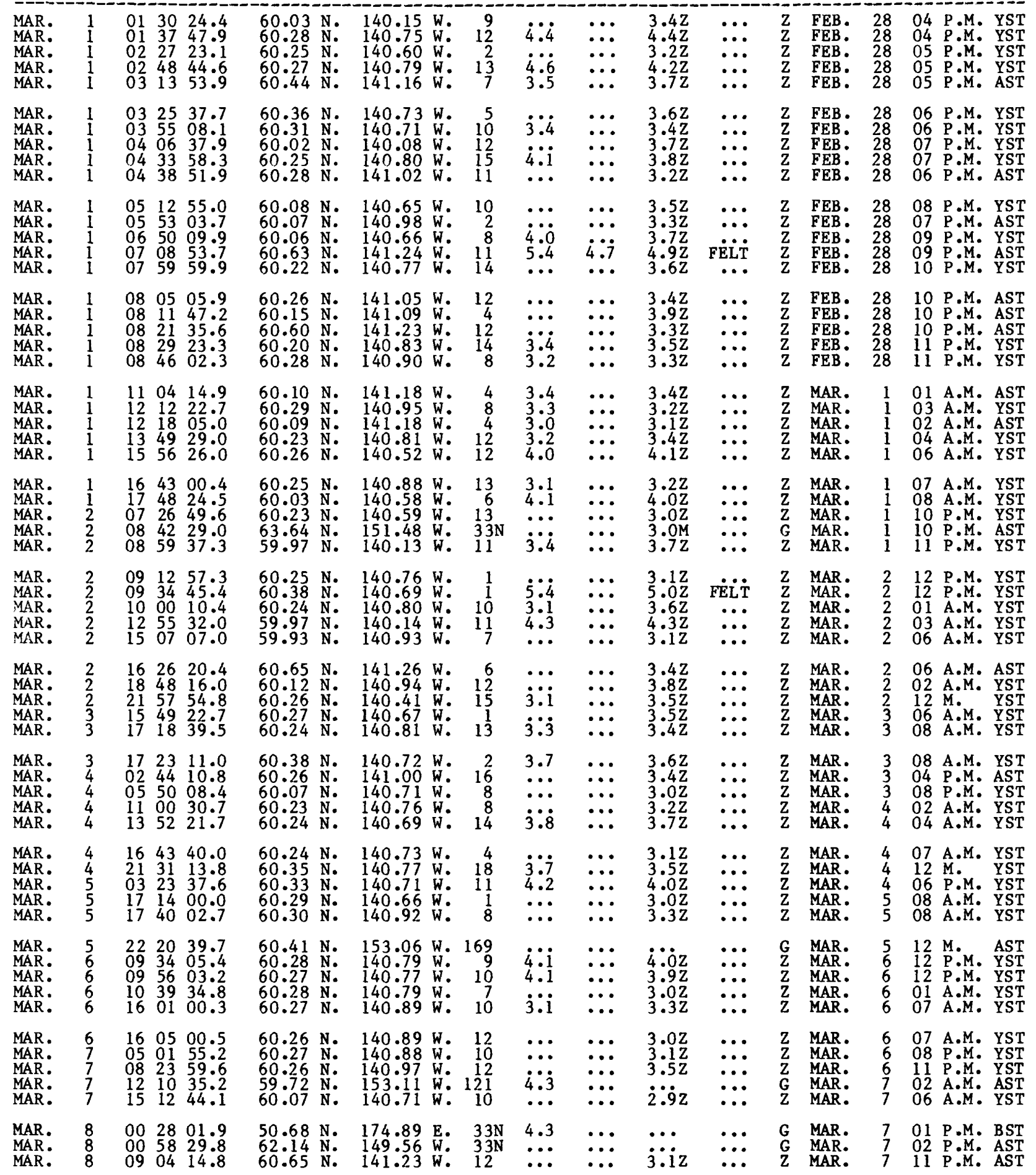


Table 1.--Summary of U.S. earthquakes for 1979.-Continued

\begin{tabular}{|c|c|c|c|c|c|c|c|c|c|c|c|}
\hline \multirow{2}{*}{$\begin{array}{c}\text { Date } \\
\text { (1979) }\end{array}$} & \multirow{2}{*}{$\begin{array}{l}\text { Origin ume } \\
\text { IUTC) } \\
\text { hr min }\end{array}$} & \multirow{2}{*}{ I at } & \multirow{2}{*}{ Long } & \multirow{2}{*}{$\begin{array}{l}\text { Depth } \\
(\mathbf{k m})\end{array}$} & \multicolumn{3}{|c|}{ Magnitude } & \multirow{2}{*}{$\begin{array}{l}\text { Maxımum } \\
\text { intensity }\end{array}$} & \multirow{2}{*}{$\begin{array}{l}\text { Hypocenter } \\
\text { source }\end{array}$} & \multicolumn{2}{|c|}{ Local ume } \\
\hline & & & & & $\mathrm{mb}$ & MS & $\begin{array}{l}\mathrm{ML} \text { or } \\
\mathrm{mblg}\end{array}$ & & & Date & Hour \\
\hline
\end{tabular}

ALASKA--Cont inued

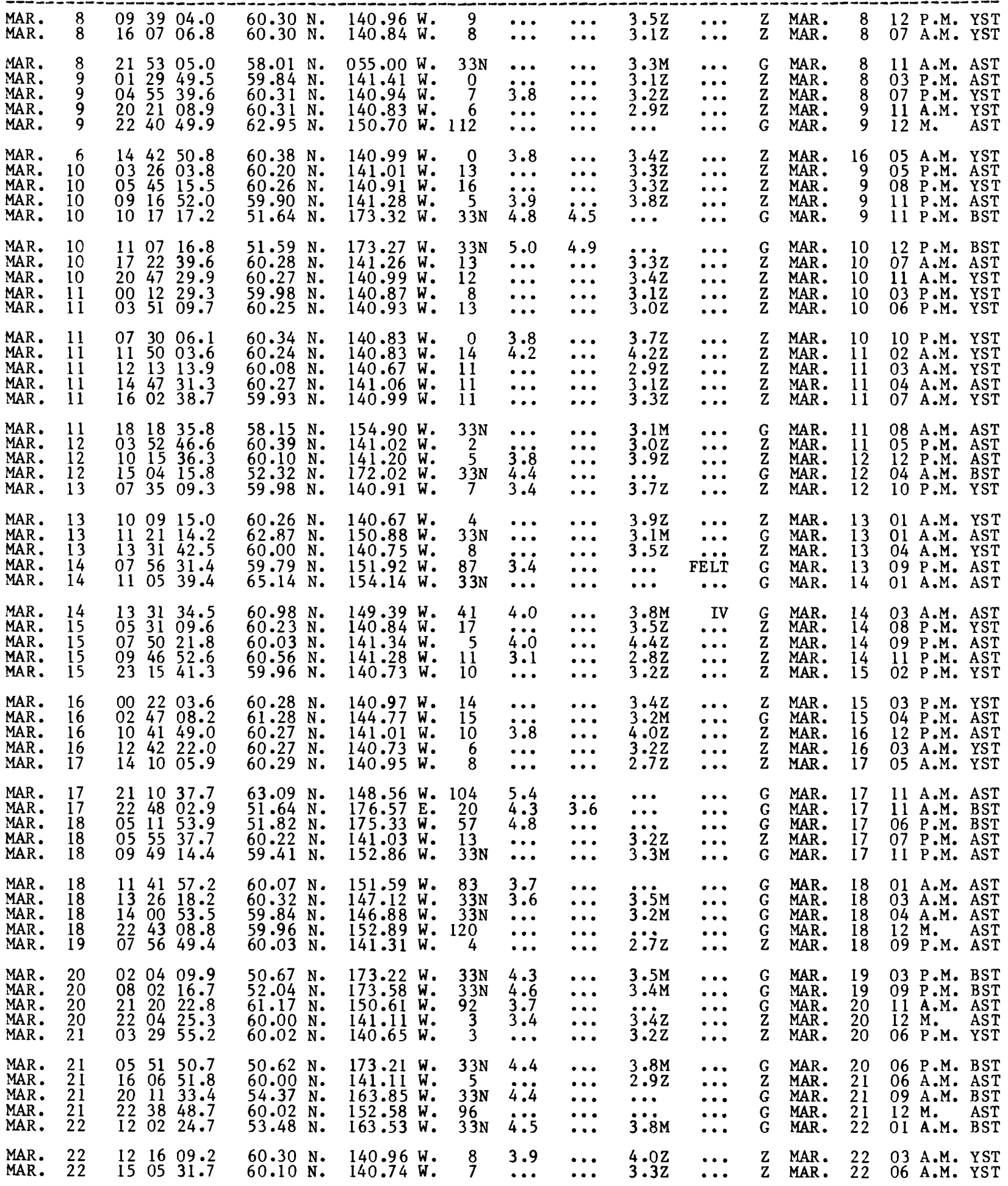


Table 1.--Summary of U.S. earthquakes for 1979--Continued

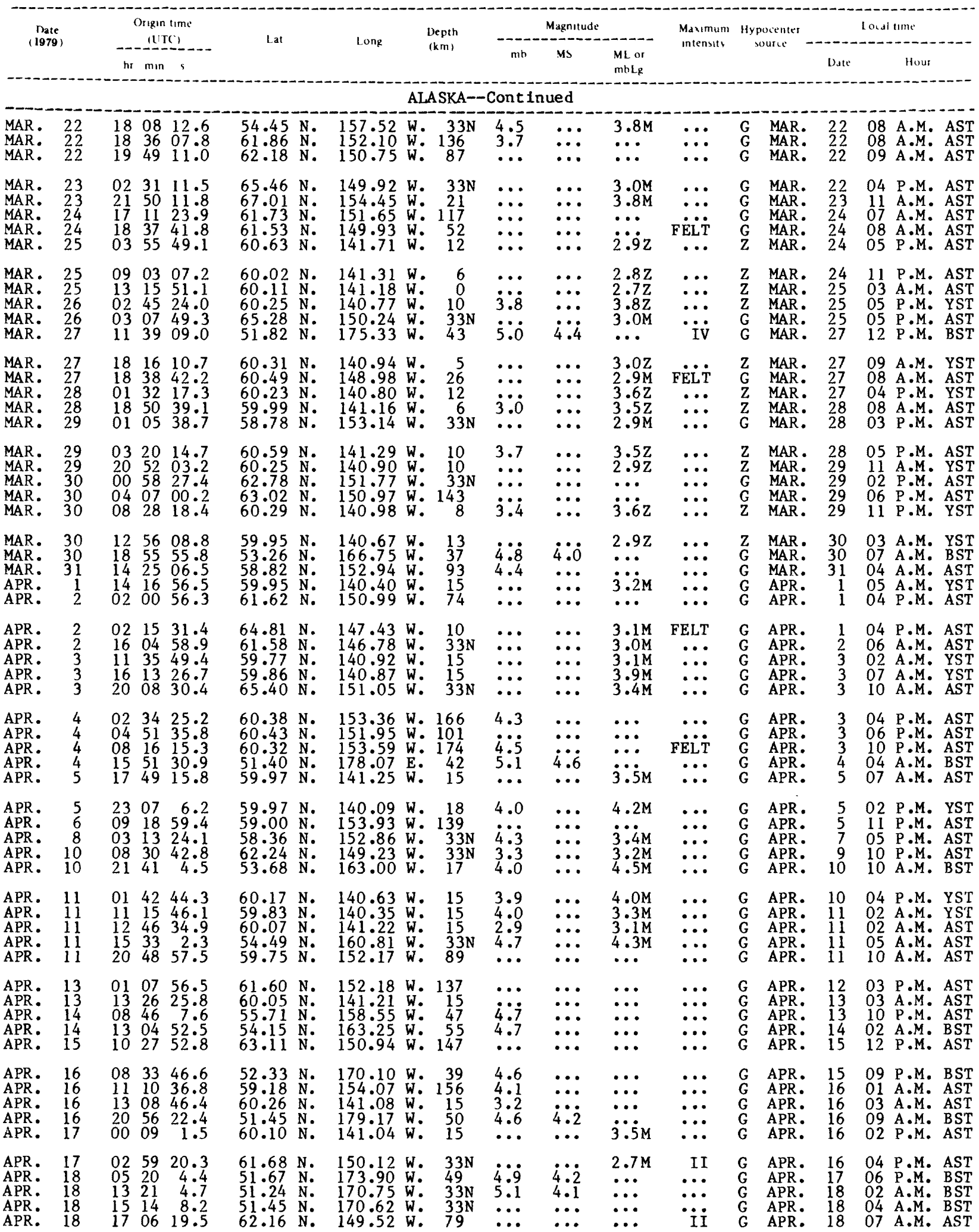


Table 1.--Summary of U.S. earthquakes for 1979--Continued

\begin{tabular}{|c|c|c|c|c|c|c|c|c|c|c|c|}
\hline \multirow{2}{*}{$\begin{array}{c}\text { Date } \\
\text { (1979) }\end{array}$} & $\begin{array}{l}\text { Origin tume } \\
\text { (UITC) }\end{array}$ & \multirow{2}{*}{ l.dt } & \multirow{2}{*}{ long } & \multirow{2}{*}{$\begin{array}{l}\text { Depth } \\
(\mathrm{km})\end{array}$} & \multicolumn{3}{|c|}{ Magnitude } & \multirow{2}{*}{$\begin{array}{l}\text { Maxımum } \\
\text { intensity }\end{array}$} & \multirow{2}{*}{$\begin{array}{c}\text { Hypocenter } \\
\text { source }\end{array}$} & \multicolumn{2}{|c|}{ Local tume } \\
\hline & $\mathrm{hr}$ min & & & & $\mathrm{mb}$ & MS & $\begin{array}{l}\mathrm{ML} \text { or } \\
\mathrm{mbLg}\end{array}$ & & & Date & Hour \\
\hline
\end{tabular}

ALASKA--Cont inued

\begin{tabular}{|c|c|c|c|c|c|c|c|c|c|c|c|c|}
\hline $\begin{array}{l}\text { APR: } \\
\text { APR: } \\
\text { APR: }\end{array}$ & $\begin{array}{l}20 \\
20\end{array}$ & $\begin{array}{rrr}05 & 07 & 9.7 \\
23 & 03 & 45.3 \\
03 & 31 & 49.9 \\
08 & 42 & 30.7 \\
12 & 49 & 6.9\end{array}$ & $\begin{array}{l}59.90 \mathrm{~N} . \\
60.30 \mathrm{~N} . \\
63.20 \mathrm{~N} \\
59.32 \mathrm{~N} \\
60.32 \mathrm{~N}\end{array}$ & $\begin{array}{l}141.05 \text { W. } 15 \\
140.86 \text { W. } 15 \\
150.74 \text { W. } 147 \\
152.36 \text { W. } 85 \\
140.87 \text { W. } 15\end{array}$ & $\begin{array}{l}3 \\
4 \\
5\end{array}$ & $\begin{array}{l}\ldots \\
\dddot{a} \\
\ddot{4}: \dot{9}\end{array}$ & $\begin{array}{l}3.0 \mathrm{M} \\
\because \ddot{\mathrm{s}} \mathrm{Oz}\end{array}$ & $\begin{array}{l}\cdots: \\
\because \because \\
\dddot{I V}\end{array}$ & $\underset{\mathbf{G}}{\mathbf{G}}$ & $\begin{array}{l}\text { APR: } \\
\text { APR: } \\
\text { APR: } \\
\text { APR: } \\
\text { APR: }\end{array}$ & $\begin{array}{l}8 \\
9 \\
9 \\
9 \\
0\end{array}$ & $\begin{array}{lll}07 & \text { P.M. AST } \\
02 & \text { P.M. YST } \\
05 & \text { P.M. AST } \\
10 & \text { P.M. AST } \\
03 & \text { A.M. YST }\end{array}$ \\
\hline $\begin{array}{l}\text { PR. } \\
P R \text { : } \\
\text { PR: } \\
\text { PR: }\end{array}$ & $\begin{array}{l}21 \\
21 \\
21\end{array}$ & $\begin{array}{lll}21 & 58 & 37.9 \\
23 & 06 & 50.9 \\
03 & 23 & 46.4 \\
12 & 36 & 53.9 \\
13 & 23 & 12.4\end{array}$ & $\begin{array}{l}60.30 \mathrm{~N} . \\
60.41 \mathrm{~N} \\
63.24 \mathrm{~N}: \\
60.31 \mathrm{~N} . \\
52.34 \mathrm{~N} .\end{array}$ & $\begin{array}{llr}140.75 & \text { W. } & 15 \\
140.82 & \text { W. } & 15 \\
149.53 & \text { W. } & 107 \\
140.77 & \text { W. } & 15 \\
169.51 & \text { W. } & 36\end{array}$ & $\because:$ & $\begin{array}{l}\ldots \\
\because \because: \\
\ddot{4} . \dot{5}\end{array}$ & $\begin{array}{l}4.4 \mathrm{M} \\
3.6 \mathrm{M} \\
\because \because 3 \mathrm{M} \\
\cdots . .\end{array}$ & $\begin{array}{l}\cdots \\
\cdots: \\
\cdots\end{array}$ & $G$ & $\begin{array}{l}\text { APR: } \\
\text { APR: } \\
\text { APR: } \\
\text { APR: } \\
\text { APR: }\end{array}$ & 21 & $\begin{array}{ll}12 & \text { M. } \\
02 & \text { YST } \\
05 & \text { P.M. YST } \\
03 & \text { AST } \\
03 & \text { A.M. YST } \\
02 & \text { A.M. BST }\end{array}$ \\
\hline R: & $\begin{array}{l}21 \\
22 \\
22\end{array}$ & $\begin{array}{rrr}15 & 08 & 3.9 \\
21 & 19 & 33.8 \\
09 & 24 & 56.7 \\
14 & 04 & 35.1 \\
16 & 11 & 38.2\end{array}$ & $\begin{array}{l}63.57 \mathrm{~N} . \\
59.91 \mathrm{~N} \\
61.68 \mathrm{~N} \\
59.96 \mathrm{~N} \\
60.23 \mathrm{~N} .\end{array}$ & 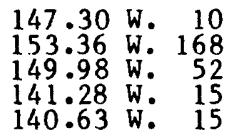 & $\begin{array}{l}\because \cdots \\
\ddot{4} \cdot \dot{2} \\
3.0\end{array}$ & $\begin{array}{l}\ldots . \\
\dddot{3}: 6 \\
\ldots\end{array}$ & $\begin{array}{l}3.5 \mathrm{M} \\
\because \because 0 \\
\dddot{4} .0 \mathrm{M} \\
3.2 \mathrm{M}\end{array}$ & $\begin{array}{l}\cdots \\
\cdots \\
\cdots\end{array}$ & $\underset{G}{G}$ & $\begin{array}{l}\text { APR: } \\
\text { APR: } \\
\text { APR: } \\
\text { APR: } \\
\text { APR: }\end{array}$ & $\begin{array}{l}21 \\
21 \\
22 \\
22\end{array}$ & $\begin{array}{l}05 \text { A.M. AST } \\
11 \text { A.M. AST } \\
11 \text { P.M. AST } \\
04 \text { A.M. AST } \\
07 \text { A.M. YST }\end{array}$ \\
\hline $\begin{array}{l}\text { PR: } \\
\text { PR: } \\
\text { PR: } \\
\text { PR: } \\
\text { PR: }\end{array}$ & $\begin{array}{l}23 \\
23\end{array}$ & $\begin{array}{rrr}17 & 05 & 6.1 \\
05 & 20 & 30.5 \\
13 & 45 & 12.5 \\
13 & 57 & 48.9 \\
20 & 14 & 6.3\end{array}$ & $\begin{array}{l}58.58 \mathrm{~N} . \\
63.63 \mathrm{~N} \\
63.56 \mathrm{~N} . \\
60.23 \mathrm{~N} . \\
62.09 \mathrm{~N} .\end{array}$ & $\begin{array}{lll}152.44 & \mathrm{~W} . & 33 \mathrm{~N} \\
150.72 & \mathrm{~W} & 33 \mathrm{~N} \\
150.72 & \mathrm{~W} & 33 \mathrm{~N} \\
141.27 & \mathrm{~W} . & 15 \\
148.12 & \mathrm{~W} . & 33 \mathrm{~N}\end{array}$ & $\begin{array}{l}3.7 \\
\cdots \\
\cdots \\
\cdots\end{array}$ & $\begin{array}{l}\ldots \\
\because: \\
\because:\end{array}$ & $\begin{array}{l}3.3 \mathrm{M} \\
3.3 \mathrm{M} \\
3.3 \mathrm{M} \\
\dddot{3} .2 \mathrm{M}\end{array}$ & $\begin{array}{l}\cdots \\
\because \cdots \\
\cdots\end{array}$ & $\mathrm{G}$ & $\begin{array}{l}\text { APR: } \\
\text { APR: } \\
\text { APR: } \\
\text { APR: } \\
\text { APR: }\end{array}$ & $\begin{array}{l}22 \\
23 \\
24 \\
24\end{array}$ & $\begin{array}{l}07 \text { A.M. AST } \\
07 \text { P.M. AST } \\
03 \text { A.M. AST } \\
03 \text { A.M. AST } \\
10 \text { A.M. AST }\end{array}$ \\
\hline $\begin{array}{l}\text { PR. } \\
\text { PR: } \\
\text { PR: } \\
\text { PR: }\end{array}$ & $\begin{array}{l}24 \\
25 \\
25 \\
26 \\
27\end{array}$ & $\begin{array}{rrr}23 & 32 & 21.1 \\
00 & 27 & 57.6 \\
09 & 39 & 0.0 \\
12 & 34 & 7.5 \\
08 & 28 & 59.7\end{array}$ & $\begin{array}{l}50.02 \mathrm{~N} . \\
63.35 \mathrm{~N} \\
64.88 \mathrm{~N} \\
59.97 \mathrm{~N} \\
52.82 \mathrm{~N}\end{array}$ & $\begin{array}{lll}177.48 & \mathrm{E} . & 33 \mathrm{~N} \\
149.50 \mathrm{~W} & 119 \\
148.83 & \mathrm{~W} & 11 \\
149.42 & \mathrm{~W} . & 36 \\
171.65 & \mathrm{E} . & 33 \mathrm{~N}\end{array}$ & $\begin{array}{l}4.4 \\
3.9 \\
\ddot{3} .2 \\
4.2\end{array}$ & $\begin{array}{l}\ldots \\
\because: \\
\because\end{array}$ & $\begin{array}{l}\ldots \\
\dddot{3}: 3 \mathrm{M} \\
3.0 \mathrm{M}\end{array}$ & $\begin{array}{l}\text { FËLT } \\
\text { III } \\
\because \ldots \\
\therefore:\end{array}$ & $\begin{array}{l}\mathbf{G} \\
\mathbf{G} \\
\mathbf{G}\end{array}$ & $\begin{array}{l}\text { APR: } \\
\text { APR: } \\
\text { APR: } \\
\text { APR: } \\
\text { APR: }\end{array}$ & $\begin{array}{l}24 \\
24 \\
24 \\
26 \\
26\end{array}$ & $\begin{array}{ll}12 & \text { M. } \\
02 & \text { P.M. } \\
11 & \text { P.M. } \\
02 & \text { A.M. } \\
09 & \text { P.M. }\end{array}$ \\
\hline $\begin{array}{l}\text { PR. } \\
\text { PR: } \\
\text { PR: }\end{array}$ & $\begin{array}{r}28 \\
28 \\
29 \\
30 \\
1\end{array}$ & $\begin{array}{rrr}07 & 33 & 6.0 \\
16 & 20 & 48.5 \\
07 & 08 & 28.7 \\
20 & 46 & 21.6 \\
01 & 48 & 31.2\end{array}$ & $\begin{array}{l}64.61 \mathrm{~N} . \\
65.80 \mathrm{~N} . \\
60.01 \mathrm{~N} . \\
63.95 \mathrm{~N} . \\
61.55 \mathrm{~N} .\end{array}$ & 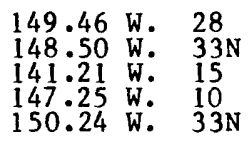 & $\ddot{3} \ddot{6}$ & $\begin{array}{l}\cdots \\
\because \\
\cdots\end{array}$ & $\begin{array}{l}3.1 \mathrm{M} \\
4.0 \mathrm{M} \\
3.3 \mathrm{M}\end{array}$ & $\begin{array}{r}\text { FELT } \\
\because: \\
\because\end{array}$ & $\mathbf{G}$ & $\begin{array}{l}\text { PR. } \\
\text { PR: } \\
\text { PR: } \\
\text { PR: } \\
\text { PR: }\end{array}$ & $\begin{array}{l}28 \\
28 \\
30 \\
30\end{array}$ & $\begin{array}{l}09 \text { P.M. } \\
06 \text { A.M. } \\
09 \text { P.M. } \\
10 \text { A.M. } \\
03 \text { P.M. }\end{array}$ \\
\hline $\begin{array}{l}y \\
y\end{array}$ & $\begin{array}{l}2 \\
4 \\
4 \\
4 \\
5\end{array}$ & $\begin{array}{lll}13 & 40 & 45.1 \\
11 & 37 & 58.7 \\
13 & 36 & 12.8 \\
19 & 16 & 54.6 \\
06 & 50 & 38.8\end{array}$ & $\begin{array}{l}60.31 \\
59.21 \\
51.35 \\
60.30 \\
62.97 \\
62 .\end{array}$ & 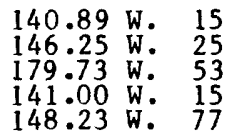 & $\begin{array}{l}3 . \\
3: \\
4 \\
3 \\
4\end{array}$ & $\begin{array}{l}\ldots \\
\because: \\
\cdots\end{array}$ & $\begin{array}{l}4.3 \mathrm{M} \\
3.1 \mathrm{M} \\
3.8 \mathrm{M}\end{array}$ & $\begin{array}{r}\because: \\
\because \because \\
\text { FËLT }\end{array}$ & $\begin{array}{l}G \\
G\end{array}$ & & $\begin{array}{l}2 \\
4 \\
4\end{array}$ & $\begin{array}{lll}04 & \text { A.M. YST } \\
01 & \text { A.M. AST } \\
02 & \text { A.M. } \\
10 & \text { BST } \\
10 & \text { A.M. YST } \\
08 & \text { P.M. AST }\end{array}$ \\
\hline$\frac{Y}{Y}$ & $\begin{array}{l}5 \\
5 \\
5 \\
7 \\
7\end{array}$ & $\begin{array}{lll}16 & 13 & 35.2 \\
16 & 54 & 20.5 \\
17 & 00 & 46.5 \\
11 & 01 & 7.2 \\
21 & 24 & 22.5\end{array}$ & $\begin{array}{l}59.88 \mathrm{~N} . \\
51.92 \mathrm{~N}: \\
59.75 \mathrm{~N} . \\
60.91 \mathrm{~N} .\end{array}$ & 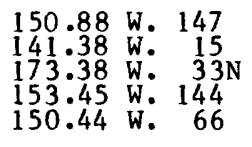 & $\begin{array}{l}3: 2 \\
4: 2\end{array}$ & $\begin{array}{l}\ldots \\
\because: \\
\cdots\end{array}$ & $\begin{array}{l}30.6 \mathrm{M} \\
4.6 \mathrm{M}\end{array}$ & $\begin{array}{l}\cdots \\
\cdots \\
\cdots\end{array}$ & $\underset{G}{G}$ & & $\begin{array}{l}5 \\
5 \\
5 \\
7 \\
7\end{array}$ & $\begin{array}{l}06 \text { A.M. BST } \\
01 \text { A.M. AST } \\
11 \text { A.M. AST }\end{array}$ \\
\hline $\begin{array}{l}\mathrm{AY} \\
\mathrm{AY} \\
\mathrm{AY} \\
\mathrm{AY}\end{array}$ & $\begin{array}{r}8 \\
9 \\
10 \\
10 \\
12\end{array}$ & $\begin{array}{lll}12 & 56 & 14.8 \\
14 & 22 & 21.0 \\
21 & 38 & 51.4 \\
21 & 57 & 39.1 \\
19 & 13 & 30.5\end{array}$ & $\begin{array}{l}52.84 \mathrm{~N} . \\
61.93 \mathrm{~N}: \\
60.24 \mathrm{~N} . \\
60.24 \mathrm{~N} . \\
54.76 \mathrm{~N} .\end{array}$ & 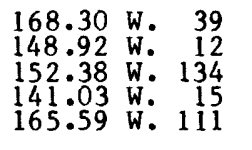 & $\begin{array}{l}5 . \\
\because \\
\ddot{4}\end{array}$ & $\begin{array}{l}5.0 \\
\cdots \\
\because \cdots\end{array}$ & $\begin{array}{l}\ddot{2} \ddot{9} \mathrm{M} \\
\ddot{4} \ddot{4} \mathrm{M}\end{array}$ & iii & G & & $\begin{array}{r}8 \\
9 \\
10 \\
10 \\
12\end{array}$ & 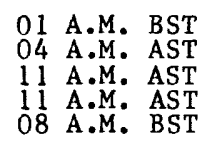 \\
\hline & $\begin{array}{l}14 \\
14 \\
15 \\
16 \\
16\end{array}$ & $\begin{array}{rrr}09 & 19 & 9.6 \\
20 & 14 & 36.0 \\
03 & 54 & 38.8 \\
09 & 57 & 13.0 \\
14 & 19 & 19.2\end{array}$ & $\begin{array}{l}60.08 \mathrm{~N} \\
61.73 \\
52.18 \\
64.73 \\
60.23 \\
\mathrm{~N}\end{array}$ & $\begin{array}{lll}140.94 & \mathrm{~W} . & 15 \\
150.89 \mathrm{~W}: & 45 \\
172.97 & \mathrm{E}: & 33 \mathrm{~N} \\
147.56 & \mathrm{~W} . & 14 \\
141.04 & \mathrm{~W} . & 15\end{array}$ & $\begin{array}{l}\because: \\
\ddot{4}: \\
\ddot{4} .6\end{array}$ & $\because:$ & $\begin{array}{l}3.5 \mathrm{M} \\
\because \\
\because\end{array}$ & $\ddot{i I}$ & $\mathbf{G}$ & & $\begin{array}{l}14 \\
14 \\
14 \\
15 \\
16\end{array}$ & $\begin{array}{ll}12 & \text { P.M. } \\
10 & \text { A.M. A } \\
04 & \text { P.M. } \\
11 & \text { P.M. A } \\
04 & \text { A.M. A }\end{array}$ \\
\hline & $\begin{array}{l}17 \\
18 \\
19 \\
19 \\
20\end{array}$ & $\begin{array}{lll}14 & 04 & 14.7 \\
05 & 35 & 22.6 \\
18 & 05 & 23.6 \\
18 & 21 & 42.7 \\
02 & 27 & 42.3\end{array}$ & $\begin{array}{l}60.99 \mathrm{~N} . \\
64.41 \mathrm{~N}: \\
60.21 \mathrm{~N}: \\
60.07 \mathrm{~N}: \\
52.12 \mathrm{~N} .\end{array}$ & $\begin{array}{lll}147.02 & \mathrm{~W} . & 10 \\
147.08 \mathrm{~W}: & 28 \\
141.01 & \mathrm{~W}: & 15 \\
141.23 & \mathrm{~W}: & 15 \\
171.21 & \mathrm{~W} . & 33 \mathrm{~N}\end{array}$ & $\begin{array}{l}\because \because \\
\ddot{4}: \\
\ddot{4}: 8\end{array}$ & $\ldots$ & $\begin{array}{l}3.2 \mathrm{M} \\
3.2 \mathrm{M} \\
4.6 \mathrm{M} \\
3.6 \mathrm{M}\end{array}$ & III & $\vec{G}$ & 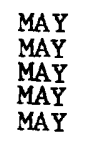 & $\begin{array}{l}17 \\
17 \\
19\end{array}$ & $\begin{array}{l}07 \text { P.M. } \\
08 \text { A.M. } \\
08 \text { A.M. } \\
03 \text { P.M. }\end{array}$ \\
\hline & $\begin{array}{l}20 \\
20 \\
20 \\
21\end{array}$ & $\begin{array}{rrr}08 & 14 & 0.1 \\
11 & 24 & 10.4 \\
22 & 28 & 38.1 \\
01 & 37 & 30.7 \\
05 & 35 & 22.6\end{array}$ & $\begin{array}{l}56.65 \mathrm{~N} . \\
56.63 \mathrm{~N} \\
62.83 \mathrm{~N} \\
60.31 \mathrm{~N} \\
64.44 \mathrm{~N}\end{array}$ & 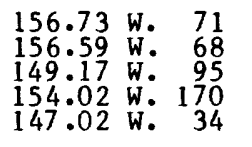 & $\begin{array}{l}6 . \\
4 . \\
\ddot{3}\end{array}$ & $\begin{array}{l}6.1 \\
\because: \\
\because\end{array}$ & & $\begin{array}{r}\mathrm{VI} \\
\text { FËL̈T } \\
\cdots\end{array}$ & $\begin{array}{l}G \\
G \\
G \\
G \\
G\end{array}$ & MAY & $\begin{array}{l}19 \\
20 \\
20 \\
20 \\
20\end{array}$ & $\begin{array}{ll}10 & \text { P.M. } \\
01 & \text { A.M. } \\
12 & \text { M.. } \\
03 & \text { P.M. } \\
07 & \text { P.M. }\end{array}$ \\
\hline AAY & 21 & $\begin{array}{lll}10 & 05 & 11.6 \\
03 & 48 & 11.2 \\
13 & 44 & 40.8\end{array}$ & $\begin{array}{l}58.68 \mathrm{~N} . \\
56.76 \mathrm{~N} .\end{array}$ & 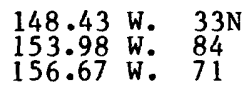 & $\ddot{4} \ddot{9}$ & & $\begin{array}{l}3.0 \mathrm{M} \\
\because \cdots\end{array}$ & $\begin{array}{l}\text { II } \\
\therefore:\end{array}$ & $G$ & $\begin{array}{l}\text { MAY } \\
\text { MAY } \\
\text { MAY }\end{array}$ & 23 & 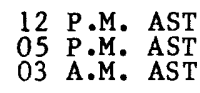 \\
\hline
\end{tabular}


Table 1.--Summary of U.S. earthquakes for 1979--Continued

\begin{tabular}{|c|c|c|c|c|c|c|c|c|c|c|c|}
\hline \multirow{2}{*}{$\begin{array}{c}\text { Date } \\
\text { (1979) }\end{array}$} & \multirow{2}{*}{$\begin{array}{l}\text { Origin tume } \\
\text { (UTC) } \\
\text { hr min }\end{array}$} & \multirow{2}{*}{ Lat } & \multirow{2}{*}{ Long } & \multirow{2}{*}{$\begin{array}{l}\text { Depth } \\
(\mathrm{km})\end{array}$} & \multicolumn{3}{|c|}{ Magnitude } & \multirow{2}{*}{$\begin{array}{l}\text { Maximum } \\
\text { Intensity }\end{array}$} & \multirow{2}{*}{$\begin{array}{c}\text { Hypocenter } \\
\text { source }\end{array}$} & \multicolumn{2}{|c|}{ Local tıme } \\
\hline & & & & & $\mathbf{m b}$ & MS & $\begin{array}{l}\mathrm{ML} \text { or } \\
\mathrm{mbLg}\end{array}$ & & & Date & Hour \\
\hline
\end{tabular}

ALASKA--Cont inued

\begin{tabular}{|c|c|c|c|c|c|c|c|c|c|c|c|c|c|c|c|c|c|}
\hline $\begin{array}{l}\text { MAY } \\
\text { MAY }\end{array}$ & $\begin{array}{l}23 \\
24\end{array}$ & $\begin{array}{ll}20 & 1 \\
07 & 2\end{array}$ & $\begin{array}{ll}5 & 39.3 \\
8 & 53.6\end{array}$ & $\begin{array}{l}57.87 \\
62.55\end{array}$ & N. & $\begin{array}{l}157.45 \\
148.92\end{array}$ & W. & $\begin{array}{r}150 \\
84\end{array}$ & $\begin{array}{l}3.7 \\
\cdots\end{array}$ & $\cdots$ & $\ldots$ & $\cdots$ & $\mathrm{G}$ & $\begin{array}{l}\text { MAY } \\
\text { MAY }\end{array}$ & $\begin{array}{l}23 \\
23\end{array}$ & $\begin{array}{l}10 \\
09\end{array}$ & $\begin{array}{l}\text { A.M. AST } \\
\text { P.M. AST }\end{array}$ \\
\hline $\begin{array}{l}\text { MAY } \\
\text { MAY } \\
\text { MAY } \\
\text { MAY } \\
\text { MAY }\end{array}$ & $\begin{array}{l}25 \\
25 \\
25 \\
25 \\
25\end{array}$ & $\begin{array}{ll}14 & 14 \\
14 & 50 \\
16 & 45 \\
17 & 46 \\
18 & 10\end{array}$ & $\begin{array}{ll}4 & 16.7 \\
0 & 16.9 \\
5 & 27.3 \\
6 & 57.5 \\
0 & 43.7\end{array}$ & $\begin{array}{l}51.59 \\
51.59 \\
52.61 \\
52.22 \\
52.90\end{array}$ & $\begin{array}{l}\mathrm{N} . \\
\mathrm{N} \\
\mathrm{N} \\
\mathrm{N} \\
\mathrm{N}\end{array}$ & $\begin{array}{l}178.03 \\
178.11 \\
167.02 \\
166.65 \\
167.09\end{array}$ & $\begin{array}{l}\text { E. } \\
\text { E. } \\
\text { W. } \\
\text { W. } \\
\text { W. }\end{array}$ & $\begin{array}{l}33 \mathrm{~N} \\
33 \mathrm{~N} \\
23 \\
33 \mathrm{~N} \\
33 \mathrm{~N}\end{array}$ & $\begin{array}{l}4.8 \\
0.0 \\
4.8 \\
4.6\end{array}$ & $\begin{array}{l}\ldots \\
\ddot{6} .2 \\
\cdots\end{array}$ & $\begin{array}{l}\cdots \\
\cdots \\
\cdots \\
\cdots\end{array}$ & $\begin{array}{l}\ddot{M} \\
\ddot{I V} \\
\ddot{\cdots}\end{array}$ & $\begin{array}{l}\mathrm{G} \\
\mathrm{G} \\
\mathrm{G} \\
\mathrm{G} \\
\mathrm{G}\end{array}$ & $\begin{array}{l}\text { MAY } \\
\text { MAY } \\
\text { MAY } \\
\text { MAY } \\
\text { MAY }\end{array}$ & $\begin{array}{l}25 \\
25 \\
25 \\
25 \\
25\end{array}$ & $\begin{array}{l}03 \\
03 \\
05 \\
06 \\
07\end{array}$ & $\begin{array}{ll}\text { A.M.M. BST } \\
\text { A.M. } \\
\text { A.MST } \\
\text { A.M. BST } \\
\text { A.M. BST } \\
\text { BST }\end{array}$ \\
\hline $\begin{array}{l}\text { MAY } \\
\text { MAY } \\
\text { MAY } \\
\text { MAY } \\
\text { MAY }\end{array}$ & $\begin{array}{l}26 \\
26 \\
27 \\
27 \\
27\end{array}$ & $\begin{array}{ll}13 & 43 \\
14 & 35 \\
07 & 33 \\
09 & 00 \\
09 & 12\end{array}$ & $\begin{array}{rr}3 & 5.7 \\
5 & 38.3 \\
3 & 56.1 \\
0 & 51.7 \\
2 & 20.3\end{array}$ & $\begin{array}{l}52.81 \\
52.87 \\
59.26 \\
59.88 \\
56.55\end{array}$ & $\begin{array}{l}\mathrm{N} . \\
\mathrm{N} . \\
\mathrm{N} \\
\mathrm{N} \\
\mathrm{N}\end{array}$ & $\begin{array}{l}166.90 \\
167.14 \\
151.37 \\
151.95 \\
153.91\end{array}$ & $\begin{array}{l}\text { W. } \\
\text { W. } \\
\text { W. } \\
\text { W. } \\
\text { W. }\end{array}$ & $\begin{array}{l}26 \\
33 \mathrm{~N} \\
59 \\
78 \\
27\end{array}$ & $\begin{array}{l}4.5 \\
4.6 \\
4.3 \\
4.1\end{array}$ & $\begin{array}{l}\cdots \\
\cdots \\
\cdots \\
\cdots\end{array}$ & $\begin{array}{l}\cdots \\
\because \\
\ddot{4} \ddot{\circ}\end{array}$ & $\because \cdots$ & $\begin{array}{l}\mathrm{G} \\
\mathrm{G} \\
\mathrm{G} \\
\mathrm{G}\end{array}$ & $\begin{array}{l}\text { MAY } \\
\text { MAY } \\
\text { MAY } \\
\text { MAY } \\
\text { MAY }\end{array}$ & $\begin{array}{l}26 \\
26 \\
26 \\
26 \\
26\end{array}$ & $\begin{array}{l}02 \\
03 \\
09 \\
11 \\
11\end{array}$ & $\begin{array}{l}\text { A.M. BST } \\
\text { A.M. BST } \\
\text { P.M. AST } \\
\text { P.M. AST } \\
\text { P.M. AST }\end{array}$ \\
\hline $\begin{array}{l}\text { MAY } \\
\text { MAY } \\
\text { MAY } \\
\text { MAY } \\
\text { MAY }\end{array}$ & $\begin{array}{l}27 \\
27 \\
28 \\
28 \\
29\end{array}$ & $\begin{array}{ll}10 & 30 \\
15 & 38 \\
06 & 58 \\
17 & 50 \\
15 & 21\end{array}$ & $\begin{array}{lr}0 & 19.1 \\
8 & 4.3 \\
8 & 27.6 \\
0 & 14.3 \\
1 & 41.5\end{array}$ & $\begin{array}{l}52.68 \\
63.05 \\
52.75 \\
61.64 \\
53.04\end{array}$ & $\begin{array}{l}\mathrm{N} . \\
\mathrm{N} \\
\mathrm{N} \\
\mathrm{N}\end{array}$ & $\begin{array}{l}167.16 \\
151.13 \\
167.01 \\
150.02 \\
170.94\end{array}$ & $\begin{array}{l}\text { W. } \\
\text { W. } \\
\text { W. } \\
\text { W. } \\
\text { E. }\end{array}$ & $\begin{array}{l}33 \mathrm{~N} \\
33 \mathrm{~N} \\
33 \mathrm{~N} \\
45 \\
33 \mathrm{~N}\end{array}$ & $\begin{array}{l}4.7 \\
\ddot{4} . \dot{4} \\
\ddot{4} .6\end{array}$ & $\begin{array}{l}\ldots \\
\ldots \\
\ldots\end{array}$ & $\begin{array}{l}\ddot{3} \ddot{0 M} \\
\cdots \\
\cdots\end{array}$ & $\ddot{\cdots}$ & $\begin{array}{l}\mathrm{G} \\
\mathrm{G} \\
\mathrm{G} \\
\mathrm{G} \\
\mathrm{G}\end{array}$ & $\begin{array}{l}\text { MAY } \\
\text { MAY } \\
\text { MAY } \\
\text { MAY } \\
\text { MAY }\end{array}$ & $\begin{array}{l}26 \\
27 \\
27 \\
28 \\
29\end{array}$ & $\begin{array}{l}11 \\
05 \\
07 \\
07 \\
04\end{array}$ & $\begin{array}{l}\text { P.M. BST } \\
\text { A.M. AST } \\
\text { P.M. BST } \\
\text { A.M. AST } \\
\text { A.M. BST }\end{array}$ \\
\hline $\begin{array}{l}\text { MAY } \\
\text { MAY } \\
\text { MAY } \\
\text { MAY } \\
\text { MAY }\end{array}$ & $\begin{array}{l}29 \\
30 \\
30 \\
31 \\
31\end{array}$ & $\begin{array}{ll}21 & 53 \\
18 & 25 \\
19 & 20 \\
04 & 22 \\
04 & 38\end{array}$ & $\begin{array}{ll}3 & 43.9 \\
5 & 40.9 \\
0 & 27.5 \\
2 & 54.3 \\
8 & 32.8\end{array}$ & $\begin{array}{l}52.83 \\
60.23 \\
56.40 \\
61.74 \\
60.05\end{array}$ & $\begin{array}{l}\mathrm{N} . \\
\mathrm{N} \\
\mathrm{N} \\
\mathrm{N}\end{array}$ & $\begin{array}{l}170.89 \\
152.84 \\
161.72 \\
149.88 \\
152.26\end{array}$ & $\begin{array}{l}\text { W. } \\
\text { W. } \\
\text { W. } \\
\text { W. } \\
\text { W. }\end{array}$ & $\begin{array}{r}113 \\
206 \\
55 \\
86\end{array}$ & $\begin{array}{l}4.9 \\
5.0 \\
3.0 \\
3.6\end{array}$ & $\begin{array}{l}\ldots \\
\cdots \\
\cdots\end{array}$ & 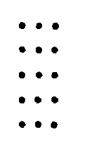 & $\begin{array}{c}\because \ldots \\
\because \cdots \\
\text { FËLT } \\
\cdots\end{array}$ & $\begin{array}{l}\mathrm{G} \\
\mathrm{G} \\
\mathrm{G} \\
\mathrm{G} \\
\mathrm{G}\end{array}$ & $\begin{array}{l}\text { MAY } \\
\text { MAY } \\
\text { MAY } \\
\text { MAY } \\
\text { MAY }\end{array}$ & $\begin{array}{l}29 \\
30 \\
30 \\
30 \\
30\end{array}$ & $\begin{array}{l}10 \\
08 \\
08 \\
06 \\
06\end{array}$ & $\begin{array}{l}\text { A.M. BST } \\
\text { A.M. AST } \\
\text { A.M. BST } \\
\text { P.M. AST } \\
\text { P.M. AST }\end{array}$ \\
\hline $\begin{array}{l}\text { JUNE } \\
\text { JUNE } \\
\text { JUNE } \\
\text { JUNE } \\
\text { JUNE }\end{array}$ & $\begin{array}{l}3 \\
3 \\
4 \\
4 \\
4\end{array}$ & $\begin{array}{ll}15 & 02 \\
20 & 41 \\
02 & 05 \\
05 & 06 \\
20 & 39\end{array}$ & $\begin{array}{rr}2 & 4.0 \\
1 & 4.1 \\
5 & 57.6 \\
6 & 58.2 \\
9 & 1.0\end{array}$ & $\begin{array}{l}60.22 \\
63.48 \\
62.86 \\
59.85 \\
53.04\end{array}$ & $\begin{array}{l}\mathrm{N} . \\
\mathrm{N} \\
\mathrm{N} \\
\mathrm{N} \\
\mathrm{N}\end{array}$ & $\begin{array}{l}140.99 \\
150.40 \\
149.66 \\
153.21 \\
167.10\end{array}$ & $\begin{array}{l}\text { W. } \\
\text { W. } \\
\text { W. } \\
\text { W. } \\
\text { W. }\end{array}$ & $\begin{array}{c}15 \\
33 \mathrm{~N} \\
99 \\
121 \\
33 \mathrm{~N}\end{array}$ & $\begin{array}{l}4.2 \\
\because \cdots \\
4.2 \\
4.6\end{array}$ & $\ddot{\cdots}$ & $\begin{array}{l}4.5 \mathrm{M} \\
3.1 \mathrm{M} \\
\cdots \\
\cdots \\
\cdots\end{array}$ & $\begin{array}{l}\cdots \\
\cdots \\
\cdots\end{array}$ & $\begin{array}{l}\mathrm{G} \\
\mathrm{G} \\
\mathrm{G} \\
\mathrm{G}\end{array}$ & $\begin{array}{l}\text { JUNE } \\
\text { JUNE } \\
\text { JUNE } \\
\text { JUNE } \\
\text { JUNE }\end{array}$ & $\begin{array}{l}3 \\
3 \\
3 \\
3 \\
4\end{array}$ & $\begin{array}{l}06 \\
10 \\
04 \\
07 \\
09\end{array}$ & $\begin{array}{l}\text { A.M. YST } \\
\text { A.M. AST } \\
\text { P.M. AST } \\
\text { P.M. AST } \\
\text { A.M. BST }\end{array}$ \\
\hline $\begin{array}{l}\text { JUNE } \\
\text { JUNE } \\
\text { JUNE } \\
\text { JUNE } \\
\text { JUNE }\end{array}$ & $\begin{array}{r}8 \\
8 \\
9 \\
10 \\
12\end{array}$ & $\begin{array}{ll}05 & 12 \\
17 & 37 \\
09 & 39 \\
03 & 53 \\
22 & 20\end{array}$ & $\begin{array}{rr}2 & 31.2 \\
7 & 39.9 \\
9 & 4.2 \\
3 & 21.6 \\
0 & 25.9\end{array}$ & $\begin{array}{l}63.99 \\
63.03 \\
60.10 \\
60.03 \\
52.99\end{array}$ & $\begin{array}{l}\mathrm{N} . \\
\mathrm{N} \\
\mathrm{N} \\
\mathrm{N} \\
\mathrm{N} .\end{array}$ & $\begin{array}{l}147.26 \\
148.80 \\
153.14 \\
152.85 \\
167.09\end{array}$ & $\begin{array}{l}\text { W. } \\
\text { W. } \\
\text { W. } \\
\text { W. } \\
\text { W. }\end{array}$ & $\begin{array}{r}33 \mathrm{~N} \\
33 \mathrm{~N} \\
133 \\
122 \\
40\end{array}$ & $\begin{array}{l}\cdots \\
\because \cdots \\
\ddot{4} \cdot \dot{5}\end{array}$ & $\begin{array}{l}\cdots \\
\cdots \\
\cdots \\
\cdots\end{array}$ & $\begin{array}{l}3.6 \mathrm{M} \\
3.0 \mathrm{M} \\
\cdots \\
\cdots \\
\cdots\end{array}$ & $\begin{array}{c}\cdots \\
\cdots \\
\cdots\end{array}$ & $\begin{array}{l}\mathrm{G} \\
\mathrm{G} \\
\mathrm{G} \\
\mathrm{G} \\
\mathrm{G}\end{array}$ & $\begin{array}{l}\text { JUNE } \\
\text { JUNE } \\
\text { JUNE } \\
\text { JUNE } \\
\text { JUNE }\end{array}$ & $\begin{array}{r}7 \\
8 \\
8 \\
9 \\
12\end{array}$ & $\begin{array}{l}07 \\
07 \\
11 \\
05 \\
11\end{array}$ & 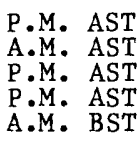 \\
\hline $\begin{array}{l}\text { JUNE } \\
\text { JUNE } \\
\text { JUNE } \\
\text { JUNE } \\
\text { JUNE }\end{array}$ & $\begin{array}{l}13 \\
15 \\
15 \\
15 \\
15\end{array}$ & $\begin{array}{ll}09 & 51 \\
01 & 12 \\
16 & 51 \\
17 & 23 \\
18 & 54\end{array}$ & $\begin{array}{ll}1 & 26.1 \\
2 & 58.6 \\
1 & 52.6 \\
3 & 57.5 \\
4 & 36.0\end{array}$ & $\begin{array}{l}59.74 \\
60.25 \\
59.93 \\
58.94 \\
57.81\end{array}$ & $\begin{array}{l}\mathrm{N} . \\
\mathrm{N} \\
\mathrm{N} \\
\mathrm{N} \\
\mathrm{N} .\end{array}$ & $\begin{array}{l}148.88 \\
140.94 \\
140.81 \\
154.47 \\
152.47\end{array}$ & $\begin{array}{l}\text { W. } \\
\text { W. } \\
\text { W. } \\
\text { W. } \\
\text { W. }\end{array}$ & $\begin{array}{c}33 \mathrm{~N} \\
15 \\
15 \\
151 \\
60\end{array}$ & $\begin{array}{l}\ddot{3} \ddot{8} \\
\ddot{3} \ddot{\dot{y}}\end{array}$ & $\begin{array}{l}\cdots \\
\therefore \\
\cdots \\
\cdots\end{array}$ & $\begin{array}{l}3.0 \mathrm{M} \\
4.1 \mathrm{M} \\
3.0 \mathrm{M} \\
\ldots . \\
\cdots\end{array}$ & $\begin{array}{l}\cdots \\
\cdots \\
\cdots\end{array}$ & $\begin{array}{l}\mathrm{G} \\
\mathrm{G} \\
\mathrm{G} \\
\mathrm{G} \\
\mathrm{G}\end{array}$ & $\begin{array}{l}\text { JUNE } \\
\text { JUNE } \\
\text { JUNE } \\
\text { JUNE } \\
\text { JUNE }\end{array}$ & $\begin{array}{l}12 \\
14 \\
15 \\
15 \\
15\end{array}$ & $\begin{array}{l}11 \\
04 \\
07 \\
07 \\
08\end{array}$ & $\begin{array}{l}\text { P.M. AST } \\
\text { P.M. YST } \\
\text { A.M. YST } \\
\text { A.M. AST } \\
\text { A.M. AST }\end{array}$ \\
\hline $\begin{array}{l}\text { JUNE } \\
\text { JUNE } \\
\text { JUNE } \\
\text { JUNE } \\
\text { JUNE }\end{array}$ & $\begin{array}{l}16 \\
17 \\
17 \\
17 \\
18\end{array}$ & $\begin{array}{ll}20 & 06 \\
08 & 08 \\
17 & 58 \\
18 & 21 \\
04 & 52\end{array}$ & $\begin{array}{lr}6 & 16.5 \\
8 & 52.4 \\
8 & 20.4 \\
1 & 27.6 \\
2 & 7.7\end{array}$ & $\begin{array}{l}63.74 \\
51.32 \\
60.22 \\
60.12 \\
60.36\end{array}$ & $\begin{array}{l}\mathrm{N} . \\
\mathrm{N} \\
\mathrm{N} \\
\mathrm{N} \\
\mathrm{N} .\end{array}$ & $\begin{array}{l}148.90 \\
179.27 \\
140.87 \\
140.90 \\
143.02\end{array}$ & $\begin{array}{l}\text { W. } \\
\text { W. } \\
\text { W. } \\
\text { W. } \\
\text { W. }\end{array}$ & $\begin{array}{r}124 \\
55 \\
15 \\
15 \\
15\end{array}$ & $\begin{array}{l}\ddot{4} .7 \\
4.4 \\
\ldots .\end{array}$ & $\begin{array}{l}\ldots \\
\ldots \\
\ldots\end{array}$ & $\begin{array}{l}\ddot{4} .4 \mathrm{M} \\
3.5 \mathrm{M} \\
3.0 \mathrm{M}\end{array}$ & $\ddot{\cdots}$ & $\begin{array}{l}\mathrm{G} \\
\mathrm{G} \\
\mathrm{G} \\
\mathrm{G}\end{array}$ & $\begin{array}{l}\text { JUNE } \\
\text { JUNE } \\
\text { JUNE } \\
\text { JUNE } \\
\text { JUNE }\end{array}$ & $\begin{array}{l}16 \\
16 \\
17 \\
17 \\
17\end{array}$ & $\begin{array}{l}10 \\
09 \\
08 \\
09 \\
06\end{array}$ & $\begin{array}{l}\text { A.M. AST } \\
\text { P.M. BST } \\
\text { A.M. YST } \\
\text { A.M. YST } \\
\text { P.M. AST }\end{array}$ \\
\hline $\begin{array}{l}\text { JUNE } \\
\text { JUNE } \\
\text { JUNE } \\
\text { JUNE } \\
\text { JUNE }\end{array}$ & $\begin{array}{l}18 \\
18 \\
19 \\
20 \\
21\end{array}$ & $\begin{array}{ll}08 & 29 \\
10 & 49 \\
21 & 10 \\
08 & 18 \\
07 & 33\end{array}$ & $\begin{array}{ll}9 & 26.9 \\
9 & 32.7 \\
0 & 56.9 \\
8 & 30.8 \\
3 & 36.1\end{array}$ & $\begin{array}{l}57.45 \\
56.39 \\
52.74 \\
60.88 \\
58.97\end{array}$ & $\begin{array}{l}\mathrm{N} . \\
\mathrm{N} \\
\mathrm{N} \\
\mathrm{N}\end{array}$ & $\begin{array}{l}154.44 \\
161.74 \\
172.33 \\
147.69 \\
152.25\end{array}$ & $\begin{array}{l}\text { W. } \\
\text { W. } \\
\text { E. } \\
\text { W. } \\
\text { W. }\end{array}$ & $\begin{array}{r}139 \\
204 \\
33 \mathrm{~N} \\
33 \mathrm{~N} \\
33 \mathrm{~N}\end{array}$ & $\begin{array}{l}\ldots \\
\ddot{4} \cdot \dot{6} \\
\cdots \\
\cdots\end{array}$ & $\begin{array}{l}\ldots \\
\ldots \\
\ldots\end{array}$ & $\begin{array}{l}\cdots \\
\because \cdots \\
3 . j \mathrm{M} \\
3.0 \mathrm{M}\end{array}$ & $\begin{array}{c}\ddot{0} \\
\ddot{F} \dot{\mathrm{L}} \dot{\mathrm{T}} \\
\cdots\end{array}$ & $\begin{array}{l}\mathrm{G} \\
\mathrm{G} \\
\mathrm{G} \\
\mathrm{G} \\
\mathrm{G}\end{array}$ & $\begin{array}{l}\text { JUNE } \\
\text { JUNE } \\
\text { JUNE } \\
\text { JUNE } \\
\text { JUNE }\end{array}$ & $\begin{array}{l}17 \\
17 \\
19 \\
19 \\
20\end{array}$ & $\begin{array}{l}10 \\
11 \\
10 \\
10 \\
09\end{array}$ & $\begin{array}{ll}P . M . & \text { AST } \\
P . M . & \text { BST } \\
\text { A.M. BST } \\
\text { P.M. AST } \\
\text { P.M. AST }\end{array}$ \\
\hline $\begin{array}{l}\text { JUNE } \\
\text { JUNE } \\
\text { JUNE } \\
\text { JUNE } \\
\text { JUNE }\end{array}$ & $\begin{array}{l}22 \\
23 \\
23 \\
23 \\
23\end{array}$ & $\begin{array}{ll}23 & 38 \\
08 & 41 \\
10 & 46 \\
12 & 11 \\
18 & 39\end{array}$ & $\begin{array}{lr}8 & 41.1 \\
1 & 3.1 \\
6 & 58.6 \\
1 & 23.6 \\
9 & 32.2\end{array}$ & $\begin{array}{l}53.65 \\
57.70 \\
61.87 \\
59.31 \\
58.03\end{array}$ & $\begin{array}{l}\text { N. } \\
\text { N. } \\
\text { N. } \\
\text { N. } \\
\text { N. }\end{array}$ & $\begin{array}{l}163.54 \\
155.22 \\
150.28 \\
141.76 \\
134.91\end{array}$ & $\begin{array}{l}\text { W. } \\
\text { W. } \\
\text { W. } \\
\text { W. } \\
\text { W. }\end{array}$ & $\begin{array}{l}33 \mathrm{~N} \\
86 \\
33 \mathrm{~N} \\
15 \\
15\end{array}$ & $\begin{array}{l}4.6 \\
4.2 \\
3.1 \\
\ddot{3} .8\end{array}$ & $\begin{array}{l}\cdots \\
\cdots \\
\cdots\end{array}$ & $\begin{array}{l}\ddot{3} \\
\dot{3} . \mathrm{MM} \\
3.5 \mathrm{M}\end{array}$ & $\begin{array}{l}\ddot{\ldots} \\
\ddot{I V} \\
\ddot{I V}\end{array}$ & $\begin{array}{l}\mathrm{G} \\
\mathrm{G} \\
\mathrm{G} \\
\mathrm{G} \\
\mathrm{G}\end{array}$ & $\begin{array}{l}\text { JUNE } \\
\text { JUNE } \\
\text { JUNE } \\
\text { JUNE } \\
\text { JUNE }\end{array}$ & $\begin{array}{l}22 \\
22 \\
23 \\
23 \\
23\end{array}$ & $\begin{array}{l}121 \\
10 \\
12 \\
02 \\
10\end{array}$ & $\begin{array}{l}\text { M. BST } \\
\text { P.M. AST } \\
\text { P.M. AST } \\
\text { A.M. AST } \\
\text { A.M. PST }\end{array}$ \\
\hline $\begin{array}{l}\text { JUNE } \\
\text { JUNE } \\
\text { JUNE } \\
\text { JUNE } \\
\text { JUNE }\end{array}$ & $\begin{array}{l}24 \\
24 \\
24 \\
25 \\
25\end{array}$ & $\begin{array}{ll}05 & 24 \\
12 & 41 \\
13 & 41 \\
01 & 38 \\
04 & 28\end{array}$ & $\begin{array}{ll}4 & 33.4 \\
1 & 33.7 \\
1 & 46.8 \\
8 & 21.9 \\
8 & 37.9\end{array}$ & $\begin{array}{l}63.12 \\
60.04 \\
63.93 \\
63.40 \\
60.59\end{array}$ & $\begin{array}{l}\text { N. } \\
\text { N. } \\
\text { N. }\end{array}$ & $\begin{array}{l}150.45 \\
148.05 \\
148.58 \\
149.56 \\
146.89\end{array}$ & $\begin{array}{l}\text { W. } \\
\text { W. } \\
\text { W. } \\
\text { W. } \\
\text { W. }\end{array}$ & $\begin{array}{l}151 \\
33 \mathrm{~N} \\
118 \\
123 \\
33 \mathrm{~N}\end{array}$ & $\begin{array}{l}\dot{4} \\
3\end{array}$ & $\ddot{\cdots}$ & $\begin{array}{l}\ddot{3} \ddot{3 M} \\
\ddot{3} \dot{O}\end{array}$ & $\ddot{\cdots}$ & $\begin{array}{l}\mathrm{G} \\
\mathrm{G} \\
\mathrm{G} \\
\mathrm{G}\end{array}$ & $\begin{array}{l}\text { JUNE } \\
\text { JUNE } \\
\text { JUNE } \\
\text { JUNE } \\
\text { JUNE }\end{array}$ & $\begin{array}{l}23 \\
24 \\
24 \\
24 \\
24\end{array}$ & $\begin{array}{l}07 \\
02 \\
03 \\
03 \\
06\end{array}$ & $\begin{array}{l}\text { P.M. AST } \\
\text { A.M. AST } \\
\text { A.M. AST } \\
\text { P.M. AST } \\
\text { P.M. AST }\end{array}$ \\
\hline $\begin{array}{l}\text { JUNE } \\
\text { JUNE } \\
\text { JUNE } \\
\text { JUNE } \\
\text { JUNE }\end{array}$ & $\begin{array}{l}25 \\
25 \\
26 \\
26 \\
28\end{array}$ & $\begin{array}{ll}05 & 07 \\
11 & 36 \\
04 & 26 \\
19 & 08 \\
02 & 09\end{array}$ & $\begin{array}{ll}7 & 59 . \\
6 & 7 . \\
5 & 33 . \\
8 & 21 . \\
9 & 47 .\end{array}$ & $\begin{array}{l}60.27 \\
63.36 \\
59.84 \\
62.36 \\
61.83\end{array}$ & $\begin{array}{l}\mathrm{N} . \\
\mathrm{N} \\
\mathrm{N} \\
\mathrm{N} \\
\mathrm{N}\end{array}$ & $\begin{array}{l}140.82 \\
147.44 \\
153.30 \\
147.83 \\
150.52\end{array}$ & $\begin{array}{l}\text { W. } \\
\text { W. } \\
\text { W. } \\
\text { W. } \\
\text { W. }\end{array}$ & $\begin{array}{c}19 \\
103 \\
132 \\
86 \\
33 \mathrm{~N}\end{array}$ & $\begin{array}{l}4.6 \\
4.0 \\
3.8 \\
\ldots .\end{array}$ & $\begin{array}{l}\ldots \\
\cdots \\
\cdots \\
\cdots\end{array}$ & $\begin{array}{l}4.8 \mathrm{M} \\
\because \\
\ddot{3} \cdot \dot{2 M}\end{array}$ & $\ddot{\cdots}$ & $\begin{array}{l}\mathrm{G} \\
\mathrm{G} \\
\mathrm{G} \\
\mathrm{G} \\
\mathrm{G}\end{array}$ & $\begin{array}{l}\text { JUNE } \\
\text { JUNE } \\
\text { JUNE } \\
\text { JUNE } \\
\text { JUNE }\end{array}$ & $\begin{array}{l}24 \\
25 \\
25 \\
26 \\
27\end{array}$ & $\begin{array}{l}08 \\
01 \\
06 \\
09 \\
04\end{array}$ & $\begin{array}{l}\text { P.M. YST } \\
\text { A.M. AST } \\
\text { P.M. AST } \\
\text { A.M. AST } \\
\text { P.M. AST }\end{array}$ \\
\hline
\end{tabular}


Table 1.--Summary of U.S. earthquakes for 1979--Continued

\begin{tabular}{|c|c|c|c|c|c|c|c|c|c|c|c|c|c|}
\hline \multirow{2}{*}{\multicolumn{2}{|c|}{$\begin{array}{c}\text { Date } \\
\text { (1979) }\end{array}$}} & \multirow{2}{*}{ 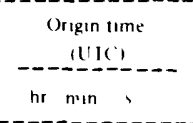 } & \multirow[b]{2}{*}{ I dat } & \multirow[b]{2}{*}{ I ong } & \multirow{2}{*}{$\begin{array}{l}\text { Depth } \\
(\mathrm{km})\end{array}$} & \multicolumn{3}{|c|}{ Magnitude } & \multirow{2}{*}{$\begin{array}{l}\text { Maximum } \\
\text { intensity }\end{array}$} & \multirow{2}{*}{\multicolumn{2}{|c|}{$\begin{array}{c}\text { Hypocenter } \\
\text { source }\end{array}$}} & \multicolumn{2}{|r|}{ Local tume } \\
\hline & & & & & & $\mathrm{mb}$ & MS & $\begin{array}{c}\text { ML or } \\
\text { mLLE }\end{array}$ & & & & \multirow[t]{2}{*}{ Date } & \multirow[t]{2}{*}{ Hour } \\
\hline \multicolumn{12}{|c|}{ ALASKA--Cont inued } & & \\
\hline $\begin{array}{l}\text { INE } \\
\text { INE } \\
\text { INE } \\
\text { ILY } \\
\text { ILY }\end{array}$ & $\begin{array}{r}28 \\
29 \\
29 \\
2 \\
2\end{array}$ & $\begin{array}{lll}02 & 36 & 11.9 \\
06 & 51 & 49.6 \\
09 & 12 & 12.2 \\
06 & 47 & 33.6 \\
18 & 20 & 20.0\end{array}$ & $\begin{array}{l}61.58 \mathrm{~N} . \\
60.04 \mathrm{~N} . \\
60.16 \mathrm{~N} . \\
61.99 \mathrm{~N} . \\
59.87 \mathrm{~N} .\end{array}$ & $\begin{array}{l}151.43 \\
151.92 \\
141.47 \\
150.87 \\
141.16\end{array}$ & $\begin{array}{l}\text { W.: } 113 \\
\text { W. } \\
\text { W. } \\
\text { W. } \\
\text { W. } \\
\text { W. } \\
15\end{array}$ & $\begin{array}{l}3.7 \\
\cdots \\
\cdots \\
\cdots\end{array}$ & $\begin{array}{c}\cdots \\
\cdots \\
\cdots\end{array}$ & $\begin{array}{l}\because: . \\
\dddot{3} .5 \mathrm{M} \\
3.0 \mathrm{M} \\
3.7 \mathrm{M}\end{array}$ & $\begin{array}{l}\cdots \\
\cdots \\
\cdots\end{array}$ & & $\begin{array}{l}\text { JUNE } \\
\text { JUNE } \\
\text { JUNE } \\
\text { JULY } \\
\text { JULY }\end{array}$ & $\begin{array}{r}27 \\
28 \\
28 \\
1 \\
2\end{array}$ & $\begin{array}{ll}04 & \text { P.M. AST } \\
08 & \text { P.M. AST } \\
11 & \text { P.M. AST } \\
08 & \text { P.M. AST } \\
08 & \text { A.M. AST }\end{array}$ \\
\hline $\begin{array}{l}\text { JULY } \\
\text { JULY } \\
\text { JULY } \\
\text { JULY } \\
\text { JULY }\end{array}$ & $\begin{array}{l}3 \\
3 \\
4 \\
4 \\
4\end{array}$ & $\begin{array}{lll}11 & 38 & 31.9 \\
13 & 45 & 55.1 \\
00 & 15 & 39: 5 \\
08 & 15 & 37.0 \\
13 & 04 & 20.2\end{array}$ & $\begin{array}{l}61.39 \mathrm{~N} . \\
64.19 \mathrm{~N}: \\
60.23 \mathrm{~N}: \\
59.83 \\
63.98 \mathrm{~N}\end{array}$ & $\begin{array}{l}150.73 \\
1500.00 \\
140.76 \\
153.65 \\
150.33\end{array}$ & $\begin{array}{ll}\text { W. } & 49 \\
\text { W. } & 33 \mathrm{~N} \\
\text { W. } & 15 \\
\text { W. } & 153 \\
\text { W. } & 33 \mathrm{~N}\end{array}$ & $\begin{array}{l}\ldots \\
3.0 \\
4.4 \\
\ldots\end{array}$ & $\begin{array}{l}\cdots \\
\cdots \\
\cdots\end{array}$ & $\begin{array}{l}\ddot{3} .0 M \\
3.9 M \\
\ddot{2} \ddot{9} M\end{array}$ & $\begin{array}{l}\cdots \\
\cdots \\
\cdots\end{array}$ & & & $\begin{array}{l}3 \\
3 \\
3 \\
3 \\
4 \\
4\end{array}$ & $\begin{array}{l}01 \text { A.M. AST } \\
03 \text { A.M. AST } \\
03 \text { P.M. YST } \\
10 \text { P.M. AST } \\
03 \text { A.M. AST }\end{array}$ \\
\hline $\begin{array}{l}\text { JULY } \\
\text { JULY } \\
\text { JULY } \\
\text { JULY } \\
\text { JULY }\end{array}$ & $\begin{array}{l}4 \\
5 \\
8 \\
8 \\
9\end{array}$ & $\begin{array}{lll}18 & 57 & 34.3 \\
07 & 48 & 49.7 \\
02 & 37 & 58.9 \\
03 & 58 & 18.9 \\
01 & 23 & 49.1\end{array}$ & $\begin{array}{l}52.84 \mathrm{~N} . \\
52.76 \mathrm{~N} . \\
52.30 \mathrm{~N} \\
59.14 \\
66.03 \mathrm{~N} .\end{array}$ & $\begin{array}{l}167.12 \\
166.85 \\
175.34 \\
152.36 \\
141.81\end{array}$ & $\begin{array}{ll}\text { W. } & 33 \mathrm{~N} \\
\text { W. } & 21 \\
\mathrm{E} . & 90 \\
\text { W. } & 135 \\
\text { W. } & 33 \mathrm{~N}\end{array}$ & $\begin{array}{l}4.7 \\
4.9 \\
4.2 \\
\ddot{4} .6\end{array}$ & $\begin{array}{l}5.1 \\
\because \cdots \\
\because \cdots \\
\cdots\end{array}$ & $\begin{array}{l}4.7 \mathrm{M} \\
\because \because \\
\dddot{3} \ddot{\mathrm{MM}}\end{array}$ & $\begin{array}{l}\ldots \\
\cdots \\
\cdots\end{array}$ & & $\begin{array}{l}\text { JULY } \\
\text { JULY } \\
\text { JULY } \\
\text { JULY } \\
\text { JULY }\end{array}$ & $\begin{array}{l}4 \\
4 \\
7 \\
7 \\
8\end{array}$ & $\begin{array}{lll}07 & \text { A.M. } & \text { BST } \\
08 & \text { P.M. BST } \\
03 & \text { P.M. BST } \\
05 & \text { P.M. AST } \\
03 & \text { P.M. AST }\end{array}$ \\
\hline $\begin{array}{l}\text { JULY } \\
\text { JULY } \\
\text { JULY } \\
\text { JULY } \\
\text { JULY }\end{array}$ & $\begin{array}{l}10 \\
10 \\
11 \\
13 \\
13\end{array}$ & $\begin{array}{llr}04 & 04 & 20.5 \\
17 & 48 & 52: 0 \\
12 & 28 & 2 \\
12 & 56 & 27.9 \\
17 & 35 & 5: 6\end{array}$ & $\begin{array}{l}63.20 \mathrm{~N} . \\
60.90 \mathrm{~N}: \\
55.32 \mathrm{~N} . \\
56.19 \mathrm{~N} . \\
62.32 \mathrm{~N}\end{array}$ & $\begin{array}{l}150.72 \\
147 . .22 \\
134.97 \\
161.83 \\
150.94\end{array}$ & $\begin{array}{l}\text { W. } 130 \\
\text { W. } 33 \mathrm{~N} \\
\text { W. } 10 \\
\text { W. } 230 \\
\text { W. } 33 \mathrm{~N}\end{array}$ & $\begin{array}{l}4.9 \\
\ddot{5} .1 \\
4.1\end{array}$ & $\ddot{3}:$ & $\begin{array}{l}\ddot{3} . \dot{M} M \\
5.8 M \\
\ddot{3} .0 M\end{array}$ & $\begin{array}{l}\text { II } \\
\because \dot{I V} \\
\cdots \\
\because \cdot\end{array}$ & & $\begin{array}{l}\text { JULY } \\
\text { JULY } \\
\text { JULY } \\
\text { JULY } \\
\text { JULY }\end{array}$ & $\begin{array}{r}9 \\
10 \\
11 \\
13 \\
13\end{array}$ & 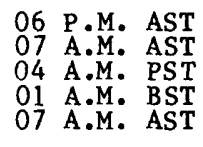 \\
\hline $\begin{array}{l}\text { JULY } \\
\text { JULY } \\
\text { JULY } \\
\text { JULY } \\
\text { JULY }\end{array}$ & $\begin{array}{l}14 \\
14 \\
14 \\
15 \\
15\end{array}$ & $\begin{array}{lll}00 & 48 & 25.7 \\
08 & 33 & 14.5 \\
19 & 12 & 38.9 \\
05 & 46 & 47.8 \\
05 & 50 & 21.1\end{array}$ & $\begin{array}{l}65.80 \mathrm{~N} . \\
53.71 \mathrm{~N} . \\
62.49 \mathrm{~N}: \\
61.05 \mathrm{~N}: \\
51.93 \mathrm{~N} .\end{array}$ & $\begin{array}{l}149.92 \\
166.96 \\
151.13 \\
149.39 \\
170.55\end{array}$ & $\begin{array}{l}\text { W. } \quad 33 \mathrm{~N} \\
\text { W. } 33 \mathrm{~N} \\
\text { W. } 114 \\
\text { W. } 33 \mathrm{~N} \\
\text { W. } 39\end{array}$ & $\begin{array}{l}\ddot{3} \ddot{8} \\
\dddot{0} \\
\ddot{5} \ddot{4}\end{array}$ & $\begin{array}{l}\ldots \\
\because \cdots \\
\ddot{4} .6\end{array}$ & $\begin{array}{l}2.7 \mathrm{M} \\
\because{ }^{\circ} \\
\ddot{3} \mathrm{M}^{\mathrm{M}}\end{array}$ & $\begin{array}{l}\cdots \\
\because \\
\because \\
\cdots\end{array}$ & & $\begin{array}{l}\text { JULY } \\
\text { JULY } \\
\text { JULY } \\
\text { JULY } \\
\text { JULY }\end{array}$ & $\begin{array}{l}13 \\
13 \\
14 \\
14 \\
14\end{array}$ & $\begin{array}{lll}02 & \text { P.M. AST } \\
09 & \text { P.M. BST } \\
09 & \text { A.M. AST } \\
07 & \text { P.M. AST } \\
06 & \text { P.M. BST }\end{array}$ \\
\hline $\begin{array}{l}\text { JULY } \\
\text { JULY } \\
\text { JULY } \\
\text { JULY } \\
\text { JULY }\end{array}$ & $\begin{array}{l}16 \\
16 \\
17 \\
17 \\
18\end{array}$ & $\begin{array}{lll}06 & 00 & 56.4 \\
23 & 45 & 58.5 \\
18 & 01 & 46.8 \\
20 & 44 & 29.5 \\
12 & 39 & 25.0\end{array}$ & $\begin{array}{l}63.24 \mathrm{~N} . \\
60.86 \mathrm{~N} . \\
51.63 \mathrm{~N} \\
62.27 \mathrm{~N} \\
56.78 \mathrm{~N} .\end{array}$ & $\begin{array}{l}150.54 \\
153.02 \\
177.73 \\
148.14 \\
156.62\end{array}$ & $\begin{array}{lr}\text { W. } & 145 \\
\text { W. } & 141 \\
\text { E. } & 89 \\
\text { W.: } & 58 \\
\text { W. } & 57\end{array}$ & $\begin{array}{l}\ddot{4}: .6 \\
4.3 \\
5.3 \\
4.8\end{array}$ & $\begin{array}{l}\cdots \\
\cdots \\
\cdots\end{array}$ & $\begin{array}{l}\cdots \\
\cdots \\
\cdots\end{array}$ & $\begin{array}{r}\text { FËLT } \\
\ddot{I} \dot{V} \\
\ldots .\end{array}$ & & $\begin{array}{l}\text { JULY } \\
\text { JULY } \\
\text { JULY } \\
\text { JULY } \\
\text { JULY }\end{array}$ & $\begin{array}{l}15 \\
16 \\
17 \\
17 \\
18\end{array}$ & $\begin{array}{ll}08 & \text { P.M. AST } \\
01 & \text { P.M. AST } \\
07 & \text { A.M. AST } \\
10 & \text { A.M. AST } \\
02 & \text { A.M. AST }\end{array}$ \\
\hline $\begin{array}{l}\text { JULY } \\
\text { JULY } \\
\text { JULY } \\
\text { JULY } \\
\text { JULY }\end{array}$ & $\begin{array}{l}18 \\
21 \\
22 \\
23 \\
23\end{array}$ & $\begin{array}{rrr}19 & 41 & 45.5 \\
10 & 29 & 30.3 \\
23 & 09 & 41.7 \\
08 & 38 & 13.0 \\
09 & 07 & 7.7\end{array}$ & $\begin{array}{l}56.78 \mathrm{~N} . \\
60.18 \mathrm{~N} . \\
52.93 \mathrm{~N} . \\
58.63 \mathrm{~N} . \\
61.64 \mathrm{~N} .\end{array}$ & $\begin{array}{l}157.00 \\
140.93 \\
166.51 \\
151.51 \\
150.51\end{array}$ & $\begin{array}{ll}\text { W. } & 80 \\
\text { W. } & 15 \\
\text { W. } & 33 \mathrm{~N} \\
\text { W. } & 33 \mathrm{~N} \\
\text { W. } & 49\end{array}$ & $\begin{array}{l}4.7 \\
3.3 \\
\because \because .4\end{array}$ & $\begin{array}{l}\ldots \\
\because \ldots\end{array}$ & $\begin{array}{l}3.2 \mathrm{M} \\
4.1 \mathrm{M} \\
4.6 \mathrm{M} \\
2.9 \mathrm{M}\end{array}$ & $\begin{array}{l}\cdots \\
\because \because \\
\text { II } \\
\text { II }\end{array}$ & 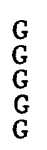 & $\begin{array}{l}\text { JULY } \\
\text { JULY } \\
\text { JULY } \\
\text { JULY } \\
\text { JULY }\end{array}$ & $\begin{array}{l}18 \\
21 \\
22 \\
22 \\
22\end{array}$ & $\begin{array}{lll}09 & \text { A.M. AST } \\
01 & \text { A.M. YST } \\
12 & \text { M. } & \text { BST } \\
10 & \text { P.M. AST } \\
11 & \text { P.M. AST }\end{array}$ \\
\hline $\begin{array}{l}\text { JULY } \\
\text { JULY } \\
\text { JULY } \\
\text { JULY } \\
\text { JULY }\end{array}$ & $\begin{array}{l}24 \\
25 \\
26 \\
27 \\
28\end{array}$ & $\begin{array}{rrr}22 & 23 & 24.8 \\
04 & 04 & 33.2 \\
17 & 49 & 11.3 \\
08 & 54 & 56.5 \\
03 & 24 & 4.7\end{array}$ & $\begin{array}{l}54.13 \mathrm{~N} . \\
60.06 \mathrm{~N}: \\
50.74 \mathrm{~N} . \\
60.43 \mathrm{~N} . \\
59.82 \mathrm{~N} .\end{array}$ & $\begin{array}{l}160 \\
148 \\
171 \\
143 \\
153\end{array}$ & $\begin{array}{l}\text { W. } \quad 33 N \\
\text { W. } \quad 33 N \\
W . \quad 33 N \\
W . \quad 33 N \\
\text { W. } 161\end{array}$ & $\begin{array}{l}4.9 \\
3.2 \\
5.0 \\
\ldots .\end{array}$ & $\begin{array}{l}5.5 \\
\ldots . \\
\ldots\end{array}$ & $\begin{array}{l}4.1 \mathrm{M} \\
3.6 \mathrm{M} \\
\ddot{4.0 \mathrm{M}} \\
\cdots\end{array}$ & $\begin{array}{l}\ldots \\
\cdots \\
\cdots\end{array}$ & $\underset{G}{G}$ & $\begin{array}{l}\text { JULY } \\
\text { JULY } \\
\text { JULY } \\
\text { JULY } \\
\text { JULY }\end{array}$ & $\begin{array}{l}24 \\
24 \\
26 \\
26 \\
27\end{array}$ & $\begin{array}{lll}12 & \text { M. } & \text { AST } \\
06 & \text { P.M. AST } \\
06 & \text { A.M. AST } \\
10 & \text { P.M. AST } \\
05 & \text { P.M. AST }\end{array}$ \\
\hline $\begin{array}{l}\text { JULY } \\
\text { JULY } \\
\text { JULY } \\
\text { JULY } \\
\text { JULY }\end{array}$ & $\begin{array}{l}28 \\
29 \\
29 \\
30 \\
30\end{array}$ & $\begin{array}{lll}07 & 46 & 33.0 \\
09 & 52 & 31.4 \\
17 & 03 & 46.8 \\
02 & 24 & 4.6 \\
05 & 11 & 49.4\end{array}$ & $\begin{array}{l}59.78 \mathrm{~N} . \\
51.99 \mathrm{~N} \\
64.61 \mathrm{~N} \\
62.04 \mathrm{~N} \\
50.52 \mathrm{~N} .\end{array}$ & $\begin{array}{l}152.05 \\
173.51 \\
152.21 \\
145.44 \\
175.84\end{array}$ & $\begin{array}{ll}\text { W. } & 113 \\
\text { W. } & 44 \\
\text { W. } & 33 \mathrm{~N} \\
\text { W. } & 14 \\
\text { W. } & 33 \mathrm{~N}\end{array}$ & $\begin{array}{l}\ddot{4} \ddot{8} \\
\dddot{8} \\
\ddot{4}: \ddot{9}\end{array}$ & $\because$ & $\begin{array}{l}\ddot{3} \cdot \ddot{5} \mathrm{G} \\
3.6 \mathrm{M} \\
3.5 \mathrm{M} \\
\cdots\end{array}$ & : & & $\begin{array}{l}\text { JULY } \\
\text { JULY } \\
\text { JULY } \\
\text { JULY } \\
\text { JULY }\end{array}$ & $\begin{array}{l}27 \\
28 \\
29 \\
29 \\
29\end{array}$ & $\begin{array}{ll}09 & \text { P.M. AST } \\
10 & \text { P.M. AST } \\
07 & \text { A.M. AST } \\
04 & \text { P.M. AST } \\
06 & \text { P.M. BST }\end{array}$ \\
\hline $\begin{array}{l}\text { JULY } \\
\text { JULY } \\
\text { JULY } \\
\text { JULY } \\
\text { AUG. }\end{array}$ & $\begin{array}{l}30 \\
31 \\
31 \\
31 \\
3\end{array}$ & $\begin{array}{lll}17 & 13 & 31.8 \\
02 & 04 & 54.9 \\
09 & 27 & 28: 1 \\
11 & 26 & 54.5 \\
00 & 19 & 40.7\end{array}$ & $\begin{array}{l}59.85 \mathrm{~N} . \\
51.09 \mathrm{~N} . \\
59.64 \mathrm{~N} \\
66.32 \mathrm{~N} \\
62.30 \mathrm{~N}\end{array}$ & $\begin{array}{l}140 \\
179 \\
152 \\
157 \\
151\end{array}$ & $\begin{array}{ll}\text { W. } & 15 \\
\text { E. } & 33 \mathrm{~N} \\
\text { W. } & 33 \mathrm{~N} \\
\mathrm{~W} . & 33 \mathrm{~N} \\
\mathrm{~W} . & 33 \mathrm{~N}\end{array}$ & $\begin{array}{l}4: 0 \\
3.4\end{array}$ & $\because$ & $\begin{array}{l}\ddot{3} \ddot{M} M \\
\ddot{3} \ddot{\circ M}\end{array}$ & $\begin{array}{l}\cdots \\
\cdots \\
\cdots\end{array}$ & & $\begin{array}{l}\text { JULY } \\
\text { JULY } \\
\text { JULY } \\
\text { JULY } \\
\text { AUG. }\end{array}$ & $\begin{array}{r}30 \\
30 \\
30 \\
31 \\
2\end{array}$ & $\begin{array}{lll}08 & \text { A.M. } & \text { YST } \\
03 & \text { P.M. BST } \\
11 & \text { P.M. AST } \\
01 & \text { A.M. AST } \\
02 & \text { P.M. AST }\end{array}$ \\
\hline $\begin{array}{l}\text { AUG: } \\
\text { AUG: } \\
\text { AUG: } \\
\text { AUG: } \\
\text { AUG: }\end{array}$ & $\begin{array}{l}4 \\
4 \\
5 \\
7 \\
7\end{array}$ & $\begin{array}{rrr}20 & 02 & 55.3 \\
20 & 12 & 10.6 \\
16 & 15 & 42.9 \\
02 & 12 & 34.8 \\
18 & 15 & 9.5\end{array}$ & $\begin{array}{l}59.83 \mathrm{~N} . \\
62.49 \mathrm{~N} . \\
56.57 \mathrm{~N} \\
58.94 \mathrm{~N} . \\
51.32 \mathrm{~N} .\end{array}$ & $\begin{array}{l}153 \\
149 \\
153 \\
154 \\
176\end{array}$ & $\begin{array}{lc}\text { W. } & 144 \\
\text { W. } & 99 \\
\text { W. } & 33 \mathrm{~N} \\
\text { W. } & 157 \\
\text { W. } & 33 \mathrm{~N}\end{array}$ & $\begin{array}{l}\ddot{4}: 1 \\
4.1 \\
\ddot{4}: \ddot{6}\end{array}$ & $\because$ & & & & $\begin{array}{l}\text { AUG: } \\
\text { AUG: } \\
\text { AUG: } \\
\text { AUG: } \\
\text { AUG: }\end{array}$ & $\begin{array}{l}4 \\
4 \\
5 \\
6 \\
7\end{array}$ & $\begin{array}{l}10 \text { A.M. AST } \\
10 \text { A.M. AST } \\
06 \text { A.M. AST } \\
04 \text { P.M. AST } \\
07 \text { A.M. BST }\end{array}$ \\
\hline $\begin{array}{l}\text { AUG: } \\
\text { AUG: } \\
\text { AUG: } \\
\text { AUG: } \\
\text { AUG: }\end{array}$ & $\begin{array}{l}8 \\
10 \\
10 \\
10 \\
11\end{array}$ & $\begin{array}{lll}10 & 56 & 42.5 \\
00 & 02 & 25.4 \\
03 & 32 & 16.7 \\
07 & 25 & 10.0 \\
20 & 08 & 12.4\end{array}$ & $\begin{array}{l}61.73 \mathrm{~N} . \\
61.97 \mathrm{~N} . \\
52.18 \mathrm{~N}: \\
52.00 \mathrm{~N} \\
59.98 \mathrm{~N} .\end{array}$ & $\begin{array}{l}151.95 \\
150.94 \\
170.49 \\
170.57 \\
140.75\end{array}$ & $\begin{array}{ll}\text { W. } & 81 \\
\text { W. } & 33 \mathrm{~N} \\
\text { W. } & 33 \mathrm{~N} \\
\text { W. } & 15\end{array}$ & $\begin{array}{l}4.0 \\
4.3 \\
4.5 \\
5.0 \\
3.6\end{array}$ & $\ddot{4}:$ & $\because \cdots$ & $\begin{array}{l}\text { III } \\
\because \cdots \\
\because \because\end{array}$ & & $\begin{array}{l}\text { AUG: } \\
\text { AUG: } \\
\text { AUG: } \\
\text { AUG: } \\
\text { AUG: }\end{array}$ & $\begin{array}{l}8 \\
9 \\
9 \\
9\end{array}$ & $\begin{array}{lll}12 & \text { P.M. AST } \\
02 & \text { P.M. AST } \\
04 & \text { P.M. AST } \\
08 & \text { P.M. BST } \\
11 & \text { A.M. YST }\end{array}$ \\
\hline $\begin{array}{l}\text { AUG: } \\
\text { AUG: }\end{array}$ & $\begin{array}{l}12 \\
13 \\
14\end{array}$ & $\begin{array}{lll}00 & 54 & 31.6 \\
10 & 58 & 28.1 \\
19 & 26 & 10.5\end{array}$ & $\begin{array}{l}60.12 \mathrm{~N} . \\
58.13 \mathrm{~N}: \\
63.66 \mathrm{~N} .\end{array}$ & $\begin{array}{l}152 \\
137 \\
148\end{array}$ & $\begin{array}{l}\text { W. } 128 \\
\text { W. } 15 \\
\text { W. } 17\end{array}$ & $\ddot{4}$ & $\because$ & 3.5 & : & & $\begin{array}{l}\text { AUG: } \\
\text { AUG: } \\
\text { AUG: }\end{array}$ & $\begin{array}{l}11 \\
13 \\
14\end{array}$ & $\begin{array}{lll}02 & \text { P.M. AST } \\
02 & \text { A.M. PST } \\
09 & \text { A.M. AST }\end{array}$ \\
\hline
\end{tabular}


Table 1...Summary of U.S. earthquakes for 1979-.Continued

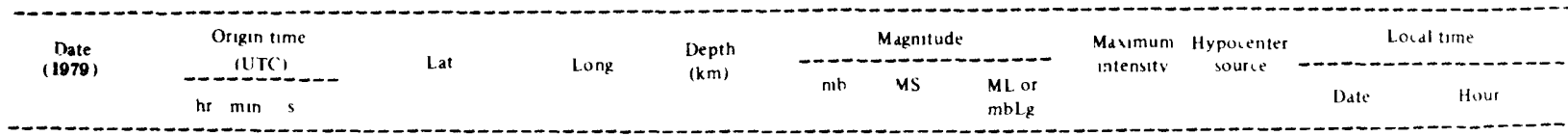

ALASKA--Cont inued

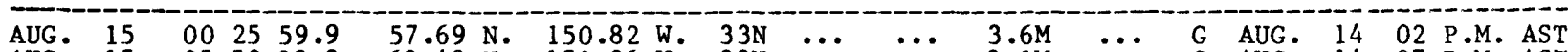

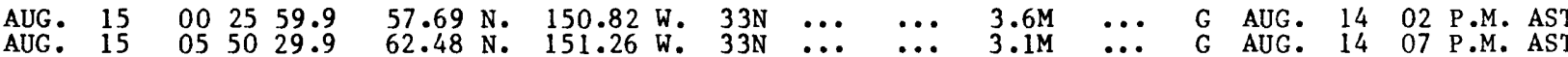

$\begin{array}{lllll}\text { AUG. } & 15 & 07 & 17 & 26.2 \\ \text { AUG. } & 15 & 16 & 48 & 34.6 \\ \text { AUG: } & 15 & 18 & 30 & 56.5 \\ \text { AUG. } & 16 & 01 & 51 & 34.8\end{array}$

AUG. $\quad$\begin{tabular}{llll}
16 & 01 & 51 & 34.8 \\
\hline & 20 & 29 & 28.6
\end{tabular}

AUG, $19 \quad 100129.3$

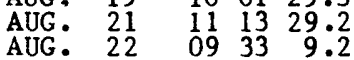

AUG. $\quad 22 \quad 22 \quad 13 \quad 38.9$

AUG. $25 \quad 08 \quad 22 \quad 59.2$

$\begin{array}{lllll}\text { AUG • } & 25 & 11 & 21 & 48.6 \\ \text { AUG. } & 25 & 20 & 36 & 19.2\end{array}$

AUG: $28 \quad 1706 \quad 9.6$

$\begin{array}{llllr}\text { AUG: } & 29 & 19 & 38 & 11.4 \\ \text { AUG. } & 30 & 14 & 43 & 1.9\end{array}$

AUG. $\quad 30 \quad 21 \quad 17 \quad 53.2$

$\begin{array}{lllll}\text { AUGG: } & 31 & 01 & 21 & 23.4 \\ \text { AUGG: } & 31 & 13 & 56 & 23.8 \\ \text { AUG } & 31 & 20 & 42 & 27.4\end{array}$

$\begin{array}{lllll}\text { AUG: } & 31 & 20 & 42 & 27.4 \\ \text { SE PT. } & 1 & 05 & 27 & 17.6\end{array}$

$\begin{array}{lllll}\text { SEPT. } \quad 1 & 16 & 20 & 30.7\end{array}$

$\begin{array}{lllll}\text { SEPT: } & 1 & 18 & 56 & 51.6 \\ \text { SEPT. } & 3 & 11 & 10 & 13.4\end{array}$

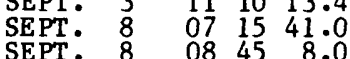

SEPT. $\quad 9 \quad 07 \quad 24 \quad 23.5$

$\begin{array}{lllll}\text { SEPT: } & 9 & 22 & 57 & 38.1 \\ \text { SEPT. } 21 & 18 & 04 & 41.5\end{array}$

SEPT: $22 \quad 03049627.7$

SEPT. $23 \quad 1017 \quad 20.8$

SEPT. $24 \quad 03 \quad 1956.7$

SEPT: 26 O0 45 19.2

$\begin{array}{ll}\text { OCT. } & 2 \\ \text { OCT. } & 2\end{array}$

$0607 \quad 57.6$

OCT. 4024847.6

OCT: $\quad \begin{array}{llll}4 & 02 & 48 & 47.6\end{array}$

OCT: 7 $\quad 055921.8$

$\begin{array}{lrrrrr} & & & \\ \text { OCT: } & 8 & 14 & 58 & 14 & 10 \\ \text { OCT. } & 10 & 23 & 36 & 45.1\end{array}$

$\begin{array}{lllll}\text { OCT. } & 10 & 23 & 46 & 7.6\end{array}$

$\begin{array}{lllll}\text { OCT. } & 13 & 07 & 03 & 19.7 \\ \text { OCT. } & 13 & 13 & 58 & 16.1\end{array}$

$\begin{array}{llllr}\text { OCT. } & 13 & 13 & 58 & 16.1 \\ \text { OCT. } & 15 & 06 & 24 & 1.2\end{array}$

$\begin{array}{lllll}\text { OCT: } 16 & 12 & 14 & 33.1\end{array}$

$\begin{array}{lllll}\text { OCT. } & 16 & 21 & 16 & 5.2\end{array}$

$\begin{array}{llllr}\text { OCT. } & 17 & 23 & 34 & 8.1 \\ \text { OCT. } & 18 & 03 & 35 & 26.9\end{array}$

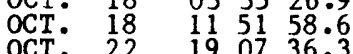

$\begin{array}{llllr}\text { OCT. } & 24 & 06 & 06 & 0.4 \\ \text { OCT. } & 24 & 06 & 13 & 42.8 \\ \text { OCT. } & 24 & 22 & 19 & 35.5\end{array}$

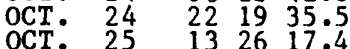

OCT: $25 \quad 17$ O1 1.8

$\begin{array}{lllll}\text { OCT. } & 27 & 06 & 32 & 2.3 \\ \text { OCT. } & 27 & 14 & 37 & 0.4\end{array}$

OCT: $27 \quad 22 \quad 16 \quad 59.2$

OCT. $28 \quad 06 \quad 24 \quad 9.8$

$\begin{array}{lllll}\text { OCT. } & 28 & 06 & 24 & 9.8 \\ \text { OCT. } & 29 & 13 & 42 & 25.5\end{array}$

$\begin{array}{lllll}\text { NOV. } & 2 & 00 & 34 & 49.8 \\ \text { NOV. } & 2 & 03 & 21 & 4.1\end{array}$

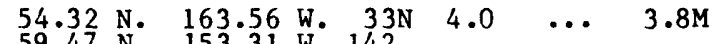

$59.69 \mathrm{~N}$

$53.59 \mathrm{~N}$.

$163.56 \mathrm{~W} .33 \mathrm{~N} \quad 4.0$

-.. $3.8 \mathrm{M}$

... G AUG.

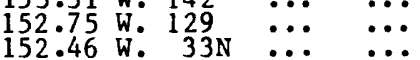

$\ldots$

$\cdots$

$\ddot{\cdots}$

G AUG:

1408 P.M. BST

63.33

$63.33 \mathrm{~N} . \quad 152.00 \mathrm{~W} . \quad 33 \mathrm{~N} \quad 4.0$

$51.70 \mathrm{~N}$.

$58.84 \mathrm{~N}$

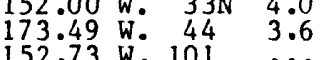

$60.12 \mathrm{~N}$.

$152.73 \mathrm{~W} \cdot 101 \mathrm{~N} \quad \ddot{4} . \dot{6}$

$60.44 \mathrm{~N}$.

$53.60 \mathrm{~N}$.

$60.85 \mathrm{~N}$.

$61.91 \mathrm{~N}$.
$53.04 \mathrm{~N}$.

$57.68 \mathrm{~N}$.

$52.43 \mathrm{~N}$.

$52.93 \mathrm{~N}$.

$54.39 \mathrm{~N}$.
$53.98 \mathrm{~N}$.

$62.84 \mathrm{~N}$

$60.03 \mathrm{~N}$

$60.05 \mathrm{~N}$

$59.49 \mathrm{~N}$

$59.46 \mathrm{~N}$

$53.00 \mathrm{~N}$
$62.94 \mathrm{~N}$

$54.65 \mathrm{~N}$

$53.73 \mathrm{~N}$
$52.29 \mathrm{~N}$

$52.19 \mathrm{~N}$

$62.45 \mathrm{~N}$.

$51.08 \mathrm{~N}$

$51.09 \mathrm{~N}$.

$147.67 \mathrm{~W}$

167.67 W. $33 \mathrm{~N}$

161.31 W. $33 \mathrm{~N}$

150.80 W. $88 \quad \ddot{3} . \dot{9}$

$\ldots \quad 4.9 \mathrm{M}$

$\ldots$...

$G$ AUG

$1506 \mathrm{~A}$

$\begin{array}{llll}73.07 & \mathrm{E} . & 79 & 4.8\end{array}$

$154.48 \mathrm{~W} .67$

$168.49 \mathrm{~W} \cdot \quad 33 \mathrm{~N}$

$\begin{array}{llll}161.84 & \mathrm{~W} . & 33 \mathrm{~N} & 4.3 \\ & & 5.1\end{array}$

$4 \cdot 4$
$4 \cdot 6$
$4 \cdot 3$
$5 \cdot 1$
5.8

3.4

$151.29 \mathrm{~W} .13$

$141.10 \mathrm{~W}$.
$152.94 \mathrm{~W} .150$

146.72 W. ${ }_{33 \mathrm{~N}} \ddot{4.7}$

$\ddot{4} \cdot \dot{7}$

$146.49 \mathrm{~W} . \mathrm{3}$

4.6

$150.50 \mathrm{~W} \cdot 120$

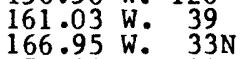

4.8

174.03 E. 43

$62.95 \mathrm{~N}$

$61.22 \mathrm{~N}$.

$59.49 \mathrm{~N}$.

$174.02 \mathrm{E} . \quad 33 \mathrm{~N}$

4.8

160.15 W. 66

$178.95 \mathrm{E} .50$

4.1

$150.62 \mathrm{~W} .117$

153.49 W. 78

$150.43 \mathrm{~W} .98 \mathrm{~g} 3.9$

3.6
3.9
$\cdots .$.

$61.49 \mathrm{~N}$

$51.96 \mathrm{~N}$.

$63.01 \mathrm{~N}$.

$51.77 \mathrm{~N}$.

135.75 W. $133 \mathrm{~N} \quad 4 . \%$

$\cdots$

$\because \quad \because \ddot{s} \quad \cdots$

$\ddot{4} \cdot \dot{5} \mathrm{M}$

$\because \cdots$

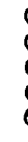

G AUG:

AUG:

$\because \quad 3.7 \mathrm{M}$

$\because 3.3 \mathrm{M}$

…

G

$\cdots \quad \ldots$

$\because$ G AUG.

iii G AUG.

-...

$\cdots+\cdots$

\begin{tabular}{l}
.70 N. 141.79 W. 15 \\
\hline
\end{tabular}

$51.85 \mathrm{~N}$

$59.96 \mathrm{~N}$

$52.39 \mathrm{~N}$

$151.92 \mathrm{~W} .114$

$179.83 \mathrm{~W} .100$

\section{$\ddot{4} . \ddot{6}$}

$\because \cdots$

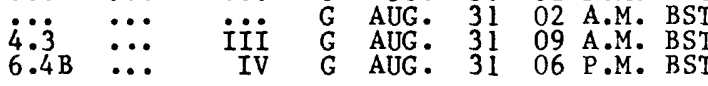

$\ddot{\cdots}$

G

AUG. 3011 A.M. AST

$62.55 \mathrm{~N} .151 .56 \mathrm{~W} .134$

$65.24 \mathrm{~N} .164 .74 \mathrm{~W} \cdot 133 \mathrm{~N}$

$63.43 \mathrm{~N}$

153.12 W. 102
150.68 W. 139

$61.70 \mathrm{~N}$

$62.03 \mathrm{~N}$.

$59.86 \mathrm{~N}$

$52.63 \mathrm{~N}$.

$\begin{array}{llll}149.58 & \mathrm{~W} . & 44 & \\ 150.55 & \mathrm{~W} . & 33 \mathrm{~N} & \because \\ 152.90 & \mathrm{~W} . & 77 & 4.1\end{array}$

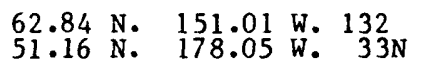

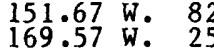

4.8

5.35 .2

6.0

$\ddot{4} \ddot{9}$

…

$\because \cdots$

$\ddot{4}: 4$

$\ddot{4}$

$\because \cdots$

$\ldots$

$\ldots$

$3.7 \mathrm{M}$

$\ldots$

G SEPT.

SEPT:

$\because \cdots$ G SEPT.

106 A.M. AST

108 A.M. AST 01
$0 . M$
P.M. AST

$4.4 \quad \ldots \quad \ldots \quad$ G SEPT. 8 0 08 P.M. BST $\because \quad \because \cdots \quad \cdots \quad$ G SEPT 9212 M. AST $\because \cdots$ G SEPT. 21 O4 P.M. BST 5.6 ... IV G SEPT. 2211 P.M. BST

$\ldots \quad \ldots$ IV G SEPT. 23 04 P.M. BST $\cdots \quad \ldots \quad \ldots$ G SEPT. 25 O2 02 P.M. AST $\because \quad \cdots \quad \cdots \quad$ G SEPT. 30 12 P.M. AST

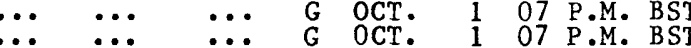

$\begin{array}{llllll}\ldots & \ldots & \ldots & \text { G OCT. } 3 & 04 & \text { P.M. AST }\end{array}$ $\because$ i. $\therefore \quad 3.1 \mathrm{M}$ FELT G OCT. 6 07 P.M. AST

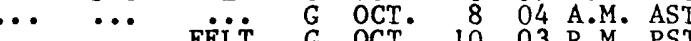
$\because \ldots \quad \cdots \quad$ FËLT G OCT. 10 03 P.M. PST

$\begin{array}{llllllll}\ldots & \ldots & \ldots & \text { G } & 0 C T . & 10 & 01 & \text { P.M. AST }\end{array}$ $\because \quad \ldots \quad \cdots \quad$ G OCT 12

$\cdots$

$\cdots$

$\because \ddot{*}$

G OCT.

13

08 P.M. BST

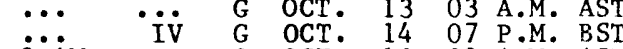

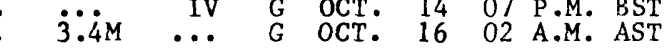


Table 1.--Summary of U.S. earthquakes for 1979--Continued

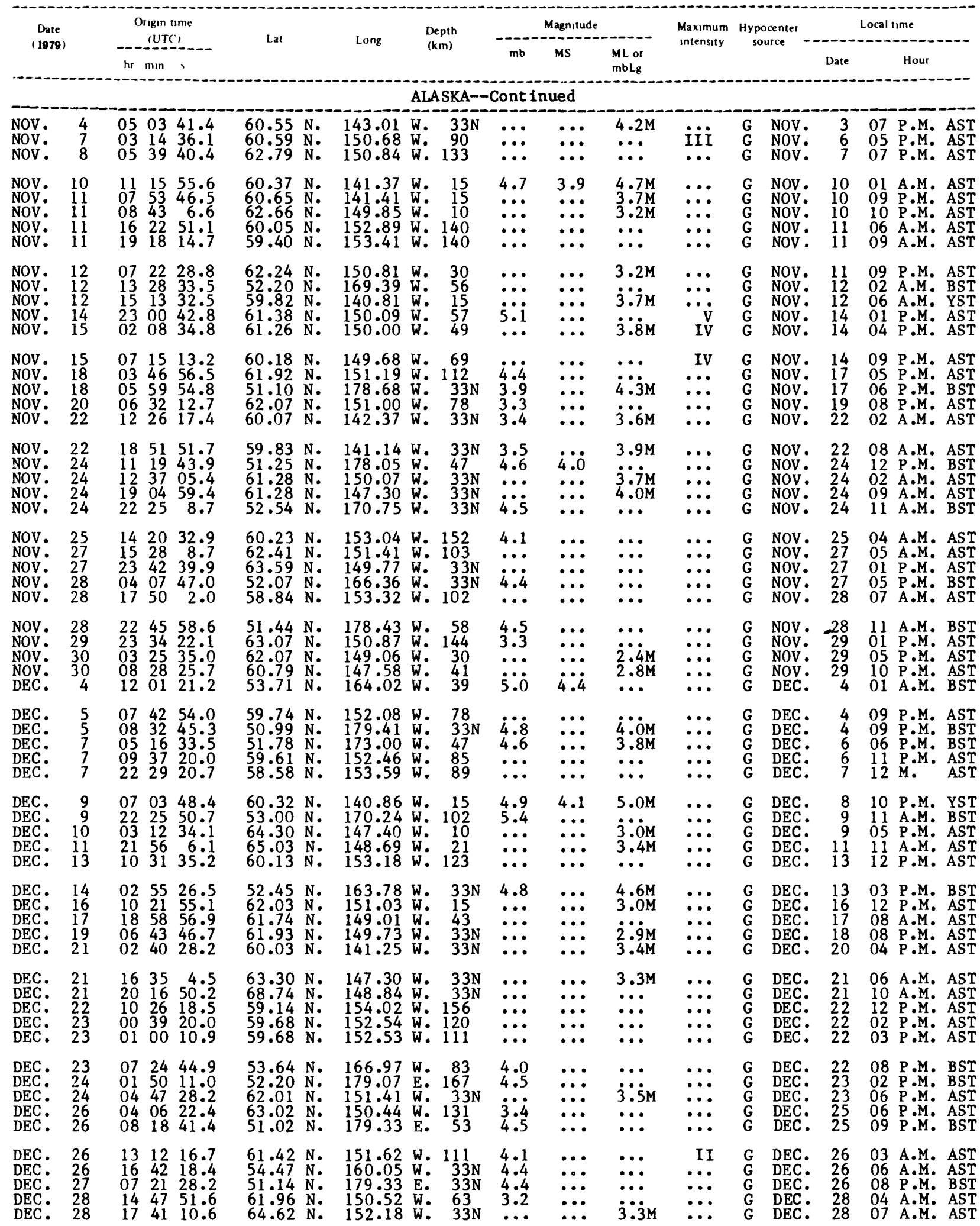


Table 1.--Summary of U.S. earthquakes for 1979--Continued

\begin{tabular}{|c|c|c|c|c|c|c|c|c|c|c|c|}
\hline \multirow{2}{*}{$\begin{array}{l}\text { Date } \\
\text { (1979) }\end{array}$} & $\begin{array}{l}\text { Origın tume } \\
\text { (UTC) }\end{array}$ & \multirow{2}{*}{ Lat } & \multirow{2}{*}{ Long } & \multirow{2}{*}{$\begin{array}{l}\text { Depth } \\
(\mathbf{k m})\end{array}$} & \multicolumn{3}{|c|}{ Magnitude } & \multirow{2}{*}{$\begin{array}{l}\text { Maxımum } \\
\text { intensitv }\end{array}$} & \multirow[t]{2}{*}{$\begin{array}{c}\text { Hypocenter } \\
\text { source }\end{array}$} & \multicolumn{2}{|c|}{ Local tume } \\
\hline & hs min s & & & & mb & MS & $\begin{array}{l}\text { ML or } \\
\mathrm{mbLg}\end{array}$ & & & Date & Hour \\
\hline
\end{tabular}

ALASKA--Cont inued

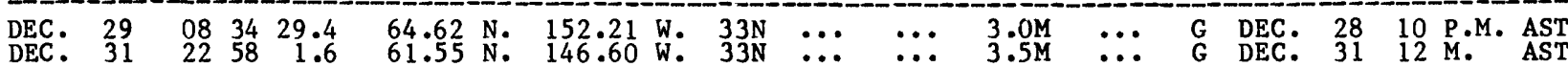

ARIZONA

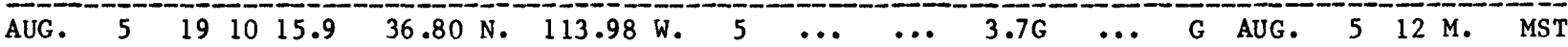

ARKANSAS

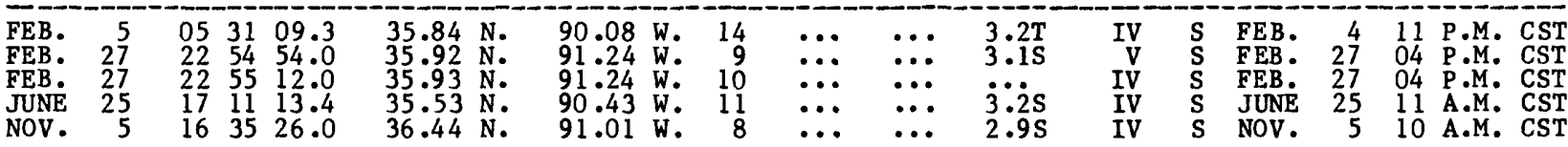

\section{CALIFORNIA}

\begin{tabular}{|c|c|c|c|c|c|c|c|c|c|c|c|c|c|c|c|c|c|c|}
\hline $\begin{array}{l}\text { JAN. } \\
\text { JAN. } \\
\text { JAN. }\end{array}$ & $\begin{array}{l}1 \\
1 \\
1 \\
1\end{array}$ & $\begin{array}{ll}17 & 12 \\
20 & 38 \\
23 & 14 \\
23 & 19 \\
23 & 21\end{array}$ & $\begin{array}{l}18.0 \\
38.9 \\
05.2 \\
36.0\end{array}$ & $\begin{array}{l}34.90 \\
33.95 \\
33.97 \\
33.95\end{array}$ & & $\begin{array}{l}116.52 \\
119.17 \\
118.68 \\
118.72 \\
118.70\end{array}$ & $\begin{array}{l}\text { W. } \\
\text { W. } \\
\text { W. }\end{array}$ & $\begin{array}{r}16 \\
1 \\
11 \\
8 \\
8\end{array}$ & $\begin{array}{l}\cdots \\
\ddot{5} \ddot{1} \\
\cdots \\
\cdots\end{array}$ & $\begin{array}{l}\ldots \\
4.7 \\
\ldots \\
\ldots\end{array}$ & $\begin{array}{l}3.3 \mathrm{P} \\
3.2 \mathrm{P} \\
5.0 \mathrm{P}\end{array}$ & $\begin{array}{c}\because \cdots \\
\ddot{v} \dot{I} \\
\cdots \\
\cdots\end{array}$ & $\begin{array}{l}P \\
P \\
P\end{array}$ & & $\begin{array}{l}1 \\
1 \\
1 \\
1 \\
1\end{array}$ & & $\begin{array}{l}A . M . \\
M . M . \\
P . M . \\
P . M .\end{array}$ & 列 \\
\hline $\begin{array}{l}\text { JAN. } \\
\text { JAN. } \\
\text { JAN. } \\
\text { JAN. }\end{array}$ & $\begin{array}{l}\frac{1}{1} \\
1 \\
1\end{array}$ & $\begin{array}{ll}23 & 22 \\
23 & 24 \\
23 & 26 \\
23 & 29 \\
23 & 32\end{array}$ & $\begin{array}{l}14.3 \\
58.1 \\
25.2 \\
25.0 \\
12.3\end{array}$ & $\begin{array}{l}33.98 \\
33.93 \\
33.95 \\
33.95\end{array}$ & : & $\begin{array}{l}118.70 \\
118.67 \\
118.68 \\
118.67 \\
118.72\end{array}$ & $\begin{array}{l}\text { W. } \\
\text { W. } \\
\text { W. } \\
\text { W. } \\
\text { W. }\end{array}$ & $\begin{array}{l}4 \\
6 \\
2 \\
9\end{array}$ & $\begin{array}{l}\cdots \\
\ddot{4} \dot{1} \\
\cdots\end{array}$ & $\begin{array}{l}\cdots \\
\because \cdots \\
\cdots\end{array}$ & $\begin{array}{l}3.0 \mathrm{P} \\
3.0 \mathrm{P} \\
3.9 \mathrm{P} \\
3.0 \mathrm{P}\end{array}$ & $\begin{array}{c}\because \ddot{\dot{T}} \\
\ldots \dot{\mathrm{T}}\end{array}$ & $\begin{array}{l}\mathrm{P} \\
\mathrm{P} \\
\mathrm{P} \\
\mathrm{P} \\
\mathrm{P}\end{array}$ & & 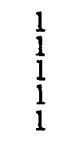 & & $\begin{array}{l}\text { M. } \\
\text { M. } \\
\text { M. }\end{array}$ & \\
\hline $\begin{array}{l}\text { JAN: } \\
\text { JAN: } \\
\text { JAN. }\end{array}$ & $\begin{array}{l}1 \\
1 \\
2 \\
2\end{array}$ & $\begin{array}{ll}23 & 36 \\
23 & 49 \\
00 & 03 \\
07 & 15 \\
07 & 41\end{array}$ & $\begin{array}{l}28.2 \\
58.8 \\
52.3 \\
51.6 \\
14.1\end{array}$ & $\begin{array}{l}33.93 \\
33.93 \\
33.97 \\
33.95\end{array}$ & vi. & $\begin{array}{l}118.75 \\
118.67 \\
118.68 \\
118.70 \\
118.70\end{array}$ & $\begin{array}{l}\text { W. } \\
\text { W. } \\
\text { W. } \\
\text { W. }\end{array}$ & $\begin{array}{l}6 \\
6 \\
6\end{array}$ & $\begin{array}{l}\cdots \\
\cdots \\
\cdots\end{array}$ & $\begin{array}{l}\cdots \\
\cdots \\
\cdots\end{array}$ & $\begin{array}{l}3.0 \mathrm{P} \\
3.7 \mathrm{P} \\
3.0 \mathrm{P} \\
3.0 \mathrm{P}\end{array}$ & $\begin{array}{c}\text { FËLT } \\
\ddot{\mathrm{F}} \dot{\mathrm{L}} \dot{\mathrm{T}}\end{array}$ & $\mathrm{F}$ & & $\begin{array}{l}1 \\
1 \\
1\end{array}$ & $\begin{array}{l}0 \\
0 \\
1\end{array}$ & $\begin{array}{l}\text { M. } \\
\text { M. } \\
\text { M. }\end{array}$ & \\
\hline $\begin{array}{l}\text { JAN. } \\
\text { JAN. } \\
\text { JAN. } \\
\text { JAN. }\end{array}$ & $\begin{array}{l}2 \\
2 \\
2 \\
3 \\
3\end{array}$ & $\begin{array}{ll}18 & 16 \\
22 & 29 \\
22 & 43 \\
00 & 20 \\
13 & 36\end{array}$ & $\begin{array}{l}31.4 \\
57.9 \\
27.1 \\
52.4 \\
50.4\end{array}$ & $\begin{array}{l}33.95 \\
33.93 \\
33.95 \\
33.90 \\
34.90\end{array}$ & $\begin{array}{l}\text { N. } \\
\text { N. } \\
\text { N. } \\
\text { N. }\end{array}$ & $\begin{array}{l}118.70 \\
118.68 \\
118.68 \\
118.68 \\
119.17\end{array}$ & $\begin{array}{l}\text { W. } \\
\text { W. } \\
\text { W. } \\
\text { W. } \\
\text { W. }\end{array}$ & $\begin{array}{r}15 \\
6 \\
11 \\
6 \\
1\end{array}$ & $\begin{array}{l}\ldots \\
\cdots \\
\cdots\end{array}$ & $\begin{array}{l}\cdots \\
\because \\
\cdots \\
\cdots\end{array}$ & $\begin{array}{l}3.4 \mathrm{P} \\
2.5 \mathrm{P} \\
2.6 \mathrm{P} \\
2.8 \mathrm{P} \\
3.5 \mathrm{P}\end{array}$ & $\begin{array}{c}\text { FELT } \\
\text { FELT } \\
\text { FELT } \\
\text { FELT } \\
\ldots .\end{array}$ & $\begin{array}{l}P \\
P \\
P\end{array}$ & & 2 & $\begin{array}{l}0 \\
0\end{array}$ & M. & \\
\hline $\begin{array}{l}\text { JAN. } \\
\text { JAN. } \\
\text { JAN. }\end{array}$ & $\begin{array}{r}3 \\
3 \\
4 \\
7 \\
11\end{array}$ & $\begin{array}{ll}16 & 54 \\
20 & 00 \\
01 & 02 \\
11 & 37 \\
19 & 57\end{array}$ & $\begin{array}{l}16.5 \\
43.0 \\
05.6 \\
32.3 \\
26.6\end{array}$ & $\begin{array}{l}33.95 \\
35.02 \\
33.92 \\
36.10 \\
37.00\end{array}$ & $\begin{array}{l}\text { N. } \\
\text { N. } \\
\text { N. } \\
\text { N. }\end{array}$ & $\begin{array}{l}118.70 \\
119.13 \\
118.68 \\
120.21 \\
121.72\end{array}$ & $\begin{array}{l}W . \\
W . \\
W \\
W\end{array}$ & $\begin{array}{r}11 \\
5 \\
6 \\
4 \\
9\end{array}$ & $\ddot{\cdots}$ & $\begin{array}{l}\cdots \\
\cdots \\
\cdots \\
\cdots\end{array}$ & $\begin{array}{l}3.0 \mathrm{P} \\
3.4 \mathrm{P} \\
3.0 \mathrm{P} \\
3.8 \mathrm{~B}\end{array}$ & \begin{tabular}{r} 
FELT \\
IV \\
\hdashline$\dot{I V}$ \\
FELT
\end{tabular} & $\begin{array}{l}P \\
P \\
P\end{array}$ & $\begin{array}{l}\text { N.: } \\
\text { N.: }\end{array}$ & $\begin{array}{r}3 \\
3 \\
3 \\
7 \\
11\end{array}$ & $\begin{array}{l}08 \\
12 \\
05 \\
03 \\
11\end{array}$ & $\begin{array}{l}\text { M. } \\
\text { M. }\end{array}$ & \\
\hline $\begin{array}{l}\text { JAN. } \\
\text { JAN. } \\
\text { JAN. } \\
\text { JAN. } \\
\text { JAN. }\end{array}$ & $\begin{array}{l}11 \\
12 \\
13 \\
13 \\
15\end{array}$ & $\begin{array}{ll}20 & 39 \\
11 & 47 \\
09 & 29 \\
11 & 07 \\
12 & 41\end{array}$ & $\begin{array}{l}23.8 \\
15.0 \\
26.5 \\
29.4 \\
18.7\end{array}$ & $\begin{array}{l}37.39 \\
33.52 \\
35.73 \\
33.95 \\
33.97\end{array}$ & $\begin{array}{l}\text { N. } \\
\text { N. } \\
\text { N. } \\
\text { N. } \\
\text { N. }\end{array}$ & $\begin{array}{l}121.75 \\
116.50 \\
118.05 \\
118.68 \\
118.72\end{array}$ & $\begin{array}{l}W \\
W \\
W \\
W \\
W\end{array}$ & $\begin{array}{r}1 \\
5 \\
3 \\
13\end{array}$ & $\begin{array}{l}\ldots \\
\cdots \\
\cdots\end{array}$ & $\begin{array}{l}\cdots \\
\because \cdots \\
\cdots\end{array}$ & $\begin{array}{l}3.6 \mathrm{~B} \\
3.2 \mathrm{P} \\
3.2 \mathrm{P} \\
2.8 \mathrm{P} \\
3.7 \mathrm{P}\end{array}$ & 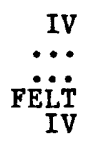 & $\begin{array}{l}\mathrm{B} \\
\mathrm{P} \\
\mathrm{P}\end{array}$ & & $\begin{array}{l}11 \\
12\end{array}$ & $\begin{array}{l}12 \\
03 \\
01 \\
03 \\
04\end{array}$ & M. & \\
\hline $\begin{array}{l}\text { JAN. } \\
\text { JAN: } \\
\text { JAN: } \\
\text { JAN: } \\
\text { JAN. }\end{array}$ & $\begin{array}{l}19 \\
19 \\
21 \\
23 \\
24\end{array}$ & $\begin{array}{ll}13 & 59 \\
18 & 10 \\
16 & 11 \\
07 & 25 \\
21 & 14\end{array}$ & $\begin{array}{l}55.4 \\
42.0 \\
36.0 \\
08.0 \\
27.2\end{array}$ & $\begin{array}{l}37.34 \\
37.55 \\
34.65 \\
34.50 \\
37.52\end{array}$ & N.: & $\begin{array}{l}121.72 \\
118.63 \\
117.73 \\
116.33 \\
118.60\end{array}$ & $\begin{array}{l}5 \\
5 \\
5 \\
h\end{array}$ & $\begin{array}{r}8 \\
9 \\
8 \\
6 \\
10\end{array}$ & $\begin{array}{l}\ldots \\
\cdots \\
\cdots\end{array}$ & $\begin{array}{l}\ldots \\
\because \cdots \\
\cdots\end{array}$ & $\begin{array}{l}3.1 \mathrm{~B} \\
4.1 \mathrm{~B} \\
3.1 \mathrm{P} \\
3.5 \mathrm{P} \\
4.6 \mathrm{~B}\end{array}$ & $\begin{array}{c}\text { FELT } \\
\text { IV } \\
\because \because \dot{\text { IV }}\end{array}$ & $\begin{array}{l}\text { B } \\
\text { B }\end{array}$ & & $\begin{array}{l}19 \\
21 \\
22 \\
24\end{array}$ & $\begin{array}{l}05 \\
10 \\
08 \\
11 \\
01\end{array}$ & $\begin{array}{l}\text { M. } \\
\text { M. }\end{array}$ & \\
\hline $\begin{array}{l}\text { JAN. } \\
\text { FEB } \\
\text { FEB: } \\
\text { FEB } \\
\text { FEB. }\end{array}$ & $\begin{array}{r}29 \\
2 \\
4 \\
5 \\
5\end{array}$ & $\begin{array}{ll}04 & 59 \\
18 & 29 \\
15 & 55 \\
02 & 08 \\
02 & 14\end{array}$ & $\begin{array}{l}22.7 \\
26.2 \\
54.7 \\
19.6 \\
09.9\end{array}$ & $\begin{array}{l}33.95 \\
38.81 \\
33.98 \\
37.77 \\
37.55\end{array}$ & : & $\begin{array}{l}118.67 \\
119.82 \\
119.18 \\
122.17 \\
118.79\end{array}$ & & $\begin{array}{r}6 \\
19 \\
5 \\
8 \\
10\end{array}$ & $\begin{array}{l}\cdots \\
\cdots \\
\cdots\end{array}$ & $\because \cdots$ & $\begin{array}{l}3.4 \mathrm{~B} \\
3.6 \mathrm{P} \\
2.7 \mathrm{~B} \\
3.7 \mathrm{~B}\end{array}$ & $\begin{array}{c}\text { FELT } \\
\cdots \\
\cdots \dot{v} \\
\ldots\end{array}$ & $\begin{array}{l}\mathrm{P} \\
\mathrm{B} \\
\mathrm{P} \\
\mathrm{B} \\
\mathrm{B}\end{array}$ & $\begin{array}{l}\text { FEB: } \\
\text { FEB } \\
\text { FEB } \\
\text { FEB }\end{array}$ & $\begin{array}{r}28 \\
2 \\
4 \\
4 \\
4\end{array}$ & $\begin{array}{l}08 \\
10 \\
07 \\
06 \\
06\end{array}$ & 1. & \\
\hline $\begin{array}{l}\text { FEB } \\
\text { FEB: } \\
\text { FEB } \\
\text { FEB } \\
\text { FEB. }\end{array}$ & $\begin{array}{r}5 \\
5 \\
7 \\
12 \\
12\end{array}$ & $\begin{array}{ll}07 & 22 \\
08 & 42 \\
04 & 20 \\
04 & 48 \\
04 & 55\end{array}$ & $\begin{array}{l}41.2 \\
23.9 \\
15.6 \\
42.3 \\
16.1\end{array}$ & $\begin{array}{l}37.32 \\
37.55 \\
37.56 \\
33.45\end{array}$ & & $\begin{array}{l}121.67 \\
118.77 \\
118.79 \\
116.43 \\
116.43\end{array}$ & & $\begin{array}{r}8 \\
10 \\
10 \\
4 \\
4\end{array}$ & $\because \cdots$ & 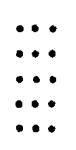 & $\begin{array}{l}3.3 \mathrm{~B} \\
3.8 \mathrm{~B} \\
4.2 \mathrm{P}\end{array}$ & $\begin{array}{c}\text { FELT } \\
\because \cdots \\
\because \dot{v} \\
\cdots\end{array}$ & $\begin{array}{l}\text { B } \\
\text { B } \\
\text { B } \\
\text { P }\end{array}$ & $\begin{array}{l}\text { FEB. } \\
\text { FEB. } \\
\text { FEB. } \\
\text { FEB } \\
\text { FEB. }\end{array}$ & $\begin{array}{r}4 \\
5 \\
6 \\
11 \\
11\end{array}$ & $\begin{array}{l}11 \\
12 \\
08 \\
08 \\
08\end{array}$ & $\begin{array}{l}\text { M. } \\
\text { M. }\end{array}$ & \\
\hline $\begin{array}{l}\text { FEB } \\
\text { FE B }\end{array}$ & 12 & $\begin{array}{ll}05 & 15 \\
20 & 26\end{array}$ & $\begin{array}{l}2 \\
2\end{array}$ & & & & 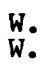 & 4 & & . & & $\ddot{I} \dot{V}$ & $\mathbf{P}$ & $\begin{array}{l}\text { FEB. } \\
\text { FEB }\end{array}$ & $1 \frac{1}{12}$ & $\begin{array}{l}09 \\
12\end{array}$ & & \\
\hline
\end{tabular}


Table 1.--Summary of U.S. earthquakes for 1979--Continued

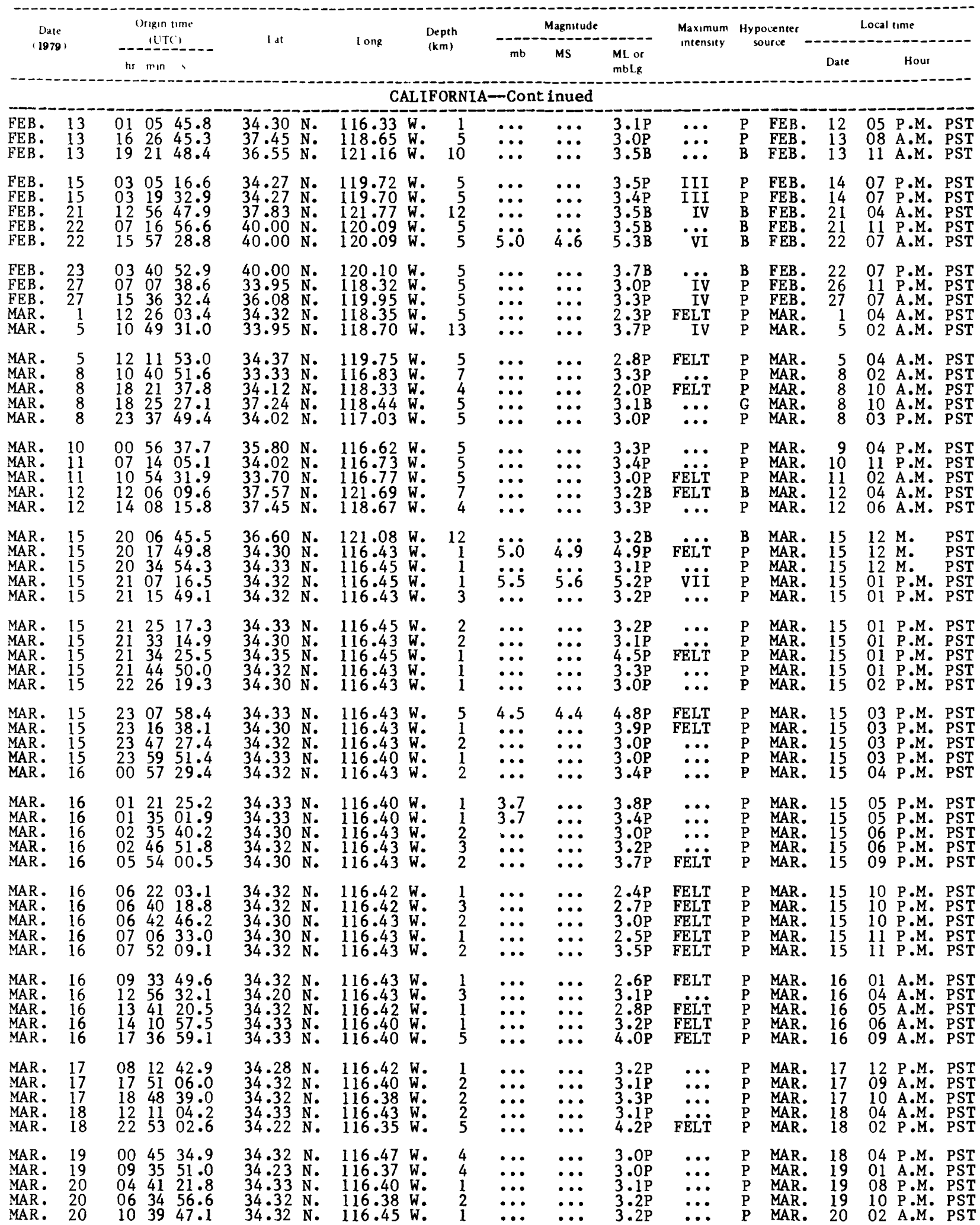


Table 1.--Summary of U.S. earthquakes for 1979--Continued

\begin{tabular}{|c|c|c|c|c|c|c|c|c|c|c|c|c|c|}
\hline \multirow{2}{*}{\multicolumn{2}{|c|}{$\begin{array}{c}\text { Date } \\
\text { (1979) }\end{array}$}} & \multirow{2}{*}{ 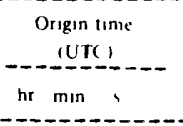 } & & \multirow{2}{*}{ cong } & \multirow{2}{*}{$\begin{array}{l}\text { Depth } \\
(\mathrm{km})\end{array}$} & \multicolumn{3}{|c|}{ Magnitude } & \multirow{2}{*}{$\begin{array}{l}\text { Maximum } \\
\text { Intensity }\end{array}$} & \multirow{2}{*}{\multicolumn{2}{|c|}{$\begin{array}{c}\text { Hypocenter } \\
\text { source }\end{array}$}} & \multicolumn{2}{|r|}{ Local time } \\
\hline & & & & & & $\mathrm{mb}$ & MS & $\begin{array}{l}\text { ML or } \\
\text { mblg }\end{array}$ & & & & \multirow[t]{2}{*}{ Date } & Hour \\
\hline \multicolumn{13}{|c|}{ CALIFORNIA-Cont inued } & \\
\hline $\begin{array}{l}\text { AR: } \\
\text { AR: } \\
\text { AR: } \\
\text { AR: }\end{array}$ & $\begin{array}{l}20 \\
21 \\
22 \\
23 \\
25\end{array}$ & $\begin{array}{lll}14 & 46 & 11.4 \\
04 & 48 & 35.8 \\
19 & 11 & 22.4 \\
03 & 09 & 53.8 \\
17 & 00 & 02.1\end{array}$ & $\begin{array}{l}34.33 \mathrm{~N} . \\
34.28 \mathrm{~N} \\
34.33 \mathrm{~N} \\
37.42 \mathrm{~N} \\
34.30 \mathrm{~N}\end{array}$ & $\begin{array}{l}116.42 \mathrm{~W} \\
116.40 \mathrm{~W} \\
116.42 \mathrm{~W} \\
118.67 \mathrm{~W} \\
116.43 \mathrm{~W} .\end{array}$ & $\begin{array}{l}1 \\
2 \\
8 \\
5 \\
7\end{array}$ & $\begin{array}{l}\cdots \\
\because: \\
\cdots\end{array}$ & $\begin{array}{l}\cdots \\
\because: \\
\cdots\end{array}$ & $\begin{array}{l}3.1 \mathrm{P} \\
3.2 \mathrm{P} \\
3.0 \mathrm{P} \\
3.0 \mathrm{P} \\
3.0 \mathrm{P}\end{array}$ & $\begin{array}{l}\cdots \\
\because \cdots \\
\cdots\end{array}$ & $\begin{array}{l}\mathrm{P} \\
\mathrm{P} \\
\mathrm{P} \\
\mathrm{P}\end{array}$ & $\begin{array}{l}\text { MAR: } \\
\text { MAR: } \\
\text { MAR: } \\
\text { MAR: } \\
\text { MAR: }\end{array}$ & $\begin{array}{l}20 \\
20 \\
22 \\
22 \\
25\end{array}$ & $\begin{array}{ll}06 & \text { A.M. PS } \\
08 & \text { P.M. PS } \\
11 & \text { A.M. PS } \\
07 & \text { P.M. PS } \\
09 & \text { A.M. PS }\end{array}$ \\
\hline $\begin{array}{l}\text { AR: } \\
\text { AR: } \\
\text { AR: } \\
\text { AR: }\end{array}$ & $\begin{array}{l}26 \\
26 \\
26 \\
26 \\
26\end{array}$ & $\begin{array}{lll}00 & 10 & 10.8 \\
06 & 29 & 02.5 \\
15 & 04 & 29: 0 \\
15 & 22 & 23.5 \\
17 & 01 & 03.1\end{array}$ & 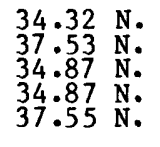 & $\begin{array}{l}116.42 \mathrm{~W} . \\
118.68 \mathrm{~W} . \\
120.50 \mathrm{~W} . \\
120.50 \mathrm{~W} . \\
118.80 \mathrm{~W} .\end{array}$ & $\begin{array}{r}1 \\
: \quad 10 \\
5 \\
10 \\
5\end{array}$ & $\begin{array}{l}\cdots \\
\because: \\
\cdots\end{array}$ & $\begin{array}{l}\cdots \\
\because: \\
\cdots\end{array}$ & $\begin{array}{l}3.0 \mathrm{P} \\
3.3 \mathrm{~B} \\
2.8 \mathrm{P} \\
3.6 \mathrm{P} \\
3.4 \mathrm{~B}\end{array}$ & $\begin{array}{r}\ldots \\
\text { FËL } \\
\text { IV } \\
\cdots\end{array}$ & $\begin{array}{l}\mathrm{B} \\
\mathrm{P} \\
\mathrm{P} \\
\mathrm{B}\end{array}$ & $\begin{array}{l}\text { AR: } \\
\text { AR: } \\
\text { AR: } \\
\text { AR: }\end{array}$ & $\begin{array}{l}25 \\
25 \\
26 \\
26 \\
26\end{array}$ & $\begin{array}{ll}04 & \text { P.M. PST } \\
10 & \text { P.M. PST } \\
07 & \text { A.M. PST } \\
07 & \text { A.M. PST } \\
09 & \text { A.M. PST }\end{array}$ \\
\hline $\begin{array}{l}\text { AR: } \\
\text { AR: } \\
\text { AR: } \\
\text { AR: }\end{array}$ & $\begin{array}{r}26 \\
29 \\
29 \\
31 \\
2\end{array}$ & $\begin{array}{lll}21 & 36 & 38.5 \\
02 & 17 & 11.3 \\
14 & 43 & 20.3 \\
00 & 16 & 09.0 \\
10 & 27 & 28.6\end{array}$ & $\begin{array}{l}37.57 \mathrm{~N} \\
33.67 \mathrm{~N} \\
34.33 \mathrm{~N} \\
34.30 \mathrm{~N} \\
34.28 \mathrm{~N}\end{array}$ & $\begin{array}{l}118.87 \mathrm{~W} \\
116.72 \mathrm{~W} \\
116.45 \mathrm{~W} . \\
116.48 \mathrm{~W} . \\
116.50 \mathrm{~W} .\end{array}$ & $\begin{array}{r}10 \\
: \quad 8 \\
: \quad 8 \\
0 \\
0\end{array}$ & $\begin{array}{l}\cdots \\
\because: \\
\cdots\end{array}$ & $\begin{array}{l}\cdots \\
\because: \\
\cdots\end{array}$ & $\begin{array}{l}3.7 \mathrm{~B} \\
3.0 \mathrm{P} \\
3.2 \mathrm{P} \\
4.2 \mathrm{P} \\
3.2 \mathrm{P}\end{array}$ & $\begin{array}{l}\cdots \\
\cdots \\
\cdots\end{array}$ & $\begin{array}{l}\mathrm{B} \\
\mathrm{P} \\
\mathrm{P} \\
\mathrm{P} \\
\mathrm{P}\end{array}$ & $\begin{array}{l}\text { IAR. } \\
\text { IAR: } \\
\text { ARR: } \\
\text { ARR: }\end{array}$ & $\begin{array}{r}26 \\
28 \\
29 \\
30 \\
2\end{array}$ & $\begin{array}{lll}01 & \text { P.M. PST } \\
06 & \text { P.M. PST } & \text { PST } \\
06 & \text { A.M. PST } & \text { PST } \\
04 & \text { P.M. PST } & \text { PS } \\
02 & \text { A.M. PST }\end{array}$ \\
\hline $\begin{array}{l}\text { PR: } \\
\text { PR: } \\
\text { PR: } \\
\text { PR: } \\
\text { PR: }\end{array}$ & $\begin{array}{l}2 \\
2 \\
6 \\
7 \\
9\end{array}$ & $\begin{array}{rrr}10 & 56 & 23.6 \\
21 & 15 & 4.1 \\
16 & 13 & 5.4 \\
05 & 55 & 39.5 \\
17 & 32 & 24.9\end{array}$ & $\begin{array}{l}38.48 \mathrm{~N} . \\
34.28 \mathrm{~N} \\
34.60 \mathrm{~N} \\
34.28 \mathrm{~N} \\
34.42 \mathrm{~N}\end{array}$ & $\begin{array}{l}119.36 \mathrm{~W} . \\
116.50 \mathrm{~W} \\
116.52 \mathrm{~W} \\
116.42 \mathrm{~W} \\
116.47 \mathrm{~W} .\end{array}$ & $\begin{array}{r}24 \\
: \quad 3 \\
: \quad 3 \\
: \quad 3\end{array}$ & $\begin{array}{l}\ldots \\
\because: \\
\because \cdots\end{array}$ & $\begin{array}{l}\cdots \\
\because \cdots \\
\cdots\end{array}$ & $\begin{array}{l}3.0 \mathrm{~B} \\
3.3 \mathrm{P} \\
3.7 \mathrm{P} \\
3.0 \mathrm{P} \\
3.5 \mathrm{P}\end{array}$ & $\begin{array}{l}\cdots \\
\cdots \\
\cdots\end{array}$ & $\begin{array}{l}\mathrm{B} \\
\mathrm{P} \\
\mathrm{P} \\
\mathrm{P} \\
\mathrm{P}\end{array}$ & $\begin{array}{l}\text { APR: } \\
\text { APR: } \\
\text { APR: } \\
\text { APR: } \\
\text { APR: }\end{array}$ & $\begin{array}{l}2 \\
2 \\
6 \\
6 \\
9\end{array}$ & $\begin{array}{lll}02 & \text { A.M. PST } \\
01 & \text { P.M. PST } \\
08 & \text { A.M. PST } \\
09 & \text { P.M. PST } \\
09 & \text { A.M. PST }\end{array}$ \\
\hline $\begin{array}{l}\text { PR. } \\
\text { PR: } \\
\text { PR: } \\
\text { PR: } \\
\text { PR: }\end{array}$ & $\begin{array}{l}11 \\
12 \\
12 \\
18 \\
19\end{array}$ & $\begin{array}{lll}23 & 53 & 55.9 \\
04 & 44 & 44.7 \\
06 & 52 & 3.7 \\
23 & 21 & 35.4 \\
14 & 22 & 47.3\end{array}$ & $\begin{array}{l}34.25 \mathrm{~N} . \\
34.28 \mathrm{~N} \\
34.27 \mathrm{~N} \\
36.15 \mathrm{~N} \\
34.10 \mathrm{~N}\end{array}$ & $\begin{array}{l}116.43 \mathrm{~W} . \\
116.50 \mathrm{~W} \\
116.52 \mathrm{~W} \\
117.77 \mathrm{~W} \\
118.33 \mathrm{~W} .\end{array}$ & $\begin{array}{l}3 \\
1 \\
1 \\
4 \\
7\end{array}$ & $\begin{array}{l}\cdots \\
\because: \\
\because \cdots\end{array}$ & $\begin{array}{l}\cdots \\
\because: \\
\cdots\end{array}$ & $\begin{array}{l}3.0 \mathrm{P} \\
3.2 \mathrm{P} \\
3 . \mathrm{P} \\
3.1 \mathrm{P} \\
2.5 \mathrm{P}\end{array}$ & $\begin{array}{r}\ldots: \\
\because \ldots \\
\text { FËLT }\end{array}$ & $\begin{array}{l}\mathrm{P} \\
\mathrm{P} \\
\mathrm{P} \\
\mathrm{P} \\
\mathrm{P}\end{array}$ & & $\begin{array}{l}11 \\
11 \\
11 \\
18 \\
19\end{array}$ & $\begin{array}{lll}03 & \text { P.M. PST } \\
08 & \text { P.M. PST } & \text { PST } \\
10 & \text { P.M. PST } \\
03 & \text { P.M. PST } & \text { PST } \\
06 & \text { A.M. PST }\end{array}$ \\
\hline $\begin{array}{l}\text { PR. } \\
\text { PR: } \\
\text { PR: } \\
\text { PR: } \\
\text { PR: }\end{array}$ & $\begin{array}{l}19 \\
21 \\
22 \\
22 \\
24\end{array}$ & $\begin{array}{lll}22 & 39 & 56.8 \\
06 & 00 & 38: 3 \\
06 & 23 & 25: 2 \\
16 & 52 & 16.9 \\
16 & 05 & 54.5\end{array}$ & $\begin{array}{l}34.37 \mathrm{~N} \\
33.78 \mathrm{~N} \\
36.83 \mathrm{~N} \\
33.43 \mathrm{~N} \\
34.00 \mathrm{~N}\end{array}$ & $\begin{array}{l}119.73 \mathrm{~W} . \\
118.07 \mathrm{~W} \\
121.40 \mathrm{~W} . \\
116.55 \mathrm{~W} \\
116.45 \mathrm{~W}\end{array}$ & $\begin{array}{r}4 \\
: \quad 10 \\
: \quad 6 \\
: \quad 5\end{array}$ & $\begin{array}{l}\cdots \\
\because: \\
\cdots\end{array}$ & $\begin{array}{l}\cdots \\
\because: \\
\cdots\end{array}$ & $\begin{array}{l}3.3 \mathrm{P} \\
3: 1 \mathrm{P} \\
3: 1 \mathrm{~B} \\
3.3 \mathrm{P} \\
3.0 \mathrm{P}\end{array}$ & $\begin{array}{r}\text { III } \\
\text { IV } \\
\text { FELT } \\
\because \cdots \\
\cdots\end{array}$ & $\begin{array}{l}\mathrm{P} \\
\mathrm{P} \\
\mathrm{B} \\
\mathrm{P} \\
\mathrm{P}\end{array}$ & $\begin{array}{l}\text { APR: } \\
\text { APR: } \\
\text { APR: } \\
\text { APR: } \\
\text { APR }\end{array}$ & $\begin{array}{l}19 \\
20 \\
21 \\
22 \\
24\end{array}$ & $\begin{array}{lll}02 & \text { P.M. PST } & \text { PST } \\
10 & \text { P.M. PST } \\
10 & \text { P.M. PST } \\
08 & \text { A.M. PST } \\
08 & \text { A.M. PST }\end{array}$ \\
\hline $\begin{array}{l}\text { PR. } \\
\text { PR: } \\
\mathrm{AY} \\
\mathrm{AY} \\
\mathrm{AY}\end{array}$ & $\begin{array}{r}28 \\
28 \\
2 \\
4 \\
4\end{array}$ & $\begin{array}{rrr}00 & 44 & 44.8 \\
07 & 52 & 4.5 \\
22 & 22 & 52.7 \\
16 & 05 & 56.3 \\
20 & 03 & 49.9\end{array}$ & $\begin{array}{l}37.65 \mathrm{~N} . \\
34.17 \mathrm{~N} \\
33.00 \mathrm{~N} \\
35.48 \mathrm{~N} \\
35.47 \mathrm{~N}\end{array}$ & $\begin{array}{l}122.46 \mathrm{~W} \\
117.33 \mathrm{~W} . \\
115.57 \mathrm{~W} \\
118.57 \mathrm{~W} \\
118.57 \mathrm{~W}\end{array}$ & & $\begin{array}{l}\cdots \\
\because \cdots \\
\because \cdots\end{array}$ & $\begin{array}{l}\cdots \\
\cdots \\
\cdots\end{array}$ & $\begin{array}{l}4.4 \mathrm{~B} \\
3.1 \mathrm{P} \\
2: 9 \mathrm{P} \\
3.2 \mathrm{P} \\
3.1 \mathrm{P}\end{array}$ & $\begin{array}{r}v \\
\text { FËLT } \\
\cdots \\
\cdots\end{array}$ & $\begin{array}{l}\mathrm{B} \\
\mathrm{P} \\
\mathrm{P} \\
\mathrm{P} \\
\mathrm{P}\end{array}$ & $\begin{array}{l}\text { APR. } \\
\text { APR: } \\
\text { MAY } \\
\text { MAY } \\
\text { MAY }\end{array}$ & $\begin{array}{r}27 \\
27 \\
2 \\
4 \\
4\end{array}$ & $\begin{array}{lll}04 & \text { P.M. PST } \\
11 & \text { P.M. } & \text { PST } \\
02 & \text { P.M. } & \text { PST } \\
08 & \text { A.M. } & \text { PST } \\
12 & \text { M. } & \text { PST }\end{array}$ \\
\hline $\begin{array}{l}\text { AY } \\
\text { IY } \\
\text { YY } \\
\text { YY }\end{array}$ & $\begin{array}{r}5 \\
5 \\
8 \\
11 \\
12\end{array}$ & $\begin{array}{rrr}03 & 49 & 4.2 \\
23 & 13 & 34: 2 \\
05 & 11 & 7.6 \\
01 & 06 & 52.8 \\
02 & 03 & 55.6\end{array}$ & $\begin{array}{l}35.50 \mathrm{~N} \\
34.30 \mathrm{~N} \\
37.31 \mathrm{~N} \\
34.30 \mathrm{~N} \\
34.22 \mathrm{~N}\end{array}$ & $\begin{array}{l}118.57 \mathrm{~W} . \\
116.45 \mathrm{~W} \\
121.67 \mathrm{~W} . \\
116.48 \mathrm{~W} \\
117.53 \mathrm{~W} .\end{array}$ & $\begin{array}{l}5 \\
4 \\
9 \\
5 \\
6\end{array}$ & $\begin{array}{l}\cdots \\
\because \because 3 \\
\cdots:\end{array}$ & $\begin{array}{c}\cdots \\
\ddot{4}: 0 \\
\cdots\end{array}$ & $\begin{array}{l}3.0 \mathrm{P} \\
3.1 \mathrm{P} \\
4.8 \mathrm{~B} \\
3.3 \mathrm{P} \\
3.4 \mathrm{P}\end{array}$ & $\dddot{\because v i}$ & $\begin{array}{l}\mathrm{P} \\
\mathrm{P} \\
\mathrm{B} \\
\mathrm{P} \\
\mathrm{P}\end{array}$ & & $\begin{array}{r}4 \\
5 \\
7 \\
10 \\
11\end{array}$ & $\begin{array}{lll}07 & \text { P.M. PST } & \text { PST } \\
03 & \text { P.M. PST } & \text { PST } \\
09 & \text { P.M. PST } & \text { PST } \\
05 & \text { P.M. PST } & \text { PST }\end{array}$ \\
\hline $\begin{array}{l}\text { IY } \\
\text { IY } \\
Y Y\end{array}$ & $\begin{array}{l}12 \\
16 \\
16 \\
16 \\
20\end{array}$ & $\begin{array}{rrr}10 & 11 & 2.3 \\
03 & 25 & 23.6 \\
04 & 26 & 0.8 \\
10 & 24 & 52.2 \\
12 & 04 & 47.9\end{array}$ & $\begin{array}{l}34.30 \mathrm{~N} . \\
33.85 \mathrm{~N} \\
33.37 \mathrm{~N} \\
32.98 \mathrm{~N} \\
34.07 \mathrm{~N} .\end{array}$ & $\begin{array}{l}116.47 \mathrm{~W} . \\
118.55 \mathrm{~W} \\
116.35 \mathrm{~W} \\
115.82 \mathrm{~W} \\
116.37 \mathrm{~W}\end{array}$ & $\begin{array}{l}7 \\
5 \\
5 \\
5 \\
5\end{array}$ & $\begin{array}{l}\cdots \\
\because: \\
\because \cdots\end{array}$ & $\begin{array}{l}\cdots \\
\because: \\
\cdots\end{array}$ & $\begin{array}{l}3.3 \mathrm{P} \\
2.7 \mathrm{P} \\
3.2 \mathrm{P} \\
3.4 \mathrm{P} \\
3.7 \mathrm{P}\end{array}$ & 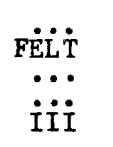 & $\begin{array}{l}\mathrm{P} \\
\mathrm{P} \\
\mathrm{P} \\
\mathrm{P} \\
\mathrm{P}\end{array}$ & & $\begin{array}{l}12 \\
15 \\
15 \\
16 \\
20\end{array}$ & $\begin{array}{lll}02 & \text { A.M. PST } \\
07 & \text { P.M. PST } \\
08 & \text { P.M. PST } \\
02 & \text { A.M. PST } \\
04 & \text { A.M. PST }\end{array}$ \\
\hline $\begin{array}{l}\text { YY } \\
\text { YY } \\
\text { IY }\end{array}$ & $\begin{array}{l}21 \\
27 \\
27 \\
27 \\
28\end{array}$ & $\begin{array}{rrr}05 & 19 & 4.0 \\
14 & 28 & 7.2 \\
14 & 51 & 50.6 \\
16 & 28 & 3.9 \\
10 & 59 & 46.3\end{array}$ & $\begin{array}{l}34.10 \mathrm{~N} . \\
36.53 \mathrm{~N} \\
37.62 \mathrm{~N} . \\
36.53 \mathrm{~N} . \\
34.93 \mathrm{~N} .\end{array}$ & $\begin{array}{l}116.37 \mathrm{~W} \\
121.13 \mathrm{~W} \\
118.93 \mathrm{~W} \\
121.13 \mathrm{~W} \\
116.68 \mathrm{~W} .\end{array}$ & : & $\begin{array}{l}\cdots \\
\because \cdots \\
\cdots\end{array}$ & $\begin{array}{l}\cdots \\
\cdots \\
\cdots\end{array}$ & $\begin{array}{l}3 . \mathrm{OP} \\
3.3 \mathrm{~B} \\
3.5 \mathrm{~B} \\
3.3 \mathrm{~B} \\
3.3 \mathrm{P}\end{array}$ & $\begin{array}{l}\text { III } \\
\cdots \\
\because \cdots \\
\cdots\end{array}$ & $\begin{array}{l}\mathrm{P} \\
\mathrm{B} \\
\mathrm{B} \\
\mathrm{B} \\
\mathrm{P}\end{array}$ & Y & $\begin{array}{l}20 \\
27 \\
27 \\
27 \\
28\end{array}$ & $\begin{array}{lll}09 & \text { P.M. PST } \\
06 & \text { A.M. PST } \\
06 & \text { A.M. PST } \\
08 & \text { A.M. PST } \\
02 & \text { A.M. PST }\end{array}$ \\
\hline $\begin{array}{l}\text { YY } \\
\text { JNE } \\
\text { INE } \\
\text { JNE }\end{array}$ & $\begin{array}{r}29 \\
30 \\
1 \\
3 \\
8\end{array}$ & $\begin{array}{lll}20 & 50 & 20.0 \\
13 & 08 & 34: 1 \\
23 & 58 & 26: 3 \\
04 & 07 & 29.4 \\
18 & 39 & 33.8\end{array}$ & $\begin{array}{l}37.58 \mathrm{~N} . \\
35.88 \mathrm{~N} \\
37.87 \mathrm{~N} \\
40.34 \mathrm{~N} \\
36.82 \mathrm{~N}\end{array}$ & $\begin{array}{l}118.44 \mathrm{~W} \\
117.42 \mathrm{~W} \\
122.21 \mathrm{~W} . \\
124.23 \mathrm{~W} . \\
121.55 \mathrm{~W} .\end{array}$ & $\begin{array}{r}10 \\
4 \\
: \quad 10 \\
12 \\
0\end{array}$ & $\because:$ & $\begin{array}{l}\cdots \\
\because: \\
\because:\end{array}$ & $\begin{array}{l}3.4 \mathrm{~B} \\
3.1 \mathrm{P} \\
2.6 \mathrm{~B} \\
3.2 \mathrm{~B} \\
3.2 \mathrm{~B}\end{array}$ & $\begin{array}{r}\because: 0 \\
\text { FËLT } \\
\text { III } \\
\cdots\end{array}$ & $\begin{array}{l}\mathrm{B} \\
\mathrm{P} \\
\mathrm{B} \\
\mathrm{B} \\
\mathrm{B}\end{array}$ & $\begin{array}{l}\text { MAY } \\
\text { MAY } \\
\text { JUNE } \\
\text { JUNE } \\
\text { JUNE }\end{array}$ & $\begin{array}{r}29 \\
30 \\
1 \\
2 \\
8\end{array}$ & $\begin{array}{lll}12 & \text { M. } & \text { PST } \\
05 & \text { A.M. PST } & \text { PST } \\
03 & \text { P.M. PST } & \text { PST } \\
08 & \text { P.M. PST } & \text { PS }\end{array}$ \\
\hline $\begin{array}{l}\text { JUNE } \\
\text { JUNE } \\
\text { JUNE } \\
\text { JUNE } \\
\text { JUNE }\end{array}$ & $\begin{array}{l}11 \\
13 \\
13 \\
13 \\
13\end{array}$ & $\begin{array}{lll}11 & 51 & 56.8 \\
03 & 36 & 15.9 \\
07 & 09 & 58.1 \\
19 & 37 & 52.3 \\
19 & 46 & 45.9\end{array}$ & $\begin{array}{l}37.97 \mathrm{~N} . \\
33.17 \mathrm{~N} \\
33.08 \mathrm{~N} \\
33.12 \mathrm{~N} \\
33.10 \mathrm{~N}\end{array}$ & $\begin{array}{l}122.05 \\
115.62 \\
115.62 \\
115.62\end{array}$ & $\begin{array}{r}12 \\
6 \\
6 \\
6 \\
6\end{array}$ & $\begin{array}{l}\cdots \\
\because \cdots \\
\cdots\end{array}$ & $\begin{array}{l}\cdots \\
\because \cdots\end{array}$ & $\begin{array}{l}2.8 \mathrm{~B} \\
3 . \mathrm{OP} \\
3.7 \mathrm{P} \\
3 . \mathrm{OP}\end{array}$ & $\begin{array}{r}\text { IV } \\
\text { FELT } \\
\cdots \ddot{V}\end{array}$ & $\begin{array}{l}\mathrm{B} \\
\mathrm{P} \\
\mathrm{P} \\
\mathrm{P} \\
\mathrm{P}\end{array}$ & $\begin{array}{l}\text { JUNE } \\
\text { JUNE } \\
\text { JUNE } \\
\text { JUNE } \\
\text { JUNE }\end{array}$ & $\begin{array}{l}11 \\
12 \\
12 \\
13 \\
13\end{array}$ & $\begin{array}{lll}03 & \text { A.M. PST } \\
07 & \text { P.M. PST } \\
11 & \text { P.M. PST } \\
11 & \text { A.M. PST } \\
11 & \text { A.M. PST }\end{array}$ \\
\hline $\begin{array}{l}\text { UNE } \\
\text { UNE } \\
\text { UNE }\end{array}$ & $\begin{array}{l}13 \\
13 \\
14\end{array}$ & $\begin{array}{rrr}20 & 19 & 30.9 \\
20 & 21 & 11.3 \\
07 & 35 & 4.9\end{array}$ & $\begin{array}{l}33.07 \mathrm{~N}: \\
33.12 \mathrm{~N}: \\
35.73 \mathrm{~N}\end{array}$ & $\begin{array}{l}115 \\
115\end{array}$ & & $\because:$ & $\because:$ & $\begin{array}{l}3.0 \mathrm{P} \\
3.3 \mathrm{P} \\
3.4 \mathrm{P}\end{array}$ & FËLT & $\begin{array}{l}\mathrm{P} \\
\mathrm{P} \\
\mathrm{P}\end{array}$ & $\begin{array}{l}\text { JUNE } \\
\text { JUNE } \\
\text { JUNE }\end{array}$ & $\begin{array}{l}13 \\
13 \\
13\end{array}$ & $\begin{array}{lll}12 & \text { M. } & \text { PST } \\
12 & \text { M: } & \text { PST } \\
11 & \text { P.M. } & \text { PST }\end{array}$ \\
\hline
\end{tabular}


Table 1..-Summary of U.S. earthquakes for 1979--Continued

\begin{tabular}{|c|c|c|c|c|c|c|c|c|c|c|}
\hline Date & $\begin{array}{l}\text { Orıgin tume } \\
\text { (UTC) }\end{array}$ & Lat & Long & Depth & & Magnitude & & Maxımum & Hypocenter & Local time \\
\hline 1878 & hr min & & & & $\mathrm{mb}$ & MS & $\begin{array}{l}\text { ML or } \\
\mathrm{mbLg}\end{array}$ & & & Date \\
\hline
\end{tabular}

\section{CALIFORNIA-- Cont inued}

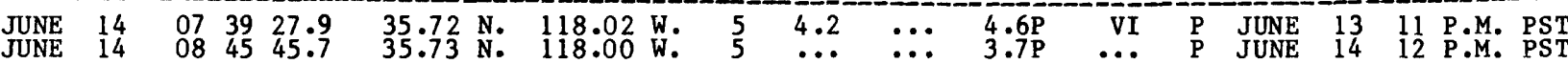

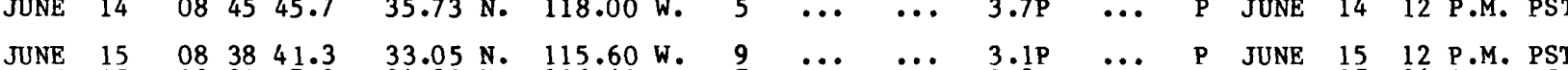

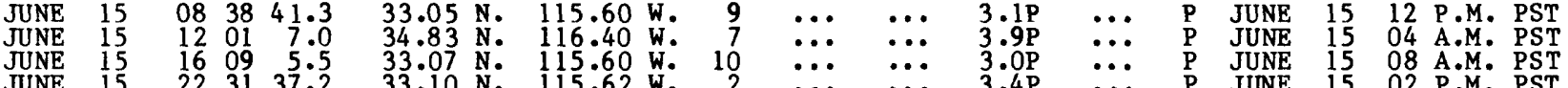

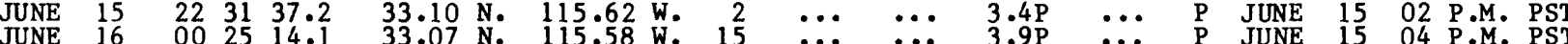

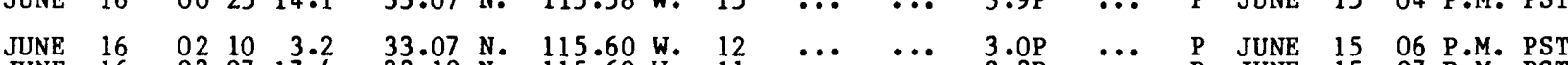
JUNE $16 \quad 0307 \quad 17.4$

JUNE $16 \quad 04$ JUNE $16 \quad 22 \quad 1349.1$

$\begin{array}{lllll}\text { JUNE } & 16 & 22 & 44 & 59 \\ \text { JUNE } & 16 & 22 & 57 & 27.5\end{array}$

$\begin{array}{lllll}\text { JUNE } & 17 & 03 & 59 & 45.8\end{array}$

JUNE $17 \quad 04$ 01 34.9

JUNE $17 \quad \begin{array}{llll}18 & 06 & 37.7\end{array}$

$\begin{array}{llllll}\text { JUNE } & 19 & 17 & 17 & 19.9 \\ \text { JUNE } & 20 & 05 & 30 & 35.8\end{array}$

$\begin{array}{lllll}\text { JUNE } & 22 & 06 & 54 & 58.4 \\ \text { JUNE } & 25 & 09 & 04 & 37.0\end{array}$

$\begin{array}{lllll}\text { JUNE } & 25 & 09 & 04 & 37.0 \\ \text { JUNE } & 26 & 14 & 28 & 55.6\end{array}$

$\begin{array}{llllll}\text { JUNE } & 26 & 15 & 13 & 58.2 \\ \text { JUNE } & 29 & 05 & 53 & 20.5\end{array}$

JUNE $30 \quad 00 \quad 34 \quad 11.6$

JUNE $30 \quad 0006243.5$

$\begin{array}{llllll}\text { JUNE } & 30 & 06 & 56 & 32.9\end{array}$

JULY 11092928.0

$\begin{array}{lllll}\text { JULY } & 2 & 06 & 51 & 40.7\end{array}$

JULY 2 11 5155.2

$\begin{array}{lllll}\text { JULY } & 2 & 12 & 42 & 37.0\end{array}$

$\begin{array}{lllll}\text { JULY } & 3 & 13 & 03 & 1.3 \\ \text { JULY } & 3 & 13 & 25 & 45.5\end{array}$

JULY $\quad 3 \quad 13 \quad 35 \quad 4.3$

$\begin{array}{lllll}\text { JULY } & 9 & 21 & 20 & 40.9\end{array}$

$\begin{array}{lllll}\text { JULY } & 10 & 05 & 20 & 27 \\ \text { JULY } & 10 & 08 & 23 & 23.3\end{array}$

JULY $13 \quad 02 \quad 26 \quad 3.4$

JULY $13 \quad 0226 \quad 56.9$

$\begin{array}{lllll}\text { JULY } & 13 & 02 & 28 & 41.0 \\ \text { JULY } & 13 & 03 & 51 & 23.5\end{array}$

JULY $13 \quad 045724.0$

JULY $13 \quad 10 \quad 57 \quad 38.2$

$\begin{array}{lllll}\text { JULY } & 14 & 06 & 39 & 42.1 \\ \text { JULY } & 14 & 12 & 07 & 53.1\end{array}$

JULY $15 \quad 0906 \quad 6.6$

$\begin{array}{lllll}\text { JULY } & 20 & 23 & 59 & 38.1 \\ \text { JULY } & 27 & 19 & 57 & 29.9\end{array}$

$\begin{array}{lllll}\text { JULY } & 27 & 23 & 23 & 8.0\end{array}$

$\begin{array}{lllll}\text { JULY } & 27 & 23 & 23 & 59.2\end{array}$

JULY $28 \quad 200921.4$

$\begin{array}{lrrrr}\text { JULY } & 31 & 12 & 51 & 11.9 \\ \text { AUG. } & 1 & 17 & 54 & 2.3\end{array}$

AUG. $2 \quad 121845.4$

AUG: $\quad 2 \quad 20 \quad 4135.5$

$\begin{array}{llllr}\text { AUG. } & 2 & 20 & 52 & 7.4 \\ \text { AUG } & 2 & 21 & 43 & 16.3\end{array}$

AUG: $3 \quad 043042.3$

AUG. $\quad 3 \quad 04 \quad 3353.2$

$\begin{array}{lllll}\text { AUG: } & 6 & 07 & 03 & 15.5 \\ \text { AUG: } & 6 & 17 & 05 & 22.7\end{array}$

AUG: $\quad 6 \quad 171043.3$

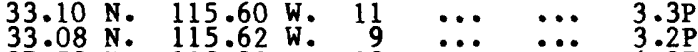

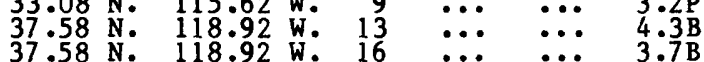

$37.97 \mathrm{~N}$

$122.04 \mathrm{~W}$

$38.10 \mathrm{~N} .122 .04 \mathrm{~W}$

$33.10 \mathrm{~N}$. $115.62 \mathrm{~W}$

$34.03 \mathrm{~N}$. $118.35 \mathrm{~W}$.

$34.95 \mathrm{~N} .120 .27 \mathrm{~W}$.

$37.85 \mathrm{~N} \cdot 121.76 \mathrm{~W}$.

$37.53 \mathrm{~N} .118 .58 \mathrm{~W}$

$34.25 \mathrm{~N}$

$116.90 \mathrm{~W}$.

$34.25 \mathrm{~N}$

$34.23 \mathrm{~N}$

$34.25 \mathrm{~N}$.

$116.90 \mathrm{~W}$

$34.22 \mathrm{~N}$.

$116.88 \mathrm{~W} .10$

$116.90 \mathrm{~W}$.

$34.05 \mathrm{~N} \cdot 117.55 \mathrm{~W} .14$

$33.52 \mathrm{~N} . \quad 116.49 \mathrm{~W} . \quad 1$

$\begin{array}{ll}34.38 \mathrm{~N} . & 119.78 \mathrm{~W} . \\ 37.60 \mathrm{~N} & 121.98 \mathrm{~W} .\end{array}$

$34.37 \mathrm{~N} .119 .78 \mathrm{~W}$

$36.55 \mathrm{~N} .121 .18 \mathrm{~W}$

$32.95 \mathrm{~N}$

$37.86 \mathrm{~N}$

$117.78 \mathrm{~W}$

N. $116.43 \mathrm{~W}$

$34.25 \mathrm{~N} .116 .43 \mathrm{~W}$

$34.25 \mathrm{~N} . \quad 116.45 \mathrm{~W}$.

$34.25 \mathrm{~N} .116 .42 \mathrm{~W}$

$37.57 \mathrm{~N}$.

$122.39 \mathrm{~W}$.

$36.02 \mathrm{~N}$

$34.33 \mathrm{~N}$

$120.12 \mathrm{~W}$

35.73 N. $119.42 \mathrm{~W}$.

$37.38 \mathrm{~N} .118 .60 \mathrm{~W}$.

$37.63 \mathrm{~N}$.

$118.94 \mathrm{~W}$

$37.63 \mathrm{~N}$

$37.63 \mathrm{~N} \cdot 118.92 \mathrm{~W}$

$37.63 \mathrm{~N} \cdot 118.93 \mathrm{~W}$

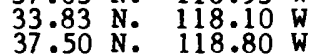

$40.17 \mathrm{~N} .123 .98 \mathrm{~W}$

$36.78 \mathrm{~N} \cdot 121.57 \mathrm{~W}$

$36.76 \mathrm{~N} \cdot 121.57 \mathrm{~W}$.

$37.63 \mathrm{~N} . \quad 118.98 \mathrm{~W}$.

$37.63 \mathrm{~N} .119 .00 \mathrm{~W}$

$33.87 \mathrm{~N} .118 .08 \mathrm{~W}$

$37.10 \mathrm{~N} \cdot 121.50 \mathrm{~W}$.

$37.09 \mathrm{~N} \cdot 121.48 \mathrm{~W}$.
18

$\begin{array}{llll}6 & \cdots & \cdots & 3.1 \mathrm{P}\end{array}$

$\because \quad \ldots 3.0 P$

$4 \ldots \ldots \quad \ldots 2.5 \mathrm{P}$

$\begin{array}{rrrr}8 & \cdots & \cdots & 3.3 \mathrm{~B} \\ 10 & \cdots & \cdots & 3.7 \mathrm{~B}\end{array}$

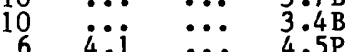

10

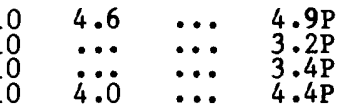

$\begin{array}{llll}10 & \ldots .0 & \cdots & 4.4 \mathrm{P} \\ & \cdots & \end{array}$

14
16
17
4

$\ldots \quad \ldots \quad 2.5 \mathrm{P}$

$\because \quad \ldots 3 \quad 3.7 \mathrm{P}$

$\because \cdots 3.6 \mathrm{P}$

$\ldots \quad \ldots 3 \quad 3.0 \mathrm{P}$

$\begin{array}{llll}4 & \ldots & \ldots & 3.3 \mathrm{P} \\ 5 & \ldots & \ldots & 3.1 \mathrm{~B}\end{array}$

$\begin{array}{rrrr}5 & \ldots & \ldots & 3.1 \mathrm{~B} \\ 17 & \ldots & \ldots & 3.1 \mathrm{P} \\ 17 & \ldots & \ldots & 3.7 \mathrm{~B}\end{array}$

5

$\because \ldots \quad 4.0 \mathrm{P}$

$\ldots \quad \ldots \quad 3.2 \mathrm{P}$

$\ddot{4.2} \quad \cdots \quad 3.5 \mathrm{P}$

$\because \ldots \quad \ldots \quad 3.1 \mathrm{P}$

$\because \ldots \quad \ldots \quad 3.0 \mathrm{~B}$

$\because \ldots \quad \cdots 3.3 \mathrm{P}$

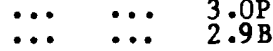

$\ldots \quad \ldots \quad 3.2 \mathrm{~B}$

$\because \cdots \quad 3.1 \mathrm{~B}$

$\because \ldots \quad \ldots \quad 3.2 \mathrm{~B}$

$\begin{array}{lll}\ldots & \ldots & 2.7 \mathrm{P} \\ \cdots & \ldots & 3.0 \mathrm{P}\end{array}$

$\ldots \ldots 3.5 B$

$\ldots \quad \ldots \quad 3.1 \mathrm{~B}$

$\because \ldots \quad \ldots \quad 3.1 \mathrm{~B}$

$\because \ldots \quad \cdots \quad 3.2 B$

... $\ldots 3.3 B$

$\begin{array}{lll}0.4 & 0.0 & 2.0 \mathrm{P} \\ 0.9 & 5 \mathrm{~B}\end{array}$

‥ $\ldots$ 3.8B $\begin{array}{rlll}5 & \cdots & \cdots & 3.9 \mathrm{~B} \\ 6 & 0 & 0 & 3.1 \mathrm{~B}\end{array}$

$\because \cdots$

$\because$ IV

$$
\begin{aligned}
& \mathrm{P} \\
& \mathrm{P} \\
& \mathrm{P} \\
& \mathrm{B} \\
& \mathrm{B} \\
& \mathrm{B}
\end{aligned}
$$$$
\text { JUNE }
$$

\begin{tabular}{rrr} 
FELT & B & JUNE \\
FELT & B & JUNE \\
IV & B & JUNE \\
\hdashline$i$ J & P & JUNE
\end{tabular}

iii $\quad \stackrel{P}{P}$ JUNE

$\begin{array}{lll}15 & 06 & \text { P.M. PST } \\ 15 & 07 & \text { P.M. PST }\end{array}$

1508 P.M. PST

$\begin{array}{lll}16 & 02 & \text { P.M. PST } \\ 16 & 02 & \text { P.M. PST }\end{array}$

FET $P$ JUNE 21

$\begin{array}{lll} & \text { P } & \text { JUNE } \\ \text { FELTT } & \text { B } & \text { JUNE } \\ \text { JUNE } & \text { JU }\end{array}$

FELT B JUNE

VI

$\begin{array}{cccc}\text { VI } & \mathrm{P} & \text { JUNE } & 29 \\ \because \cdots & \mathrm{P} & \text { JUNE } & 2 \\ \text { FËंT } & \mathrm{P} & \text { JUNE } & 2 \\ & \mathrm{P} & \text { JUNE } & 2\end{array}$

FELT $P$ JULY

1607 P.M. PST

1608 P.M. PST

19 A.M. PST

1909 P.M. PST

FEL

$\begin{array}{cc}P & \text { JULY } \\ \text { P } & \text { JULY } \\ \text { P } & \text { JULY } \\ P & \text { JULY }\end{array}$

21510 P.M. PST

2606 A.M. PST

267 A.M. PST

AUG. $\quad \begin{array}{lll}6 & 1722 & 47.6\end{array}$

,....
II

III P JULY

$\because \cdots \quad$ B JULY

$\begin{array}{ccc}\text { V } & \text { B } & \text { JULY } \\ \text { IV } & P & \text { JULY }\end{array}$

iî

FËL̇T

P Jul

JULY

$\mathrm{P}$
$\mathrm{P}$
$\mathrm{P}$

JULY

JULY

…

$\because \quad$ P JULY

$\because \ldots$ P JULY

$\because$

FELT

…

iv

III

iv

IV

B JUL

JULY

JULY

JULG.

FËLT

FELT
AUG.

B AUG.

B AUG:

AUG:

B AUG .

P AUG:

B AUG.

AUG:
2904 P.M. PST

04 P.M. PST

9 11 P.M. PST

1 A.M. PST

1 10 P.M. PST 204 A.M. PST 3 O5 A.M. PST

3 05 A.M. PST $\begin{array}{rrr}9 & 09 & \text { P.M. PST } \\ 10 & 12 & \text { P.M. PST }\end{array}$ 1206 P.M. PST

1206 P.M. PST $\begin{array}{lll}2 & 06 & \text { P.M. PST } \\ 2 & 07 & \text { P.M. PST }\end{array}$ 1208 P.M. PST 1302 A.M. PST

1310 P.M. PST 2003 P.M. PST 2711 A.M. PST

2703 P.M. PST 2703 P.M. PST $\begin{array}{llll}31 & 04 & \text { A.M. PST } \\ 1 & 09 & \text { A.M. PST }\end{array}$ 204 A.M. PST 2 12 M. PST $\begin{array}{llll}2 & 01 & \text { P.M. } \\ 2 & 08 & \text { P.M. PST }\end{array}$

208 P.M. PST 5 11 P.M. PST 6 O9 A.M. PST O9 A.M. PST 203 A.M. PST 01 P.M. PST 1404 A.M. PST 
Table 1.--Summary of U.S. earthquakes for 1979-.-Continued

\begin{tabular}{|c|c|c|c|c|c|c|c|c|c|c|c|}
\hline \multirow{2}{*}{$\begin{array}{l}\text { Mate } \\
\text { (1979) }\end{array}$} & $\begin{array}{l}\text { Origin tume } \\
\text { (UTC) }\end{array}$ & \multirow{2}{*}{ Lat } & \multirow{2}{*}{ Long } & \multirow{2}{*}{$\begin{array}{l}\text { Depth } \\
(\mathrm{km})\end{array}$} & \multicolumn{3}{|c|}{ Magnitude } & \multirow{2}{*}{$\begin{array}{l}\text { Maximum } \\
\text { intensitv }\end{array}$} & \multirow{2}{*}{$\begin{array}{c}\text { Hypocenter } \\
\text { source }\end{array}$} & \multicolumn{2}{|c|}{ Local time } \\
\hline & $\mathrm{hr} \min \mathrm{s}$ & & & & $\mathrm{mb}$ & MS & $\begin{array}{l}\text { ML or } \\
\text { mbLg }\end{array}$ & & & Date & Hour \\
\hline
\end{tabular}

CALIFORNIA--Cont inued

\begin{tabular}{|c|c|c|c|c|c|c|c|c|c|c|c|c|c|c|c|c|c|}
\hline $\begin{array}{l}\text { AUG. } \\
\text { AUG: } \\
\text { AUG: } \\
\text { AUG: } \\
\text { AUG: }\end{array}$ & $\begin{array}{l}6 \\
6 \\
6 \\
6 \\
6\end{array}$ & $\begin{array}{ll}18 & 04 \\
22 & 21 \\
22 & 33 \\
22 & 35 \\
22 & 36\end{array}$ & $\begin{array}{r}57.4 \\
1.7 \\
55.4 \\
57.6 \\
4.9\end{array}$ & $\begin{array}{l}34.42 \\
37.03 \\
37.00 \\
36.98 \\
36.99\end{array}$ & $\begin{array}{l}\mathrm{N} . \\
\mathrm{N} \\
\mathrm{N} \\
\mathrm{N}\end{array}$ & $\begin{array}{l}118.40 \\
121.47 \\
121.48 \\
121.49 \\
121.48\end{array}$ & $\begin{array}{l}\text { W. } \\
\text { W. } \\
\text { W. } \\
\text { W. } \\
\text { W. }\end{array}$ & $\begin{array}{l}6 \\
6 \\
4 \\
5 \\
1\end{array}$ & $\ddot{\cdots}$ & $\begin{array}{l}\cdots \\
\cdots \\
\cdots\end{array}$ & $\begin{array}{l}2.8 \mathrm{P} \\
3.6 \mathrm{~B} \\
4.4 \mathrm{~B} \\
2.9 \mathrm{~B} \\
3.8 \mathrm{~B}\end{array}$ & $\begin{array}{l}\text { FELT } \\
\text { FELT } \\
\text { FEL'T } \\
\text { FELT } \\
\text { FELT }\end{array}$ & $\begin{array}{l}\text { P } \\
\text { B } \\
\text { B } \\
\text { B }\end{array}$ & $\begin{array}{l}\text { AUG. } \\
\text { AUG: } \\
\text { AUG: } \\
\text { AUG: } \\
\text { AUG. }\end{array}$ & $\begin{array}{l}6 \\
6 \\
6 \\
6 \\
6\end{array}$ & $\begin{array}{l}10 \\
02 \\
02 \\
02 \\
02\end{array}$ & $\begin{array}{l}\text { A.M. } \\
\text { P.M. } \\
\text { P.M. } \\
\text { P.M. } \\
\text { P.M. }\end{array}$ \\
\hline $\begin{array}{l}\text { AUG: } \\
\text { AUG: } \\
\text { AUG: } \\
\text { AUG: } \\
\text { AUG: }\end{array}$ & $\begin{array}{l}6 \\
7 \\
7 \\
7 \\
7\end{array}$ & $\begin{array}{ll}23 & 36 \\
02 & 32 \\
05 & 56 \\
18 & 51 \\
19 & 01\end{array}$ & $\begin{array}{r}0.6 \\
31.6 \\
51.6 \\
46.5 \\
41.3\end{array}$ & $\begin{array}{l}37.05 \\
36.98 \\
37.06 \\
36.99 \\
36.98\end{array}$ & $\begin{array}{l}\mathrm{N} \text {. } \\
\mathrm{N} \\
\mathrm{N} \\
\mathrm{N}\end{array}$ & $\begin{array}{l}121.47 \\
121.47 \\
121.49 \\
121.46 \\
121.47\end{array}$ & $\begin{array}{l}\text { W. } \\
\text { W. }\end{array}$ & $\begin{array}{l}4 \\
5 \\
4 \\
1 \\
2\end{array}$ & $\because \cdots$ & 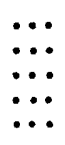 & $\begin{array}{l}2.9 \mathrm{~B} \\
3.1 \mathrm{~B} \\
2.5 \mathrm{~B} \\
2.5 \mathrm{~B}\end{array}$ & $\begin{array}{c}\ddot{0} \\
\dot{F E L T} \\
\ddot{0}\end{array}$ & $\begin{array}{l}\text { B } \\
\text { B } \\
\text { B } \\
\text { B }\end{array}$ & $\begin{array}{l}G \text {. } \\
G \text { G: } \\
G \text { : }\end{array}$ & $\begin{array}{l}6 \\
6 \\
6 \\
7 \\
7\end{array}$ & $\begin{array}{l}03 \\
06 \\
09 \\
10 \\
11\end{array}$ & $\begin{array}{l}\mathrm{P} \\
\mathrm{A} \\
\mathrm{A}\end{array}$ \\
\hline $\begin{array}{l}\text { AUG. } \\
\text { AUG. } \\
\text { AUG. } \\
\text { AUG. } \\
\text { AUG. }\end{array}$ & $\begin{array}{l}7 \\
8 \\
8 \\
9 \\
9\end{array}$ & $\begin{array}{ll}19 & 11 \\
03 & 52 \\
22 & 56 \\
05 & 28 \\
07 & 03\end{array}$ & $\begin{array}{l}25.7 \\
14.4 \\
7.9 \\
48.6 \\
20.2\end{array}$ & $\begin{array}{l}36.99 \\
37.03 \\
36.98 \\
37.01\end{array}$ & $\begin{array}{l}\mathrm{N} . \\
\mathrm{N} . \\
\mathrm{N} \\
\mathrm{N}\end{array}$ & $\begin{array}{l}121.47 \\
121.47 \\
121.47 \\
121.46 \\
121.45\end{array}$ & $\begin{array}{l}\text { W. } \\
\text { W. } \\
\text { W. } \\
\text { W. } \\
\text { W. }\end{array}$ & $\begin{array}{l}2 \\
4 \\
6 \\
6\end{array}$ & $\begin{array}{l}\ldots \\
\cdots \\
\cdots\end{array}$ & $\begin{array}{l}\ldots \\
\cdots \\
\cdots \\
\cdots\end{array}$ & $\begin{array}{l}2.6 \mathrm{~B} \\
3.4 \mathrm{~B} \\
2.7 \mathrm{~B} \\
4.2 \mathrm{~B}\end{array}$ & $\begin{array}{l}\text { FELT } \\
\text { FË } \ddot{L} \text { T } \\
\text { FËLi }\end{array}$ & $\begin{array}{l}\text { B } \\
\text { B } \\
\text { B } \\
\text { B }\end{array}$ & $\begin{array}{l}\text { AUG : } \\
\text { AUG : } \\
\text { AUG : } \\
\text { AUG : } \\
\text { AUG. }\end{array}$ & $\begin{array}{l}7 \\
7 \\
8 \\
8 \\
8\end{array}$ & $\begin{array}{l}07 \\
02 \\
09 \\
11\end{array}$ & 1 \\
\hline $\begin{array}{l}\text { AUG. } \\
\text { AUG: } \\
\text { AUG: } \\
\text { AUG. } \\
\text { AUG. }\end{array}$ & $\begin{array}{r}9 \\
9 \\
9 \\
10 \\
10\end{array}$ & $\begin{array}{ll}12 & 49 \\
12 & 51 \\
14 & 39 \\
00 & 25 \\
04 & 50\end{array}$ & $\begin{array}{r}27.5 \\
41.7 \\
5.6 \\
20.8 \\
40.0\end{array}$ & $\begin{array}{l}36.98 \\
36.97 \\
37.48 \\
37.02 \\
36.96\end{array}$ & $\begin{array}{l}\mathrm{N} . \\
\mathrm{N} . \\
\mathrm{N} . \\
\mathrm{N} . \\
\mathrm{N} .\end{array}$ & $\begin{array}{l}121.46 \\
121.46 \\
118.67 \\
121.46 \\
121.48\end{array}$ & $\begin{array}{l}\text { W. } \\
\text { W. } \\
\text { W. } \\
\text { W. } \\
\text { W. }\end{array}$ & $\begin{array}{l}3 \\
5 \\
5 \\
5 \\
5\end{array}$ & $\begin{array}{l}\ldots \\
\cdots \\
\cdots \\
\cdots\end{array}$ & $\begin{array}{l}\ldots \\
\cdots \\
\cdots \\
\cdots\end{array}$ & $\begin{array}{l}2.5 \mathrm{~B} \\
3.0 \mathrm{P} \\
3.7 \mathrm{~B} \\
3.0 \mathrm{~B}\end{array}$ & $\begin{array}{c}\text { FELT } \\
\ddot{0} \\
\text { FËLT } \\
\text { FELT }\end{array}$ & $\begin{array}{l}\text { B } \\
\text { B } \\
\text { G } \\
\text { B }\end{array}$ & $\begin{array}{l}\text { UG. } \\
\text { UG. } \\
\text { UG: } \\
\text { UG. }\end{array}$ & $\begin{array}{l}9 \\
9 \\
9 \\
9 \\
9\end{array}$ & $\begin{array}{l}04 \\
04 \\
06 \\
04 \\
08\end{array}$ & $\begin{array}{l}\mathrm{A} \\
\mathrm{p} \\
\mathrm{P}\end{array}$ \\
\hline $\begin{array}{l}\text { AUG: } \\
\text { AUG: } \\
\text { AUG: } \\
\text { AUG : } \\
\text { AUG: }\end{array}$ & $\begin{array}{l}10 \\
10 \\
10 \\
11 \\
11\end{array}$ & $\begin{array}{ll}05 & 10 \\
12 & 37 \\
19 & 22 \\
09 & 40 \\
16 & 42\end{array}$ & $\begin{array}{r}42.9 \\
0.3 \\
26.8 \\
19.3 \\
32.7\end{array}$ & $\begin{array}{l}36.98 \\
36.96 \\
36.97 \\
36.98 \\
36.97\end{array}$ & $\begin{array}{l}\text { N. } \\
\text { N. } \\
\text { N. } \\
\text { N. }\end{array}$ & $\begin{array}{l}121.44 \\
121.47 \\
121.47 \\
121.46 \\
121.48\end{array}$ & $\begin{array}{l}\text { W. } \\
\text { W. } \\
\text { W. } \\
\text { W. }\end{array}$ & $\begin{array}{l}5 \\
5 \\
1 \\
2 \\
5\end{array}$ & $\ddot{\cdots}$ & $\ddot{\cdots}$ & $\begin{array}{l}2.5 \mathrm{~B} \\
2.5 \mathrm{~B} \\
2.8 \mathrm{~B} \\
2.6 \mathrm{~B}\end{array}$ & $\because \cdots$ & B & $\begin{array}{l}\text { UG. } \\
\text { UG } \\
\text { UG. } \\
\text { UG. }\end{array}$ & $\begin{array}{l}9 \\
10 \\
10 \\
11 \\
11\end{array}$ & $\begin{array}{l}09 \\
04 \\
11 \\
01 \\
08\end{array}$ & 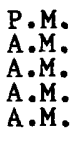 \\
\hline $\begin{array}{l}\text { AUG: } \\
\text { AUG: } \\
\text { AUG: } \\
\text { AUG: } \\
\text { AUG. }\end{array}$ & $\begin{array}{l}11 \\
13 \\
13 \\
13 \\
14\end{array}$ & $\begin{array}{ll}20 & 29 \\
10 & 13 \\
19 & 02 \\
19 & 18 \\
03 & 15\end{array}$ & $\begin{array}{r}35.2 \\
1.0 \\
52.5 \\
46.8 \\
57.0\end{array}$ & $\begin{array}{l}37.14 \\
34.28 \\
37.88 \\
37.86 \\
36.99\end{array}$ & $\begin{array}{l}\mathrm{N} . \\
\mathrm{N} . \\
\mathrm{N} \\
\mathrm{N} \\
\mathrm{N}\end{array}$ & $\begin{array}{l}121.52 \\
116.42 \\
122.21 \\
122.17 \\
121.47\end{array}$ & $\begin{array}{l}\text { W. } \\
\text { W. } \\
\text { W: } \\
\text { W: }\end{array}$ & $\begin{array}{r}5 \\
4 \\
13 \\
9 \\
4\end{array}$ & $\begin{array}{l}\cdots \\
\cdots \\
\cdots \\
\cdots\end{array}$ & $\begin{array}{l}\cdots \\
\cdots \\
\cdots \\
\cdots\end{array}$ & $\begin{array}{l}3.3 \mathrm{P} \\
2.3 \mathrm{~B} \\
3.5 \mathrm{~B} \\
3.6 \mathrm{~B}\end{array}$ & $\begin{array}{l}\text { FELT } \\
\text { FEL' } \\
\text { IV } \\
\text { FELT }\end{array}$ & $\begin{array}{l}\mathrm{B} \\
\mathrm{P} \\
\mathrm{B} \\
\mathrm{B}\end{array}$ & $\begin{array}{l}\text { AUG. } \\
\text { AUG: } \\
\text { AUG: } \\
\text { AUG: } \\
\text { AUG. }\end{array}$ & $\begin{array}{l}11 \\
13 \\
13 \\
13 \\
13\end{array}$ & $\begin{array}{l}12 \\
02 \\
11 \\
11 \\
07\end{array}$ & $F$ \\
\hline $\begin{array}{l}\text { AUG. } \\
\text { AUG : } \\
\text { AUG: } \\
\text { AUG. } \\
\text { AUG. }\end{array}$ & $\begin{array}{l}14 \\
14 \\
16 \\
16 \\
16\end{array}$ & $\begin{array}{ll}04 & 20 \\
17 & 19 \\
02 & 20 \\
06 & 39 \\
11 & 47\end{array}$ & $\begin{array}{l}18.6 \\
17.6 \\
13.5 \\
21.1 \\
44.9\end{array}$ & $\begin{array}{l}33.80 \\
34.28 \\
33.42 \\
34.23 \\
37.16\end{array}$ & $\begin{array}{l}\text { N. } \\
\text { N. } \\
\text { N. } \\
\text { N. }\end{array}$ & $\begin{array}{l}117.80 \\
116.43 \\
116.62 \\
116.90 \\
121.55\end{array}$ & $\begin{array}{l}\text { W. } \\
\text { W. } \\
\text { W. } \\
\text { W. }\end{array}$ & $\begin{array}{r}6 \\
5 \\
10 \\
5 \\
3\end{array}$ & $\ddot{\cdots}$ & $\begin{array}{l}\ldots \\
\cdots \\
\cdots\end{array}$ & $\begin{array}{l}3 . \\
3 . \\
3 . \\
2 .\end{array}$ & $\begin{array}{c}\text { FELT } \\
\because \ldots \\
\because \cdots \\
\cdots\end{array}$ & $\begin{array}{l}\mathrm{P} \\
\mathrm{P} \\
\mathrm{P}\end{array}$ & $\begin{array}{l}\text { UG. } \\
\text { UG. } \\
\text { UG. } \\
\text { UG. }\end{array}$ & $\begin{array}{l}13 \\
14 \\
15 \\
15 \\
16\end{array}$ & $\begin{array}{l}08 \\
09 \\
06 \\
10 \\
03\end{array}$ & A \\
\hline $\begin{array}{l}\text { AUG: } \\
\text { AUG: } \\
\text { AUG: } \\
\text { AUG: } \\
\text { AUG: }\end{array}$ & $\begin{array}{l}17 \\
19 \\
19 \\
21 \\
22\end{array}$ & $\begin{array}{ll}15 & 43 \\
03 & 13 \\
08 & 45 \\
13 & 18 \\
02 & 01\end{array}$ & $\begin{array}{l}03.3 \\
51.2 \\
50.8 \\
7.0 \\
36.4\end{array}$ & $\begin{array}{l}37.84 \\
34.08 \\
36.97 \\
34.55 \\
33.70\end{array}$ & $\begin{array}{l}\text { N. } \\
\text { N. } \\
\text { N. } \\
\text { N. }\end{array}$ & $\begin{array}{l}122.23 \\
117.22 \\
121.46 \\
119.72 \\
116.85\end{array}$ & $\begin{array}{l}\mathrm{W} . \\
\mathrm{W} . \\
\mathrm{W} . \\
\mathrm{W} .\end{array}$ & $\begin{array}{r}8 \\
5 \\
5 \\
6 \\
16\end{array}$ & $\ldots$ & $\begin{array}{l}\cdots \\
\cdots \\
\cdots\end{array}$ & $\begin{array}{l}2.7 \mathrm{P} \\
2.3 \mathrm{~B} \\
3.1 \mathrm{P} \\
4.0 \mathrm{P}\end{array}$ & $\begin{array}{l}\text { FELT } \\
\text { FELT } \\
\text { IV } \\
\text { IV } \\
\text { IV }\end{array}$ & $\begin{array}{l}\text { B } \\
\text { P } \\
\text { B }\end{array}$ & $\begin{array}{l}\text { AUG. } \\
\text { AUG: } \\
\text { AUG: } \\
\text { AUG. } \\
\text { AUG. }\end{array}$ & $\begin{array}{l}17 \\
18 \\
19 \\
21 \\
21\end{array}$ & $\begin{array}{l}07 \\
12 \\
05 \\
06\end{array}$ & $\mathrm{P}$ \\
\hline $\begin{array}{l}\text { AUG: } \\
\text { AUG: } \\
\text { AUG: } \\
\text { AUG: } \\
\text { AUG. }\end{array}$ & $\begin{array}{l}24 \\
25 \\
27 \\
27 \\
28\end{array}$ & $\begin{array}{ll}04 & 46 \\
18 & 33 \\
05 & 19 \\
07 & 23 \\
08 & 57\end{array}$ & $\begin{array}{l}51.6 \\
17.9 \\
40.0 \\
53.5 \\
56.3\end{array}$ & $\begin{array}{l}37.84 \\
37.45 \\
33.88 \\
32.70 \\
34.42\end{array}$ & $\begin{array}{l}\mathrm{N} . \\
\mathrm{N} . \\
\mathrm{N} \\
\mathrm{N} \\
\mathrm{N} .\end{array}$ & $\begin{array}{l}122.25 \\
118.67 \\
115.90 \\
115.90 \\
117.73\end{array}$ & W. & $\begin{array}{l}7 \\
5 \\
5 \\
5 \\
9\end{array}$ & $\ddot{\cdots}$ & $\begin{array}{l}\cdots \\
\because \cdots \\
\cdots\end{array}$ & $\begin{array}{l}2.9 \mathrm{~B} \\
3.2 \mathrm{P} \\
3.4 \mathrm{P} \\
3.5 \mathrm{P} \\
3.9 \mathrm{P}\end{array}$ & 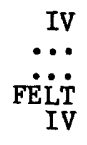 & B & $\begin{array}{l}\text { AUG. } \\
\text { AUG: } \\
\text { AUG: } \\
\text { AUG: } \\
\text { AUG. }\end{array}$ & $\begin{array}{l}23 \\
25 \\
26 \\
26 \\
28\end{array}$ & $\begin{array}{l}08 \\
10 \\
09 \\
11 \\
12\end{array}$ & \\
\hline $\begin{array}{l}\text { AUG. } \\
\text { AUG. } \\
\text { SEPT. } \\
\text { SEPT. } \\
\text { SEPT. }\end{array}$ & $\begin{array}{r}29 \\
31 \\
2 \\
3 \\
3\end{array}$ & $\begin{array}{ll}09 & 19 \\
18 & 53 \\
07 & 38 \\
06 & 40 \\
11 & 44\end{array}$ & $\begin{array}{l}24.9 \\
45.1 \\
00.1 \\
16.4 \\
17.0\end{array}$ & $\begin{array}{l}33.97 \\
37.84 \\
39.20 \\
37.05 \\
33.38\end{array}$ & $\begin{array}{l}\text { N. } \\
\text { N. } \\
\text { N. } \\
\text { N. }\end{array}$ & $\begin{array}{l}118.70 \\
122.03 \\
122.86 \\
121.49 \\
116.33\end{array}$ & $\begin{array}{l}\mathrm{W} . \\
\mathrm{W} . \\
\mathrm{W} . \\
\mathrm{W} .\end{array}$ & $\begin{array}{r}7 \\
8 \\
22 \\
5 \\
9\end{array}$ & $\begin{array}{l}\cdots \\
\cdots \\
\cdots\end{array}$ & $\ddot{\cdots}$ & $\begin{array}{l}2.7 \mathrm{P} \\
2.7 \mathrm{~B} \\
2.6 \mathrm{~B} \\
3.2 \mathrm{~B} \\
3.8 \mathrm{P}\end{array}$ & $\begin{array}{c}\text { FELT } \\
\text { FELT } \\
\text { III } \\
\because \therefore \\
\ldots .\end{array}$ & $\begin{array}{l}\mathrm{P} \\
\mathrm{B} \\
\mathrm{B}\end{array}$ & $\begin{array}{l}\text { AUG. } \\
\text { AUG: } \\
\text { SEPT. } \\
\text { SEPT: } \\
\text { SEPT. }\end{array}$ & $\begin{array}{r}29 \\
31 \\
1 \\
2 \\
3\end{array}$ & $\begin{array}{l}01 \\
10 \\
11 \\
10 \\
03\end{array}$ & \\
\hline $\begin{array}{l}\text { SEPT. } \\
\text { SEPT. } \\
\text { SEPT. } \\
\text { SEPT. } \\
\text { SEPT. }\end{array}$ & $\begin{array}{r}5 \\
7 \\
7 \\
9 \\
10\end{array}$ & $\begin{array}{ll}17 & 11 \\
09 & 43 \\
10 & 17 \\
20 & 48 \\
06 & 16\end{array}$ & $\begin{array}{r}7.1 \\
47.3 \\
20.4 \\
30.7 \\
4.2\end{array}$ & $\begin{array}{l}34.07 \\
37.62 \\
33.40 \\
37.84 \\
37.15\end{array}$ & $\begin{array}{l}\text { N. } \\
\text { N. } \\
\text { N. } \\
\text { N. }\end{array}$ & $\begin{array}{l}118 \\
118 \\
116 \\
121 \\
121\end{array}$ & $\begin{array}{l}\mathrm{W} \\
\mathrm{W} \\
\mathrm{W} \\
\mathrm{W} \\
\mathrm{W}\end{array}$ & $\begin{array}{l}7 \\
3 \\
7 \\
1\end{array}$ & $\because \cdots$ & $\begin{array}{l}\cdots \\
\cdots \\
\cdots\end{array}$ & $\begin{array}{l}3.4 \mathrm{P} \\
4.2 \mathrm{~B} \\
3.0 \mathrm{P} \\
2.9 \mathrm{~B} \\
3.0 \mathrm{~B}\end{array}$ & $\begin{array}{r}\text { FELT } \\
\text { IV } \\
\text { FËLT } \\
\cdots . .\end{array}$ & $\begin{array}{l}\mathbf{P} \\
\mathbf{B} \\
\mathbf{P} \\
\mathrm{B}\end{array}$ & $\begin{array}{l}\text { SEPT. } \\
\text { SEPT: } \\
\text { SEPT: } \\
\text { SEPT. } \\
\text { SEPT. }\end{array}$ & $\begin{array}{l}5 \\
7 \\
7 \\
9 \\
9\end{array}$ & $\begin{array}{l}09 \\
01 \\
02 \\
12 \\
10\end{array}$ & 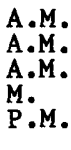 \\
\hline $\begin{array}{l}\text { SEPT. } \\
\text { SEPT. } \\
\text { SEPT. } \\
\text { SEPT. } \\
\text { SEPT. }\end{array}$ & $\begin{array}{l}10 \\
14 \\
14 \\
16 \\
17\end{array}$ & $\begin{array}{ll}19 & 26 \\
01 & 04 \\
07 & 41 \\
08 & 55 \\
19 & 19\end{array}$ & 52 & $\begin{array}{l}37.55 \\
37.11 \\
37.46 \\
33.47 \\
37.04\end{array}$ & $\begin{array}{l}\mathrm{N} . \\
\mathrm{N} \\
\mathrm{N} \\
\mathrm{N}\end{array}$ & $\begin{array}{l}118.68 \\
121.94 \\
118.54 \\
116.52 \\
121.49\end{array}$ & $\begin{array}{l}W . \\
W \\
W\end{array}$ & $\begin{array}{r}5 \\
15 \\
19 \\
17 \\
5\end{array}$ & $\cdots$ & $\begin{array}{l}\cdots \\
\cdots \\
\cdots \\
\cdots\end{array}$ & $\begin{array}{l}2.7 \mathrm{P} \\
3.2 \mathrm{~B} \\
3.0 \mathrm{~B} \\
3.0 \mathrm{P} \\
3.0 \mathrm{~B}\end{array}$ & $\begin{array}{c}\text { FELT } \\
\text { FELT } \\
\because \cdots \\
\because \cdots\end{array}$ & $\begin{array}{l}\mathrm{P} \\
\mathrm{B} \\
\mathrm{B} \\
\mathrm{P} \\
\mathrm{B}\end{array}$ & $\begin{array}{l}\text { SEPT: } \\
\text { SEPT: } \\
\text { SEPT: } \\
\text { SEPT: } \\
\text { SEPT. }\end{array}$ & $\begin{array}{l}10 \\
13 \\
13 \\
16 \\
17\end{array}$ & $\begin{array}{l}11 \\
05 \\
11 \\
12 \\
11\end{array}$ & $M$ \\
\hline $\begin{array}{l}\text { SEPT. } \\
\text { SEPT } \\
\text { SEPT. }\end{array}$ & 20 & $\begin{array}{ll}02 & 44 \\
03 & 05 \\
09 & 09\end{array}$ & $\begin{array}{l}24 \\
49\end{array}$ & $\begin{array}{l}39.79 \\
37.88 \\
32.98\end{array}$ & $\begin{array}{l}\mathrm{N} . \\
\mathrm{N} \text {. } \\
\mathrm{N} \text {. }\end{array}$ & 12 & $\mathrm{~W}$ & $\begin{array}{r}14 \\
10 \\
7\end{array}$ & $\because$ & & & $\begin{array}{c}\text { FËLT } \\
\ldots\end{array}$ & $\begin{array}{l}\mathrm{B} \\
\mathrm{B} \\
\mathrm{P}\end{array}$ & $\begin{array}{l}\text { SEPT } \\
\text { SEPT. }\end{array}$ & 22 & 0 & 3 \\
\hline
\end{tabular}


Table 1.--Summary of U.S. earthquakes for 1979--Continued

\begin{tabular}{|c|c|c|c|c|c|c|c|c|c|c|c|}
\hline \multirow{2}{*}{$\begin{array}{l}\text { Date } \\
\text { (1979) }\end{array}$} & \multirow{2}{*}{$\begin{array}{l}\text { Origin tume } \\
\text { hUrCl } \\
\text { hr min }\end{array}$} & \multirow{2}{*}{ Lat } & \multirow{2}{*}{ I ong } & \multirow{2}{*}{$\begin{array}{l}\text { Depth } \\
(\mathrm{km})\end{array}$} & \multicolumn{3}{|c|}{ Magnitude } & \multirow{2}{*}{$\begin{array}{l}\text { Maximum } \\
\text { intensity }\end{array}$} & \multirow{2}{*}{$\begin{array}{c}\text { Hypocenter } \\
\text { source }\end{array}$} & \multicolumn{2}{|c|}{ Local time } \\
\hline & & & & & $\mathrm{mb}$ & MS & $\begin{array}{l}\mathrm{ML} \text { or } \\
\mathrm{mbLg}\end{array}$ & & & Date & Hour \\
\hline
\end{tabular}

CALIFORNIA-Cont inued

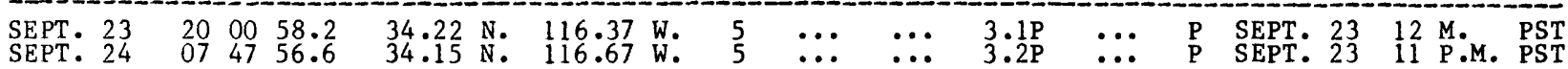
SEP'T. 24

SEPT: 24

SEPT. 26

$\begin{array}{rrr}13 & 05 & 3.2 \\ 14 & 26 & 18.5\end{array}$

15 01 19.3

$37.66 \mathrm{~N} .118 .94 \mathrm{~W}$.

$\begin{array}{lll}21 & 45 & 35.2 \\ 22 & 29 & 36.9\end{array}$

$37.66 \mathrm{~N} \cdot 118.94 \mathrm{~W}$.

SEPT. 26

$\begin{array}{lll}22 & 30 & 12.7\end{array}$

$37.66 \mathrm{~N} . \quad 118.94 \mathrm{~W}$.

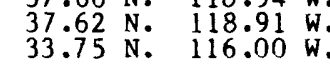

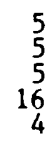

$33.75 \mathrm{~N} .116 .05 \mathrm{~W}$.

SEPT: 27

$\begin{array}{lllll}\text { OCT. } & 1 & 11 & 52 & 00.7 \\ \text { OCT. } & 11 & 52 & 20.6\end{array}$

$\begin{array}{llllr}\text { OCT. } & 1 & 12 & 37 & 2.3 \\ \text { OCT: } & 3 & 08 & 54 & 24.8 \\ \text { OCT. } & 3 & 08 & 58 & 30.8 \\ \text { OCT. } & 4 & 13 & 44 & 17.8\end{array}$

$\begin{array}{lllll}\text { OCT: } & 4 & 13 & 44 & 17.8 \\ \text { OCT. } & 5 & 04 & 51 & 38.6\end{array}$

$\begin{array}{lllll}\text { OCT. } \quad 7 & 20 & 54 & 41.4\end{array}$

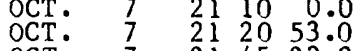

$\begin{array}{lllll}\text { OCT. } & 7 & 21 & 45 & 23.8 \\ \text { OCT. } & 7 & 23 & 31 & 44.8\end{array}$

OCT. $\quad 8 \quad 0023 \quad 54.6$

OCT. $\quad 8 \quad 004744.8$

OCT. 8033424.0

$\begin{array}{lllll}\text { OCT: } & 8 & 09 & 38 & 36.4 \\ \text { OCT. } & 8 & 11 & 26 & 43.1\end{array}$

$\begin{array}{lllll}\text { OCT. } & 8 & 12 & 14 & 2.0\end{array}$

OCT. $\quad 9 \quad 2200 \quad 10.4$

$\begin{array}{lllll}\text { OCT. } & 13 & 20 & 46 & 12.0 \\ \text { OCT. } & 15 & 23 & 16 & 54.5\end{array}$

OCT. $15 \quad \begin{array}{llll}15 & 23 & 35 & 54.5 \\ \text { OCT. }\end{array}$

OCT. $15 \quad 234314.1$

OCT: 15

OCT. 16

OCT. 16

$\begin{array}{lll}23 & 55 & 4.7 \\ 01 & 00 & 13.9\end{array}$

$0107 \quad 12.3$

OCT. 16

OCT. 16

$\begin{array}{ll}\text { OCT: } & 16 \\ \text { OCT. } & 16\end{array}$

OCT. 16

OCT. 16

$\begin{array}{ll}\text { OCT. } & 16 \\ \text { OCT: } & 16 \\ \text { OCT. } & 16\end{array}$

OCT. 16

$\begin{array}{ll}\text { OCT. } & 16 \\ \text { OCT. } & 16\end{array}$

$\begin{array}{ll}\text { OCT. } & 16 \\ \text { OCT. } & 16 \\ \text { OCT. } & 16\end{array}$

OCT. 16

$\begin{array}{ll}\text { OCT. } & 16 \\ \text { OCT. } & 16 \\ \text { OCT. } & 16\end{array}$

OCT. 16

$\begin{array}{llll}01 & 14 & 23.0\end{array}$

$0133 \quad 49.0$

$0139 \quad 6.6$

03 01 57.8

$\begin{array}{llll}03 & 01 & 57.8 \\ 03 & 09 & 44.9\end{array}$

$0310 \quad 47.1$

$0316 \quad 27.5$

$\begin{array}{lll}03 & 39 & 34.8 \\ 04 & 32 & 33.9\end{array}$

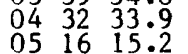

$\begin{array}{lll}05 & 18 & 3.6\end{array}$

$\begin{array}{lll}05 & 23 & 1.8 \\ 05 & 38 & 2.3\end{array}$

$\begin{array}{llr}05 & 38 & 2.3 \\ 05 & 41 & 17.7\end{array}$

$\begin{array}{lll}05 & 41 & 17.7 \\ 05 & 10.8\end{array}$

$\begin{array}{lll}06 & 12 & 0.9\end{array}$

$\begin{array}{lll}06 & 19 & 48.7 \\ 06 & 55 & 23.6\end{array}$

$0658 \quad 43.2$

$\begin{array}{ll}\text { OCT. } & 16 \\ \text { OCT. } & 16 \\ \text { OCT. } & 16\end{array}$

OCT: 16

$\begin{array}{llr}07 & 35 & 3.2 \\ 08 & 09 & 43.1\end{array}$

08 14 34.0

$\begin{array}{lll}08 & 37 & 54.3 \\ 09 & 23 & 21.8\end{array}$

OCT. 16

$\begin{array}{lll}09 & 33 & 53.3 \\ 09 & 36 & 43.0\end{array}$
$36.79 \mathrm{~N} . \quad 121.59 \mathrm{~W}$.

$34.03 \mathrm{~N} . \quad 118.32 \mathrm{~W}$.

$37.54 \mathrm{No}, 118.82 \mathrm{~W} .10$

$37.60 \mathrm{~N}$.

$37.63 \mathrm{~N}$.

$37.62 \mathrm{~N}$.

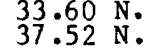

$118.85 \mathrm{~W}$

$38.22 \mathrm{~N}$.

$38.23 \mathrm{~N}:$

$38.21 \mathrm{~N}$.

$38.21 \mathrm{~N}$.

$38.23 \mathrm{~N}$.

$38.22 \mathrm{~N}$.

$\begin{array}{ll}38.21 & \mathrm{~N} . \\ 38.21 & \mathrm{~N} \\ 32.98 & \mathrm{~N} .\end{array}$

$38.23 \mathrm{~N}$

$38.21 \mathrm{~N}$.

$\begin{array}{lll}36.81 & \mathrm{~N} . & 121.56 \mathrm{~W} . \\ 32.63 & \mathrm{~N} . & 115.33 \mathrm{~W} .\end{array}$

$32.92 \mathrm{~N}$. $115.55 \mathrm{~W}$.

$32.58 \mathrm{~N}$.

$32.90 \mathrm{~N}$.

$32.83 \mathrm{~N}$.

$115.43 \mathrm{~W}$

$115.55 \mathrm{~W}$.

$115.48 \mathrm{~W}$.

$32.88 \mathrm{~N}$. $115.45 \mathrm{~W}$.

$32.83 \mathrm{~N}$.

$32.97 \mathrm{~N}$.

$32.82 \mathrm{~N}$.

$115.47 \mathrm{~W}$.

$115.40 \mathrm{~W}$.

$32.80 \mathrm{~N} . \quad 115.45 \mathrm{~W}$.

$32.96 \mathrm{~N}$.

$32.83 \mathrm{~N}$.

$32.97 \mathrm{~N}$.
$32.87 \mathrm{~N}$.
$32.83 \mathrm{~N}$.

$115.55 \mathrm{~W}$.

$115.42 \mathrm{~W}$.

$115.55 \mathrm{~W}$.
$115.45 \mathrm{~W}$.
$115.48 \mathrm{~W}$.

$32.98 \mathrm{~N}$.

$32.82 \mathrm{~N}$.

$32.88 \mathrm{~N}$.

$33.02 \mathrm{~N}$.

$115.48 \mathrm{~W}$.

$115.47 \mathrm{~W}$.

$115.50 \mathrm{~W}$.

$32.91 \mathrm{~N}$.

$32.93 \mathrm{~N}$.

$112.52 \mathrm{~W}$.

$32.82 \mathrm{~N} . \quad 115.42 \mathrm{~W}$.

$32.82 \mathrm{~N}$.
$32.95 \mathrm{~N}$. $115.48 \mathrm{~W}$.

$32.82 \mathrm{~N}$.

$32.82 \mathrm{~N}$.

$115.47 \mathrm{~W}$.

$32.92 \mathrm{~N}$. $115.52 \mathrm{~W}$.

$32.97 \mathrm{~N}$.

$32.90 \mathrm{~N}$.
$115.58 \mathrm{~W}$.

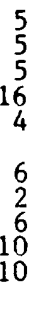

$\ldots \ldots$

$\ldots \ldots$

-.

$\cdots \quad 3.1 \mathrm{~B}$

$\ldots \quad \ldots 3.4 \mathrm{~B}$

$\ldots \ldots$

$\ldots$

$\because \ldots \quad \cdots$

$\because \ldots$

$3.1 \mathrm{P}$
$2.9 \mathrm{~B}$
$2.2 \mathrm{P}$
$2.9 \mathrm{~B}$

$\ldots \quad \ldots$

$\because \cdots \quad \cdots$

$\because \ldots \quad \cdots$

$3.2 \mathrm{~B}$

3. $0 \mathrm{~B}$

$3.1 \mathrm{~B}$
$3.0 \mathrm{~B}$
$3.4 \mathrm{P}$

$\ldots \quad \ldots 3.0 \mathrm{P}$

$\begin{array}{lll}4.1 & \ldots & 5.0 \mathrm{~B} \\ \because \ldots & \because . . & 3.9 \mathrm{~B} \\ \cdots & \ddots .4 & 4.4 \mathrm{~B}\end{array}$

$\because \cdots$

$\because \ldots \quad \ldots \quad 4.1 \mathrm{~B}$

$\ldots \quad \ldots 3.7 \mathrm{~B}$

$\begin{array}{lll}\cdots & \cdots & 3.7 \mathrm{~B} \\ \cdots & \cdots & 4.0 \mathrm{~B}\end{array}$

$\ldots$

$\because \cdots \quad \cdots$

$\cdots \quad \cdots$

$\ldots$

$\ddot{5.7} \quad \ddot{6}$

‥

$\begin{array}{lll}4.2 & \cdots & 3.4 \mathrm{P} \\ 4.3 & \ldots & 4.3 \mathrm{P} \\ 0.6 \mathrm{P}\end{array}$

$\begin{array}{lll}4.3 & \ldots & 4.6 \mathrm{P} \\ \cdots & \cdots & 3.6 \mathrm{P} \\ \cdots & \ldots & 4.3 \mathrm{P}\end{array}$

$\ldots \ldots$

$\because \cdots \quad \ldots$

$\because \cdots$

$3.5 \mathrm{P}$

4.0P

$3.8 \mathrm{P}$

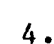

4.

$4.5 \quad \ldots \quad 4.5 \mathrm{P}$

$\ddot{4} .4 \quad \cdots \quad 4.1 \mathrm{P}$

\begin{tabular}{lll}
4.4 & $\ldots$ & $4.4 \mathrm{P}$ \\
\hdashline. & $\because$. & $3.8 \mathrm{P}$ \\
\hdashline & $3.5 \mathrm{P}$
\end{tabular}

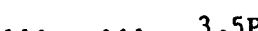

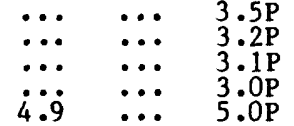

$\ddot{4} \cdot \dot{8} \quad \dot{5}$

$4.3 \quad \cdots 4 \quad 4.5 \mathrm{P}$

$4.3 \quad 5.7 \quad 5.4 \mathrm{P}$

$\ldots \ldots$

$\ldots \ldots$

$\begin{array}{lll}\cdots & \cdots & 3.5 \mathrm{P}\end{array}$

$\begin{array}{lll}\ldots & \ldots & 3.4 \mathrm{P} \\ \ldots & \ldots & 3.9 \mathrm{P}\end{array}$

$\because \because \quad \cdots \quad 3.6 \mathrm{P}$

\section{IV}

...

$\ldots$

FËLT

FELT

FELT

FELT
FELT
FELT

\section{IV}

FË $\dot{\mathrm{T}}$

...

$\because \ddot{0}$

FELT

…

$\ldots$

.

IX

-..

$\ldots$

$\ldots$

$\because$

$\ldots$

$\because \ldots$

$\ddot{\ldots}$

$\ldots$

$\cdots$

$\ldots$

$\ldots$

$\ldots$

…

$$
\begin{array}{lll}
\mathrm{P} & \text { OCT: } & 15 \\
\mathrm{P} & \text { OCT: } & 15 \\
\mathrm{P} & \text { OCT: } & 15 \\
\mathrm{P} & \text { OCT: } & 15 \\
\mathrm{P} & \text { OCT: } & 15
\end{array}
$$

...

P OCT

vì

$\begin{array}{ll}\mathrm{P} & O C T \\ \mathrm{P} & O C T \\ \mathrm{P} & O C T \\ \mathrm{P} & O C T \\ \mathrm{P} & O C T\end{array}$

CT:

15
15
15
15
15

$\begin{array}{lll}\mathrm{P} & \text { OCT. } & 15 \\ \mathrm{P} & \text { OCT: } & 16 \\ \mathrm{P} & \text { OCT } & 16\end{array}$

$\begin{array}{lll}P & \text { OCT: } & 16 \\ P & \text { OCT: } & 16\end{array}$

$\because \cdots$

$\cdots$ $\begin{array}{lll}\mathrm{P} & \text { OCT. } & 16 \\ \mathrm{P} & \text { OCT. } & 16\end{array}$

05 A.M. PST 06 A.M. PST 07 A.M. PST O1 P.M. PST 02 P.M. PST 10 P.M. PST 12 M.M. PST 03 A.M. PST

04 A.M. PST 12 P.M. PST 05 A.M. PST 08 P.M. PST

12 M. PST OI P.M. PST 01 P.M. PST 03 P.M. PST

04 P.M. PST 04 P.M. PST 07 P.M. PST 01 A.M. PST 04 A.M. PST 02 P.M. PST $12 \mathrm{M} \cdot \mathrm{PST}$ 03 P.M. PST

03 P.M. PST 05 P.M. PST 05 P.M. PST 05 P.M. PST 05 P.M. PST 05 P.M. PST 07 P.M. PST 07 P.M. PST

07 P.M. PST 07 P.M. PST 07 P.M. PST 09 P.M. PST

09 P.M. PST 09 P.M. PST 09 P.M. PST 09 P.M. PST

10 P.M. PST 10 P.M. PST 10 P.M. PST 11 P.M. PST

11 P.M. PST 
Table 1.--Summary of U.S. earthquakes for 1979--Continued

\begin{tabular}{|c|c|c|c|c|c|c|c|c|c|c|c|}
\hline \multirow{2}{*}{$\begin{array}{l}\text { Mate } \\
\text { (1979) }\end{array}$} & $\begin{array}{l}\text { Origin tume } \\
\text { (UTC) }\end{array}$ & \multirow{2}{*}{ Lat } & \multirow{2}{*}{ Long } & \multirow{2}{*}{$\begin{array}{l}\text { Depth } \\
(\mathrm{km})\end{array}$} & \multicolumn{3}{|c|}{ Magnıtude } & \multirow{2}{*}{$\begin{array}{l}\text { Maximum } \\
\text { intensity }\end{array}$} & \multirow{2}{*}{$\begin{array}{l}\text { Hypocenter } \\
\text { source }\end{array}$} & \multicolumn{2}{|c|}{ Loud tume } \\
\hline & $\mathrm{hr}$ min $\mathrm{s}$ & & & & nib & us & $\begin{array}{l}\text { ML. of } \\
\text { mbLg }\end{array}$ & & & Date & Hour \\
\hline
\end{tabular}

\section{CALIFORNIA--Cont inued}

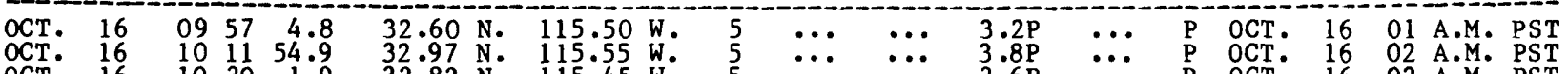

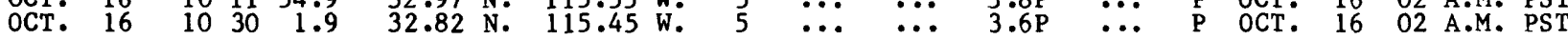

$\begin{array}{lllll}\text { OCT. } & 16 & 10 & 34 & 38.5 \\ \text { OCT. } & 16 & 10 & 51 & 27.8\end{array}$

$\begin{array}{lllll}\text { OCT. } & 16 & 10 & 51 & 27.8 \\ \text { OCT. } & 16 & 11 & 15 & 57.0\end{array}$

OCT. $16 \quad 111912.7$

$32.97 \mathrm{~N} .115 .52 \mathrm{~W}$

$32.93 \mathrm{~N} .115 .55 \mathrm{~W}$.

$33.05 \mathrm{~N} . \quad 115.62 \mathrm{~W}$

$32.90 \mathrm{~N} . \quad 115.55 \mathrm{~W}$.

OCT. $16 \quad 12014507$

$32.88 \mathrm{~N}$. $115.48 \mathrm{~W}$

$\begin{array}{lllll}\text { OCT. } & 16 & 12 & 01 & 45.7 \\ \text { OCT: } & 16 & 12 & 25 & 47.4 \\ \text { OCT. } & 16 & 12 & 49 & 5.5 \\ \text { OCT. } & 16 & 12 & 54 & 16.2\end{array}$

$\begin{array}{lll}32.88 & \mathrm{~N} . & 115.48 \\ 32.98 & \mathrm{~N} . & 115.55 \\ 33.00 & \mathrm{~N} . & 115.57 \mathrm{~W}\end{array}$

$32.85 \mathrm{~N} . \quad 115.57 \mathrm{~W}$.

$33.05 \mathrm{~N}$.

$115.57 \mathrm{~W}$.

$\begin{array}{lll}32.80 & \mathrm{~N} . & 115.47 \mathrm{~W} . \\ 33.05 & \mathrm{~N} . & 115.57 \mathrm{~W} .\end{array}$

$\begin{array}{lllll}\text { OCT. } & 16 & 13 & 14 & 57.5 \\ \text { OCT. } & 16 & 13 & 33 & 32.8\end{array}$

$33.05 \mathrm{~N} . \quad 115.57 \mathrm{~W}$.

$32.03 \mathrm{~N} . \quad 115.68 \mathrm{~W}$.

OCT. $16 \quad 1408073$

$\begin{array}{llll}\text { OCT. } 16 & 15 & 00 & 2.0\end{array}$

$\begin{array}{lllll}\text { OCT. } & 16 & 15 & 05 & 41.7\end{array}$

$\begin{array}{lllll}\text { OCT. } & 16 & 15 & 09 & 6.6 \\ \text { OCT. } & 16 & 15 & 13 & 14.2\end{array}$

$33.07 \mathrm{~N} .115 .55 \mathrm{~W}$.

$33.07 \mathrm{~N} . \quad 115.60 \mathrm{~W}$

$32.93 \mathrm{~N} . \quad 115.63 \mathrm{~W}$.

$\begin{array}{lll}33.07 & \mathrm{~N} . & 115.55 \\ 33.03 & \mathrm{~N} . & 115.60 \\ 32.98 & \mathrm{~N} . & 115.58 \mathrm{~W} .\end{array}$

$\begin{array}{llllll}\text { OCT. } 16 & 16 & 37 & 16.3\end{array}$

$\begin{array}{lllll}\text { OCT. } & 16 & 17 & 22 & 54.9 \\ \text { OCT. } & 16 & 19 & 07 & 56.4\end{array}$

$\begin{array}{lllll}\text { OCT. } & 16 & 19 & 07 & 56.4 \\ \text { OCT. } & 16 & 21 & 48 & 43.9 \\ \text { OCT. } & 16 & 22 & 32 & 22.2\end{array}$

$33.02 \mathrm{~N} .115 .53 \mathrm{~W}$.

$33.03 \mathrm{~N} .115 .60 \mathrm{~W}$

$33.07 \mathrm{~N} . \quad 115.60 \mathrm{~W}$.

OCT. $16 \quad 23 \quad 12 \quad 36.9$

$33.07 \mathrm{~N}$

$115.58 \mathrm{~W}$.

$\begin{array}{llllll}\text { OCT. } \quad 16 & 23 & 16 & 32.7\end{array}$

OCT. $16 \quad 232352.4$

33.07 N. 115.57 W.

$32.82 \mathrm{~N} . \quad 115.47 \mathrm{~W}$.

$33.18 \mathrm{~N} . \quad 115.55 \mathrm{~W}$.

$\begin{array}{lll}00 & 06 & 22.0 \\ 00 & 14 & 55.7\end{array}$

$33.07 \mathrm{~N}$

$115.55 \mathrm{~W}$.
$115.62 \mathrm{~W}$.

OCT. $17 \quad 00 \quad 15 \quad 17.2$

$32.78 \mathrm{~N} .115 .50 \mathrm{~W}$.

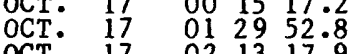

OCT. $17 \quad 021317.9$

$\begin{array}{llllr}\text { OCT. } 17 & 02 & 28 & 18.8 \\ \text { OCT. } & 17 & 06 & 14 & 2.3\end{array}$

$32.97 \mathrm{~N} \cdot \quad 115.55 \mathrm{~W}$.

$33.25 \mathrm{~N} .115 .67 \mathrm{~W}$.

$33.08 \mathrm{~N} . \quad 115.55 \mathrm{~W}$.

$\begin{array}{lllll}\text { OCT. } & 17 & 08 & 38 & 52.7 \\ \text { OCT. } & 17 & 09 & 17 & 22.8\end{array}$

$33.03 \mathrm{~N} .115 .38 \mathrm{~W}$.

$33.15 \mathrm{~N} . \quad 115.65 \mathrm{~W}$

$33.00 \mathrm{~N}$. $115.57 \mathrm{~W}$

$32.82 \mathrm{~N}$.
$32.97 \mathrm{~N}$.
$1115.48 \mathrm{~W}$.

$\begin{array}{llllr}\text { OCT. } & 17 & 16 & 17 & 36.3 \\ \text { OCT. } & 17 & 19 & 14 & 2.3 \\ \text { OCT } & & & & \end{array}$

$\begin{array}{lllll}\text { OCT. } \quad 17 & 20 & 52 & 36.8\end{array}$

$\begin{array}{lllll}\text { OCT. } & 17 & 22 & 45 & 33.4 \\ \text { OCT. } & 17 & 22 & 50 & 32.0 \\ \text { OCT. } & 17 & 22 & 54 & 20.5\end{array}$

$33.90 \mathrm{~N} .118 .63 \mathrm{~W}$

$33.10 \mathrm{~N} . \quad 115.55 \mathrm{~W}$

$33.03 \mathrm{~N} .115 .50 \mathrm{~W}$.

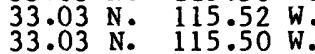

OCT: $17 \quad 2327 \quad 31.1$

OCT. $\quad 17 \quad 23 \quad 3529.2$

$33.08 \mathrm{~N} .115 .48 \mathrm{~W}$

33.17 N. $115.67 \mathrm{~W}$

$33.15 \mathrm{~N} . \quad 115.65 \mathrm{~W}$.

$\begin{array}{lllll}\text { OCT. } & 18 & 00 & 29 & 48.4 \\ \text { OCT. } & 18 & 02 & 14 & 47.9\end{array}$

32.97 N. $115.60 \mathrm{~W}$.

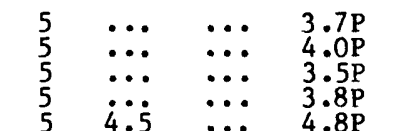

$\because$ P OCT. 16 02 A.M. PST

$\because \quad$ P OCT: 16 O2 A.M. PST

$\therefore \quad P$ OCT. 16 03 A.M. PST

$\therefore \quad$ P OCT. 16 03 A.M. PST

$\begin{array}{lllllllllll}5 & 4.2 & \ldots & 4.0 \mathrm{P} & \ldots & \mathrm{P} & \text { OCT. } & 16 & 04 & \text { A.M. PST }\end{array}$

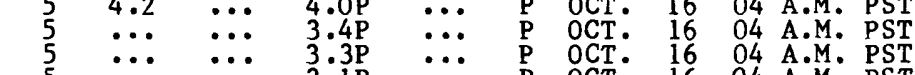

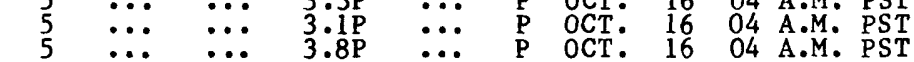

$\begin{array}{llllll}\text { OCT: } & 18 & 03 & 17 & 16.5 \\ \text { OCT. } & 18 & 04 & 25 & 43.2\end{array}$

OCT. $18 \quad 04 \quad 4055.5$

33.15 N. 115.63 W.

$\begin{array}{llllr}\text { OCT. } & 18 & 12 & 01 & 9.7 \\ \text { OCT. } & 18 & 13 & 20 & 26.9\end{array}$

$32.97 \mathrm{~N} .115 .62 \mathrm{~W}$

$32.88 \mathrm{~N} . \quad 115.50 \mathrm{~W}$.

$\begin{array}{lllll}\text { OCT: } & 18 & 14 & 56 & 19.9 \\ \text { OCT. } & 18 & 19 & 18 & 57.9\end{array}$

$32.97 \mathrm{~N}$.

$115.50 \mathrm{~W}$.

$\begin{array}{llllr}\text { OCT. } & 19 & 10 & 35 & 8.6 \\ \text { OCT. } & 19 & 12 & 22 & 37.7\end{array}$

$32.98 \mathrm{~N} .115 .58 \mathrm{~W}$

OCT. $19 \quad 1942 \quad 38.3$

$\begin{array}{lllll}\text { OCT. } & 20 & 05 & 04 & 7.3 \\ \text { OCT. } & 20 & 06 & 25 & 38.5\end{array}$

$34.20 \mathrm{~N} \cdot 117.53 \mathrm{~W}$.

$32.73 \mathrm{~N} .115 .37 \mathrm{~W}$

$\cdots \quad \cdots \quad 3.8 \mathrm{P}$

$\cdots$

P OCT. 16 05 A.M. PST

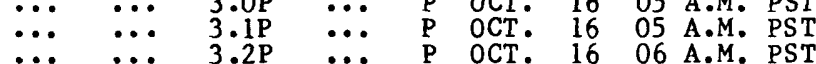

$\because \cdots \quad \because \cdots \quad 3.2 \mathrm{P}$

$\because \cdots \quad \cdots \cdots \quad 3.3 P$

$\because \ldots$

P OCT.

$\because \quad P$ OCT. $16 \quad 06$ A.M. PST

$\begin{array}{llll}\cdots & P & \text { OCT. } 16 & 07 \text { A.M. PST }\end{array}$

$\begin{array}{lllllllll}5 & \cdots & \cdots & 3.3 \mathrm{P} & \ldots & \mathrm{P} & \mathrm{OCT} & 16 & 07 \\ 5 & \cdots & \cdots & 3 . \mathrm{M} \text {. PST }\end{array}$

$\begin{array}{llllllll}6 & \cdots & \cdots & 3.0 P & \cdots & \text { P OCT. } 16 & 07 \text { A.M. PST }\end{array}$

$\because \cdots \quad \cdots .3 .3 \mathrm{P} \quad \cdots \quad$ P OCT: 16 o7 A.M. PST

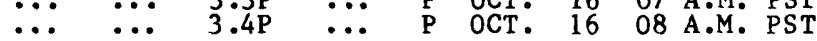

$\begin{array}{llllllllll}5 & \ldots & \ldots & 3.8 \mathrm{P} & \ldots & \mathrm{P} & \text { OCT. } & 16 & 09 & \text { A.M. PST }\end{array}$

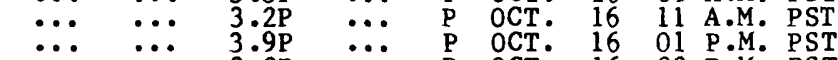

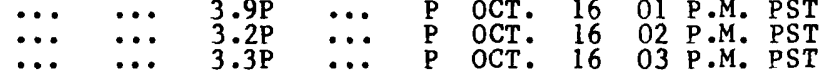

$\begin{array}{llllllllll}5.4 & 4.8 & 4.9 \mathrm{P} & \ldots & \mathrm{P} & \text { OCT. } & 16 & 03 & \mathrm{P} . \mathrm{M} . & \mathrm{PST}\end{array}$

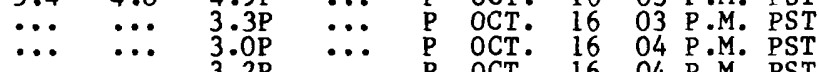

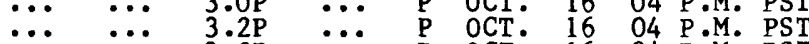

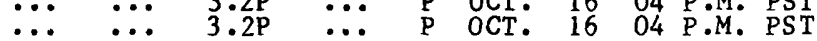

$\begin{array}{llllllllllllll}\ldots & \ldots & 3.2 \mathrm{P} & \ldots & \mathrm{p} & \mathrm{OCT} . & 16 & 04 & \mathrm{P} . \mathrm{M} . & \mathrm{PST}\end{array}$

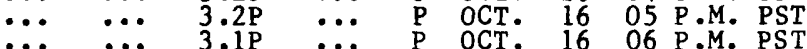

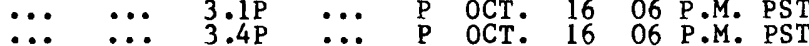

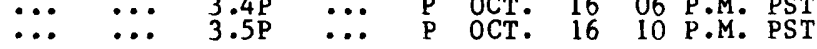

$\begin{array}{llllllllll}\ldots & \ldots & 3.1 \mathrm{P} & \ldots & \mathrm{P} & \mathrm{OCT} & 17 & 12 & \mathrm{P} . \mathrm{M} . & \mathrm{PST}\end{array}$

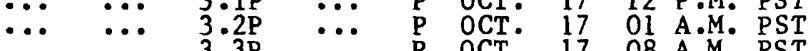

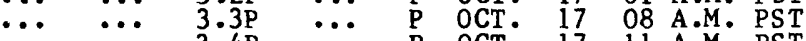

$\because \ldots \quad \cdots \quad 3.4 \mathrm{P} \quad \because \cdots \quad$ P OCT: 17 11 A.M. PST

$\because \ldots \quad \cdots \quad 4.1 \mathrm{P}$ FE் $\stackrel{P}{\mathrm{P}}$ OCT: 17 11 A.M. PST

$4.5 \quad \cdots \quad 4.2 \mathrm{P} \quad \mathrm{V} \quad \mathrm{P}$ OCT. $17 \quad 12 \mathrm{M} . \mathrm{PST}$

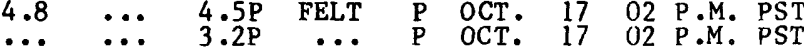

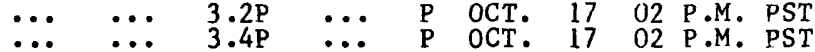

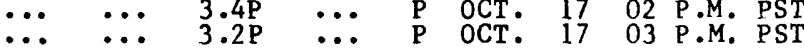

$\begin{array}{lllllllll}\ldots & \ldots & 3.2 \mathrm{P} & \ldots & \mathrm{P} & \mathrm{OCT} . & 17 & 03 & \mathrm{P} . \mathrm{M} . \mathrm{PST}\end{array}$

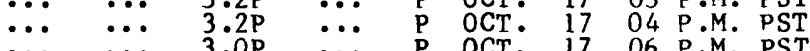

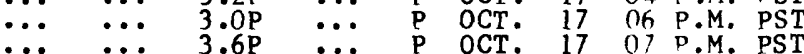

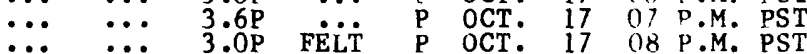
$36.56 \mathrm{~N}$. $121.20 \mathrm{~W}$.

$\begin{array}{lll}\ldots & \ldots & 3.0 \mathrm{OP} \\ \because \cdots & \because \ldots & 3.5 \mathrm{P} \\ \because \cdots & \because .2 \mathrm{P}\end{array}$

$\begin{array}{llllll}\ldots & \text { P OCT. } 17 & 08 & \text { P.M. PST }\end{array}$

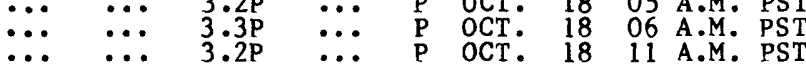

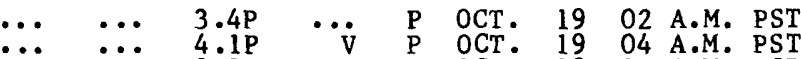

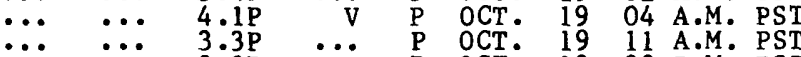

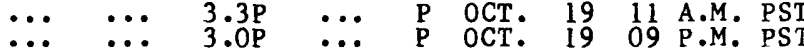

$\begin{array}{lllllllll}\ldots & \ldots & 3.0 \mathrm{P} & \ldots & \mathrm{P} & \text { OCT. } & 19 & 09 & \text { P.M. PST } \\ \cdots & \cdots & 3.4 \mathrm{~B} & \ldots & \mathrm{B} & \text { OCT. } & 19 & 10 & \text { P.M. PST }\end{array}$ 
Table 1.--Summary of U.S. earthquakes for 1979--Continued

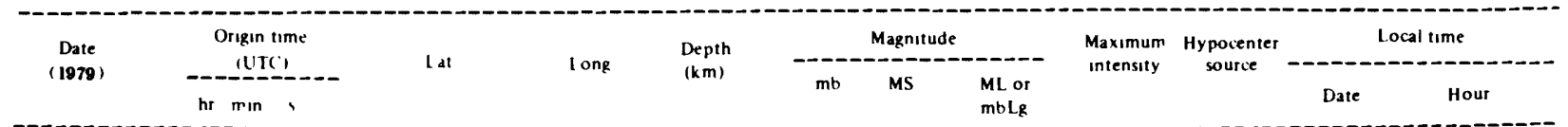

\section{CALIFORNIA--Cont inued}

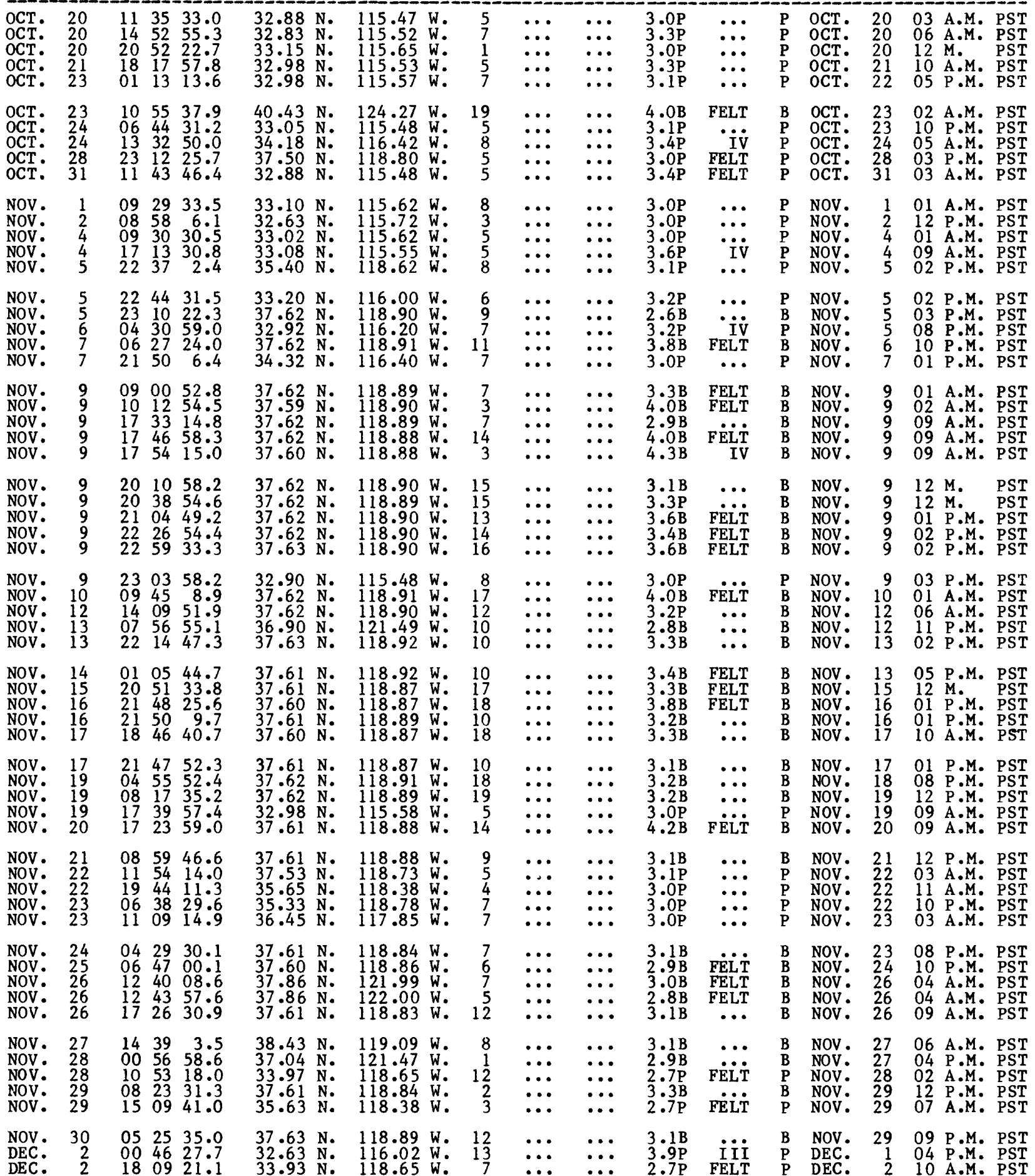


Table 1.--Summary of U.S. earthquakes for 1979--Continued

Origin time
Date
(1979) $\quad$ Lat $\quad$ Long $\quad \begin{aligned} & \text { Depth } \\ & (\mathbf{k m})\end{aligned}$

CAL IFORNIA--Cont inued

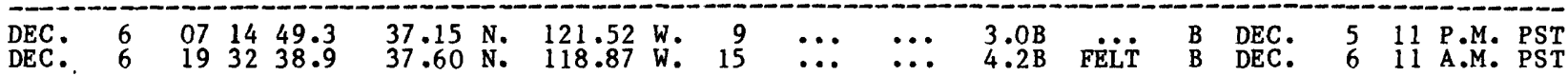

DEC. $\quad \begin{array}{llll}7 & 23 & 54 & 36.1\end{array}$

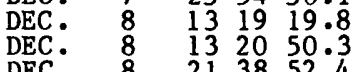

$33.98 \mathrm{~N} .116 .70 \mathrm{~W}$

$37.61 \mathrm{~N} . \quad 118.88 \mathrm{~W}$.

$37.61 \mathrm{~N} .118 .88 \mathrm{~W}$.

5
8
10
16
14

$\because \ldots \quad \ldots$

$3.3 \mathrm{P}$
$3.0 \mathrm{~B}$
$3.0 \mathrm{~B}$

$\begin{array}{lllll}\text { DEC: } & 8 & 21 & 38 & 52.4 \\ \text { DEC. } & 9 & 02 & 08 & 16.8\end{array}$

$\begin{array}{llll}37.60 \mathrm{~N} . & 118.90 \mathrm{~W} . & 16 \\ 37.61 \mathrm{~N} . & 118.86 \mathrm{~W} . & 14\end{array}$

$\cdots$

$\cdots \quad \cdots$

$\because \cdots$

DEC

03 P.M. PST

$\begin{array}{lrrrr}\text { DEC. } & 9 & 08 & 32 & 3.3 \\ \text { DEC. } & 10 & 11 & 11 & 59.3 \\ \text { DEC. } & 11 & 12 & 05 & 02.3\end{array}$

$37.62 \mathrm{~N} .118 .90 \mathrm{~W}$

$37.62 \mathrm{~N} . \quad 118.80 \mathrm{~W}$.

:

$\begin{array}{lllll}\text { DEC: } & 11 & 18 & 32 & 39.7 \\ \text { DEC. } & 14 & 06 & 02 & 11.4\end{array}$

$37.60 \mathrm{~N}$. $118.89 \mathrm{~W}$.

$\ldots \quad \ldots$

$37.60 \mathrm{~N} .118 .95 \mathrm{~W}$.

10
5
6
5
6

$\because \cdots$

$\because \ldots$

$\because \cdots$

\section{$3.5 \mathrm{~B}$}

FËL̇

$3.2 \mathrm{~B}$
$3.0 \mathrm{P}$

FELT

$\begin{array}{lll}33.97 & \mathrm{~N} \cdot & 118.67 \mathrm{~W} . \\ 37.59 & \mathrm{~N} \cdot & 118.86 \mathrm{~W} .\end{array}$

$\begin{array}{lllll}\text { DEC. } & 16 & 06 & 00 & 54.3 \\ \text { DEC. } & 16 & 06 & 29 & 27.0\end{array}$

$\begin{array}{lllll}\text { DEC. } & 16 & 06 & 51 & 53.3 \\ \text { DEC. } & 16 & 10 & 44 & 15.8\end{array}$

$\begin{array}{lllll}\text { DEC. } & 16 & 10 & 44 & 15.8 \\ \text { DEC. } & 17 & 06 & 54 & 53.1\end{array}$

$37.16 \mathrm{~N}$.

$\begin{array}{ll}37.60 \mathrm{~N} . & 118.87 \mathrm{~W} . \\ 37.06 & \mathrm{~N} . \\ 121.50 \mathrm{~W}\end{array}$

9
2
7
13

2.5B FËLT

$\because \cdots \quad \cdots \quad 3.2 \mathrm{P}$ FELT

$\because \cdots \quad \cdots \quad 3.6 \mathrm{~B}$

$3.4 \mathrm{~B}$

$37.06 \mathrm{~N} .121 .50 \mathrm{~W}$.

$\begin{array}{lllll}\text { DEC. } & 18 & 00 & 59 & 23.5 \\ \text { DEC. } & 18 & 11 & 59 & 48.5\end{array}$

$\begin{array}{lllll}\text { DEC. } & 18 & 11 & 59 & 48.5 \\ \text { DEC. } & 18 & 12 & 00 & 16.5\end{array}$

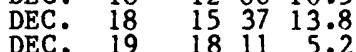

$\begin{array}{lll}35.64 & \mathrm{~N} \cdot & 118.08 \mathrm{~W} . \\ 34.07 & \mathrm{~N} . & 117.15 \\ 34.07 & \mathrm{~N} & 117.13 \\ 3 & \text { W. }\end{array}$

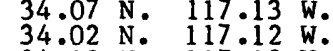

11

$\ldots \quad \ldots \quad 2.9 \mathrm{~B}$

FËĹT

$34.02 \mathrm{~N} .117 .12 \mathrm{~W}$.

5
6
2
8
5

$\because \cdots \quad \cdots$

$3.2 \mathrm{~B}$

DEC. $\quad 20 \quad 02 \quad 2736.8$

37.62 N. 118.96 W. 10

$38.80 \mathrm{~N}$.

$118.96 \mathrm{~W}$
$122.80 \mathrm{~W}$
$122.37 \mathrm{~W}$

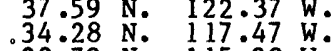

10
4
15
6
5

$\because \cdots \quad \cdots \quad 2.3 \mathrm{P}$

$\dddot{i} \dot{\mathrm{I}}$
FELT

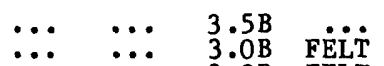

$\ldots \quad \cdots \quad 2.0 B$ FELT

DEC. $20 \quad 203152.0$

$\begin{array}{lll}34.28 & \text { N. } & 117.47 \\ 32.78 & \text { W. } & 115.38 \text { W. }\end{array}$

$\ddot{4.5} \quad \because \quad 3.2 \mathrm{P}$

vi

$37.70 \mathrm{~N}$.

$118.87 \mathrm{~W}$

$33.10 \mathrm{~N}$.

$121.37 \mathrm{~W}$.

5
5
10
8

$\because \ldots \quad \cdots$

$\begin{array}{lll}36.98 & \text { N. } & 122.20 \mathrm{~W} . \\ 37.27 & \mathrm{~N} . & 117.06 \mathrm{~W} .\end{array}$

$\cdots \quad \cdots \quad 3.3 \mathrm{P}$

DEC. $24 \quad 130940.1$

$\begin{array}{lllll}\text { DEC. } \quad 25 & 14 & 17 & 10.8\end{array}$

$37.53 \mathrm{~N}$.

$118.80 \mathrm{~W}$.

$\begin{array}{lllll}\text { DEC. } & 26 & 08 & 09 & 4.4 \\ \text { DEC. } & 28 & 02 & 52 & 38.1\end{array}$

DEC. $28 \quad 032949.5$

$\begin{array}{lllll}\text { DEC. } & 28 & 04 & 40 & 38.7 \\ \text { DEC. } & 31 & 06 & 03 & 40.3\end{array}$

$37.63 \mathrm{~N}:$

$37.66 \mathrm{~N} . \quad 118.87 \mathrm{~W}$.

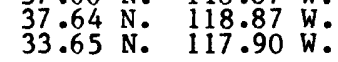

CALIFORNIA--OFF THE COAST

\begin{tabular}{lrrrr}
\hline JAN. & 1 & 02 & 19 & 44.5 \\
FEB. & 3 & 09 & 58 & 16.0 \\
MAR: & 4 & 06 & 24 & 43.7 \\
MAR. & 18 & 04 & 41 & 50.9
\end{tabular}

MAR. $18 \quad 04 \quad 41 \quad 50.9$

$\begin{array}{lllll}\text { MAR. } & 18 & 04 & 42 & 17.3\end{array}$

$\begin{array}{llllll}\text { MAR. } & 18 & 16 & 18 & 31.2 \\ \text { MAR. } & 22 & 15 & 14 & 00.8\end{array}$

MAR. $22 \quad 1541 \quad 56.3$

$\begin{array}{lllll}\text { APR: } & 7 & 06 & 18 & 33.0 \\ \text { APR } & 7 & 10 & 17 & 38.2\end{array}$

APR. $\quad 13 \quad 08 \quad 07 \quad 43.2$

$\begin{array}{llllr}\text { APR: } & 25 & 04 & 48 & 8.8 \\ \text { APR: } & 25 & 19 & 29 & 57.2\end{array}$

$\begin{array}{llllr}\text { APR } & 25 & 19 & 29 & 57.2 \\ \text { MAY } & 8 & 02 & 49 & 4.7\end{array}$

$\begin{array}{llllll}\text { MAY } & 28 & 04 & 12 & 13.1\end{array}$

AUG • $\quad 1 \quad 105024.7$

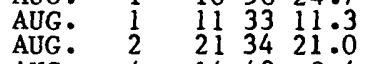

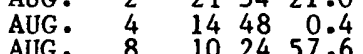

AUG. 8102457.6

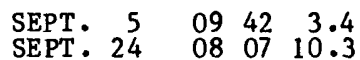

OCT. 24 15 2350.6

$\begin{array}{lllll}\text { OCT. } & 25 & 09 & 01 & 40.3 \\ \text { NOV. } & 8 & 04 & 30 & 27.9\end{array}$

$40.47 \mathrm{~N} . \quad 126.35 \mathrm{~W}$.

40.92 N. $124.42 \mathrm{~W}$.

$34.80 \mathrm{~N}$.
$40.37 \mathrm{~N}$.
40.321 .13

$40.34 \mathrm{~N}$. $124.46 \mathrm{~W}$.

$40.34 \mathrm{~N} .124 .71 \mathrm{~W}$

$41.87 \mathrm{~N} . \quad 126.71 \mathrm{~W}$.

41.74 N. 127.01 W. 15

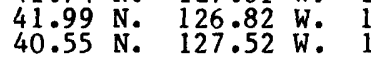

$40.60 \mathrm{~N} .127 .83 \mathrm{~W}$.

$40.35 \mathrm{~N} . \quad 125.28 \mathrm{~W}$.

$33.75 \mathrm{~N}$.
$32.68 \mathrm{~N}$. $119.37 \mathrm{~W}$.

$40.98 \mathrm{~N} . \quad 125.12 \mathrm{~W}$.

$40.87 \mathrm{~N} .127 .43 \mathrm{~W}$.

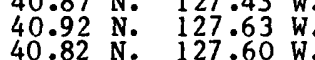

40.31 N. 124.60 W.

$40.31 \mathrm{~N} . \quad 124.68 \mathrm{~W} .29$

41.79 N. $125.78 \mathrm{~W}$.

$40.21 \mathrm{~N} . \quad 125.66 \mathrm{~W}$.

$40.43 \mathrm{~N} . \quad 124.70 \mathrm{~W} .24$

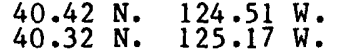

\section{$4.2 \quad \cdots \quad 4.2$}

$\begin{array}{lll}5.2 & 4.6 & 5.2 \mathrm{~B} \\ \cdots & \ldots & 3.3 \mathrm{~B}\end{array}$

$\because \cdots \quad \cdots \quad 3.3 \mathrm{~B}$

vii

$\ldots$

$\because \cdots$

$4.0 \quad \ddot{4.8} \quad 4.1 \mathrm{~B}$

$\begin{array}{lll}4.2 & 4.8 & 4.2 \mathrm{~B} \\ 4.4 & \cdots & 3.3 \mathrm{~B}\end{array}$

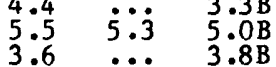

:

\section{$4.7 \quad \ldots \quad 4.7$}

$\begin{array}{lll}4.7 & \because . & 4.7 \mathrm{~B} \\ \because . . & \because \cdots & 3.4 \mathrm{~B}\end{array}$

$\because \ldots \quad \cdots \quad 3.1 \mathrm{P}$

$\because \cdots$

$\because \cdots$

$\ldots$

$\begin{array}{lll}5.3 & 5.2 & 4.7 \mathrm{~B} \\ 4.2 & \ddot{0} & 3.5 \mathrm{~B} \\ 4.6 & 4.0 & 3.9 \mathrm{~B}\end{array}$

$\ddot{3.8} \quad \ldots \quad 3.8 \mathrm{~B}$

.

$\because \ldots$ B AUG.

$\therefore$ B AUG.

ï B AUG.

$4.3 \quad \ldots \quad 4.3 \mathrm{~B}$

$\begin{array}{lll}4.8 & \cdots & 3.8 \mathrm{~B} \\ 0.5 & 4.5 \mathrm{~B}\end{array}$

$\because \ddot{\text { Iv }}$

$\ddot{4.7} \quad \ddot{3 . j} \quad 4.5 \mathrm{~B}$

05 A.M. PST 01 P.M. PST 06 P.M. PST

DEC

DEC:
DEC:
DEC:
DEC:

$9 \quad 12$ P.M. PST

1003 A.M. PST

1 A.M. PST 10 P.M. PST

P DEC. 15 10 P.M. PST $B$ DEC. 15 10 P.M. PST $B$ DEC: $16 \quad 02$ A.M. PST DEC. 1610 P.M. PST

G DEC. 1704 P.M. PST DEC. 18 03 A.M. PST DEC. 18 07 A.M. PST DEC. 1910 A.M. PST

B DEC. 1906 P.M. PST DEC. 1909 P.M. PST B DEC. 20 04 A.M. PST

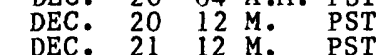
DEC. 22 01 A.M. DEC. 22 10 A.M. PST DEC. 22 10 P.M. PST $\begin{array}{llll}\text { DEC. } & 24 & 05 & \text { A.M.M. PST } \\ \text { DEC. } & 25 & 06 & \text { A.M. PST }\end{array}$ DEC. $26 \quad 12$ P.M. PST

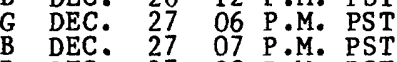
DEC. $27 \quad 08$ P.M. PST DEC. 3010 P.M. PST 
Table 1.--Summary of U.S. earthquakes for 1979-.-Continued

\begin{tabular}{|c|c|c|c|c|c|c|c|c|c|c|}
\hline \multirow{2}{*}{$\begin{array}{l}\text { Date } \\
\text { (1979) }\end{array}$} & $\begin{array}{l}\text { Origin ume } \\
\text { (U) IC) }\end{array}$ & \multirow[t]{2}{*}{$\mathrm{t}$ dt } & \multirow{2}{*}{ I ong } & \multirow{2}{*}{$\begin{array}{l}\text { Depth } \\
(\mathrm{km})\end{array}$} & \multicolumn{2}{|l|}{ Magnitude } & \multirow{2}{*}{$\begin{array}{l}\text { Maximum } \\
\text { Intensity }\end{array}$} & \multirow{2}{*}{$\begin{array}{l}\text { Hypocenter } \\
\text { source }\end{array}$} & \multicolumn{2}{|c|}{ Local time } \\
\hline & hr $\min$ & & & & $\mathrm{mb}$ & $\begin{array}{l}\text { ML or } \\
\text { mbLg }\end{array}$ & & & Date & Hour \\
\hline
\end{tabular}

CAL IFORNIA-OOFF THE COAST--Cont Inued

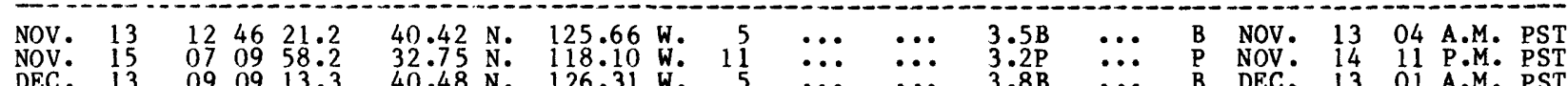

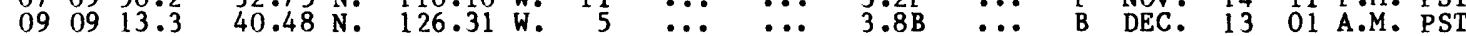

\begin{tabular}{|c|c|c|c|c|c|c|c|c|c|c|c|c|c|}
\hline & & & & & & ADO & & & & & & & \\
\hline $\begin{array}{l}\text { JAN. } \\
\text { JAN. } \\
\text { MAR. } \\
\text { MAR. }\end{array}$ & $\begin{array}{r}6 \\
20 \\
19 \\
29\end{array}$ & $\begin{array}{lll}01 & 58 & 55.3 \\
06 & 59 & 08.4 \\
14 & 59 & 29.7 \\
22 & 07 & 13.3\end{array}$ & 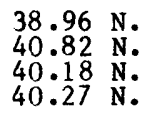 & $\begin{array}{l}105.16 \mathrm{~W} . \\
107.86 \mathrm{~W} . \\
108.90 \mathrm{~W} . \\
108.81 \mathrm{~W} .\end{array}$ & $\begin{array}{l}5 \\
5 \\
2 \\
2\end{array}$ & $\because \cdots$ & $\because \cdots$ & $\begin{array}{l}2.9 \mathrm{G} \\
3.3 \mathrm{G} \\
3.1 \mathrm{G} \\
2.6 \mathrm{G}\end{array}$ & $\begin{array}{l}\text { VI } \\
\ddot{I V} \\
\text { IV }\end{array}$ & $\begin{array}{l}\mathbf{G} \\
\mathbf{G} \\
\mathbf{G}\end{array}$ & $\begin{array}{l}\text { JAN. } \\
\text { JAN. } \\
\text { MAR: } \\
\text { MAR. }\end{array}$ & $\begin{array}{l}5 \\
19 \\
19 \\
29\end{array}$ & $\begin{array}{lll}06 & \text { P.M. MST } \\
11 & \text { P.M. MST } \\
07 & \text { A.M. MST } \\
03 & \text { P.M. MST }\end{array}$ \\
\hline
\end{tabular}

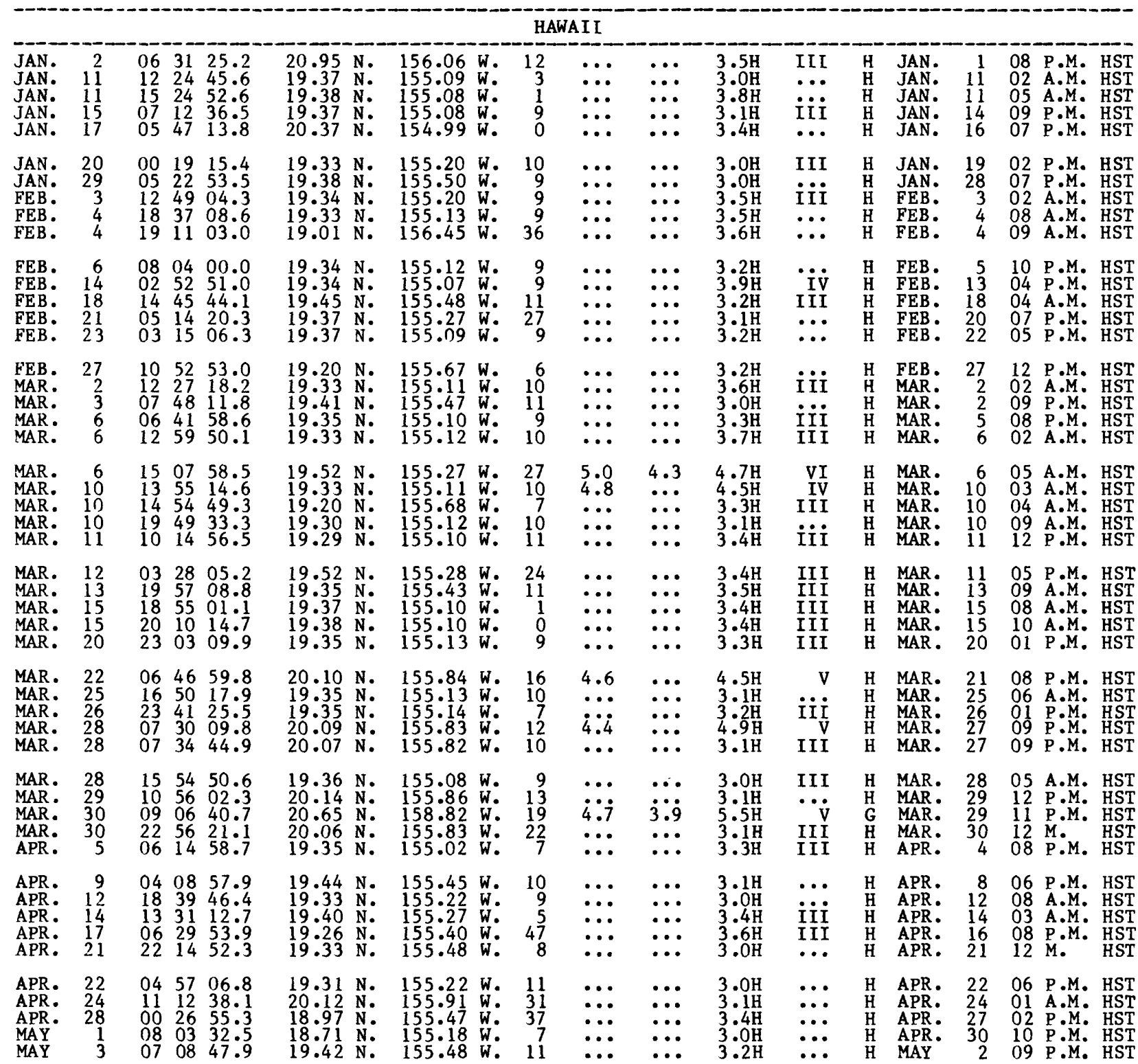


Table 1.--Summary of U.S. earthquakes for 1979--Continued

$\begin{aligned} & \text { Date } \\ & \text { (1979) }\end{aligned}$
Origin time
(UT) LIns)

HAWAI I--Cont 1 nued

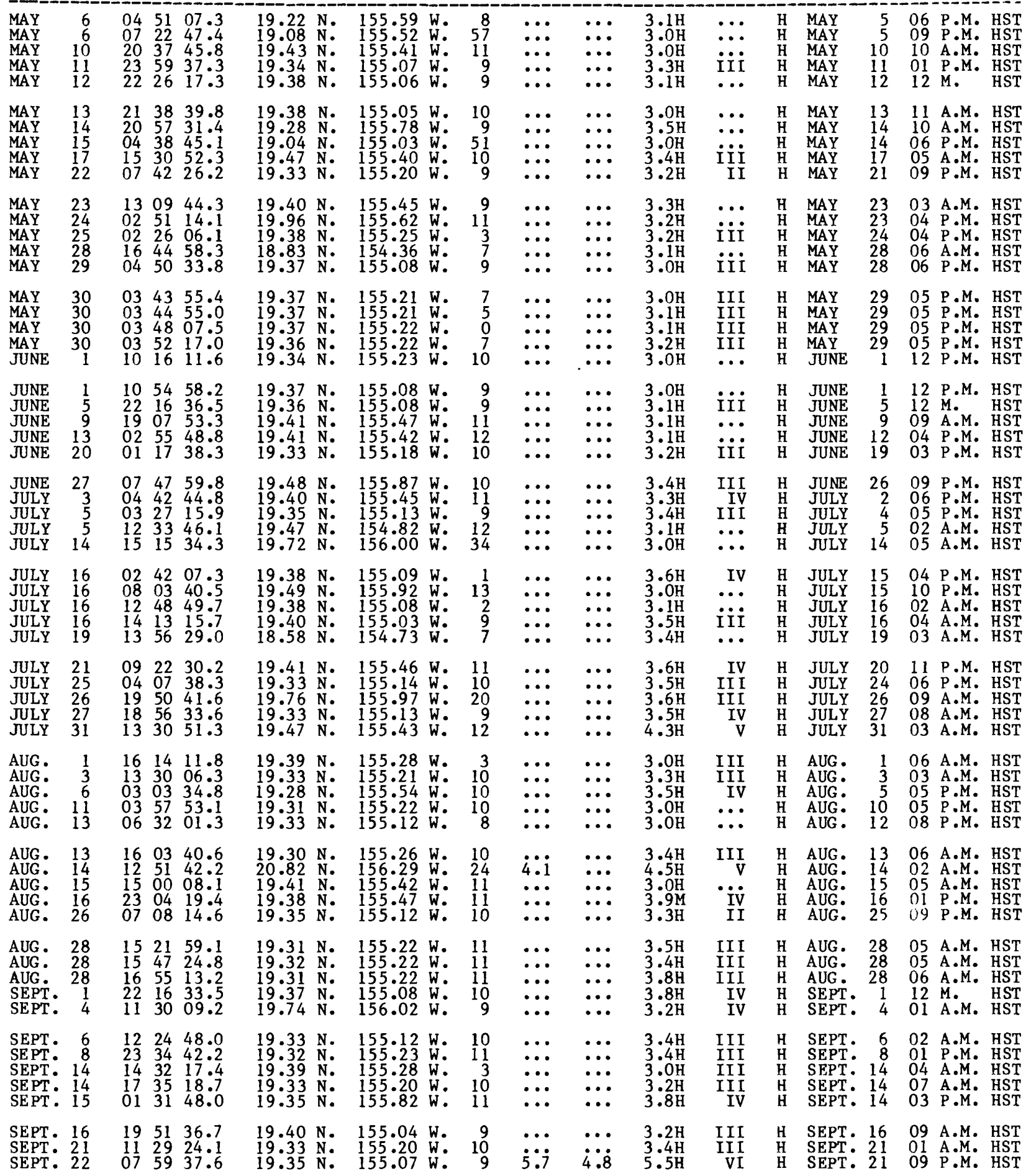


Table 1.--Summary of U.S. earthquakes for 1979.-Continued

Orgin time
$\begin{aligned} & \text { Date } \\ & \text { (1979) }\end{aligned}$
$\mathrm{hr}$ min

HAWAII--Cont inued

\begin{tabular}{|c|c|c|c|c|c|c|c|c|c|c|c|}
\hline $\begin{array}{l}\text { SEPT. } 22 \\
\text { SEPT. } 22\end{array}$ & $\begin{array}{lll}9 & 29 & 12.3 \\
9 & 36 & 17.3\end{array}$ & $\begin{array}{l}35 \mathrm{~N} . \\
35 \mathrm{~N} .\end{array}$ & $\begin{array}{l}5.03 \text { W. } \\
5.04 \text { W. }\end{array}$ & $\begin{array}{l}9 \\
8\end{array}$ & $\begin{array}{l}4.8 \\
\cdots .\end{array}$ & $\because$ & $\begin{array}{l}4 \\
3\end{array}$ & IIV & & $\begin{array}{l}\text { SEPT. } \\
\text { SEPT. }\end{array}$ & $\begin{array}{ll}11 & \text { P.M. HST } \\
11 & \text { P.M. HST }\end{array}$ \\
\hline $\begin{array}{l}\text { SEPT. } 23 \\
\text { SEPT: } 23 \\
\text { SEPT: } 25 \\
\text { SEPT: } 26 \\
\text { SEPT. } 27\end{array}$ & $\begin{array}{lll}11 & 28 & 19.9 \\
19 & 25 & 25.8 \\
03 & 50 & 23.1 \\
16 & 21 & 22.8 \\
01 & 01 & 32.4\end{array}$ & $\begin{array}{l}19.37 \mathrm{~N} . \\
19.37 \mathrm{~N} . \\
19.36 \mathrm{~N} . \\
19.54 \mathrm{~N} .\end{array}$ & $\begin{array}{l}155.07 \text { W. } \\
155.27 \text { W. } \\
155.08 \text { W. } \\
155.04 \text { W. } \\
155.92 \text { W. }\end{array}$ & $\begin{array}{r}9 \\
36 \\
9 \\
9 \\
11\end{array}$ & 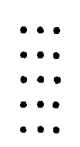 & $\because \cdots$ & $\begin{array}{l}3.3 \mathrm{H} \\
3.6 \mathrm{H} \\
3.0 \mathrm{H} \\
3.2 \mathrm{H}\end{array}$ & $\begin{array}{l}\text { III } \\
\text { IiI } \\
\text { I } \ddot{I}\end{array}$ & ${ }_{H}^{H}$ & $\begin{array}{ll}\text { SEPT. } & 23 \\
\text { SEPT: } & 23 \\
\text { SEPT: } 24 \\
\text { SEPT: } 26 \\
\text { SEPT: } 26\end{array}$ & $\begin{array}{ll}01 & \text { A.M. HST } \\
09 & \text { A.M. HST } \\
05 & \text { P.M. HST } \\
06 & \text { A.M. HST } \\
03 & \text { P.M. HST }\end{array}$ \\
\hline $\begin{array}{lr}\text { SEPT. } & 27 \\
\text { SEPT } & 27 \\
\text { SEPT. } & 30 \\
\text { OCT: } & 6 \\
\text { OCT. } & 9\end{array}$ & $\begin{array}{lll}15 & 35 & 45.5 \\
15 & 38 & 31.2 \\
00 & 02 & 26.3 \\
10 & 46 & 12.2 \\
02 & 40 & 19.8\end{array}$ & $\begin{array}{l}19.33 \mathrm{~N} . \\
19.33 \mathrm{~N} . \\
19.37 \mathrm{~N} . \\
19.33 \mathrm{~N} . \\
19.33 \mathrm{~N} .\end{array}$ & $\begin{array}{l}155.12 \text { W. } \\
155.13 \text { W. } \\
155.11 \text { W. } \\
155.22 \text { W. } \\
155.19 \text { W. }\end{array}$ & $\begin{array}{r}10 \\
9 \\
8 \\
10 \\
10\end{array}$ & $\begin{array}{l}4.7 \\
\because \because . \\
\because \cdots \\
\because \cdots\end{array}$ & $\begin{array}{l}\cdots \\
\because \cdots \\
\cdots\end{array}$ & $\begin{array}{l}4.3 \mathrm{H} \\
3: 2 \mathrm{H} \\
3: 2 \mathrm{H} \\
3.9 \mathrm{H} \\
3.7 \mathrm{H}\end{array}$ & $\begin{array}{r}\text { V } \\
\text { IV } \\
\text { II } \\
\text { IV } \\
\text { III }\end{array}$ & 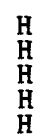 & $\begin{array}{lr}\text { SEPT. } & 27 \\
\text { SEPT: } & 27 \\
\text { SEPT: } & 29 \\
\text { OCT. } & 6 \\
\text { OCT. } & 8\end{array}$ & $\begin{array}{lll}05 & \text { A.M. HST } & \text { HST } \\
05 & \text { A.M. HST } & \text { HST } \\
02 & \text { P.M. HST } \\
12 & \text { P.M. HST } \\
04 & \text { P.M. HST }\end{array}$ \\
\hline $\begin{array}{ll}\text { OCT: } & 13 \\
\text { OCT: } & 13 \\
\text { OCT: } & 13 \\
\text { OCT: } & 14 \\
\text { OCT: } & 15\end{array}$ & $\begin{array}{lll}01 & 59 & 25.8 \\
11 & 16 & 26.0 \\
12 & 58 & 51.0 \\
17 & 37 & 17.5 \\
10 & 44 & 12.3\end{array}$ & $\begin{array}{l}19.38 \text { N. } \\
19.44 \text { N. } \\
19.45 \text { N. } \\
19.91 \text { N. } \\
19.93 \text { N. }\end{array}$ & $\begin{array}{l}155.25 \text { W. } \\
155.35 \text { W. } \\
155.36 \text { W. } \\
155.19 \text { W. } \\
156.46 \text { W. }\end{array}$ & $\begin{array}{r}4 \\
8 \\
7 \\
14 \\
3\end{array}$ & $\begin{array}{l}\ldots \\
\because:\end{array}$ & $\because \cdots$ & $\begin{array}{l}3 . \mathrm{OH} \\
3.8 \mathrm{H} \\
3.1 \mathrm{H} \\
4 . \mathrm{H} \\
3.1 \mathrm{H}\end{array}$ & $\begin{array}{l}\text { II } \\
\text { III } \\
\text { IV }\end{array}$ & $\mathrm{H}$ & $\begin{array}{ll}\text { OCT. } & 12 \\
\text { OCT: } & 13 \\
\text { OCT: } & 13 \\
\text { OCT: } & 14 \\
\text { OCT. } & 15\end{array}$ & $\begin{array}{lll}03 & \text { P.M. HST } \\
01 & \text { A.M. HST } \\
02 & \text { A.M. HST } \\
07 & \text { A.M. HST } \\
12 & \text { P.M. HST }\end{array}$ \\
\hline $\begin{array}{ll}\text { OCT: } & 17 \\
\text { OCT: } & 19 \\
\text { OCT: } & 20 \\
\text { OCT: } & 21 \\
\text { OCT: } & 28\end{array}$ & $\begin{array}{llll}05 & 54 & 37.8 \\
06 & 14 & 32.4 \\
23 & 59 & 12.0 \\
05 & 57 & 02.0 \\
18 & 36 & 49.3\end{array}$ & $\begin{array}{l}19.32 \\
19.78 \\
19.41 \\
19.3 \\
19.32 \\
19.33 \\
\text { N. }\end{array}$ & $\begin{array}{l}155.14 \text { W. } \\
156.05 \text { W. } \\
155.47 \text { W. } \\
155.20 \text { W. } \\
155.27 \text { W. }\end{array}$ & $\begin{array}{r}9 \\
9 \\
11 \\
10 \\
37\end{array}$ & $\cdots$ & $\ldots$ & $\begin{array}{l}3.1 \mathrm{H} \\
3.1 \mathrm{H} \\
3.3 \mathrm{H} \\
3.5 \mathrm{H} \\
3.1 \mathrm{H}\end{array}$ & $\begin{array}{l}\because \ldots \\
\dddot{i I I}\end{array}$ & $\stackrel{\mathrm{H}}{\mathrm{H}}$ & $\begin{array}{ll}\text { OCT. } & 16 \\
\text { OCT. } & 18 \\
\text { OCT. } & 20 \\
\text { OCT. } & 20 \\
\text { OCT. } & 28\end{array}$ & 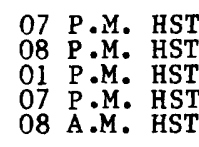 \\
\hline $\begin{array}{lr}\text { OCT: } & 31 \\
\text { OCT: } & 31 \\
\text { NOV: } & 1 \\
\text { NOV: } & 3 \\
\text { NOV: } & 4\end{array}$ & $\begin{array}{lll}05 & 35 & 11.7 \\
15 & 23 & 30.1 \\
02 & 57 & 50.7 \\
16 & 58 & 03.1 \\
04 & 09 & 51.6\end{array}$ & $\begin{array}{l}19.88 \mathrm{~N} . \\
19.97 \\
19.29 \\
19.28 \\
20.06 \\
20 .\end{array}$ & $\begin{array}{l}156.34 \text { W. } \\
155.80 \text { W. } \\
154.99 \text { W. } \\
155.27 \text { W. } \\
155.64 \text { W. }\end{array}$ & $\begin{array}{l}1 \\
10 \\
39 \\
11 \\
13\end{array}$ & $\begin{array}{l}4.1 \\
\cdots \\
\cdots\end{array}$ & $\because \cdots$ & $\begin{array}{l}4.2 \mathrm{H} \\
3.0 \mathrm{H} \\
3.0 \mathrm{H} \\
3.3 \mathrm{H} \\
3.0 \mathrm{H}\end{array}$ & $\begin{array}{l}\text { IV } \\
\because: \\
\dddot{I} i \dot{I}\end{array}$ & $\mathrm{H}$ & $\begin{array}{lr}\text { OCT. } & 30 \\
\text { OCT: } & 31 \\
\text { OCT: } & 31 \\
\text { NOV: } & 3 \\
\text { NOV. } & 3\end{array}$ & 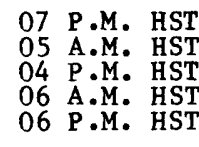 \\
\hline $\begin{array}{lr}\text { NOV: } & 4 \\
\text { NOV: } & 11 \\
\text { NOV: } & 15 \\
\text { NOV: } & 16 \\
\text { NOV: } & 16\end{array}$ & $\begin{array}{lll}12 & 10 & 33.3 \\
10 & 25 & 33.6 \\
14 & 13 & 00.9 \\
09 & 54 & 29.5 \\
20 & 24 & 26.1\end{array}$ & $\begin{array}{l}19.33 \\
19.36 \\
19.38 \\
19.35 \\
19.35 \\
19.37\end{array}$ & $\begin{array}{l}155.19 \text { W. } \\
155.25 \text { W. } \\
155.24 \text { W. } \\
155.23 \text { W. } \\
155.24 \text { W. }\end{array}$ & $\begin{array}{r}10 \\
11 \\
4 \\
1 \\
2\end{array}$ & $\ldots$ & $\ldots$ & $\begin{array}{l}3.0 \mathrm{H} \\
3.5 \mathrm{H} \\
3.4 \mathrm{H} \\
3.4 \mathrm{H} \\
3.1 \mathrm{H}\end{array}$ & $\begin{array}{l}\text { Iii } \\
\text { IV } \\
\text { III } \\
\cdots .\end{array}$ & $\mathrm{H}$ & $\begin{array}{ll}\text { NOV: } & 4 \\
\text { NOV: } & 11 \\
\text { NOV: } & 15 \\
\text { NOV: } & 15 \\
\text { NOV: } & 16\end{array}$ & $\begin{array}{ll}02 & \text { A.M. HST } \\
12 & \text { P.M. HST } \\
04 & \text { A.M. HST } \\
11 & \text { P.M. HST } \\
10 & \text { A.M. HST }\end{array}$ \\
\hline $\begin{array}{ll}\text { NOV: } & 17 \\
\text { NOV: } & 20 \\
\text { NOV: } & 21 \\
\text { NOV: } & 21 \\
\text { NOV: } & 23\end{array}$ & $\begin{array}{lll}16 & 11 & 59.5 \\
02 & 58 & 13.9 \\
07 & 29 & 38.0 \\
19 & 07 & 27.6 \\
03 & 42 & 30.7\end{array}$ & $\begin{array}{l}19.35 \mathrm{~N} . \\
19.33 \mathrm{~N} . \\
19.38 \mathrm{~N} . \\
19.27 \\
19.31 \mathrm{~N} .\end{array}$ & $\begin{array}{l}155.22 \text { W. } \\
155.13 \text { W. } \\
155.24 \text { W. } \\
155.78 \text { W. } \\
155.22 \text { W. }\end{array}$ & $\begin{array}{r}10 \\
9 \\
3 \\
10 \\
9\end{array}$ & ... & $\ldots$ & $\begin{array}{l}3.3 \mathrm{H} \\
3.2 \mathrm{H} \\
3.2 \mathrm{H} \\
3.1 \mathrm{H} \\
3.1 \mathrm{H}\end{array}$ & $\begin{array}{l}\text { IV } \\
i \mathfrak{i} \dot{I} \\
\cdots:\end{array}$ & $\begin{array}{l}\mathrm{H} \\
\mathrm{H} \\
\mathrm{H}\end{array}$ & $\begin{array}{ll}\text { Nov: } & 17 \\
\text { Nov: } & 19 \\
\text { NOV: } & 20 \\
\text { NOV: } & 21 \\
\text { NOV: } & 22\end{array}$ & $\begin{array}{ll}06 & \text { A.M. HST } \\
04 & \text { P.M. HST } \\
09 & \text { P.M. HST } \\
09 & \text { A.M. HST } \\
05 & \text { P.M. HST }\end{array}$ \\
\hline $\begin{array}{ll}\text { NOV: } & 23 \\
\text { NOV: } & 23 \\
\text { NOV: } & 24 \\
\text { NOV: } & 25 \\
\text { NOV: } & 25\end{array}$ & $\begin{array}{lll}16 & 41 & 34.0 \\
20 & 45 & 38.0 \\
04 & 48 & 27.7 \\
07 & 31 & 06.8 \\
10 & 50 & 01.9\end{array}$ & $\begin{array}{l}19.38 \mathrm{~N} . \\
19.36 \mathrm{~N} . \\
19.44 \mathrm{~N} . \\
19.40 \mathrm{~N} . \\
19.32 \mathrm{~N} .\end{array}$ & $\begin{array}{l}155.25 \text { W. } \\
155.25 \text { W. } \\
155.39 \text { W. } \\
155.45 \text { W. } \\
155.19 \text { W. }\end{array}$ & $\begin{array}{r}4 \\
1 \\
9 \\
13 \\
9\end{array}$ & 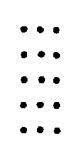 & & $\begin{array}{l}3.4 \mathrm{H} \\
3.5 \mathrm{H} \\
3.0 \mathrm{H} \\
3.5 \mathrm{H} \\
3.4 \mathrm{H}\end{array}$ & $\begin{array}{l}\text { IV } \\
\text { IV } \\
\because \text { IV } \\
\text { IV }\end{array}$ & $\begin{array}{l}\mathrm{H} \\
\mathrm{H} \\
\mathrm{H}\end{array}$ & $\begin{array}{ll}\text { Nov: } & 23 \\
\text { Nov: } & 23 \\
\text { NOV: } & 23 \\
\text { Nov: } & 24 \\
\text { NOV: } & 25\end{array}$ & $\begin{array}{ll}06 & \text { A.M. HST } \\
10 & \text { A.M. HST } \\
06 & \text { P.M. HST } \\
09 & \text { P.M. HST } \\
12 & \text { P.M. HST }\end{array}$ \\
\hline $\begin{array}{lr}\text { NOV: } & 26 \\
\text { NOV: } & 29 \\
\text { NOV: } & 30 \\
\text { NOV. } & 30 \\
\text { DEC. } & 5\end{array}$ & $\begin{array}{lll}03 & 51 & 25.0 \\
08 & 03 & 30.3 \\
10 & 55 & 47 \\
20 & 15 & 41.8 \\
22 & 05 & 04.8\end{array}$ & $\begin{array}{l}19.33 \\
19.38 \\
19.58 \\
19.39 \\
19.33 \\
\text { N. }\end{array}$ & $\begin{array}{l}155.32 \text { W. } \\
155.08 \text { W. } \\
155.98 \text { W. } \\
155.25 \text { W. } \\
155.22 \text { W. }\end{array}$ & $\begin{array}{r}32 \\
8 \\
11 \\
3 \\
10\end{array}$ & $\because$. & & $\begin{array}{l}3.1 \mathrm{H} \\
3.1 \mathrm{H} \\
3.1 \mathrm{H} \\
3.0 \mathrm{H} \\
3.4 \mathrm{H}\end{array}$ & $\begin{array}{c}\cdots: \\
\because \dot{\text { IV }} \\
\text { IV } \\
\cdots\end{array}$ & $\begin{array}{l}\mathrm{H} \\
\mathrm{H} \\
\mathrm{H} \\
\mathrm{H}\end{array}$ & $\begin{array}{ll}\text { NOV. } & 25 \\
\text { NOV: } & 28 \\
\text { NOV: } & 30 \\
\text { NOV: } & 30 \\
\text { DEC. } & 5\end{array}$ & 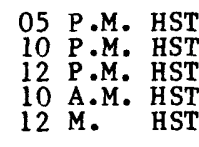 \\
\hline $\begin{array}{lr}\text { DEC. } & 6 \\
\text { DEC: } & 14 \\
\text { DEC: } & 16 \\
\text { DEC. } & 17 \\
\text { DEC: } & 17\end{array}$ & $\begin{array}{lll}01 & 32 & 27.2 \\
03 & 44 & 3.1 \\
03 & 45 & 13.1 \\
04 & 11 & 03.8 \\
09 & 44 & 25.4\end{array}$ & $\begin{array}{l}19.41 \\
19.42 \\
19.35 \\
19.19 \\
19.39 \\
19.39\end{array}$ & $\begin{array}{l}155.47 \text { W. } \\
155.41 \text { W. } \\
155.31 \text { W. } \\
155.60 \text { W. } \\
155.28 \text { W. }\end{array}$ & $\begin{array}{r}11 \\
11 \\
14 \\
6 \\
4\end{array}$ & $\because:$ & & $\begin{array}{l}3.8 \mathrm{H} \\
4.0 \mathrm{H} \\
3.6 \mathrm{H} \\
3.0 \mathrm{H} \\
3.2 \mathrm{H}\end{array}$ & $\begin{array}{l}\text { IV } \\
\text { IV } \\
\text { IV } \\
\because:\end{array}$ & $\begin{array}{l}\mathrm{H} \\
\mathrm{H} \\
\mathrm{H} \\
\mathrm{H}\end{array}$ & $\begin{array}{lr}\text { DEC. } & 5 \\
\text { DEC. } & 13 \\
\text { DEC. } & 15 \\
\text { DEC } & 16 \\
\text { DEC. } & 16\end{array}$ & $\begin{array}{ll}03 & \text { P.M. HST } \\
05 & \text { P.M. HST } \\
05 & \text { P.M. HST } \\
06 & \text { P.M. HST } \\
11 & \text { P.M. HST }\end{array}$ \\
\hline $\begin{array}{ll}\text { DEC. } & 23 \\
\text { DEC: } & 24 \\
\text { DEC: } & 24 \\
\text { DEC. } & 25 \\
\text { DEC. } & 28\end{array}$ & $\begin{array}{lll}11 & 06 & 02.1 \\
11 & 44 & 08.2 \\
23 & 39 & 39: 2 \\
15 & 55 & 54.9 \\
21 & 25 & 49.9\end{array}$ & $\begin{array}{l}19.38 \mathrm{~N} . \\
19.38 \text { N. } \\
20.14 \text { N. } \\
20.47 \text { N. } \\
19.30 \mathrm{~N} .\end{array}$ & $\begin{array}{l}155.24 \text { W. } \\
155.10 \text { W. } \\
155.87 \text { W. } \\
156.81 \text { W. } \\
155.24 \text { W. }\end{array}$ & $\begin{array}{r}3 \\
8 \\
34 \\
33 \\
10\end{array}$ & $:$ & & $\begin{array}{l}3.6 \mathrm{H} \\
3.1 \mathrm{H} \\
3: 1 \mathrm{H} \\
3.2 \mathrm{H} \\
3.1 \mathrm{H}\end{array}$ & $\begin{array}{l}\cdots: \\
\because \because \\
\text { ii }\end{array}$ & $\begin{array}{l}\mathrm{H} \\
\mathrm{H} \\
\mathrm{H}\end{array}$ & $\begin{array}{ll}\text { DEC. } & 23 \\
\text { DEC : } & 24 \\
\text { DEC.: } & 24 \\
\text { DEC. } & 25 \\
\text { DEC. } & 28\end{array}$ & $\begin{array}{lll}01 & \text { A.M. HST } \\
01 & \text { H.M. HST } \\
01 & \text { P.M. HST } \\
05 & \text { A.M. HST } \\
11 & \text { A.M. HST }\end{array}$ \\
\hline $\begin{array}{l}\text { DEC. } \\
\text { DEC. }\end{array}$ & $\begin{array}{lll}02 & 04 & 10.0 \\
04 & 59 & 57.9\end{array}$ & $\begin{array}{l}19.94 \mathrm{~N} . \\
19.38 \mathrm{~N} .\end{array}$ & $\begin{array}{l}55.72 \text { W. } \\
5.48 \text { W. }\end{array}$ & 10 & $\because$ & & & ... & & $\begin{array}{ll}\text { DEC. } & 30 \\
\text { DEC. } & 30\end{array}$ & $\begin{array}{ll}04 & \text { P.M. } \\
06 & \text { P.M. HST }\end{array}$ \\
\hline
\end{tabular}

IDAHO

JUNE $3 \quad 045825.4 \quad 42.51$ N. 111.36 W. 5 
Table 1.--Sum mary of U.S. earthquakes for 1979-.Continued

\begin{tabular}{|c|c|c|c|c|c|c|c|c|c|c|c|}
\hline \multirow{2}{*}{$\begin{array}{c}\text { Date } \\
(1979)\end{array}$} & \multirow{2}{*}{$\begin{array}{l}\text { Origin time } \\
\text { hr } \min \end{array}$} & \multirow{2}{*}{ L.at } & \multirow{2}{*}{ Long } & \multirow{2}{*}{$\begin{array}{l}\text { Depth } \\
(\mathbf{k m})\end{array}$} & \multicolumn{3}{|c|}{ Magnitude } & \multirow{2}{*}{$\begin{array}{l}\text { Maximum } \\
\text { intensity }\end{array}$} & \multirow{2}{*}{$\begin{array}{c}\text { Hypocenter } \\
\text { source }\end{array}$} & \multicolumn{2}{|c|}{ Local tume } \\
\hline & & & & & $\mathrm{mb}$ & MS & $\begin{array}{l}\mathrm{ML} \text { or } \\
\mathrm{mbLg}\end{array}$ & & & Date & Hour \\
\hline
\end{tabular}

\section{KANSAS}

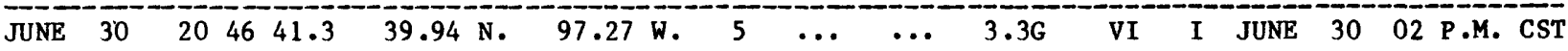

KENTUCKY

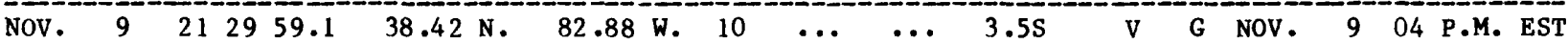

MAINE

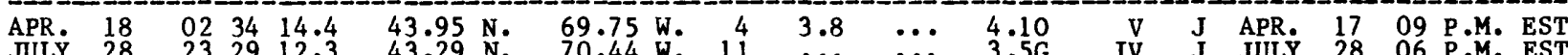

MINNESOTA

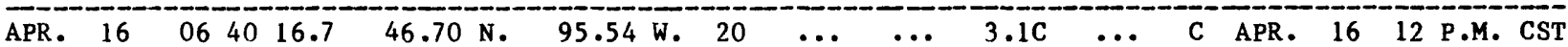

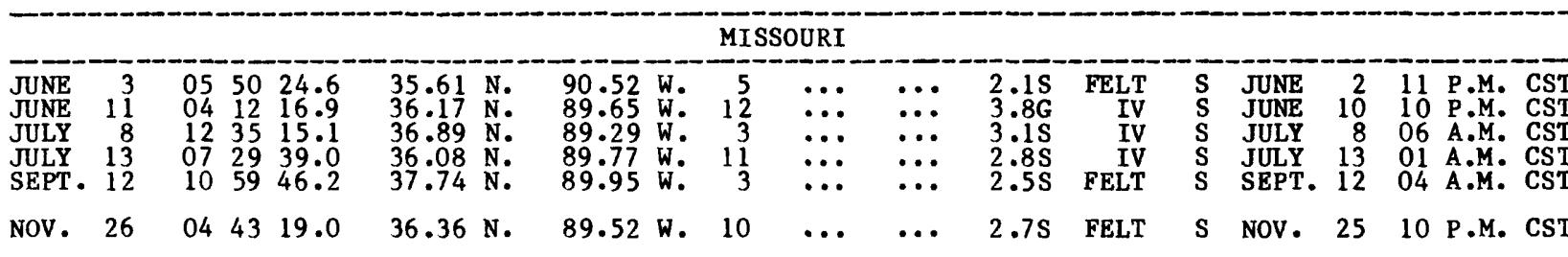

\begin{tabular}{|c|c|c|c|c|c|c|c|c|c|c|c|c|c|c|c|c|c|}
\hline \multirow{2}{*}{$\begin{array}{l} \\
\text { JAN. } \\
\text { JAN. } \\
\text { APR } \\
\text { MAY } \\
\text { MAY }\end{array}$} & \multicolumn{17}{|c|}{ MONTANA } \\
\hline & $\begin{array}{r}4 \\
6 \\
14 \\
4 \\
7\end{array}$ & $\begin{array}{ll}14 & 51 \\
01 & 25 \\
09 & 39 \\
18 & 58 \\
17 & 15\end{array}$ & $\begin{array}{r}24.8 \\
48.7 \\
6.4 \\
49.3 \\
43.4\end{array}$ & $\begin{array}{l}47.31 \\
44.84 \\
48.59 \\
47.09 \\
44.76\end{array}$ & $\begin{array}{l}\text { N. } \\
\text { N. } \\
\text { N. } \\
\text { N: } \\
\text { N. }\end{array}$ & $\begin{array}{l}113.14 \\
111.45 \\
112.41 \\
112.79 \\
111.14\end{array}$ & $\begin{array}{l}\text { W. } \\
\text { W. } \\
\text { W. } \\
\text { W. } \\
\text { W. }\end{array}$ & $\begin{array}{l}5 \\
5 \\
5 \\
5 \\
5\end{array}$ & $\because \cdots$ & $\because \cdots$ & $\begin{array}{l}3.0 \mathrm{D} \\
4.1 \mathrm{G} \\
3.2 \mathrm{G} \\
3.5 \mathrm{G} \\
3.2 \mathrm{G}\end{array}$ & $\ddot{\cdots}$ & $\begin{array}{l}\mathbf{G} \\
\mathbf{G} \\
\mathbf{G} \\
\mathbf{G} \\
\mathbf{G}\end{array}$ & $\begin{array}{l}\text { JAN. } \\
\text { JAN. } \\
\text { APR: } \\
\text { MAY } \\
\text { MAY }\end{array}$ & $\begin{array}{r}4 \\
5 \\
14 \\
4 \\
7\end{array}$ & $\begin{array}{ll}07 & \text { A.M. } \\
06 & \text { P.M. } \\
02 & \text { A.M. } \\
11 & \text { A.M. } \\
10 & \text { A.M. }\end{array}$ & 15 \\
\hline $\begin{array}{l}\text { MAY } \\
\text { MAY } \\
\text { MAY } \\
\text { MAY } \\
\text { MAY }\end{array}$ & $\begin{array}{r}8 \\
8 \\
8 \\
8 \\
30\end{array}$ & $\begin{array}{ll}00 & 56 \\
00 & 57 \\
00 & 58 \\
01 & 23 \\
15 & 19\end{array}$ & $\begin{array}{l}34.1 \\
42.9 \\
44.8 \\
18.3 \\
25.7\end{array}$ & $\begin{array}{l}44.77 \\
44.74 \\
44.75 \\
44.78 \\
44.95\end{array}$ & $\begin{array}{l}\text { N. } \\
\text { N. } \\
\text { N. } \\
\text { N. } \\
\text { N. }\end{array}$ & $\begin{array}{l}111.12 \\
111.20 \\
111.38 \\
111.08 \\
111.87\end{array}$ & $\begin{array}{l}\text { W. } \\
\text { W. } \\
\text { W. } \\
\text { W. } \\
\text { W. }\end{array}$ & $\begin{array}{l}5 \\
5 \\
5 \\
5 \\
5\end{array}$ & $\because \cdots$ & $\ddot{\cdots}$ & $\begin{array}{l}3.3 \mathrm{G} \\
3.9 \mathrm{G} \\
4.6 \mathrm{G} \\
3.4 \mathrm{G} \\
3.6 \mathrm{G}\end{array}$ & $\begin{array}{l}\text { III } \\
\text { IV } \\
\text { IV } \\
\text { III } \\
\ldots .\end{array}$ & $\begin{array}{l}\mathbf{G} \\
\mathbf{G} \\
\mathbf{G} \\
\mathbf{G}\end{array}$ & $\begin{array}{l}\text { MAY } \\
\text { MAY } \\
\text { MAY } \\
\text { MAY } \\
\text { MAY }\end{array}$ & $\begin{array}{r}7 \\
7 \\
7 \\
7 \\
30\end{array}$ & $\begin{array}{ll}05 & \text { P.M. } \\
05 & \text { P.M. } \\
05 & \text { P.M. } \\
06 & \text { P.M. } \\
08 & \text { A.M. }\end{array}$ & MS \\
\hline $\begin{array}{l}\text { JUNE } \\
\text { JULY } \\
\text { AUG. } \\
\text { OCT. } \\
\text { NOV. }\end{array}$ & $\begin{array}{r}22 \\
21 \\
9 \\
16 \\
30\end{array}$ & $\begin{array}{ll}12 & 02 \\
22 & 18 \\
17 & 12 \\
18 & 33 \\
07 & 07\end{array}$ & $\begin{array}{l}26.8 \\
47.3 \\
55.4 \\
44.6 \\
28.9\end{array}$ & $\begin{array}{l}45.32 \\
47.72 \\
48.49 \\
48.24 \\
45.75\end{array}$ & $\begin{array}{l}\text { N. } \\
N . \\
N: \\
N: \\
N .\end{array}$ & $\begin{array}{l}112.83 \\
114.15 \\
111.47 \\
114.54 \\
111.56\end{array}$ & $\begin{array}{l}\text { W. } \\
\text { W. } \\
\text { W. } \\
\text { W. } \\
\text { W. }\end{array}$ & $\begin{array}{l}5 \\
5 \\
5 \\
5 \\
5\end{array}$ & $\ddot{\because}$ & $\because \ldots$ & $\begin{array}{l}4.4 \mathrm{G} \\
3.5 \mathrm{G} \\
3.8 \mathrm{G} \\
3.1 \mathrm{G} \\
3.1 \mathrm{D}\end{array}$ & $\begin{array}{c}\text { IV } \\
\text { FELT } \\
\text { FELT } \\
\cdots . .\end{array}$ & $\begin{array}{l}\mathbf{G} \\
\mathbf{G} \\
\mathbf{G} \\
\mathbf{G} \\
\mathbf{G}\end{array}$ & $\begin{array}{l}\text { JUNE } \\
\text { JULY } \\
\text { AUG. } \\
\text { OCT. } \\
\text { NOV. }\end{array}$ & $\begin{array}{r}22 \\
21 \\
9 \\
16 \\
30\end{array}$ & $\begin{array}{ll}05 & \text { A.M. } \\
02 & \text { P.M. } \\
10 & \text { A.M. } \\
11 & \text { A.M. } \\
12 & \text { P.M. }\end{array}$ & MS \\
\hline
\end{tabular}

NEBRASKA

\begin{tabular}{|c|c|c|c|c|c|c|c|c|c|c|c|c|c|}
\hline $\begin{array}{l}\text { RNE } \\
\text { JLY } \\
\text { JLG }\end{array}$ & $\begin{array}{r}8 \\
6 \\
16 \\
2\end{array}$ & $\begin{array}{rrr}22 & 46 & 10.4 \\
16 & 16 & 22.4 \\
00 & 03 & 47.8 \\
4 & 16 & 22.2 \\
8 & 00 & 11.6\end{array}$ & $\begin{array}{l}40.97 \mathrm{~N} . \\
40.14 \mathrm{~N} . \\
40.18 \mathrm{~N} . \\
40.17 \mathrm{~N} . \\
40.16 \mathrm{~N} .\end{array}$ & $\begin{array}{rl}98.56 & \mathrm{~W} \\
100.41 & \mathrm{~W} \\
100.35 & \mathrm{~W} \\
100.40 & \mathrm{~W} \\
100.33 & \mathrm{~W}\end{array}$ & $\begin{array}{r}1 \\
2 \\
14 \\
1 \\
12\end{array}$ & $\because$ & $\ddot{\cdots}$ & $\begin{array}{l}2 . \\
2 \\
3 \\
2 \\
2\end{array}$ & iii & $\begin{array}{l}\mathbf{K} \\
\mathbf{K} \\
\mathbf{K} \\
\mathbf{K} \\
\mathbf{K}\end{array}$ & & 15 & $\begin{array}{l}04 \mathrm{P} \\
10 \\
06 \\
10 \\
10\end{array}$ \\
\hline
\end{tabular}

NEVADA

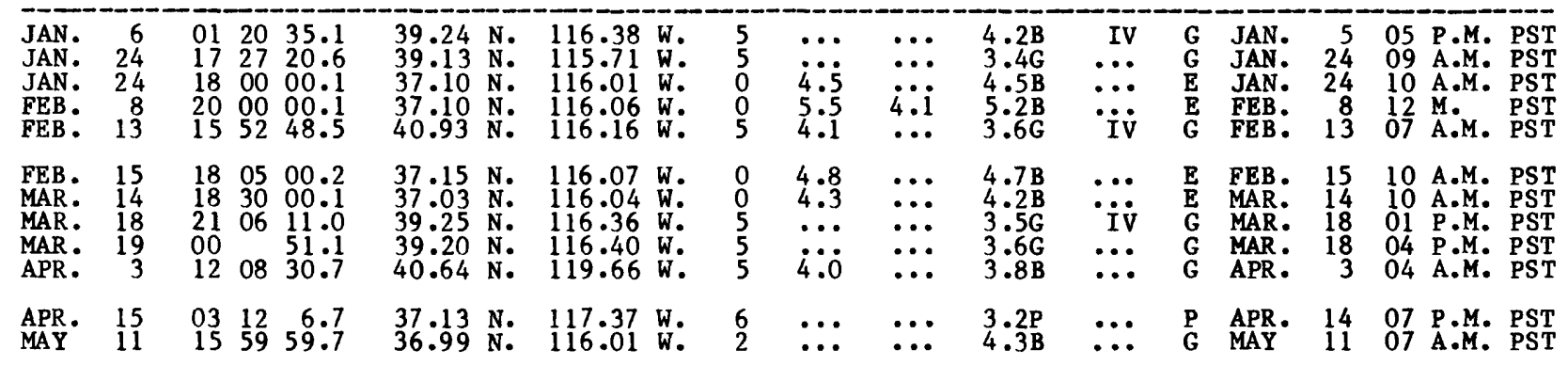


Table 1.--Summary of U.S. earthquakes for 1979--Continued

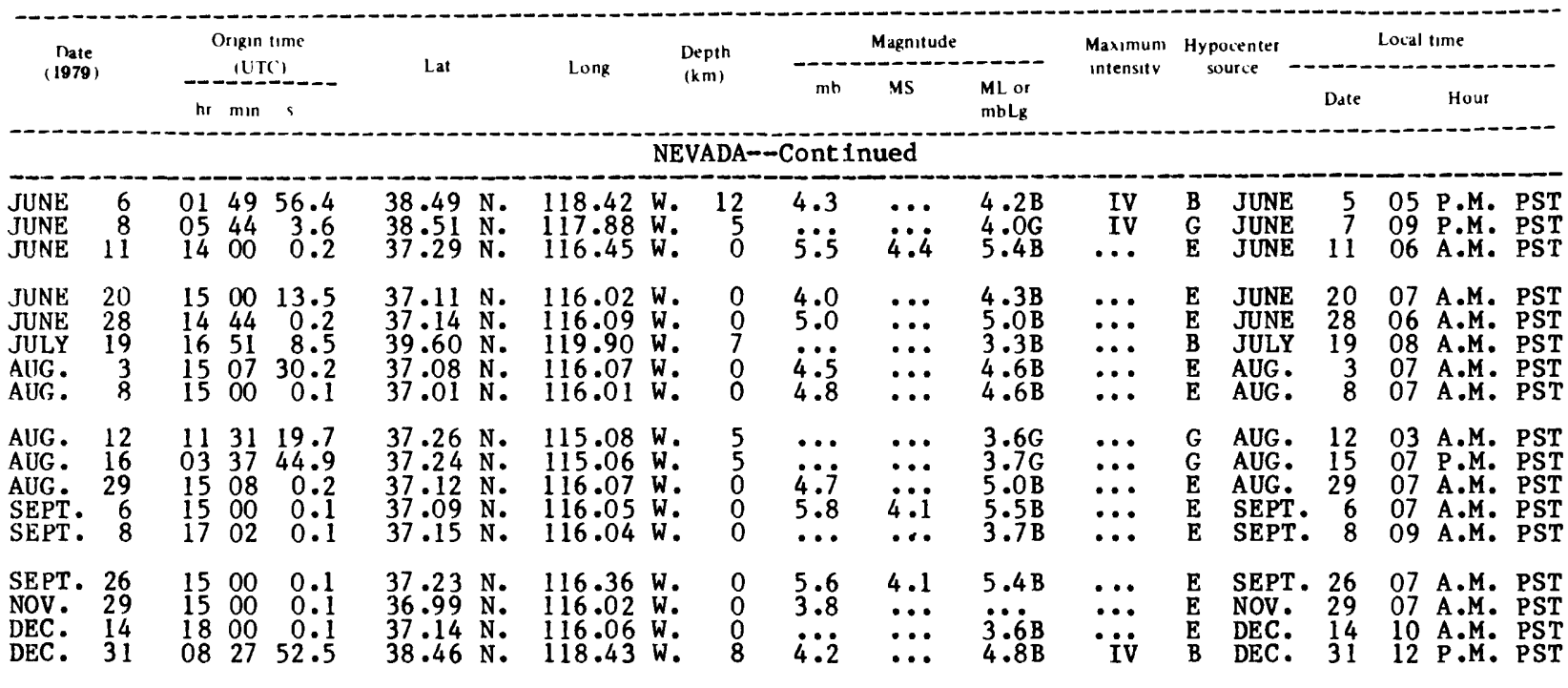

NEW HAMPSHIRE

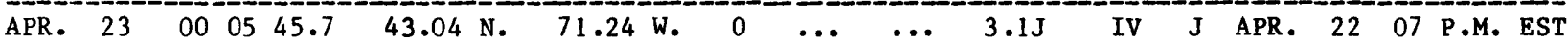

NEW JERSEY

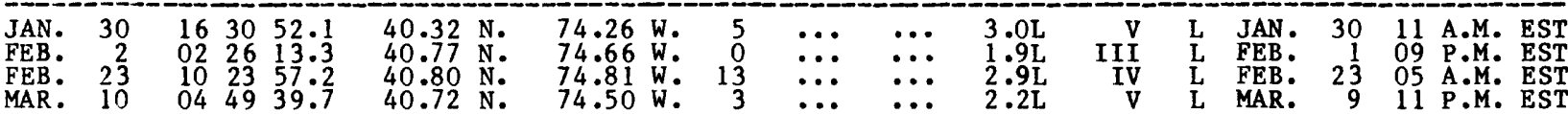

NEW YORK

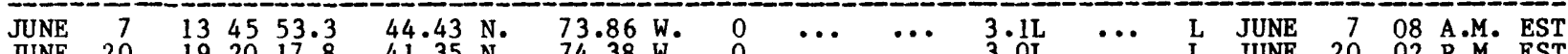

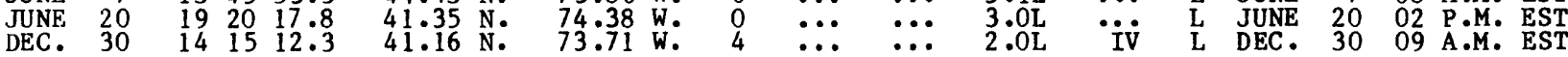

\begin{tabular}{|c|c|c|c|c|c|c|c|c|c|c|c|c|c|}
\hline \multirow{2}{*}{$\begin{array}{l}\text { MAR. } \\
\text { MAR: } \\
\text { MAR: } \\
\text { MAR: } \\
\text { MAR: }\end{array}$} & \multicolumn{13}{|c|}{ OKLАНОMA } \\
\hline & $\begin{array}{l}13 \\
14 \\
14 \\
18 \\
18\end{array}$ & $\begin{array}{lll}23 & 29 & 22.6 \\
03 & 10 & 56.8 \\
04 & 37 & 15.3 \\
20 & 44 & 19.5 \\
23 & 19 & 01.3\end{array}$ & $\begin{array}{l}35.42 \text { N. } \\
35.50 \\
35.52 \\
35.38 \\
34.10\end{array}$ & $\begin{array}{l}97.85 \text { W. } \\
97.83 \text { W. } \\
97.78 \text { W. } \\
98.12 \text { W. } \\
97.45 \text { W. }\end{array}$ & $\begin{array}{l}5 \\
5 \\
5 \\
5 \\
5\end{array}$ & $\because \cdots$ & $\begin{array}{l}\cdots \\
\cdots \\
\cdots\end{array}$ & $\begin{array}{l}1.7 \mathrm{~T} \\
1.9 \mathrm{~T} \\
2.2 \mathrm{~T} \\
2.9 \mathrm{~T} \\
2.3 \mathrm{~T}\end{array}$ & $\begin{array}{l}\text { II } \\
\text { IV } \\
\text { V } \\
\text { III } \\
\text { III }\end{array}$ & $\begin{array}{l}\mathrm{T} \\
\mathrm{T} \\
\mathrm{T} \\
\mathrm{T} \\
\mathrm{T}\end{array}$ & $\begin{array}{l}\text { MAR. } \\
\text { MAR: } \\
\text { MAR: } \\
\text { MAR: } \\
\text { MAR. }\end{array}$ & $\begin{array}{l}13 \\
13 \\
13 \\
18 \\
18\end{array}$ & $\begin{array}{lll}05 & P . M . & \text { CST } \\
09 & \text { P.M. CST } \\
10 & \text { P.M. CST } \\
02 & \text { P.M. CST } \\
05 & \text { P.M. CST }\end{array}$ \\
\hline $\begin{array}{l}\text { MAY } \\
\text { JUNE } \\
\text { JULY } \\
\text { SEPT. } \\
\text { SEPT. }\end{array}$ & $\begin{array}{l}22 \\
25 \\
13 \\
16\end{array}$ & $\begin{array}{lll}03 & 49 & 23.8 \\
07 & 39 & 35.6 \\
03 & 15 & 37.3 \\
00 & 49 & 23.0 \\
15 & 57 & 20.8\end{array}$ & $\begin{array}{l}34.03 \mathrm{~N} . \\
35.19 \\
33.97 \\
35.22 \\
35.34 \\
\text { N. }\end{array}$ & $\begin{array}{l}97.47 \text { W. } \\
99.81 \text { W. } \\
97.55 \text { W. } \\
99.36 \text { W. } \\
98.00 \text { W. }\end{array}$ & $\begin{array}{r}4 \\
5 \\
5 \\
15 \\
5\end{array}$ & $\begin{array}{l}\cdots \\
\cdots \\
\cdots\end{array}$ & $\begin{array}{l}\cdots \\
\cdots \\
\cdots\end{array}$ & $\begin{array}{l}1.9 \mathrm{~T} \\
3.0 \mathrm{~T} \\
2.7 \mathrm{~T} \\
3.4 \mathrm{~T} \\
2.5 \mathrm{~T}\end{array}$ & $\begin{array}{l}\text { III } \\
\text { IV } \\
V \\
\text { IV } \\
\text { IV }\end{array}$ & $\begin{array}{l}\mathrm{T} \\
\mathrm{T} \\
\mathrm{T} \\
\mathrm{T} \\
\mathrm{T}\end{array}$ & $\begin{array}{l}\text { MAY } \\
\text { JUNE } \\
\text { JULY } \\
\text { SEPT. } \\
\text { SEPT. }\end{array}$ & $\begin{array}{l}21 \\
7 \\
24 \\
12 \\
16\end{array}$ & $\begin{array}{ll}09 & \text { P.M. CST } \\
01 & \text { A.M. CST } \\
10 & \text { P.M. CST } \\
06 & \text { P.M. CST } \\
09 & \text { A.M. CST }\end{array}$ \\
\hline $\begin{array}{l}\text { SEPT. } \\
\text { DEC. }\end{array}$ & $\begin{array}{r}17 \\
9\end{array}$ & $\begin{array}{lll}20 & 41 & 50.5 \\
23 & 12 & 58.7\end{array}$ & $\begin{array}{l}35.32 \mathrm{~N} . \\
33.99 \mathrm{~N} .\end{array}$ & $\begin{array}{l}97.97 \text { W. } \\
97.35 \text { W. }\end{array}$ & $\begin{array}{l}5 \\
5\end{array}$ & & & $\begin{array}{l}2.5 \mathrm{~T} \\
2.5 \mathrm{~T}\end{array}$ & IV & $\begin{array}{l}\mathrm{T} \\
\mathrm{T}\end{array}$ & $\begin{array}{l}\text { SEPT. } \\
\text { DEC. }\end{array}$ & $\begin{array}{r}17 \\
9\end{array}$ & $\begin{array}{ll}02 & \mathrm{P} \cdot \mathrm{M} \\
05 & \mathrm{P} \cdot \mathrm{M}\end{array}$ \\
\hline
\end{tabular}

OREGON-OFF THE COAST

\begin{tabular}{|c|c|c|c|c|c|c|c|c|c|c|c|c|c|c|c|c|}
\hline $\begin{array}{l}\text { FEB. } \\
\text { FEB. } \\
\text { MAR. } \\
\text { MAR. }\end{array}$ & $\begin{array}{r}1 \\
1 \\
3 \\
15 \\
21\end{array}$ & $\begin{array}{ll}11 & 2 \\
16 & 2 \\
09 & 4 \\
09 & 5 \\
14 & 4\end{array}$ & $\begin{array}{ll}26 & 46.4 \\
23 & 51.4 \\
46 & 55.3 \\
50 & 24.2 \\
49 & 24.3\end{array}$ & $\begin{array}{l}42.57 \\
42.55 \\
42.71 \\
43.11 \\
42.09\end{array}$ & $\begin{array}{l}\text { N. } \\
\text { N. } \\
\text { N. } \\
\text { N. }\end{array}$ & $\begin{array}{l}126.35 \mathrm{~W} . \\
126.36 \mathrm{~W} . \\
126.02 \mathrm{~W} . \\
126.35 \mathrm{~W} . \\
126.79 \mathrm{~W} .\end{array}$ & $\begin{array}{l}15 \\
15 \\
15 \\
15 \\
15\end{array}$ & $\begin{array}{l}4.8 \\
4.3 \\
3.9 \\
3.9 \\
4.5\end{array}$ & $\begin{array}{l}4.2 \\
3.9 \\
\because ? \\
\because \cdots\end{array}$ & $\because \cdots$ & $\because \cdots$ & 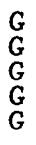 & ?. & $\begin{array}{r}1 \\
1 \\
3 \\
15\end{array}$ & $\begin{array}{l}03 \\
08 \\
01 \\
01 \\
06\end{array}$ & $\begin{array}{l}\text { A.M. PS } \\
\text { A.M. PS } \\
\text { A.M. PS } \\
A \cdot M \cdot \text { PS } \\
\text { A.M. PS }\end{array}$ \\
\hline $\begin{array}{l}\text { AY } \\
\text { AY } \\
\text { UNE } \\
\text { UNE } \\
\text { UNE }\end{array}$ & $\begin{array}{r}4 \\
22 \\
7 \\
19 \\
27\end{array}$ & $\begin{array}{ll}08 & 0 \\
14 & 4 \\
09 & 5 \\
18 & 4 \\
12 & 4\end{array}$ & $\begin{array}{ll}08 & 49.9 \\
41 & 15.9 \\
50 & 30.4 \\
44 & 38.2 \\
48 & 21.5\end{array}$ & $\begin{array}{l}43.57 \\
44.21 \\
43.53 \\
43.26 \\
43.30\end{array}$ & $\begin{array}{l}\mathrm{N}: \\
\mathrm{N}: \\
\mathrm{N}: \\
\mathrm{N} \text {. }\end{array}$ & $\begin{array}{l}127.21 \mathrm{~W} \\
128.86 \mathrm{~W} \\
127.09 \mathrm{~W} \\
126.20 \mathrm{~W} \\
126.55 \mathrm{~W}\end{array}$ & $\begin{array}{l}1 \\
1 \\
1 \\
1 \\
1\end{array}$ & $\begin{array}{l}4 \\
4 \\
4\end{array}$ & $\begin{array}{l}3 . \\
4\end{array}$ & $\ddot{\cdots}$ & $\ddot{\cdots}$ & & & 22 & $\begin{array}{l}12 \\
06 \\
01 \\
10 \\
04\end{array}$ & 28020 \\
\hline J & & $\begin{array}{l}01 \\
18\end{array}$ & $\begin{array}{ll}23 & 56 \\
43 & 12 .\end{array}$ & $\begin{array}{l}3.3 \\
3.9\end{array}$ & $\begin{array}{l}\mathrm{N} \\
\mathrm{N}\end{array}$ & $\begin{array}{l}126.34 \mathrm{~W} \\
128.34\end{array}$ & $\begin{array}{l}15 \\
15\end{array}$ & $\begin{array}{l}4.2 \\
4.7\end{array}$ & & & $\cdots$ & & $\begin{array}{l}\text { AUG. } \\
\text { OCT. }\end{array}$ & 31 & $\begin{array}{l}05 \\
10\end{array}$ & \\
\hline
\end{tabular}


Table 1.--Summary of U.S. earthquakes for 1979--Continued

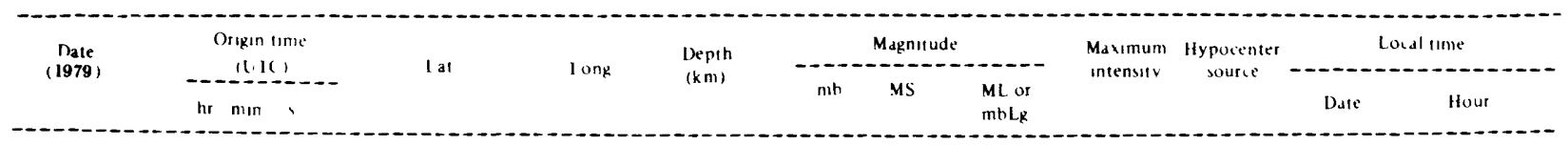

OREGON-OFF THE COAST-Continued

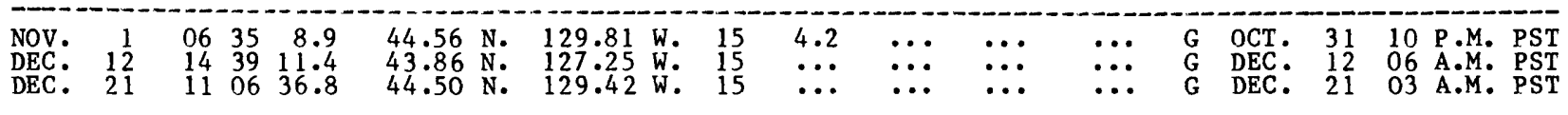

SOUTH CAROLINA

\begin{tabular}{|c|c|c|c|c|c|c|c|c|c|c|c|c|c|c|c|}
\hline $\begin{array}{l}\text { JAN. } \\
\text { FEB: } \\
\text { AUG: } \\
\text { AUG: } \\
\text { OCT. }\end{array}$ & $\begin{array}{r}19 \\
16 \\
11 \\
26 \\
8\end{array}$ & $\begin{array}{l}08 \\
14 \\
02 \\
01 \\
23\end{array}$ & $\begin{array}{ll}55 & 36.9 \\
37 & 08.4 \\
11 & 56.6 \\
31 & 45.0 \\
20 & 10.1\end{array}$ & $\begin{array}{ll}34.64 & \mathrm{~N} \\
34.34 & \mathrm{~N} \\
32.99 & \mathrm{~N} \\
34.93 & \mathrm{~N} \\
34.31 & \mathrm{~N}\end{array}$ & $\begin{array}{l}82.84 \\
81.36 \\
80.22 \\
82.97 \\
81.36\end{array}$ & $\begin{array}{l}\text { W. } \\
\text { W. } \\
\text { W: } \\
\text { W. } \\
\text { W. }\end{array}$ & $\begin{array}{r}1 \\
3 \\
10 \\
2 \\
5\end{array}$ & $\because \cdots$ & $\because \cdots$ & $\begin{array}{l}2.8 \mathrm{G} \\
3.3 \mathrm{G} \\
2.5 \mathrm{G} \\
3.7 \mathrm{~V} \\
2.9 \mathrm{G}\end{array}$ & $\begin{array}{r}\text { IV } \\
\text { IIII } \\
\text { VII }\end{array}$ & $\begin{array}{l}\mathrm{G} \\
\mathrm{G} \\
\mathrm{F} \\
\mathrm{G} \\
\mathrm{G}\end{array}$ & $\begin{array}{l}\text { JAN. } \\
\text { FEB: } \\
\text { AUG: } \\
\text { AUG: } \\
\text { OCT. }\end{array}$ & $\begin{array}{l}19 \\
16 \\
10 \\
25 \\
8\end{array}$ & 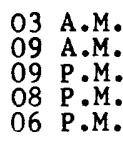 \\
\hline DEC. & 7 & 05 & 4335.0 & $33.01 \mathrm{~N}$ & 80.17 & w. & 6 & $\ldots$ & $\bullet$ & $2.9 \mathrm{G}$ & IV & G & DEC. & 7 & 12 P.M. \\
\hline
\end{tabular}

\section{TENNESSEE}

\begin{tabular}{|c|c|c|c|c|c|c|c|c|c|c|c|c|c|c|c|c|c|}
\hline $\begin{array}{l}\text { FEB. } \\
\text { FEB } \\
\text { FE B. } \\
\text { FE B. }\end{array}$ & $\begin{array}{r}2 \\
2 \\
2 \\
3 \\
13\end{array}$ & $\begin{array}{ll}11 & 17 \\
18 & 49 \\
18 & 50 \\
06 & 56 \\
05 & 18\end{array}$ & $\begin{array}{l}04.9 \\
33.0 \\
18.9 \\
42.3\end{array}$ & $\begin{array}{l}36.27 \\
36.26 \\
36.27 \\
36.26 \\
35.24\end{array}$ & $\begin{array}{l}\text { N. } \\
\text { N: } \\
\text { N: } \\
\text { N: }\end{array}$ & $\begin{array}{l}89.47 \mathrm{~W} \\
89.45 \mathrm{~W} \\
89.46 \mathrm{~W} \\
89.47 \mathrm{~W} \\
84.38 \mathrm{~W}\end{array}$ & N.: & $\begin{array}{l}2 \\
3 \\
4 \\
4\end{array}$ & $\because \cdots$ & $\because \ldots$ & $\begin{array}{l}2 . \\
1 . \\
2 \\
2\end{array}$ & $\begin{array}{r}\text { III } \\
\text { II } \\
\text { IIII } \\
\text { FELT }\end{array}$ & $\begin{array}{l}S \\
S \\
S\end{array}$ & & $\begin{array}{l}2 \\
2 \\
2 \\
2\end{array}$ & $\begin{array}{l}05 \text { A.M. } \\
12 \text { M. } \\
12 \text { M. } \\
12 \text { P.M. } \\
12 \text { P.M. }\end{array}$ & $\begin{array}{l}\mathrm{CST} \\
\mathrm{CST} \\
\mathrm{CST}\end{array}$ \\
\hline 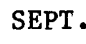 & & 062 & 3.6 & 5.59 & & $83.90 \mathrm{~W}$ & N. & & $\cdots$ & 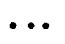 & $.0 v$ & & & EP1. & 12 & $01 \mathrm{~A} . \mathrm{M}$ & \\
\hline
\end{tabular}

\section{TEXAS}

JULY 5 01 05 1.0 32.95 N. 100.90 W. 4 ... UTAH

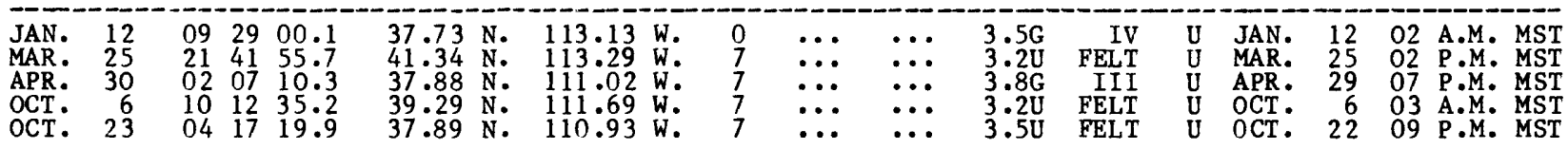

\section{VERMONT}

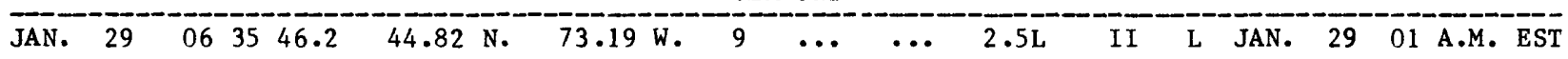

WASHINGTON

\begin{tabular}{|c|c|c|c|c|c|c|c|c|c|c|c|c|c|c|c|c|}
\hline $\begin{array}{l}\text { JAN. } \\
\text { FEB: } \\
\text { MAR: } \\
\text { MAR: } \\
\text { APR. }\end{array}$ & $\begin{array}{r}19 \\
1 \\
11 \\
12 \\
8\end{array}$ & $\begin{array}{ll}14 & 55 \\
20 & 18 \\
14 & 39 \\
12 & 41 \\
07 & 29\end{array}$ & $\begin{array}{l}16.0 \\
28.1 \\
32.8 \\
37.0 \\
37.4\end{array}$ & $\begin{array}{l}47.90 \\
47.53 \\
46.45 \\
48.19 \\
46.00\end{array}$ & $\begin{array}{l}\text { N. } \\
\text { N. } \\
\text { N. } \\
\text { N. } \\
\text { N. }\end{array}$ & $\begin{array}{l}119.69 \\
121.92 \\
122.40 \\
122.76 \\
118.45\end{array}$ & $\begin{array}{l}\text { W. } \\
\text { W. } \\
\text { W. } \\
\text { W. } \\
\text { W. }\end{array}$ & $\begin{array}{r}7 \\
9 \\
16 \\
24 \\
5\end{array}$ & $\begin{array}{l}\ddot{3} \\
\ddot{3} \ddot{8} \\
3.8 \\
\cdots\end{array}$ & $\ddot{\cdots}$ & $\begin{array}{l}3.6 \mathrm{G} \\
3.6 \mathrm{G} \\
3.8 \mathrm{G} \\
3.4 \mathrm{G} \\
3.2 \mathrm{G}\end{array}$ & $\begin{array}{l}\text { V } \\
\text { IV } \\
\text { VI } \\
\text { V } \\
\text { V }\end{array}$ & $\begin{array}{l}\text { W } \\
\text { W } \\
\text { W } \\
\text { W } \\
\text { W }\end{array}$ & $\begin{array}{l}\text { JAN. } \\
\text { FEB : } \\
\text { MAR: } \\
\text { MAR: } \\
\text { APR. }\end{array}$ & $\begin{array}{l}19 \\
11 \\
11 \\
12 \\
7\end{array}$ & $\begin{array}{ll}06 & \text { A.M. } \\
12 & \text { M. } \\
06 & \text { A.M. } \\
04 & \text { A.M. } \\
11 & \text { P.M. }\end{array}$ \\
\hline $\begin{array}{l}\text { JULY } \\
\text { JULY } \\
\text { SEPT. } \\
\text { NOV. } \\
\text { NOV. }\end{array}$ & $\begin{array}{r}7 \\
28 \\
5 \\
26 \\
27\end{array}$ & $\begin{array}{ll}20 & 50 \\
02 & 19 \\
03 & 49 \\
23 & 18 \\
02 & 13\end{array}$ & $\begin{array}{r}1.5 \\
6.9 \\
59.4 \\
27.0 \\
46.5\end{array}$ & $\begin{array}{l}46.52 \\
46.67 \\
47.52 \\
48.54 \\
48.59\end{array}$ & $\begin{array}{l}\text { N. } \\
\text { N. } \\
\text { N. } \\
\text { N. } \\
\text { N. }\end{array}$ & $\begin{array}{l}122.17 \\
120.59 \\
122.00 \\
122.41 \\
122.41\end{array}$ & $\begin{array}{l}\text { W. } \\
\text { W. } \\
\text { W. } \\
\text { W. } \\
\text { W. }\end{array}$ & $\begin{array}{r}5 \\
0 \\
7 \\
20 \\
20\end{array}$ & $\ddot{4} \ddot{1}$ & & $\begin{array}{l}3.8 \mathrm{G} \\
3.1 \mathrm{G} \\
2.1 \mathrm{~W} \\
3.9 \mathrm{G} \\
3.3 \mathrm{G}\end{array}$ & $\begin{array}{r}\text { IV } \\
\text { IV } \\
\text { FELT } \\
\text { IV } \\
\text { III }\end{array}$ & $\begin{array}{l}\mathrm{G} \\
\mathbf{W} \\
\mathrm{W} \\
\mathrm{W} \\
\mathbf{G}\end{array}$ & $\begin{array}{l}\text { JULY } \\
\text { JULY } \\
\text { SEPT. } \\
\text { NOV. } \\
\text { NOV. }\end{array}$ & $\begin{array}{r}7 \\
27 \\
4 \\
26 \\
26\end{array}$ & $\begin{array}{ll}12 & \text { M. } \\
06 & \text { P.M. } \\
07 & \text { P.M. } \\
03 & \text { P.M. } \\
06 & \text { P.M. }\end{array}$ \\
\hline EC. & 10 & 0540 & 6.1 & 46.66 & N. & 120.58 & W. & 5 & 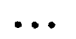 & 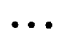 & $.2 \mathrm{G}$ & IV & W & $\mathrm{EC}$. & 9 & 09 \\
\hline
\end{tabular}

WASHINGTON-OFF THE COAST

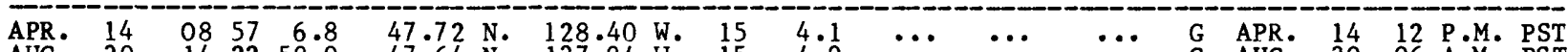

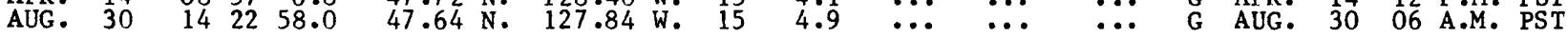

\section{WYOMING}

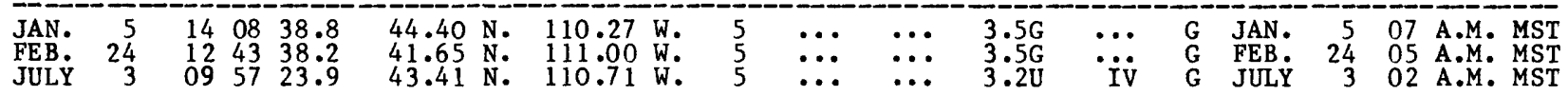




\section{Network Operations}

\section{ALASKA EARTHQUAKES, 1979}

\author{
By Larry Gedney \\ Geophysical Institute \\ University of Alaska \\ Fairbanks, Alaska 99701
}

During 1979, the Geophysical Institute of the University of Alaska located 3,761 Alaskan earthquakes occurring within the boundaries of its various networks. This figure is down slightly from the 4,281 located in 1978, and this is probably due in part to slight reconfigurations in the network mandated by changing research objectives.

During 1979, the National Earthquake Information Service published the parameters of 476 Alaskan earthquakes which were deemed large enough to include in the Preliminary Determination of Epicenters bulletin and in the Earthquake Data Report. This figure compares with a total of 261 events appearing in these publications for all the other states combined. In spite of the large number of locatable earthquakes in Alaska, felt reports were received from only 65 of them, 11lustrating the remoteness of most of Alaska from population centers. As might be expected, more than half (35) of these earthquakes occurred in southcentral Alaska around the population centers of Anchorage and the Kenal Peninsula, and another 15 centered around Fairbanks and nearby populated areas of the Central Interior.

One of the largest earthquakes to occur worldwide during the decade was centered near Mt. St. Eli as on 28 February, 1979. This earthquake had a surface-wave magnitude of about 7.4 . The Mt. St. Ellas area, near where the panhandle of southeast Alaska joins the rest of the state, occupies one of the "seismic gaps" around the northeast Pacific rim, thought to be potential candidates for future great earthquakes. This earthquake and its aftershock sequence, however, only partially filled this gap.

Other large Alaskan earthquakes ocurring in 1979 included events of magnitude 6.0 and 6.4 on the Alaska Peninsula on January 27 and May 20 , respectively. At least 10 other earthquakes with magnitudes greater than 5.0 occurred during the year, with about half of those in the Aleutians.

One 1979 Alaskan earthquake was interesting, not by virtue of its large size, but from the time-space profile exhibited by it and its aftershocks. This was one of a sequence of small earthquake swarms which have intermittent1y occurred near Fairbanks since a series of large earthquakes there in 1967. The main 1979 shock occurred on February 22 local time, and had an ML of 4.6. The point of interest is that it and its aftershock sequence extended the aftershock zone of a similar swarm in 1977 1inearly to the northwest and to greater depths (figures $27,28,29$, and 30 ).

The configuration of the seismographic net operated by the Geophysical Institute during 1979 is shown in figure 31. In general, most of the stations around the coastal margins are operated under the auspices of the Outer Continental Shelf Environmental Assessment Program, administered by NOAA. Some support for the southern net is also recelved from the U.S. Department of Energy. Stations in the Alaskan Interior are primarily funded by the state of Alaska.

Data originating at the various seismometers were transmitted in analog format to central recording sites at Fairbanks and Homer, Alaska, via combinations of VHF, tropospheric scatter and satellite communication links. Communication ties with the NOAA Alaska Tsunami Warning Center at Palmer, Alaska, permit realtime mutual data exchange with both the USGS and NOAA. Cooperative data acquisition and analysis is also carried out with the Lamont-Doherty Geological observatory, which operated stations in the Shumagin Islands region of the Aleutians.

\section{NORTHERN AND CENTRAL CALIFORNIA EARTHQUAKES, 1979}

\author{
By Robert A. Uhrhammer \\ Selsmographic Station \\ 475 Earth Sciences Building \\ University of California, Berkeley \\ Berkeley, California 94720
}

Some 5,800 events were noted on summary sheets and 1,150 teleseisms and 477 local earthquakes were analyzed during 1979. The Bullet in of the Seismographic Stations, Volume 49, No. 1 (January-June, 1979, by Murtha and others, 1980), and No. 2 (July-December, 1979, by McKenzie and others, 1981), contain location and magnitude data for 136 earthquakes ( $3.0<M L<5.8$ ) located in northern and central California and adjoining regions. The epicentral locations are plotted in figure 32 . 


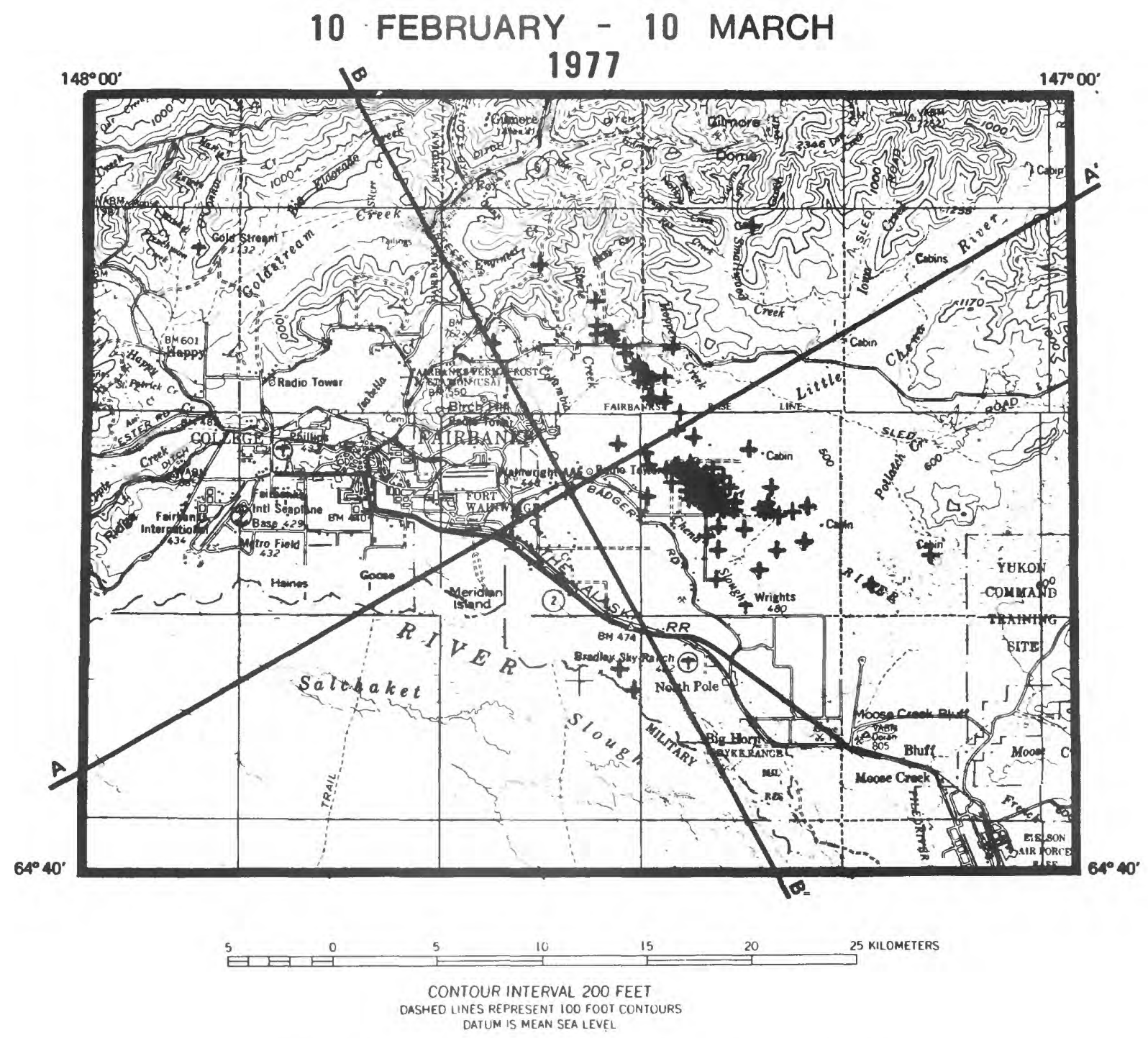

FIGURE 27.--Locations of the 1977 Fairbanks earthquake swarm.

A plot of the cumulative number of earthquakes versus local Richter magnitude (ML) is given in figure 33. The data set consists of 895 earthquakes ( $3.0<\mathrm{ML}<5.9)$ 1isted in the U.C. Bulletin of the Selsmographic stations, in a $280,000 \mathrm{sq} \mathrm{km}$ region in northern and central California during the decade of January 1, 1967 to December 31,1976 . The region is bounded on the north and east by the California border, on the southeast by the dashed line in figure 33, on the southwest by a line connecting $35^{\circ} \mathrm{N}$. by $121^{\circ}$ W. and $39^{\circ} \mathrm{N}$. by $125^{\circ} \mathrm{W}$. , and on the west by $125^{\circ}$ W. longitude. The earthquakes are grouped into 20 consecutive 6-month intervals for analysis, and the average cumulative number of earthquakes $N$ (total number with magnitude > ML) in a 6-month interval is given by

$$
\log N=4.412-0.912 \mathrm{ML}
$$

(valid for $3.0<M L<5.9$ ). The shaded zone in figure 33 depicts the $95 \%$ confidence interval for $\log \mathrm{N}$.

The open circles in figure 33 give the cumulative number of earthquakes ( 49 earthquakes, $3.0 \leq M L \leq 5.9)$ in the first 6 months of 1979, and the solid circles give the cumulative number of earthquakes ( 87 earthquakes, $3.0<M L<5.8$ ) in the last 6 months of 1979. There is thus no indication that the rate of seismicity for the first 6 months of 1979 is significantly different from the average semiannual rate of seismicity over the past decade. However, the rate of seismicity for the last 6 months of 1979 is significantly higher than the average semiannual rate of seismicity over the past decade. The high rate of seismicity for the last 6 months of 1979 is primarily due to 


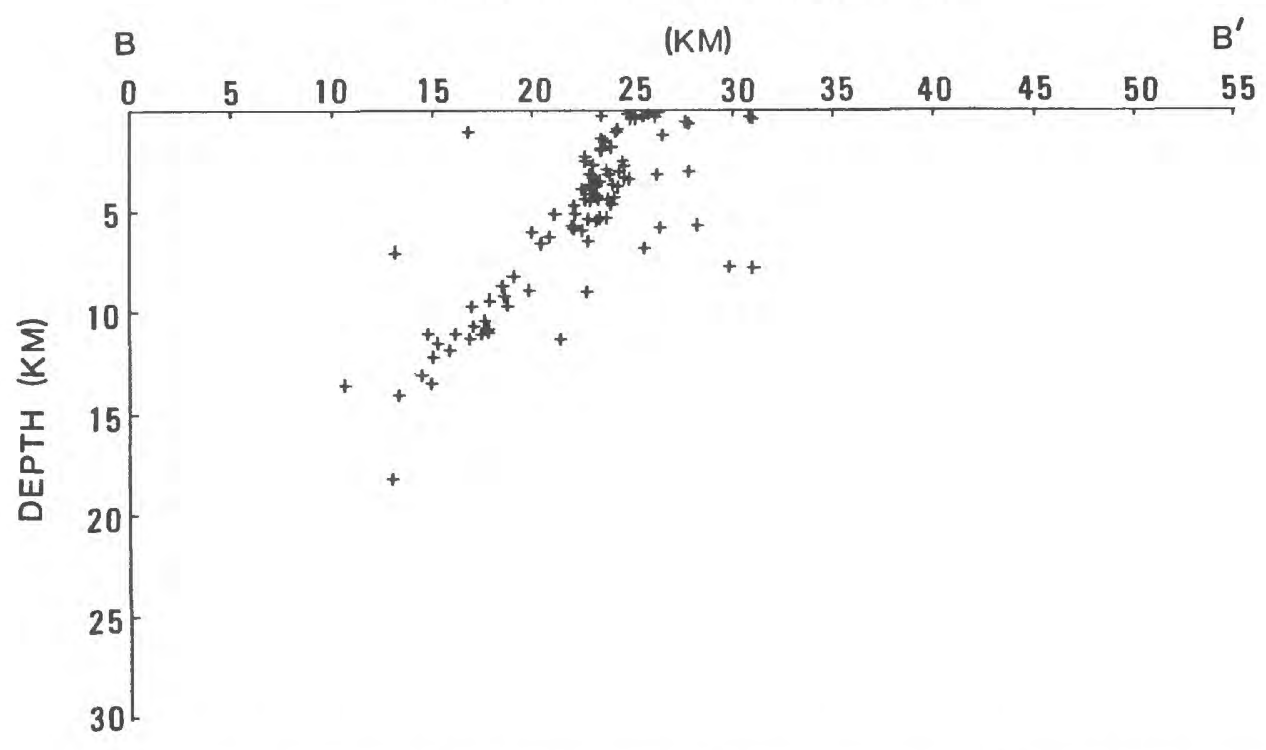

FIGURE 28.--Plot of distance versus depth for the 1977 earthquake swarm.

the occurrence of earthquake sequences at Coyote Lake and Bridgeport.

A sequence of 19 earthquakes $(3.0<M L<5.8)$ centered in the vicinity of Coyote lake, approximately $30 \mathrm{~km}$ north of Hollister, occurred during August, 1979. This sequence contained the largest earthquake $(M L=5.8)$ to have occurred in northern and central California during 1979.

The Seismograhic Station operated a network of 19 stations during 1979. One set of instruments located at Berkeley (BKS), a threecomponent ultralong-period seismograph ( $\mathrm{Ts}=100$ sec) which is recorded photographically and on magnetic tape, is of particular interest. Displacement transducers are used on the selsmometers to detect the boom deflection and the displacement signals are recorded photographically with a peak magnification of 500 at a period of 100 seconds, after being filtered to simulate a velocity transducer coupled to a 300 second galvonometer. The displacement signals are also recorded on analog magnetic tape at two gain levels, + 20 microns full scale (flat in displacement response from $0.1 \mathrm{sec}$ to $100 \mathrm{sec}$ ) and $+2 \mathrm{~mm}$ full scale (flat from $0-10 \mathrm{~Hz}$ ). As an example, figure 34 shows the displacement selsmograms of the Coyote Lake mainshock (ML 5.8 on August 6,1979 , centered $120 \mathrm{~km}$ southeast of Berkeley) recorded by the ultralong-period selsmograph at Berkeley.

\section{SOUTHERN CALIFORNIA EARTHQUAKES, 1979}

By L. K. Hutton, J. H. Whitcomb, C. R. Allen Seismological Laboratory

Calffornia Institute of Technology

Pasadena, California 91125

and

C. E. Johnson

U.S. Geological Survey at Seismological Laboratory

Calffornia Institute of Technology

Pasadena, California 91125

During the calendar year 1979, 8453 local earthquakes were located by the 138-station Southern California Seismographic Network, which is operated jointly by the California Institute of Technology and the U.S. Geological Survey. Figure 35 shows these events plotted on a map of the region, with the major faults indicated. Caltech maintains an earthquake catalogue complete above magnitude 3.0 in the area enclosed by the box in the figure.

Sixty-nine of the year's earthquakes were 4.0 or greater in magnitude. The most significant sequences were: (1) the January 1 Malibu earthquake ( $M L=5.0$ ) and af tershocks; (2) the 


\section{3-25 FEBRUARY 1979}
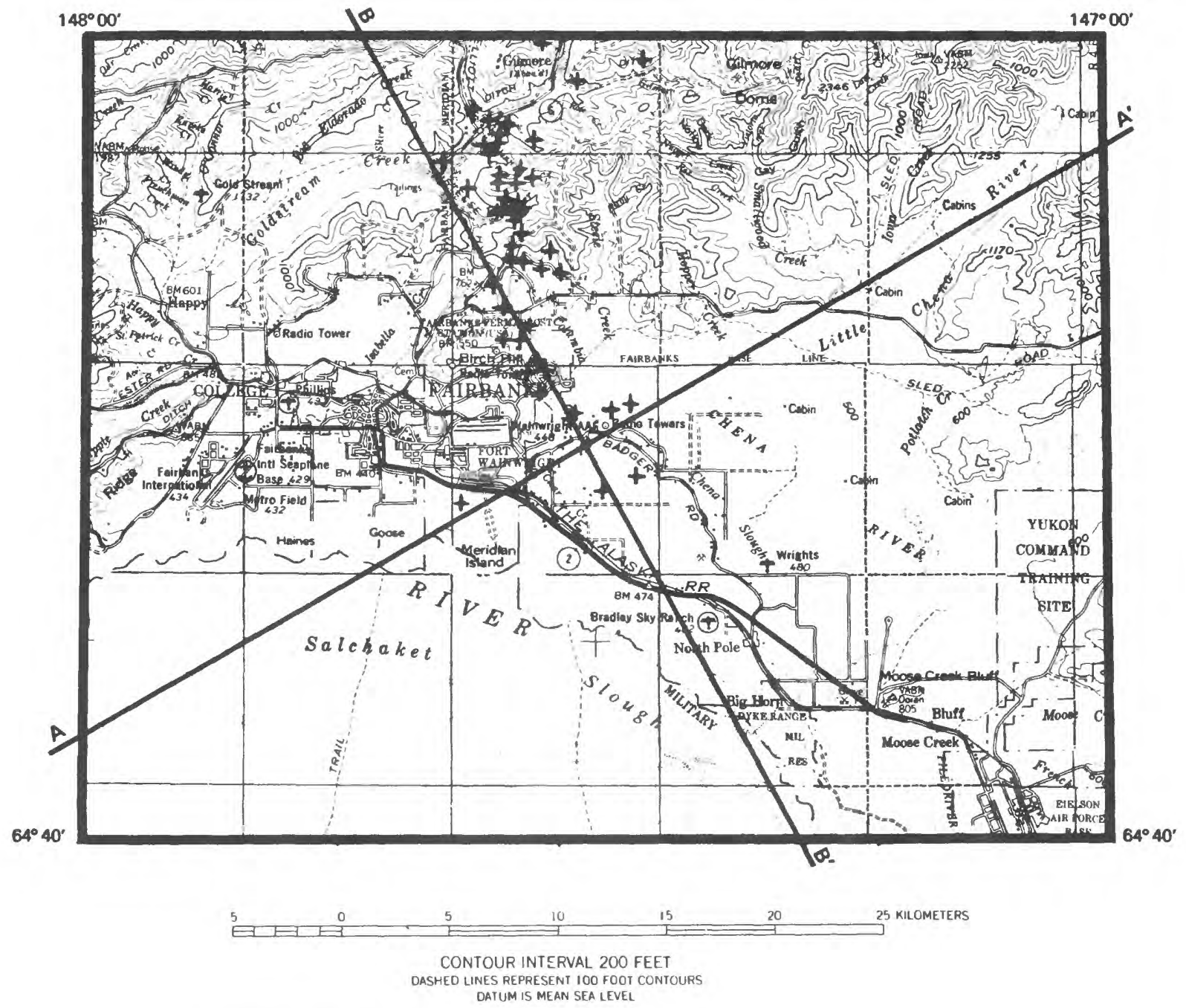

FIGURE 29.--Locations of the 1979 Fairbanks earthquake swarm.

March 15 Homestead Valley sequence (1argest events ML $=4.9,5.2$, and 4.5) with its 2300 locatable members (Hutton and others, 1980); (3) a Big Bear Lake sequence (largest event ML = 4.9) In late June and early July; and (4) the October 15 Imperial Valley earthquake $(M L=6.6$ ) and Its aftershocks (C. E. Johnson and L. K. Hutton, unpub. data, 1981). The first three caused minor damage, while the Imperial Valley sequence caused extensive damage in the towns of E1 Centro and Brawley. Figures 36 and 37 show detalls of the epicentral distributions of the Homestead Valley and Imperial Valley sequences.

This level of seismic activity represents a substantial increase over the previous few years. During 1978 and 1979, five events of ML $>5.0$ occurred, as compared to one each in 1973 (Pt. Mugu ML $=5.9$ ) and 1976 (Galway Lake $M L=$ 5.2). The Imperial Valley shock was the first
ML > 6.0 event since 1971 , and the largest since 1952. Southern Callfornia has apparently returned to the selsmicity level that it had prior to the 1952 Kern County earthquake.

\section{HAWAII EARTHQUAKES, 1979}

By Fred W. Klein

Hawalian Volcano Observatory

U.S. Geological Survey

Hawali Natłonal Park, Hawa11 96718

The emphasis in 1979 by the Hawalian Volcano Observatory (HVO) in both station coverage and detalled data analysis was on the highly active south flank of the 1sland of Hawali. Hundreds of earthquakes too small to locate were counted dally, and the set of located earthquakes in the Kilauea region is nearly complete 


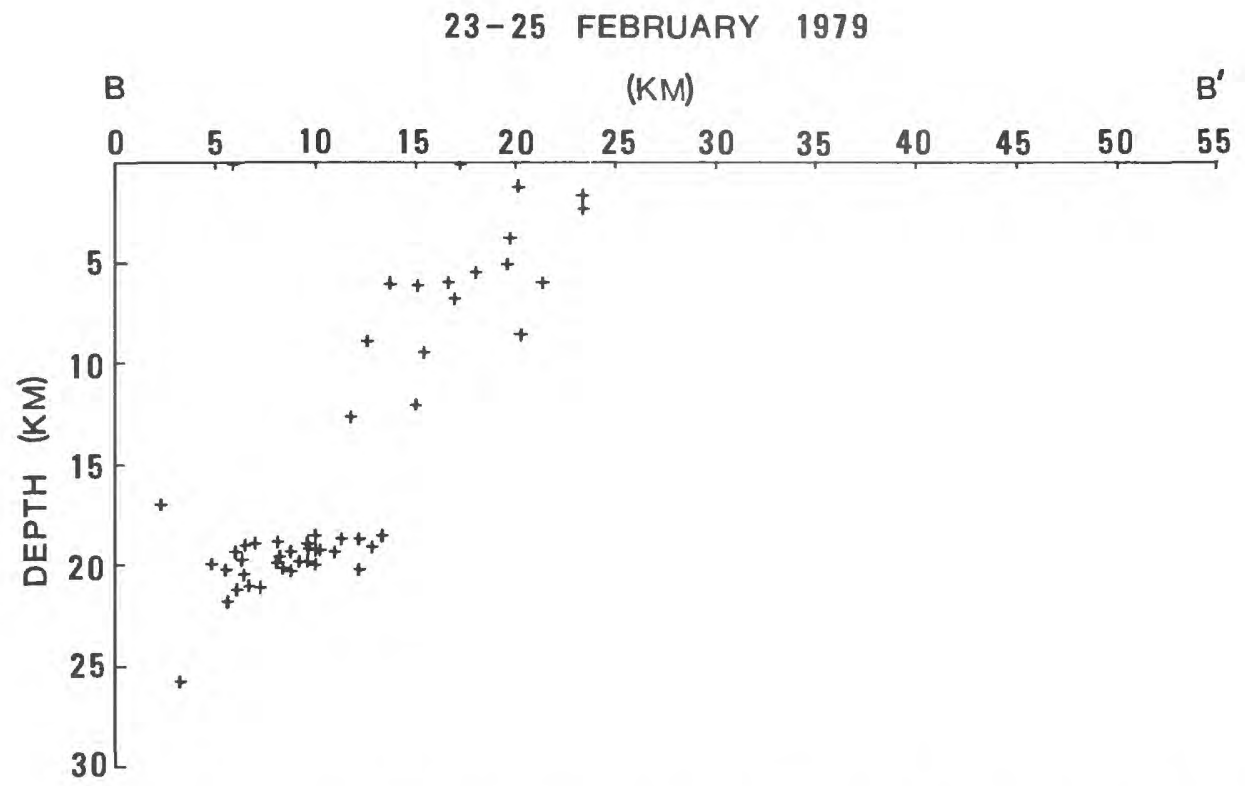

FIGURE 30.--Plot of distance versus depth for the 1979 earthquake swarm.

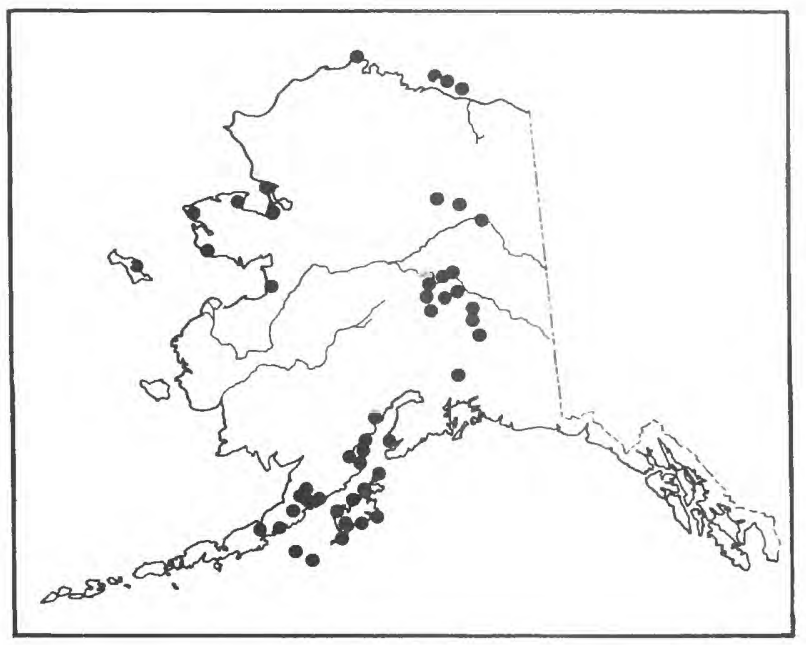

FIGURE 31.--University of Alaska seismographic stations operated in 1979. 


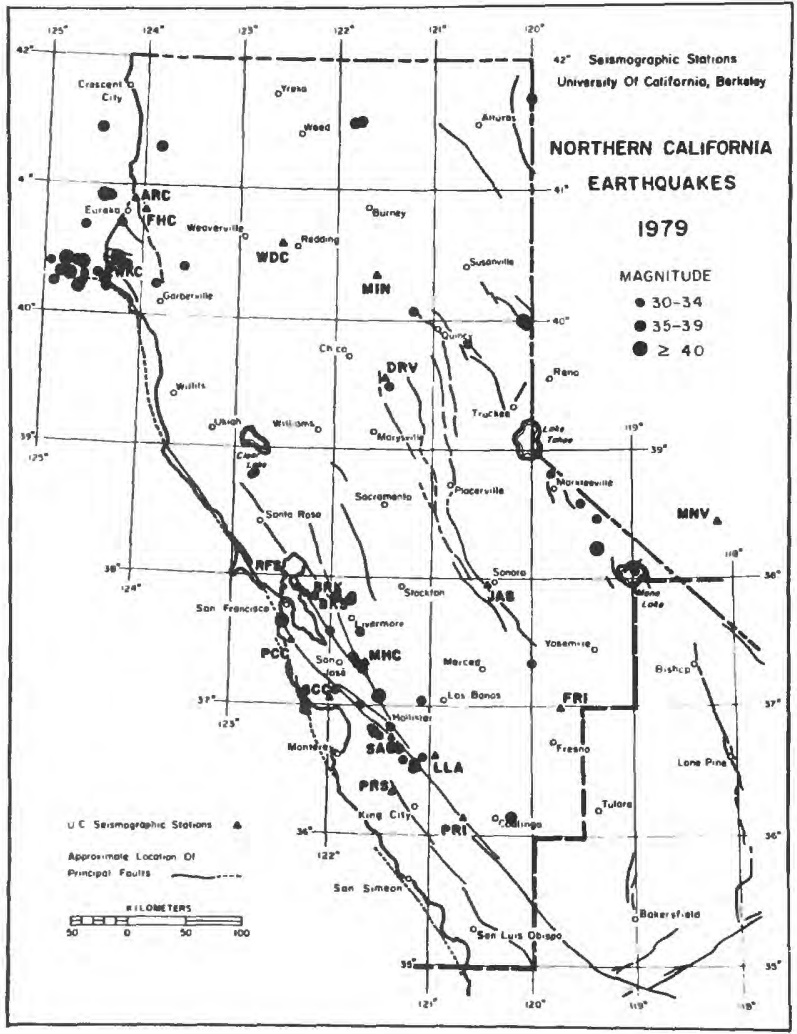

FIGURE 32.--Northern and centra1 Ca1ifornia earthquakes during 1979.

RECENT RATE OF SEISMICITY FOR NORTHERN A CENTRAL CALIFORNIA

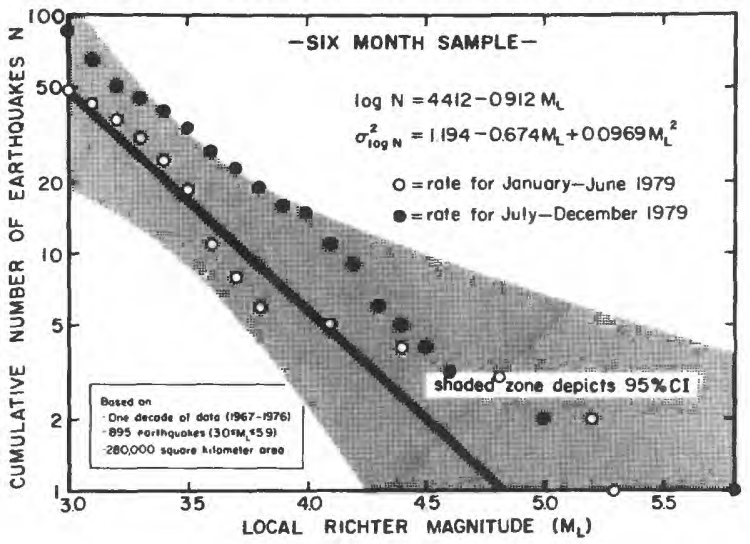

FIGURE 33.--P1ot of the cumulative number of earthquakes versus local Richter magnitude (ML).

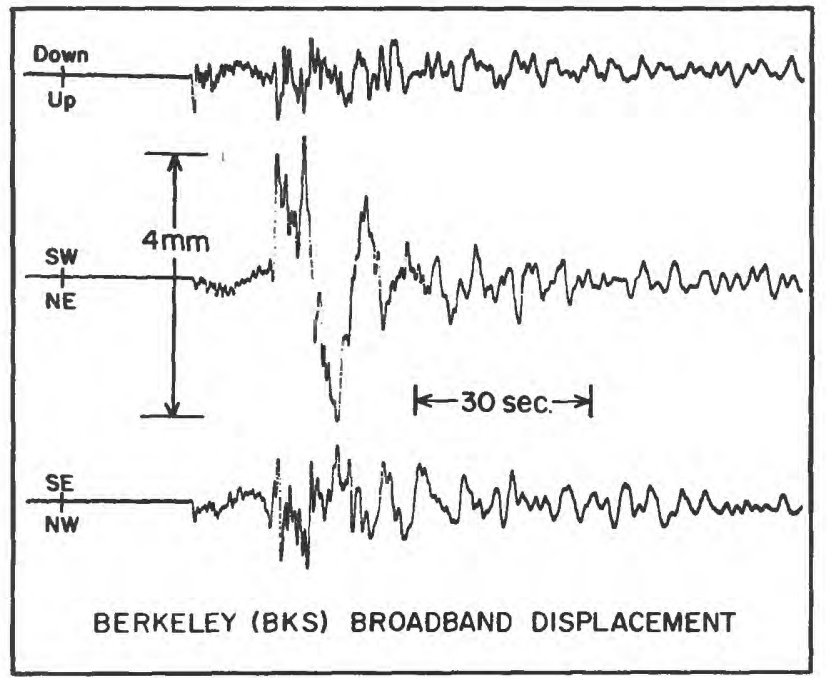

FIGURE 34.-Displacement selsmograms of the Coyote Lake mainshock ( 6 August 1979, ML = 5.8) recorded by the u1tralong-period seismograph at Berkeley. 


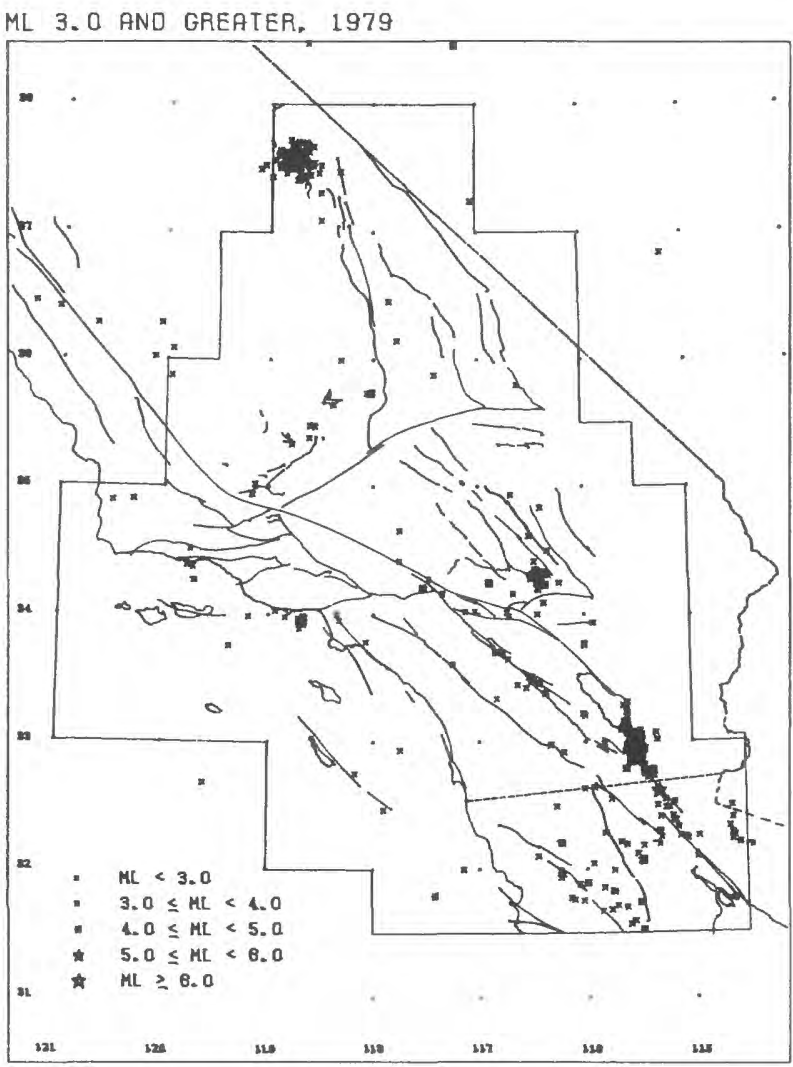

FIGURE 35.--Southern California earthquakes of magnitude 3.0 ML or greater during 1979.

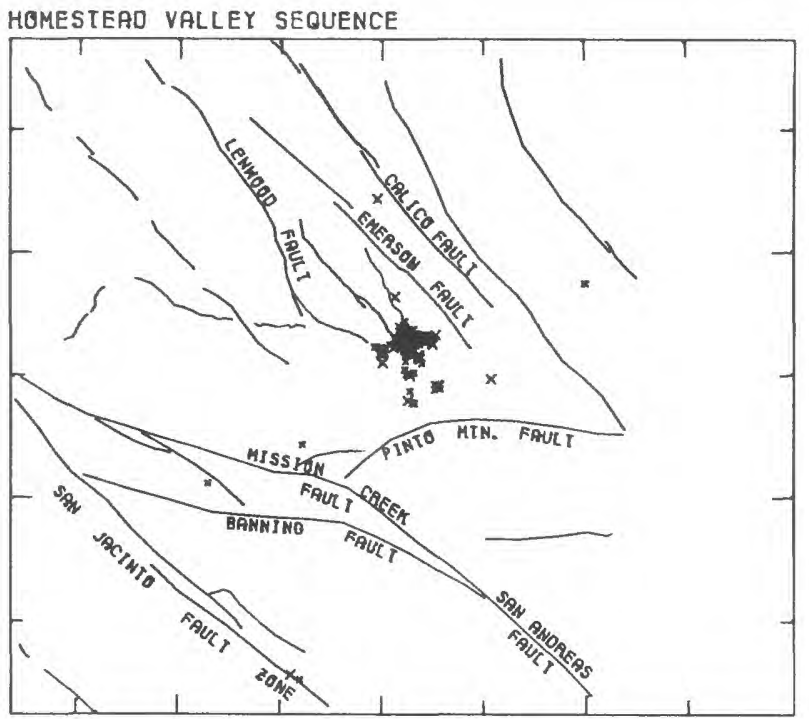

FIGURE 36.--The Homestead Valley, California earthquake sequence (ML $\geq 2.5$ ) of 15 March 1979.
IMPERIAL VALLEY SEQUENCE

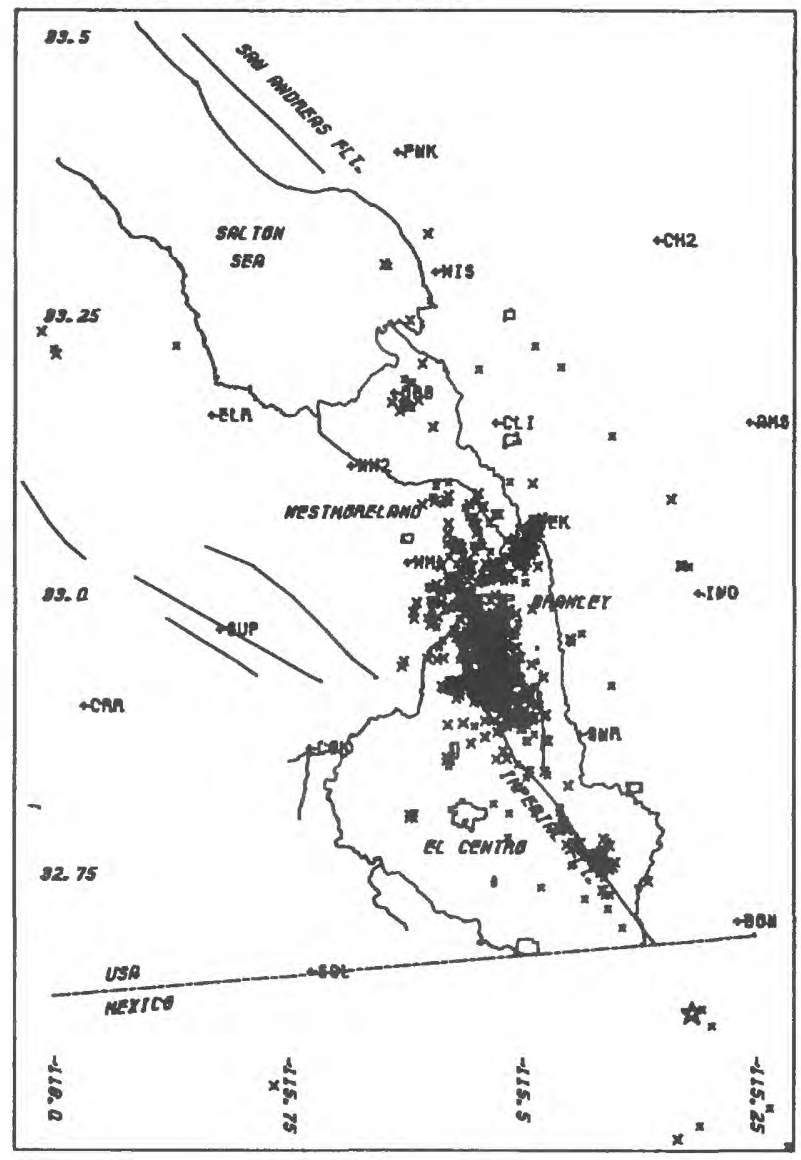

FIGURE 37.--The Imperial Valley, California earthquake and its aftershocks (ML $\geq 2.5$ ) of 15 October 1979. 
above magnitude about 2.0. Many smaller events were also located. Substantial effort was made to locate earthquakes elsewhere on the 1sland and within about $150 \mathrm{~km}$ of the 1sland. Such coverage cannot be as complete as on the south flank (fig. 38), but nearly all events above magnitude 3.0 to 3.5 were located.

There was a marked increase in the frequency of felt earthquakes at Kilauea during March, and shallow summit quake counts increased to nearly 500 per day during April-May. This activity culminated in an east rift zone intrusion on May 29-30. The event was heralded by several felt earthquakes which roughly coincided with the onset of summit deflation at 0.3 microradians/hour. This modest rate was maintained for roughly 5 hours, after which subsidence slowed before levelling off early on May 30 after a net deflation of 2.7 microradians. A simultaneous swarm of shallow earthquakes which began near buried Aloi crater migrated slightly uprift at an average rate of $1.3 \mathrm{~km} / \mathrm{hr}$ during the first 1.5 hours of intense activity, then moved downrift to Makaopuhi crater at roughly $0.6 \mathrm{~km} / \mathrm{hr}$. Nearly 2,000 earthquakes ranging upward in magnitude to $M=3.3$ were recorded by the HVO seismic network during the first 15 hours of anomalous activity.

Attention was again focused on Kilauea's upper east rift zone during June-July, when shallow earthquakes became concentrated between Keanakakol and Pauahi craters. $A M=4.0$ earthquake along the middle east rift zone on July 15 was followed by a brief seismic flurry, but no discernible harmonic tremor or summit deflation. On August 12, a swarm of shallow earthquakes and rapid summit deflation totalling 1 microradian marked a second intrusion in the upper east rift zone. During the first few hours of activity, earthquakes migrated downrift from Keanakakoi to Kokoolau at a mean rate of $1.4 \mathrm{~km} / \mathrm{hr}$. No measureable ground deformation within the epicentral

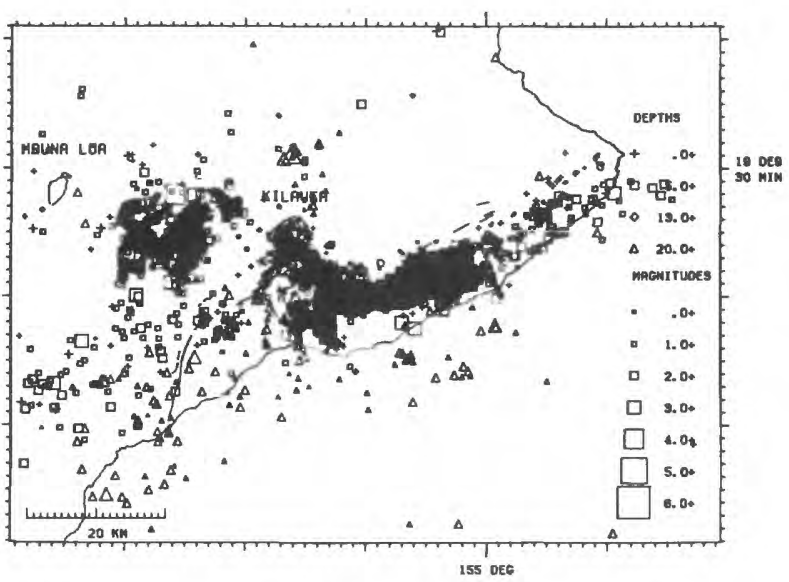

FIGURE 38.--1979 epicenter map of K1laueaMauna Loa showing all located earthquakes. zone accompanied this relatively minor intrusive event.

The September-November period was characterized by resumed summit inflation at roughly $10 \mathrm{microradians} / \mathrm{mon}$ th and generally increasing seismicity at the summit and along the upper east rift zone. Hawail's largest seismic event since November 1975 occurred on September 21, when a $M=5.4$ quake struck the south flank of Kilauea roughly $7 \mathrm{~km}$ south of Kalalua. The quake followed a substantial inflation of the east rift zone between Makaopuhi and Heiheiahulu since the September 1977 eruption, and was presumably caused in part by accumulated magma pressure. Dry tilt measurements along the rift zone in early September revealed as much as 125 microradians inflation since October 1977, but another survey after the $M=5.4$ earthquake indicated a distinct reversal of this trend. Presumably, ground movements associated with the quake at least partially relleved accumulated stress caused by shallow magma storage within the rift zone.

The Hawalian Volcano Observatory has installed and maintains an extensive telemetering seismometer network on the island of Hawail (fig. 39). In December 1979 the seismometer network consisted of 44 stations spread over an area with a diameter of $125 \mathrm{~km}$ on the island of Hawail. Of these 44 stations, 2 are low-gain multicomponent stations (optical), 6 are 2component, 4 are 3 -component, and 32 are vertical only. The coverage is most complete on and around the main center of seismic and volcanic activity, Kilauea Volcano. other stations in the network are part of a larger net located on other volcanoes of the island of Hawail. With

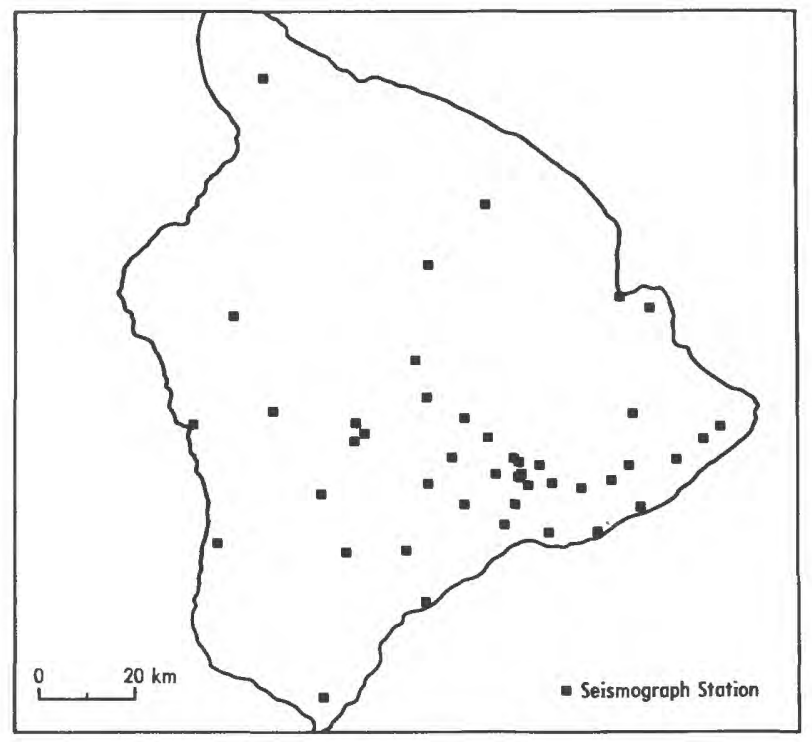

FIGURE 39.--Seismometer network on the island of Hawali. 
the exception of the station at Hilo, all seismometer signals from the short period network are telemetered to the observatory for recording.

In addition, optical selsmographs are maintained at Uwekahuna (HVO), H1lo, Maui, and on Oahu (Kipapa station operated by the Pacific Tsunami Warning Center). The less sensitive short period records are used primarily for amplitude measurements for magnitude calculations to supplement readings from the high-gain stations. Hilo and Haleakala are each equipped with two low-gain Wood-Anderson torsion selsmographs. Long perlod Press-Ewing seismographs record in three components in the Uwekahuna vault. The paper (optical) records as well as the $16 \mathrm{~mm}$ develocorder microfilm are archived at HVO.

\section{KANSAS EARTHQUAKES, 1979}

\author{
By Don W. Steeples \\ Kansas Geological Survey \\ Universfty of Kansas \\ Lawrence, Kansas 66044
}

Table 2 lists all earthquakes located in Kansas and western Missouri during 1979. These locations were done using the earthquake location computer program (Lee and Lahr, 1972). Figure 40 shows all microearthquake activity recorded since December 1, 1977. Also shown on figure 40 are events located in Nebraska (from table 5 below) which show trends of microearthquake activity that cross the Kansas-Nebraska border.

In northeast Kansas an interesting earthquake trend has developed along the northwest flank of the Midcontinent Geophysical Anomaly (MGA) since November 1, 1978 (fig. 41). This activity includes a felt event (MM Intensity IV) on June 30,1979 , that represents the largest earthquake in Kansas since 1961. The University of Minnesota has also recorded at least two earthquakes of about magnitude 1.5 along the western flank of the MGA in Minnesota during 1979 (Mooney and Walton, 1980). The Iowa Geological Survey has recently installed a 5station network along the MGA in southwestern Iowa, so monitoring of this important Midcontinent feature will be available for much of its leng th.

Three events have recently been recorded in Barber County, southcentral Kansas, in an area where no microearthquake activity had previously been noted. These epicenters are within about $25 \mathrm{~km}$ of a MM Intensity $\mathrm{V}$ event that occurred in 1956. When one considers that the uncertainties in the microearthquake locations are 5 to $10 \mathrm{~km}$ and that the uncertainty of the location of the 1956 event is perhaps $30 \mathrm{~km}$ or more, it is very possible that the recent activity and the 1956 event were on the same structure. The seismicity is coincident with a pre-Desmoinesian post-Mississippian structure known as the Pratt ant icline.

This activity in Barber County is about the same distance west of the Humboldt fault zone as the activity along the MGA in northern Kansas. This spatial relationship to the Humboldt fault zone and the north-northeasterly trend of Precambrian basement faults in Pratt County north of Barber County

may suggest the continuation of

a much-subdued MGA southward into Oklahoma along a trend just east of Pratt and Barber counties, Kansas. A second vertical derivative map of aeromagnetic data indicates such a continuation as pointed out by Yarger (1981).

Microearthquake activity between McCook, Nebraska and Norton, Kansas has been pinpointed southeast of Indianola, Nebraska on the Central Kansas Uplift. It is not certain that all the seismicity occurred there, but the concentration has been there since March, 1979, when three portable stations were installed in the area (fig. 42). This selsmicity is discussed in detall in Nebraska Earthquakes, 1979 below.

Elsewhere, selsmicity along the Humboldt fault zone continued at a low leve1. Both the pattern of earthquakes and other geological and geophysical studies indicate a complex pattern of structures on both sides of the Nemaha Ridge.

Table 2.--Kansas earlhquakes, 1979

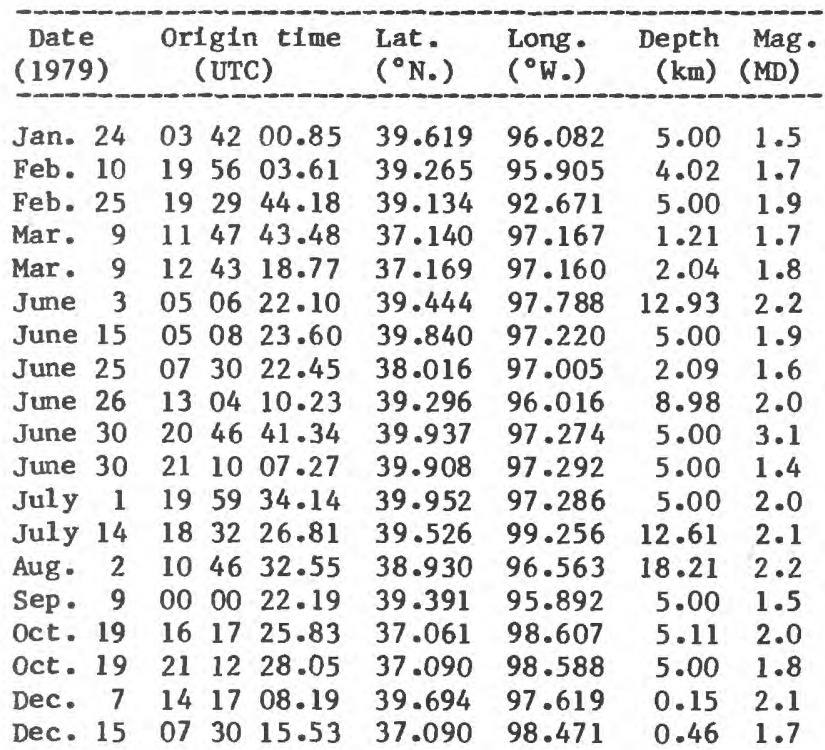




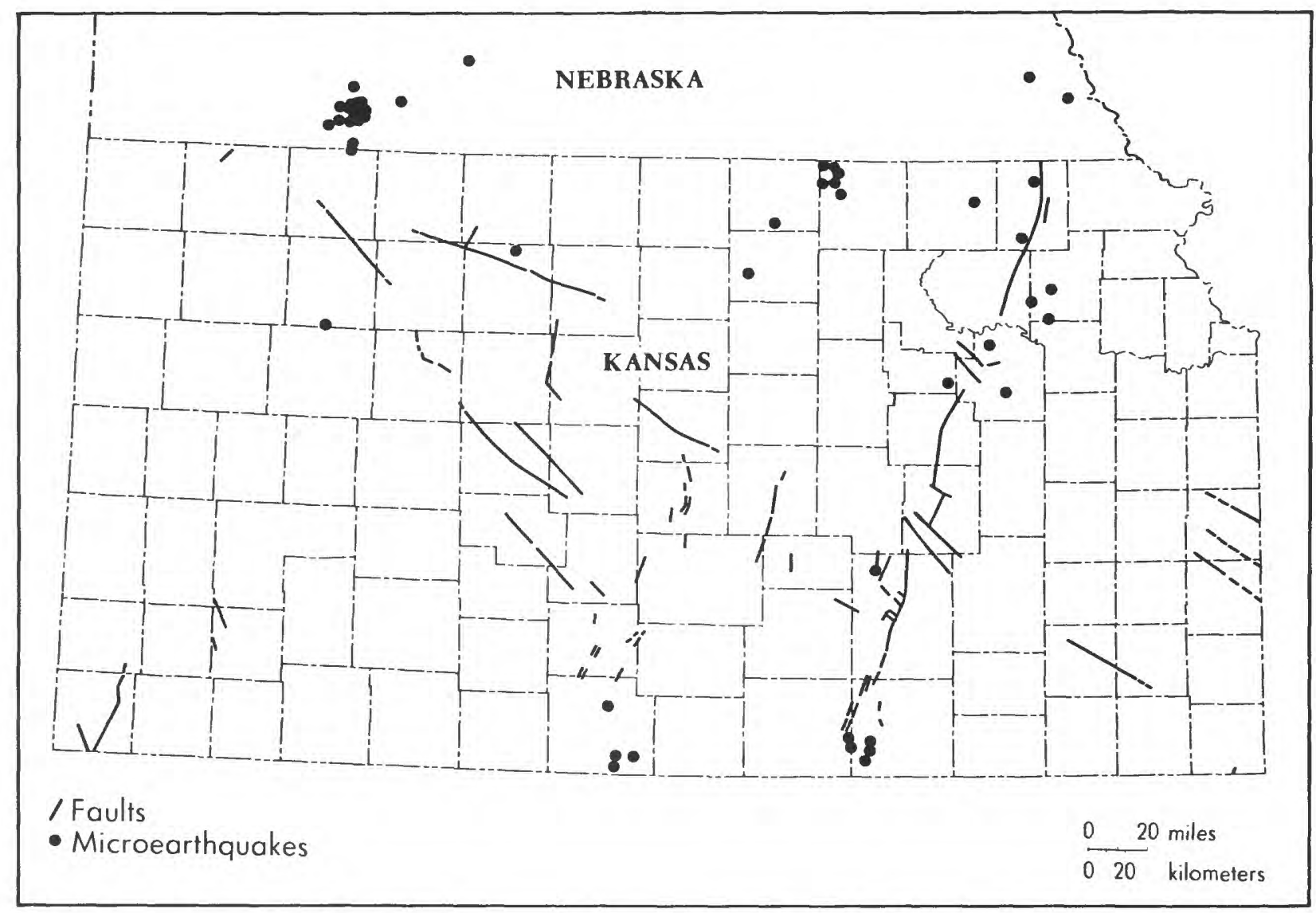

FIGURE 40.-Microearthquake activity in Kansas and southern Nebraska from December 1,1977 to February 28, 1980.

\section{MINNESOTA EARTHQUAKES, 1979}

By Harold M. Mooney

Department of Geology and Geophysics

University of Minnesota

Minneapolis, Minnesota 55455

A six-element array is operated in eastcentral Minnesota by the University of Minnesota and the Minnesota Geological Survey. Each element is based upon a $1 \mathrm{~Hz}$ vertical seismometer. Diameter of the array is $27 \mathrm{~km}$. The array location with respect to the state of Minnesota is shown in figure 43. Station locations are given in table 3. Seismometer outputs are multiplexed and transmitted by phone 1 ine $100 \mathrm{~km}$ to Minneapolis, where they are recorded on magnetic tape using a common time base along with WWVB time code.

Three earthquakes within Minnesota were recorded by the Central Minnesota Seismic Array in 1979. Their parameters are 1isted in table 4 and their locations are shown in figure 43 .
Table 3.--Station locations for the Central

Minnesota Seismic Array

\begin{tabular}{|c|c|c|c|c|c|}
\hline Code & $\begin{array}{l}\text { Station } \\
\text { Number }\end{array}$ & $\begin{array}{l}\text { Lat. } \\
\left({ }^{\circ} \mathrm{N}_{0}\right)\end{array}$ & $\begin{array}{l}\text { Long. } \\
\text { ('W.) }\end{array}$ & $\begin{array}{r}\text { Bleva } \\
\text { (neters) }\end{array}$ & $\begin{array}{l}\text { Ion } \\
\text { See }\end{array}$ \\
\hline CMI & 1 & 45.934 & 93.353 & 324.6 & 1065 \\
\hline $\mathrm{CM} 2$ & 2 & 45.974 & 93.162 & 323.1 & 1060 \\
\hline $\mathrm{CM}_{3}$ & 3 & 45.875 & 93.010 & 294.1 & 965 \\
\hline CM4 & 4 & 45.750 & 93.102 & 298.7 & 980 \\
\hline CMS & 5 & 45.783 & 93.323 & 298.7 & 980 \\
\hline CM6 & 6 & 45.860 & 93.198 & 310.9 & 1020 \\
\hline
\end{tabular}

Table 4,--1979 Minnesota earlhquakes recorded by the Central Minnesola Seismic Array

\begin{tabular}{|c|c|c|c|c|c|c|}
\hline $\begin{array}{l}\text { Date } \\
(1979)\end{array}$ & $\begin{array}{l}\text { Origin time } \\
\text { (UTC) }\end{array}$ & $\begin{array}{l}\text { Lat. } \\
\left({ }^{\circ} \mathrm{N}_{2}\right)\end{array}$ & $\begin{array}{l}\text { Long: } \\
\text { ( } \mathrm{W},)^{-}\end{array}$ & $\begin{array}{l}\text { Depth } \\
(\mathrm{km})\end{array}$ & Mag. & Location \\
\hline $\begin{array}{lr}\text { Mar. } & 6 \\
\text { Apr. } & 16 \\
\text { May } 14\end{array}$ & $\begin{array}{lll}00 & 27 & 56.1 \\
06 & 40 & 16.7 \\
19 & 27 & 38.5\end{array}$ & $\begin{array}{l}45.848 \\
46.697 \\
45.720\end{array}$ & $\begin{array}{l}93.748 \\
95.540 \\
92.992\end{array}$ & $\begin{array}{r}5 \\
20 \\
6\end{array}$ & $\begin{array}{l}1.0 \\
3.1 \\
0.1\end{array}$ & $\begin{array}{l}\text { Milaca } \\
\text { Detrolt Lakes } \\
\text { Rush City }\end{array}$ \\
\hline
\end{tabular}




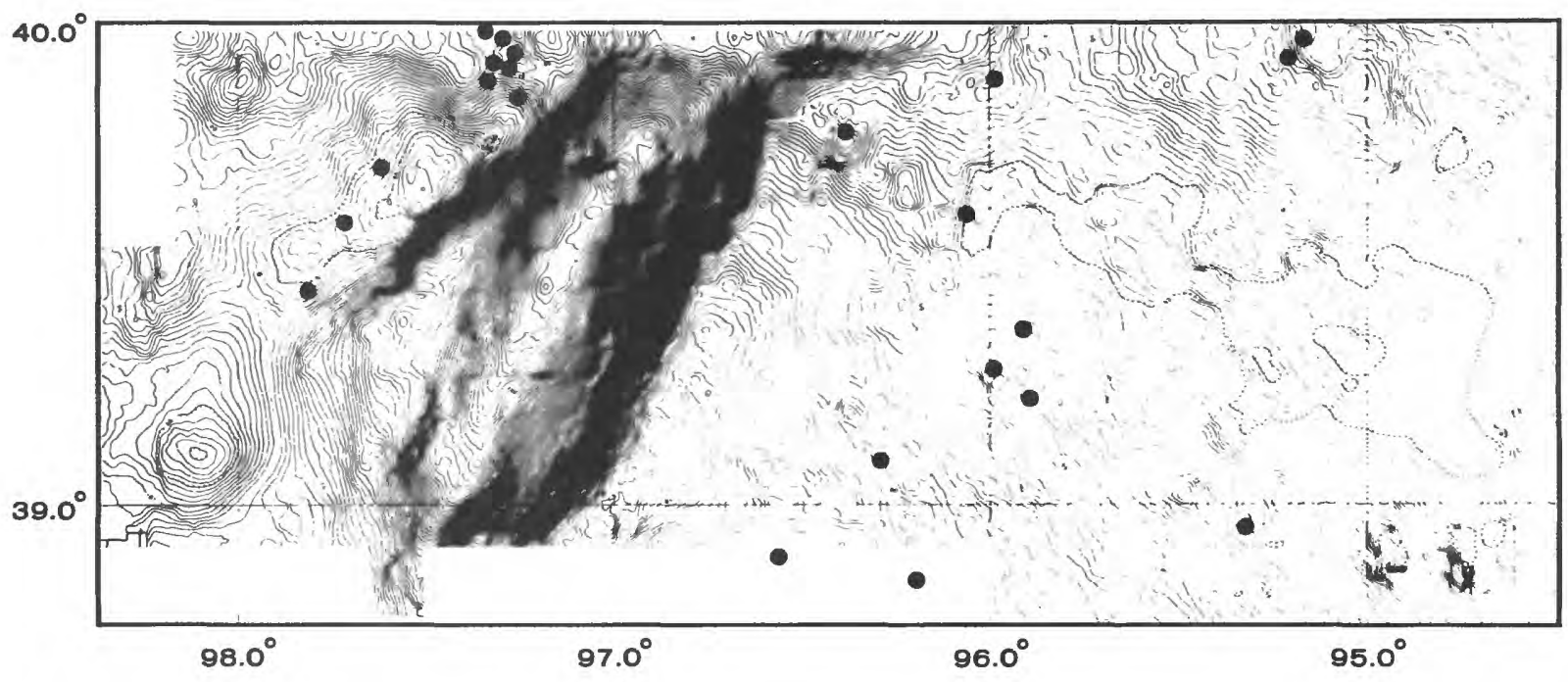

Contour interval $=1$ milligal

Microearthquake
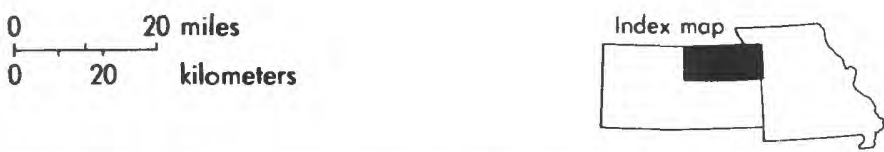

FIGURE 41.--Microearthquakes and Bouguer Gravity Map of northeastern Kansas. Note coincidence of microearthquakes and northwest flank of MGA (Midcontinent Gravity Anomaly). Gravity data were gathered by the Kansas Geological Survey; some of the east-west 1inear trends are caused by machine contouring and the fact that east-west data traverses were 6 miles apart with 1 mile between points on each traverse.

\section{CENTRAL MISSISSIPPI VALLEY EARTHQUAKES, 1979}

By W. Stauder, R. Herrmann, S. Singh, D. Reidy, R. Perry, S. Morrissey, and E. Haug Department of Earth and Atmospheric Sclences Saint Louis University

St. Louls, Missour1 63156

During 1979, 238 earthquakes were located by the 25 station regional microearthquake network operated by Saint Louis University under contract with the USGS and NRC. Another 485 earthquakes were recorded by one or more stations of the network but not by a sufficient number of stations to allow location of the events. Hypocentral coordinates and arrival times of $P$ and $S$ phases read at each station are published in the quarterly Central Mississippi Valley Earthquake Bulletin, avallable on request. Data from the SLU network are supplemented by data from the four permanent and several temporary stations of the Tennessee Earthquake Information Center.

Figure 44 shows the 238 earthquakes located within a $4^{\circ}$ by $4^{\circ}$ region centered on $37.0^{\circ} \mathrm{N}$., and $89.5^{\circ} \mathrm{W}$. The magnitudes of the events are indicated by the size of the open symbols. Station locations are indicated by the triangles. Figure 45 shows the locations and magnitudes of 207 earthquakes located within a $1.5^{\circ}$ by $1.5^{\circ}$ region centered at $36.25^{\circ} \mathrm{N}$, and $89.75^{\circ} \mathrm{W}$. , the immediate region of the New Madrid selsmic zone.

The operation of the network continues to contribute to the delineation of the active selsmic features of the New Madrid zone. The northeast-southwest trend of hypocenters is apparent. The clustering of hypocenters between the station at Gratio, Temessee (GRT), and that at New Madrid, Missouri (NMMO), has been and is the subject of special investigations.

$$
\text { Significant earthquakes during }
$$
included the following:

1. 2 February 1115 UTC, $36.25^{\circ}$ N., $89.46^{\circ}$ W., the first locatable event of an earthquake swarm of unusual duration from 2 February to 4 February; 135 earthquakes were recorded in 57 hours. At least 8 of the earthquakes were felt in the immediate vicinity of the swarm epicenters. The 4 largest were of MM Intensity II-III in Ridgely, Tennessee. Focal depths for most of the events were less than $5 \mathrm{~km}$.

2. 5 February 0531 UTC, $35.85^{\circ}$ N., $90.08^{\circ}$ W., felt in Blytheville area, Arkansas MM IV, $\mathrm{mb} 3 \mathrm{~Hz}=3.0$ (FVM).

3. 27 February 2254 UTC, $35.92^{\circ}$ N., $91.24^{\circ}$ W., main event of a 42 earthquake sequence in 22 


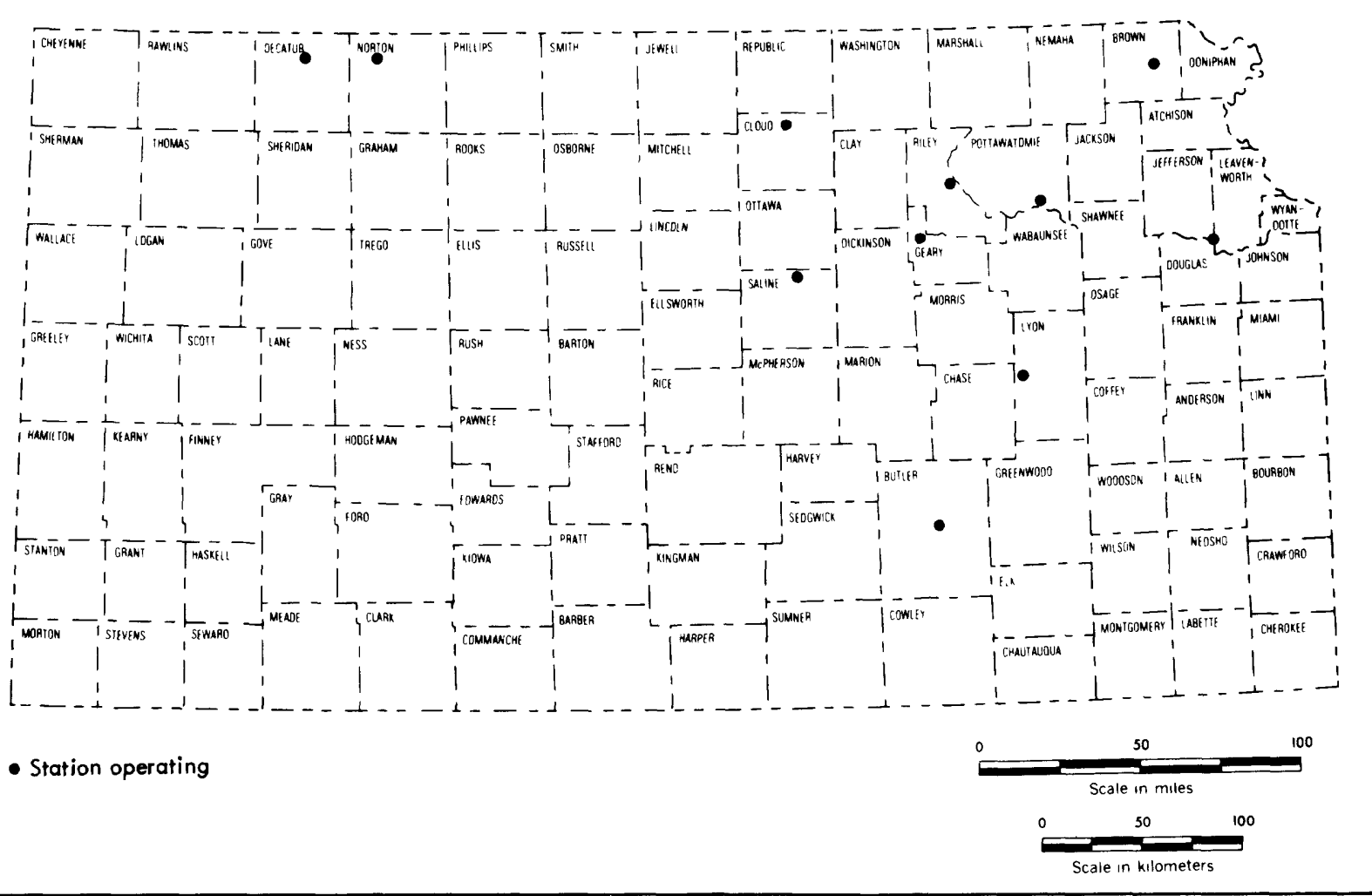

FIGURE 42.--Kansas Geological Survey seismograph network in 1979. Stations in eastern Kansas are telemetered to Lawrence. Stations in western Kansas are operated by volunteers at the station sites.

hours. Felt strongly in Powhattan, Arkansas, $M \mathrm{~V}, \mathrm{mb} 3 \mathrm{~Hz}=3.5$ (FVM).

4. 11 June 0412 UTC, $36.17^{\circ} \mathrm{N} ., 89.95^{\circ} \mathrm{W} .$, felt widely in Caruthersville, Missouri region and in Dyersburg, Tennessee, $\mathrm{mb} 3 \mathrm{~Hz}=3.9$ (FVM).

5. 25 June 1711 UTC, $35.53^{\circ} \mathrm{N} ., 90.43^{\circ} \mathrm{W} .$, felt in Marked Tree, Arkansas region, $\mathrm{mb} 3 \mathrm{~Hz}=3.2$ (FVM).

6. $08 \mathrm{July} 1235 \mathrm{UTC}, 36.89^{\circ} \mathrm{N},, 89.29^{\circ} \mathrm{W} .$, felt in Charleston area, Missouri $\mathrm{mb} 3 \mathrm{~Hz}=3.1$ (FVM).

7. 05 November 1635 UTC, $36.44^{\circ}$ N., $91.01^{\circ}$ W., felt in Dalton, Arkansas, MM IV, mbLg $=3.2$ (FVM).

\section{NEBRASKA EARTHQUAKES, 1979}

By George H. Rothe Department of Geology The University of Kansas Lawrence, Kansas 66044

The operation of several local seismograph networks has significantly increased our knowledge of the seismotectonics of the Midwest. The nine-station Kansas Geological Survey (KGS) seismic network and the five-station Nebraska Geological Survey (NGS) selsmic network were installed in the fall of 1977 to evaluate the seismic risk associated with the Nemaha Ridge and 1 ts eastern bounding fault - the Humboldt fault. The operation of these networks and a four-station temporary expansion of the KGS network into western Kansas and south-central 


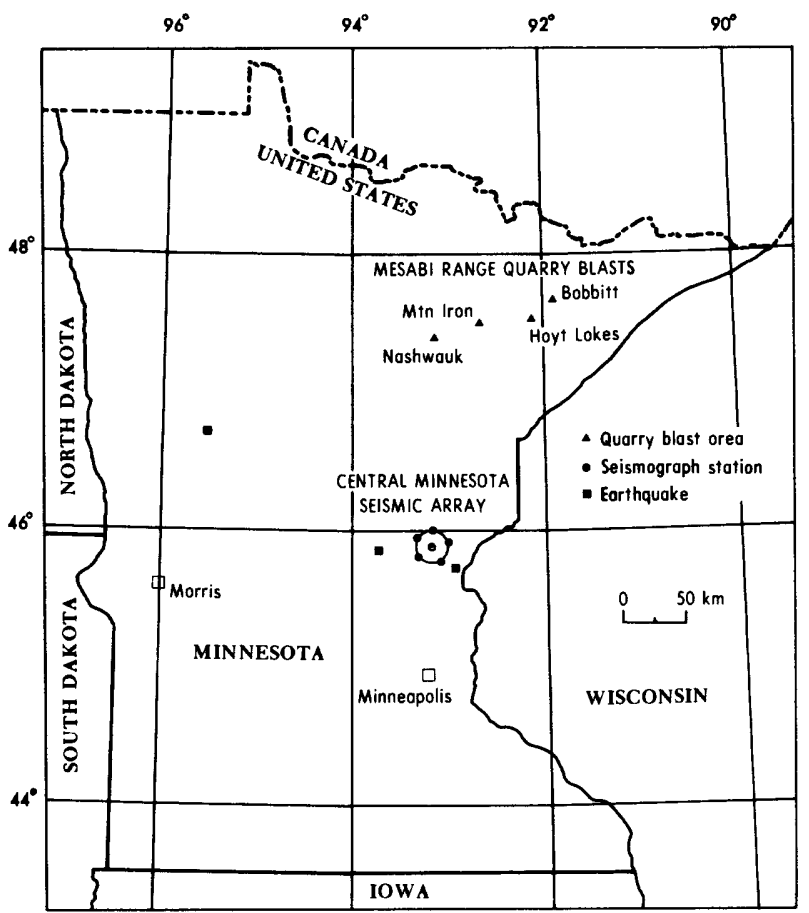

FIGURE 43.-Map of Central Minnesota Seismic Array, quarry blasts, and earthquakes during 1979.

Nebraska has lead to the location of twentythree (23) earthquakes during 1979. This inst rumentally recorded seismicity is summarized in table 5 and figure 46.

The relationship of this activity to the sleepy Hollow 011 Field can be seen in figure 47. The Sleepy Hollow Field has been the highest producing field in Nebraska and is currently produced by the Amoco Production Company. Injection (for secondary recovery) into perimeter wells has been primarily at the base of the sedimentary section $(1.2 \mathrm{~km}$ deep). The shallow nature of some of the seismicity as deduced from intensity-magnitude considerations and hypocenter determinations, the fact that injection continues in the Sleepy Hollow Field, and reported cases of cause and effect relationships of fluid injection to earthquakes elsewhere (Healy and others, 1968, and Rogers and Malkiel, 1979) suggest injection of fluids as a cause for the shallower selsmic activity in the sleepy Hollow Field. Injection records from the Nebraska 011 and Gas Commission consist of sixmonth averages combined for all wells in the field. Comparison of the net injection and seismicity has revealed no obvious correlation. More detailed injection and seismicity data are needed to examine the possibility that some of the earthquakes are induced by the fluid injection.

The University of Kansas (Kansas Geological Survey and Department of Geology) is in the process of modifying the temporary expansion of the

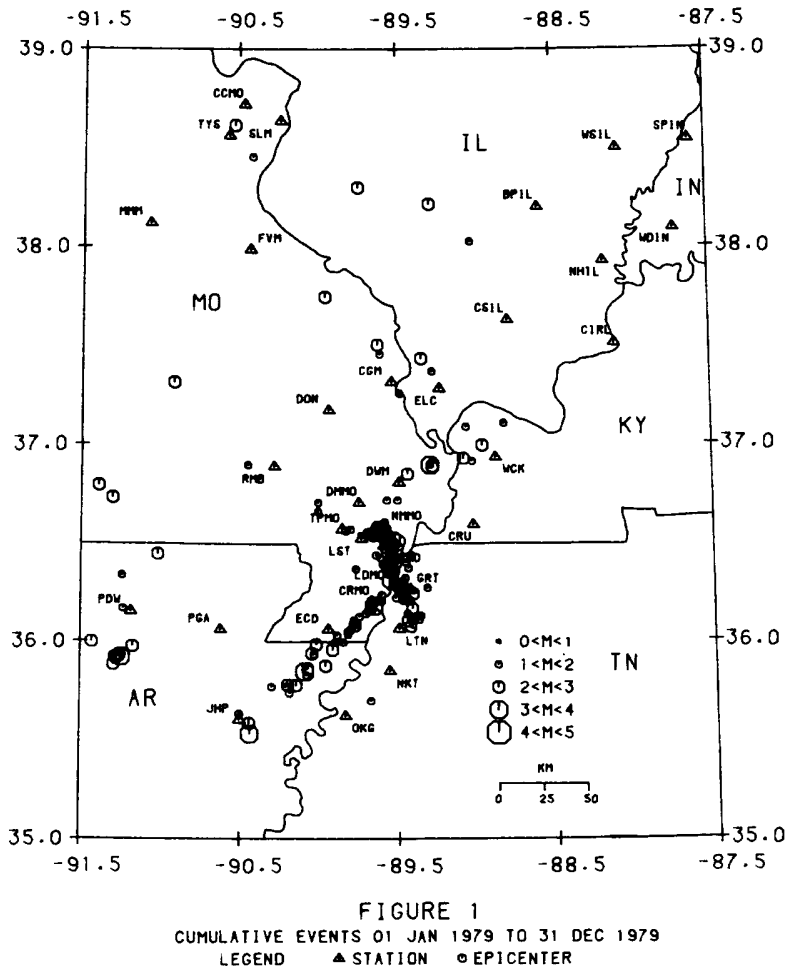

FIGURE 44.--Central Mississippi Valley earthquakes during 1979 within a $4^{\circ} \times 4^{\circ}$ region centered at $37.0^{\circ} \mathrm{N}$. and $89.5^{\circ} \mathrm{W}$.

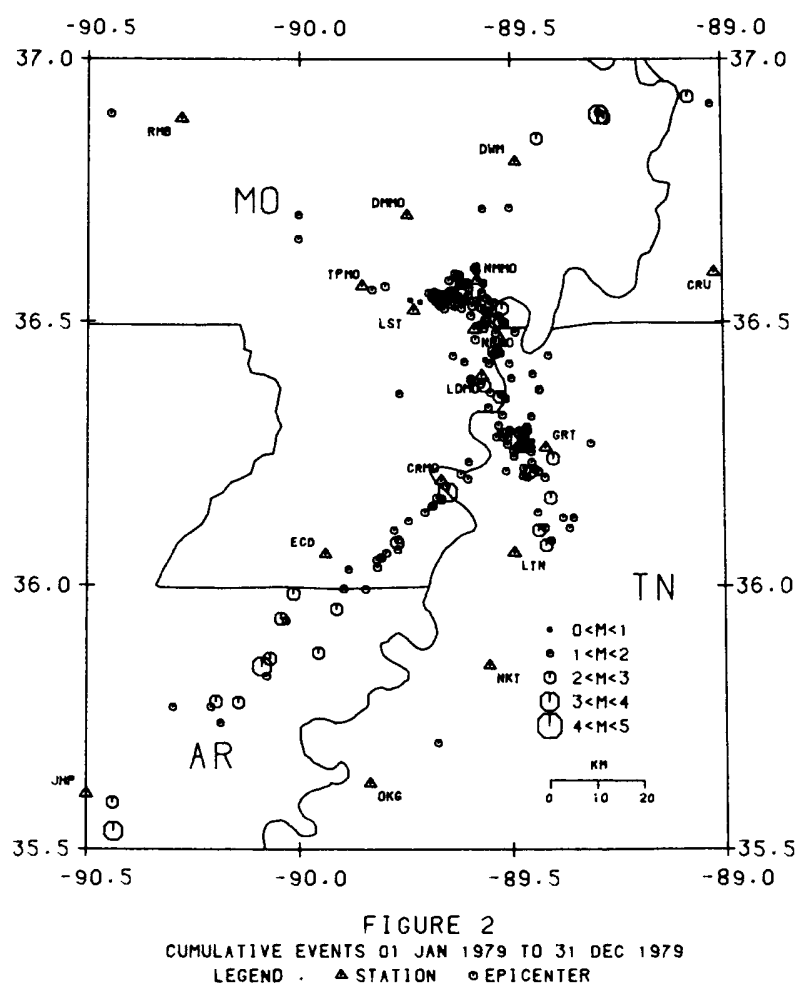

FIGURE 45.--Central Mississippi Valley earthquakes during 1979 within a $1.5^{\circ} \mathrm{x}$ $1.5^{\circ}$ region centered at $36.25^{\circ} \mathrm{N}$. and $89.75^{\circ} \mathrm{W}$. 


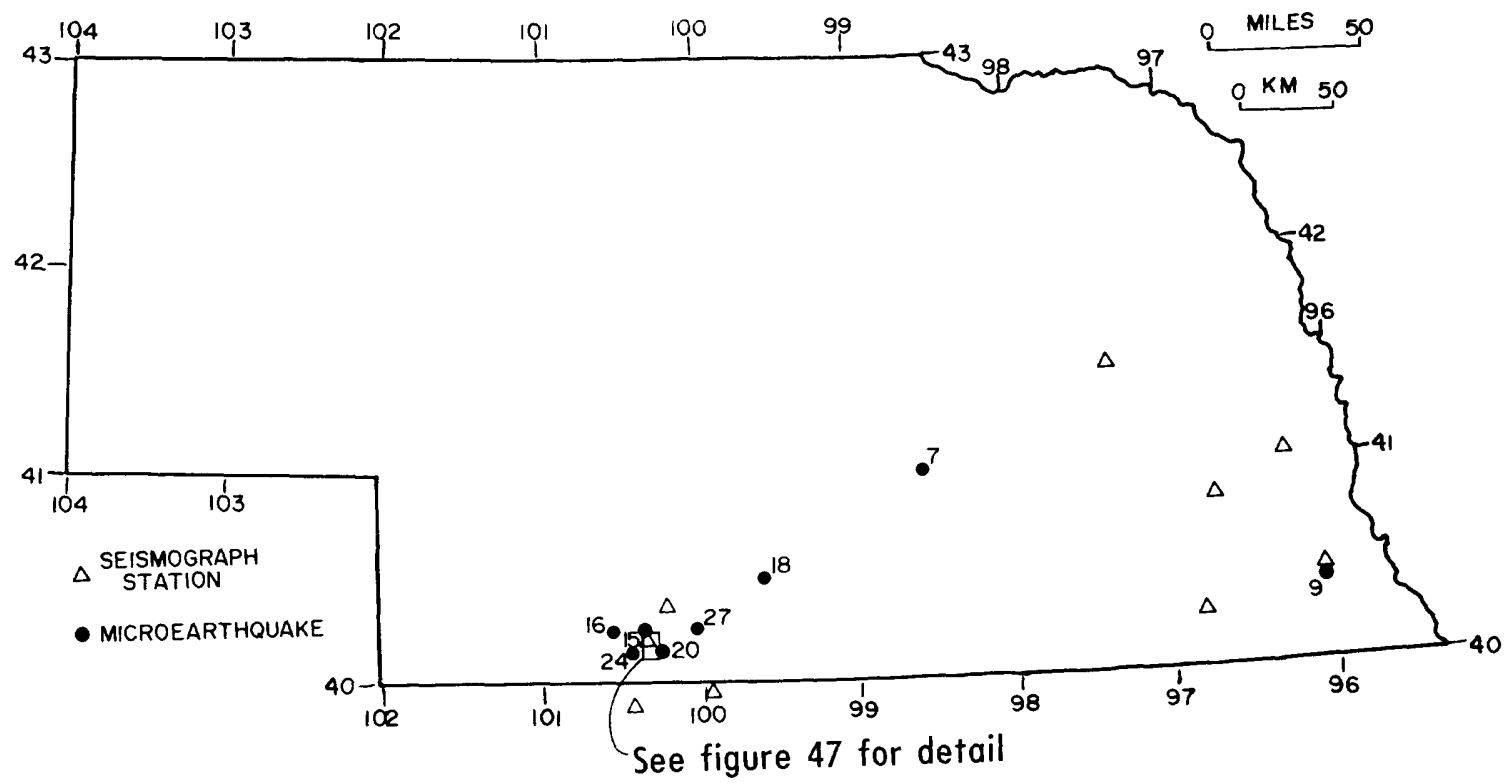

FIGURE 46.--Map of the Nebraska Geological Survey seismic network and earthquake epicenters in Nebraska during 1979.

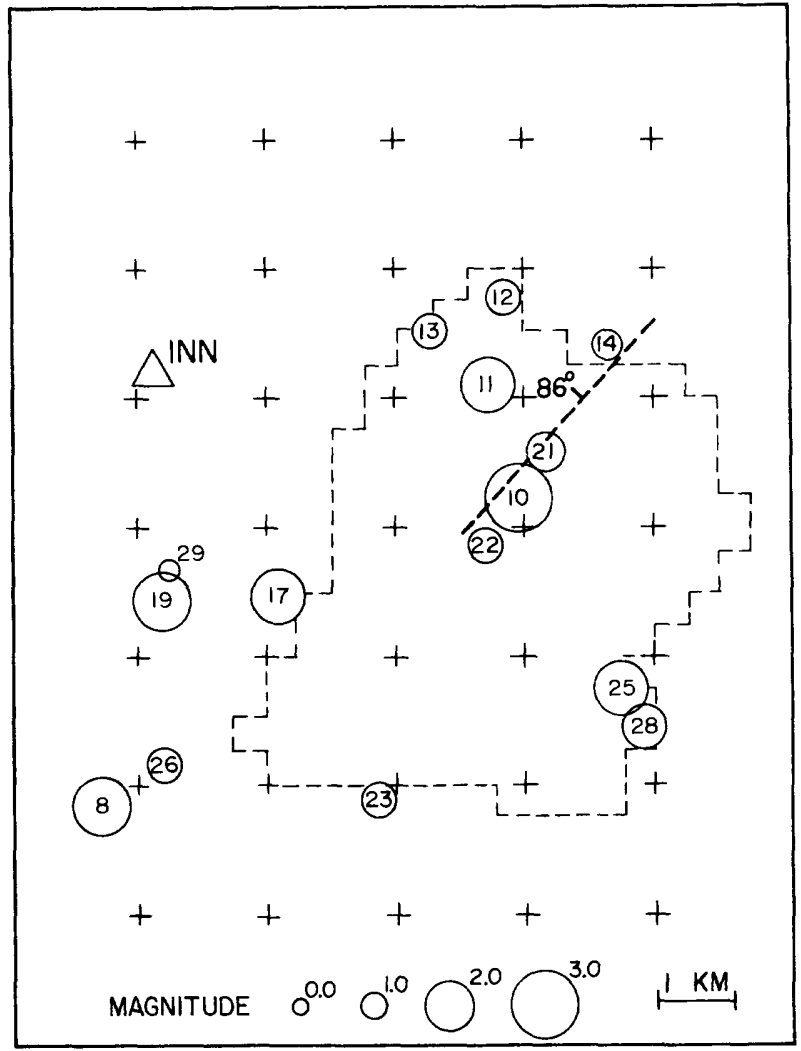

FIGURE 47.--Seismicity for 1979 in the area of the Sleepy Hollow Oil Field, Nebraska. Numbers correspond to event numbers in table 5 .
KGS network to create a semi-permanent, semiregional, seven-station, telemetered network known as the University of Kansas South-Central Nebraska seismic network. The goal of this expansion is to increase the station density along the southern end of the Cambridge Arch and improve the timing accuracy by telemetering the seismic signals to Lawrence where uniform timing information $c$ an be applied. Improved timing accuracy is needed to achieve improved location resolution over the temporary network expansion. The spatial distribution of the stations has been designed to improve both depth resolution (a good epicentral distance distribution including a station directly over the area of highest activity) and epicentral resolution (a uniform azimuthal distribution).

In addition to the installation of the University of Kansas South-Central Nebraska network, the Induced Seismicity Program of the office of Earthquake Studies of the U.S. Geological Survey is funding the installation and maintenance of a dense, eight-station telemetered seismograph network (the Sleepy Hollow seismic network) for a period of at least 2 years beginning in the fall of 1981. The network will have an average station spacing of about $3 \mathrm{~km}$ centered on the oil field and should enable us to more accurately determine foct and focal mechanisms of earthquakes within the ofl field and study the possibility that they are induced. The seismic signals will be radio and telephone telemetered to the University of Kansas in Lawrence where they will be recorded on inked-paper recorders. 
The installation of the seven-station South-Central Nebraska network and the eightstation Sleepy Hollow network will bring the total number of stations being recorded in Lawrence to 24. In addition to the analog recording, planning is underway to record all 24 stations digitally in the "event" mode.

Table 5.-.. Vebraska earthquakes, 1979

\begin{tabular}{|c|c|c|c|c|c|c|c|c|c|}
\hline $\begin{array}{l}\text { Event } \\
\text { Number }\end{array}$ & $\begin{array}{r}\text { Date } \\
\text { (1979) }\end{array}$ & & $\begin{array}{r}\text { origin } \\
\text { (UT }\end{array}$ & $t_{1}$ & Lat. & $\begin{array}{l}\text { Long: } \\
\left({ }^{\circ} \mathrm{W} .2\right.\end{array}$ & $\begin{array}{c}\text { Depth } \\
(\mathrm{km})\end{array}$ & $\begin{array}{l}\text { Magnit ude } \\
\text { (MD) }\end{array}$ & $\begin{array}{l}\text { Modified } \\
\text { Mercalli } \\
\text { (MM) }\end{array}$ \\
\hline 7 & Apr. & 8 & 2246 & 10.41 & 40.969 & 98.564 & 0.67 & 2.4 & --- \\
\hline 8 & June & 6 & 1616 & 22.40 & 40.144 & 100.407 & 1.62 & 2.6 & I I I \\
\hline 9 & June & 12 & 1113 & 11.88 & 40.406 & 96.054 & 2.07 & 1.8 & - \\
\hline 10 & July & 16 & 0003 & 47.79 & 40.179 & 100.347 & 14.05 & 2.9 & I I I \\
\hline 11 & July & 16 & 0134 & 20.31 & 40.191 & 100.351 & 8.37 & 2.4 & -- \\
\hline 12 & July & 16 & $05 \quad 27$ & 01.04 & 40.201 & 100.349 & 16.64 & 1.5 & -- \\
\hline 13 & July & 16 & 0608 & 09.59 & 40.197 & 100.360 & 16.87 & 1.5 & -- \\
\hline 14 & July & 16 & 0705 & 56.23 & 40.196 & 100.334 & 1.59 & 1.2 & -- \\
\hline 15 & Ju1y & 16 & 1802 & 49.70 & 40.256 & 100.401 & 6.18 & 1.5 & -- \\
\hline 16 & July 2 & 20 & 1343 & 02.74 & 40.252 & 100.589 & 1.80 & 1.4 & -- \\
\hline 17 & July 2 & 24 & 0416 & 46.42 & 40.168 & 100.381 & 1.62 & 2.2 & -- \\
\hline 18 & July 2 & 24 & 0804 & 46.35 & 40.757 & 100.632 & 2.00 & 1.2 & - \\
\hline 19 & Aug. & 2 & 0416 & 22.23 & 40.167 & 100.399 & 1.11 & 2.5 & I I I \\
\hline 20 & Aug. & 4 & 2250 & 05.52 & 40.165 & 100.306 & 1.62 & 1.5 & -- \\
\hline 21 & Aug. & 13 & 1109 & 50.38 & 40.184 & 100.343 & 9.24 & 1.7 & -- \\
\hline 22 & Aug. & 13 & 2359 & 31.60 & 40.173 & 100.351 & 1.91 & 1.5 & -- \\
\hline 23 & Aug. & 15 & 0645 & 53.46 & 40.145 & 100.367 & 12.47 & 1.5 & - \\
\hline 24 & Aug. & 15 & $16 \quad 07$ & 07.17 & 40.143 & 100.462 & 1.76 & 1.3 & -- \\
\hline 25 & Aug. & 31 & 0800 & 11.50 & 40.157 & 100.331 & 11.93 & 2.2 & IV \\
\hline 26 & Nov. & 19 & 0440 & 02.96 & 40.149 & 100.398 & 2.00 & 1.5 & -- \\
\hline 27 & Nov. & 19 & 0458 & 43.40 & 40.248 & 100.361 & 3.15 & 1.9 & --- \\
\hline 28 & Nov. & 29 & 2202 & 31.31 & 40.153 & 100.328 & 1.66 & 1.9 & --- \\
\hline 29 & Dec. & 10 & $12 \quad 20$ & 28.78 & 40.171 & 100.398 & 1.69 & 0.9 & $-\cdots$ \\
\hline
\end{tabular}

\section{NEW ENGLAND EARTHQUAKES. 1979}

\author{
By John E. Ebel \\ Weston Observatory \\ Department of Geology and Geophysics \\ Boston College \\ 381 Concord Road \\ Weston, Massachusetts 02193
}

Weston Observatory of Boston College continued to expand its seismic station coverage in New England during 1979. By the end of the year Weston observatory was operating 36 telemetered stations, 8 of which were newly installed. Five of the new stations are for the purpose of monitoring microearthquake activity near the towns of Haddam and Moodus in central Connecticut. This area was the site of a locally strong tremor in 1791 and has had numerous heard earthquakes reported in the historic record. Two stations were installed near Passamaquoddy Bay in eastern Maine also to improve microearthquake detection capabilities.

During 1979, Weston Observatory detected 46 earthquakes in New England. Of these, 21 were large enough to be located and 4 were reported felt (fig. 48). The largest New England event had a magnitude (mblg) of 4.0. In addition, Weston Observatory detected 98 events from neighboring areas in the United States and

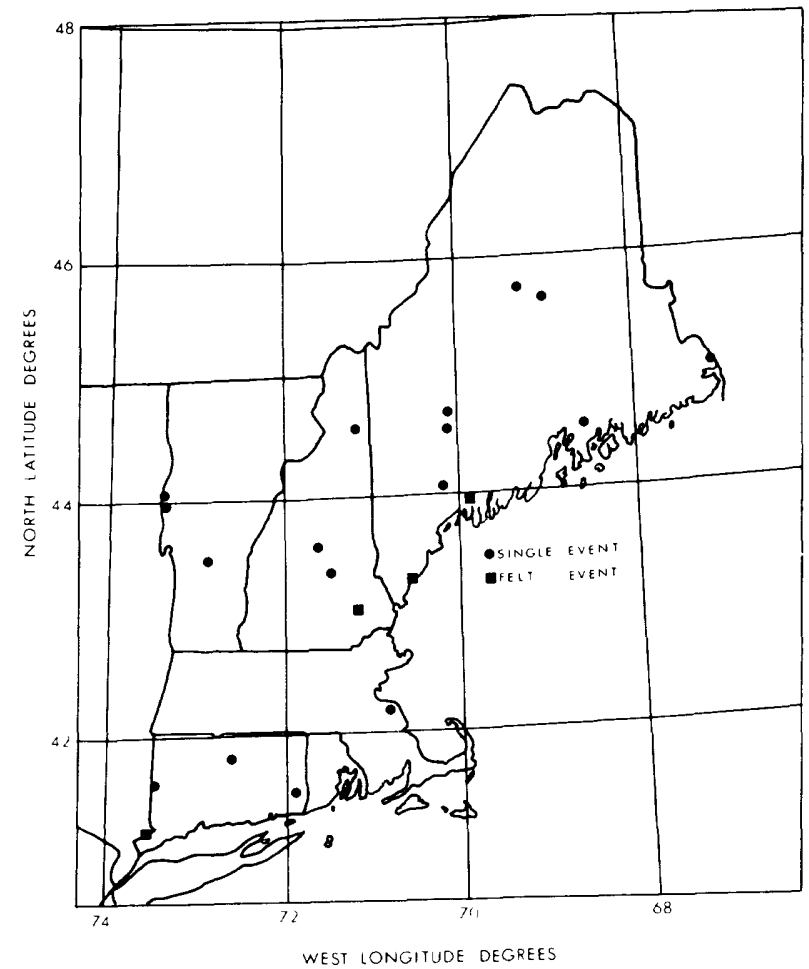

FIGURE 48.--New England earthquake epicenters during 1979.

Canada, 38 of these events were located and 5 of them were felt. The largest event detected was the Charlevoix, Ouebec, earthquake of August 19, $1979(\mathrm{mbLg}=5.0)$.

The Bath, Maine, earthquake of April 18 , 1979, $\left(43.95^{\circ} \mathrm{N} ., 69.75^{\circ} \mathrm{W} .\right.$, mbLg $\left.=4.0\right)$ was the largest New England event in several years. The maximum Modified Mercalli intensity reported for the earthquake was $V$, and the event was felt as far away as Boston, which is $220 \mathrm{~km}$ from the epicenter. A couple of weeks after the main shock occurred, portable seismographs were installed near the epicenter to monitor the aftershock activity. A total of 17 aftershocks were detected, 7 of them being magnitude $2 . n$ or greater.

Weston observatory continued to pubiish the quarterly seismic bulletin of the Northeastern United States Seismic Network (NEUSSN). The bulletin lists locations and magnitudes for events in the Northeastern United States and adjacent areas in Canada. Sources of data for the information in the bulletin are: LamontDoherty Geological Observatory, Massachusetts Institute of Technology, Pennsylvania State University, Delaware Geological Survey, Maine Geological Survey and the State University of New York at Stony Brook. 


\section{EARTHQUAKES IN NEW YORK STATE AND ADJACENT AREAS, 1979}

By A. L. Kafka, E. Schlesinger-Miller, and L. R. Sykes

Lamont-Doherty Geological Observatory of Columbia University

Palisades, New York 10964

Lamont-Doherty Geological Observatory operates a seismic network of 38 short-period stations in the states of New York, New Jersey, and Vermont. The present configuration of this network consists of 38 stations and is shown in figure 49. The signals are telemetered by telephone line and radio to a central recording site at Palisades, New York, and recorded on a common time base. Twenty-elght channels are recorded on two develocorders and all are recorded on an analog magnetic tape recorder. Seven helicorders are used to monitor activity in real time, enabling rapid detection of earthquakes. The magnetic tapes are digitized for detafled analysis of particular events.

Figure 50 shows the distribution of earthquakes recorded by the Lamont-Doherty network during 1979. The longer term distribution of seismicity in New York State and adjacent areas can be seen in figure 51 , which shows the locations of all earthquakes ( $\mathrm{mb}>2$ ) recorded by the network from its inception in 1970 through 1980. In this figure we chose a magnitude threshold of $\mathrm{mb}=2$ so as to reduce the bias introduced by non-uniform coverage in space and time. The major features of interest in figure 51 are:

1. A NNW trending zone of seismicity extending from northern New York to western Quebec.

2. A notheasterly trending belt of seismic activity extending from New Jersey into Connecticut.

3. Concentrations of seismicity in western New York and western Lake Ontario.

4. Relative absence of activity in the central part of New York State, Vermont, and western Massachusetts.

A comparison of the instrumentally recorded seismicity with the historical earthquake record for this region reveals that these features are relatively stationary. Those areas of the New York State region that have had little or no seismicity historically are relatively aseismic today, whereas the historically active areas are also active today.

Forty-eight earthquakes ranging in magnitude from 1 to 5 were recorded during 1979 in New York State and its vicinity. Significant activity has been recorded during this year in northern New York and western Quebec, and also in the New York City region. During 1979 very little activity was recorded in western New

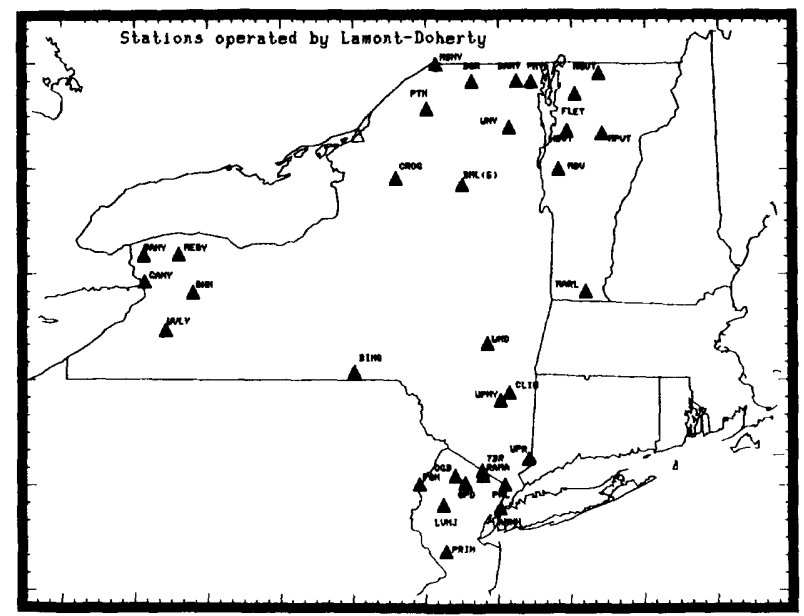

FIGURE 49.--Distribution of short-period seismic stations operated by the LamontDoherty Geological Observatory in New York State and adjacent areas.

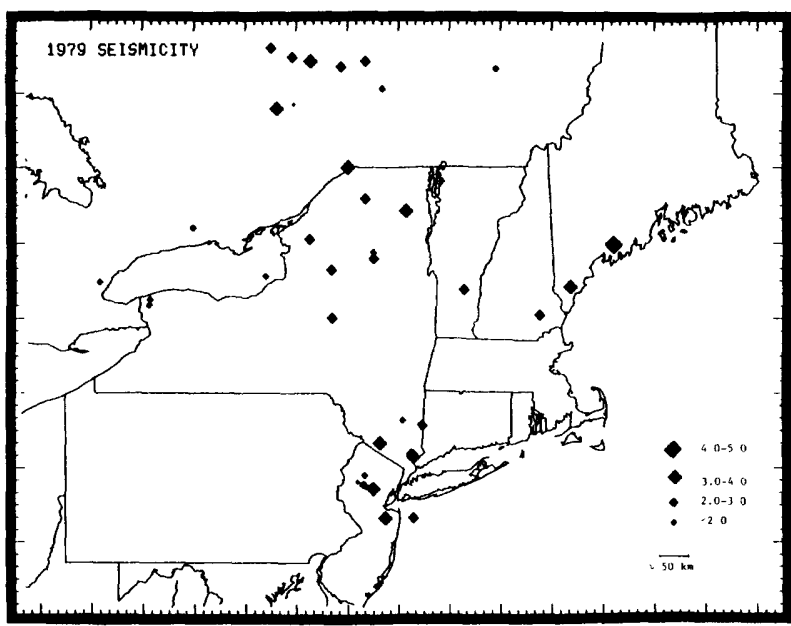

FIGURE 50.--All earthquakes recorded by the Lamont-Doherty network in New York State and adjacent areas during 1979 .

York. The most significant earthquakes which occurred this year within the area covered by the network were:

1. An earthquake in northern New Jersey (mbLg = $3.0)$ approximately $20 \mathrm{~km}$ south of New York City (Cheesequake, New Jersey; January 30, 1979). This earthquake generated Modified Mercalli intensity VI shaking in the epicentral region and was felt over an area of approximately $15,000 \mathrm{sq} \mathrm{km}$.

2. An earthquake in northern New Jersey (mbLg $=$ 2.2 ) about $40 \mathrm{~km}$ west of New York City (Bernardsville, New Jersey; March 10, 1979). This event generated Modified Mercalli 


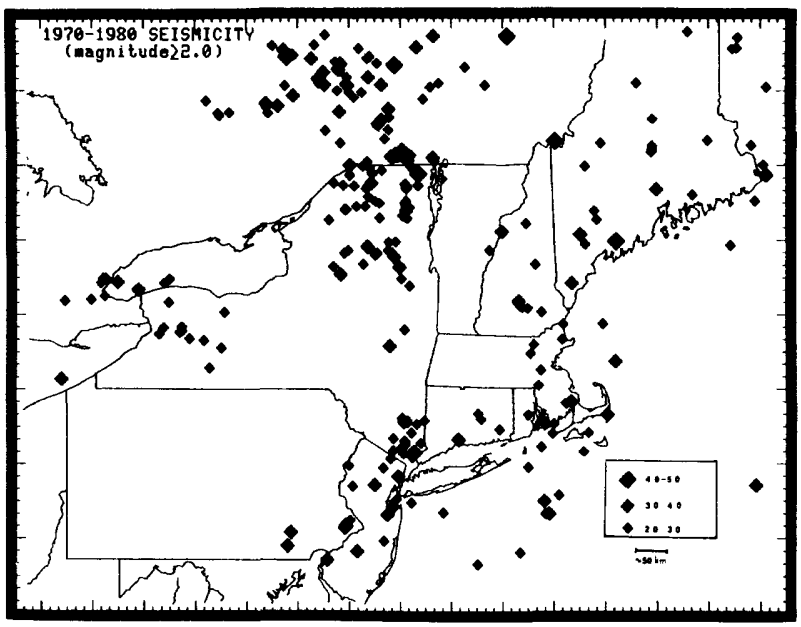

FIGURE 51.--Distribution of earthquakes $(\mathrm{mb} \geq$ 2) recorded by the Lamont-Doherty network in New York State and adjacent areas from 1970 through 1980.

intensity IV shaking in the epicentral region and was felt over at least 2,000 sq $\mathrm{km}$. During the past decade other earthquakes have been located by the network which occurred to the northeast of this event, and these earthquakes appear to be associated with the Ramapo fault zone of northern New Jersey and southeastern New York. The surface trace of the Ramapo fault terminates about $10 \mathrm{~km}$ to the southwest of the Bernardsville earthquake.

3. An earthquake in Westchester County (mbLg= 2.0 ) about $20 \mathrm{~km}$ north of New York City (Mt. Kisco, New York, December 30, 1979). This event generated Modified Mercalli intensity IV shaking in the epicentral region, and was felt over a small area surrounding $M t$. Kisco.

\section{OKLAHOMA EARTHQUAKES, 1979}

By James E. Lawson, Jr. Oklahoma Geological Survey Leonard, Oklahoma 74043

and

Kenneth V. Luza

Oklahoma Geological Survey

University of Oklahoma

Norman, Oklahoma 73019

The article below is a condensed version of a paper by Lawson and Luza originally published in Oklahoma Geology Notes, v. 40, June 1980.
A statewide network of 11 seismograph stations is recording seismological data in Oklahoma (fig. 52). The Oklahoma Geophysical observatory station, TUL, has been recording earthquake data since December 1961. The Observatory, located near Leonard, Oklahoma, in southern Tulsa County, operates seven seismometers, three long-period and four short-period, which are installed in a vault detached from the main building. The seismograph instrumentation and recording equipment were described in United States Earthquakes, 1978. From January 1, 1979, to December 31,1979 , station coverage was relatively uniform. However, a third radiotelemetry station, named GBO (Fort Gibson), was established July 7, 1979. This site, northeast of Fort Gibson, Cherokee County, has a $55-\mathrm{km}$ line-of-sight path to TUL.

In 1979, 96 Oklahoma earthquakes were located (fig. 53) by the Oklahoma Geophysical observatory staff. Magnitude values range from a low of 1.2 (mbLg) in Hughes County to a high of 3.4 (mbLg) in Beckham County (table 6). The listing represents only those earthquakes that could be located by using three or more seismograph records. Twelve earthquakes were reported felt by people living in the vicinity of an earthquake epicenter.

Almost one-half of the earthquakes, approximately 42, have epicentral locations in Canadian County (fig. 54). Two earthquake swarms, one north of Cogar and the other northwest of Minco, account for most of the locatable earthquakes in Canadian County. The first earthquake swarm began on March 18 (near Cogar) and lasted until April 1. Thirty earthquakes, with magnitudes ranging from 0.8 (MD) to 2.5 (MD), had epicentral locations in Canadian, Caddo, and Grady Counties. Only one of these earthquakes, MM III, was reported felt. A second earthquake swarm, northwest of Minco, Grady County, occurred on September 15 and lasted through September 17,1979 . Six earthquakes, with magnitudes ranging from 1.6 (MD) to 2.3 (MD), had epicentral locations in Grady and Canadian Counties (fig. 54). Of these six, two earthquakes, with MM IV intensities, were reported felt.

In south-central oklahoma, earthquakes are concentrated in the Wilson area, Carter and Love Counties. Twelve earthquakes, of which four were felt, were located in this region in 1979. In the past, this area has also been the site of numerous small earthquakes. A third general area of earthquake activity is located along and north of the Ouachita front (Arkoma Basin) in southeastern Oklahoma. Twelve earthquakes, with (MD) magnitudes that range from 1.7 to 2.4 were instrumentally detected in this region. 


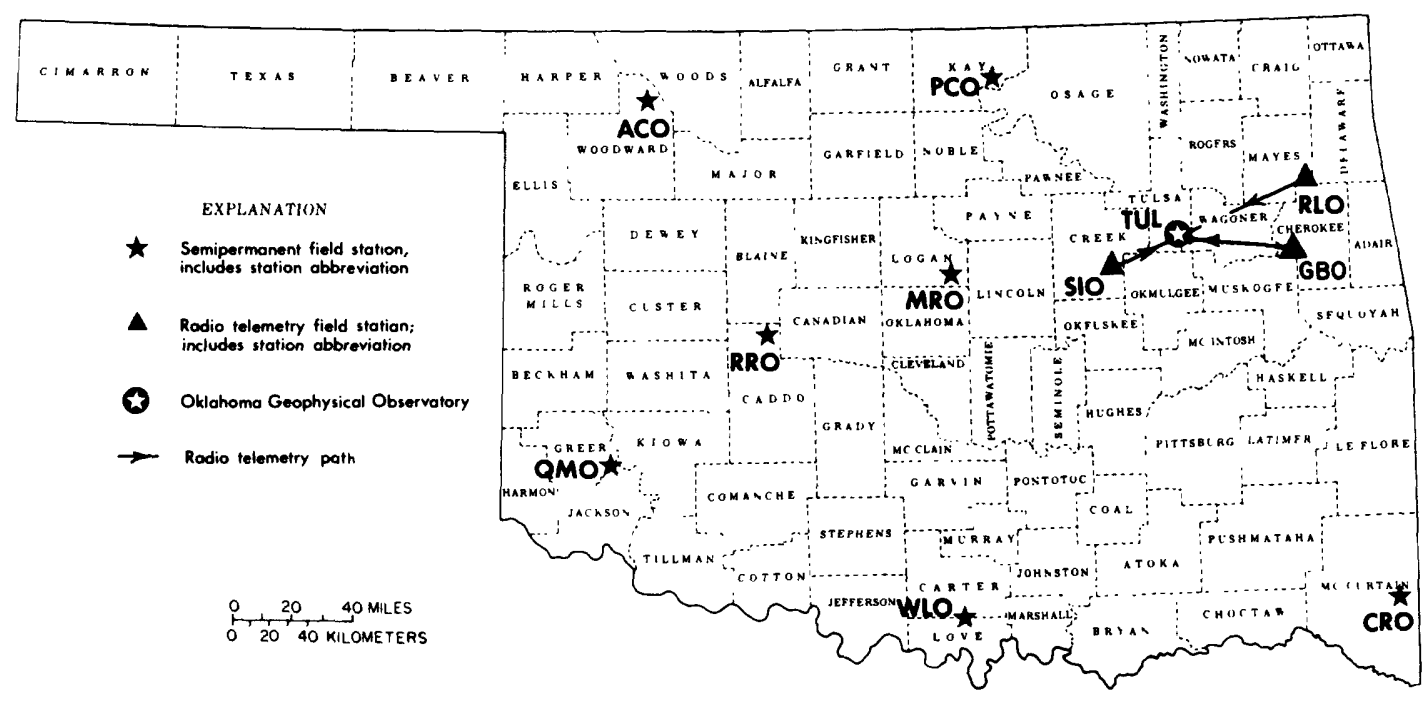

FIGURE 52.--Active seismograph stations in Oklahoma.

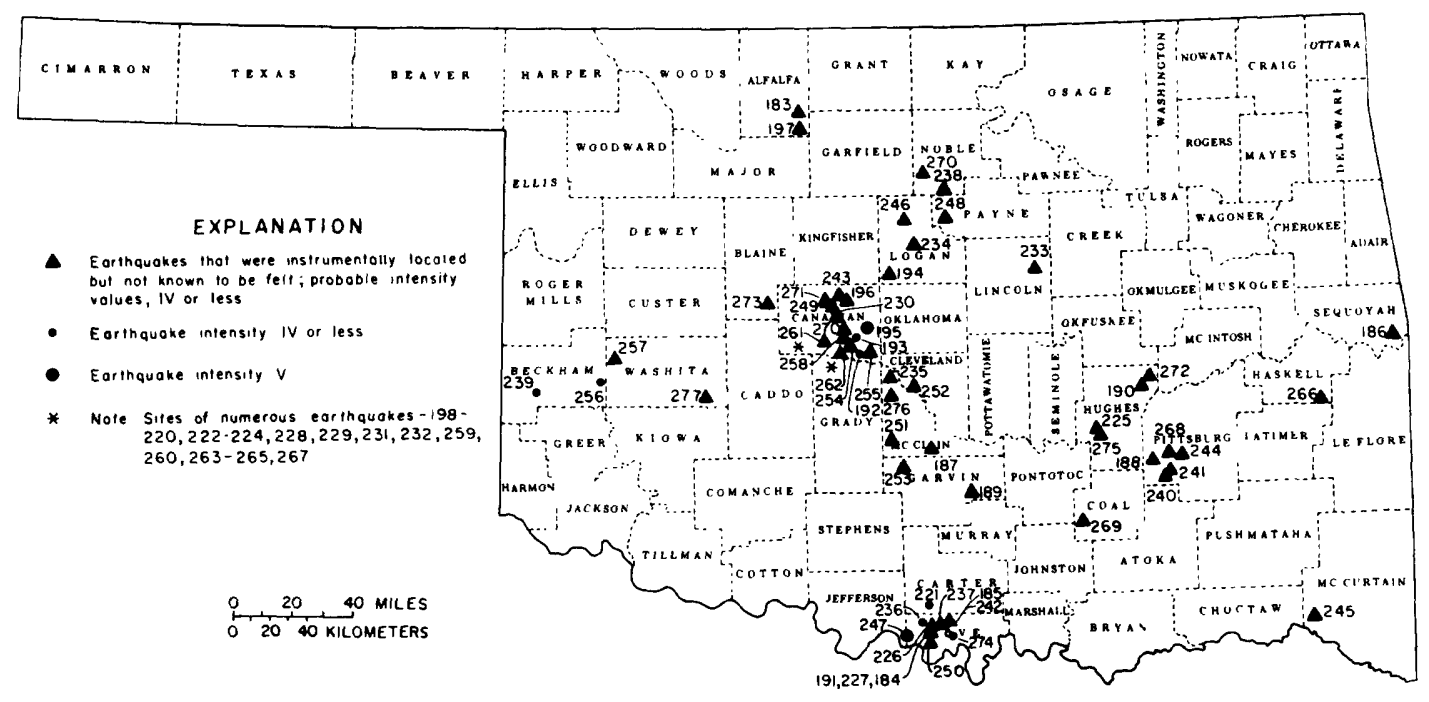

FIGURE 53.--Distribution of Oklahoma earthquakes during 1979. Numbers correspond to event numbers in table 6 . 
Table 6.-.Oklahoma earthquake catalog for 1979

\begin{tabular}{|c|c|c|c|c|c|c|c|c|c|}
\hline \multirow{2}{*}{$\begin{array}{l}\text { Event } \\
\text { number } \\
183 \\
184\end{array}$} & \multicolumn{2}{|c|}{$\begin{array}{l}\text { Date and origin time } \\
\text { (UTC) }\end{array}$} & \multirow{2}{*}{ 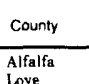 } & $\begin{array}{c}\text { Intensity } \\
\text { (MM) }\end{array}$ & \multicolumn{2}{|c|}{ 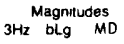 } & $\begin{array}{l}\text { Laturude } \\
\text { (N) }\end{array}$ & $\begin{array}{l}\text { Longtude } \\
\text { ('w) }\end{array}$ & $\begin{array}{l}\text { Depth } \\
(\mathrm{km}) 1\end{array}$ \\
\hline & $\begin{array}{l}\text { JAN } 8 \\
\text { JAN } 24\end{array}$ & $\begin{array}{l}11354299 \\
05154635\end{array}$ & & & $\begin{array}{ll}2021 \\
14\end{array}$ & $\begin{array}{l}19 \\
15\end{array}$ & & $\begin{array}{l}98146 \\
974744\end{array}$ & 508 \\
\hline 185 & JAN 24 & 05253200 & $\begin{array}{l}\text { Love } \\
\text { Love }\end{array}$ & & $\begin{array}{ll}14 \\
18 & 21\end{array}$ & $\begin{array}{l}19 \\
19\end{array}$ & $\begin{array}{l}33960 \\
34022\end{array}$ & $\begin{array}{l}97484 \\
97381\end{array}$ & $\begin{array}{l}50 R \\
50 R\end{array}$ \\
\hline $\begin{array}{l}186 \\
187\end{array}$ & JAN 28 & 10240934 & Sequoyah & & 14 & 17 & 35483 & 94568 & $50 R$ \\
\hline 188 & $\begin{array}{l}\text { AAN } 29 \\
\text { FEB } 1\end{array}$ & $\begin{array}{l}192313240 \\
123228\end{array}$ & $\begin{array}{l}\text { Meclain } \\
\text { Pitssburg }\end{array}$ & & & $\begin{array}{l}23 \\
21 \\
21\end{array}$ & 34916 & 97383 & $50 \mathrm{R}$ \\
\hline . & FEB 4 & $\begin{array}{l}16555998 \\
16595\end{array}$ & $\begin{array}{l}\text { Pittoburrg } \\
\text { Garvin }\end{array}$ & & $\begin{array}{lll}18 & 17 \\
26 & 25\end{array}$ & $\begin{array}{l}21 \\
26\end{array}$ & $\begin{array}{l}34830 \\
34672\end{array}$ & $\begin{array}{l}96062 \\
97157\end{array}$ & \\
\hline 190 & FEB 5 & 14234005 & Hughes & & & 22 & 35177 & 96092 & $\begin{array}{l}50 \mathrm{R} \\
50 \mathrm{R}\end{array}$ \\
\hline $\begin{array}{l}191 \\
192\end{array}$ & MAR 13 & $\begin{array}{l}03421877 \\
2322922\end{array}$ & $\begin{array}{l}\text { Love } \\
\text { Canadiug }\end{array}$ & & 1920 & 18 & $\begin{array}{r}33969 \\
35421\end{array}$ & $\begin{array}{l}97446 \\
978751\end{array}$ & $50 \mathrm{R}$ \\
\hline 193 & MAR 14 & $\begin{array}{l}23292256 \\
03105686\end{array}$ & $\begin{array}{l}\text { Canaddann } \\
\text { Canadian }\end{array}$ & IIV & $\begin{array}{ll}17 \\
20 & 19\end{array}$ & 18 & $\begin{array}{l}35421 \\
35498\end{array}$ & $\begin{array}{l}97851 \\
97826\end{array}$ & $\begin{array}{l}50 R \\
50 R\end{array}$ \\
\hline 194 & MAR 14 & 04024305 & Logan & & 14 & 15 & $\begin{array}{l}35488 \\
35781\end{array}$ & 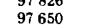 & $\begin{array}{l}50 R \\
50 R\end{array}$ \\
\hline $\begin{array}{l}195 \\
196\end{array}$ & MAR 14 & 04371527 & Canadian & $\mathrm{v}$ & & & 35519 & 97781 & $50 R$ \\
\hline & $\begin{array}{l}\text { MAR } 15 \\
\text { MAR } 16\end{array}$ & $\begin{array}{l}10381048 \\
12381742\end{array}$ & $\begin{array}{l}\text { Canadian } \\
\text { Alfalfa }\end{array}$ & & 16 & 16 & $\begin{array}{l}35689 \\
36517\end{array}$ & 97923 & $50 R$ \\
\hline 198 & MAR 18 & $\begin{array}{l}17253962 \\
129\end{array}$ & $\begin{array}{l}\text { Manala } \\
\text { Canadian }\end{array}$ & & 16 & $\begin{array}{l}20 \\
15\end{array}$ & $\begin{array}{l}\begin{array}{l}36517 \\
35377\end{array} \\
353\end{array}$ & $\begin{array}{l}98123 \\
981200\end{array}$ & $\begin{array}{l}50 R \\
50 R\end{array}$ \\
\hline 199 & MAR 18 & 17330923 & Canadian & & & 08 & 35410 & 98115 & $\begin{array}{l}50 \mathrm{R} \\
50 \mathrm{R}\end{array}$ \\
\hline 200 & MAR 18 & 17351641 & Canadian & & & 10 & 35410 & 98115 & \\
\hline 201 & MAR 18 & 17395171 & Canadian & & 15 & 13 & 35410 & 98115 & \\
\hline${ }_{203}^{202}$ & MAR & $\begin{array}{l}17444159 \\
17525220\end{array}$ & $\begin{array}{l}\text { Canadian } \\
\text { Grady }\end{array}$ & & 16 & 14 & $\begin{array}{l}35410 \\
35344\end{array}$ & 98115 & \\
\hline 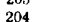 & $\begin{array}{l}\text { MAR I8 } \\
\text { MAR } 18\end{array}$ & 17553684 & $\begin{array}{l}\text { Grady } \\
\text { Canadıan }\end{array}$ & & $\begin{array}{l}18 \\
16\end{array}$ & $\begin{array}{l}15 \\
11\end{array}$ & $\begin{array}{l}\begin{array}{l}353444 \\
35384\end{array} \\
3\end{array}$ & $\begin{array}{l}98053 \\
98110\end{array}$ & $50 R$ \\
\hline 205 & MAR 18 & 18071757 & Canadian & & 2120 & 18 & 35439 & $\begin{array}{l}98110 \\
98118\end{array}$ & $\begin{array}{l}50 R \\
50 R\end{array}$ \\
\hline 206 & MAR 18 & 18145381 & Canadian & & 1917 & 15 & 35410 & 98116 & $\begin{array}{l}50 R \\
50 R\end{array}$ \\
\hline 207 & MAR 18 & 18303685 & Canadian & & $\begin{array}{ll}23 & 23\end{array}$ & & 35418 & 98108 & \\
\hline 208 & MAR 18 & 18462965 & Canadian & & & & 35443 & & \\
\hline $\begin{array}{l}209 \\
210\end{array}$ & $\begin{array}{l}\text { MAR } 18 \\
\text { MAR 18 }\end{array}$ & $\begin{array}{l}18572395 \\
19135060\end{array}$ & $\begin{array}{l}\text { Canaddan } \\
\text { Canadian }\end{array}$ & & $\begin{array}{ll}20 & 20 \\
24 & 24\end{array}$ & 18 & $\begin{array}{l}35416 \\
35418\end{array}$ & 98130 & 5 OR \\
\hline 211 & MAR 18 & $\begin{array}{l}19302123 \\
193020\end{array}$ & $\begin{array}{l}\text { anaconn } \\
\text { Canadian }\end{array}$ & & $\begin{array}{ll}24 & 24 \\
22 & 22\end{array}$ & $\begin{array}{l}19 \\
18\end{array}$ & $\begin{array}{l}\begin{array}{l}35418 \\
35418\end{array} \\
35\end{array}$ & $\begin{array}{l}98155 \\
98101\end{array}$ & $\begin{array}{l}50 R \\
50 R\end{array}$ \\
\hline 212 & MAR 18 & 19415726 & Canadian & & 2220 & 18 & 35406 & $\begin{array}{l}981110 \\
98110\end{array}$ & $\begin{array}{l}5 \text { OR } \\
5 \text { OR }\end{array}$ \\
\hline 213 & MAR 18 & 20053054 & Canadian & & 2725 & & 35416 & 98110 & $\begin{array}{l}5 \text { OR } \\
50 R\end{array}$ \\
\hline 214 & $\begin{array}{l}\text { MAR } 18 \\
\end{array}$ & 20241190 & Canadian & & & 18 & & 98110 & $\begin{array}{l}50 R \\
50 R\end{array}$ \\
\hline $\begin{array}{l}215 \\
216\end{array}$ & $\begin{array}{l}\text { MAR } 18 \\
\text { MAR } 18\end{array}$ & $\begin{array}{l}2044194797 \\
210741\end{array}$ & $\begin{array}{l}\text { Canadian } \\
\text { Canadogn }\end{array}$ & III & & 25 & 35379 & 98124 & $50 R$ \\
\hline $\begin{array}{l}210 \\
217\end{array}$ & $\begin{array}{l}\text { MAR } 18 \\
\text { MAR } 18\end{array}$ & $\begin{array}{l}21707109409 \\
21165463\end{array}$ & $\begin{array}{l}\text { Canadian } \\
\text { Canadian }\end{array}$ & & $\begin{array}{l}20 \\
1918 \\
19\end{array}$ & $\begin{array}{l}15 \\
13\end{array}$ & $\begin{array}{l}35429 \\
35379\end{array}$ & 98114 & 5 OR \\
\hline 218 & MAR 18 & 21421054 & Canadian & & 2425 & 21 & 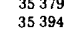 & $\begin{array}{l}98118 \\
98108\end{array}$ & $\begin{array}{l}50 R \\
50 R\end{array}$ \\
\hline 219 & MAR 18 & 22082053 & Canadan & & 2119 & 17 & 35396 & $98 \quad 126$ & $50 R$ \\
\hline $\begin{array}{l}{ }_{2220}^{220} \\
221\end{array}$ & $\begin{array}{l}\text { MAR } 18 \\
\text { MAR } 18\end{array}$ & $\begin{array}{l}224217444 \\
23190129\end{array}$ & $\begin{array}{l}\text { Canadian } \\
\text { Carter }\end{array}$ & & $\begin{array}{ll}20 & 19 \\
25 & 23\end{array}$ & 15 & 35416 & 98126 & $\begin{array}{l}5 \mathrm{OR} \\
50 \mathrm{R}\end{array}$ \\
\hline 222 & MAR 18 & 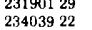 & $\begin{array}{l}\text { Carter } \\
\text { Canadian }\end{array}$ & III & $\begin{array}{ll}25 & 23 \\
22 & 20\end{array}$ & $\begin{array}{l}22 \\
17\end{array}$ & $\begin{array}{l}\begin{array}{r}34100 \\
35433\end{array} \\
35\end{array}$ & $\begin{array}{l}97.448 \\
98102\end{array}$ & $\begin{array}{l}50 R \\
50 R\end{array}$ \\
\hline 223 & MAR 19 & 00543265 & Canadian & & $21 \quad 20$ & 17 & $\begin{array}{l}35408 \\
35408\end{array}$ & 98102 & $\begin{array}{l}50 R \\
50 R\end{array}$ \\
\hline${ }_{225}^{224}$ & MAR 19 & 03425514 & Canadian & & $\begin{array}{ll}25 & 25\end{array}$ & & 35400 & 98110 & $\begin{array}{l}50 R \\
50 R\end{array}$ \\
\hline $\begin{array}{l}225 \\
226\end{array}$ & $\begin{array}{l}\text { MAR } 211 \\
\text { MAR } 23\end{array}$ & $\begin{array}{l}0455561969 \\
013148\end{array}$ & $\begin{array}{l}\text { Hughes } \\
\text { Lope }\end{array}$ & & 1812 & 17 & 35043 & 96349 & $50 R$ \\
\hline 227 & MAR 23 & $\begin{array}{l}06013990 \\
09\end{array}$ & $\begin{array}{l}\text { Dove } \\
\text { Love }\end{array}$ & & & $\begin{array}{l}13 \\
18\end{array}$ & $\begin{array}{l}34034 \\
34022\end{array}$ & $\begin{array}{l}97 \mathbf{4 3 0} \\
97440\end{array}$ & 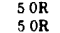 \\
\hline 228 & MAR 23 & 07573746 & Caddo & & 1918 & $\begin{array}{l}18 \\
17\end{array}$ & $\begin{array}{l}54022 \\
35361\end{array}$ & $\begin{array}{l}97440 \\
98108\end{array}$ & $\begin{array}{l}50 R \\
50 R \\
5\end{array}$ \\
\hline 229 & $\begin{array}{l}\text { MAR } 23 \\
M A R 23\end{array}$ & 08411413 & Canadian & & 2019 & 19 & $\begin{array}{l}35387 \\
35605\end{array}$ & 98108 & $50 \mathrm{R}$ \\
\hline $\begin{array}{l}230 \\
231\end{array}$ & $\begin{array}{l}\text { MAR } 23 \\
\text { MAR } 23\end{array}$ & $\begin{array}{l}10435467 \\
17260240\end{array}$ & $\begin{array}{l}\text { Canadian } \\
\text { Canadian }\end{array}$ & & $\begin{array}{l}15 \\
21\end{array}$ & $\begin{array}{l}09 \\
18\end{array}$ & $\begin{array}{l}35605 \\
35411\end{array}$ & & $\begin{array}{l}50 \mathrm{R} \\
50 \mathrm{R}\end{array}$ \\
\hline 232 & APR 1 & $\begin{array}{l}17260240 \\
12291076\end{array}$ & $\begin{array}{l}\text { Canaddan } \\
\text { Canadian }\end{array}$ & & $\begin{array}{ll}\begin{array}{l}11 \\
18\end{array} & 17\end{array}$ & $\begin{array}{l}18 \\
19\end{array}$ & $\begin{array}{l}35411 \\
35420\end{array}$ & $\begin{array}{l}98163 \\
98132\end{array}$ & 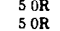 \\
\hline $\begin{array}{l}233 \\
234 \\
234\end{array}$ & APR 22 & 09225246 & Lincoln & & 16 & 18 & 35789 & 96711 & $\begin{array}{l}50 \mathrm{R} \\
50 \mathrm{R}\end{array}$ \\
\hline $\begin{array}{l}234 \\
235 \\
235\end{array}$ & $\begin{array}{l}\text { MAY } 8 \\
\text { MAY } 12\end{array}$ & $\begin{array}{l}11233488 \\
2156411\end{array}$ & Logan & & $\begin{array}{ll}21 & 19 \\
2\end{array}$ & 22 & 35923 & 97480 & $50 R$ \\
\hline $\begin{array}{l}236 \\
236\end{array}$ & MAY 22 & $\begin{array}{l}03492318 \\
037\end{array}$ & $\begin{array}{l}\text { Love } \\
\text { Lental }\end{array}$ & IIII & 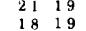 & $\begin{array}{l}23 \\
20\end{array}$ & $\begin{array}{l}35301 \\
34027\end{array}$ & $\begin{array}{l}97601 \\
97470\end{array}$ & $50 R$ \\
\hline 237 & MAY 23 & 173008.30 & Love & & 22 & 20 & $\begin{array}{l}34055 \\
3405\end{array}$ & 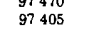 & 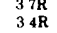 \\
\hline 238 & JUN 1 & 11000161 & Noble & 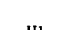 & 1614 & 11 & 36207 & 97330 & $50 R$ \\
\hline $\begin{array}{l}239 \\
240\end{array}$ & $\begin{array}{l}\text { JUN } 7 \\
\text { JUN } 19\end{array}$ & $\begin{array}{l}073935556 \\
04955695\end{array}$ & $\begin{array}{l}\text { Beekham } \\
\text { Pittsburg }\end{array}$ & III & $\begin{array}{l}32 \\
\begin{array}{ll}32 \\
19\end{array}\end{array}$ & 20 & $\begin{array}{l}35187 \\
34715\end{array}$ & $\begin{array}{l}99812 \\
95965\end{array}$ & $50 \mathrm{R}$ \\
\hline 241 & JUN 19 & 04531353 & Pittsburg & & 18 & 19 & 34746 & 95932 & $50 \mathrm{R}$ \\
\hline $\begin{array}{l}242 \\
242 \\
243\end{array}$ & JUL 1 & 07001628 & Love & & $\begin{array}{ll}19 & 18 \\
23 & 23\end{array}$ & 20 & $\begin{array}{l}34028 \\
35705\end{array}$ & $\begin{array}{l}97383 \\
979798\end{array}$ & $50 \mathrm{R}$ \\
\hline $\begin{array}{l}243 \\
244\end{array}$ & $\begin{array}{l}\text { JUL } 4 \\
\text { JUL } 7\end{array}$ & $\begin{array}{l}03452129 \\
0153323\end{array}$ & $\begin{array}{l}\text { Canadan } \\
\text { P.trtsbure }\end{array}$ & & $\begin{array}{ll}23 & 23 \\
24 & 16\end{array}$ & $\begin{array}{l}22 \\
21\end{array}$ & $\begin{array}{l}35705 \\
34879\end{array}$ & $\begin{array}{l}97978 \\
95814\end{array}$ & $\begin{array}{l}50 \mathrm{R} \\
50 \mathrm{R}\end{array}$ \\
\hline 245 & JUL 13 & 0 & MeCurtann & & $\begin{array}{l}24 \\
13\end{array}$ & $\begin{array}{l}21 \\
18\end{array}$ & $\begin{array}{l}34879 \\
34033\end{array}$ & $\begin{array}{l}90814 \\
95087\end{array}$ & $\begin{array}{l}50 R \\
50 R\end{array}$ \\
\hline $\begin{array}{l}246 \\
247 \\
247\end{array}$ & $\begin{array}{l}\text { JUL } 24 \\
\text { JUL }\end{array}$ & $\begin{array}{l}022406.27 \\
031537.27\end{array}$ & $\begin{array}{l}\text { Logan } \\
\text { Love }\end{array}$ & $\mathrm{y}$ & $\begin{array}{ll}28 & 25 \\
28\end{array}$ & $\begin{array}{l}25 \\
23\end{array}$ & $\begin{array}{l}\begin{array}{l}36070 \\
33967\end{array} \\
3\end{array}$ & $\begin{array}{l}97506 \\
97549\end{array}$ & $\begin{array}{l}50 R \\
50 R\end{array}$ \\
\hline $\begin{array}{l}241 \\
248\end{array}$ & JUL 31 & 19110562 & $\begin{array}{l}\text { Love } \\
\text { Payne }\end{array}$ & $v$ & $\begin{array}{l}24 \quad 27 \\
2425\end{array}$ & 19 & $\begin{array}{l}33967 \\
36086\end{array}$ & $\begin{array}{l}97549 \\
97305\end{array}$ & \\
\hline 249 & AUG 3 & 10291163 & Canadian & & $20 \quad 19$ & & 35683 & 98005 & \\
\hline 250 & AUG 9 & 00041486 & Love & & 1824 & 20 & $\begin{array}{r}33930 \\
\end{array}$ & 97432 & 5 \\
\hline $\begin{array}{l}251 \\
251\end{array}$ & AUG 16 & 07271282 & McClain & & 1719 & 17 & & & \\
\hline $\begin{array}{l}252 \\
253\end{array}$ & $\begin{array}{l}\text { AUG } 19 \\
\text { SEP } 4\end{array}$ & $\begin{array}{l}01580785 \\
07401197\end{array}$ & $\begin{array}{l}\text { Cleveland } \\
\text { Garving }\end{array}$ & & $\begin{array}{l}24222 \\
22223\end{array}$ & $\begin{array}{l}21 \\
21\end{array}$ & $\begin{array}{l}\begin{array}{r}35203 \\
34799\end{array} \\
34799\end{array}$ & $\begin{array}{l}97445 \\
97557\end{array}$ & \\
\hline 254 & $\begin{array}{l}\text { SEF } 4 \\
\text { SEP } 5\end{array}$ & $\begin{array}{l}07401197878 \\
0234848\end{array}$ & $\begin{array}{l}\text { Garvin } \\
\text { Canadian }\end{array}$ & & $\begin{array}{l}22 \\
17 \\
179\end{array}$ & $\begin{array}{l}21 \\
15\end{array}$ & $\begin{array}{l}34799 \\
35429\end{array}$ & $\begin{array}{l}97571 \\
97871\end{array}$ & \\
\hline 255 & SEP 5 & 04043449 & $\begin{array}{l}\text { Canadian } \\
\text { (a) }\end{array}$ & & & 15 & 35427 & 97717 & $\begin{array}{l}50 R \\
50 R\end{array}$ \\
\hline 256 & SEP 13 & 00492297 & Beckham & IV & $\begin{array}{l}33 \\
34\end{array}$ & 31 & 35217 & 99362 & $145 \mathrm{R}$ \\
\hline 257 & SEP 13 & 02195128 & Washita & & 19 & 21 & & & 14 \\
\hline $\begin{array}{l}258 \\
259 \\
259\end{array}$ & $\begin{array}{l}\text { SEP } \\
\text { SEP }\end{array}$ & $\begin{array}{l}03422539 \\
\\
\end{array}$ & $\begin{array}{l}\text { Canadian } \\
\text { Grady }\end{array}$ & & & 17 & $\begin{array}{l}\begin{array}{l}35493 \\
35369\end{array} \\
353\end{array}$ & $\begin{array}{l}97882 \\
97952\end{array}$ & \\
\hline 260 & $\begin{array}{l}\text { SEP 15 } \\
\text { SEP 16 }\end{array}$ & $\begin{array}{l}\begin{array}{l}4001938 \\
06045311\end{array}\end{array}$ & $\begin{array}{l}\text { Grady } \\
\text { Grady }\end{array}$ & & $\begin{array}{l}20 \\
17 \\
17\end{array}$ & $\begin{array}{l}19 \\
16\end{array}$ & $\begin{array}{l}35369 \\
35355\end{array}$ & $\begin{array}{l}97952 \\
979997\end{array}$ & \\
\hline 261 & SEP 16 & 062758.42 & $\begin{array}{l}\text { Wray } \\
\text { Canadi }\end{array}$ & & 17 & 15 & 35435 & 97981 & \\
\hline 262 & SEP & 104205.85 & Canadian & & 2020 & 19 & 35455 & 97 905 & \\
\hline 263 & SEP & 11070023 & Grady & & 1918 & 18 & $\begin{array}{r}35355 \\
35353\end{array}$ & 97989 & $50 \mathrm{R}$ \\
\hline 4 & & 15572084 & Grady & IV & $\begin{array}{ll}25 & 25 \\
2\end{array}$ & 22 & $\begin{array}{r}35 \\
35 \\
35\end{array}$ & 97997 & \\
\hline 56 & $\begin{array}{l}\text { SEP } \\
\text { SEP }\end{array}$ & $\begin{array}{l}221164217 \\
14380960\end{array}$ & $\begin{array}{l}\text { Grady } \\
\text { Haskell }\end{array}$ & & $\begin{array}{ll}21 & 19 \\
16 & 18\end{array}$ & $\begin{array}{l}19 \\
17\end{array}$ & $\begin{array}{l}\begin{array}{l}35 \\
35 \\
35\end{array} 065 \\
3563\end{array}$ & $\begin{array}{l}97966 \\
94937\end{array}$ & \\
\hline 267 & SEP 17 & $\begin{array}{l}145045050 \\
20415053\end{array}$ & $\begin{array}{l}\text { Harke } \\
\text { Grady }\end{array}$ & IV & $\begin{array}{ll}16 & 18 \\
26 & 25\end{array}$ & 23 & 35320 & $\begin{array}{l}94 \\
97 \\
\end{array}$ & \\
\hline 268 & OCT 6 & 11085192 & Pittsburg & & $\begin{array}{ll}15 & \\
23 & 22\end{array}$ & 16 & $\begin{array}{l}34887 \\
34502\end{array}$ & & \\
\hline $\begin{array}{l}269 \\
270\end{array}$ & Nov 7 & $\begin{array}{l}07290755 \\
05540984\end{array}$ & $\begin{array}{l}\text { Coal } \\
\text { Canadıan }\end{array}$ & & 2122 & $\begin{array}{l}24 \\
19\end{array}$ & $\begin{array}{l}\begin{array}{r}34502 \\
35510\end{array} \\
3510\end{array}$ & $\begin{array}{l}96432 \\
97888\end{array}$ & \\
\hline 11 & NOV i1 & 10265733 & Canadian & & 22 & 19 & 35695 & 98050 & R \\
\hline 272 & Nov 16 & 05501560 & Hughes & & & 13 & 35285 & 95987 & \\
\hline o & NOV 27 & 09103679 & Blaine & Wh & 33 & 29 & 30 & 98408 & \\
\hline $\begin{array}{l}274 \\
275 \\
275\end{array}$ & $\begin{array}{l}\text { DEC } 9 \\
\text { DEC } 10\end{array}$ & $\begin{array}{r}23125866 \\
6250\end{array}$ & Love & III & $\begin{array}{r}2925 \\
29\end{array}$ & 24 & $\begin{array}{l}\begin{array}{l}339988 \\
34965\end{array} \\
3\end{array}$ & $\begin{array}{l}97353 \\
96307\end{array}$ & \\
\hline 76 & DEC & $\begin{array}{l}08251482 \\
13200902\end{array}$ & $\begin{array}{l}\text { Hughes } \\
\text { McClayn }\end{array}$ & & 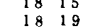 & $\begin{array}{l}20 \\
18\end{array}$ & 35187 & $\begin{array}{l}96307 \\
97664\end{array}$ & $\begin{array}{l}50 R \\
50 R\end{array}$ \\
\hline 2 & & 12373749 & Washita & & $\begin{array}{l}18 \\
25\end{array}$ & & 35158 & $\begin{array}{l}98741 \\
9874\end{array}$ & Sor \\
\hline 278 & & 882681 & Noble & & & & 36367 & 列 97379 & $50 \mathrm{KK}$ \\
\hline
\end{tabular}

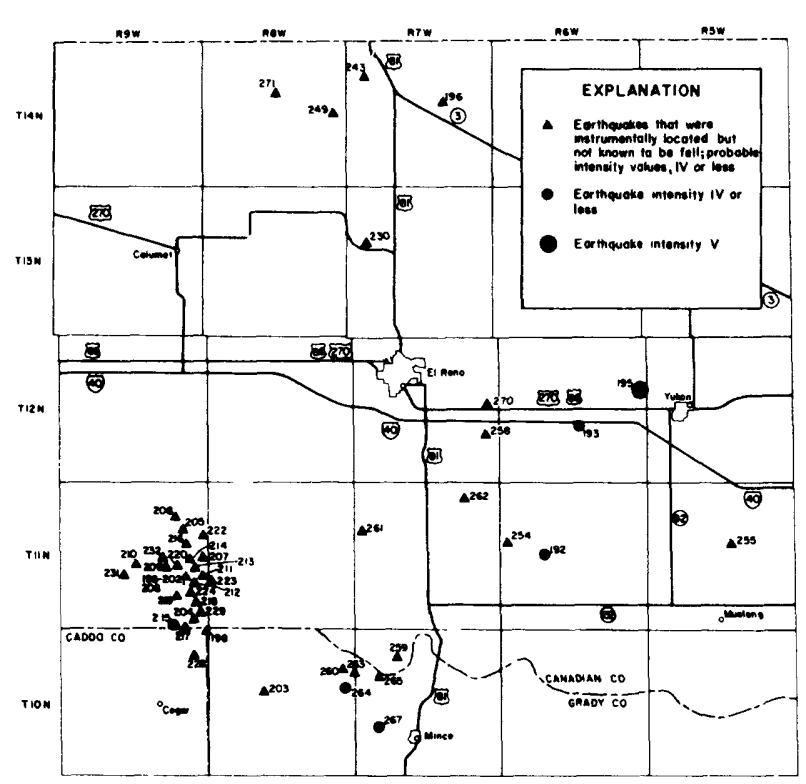

FIGURE 54.--Earthquake epicentral locations for 1979 in Canadian County and nearby Grady and Caddo Counties, Oklahoma.

\section{SOUTHEASTERN UNITED STATES EARTHQUAKES, 1979}

By G. A. Bollinger

Seismological Observatory

Virginia Polytechnic Institute

and State University

Blacksburg, Virginia 24061

There were 44 earthquakes located in the southeastern United States during 1979 (fig. 55). Of these, eight had $M \geq 3$ and/or were felt (table 7). Additionally, seven events were reported (TVA/Georgia Tech) in an aftershock study of the August 13 Tennessee earthquake ( $\mathrm{mbLg}=3.7$ ) and a single coalburst event (pillar failure in an underground mine) was reported (Virginia Tech) in western Virginia on November 13 (MD Mag $=0.2$ ). Finally, some 113 microearthquakes $\quad(M<3)$ were reported as detected, but not located. Most of these events were in the vicinity of reservoirs.

A full data listing for all 1979 earthquakes was given in Southeastern United States Seismic Network Bulletins No. 4 and 5. A discussion of the "Detection and Location Capability of the Southeastern United States Seismic Network" by Arthur C. Tarr is presented in Bulletin No. 5. Copies of both reports may be obtained by contacting the author. 
The number of seismograph stations operating in the region varied from 79 to 83 . Figure 56 shows the station distribution (83) at the end of 1979 .

Table 7.--Southeastern L'nited States earthquakes, 1979

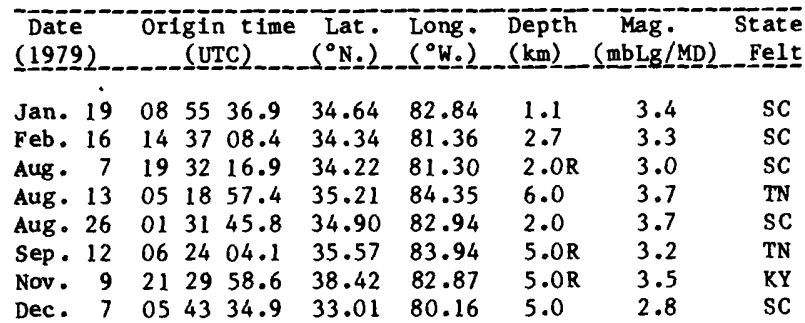

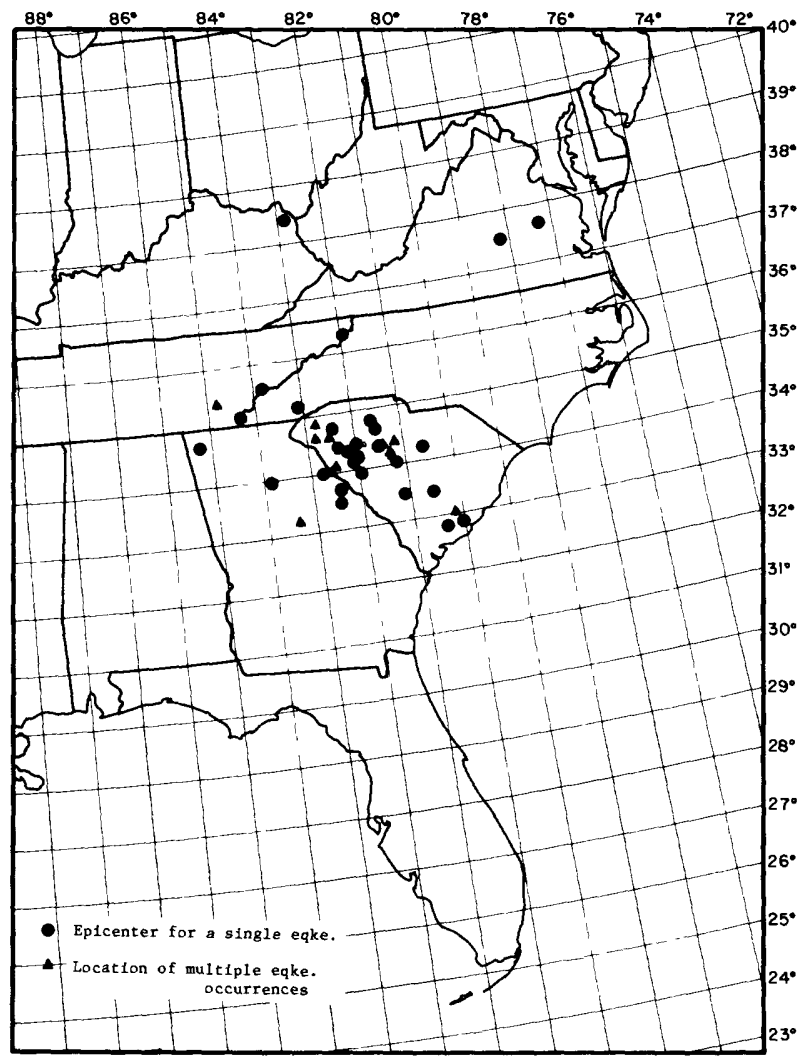

FIGURE 55.--Southeastern United States earthquake epicenters during 1979.

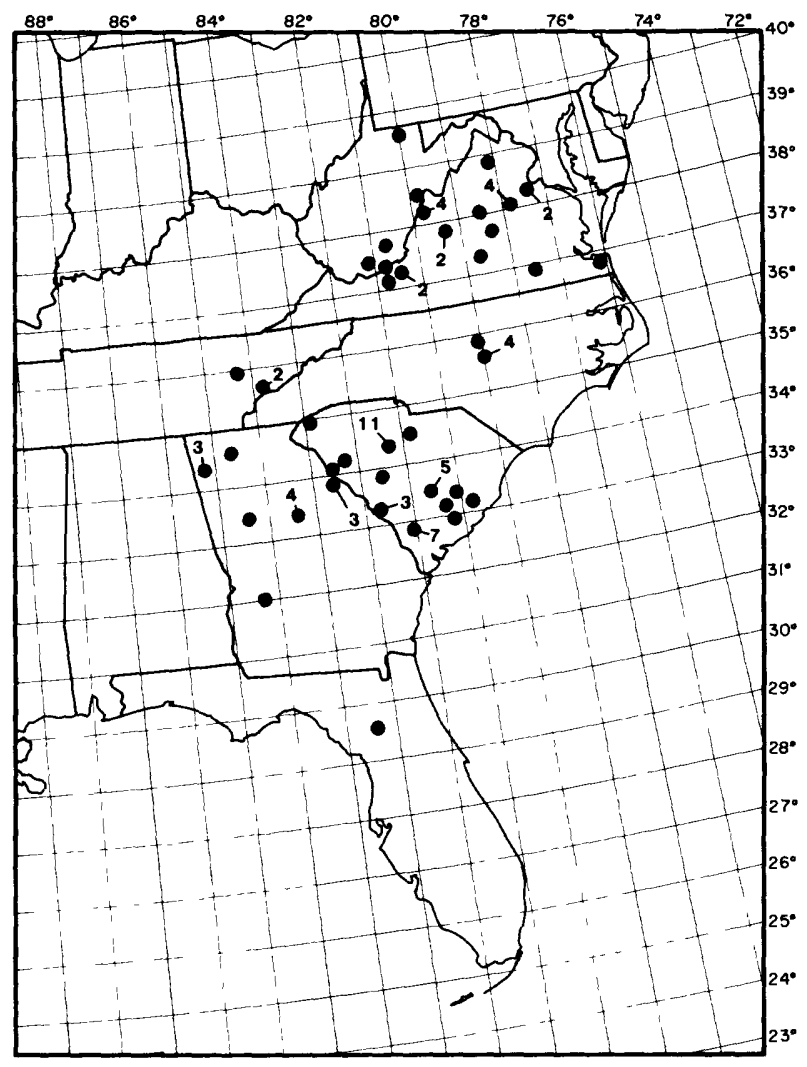

FIGURE 56.--Southeastern United States seismic stations (solid circles) operating at the close of 1979. Numbers indicate the number of closely spaced multiple stations at a given location.

\section{WASHINGTON EARTHQUAKES, 1979}

By R. S. Crosson, L. J. Noson, and S. M. Malone University of Washington Seattle, Washington 98195

During 1979, 23 telemetered short-period seismograph stations were operated west of the Cascade Mountains and 33 stations were operated east of the Cascades. All central recording was done at the University of Washington. Six additional stations were added on the east flank of the Cascade Range late in 1979. Five strongmotion stations were also maintained by the 
University. Substational expansion of this network has occurred since 1979. In western Washington, 375 earthquakes were located and in eastern Washington, 243 were located. Eight earthquakes had felt reports in the western part of the state and four were reported felt in the eastern part of the state.

Several events were of particular significance or interest in 1979. In southwest Washington, a magnitude 3.9 earthquake occurred on March 11 near Riffe Lakes which is about $30 \mathrm{~km}$ NNE of Mt. St. Helens. Again on July 7, another event of magnitude 3.6 occurred in the same area. For comparison, the largest earthquake previously recorded from that area was approximately magnitude 3.0 . A total of 23 earthquakes were located in this area compared to a previous background level of approximately 5 events/year.
East of the Cascade range a magnitude 4.0 earthquake occurred on January 19 south of Chief Joseph Dam on the upper Columbia River. Numerous aftershocks, the largest being magnitude 3 on January 21, were recorded over the next few weeks. An unusual earthquake of magnitude approximately 4.1 occurred near Walla Walla, Washington on April 8. Contrary to usual experience with shallow earthquakes in the Columbia basin, no foreshock or aftershock activity was detected associated with this earthquake.

A bulletin for eastern Washington is included in technical reports prepared for the Department of Energy under contract EY-76-8-062225. A bulletin covering just the region west of the Cascade range is being prepared for publication through the Washington state Department of Natural Resources, Geology and Earth Resources Division, Olympia, Washington. 


\section{Miscellaneous Activities}

\section{CRUSTAL MOVEMENT STUDIES}

\author{
Vertical Control Surveys \\ By Sand ford R. Holdahl \\ NOAA, National Ocean Survey \\ National Geodetic Survey \\ Rockville, Maryland 208 ₹2
}

Recomputation of the Palmdale Bulge

The area of southern California surrounding palmdale has been undergoing further study. In 1976, analysis of leveling data had indicated uplift near Palmdale to be up to $25 \mathrm{~cm}$, according to Robert Castle of the U.S. Geological Survey (USGS). The National Geodetic Survey (NGS) estimates of the uplift, using another method, were about half as large. Recomputation of the Palmdale data was undertaken because of several shortcomings in the original analyses:

1. Refraction was found to be a considerably larger source of error than previously as sumed.

2. One pair of rods with apparent calibration problems was suspect.

3. The original adjustment by NGS was not performed in geopotential units.

In the revised computation the above problems were eliminated. A refraction correction was applied to the data based on a new model for temperature stratification near the ground. All rod calibrations were recomputed, and the adjustment was calculated using geopotential units. The new results now show that Palmdale has moved very little by comparison to most areas in southern California. The revised est1mates of motion in the region could not be considered alarming because they amounted to only a few centimeters between 1959 and 1975. The primary leveling routes to Palmdale are very conducive to large accumulations of refraction error. Some routes traverse subsidence pockets or pass through locations of recent earthquakes. Refraction error is the cause of the original weak estimates. The sight lengths used in leveling have shortened considerably since 1955. Refraction error is proportional to the square of the sight length, and during most of the work day it will make the observed height differences be too small. Because of the recently shortened sight lenghts, high locations such as Palmdale (approached by low gradient level routes) will appear to have moved upward with time. The study indicates that refraction correction should be considered a necessary and important correction prior to extracting vertical crustal motions from leveling records.

Refraction Studies

Leveling refraction has been studied intensively by NGS because of its harmful influence on data used for estimating vertical crustal motion.

Refraction causes leveled height differences to be too small. It is usually considered to be the largest known systematic error in leveling measurements, amounting to as much as 1.0 $\mathrm{cm} / \mathrm{km}$.

Refraction error is proportional to the square of the sight length used in a leveling measurement. Recent modern leveling is accomplished with much shorter sight lengths than leveling performed prior to 1964. Consequently, there is less refraction in the newer measurements, thus giving the appearance of crustal movement when comparisons are made to older measurements.

T. J. Kukkamaki developed a refraction correction which is proportional to the temperature difference, $\Delta t$, between heights of 0.5 and $2.5 \mathrm{~m}$. $\Delta t$ was to be measured, requiring extra effort and equipment. The United States and most other countries did not adopt the correction. However, it is now realized that the correction is necessary, especially in the middle and lower latitudes.

Removing refraction bias from old leveling measurements requires that $t$ be estimated by $a$ temperature stratification model. Such a model has been developed by NGS, and is based on historical records of solar radiation, sky cover, precipitation, and ground albedo from many locations in the conterminous United States. Tests have shown the average difference between the predicted $t$ and observed $t$ to be $-0.12^{\circ}$, $+0.14^{\circ}$, and $-0.22^{\circ} \mathrm{C}$ for data sets from Maryland, California, and Arizona, respectively. These accurate $t$ values now make refraction correction possible for old levellings, and consequently the calculations and interpretations of crustal motion can be more reliable. 
Horizontal Control Surveys

By Richard A. Snay

NOAA, National Ocean Survey

National Geodetic Survey

Rockville, Maryland 2085?

Imperial Valley, California

A triangulation-trilateration survey was performed by the NGS 4 months prior to the October 15, 1979, Imperial valley earthquake (M $=6.6)$. The survey was repeated in FebruaryMarch, 1980 to gauge the coseismic displacement. These data, combined with triangulation surveys performed in 1934, 1939, 1941, 1954, and 1967, provide a historical record of crustal deformation over a time period that also includes the 1940 E1 Centro earthquake $(M=7.1)$. The total data set was analyzed in terms of a dislocation model which relates the observed surface deformation to slippage on prescribed geologic faults. According to the model, the 1941-80 fault slippage at depths $10 \mathrm{~km}$ and greater is $1.9 \pm 0.3 \mathrm{~m}$. This is approximately twice the amount of estimated movement, $1.0+0.1 \mathrm{~m}$, for the 1941-80 slippage on the Imperial fault in the 0- to 10-km depth range. This discrepancy can be explained by a range of possibilities some of which were postulated by Thatcher (1979) in his study of triangulation throughout southern California. These possibilities include: (1) the existence of permanent inelastic deformation, (2) massive post-seismic slippage at depth following the 1940 event, (3) distribution of the shallow slippage over several subparallel faults, and (4) a mechanism other than slippage to accomodate deformation at depth.

Salt Lake City, Utah

Estimates of horizontal strain rates in the vicinity of Salt Lake City, Utah were derived from triangulation-trilateration data observed by the NGS between 1962 and 1974. The data which spans the Wasatch fault zone around and south of the city produce an estimate of $N 79^{\circ} \mathrm{E}$ $+14^{\circ}$ for the direction of maximum extension. This estimate is in accordance with an expected trend of east-west extension across the fault zone. The maximum extension direction, $\mathrm{N} 35^{\circ} \mathrm{W}$ $+10^{\circ}$, derived for data north of the city, differs significantly from the expectation. Nevertheless, the northern estimate is in general agreement with the previously published estimate $\mathrm{N} 17^{\circ} \mathrm{W}+10^{\circ}$ derived for the slightly more northerly Ogden area from 1972-78 trilateration data observed by the U.S. Geological Survey. The unexpected strain pattern north of salt Lake City may be related to the seismic quiescence realized on this sector of the Wasatch fault zone since 1962 or earlier.

\section{TSUNAMIS}

By Mark G. Spaeth

National Oceanic and Atmospheric Administration National Weather Service

S1lver Spring, Maryland 20910

During 1979, nine tsunamis were reported to the National Oceanic and Atmospheric Administration (NOAA), including three which were recorded on NOAA tide gages.

On February 28, an earthquake (mag. 7.1) in southeastern Alaska $\left(60.6^{\circ} \mathrm{N} ., 141.6^{\circ}\right.$ W.), generated a small tsunami which was recorded at Yakutat with a maximum amplitude of $30 \mathrm{~cm}$.

An earthquake (mag. 7.6) near the coast of Guerrero, Mexico (17.8 N., 101.3 ${ }^{\circ}$ W.), on March 14 , caused a minor tsunami that was recorded at Pago Pago, American Samoa, with a maximum amplitude of $14 \mathrm{~cm}$.

An earthquake (mag. 7.0) on April 15, in Yugoslavia $\left(41.1^{\circ} \mathrm{N}_{\text {., }} 19.1^{\circ} \mathrm{E}.\right)$, was reported to have generated a tsunami in Kotor Bay which caused considerable damage.

On July 17, a tsunami generated by a landslide struck the south coast of Lomblen Island, Lesser Sunda Islands, Indonesia. The landslide, which occurred on the south coast of Lembata Island, was possibly triggered by a small earthquake in the Sawu Sea. Four villages on Lomblen were destroyed with 187 killed and 364 missing.

A second tsunami caused by landsliding was reported to have struck the south coast of Lomblen Island on August 9, with waves reaching more than $120 \mathrm{~m}$ inland.

The September 12 earthquake (mag. 8.1) in the West Irian region $\left(1.7^{\circ} \mathrm{S} ., 135.9^{\circ} \mathrm{E}\right.$ ) generated a local tsunami on the islands of Biak and Yapen. The waves killed 100 and destroyed 400 houses on Yapen. Two meter waves were reported from Biak.

On October 16 about 1300 UTC, a tsumami thought to be generated by a submarine landslide of sediments at the mouth of the Var River, struck a $60 \mathrm{~km}$ stretch of the French Riviera. Waves in excess of $10 \mathrm{~m}$ killed six people at Nice and one at Antibes and left three missing. The tsunami also caused widespread dandge.

On November 16 the Fiji Island earthquake $\left(16.5^{\circ} \mathrm{S} ., 179.9^{\circ} \mathrm{E} ., \mathrm{mag} .6 .9\right)$ caused a small tsunamf which penetrated $150 \mathrm{~m}$ inland on the arthern tip of Taveuni Island. 
The most destructive and most widely recorded tsunami of the year was generated on December 12 by an earthquake (mag. 7.9) near the coast of Ecuador $\left(1.6^{\circ} \mathrm{N}_{0}, 79.4^{\circ} \mathrm{W.}\right)$. Two-tofive meter waves were reported along the Colombian coast. Six fishing villages were practically destroyed, fifteen others were damaged, and several hundred people were killed. The tsunami was recorded with the following maximum amplitudes: Hilo $-73 \mathrm{~cm}$; Kahului $-75 \mathrm{~cm}$; Nawl liwili - $14 \mathrm{~cm}$; Pago Pago $-12 \mathrm{~cm}$.

\section{PRINCIPAL EARTHQUAKES OF THE WORLD}

Table 8 lists princlpal world earthquakes for 1979. The 1ist has been included in this annual series since 1941. It includes earthquakes of magnitude 6.8 or greater; those of smaller magnitude that were locally destructive to life and property; and events of unusual interest. 


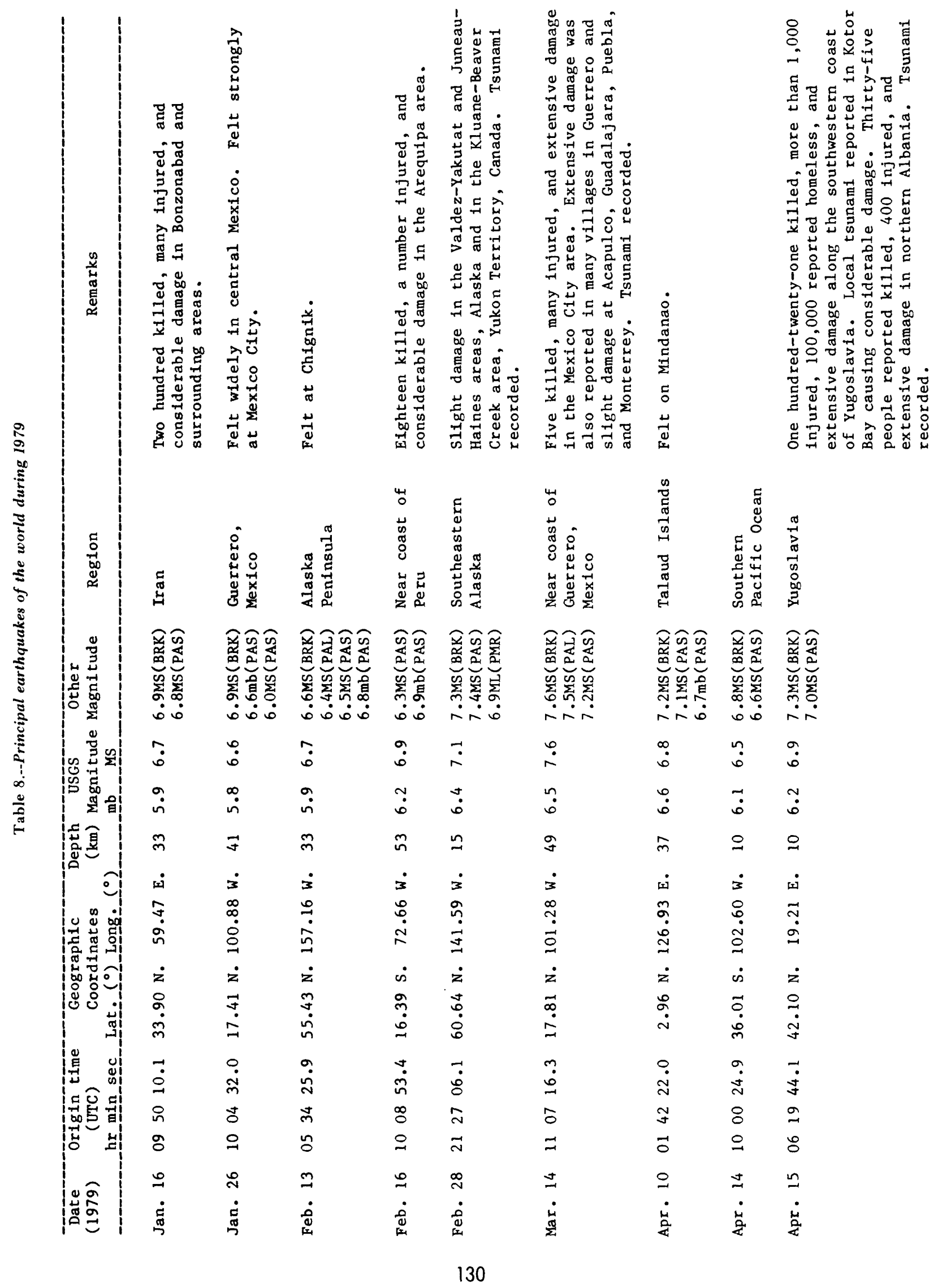




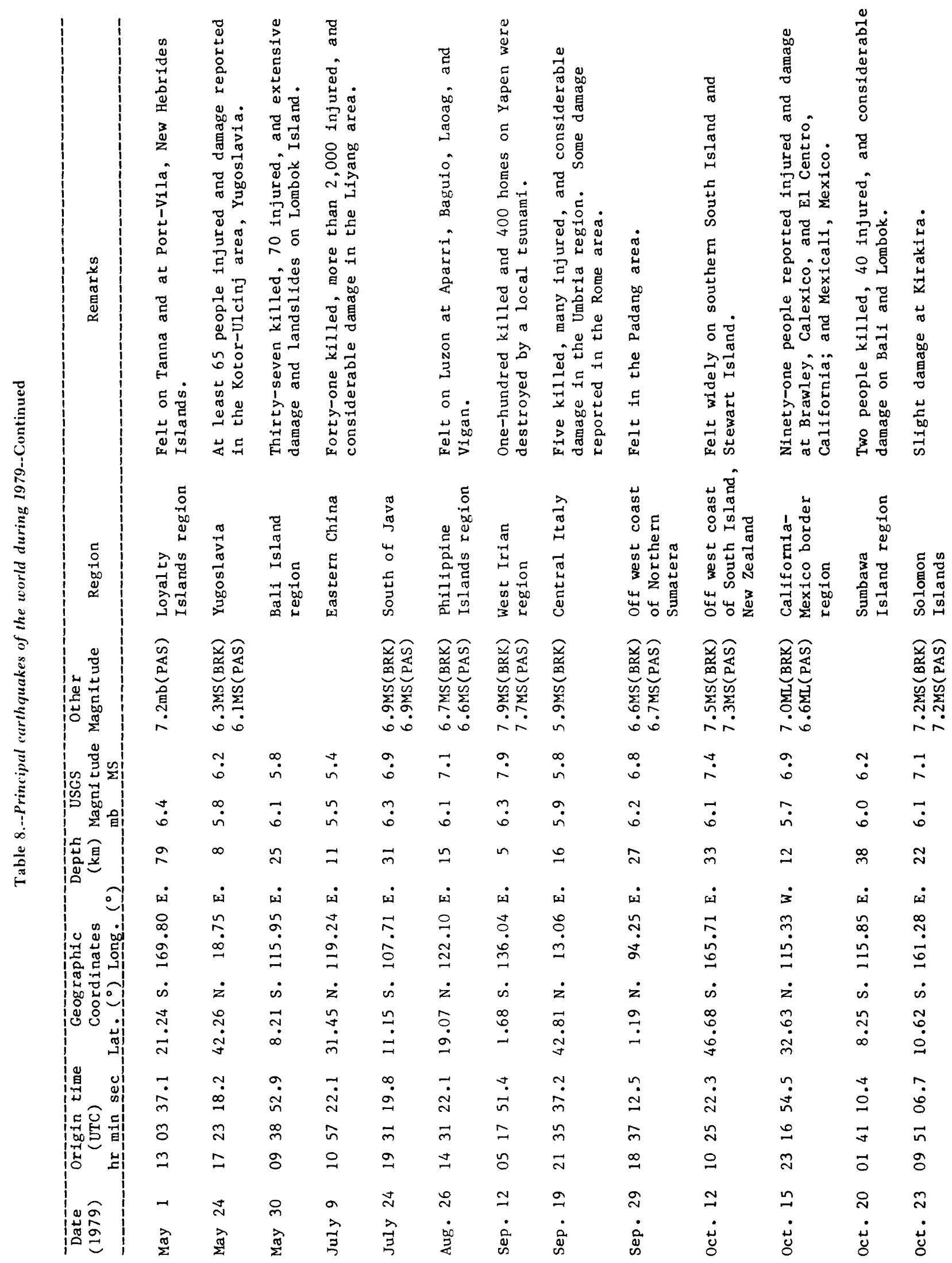




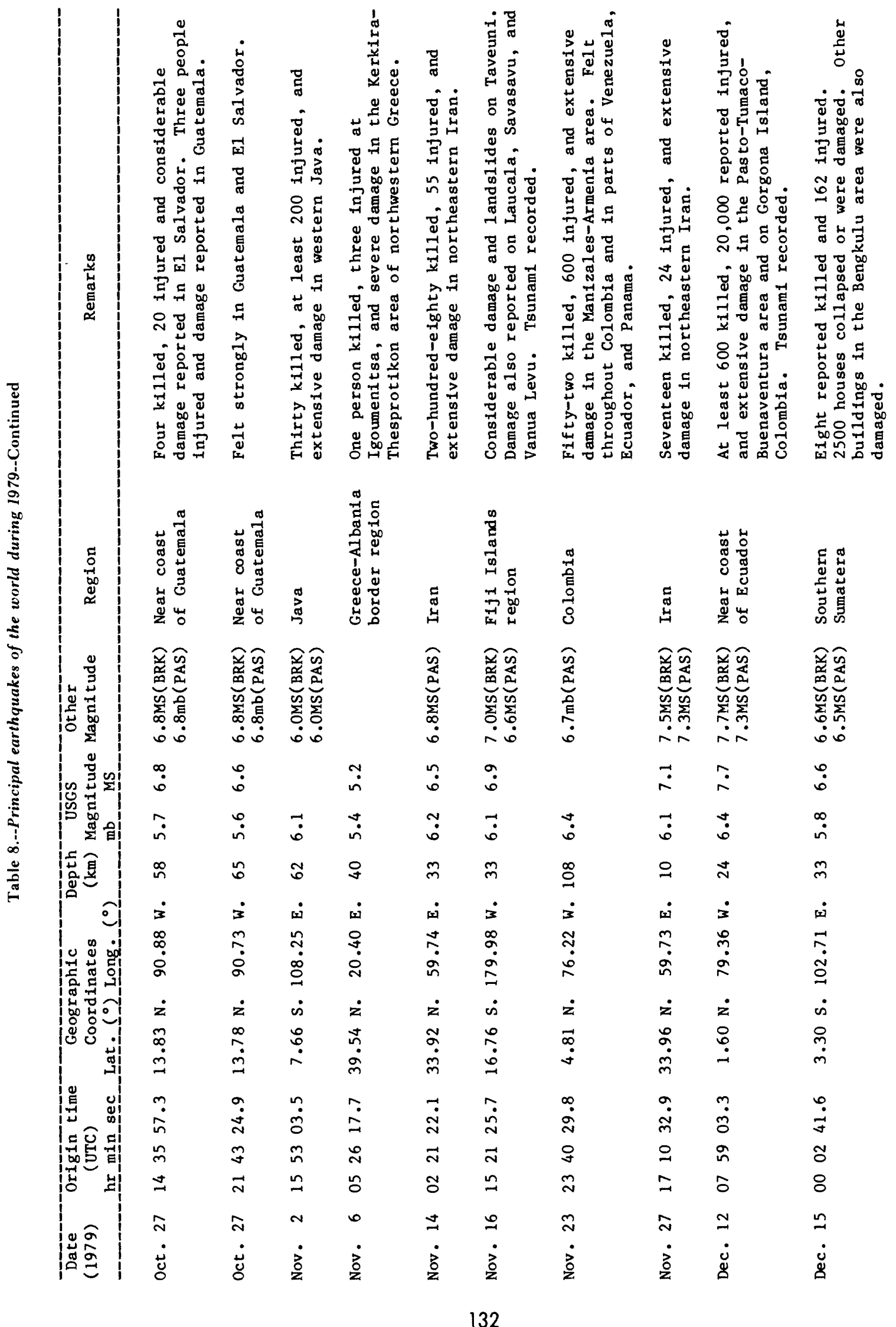




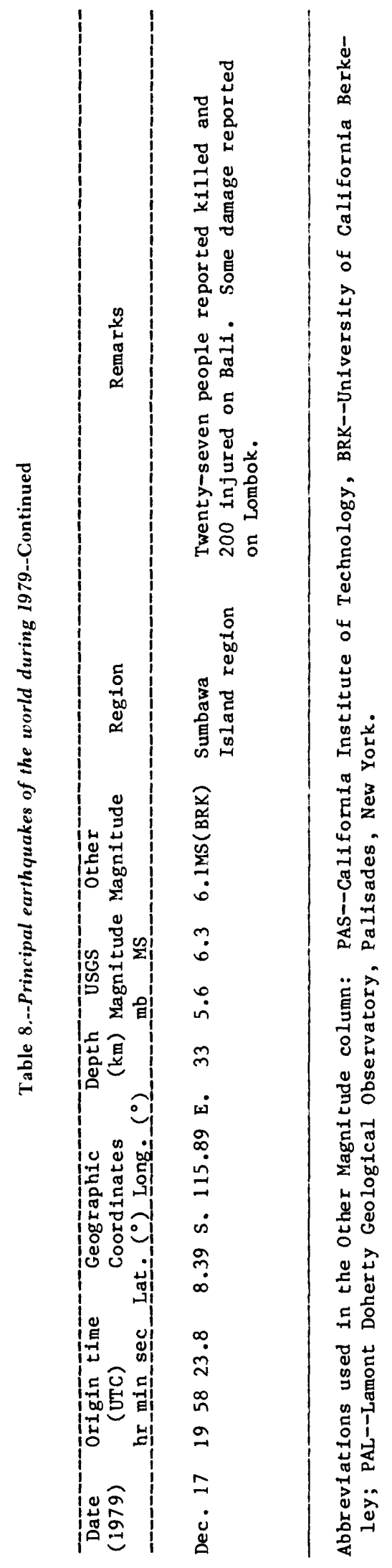




\section{Strong-Motion Seismograph Data}

\author{
By Ronald L. Porcella \\ Seismic Engineering Branch \\ U.S. Geological Survey \\ Menlo Park, California 94025
}

\section{INTRODUCTION}

The first engineering seismology program in the United States was administered by the Seismological Field Survey of the Coast and Geodetic Survey ( $C \& G S$ ). This program was begun in 1931 and effectively remained the responsibility of the Seismological Field Survey (SFS) for more than 40 years. During this period the SFS was shifted from one acronymic agency to another, including C\&GS, ESSA, NOS, NOAA, ERL, ESL, and finally, in 1973, USGS; soon afterwards the SFS became the Seismic Engineering Branch of the USGS. In spite of these numerous high-level administrative changes, the program has retained a distinct identity and its basic objectives and field-level operations have remained remarkably consonant throughout the years.

The current program of strong-motion instrumentation administered by the USGS is supported by the National Science Foundation (Grant CA-114) in cooperation with both private industry and educational institutions, as well as numerous Federal, State, and local agencies and organizations. The objectives of the program are to record strong ground motions and the response of representative types of engineered structures during potentially damaging earthquakes and to disseminate processed data and information about the records, sites, and structures to external users in earthquake engineering research and design practice and engineering seismology. The dissemination of this information and data is achieved in various ways.

Preliminary earthquake reports and a summary of recent accelerograph records are presented on a regular basis in Seismic Engineering Program Reports ${ }^{1}$, a USGS Circular. These summaries include a brief description of the earthquake and strong-motion recording station, the results of routine scalings of those

${ }^{1}$ Copies of these reports are available free on application to Branch of Distribution, U.S. Geological Survey, 1200 South Eads Street, Arlington, Va. 22202 . records that contain peak accelerations greater than $0.05 \mathrm{~g}$, and photographic reproductions of many of the more significant accelerograms. The program reports also contain abstracts of recent reports, notes on strong-motion information sources and the availability of digitized data, and other information pertinent to the USGS and other strong-motion programs.

Strong-Motion event and strong-motion data reports are periodically published as USGS Open-file Reports and include the results of digitization and routine analyses of strongmotion accelerograms that contain peak accelerations greater than $0.10 \mathrm{~g}$ or are related to a specific event, particular strong-motion station, or geographic group of stations. The minimum acceleration level is based primarily on the current capability of the USGS to process strong-motion records and may vary with both the degree of seismic activity and number of personnel available at any given time. Although maximum acceleration is not directly related to frequency content or duration of strong-motion, the peak acceleration can be readily obtained from an accelerogram and thus the value is commonly used as a general indicator of the potential significance of the record. Detailed information on the availability of digitized data from various sources is published regularly in Seismic Engineering Program Reports.

The Strong-Motion Accelerograph Station List is periodically published as a USGS Openfile Report and includes information on all of the accelerograph stations in the western hemisphere known to the USGS. Because of the everchanging nature of this information, it is impossible to have a complete 1 ist of all of the stations in existence at any one time. Rather, the 1 ist is intended to provide that community of persons interested in strong-motion programs with a reasonably complete indication of the current status of the various strong-motion networks. Information presented in this 1 ist includes the station name and geographic coordinates, site characteristics, type and size of structure, location of instruments, and the primary sources of data. The current 1 ist contains information on approximately 1200 stations located in 38 states, Canada, the Caribbean, and throughout Central and South America (Seismic Enginee ring Branch, 1977).

A strong-motion information retrieval system (SMIRS) has been developed to provide upto-date information about strong-motion records 
and the circumstances in which they were recorded. The system is accessible through a data terminal ( 30 cps, half duplex) A user's manual is avallable (Converse, 1978). To retrieve information, dial (415) 329-8600 and place the telephone handset into the terminal. When the carrier light comes on press the "line-feed" key and wait for the computer to respond (two lines will be printed); type the following:

\section{enter yourname SMIRS}

Type the "enter" and "SMIRS" exactly as shown above, but replace yourname with your own name. The word "enter" is five lowercase characters followed by one space; your name is typed as one continuous character string and followed by one space; and "SMIRS" is five uppercase characters. Type the carriage-return key and then the linefeed key; then you will be given instructions.

\section{ACCELEROGRAPH DATA}

Table 9 is a summary of the 511 records recovered from USGS strong-motion stations during 1979. This number is contrasted with a yearly average of 174 records for the period 1972 to 1978 inclusive; however, 70 percent of the 1979 records were related to either the August 6 Gilroy (Coyote Lake) or October 15 Imperial Valley earthquakes, both of which occurred in areas that contained extensive arrays of accelerographs operated under the USGS Strong-Motion Program that is funded by the National Science Foundation. Other organizations involved in the planning of these groundmotion arrays (Gilroy, Bear Valley, and Imperial Valley) include the California Institute of Technology, the California Division of Mines and Geology, and the Federal Highways Administration. Although the number of accelerograms recorded at these arrays is impressive (table 9), of much greater significance is the comprehensive azimuthal distribution and number (23) of close-in accelerograms (fault-station distance less than $20 \mathrm{~km}$ ) recorded during the Gilroy and Imperial Valley earthquakes (Porcella and others, 1979; Porcella and Matthiesen, 1979).

Additionally, many accelerograms were recovered in 1979 at stations operated by the California Division of Mines and Geology's office of Strong-Motion Studies (OSMS). Recent state legislation has given responsibility to OSMS for the dissemination of that organization's strong-motion data, which is no longer routinely listed in Seismic Engineering Program Reports (see Calif. Div. of Mines and Geology, 1979, and Porter, 1980). Brune and others, 1980, discuss strong-motion data obtained in Mexico for the Imperial Valley earthquake, which was recorded at stations operated jointly by the University at Mexico City and the University of California at San Diego.
The earthquakes (table 9) are listed in chronological order and include date, time (UTC), general location, geographic coordinates, and magnitude. Information about the recording station consists of the name and location, owner, and geographic coordinates. Record data include $S$-wave minus trigger time and the orientation, maximum acceleration, and duration of strong-motion (greater than $0.10 \mathrm{~g}$ ) for each instrument component. Record data is included only when one or more components recorded at least $0.05 \mathrm{~g}$ at ground stations or $0.10 \mathrm{~g}$ at upper floors of buildings. The event information has been complied principally from the Preliminary Determination of Epicenters, pub1 ished by the Geological Survey.

The following paragraphs summarize the results of the most significant earthquakes from which strong-motion records were obtained in 1979; these abridged reports have been abstracted from 1979 Seismic Engineering Program Reports (Geological Survey Circulars 818A, 818B, and $818 \mathrm{C}$ ).

\section{ST. ELIAS, ALASKA - February 28}

A magnitude 7.1 (MS) earthquake occurred on February 28, 1979 (1127 local time) approximately $75 \mathrm{~km}$ north of Icy Bay, Alaska. The hypocenter was located at a depth of about $15 \mathrm{~km}$ $(+10)$ in the vicinity of the St. Ellas Mountains in southeastern Alaska (Lahr and others, 1979), which is a highly faulted and tectonically very complex region. Strong-motion accelerograph records were recovered at the U.S. Geological Survey's Icy Bay station, Shell 011 Company's Munday Creek station, and Lamont-Doherty Geological Observatory's Yakutat station; maximum recorded ground accerlerations and the corresponding epicentral distances were $0.16 \mathrm{~g}$ $(73 \mathrm{~km})$ at Icy Bay, $0.06 \mathrm{~g}(92 \mathrm{~km})$ at Munday Creek, and $0.09 \mathrm{~g}(161 \mathrm{~km})$ at Yakutat (table 9). These stations are part of an informal Alaska strong-motion network operated by the U.S. Geological Survey, Lamont-Doherty Geological Observatory, the University of Alaska, and Shell 011 Company (fig. 57); additional accelerographs within this network that did not trigger include Cape Yakataga, Kayak Island, and Cordova at epicentral distances of $79 \mathrm{~km}, 200 \mathrm{~km}$, and $214 \mathrm{~km}$, respectively. The Icy Bay and Yakutat accelerograms are shown in figure 58 .

\section{GILROY, CALIFORNIA (COYOTE LAKE) - August 6}

A magnitude 5.7 (ML) earthquake occurred at 10:05:23 local time on August 6, 1979 in the central California coastal region at a depth of about $6 \mathrm{~km}$; the epicenter was located at $37.10^{\circ}$ $\mathrm{N}$. and $121.50^{\circ} \mathrm{W}$. In the Calaveras fault zone near Coyote Lake, approximately $10 \mathrm{~km}$ northnortheast of Gilroy ( $\mathrm{fig} \cdot 59$ ). This event was the largest to occur in the region since a magnitude 6.6 earthquake near the town of Coyote on July 1, 1911, and was reported felt from Santa Rosa south to the San Fernando Valley and east 


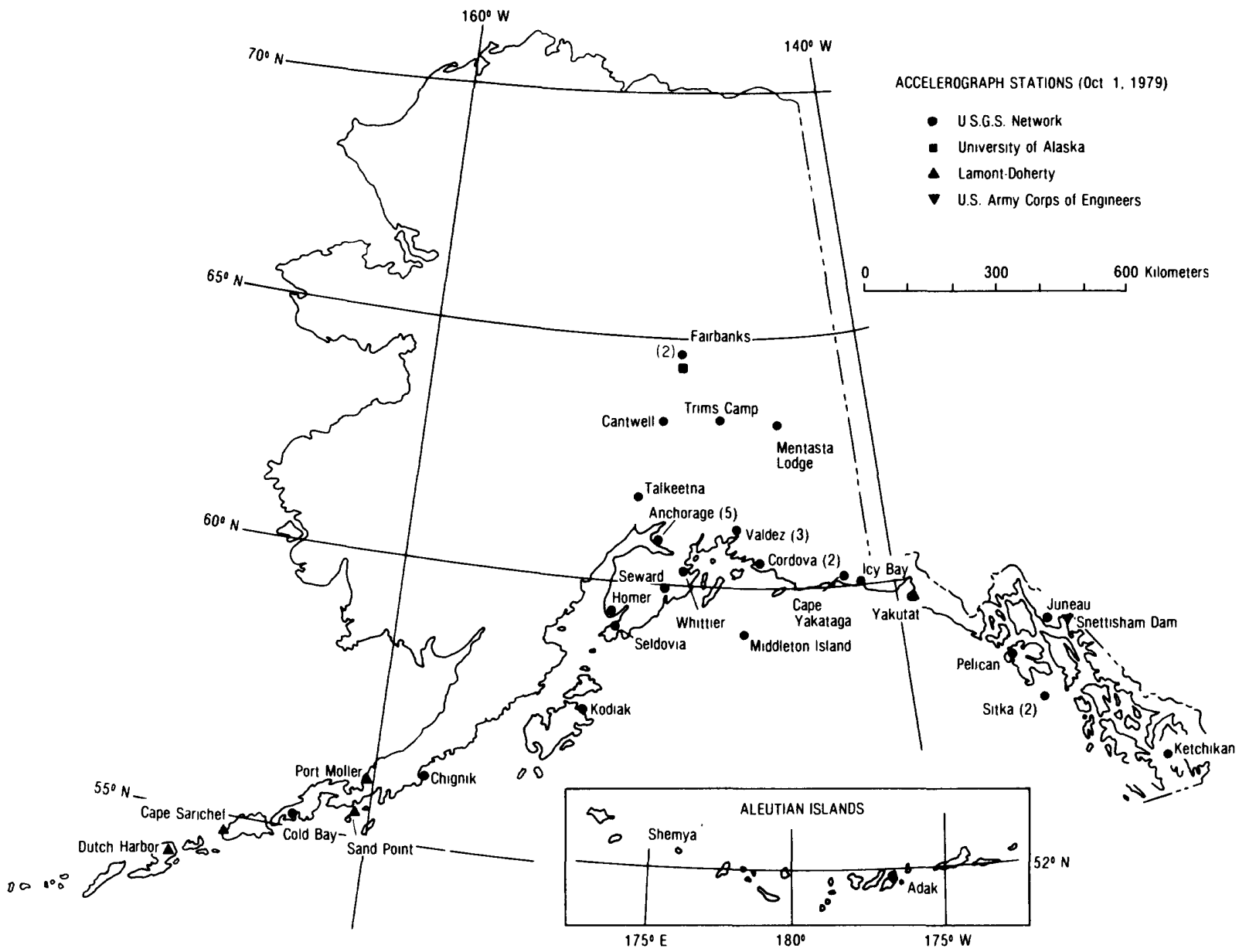

FIGURE 57.--Accelerograph stations in Alaska; numbers in parentheses show the total number of accelerograph stations at the indicated locality.

to Reno, Nevada. Some damage was reported in the Gilroy-Hollister area and included cracked plaster and stucco, broken windows, and fallen stock from store shelves.

The Gilroy (Coyote Lake) earthquake triggered all accelerographs within a radius of approximately $40 \mathrm{~km}$ of the epicenter; the most distant instrument triggered was located approximately $114 \mathrm{~km}$ from the epicenter. The locations of ground-motion instruments relative to the epicenter are shown in figure 59. The dots in this figure indicate instruments from which a record was obtained, and the circles indicate instruments that were operational at the time of the earthquake but did not trigger; stations that are not known to have been operational at the time of the earthquake are omitted from the figure.

Figure 59 (inset) shows the locations of close-in stations and their relation to the epicenter. Two arrays of ground stations, the Gilroy and Bear Valley arrays, recorded the event.
All stations in the Gilroy array are within 16 $\mathrm{km}$ of the epicenter and extend from a rock site across an alluvial valley to a rock site. Therefore, the Gilroy array characteristics provide data that are important in studies of source mechanism, wave propagation, near-field motions, and site effects. Refraction surveys and down-hole shear-wave velocity studies are being conducted to determine the subsurface conditions at each of the Gilroy array stations. Stations in the Bear Valley array are located between 50 and $75 \mathrm{~km}$ from the epicenter and are within a relatively narrow azimuthal range; the stations are situated on both sides of the San Andreas fault on a variety of surficial materials. Data from this array exhibit a considerable range of peak accelerations and provide additional information for studies of propagation path and site effects. Full-scale reproductions of records from the Gilroy array are shown in figure 60. The data from instruments at ground level are summarized in table 9 (see event of 6 August 1979, 1705 UTC) and are presented in order of increasing epicentral distance. 

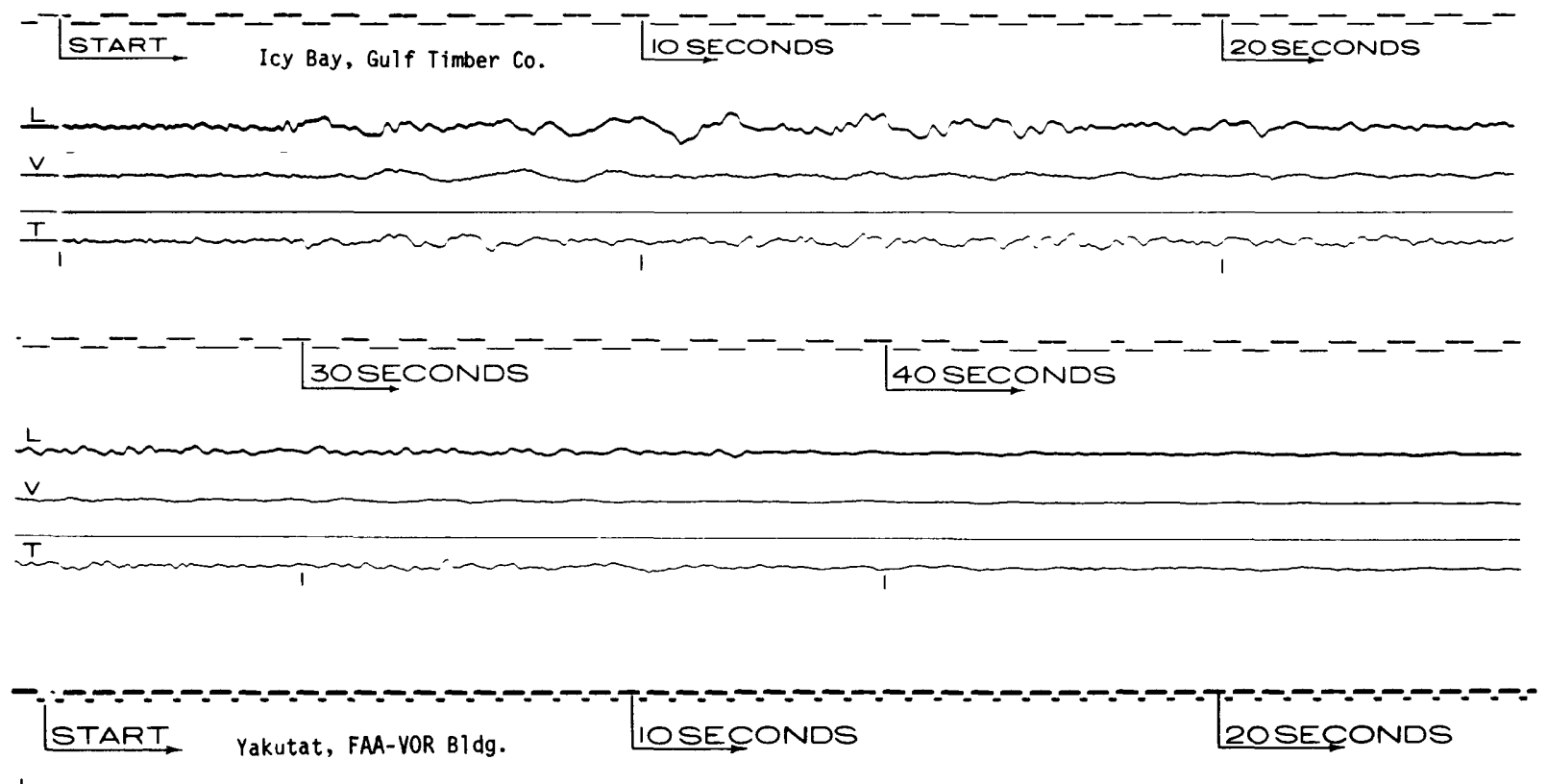

느

$\underline{\mathrm{V}}$

$\frac{T}{1}$

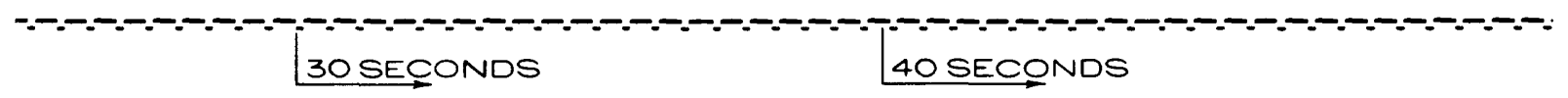

L

$\underline{\underline{v}}$

T

FIGURE 58.--Icy Bay and Yakutat accelerograms from the magnitude 7.1 St. E11as, Alaska, earthquake of 28 February 1979 (epicentral distances $73 \mathrm{~km}$ and $161 \mathrm{~km}$, respectively).

All instrumented structures from which records were obtained were at sufficiently large distances that the recorded motions at these stations were small relative to those associated with damage; however, these records do provide important structural response data for the study of a freeway overpass, the torsional response of bulldings, and deformation of diaphragms and walls.

\section{IMPERIAL VALLEY, CALIFORNIA - OCTOBER 15}

The October 15, 1979 Imperial Valley earthquake, which was centered at lat $32.63^{\circ} \mathrm{N}$. and long $115.33^{\circ}$ W., triggered all of the USGS accelerographs within about $100 \mathrm{~km}$ of the epicenter and one as far away as $196 \mathrm{~km}$ (Porcella and Matthiesen, 1979). With this initial information, all of the stations within about $200 \mathrm{~km}$ of the epicenter were inspected to ascertain which instruments had been triggered. The complete set of data including that from Baja Cal1forrita is, in several respects, the most significant set of ground motion data collected from a single event and provides a rewarding result from several years of planning and execution of a cooperative effort by the U.S. Geological Survey (USGS), the California Division of Mines and Geology (CDMG), and the Earthquake Engineering Research Laboratory of the California Institute of Technology (CIT) and a similar effort in Baja California by the National University at Mexico City (UNAM) and the University of California at San Diego (UCSD). The locations of the instruments known to be operational in the greater Imperial valley region at the time of the earthquake are shown in figure 61.

The strong-motion accelerograph network in the Imperial Valley operated by the USGS ( $f$ ig. 


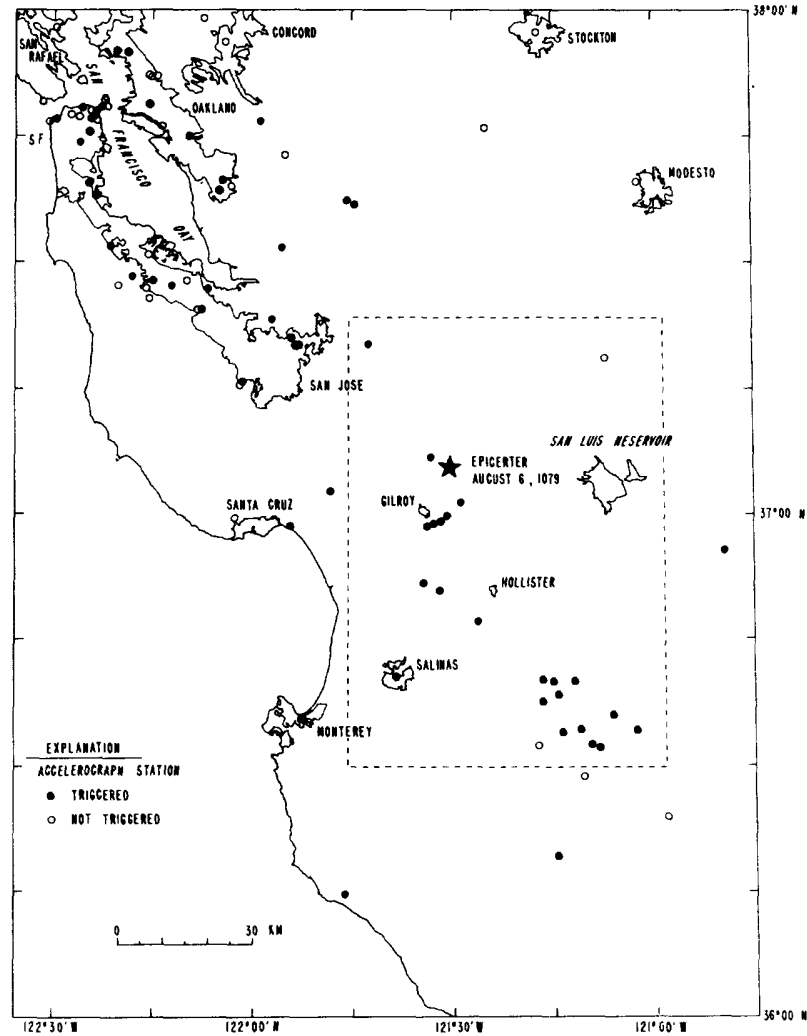

FIGURE 59.--Location of strong-motion stations in the region of the 6 August 1979 Gilroy, California earthquake (from Porcella and others, 1979).

62) consists of 24 stations; 21 of these stations are instrumented with triaxial filmrecording accelerographs (Kinemetrics model SMA-IT) equipped with vertical starters (capable of bringing the instrument into full operation within $0.2 \mathrm{sec}$ of the first vertical motion greater than $0.01 \mathrm{~g}$ ) and WWVB radio receivers that record absolute time codes on the accelerograms. Consequently, during the October 15 earthquake and aftershocks, each accelerograph typically triggered on the first-arriving $p$ wave; the resultant accelerogram commonly displays a time interval between the first Swave arrival and the trigger time $(S-t)$ that can be used with the WWVB time code in epicenter determinations.
Copies of the main-shock accelerograph records from the USGS stations within $30 \mathrm{~km}$ of the fault rupture are shown in figure 63. of particular significance is the long-period pulse that is evident in all of the records from stations within $10 \mathrm{~km}$ of the fault. This acceleration pulse can be integrated to yield significant velocfty and displacement changes. In that regard, the close-in records from the main shock have been digitized and processed to obtain velocity and displacement time-histories and spectra (Brady and others, 1980). A comparison of the accelerograms from El Centro array station 9 (302 Commercial Avenue, E1 Centro) that were recorded during the May 18,1940 and October 15, 1979 earthquakes is shown in figure 64.

The close-in Imperial Valley accelerograph network recorded at least 82 identffiable aftershocks at 21 stations during the first week after the October 15 main shock; 14 of these af tershocks were recorded at three or more stations. This data set contains more than 150 records that can be used in epicenter and magnitude determinations, as well as for studies of source mechanisms and ground motion attenuation. In all, 22 stations within $30 \mathrm{~km}$ of the mainshock surface rupture produced at least 165 aftershock records; 49 of these records contain peak accelerations greater than $0.1 \mathrm{~g}$.

In summary, forty-three U.S. strong-motion stations within an epicentral distance of $150 \mathrm{~km}$ were in operation during the main shock of the October 15, 1979 Imperial Valley earthquake; more than 265 aftershock records were obtained at 20 stations within $25 \mathrm{~km}$ of the main-shock surface rupture. Maximum horizontal ground accelerations of greater than $0.5 \mathrm{~g}$ were measured at seven stations within $10^{-\mathrm{km}}$ of the Imperial fault rupture; a maximum vertical acceleration of $1.74 \mathrm{~g}$ recorded at EI Centro array station 6 exhibits a duration (peak accelerations grearer than $0.1 \mathrm{~g}$ ) of more than 6 sec. These accelerograms contain the most comprehensive collection of close-in strongmotion data ever recorded. Because abolute times were recorded on many of the records, detailed studies of the source mechanism and ground-motion characteristics are possible. 


\section{GILROY ARRAY STATION 1}

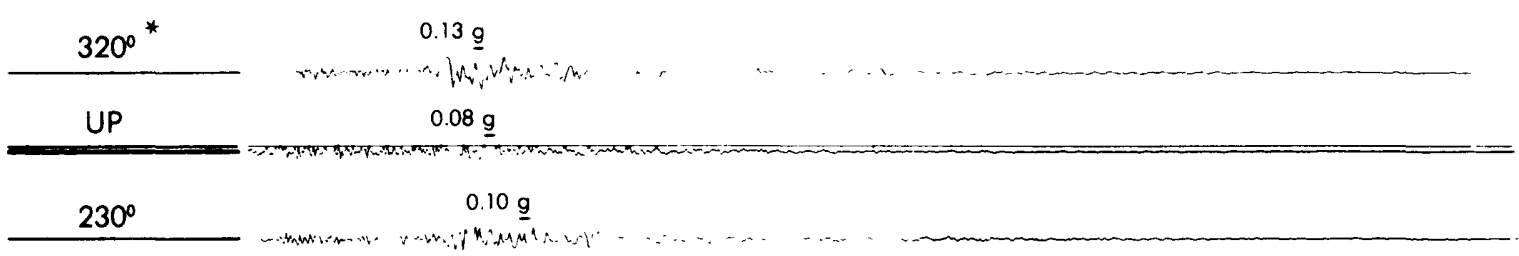

S-1 -1

_-_._-

\section{GILROY ARRAY STATION 2}

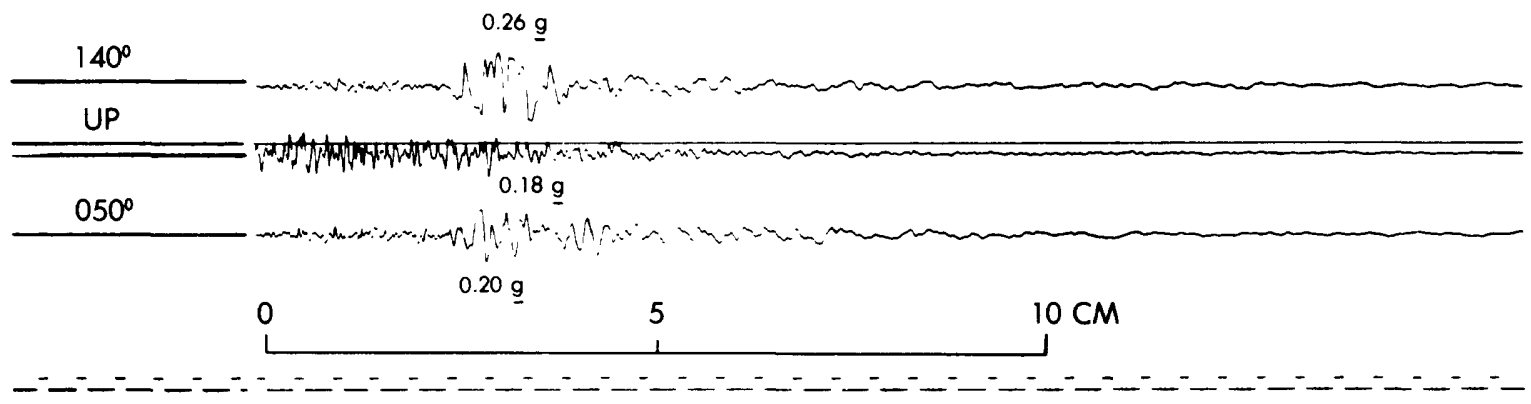

\section{GILROY ARRAY STATION 3}

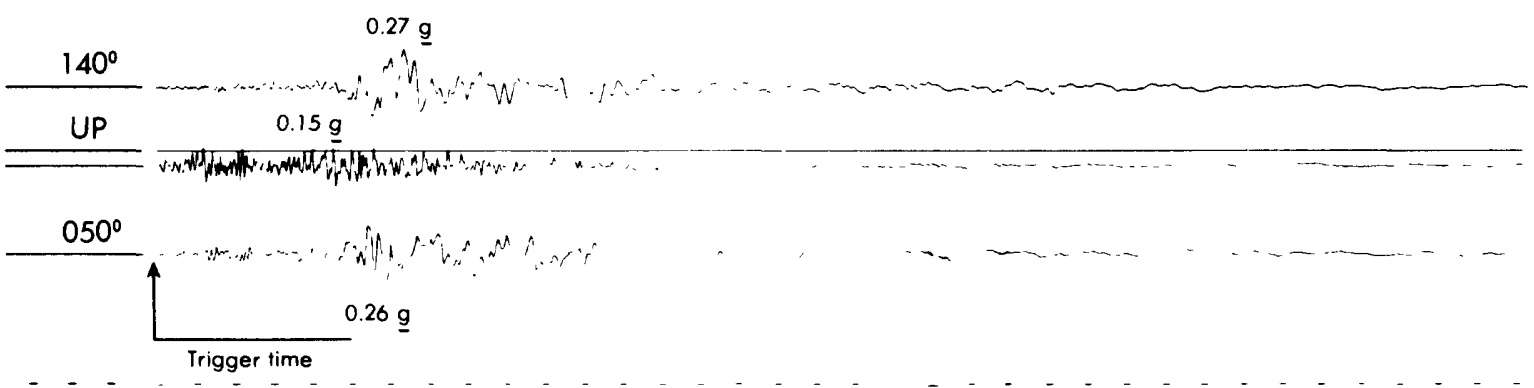

* Azimuthal direction of case acceleration for upward trace deflection.

FIGURE 60.--Gilroy array accelerograms from the magnitude 5.9 earthquake of 6 August 1979. 


\section{GILROY ARRAY STATION 4}

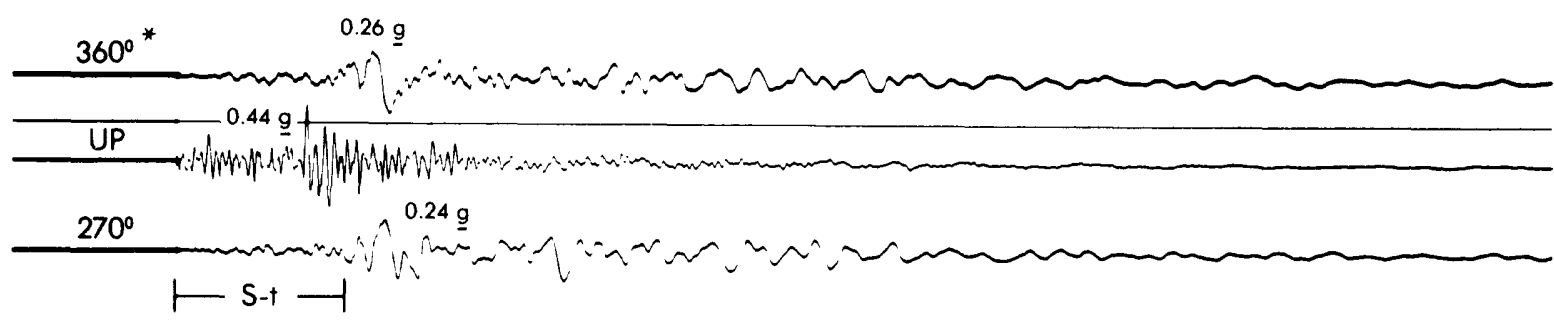

- - -
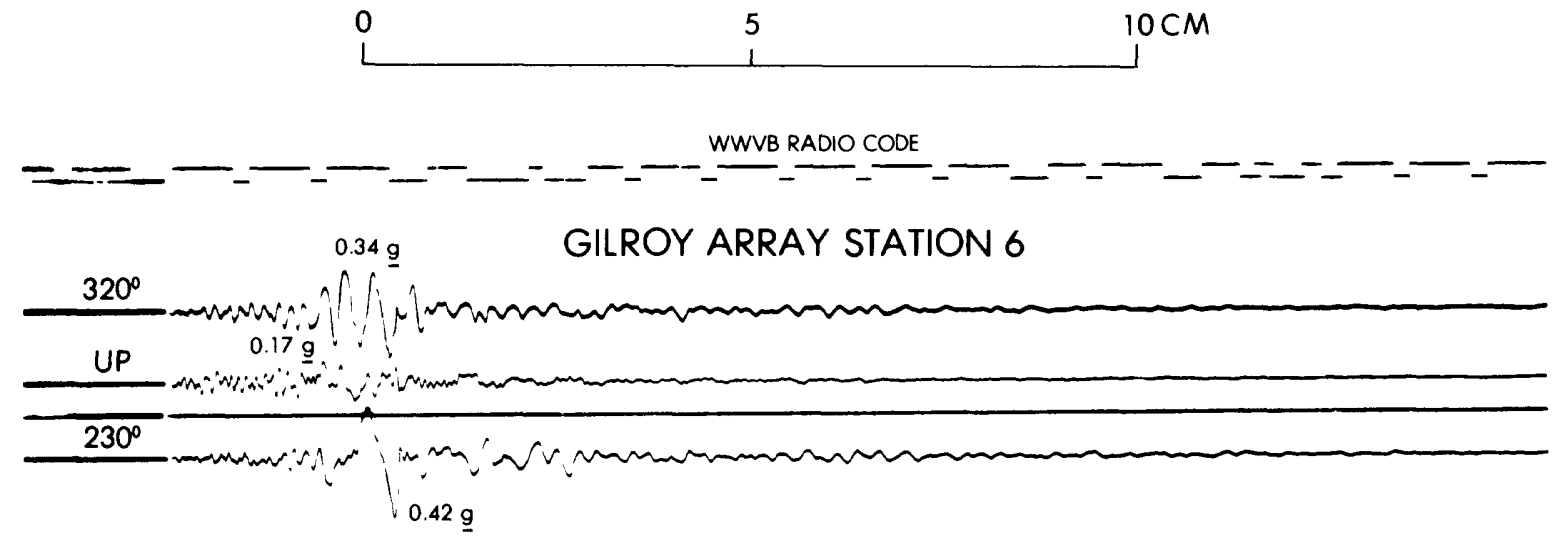

- - - - - - - - - - - - - - - - - - - - - - - - - - - - - - - - - - - -

* Azimuthal direction of case acceleration for upward trace deflection.

FIGURE 60.--Gilroy array accelerograms --continued. 


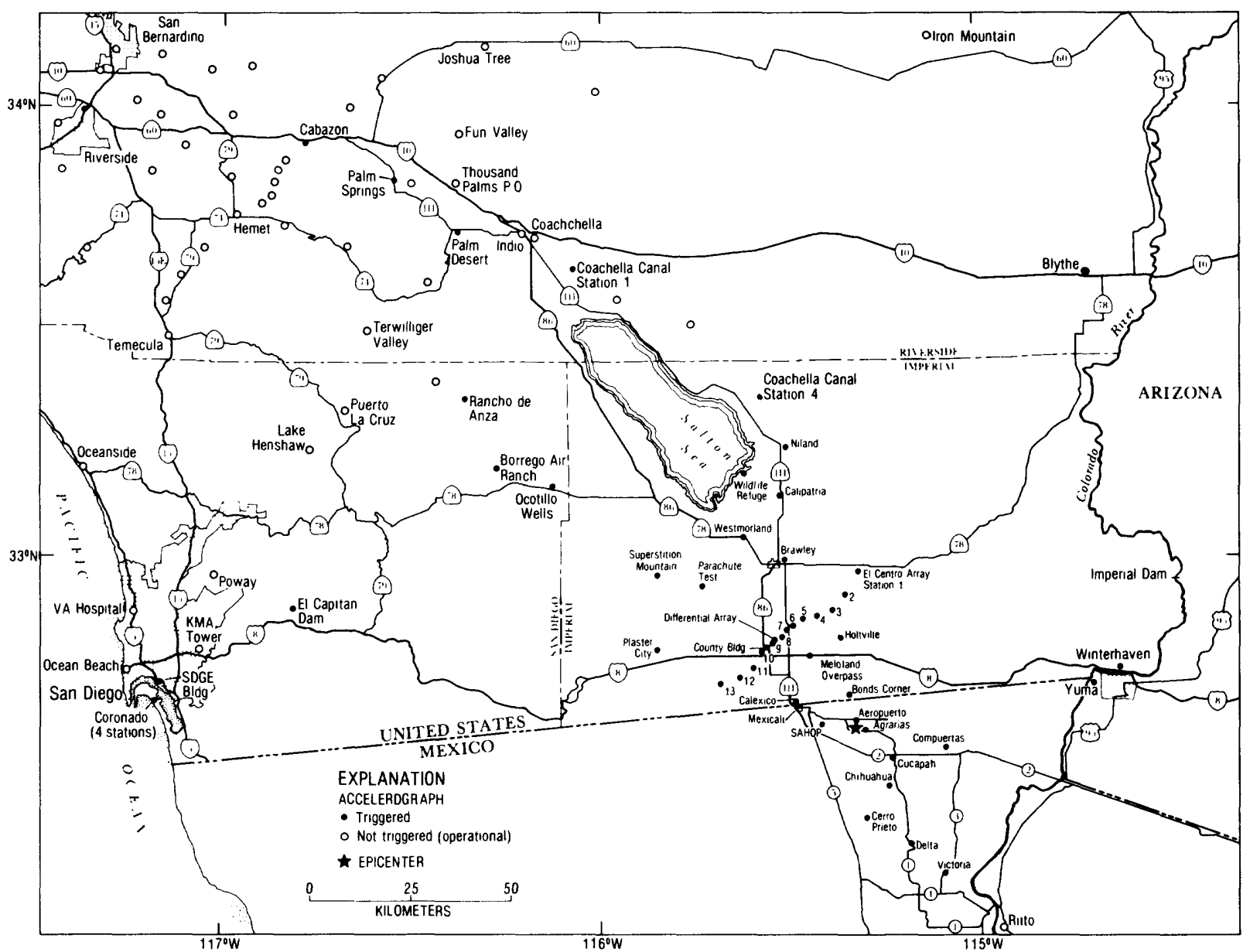

FIGURE 61.--Strong-motion stations in the greater Imperial Valley region that are known to have been operational at the time of the 15 October 1979 earthquake (from Seismic Engineering Program Report, U.S. Geological Survey Circular 818C, 1980). 


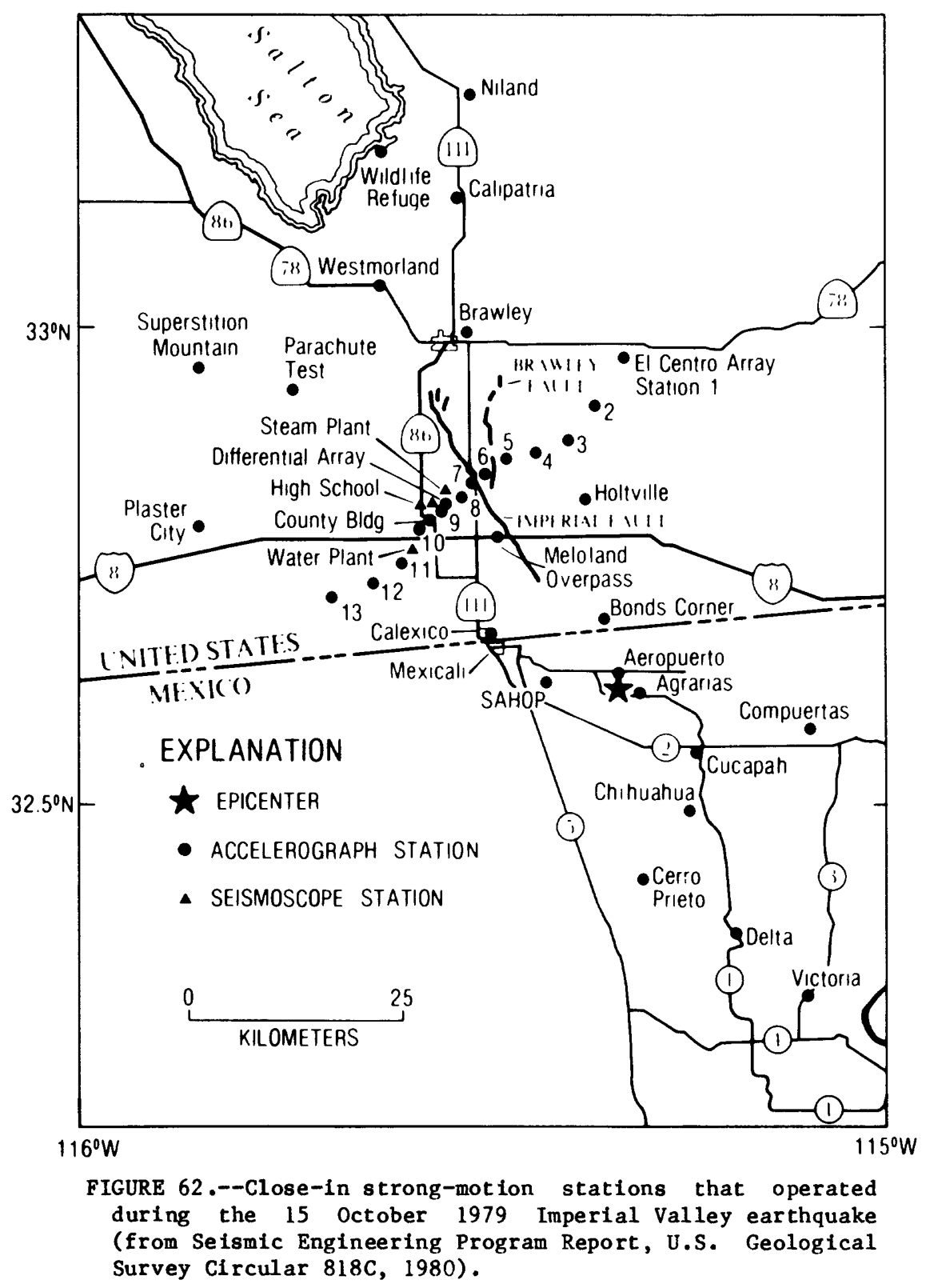


EL CENTRO ARRAY STATION 7

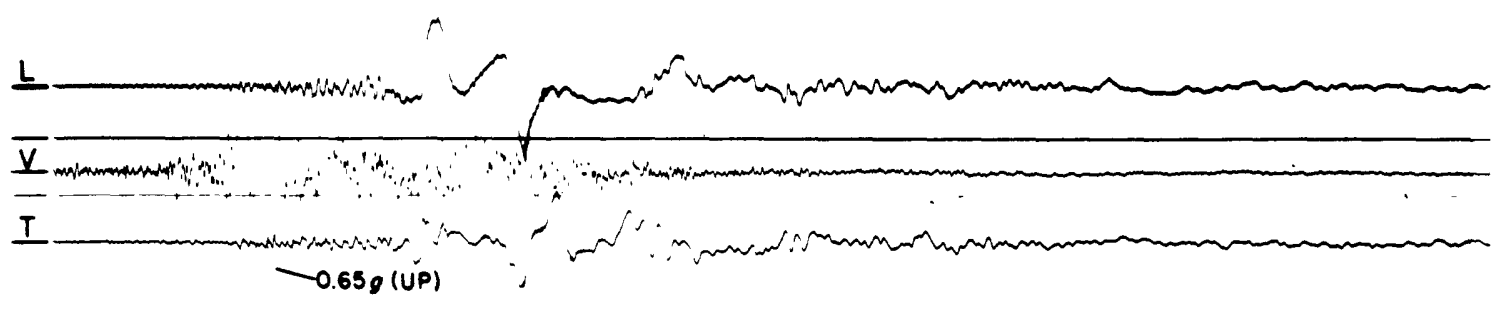

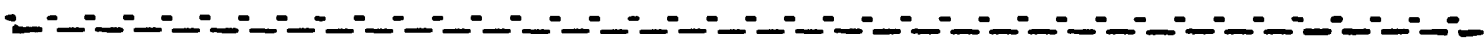

EL CENTRO ARRAY STATION 6

$5 \mathrm{~cm}$

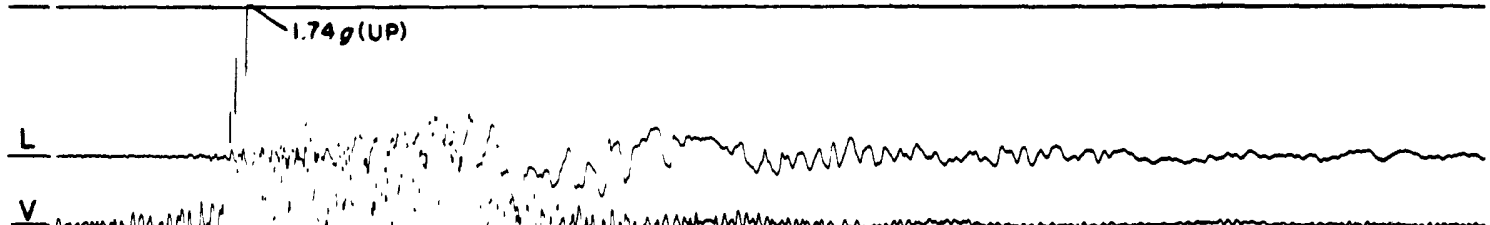

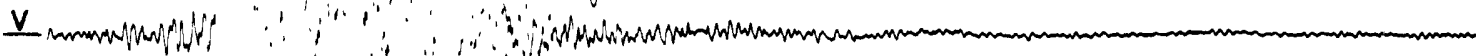
I

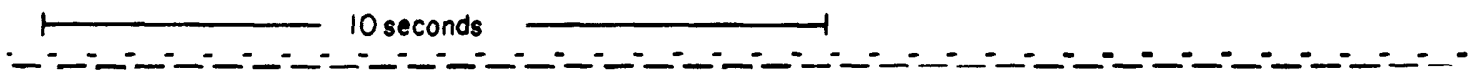

BONDS CORNER

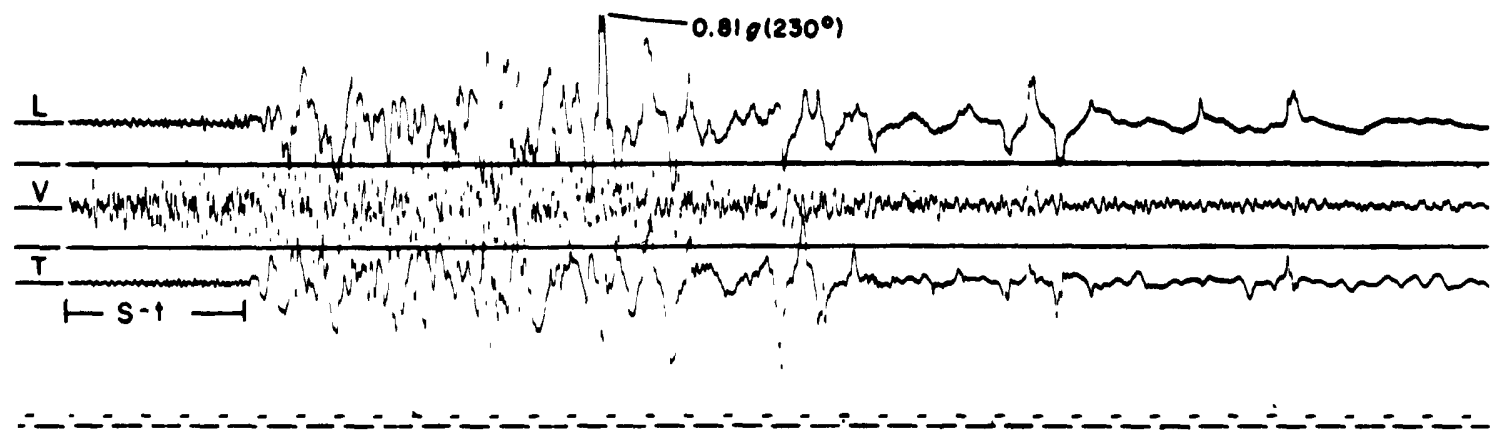

FIGURE 63.--Selection of USGS accelerograms from the magnitude 6.6 Imperial Valley earthquake of 15 October 1979. 


\section{EL CENTRO ARRAY STATION 8}

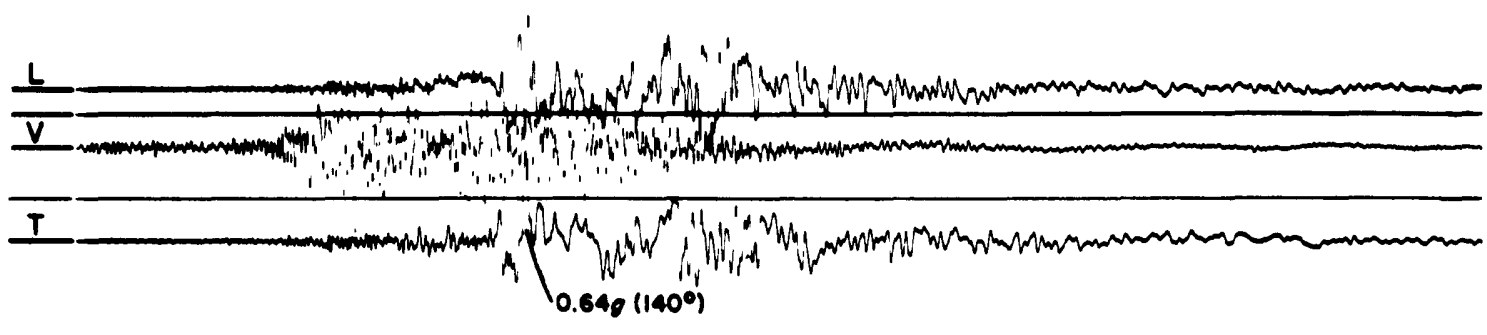

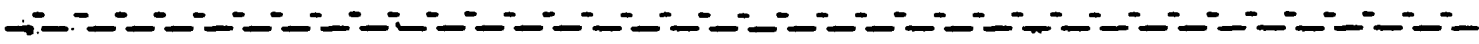

EL CENTRO ARRAY STATION 5
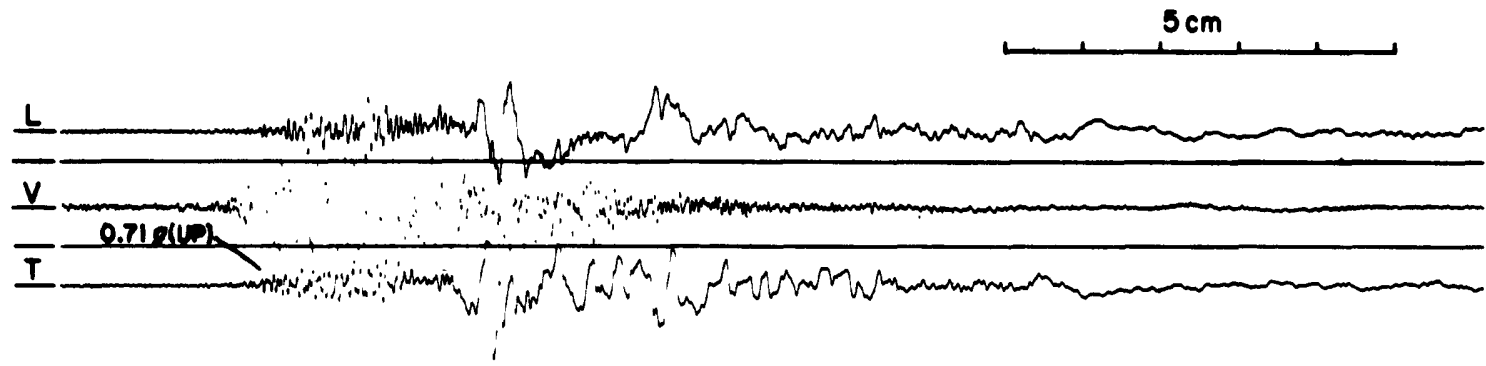

-_-

EL CENTRO DIFFERENTIAL ARRAY

L_C V 0.20 atuping I

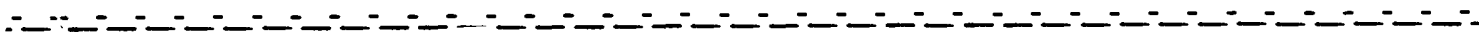

FIGURE 63.--Selection of USGS accelerograms from Imperial Valley - continued. 

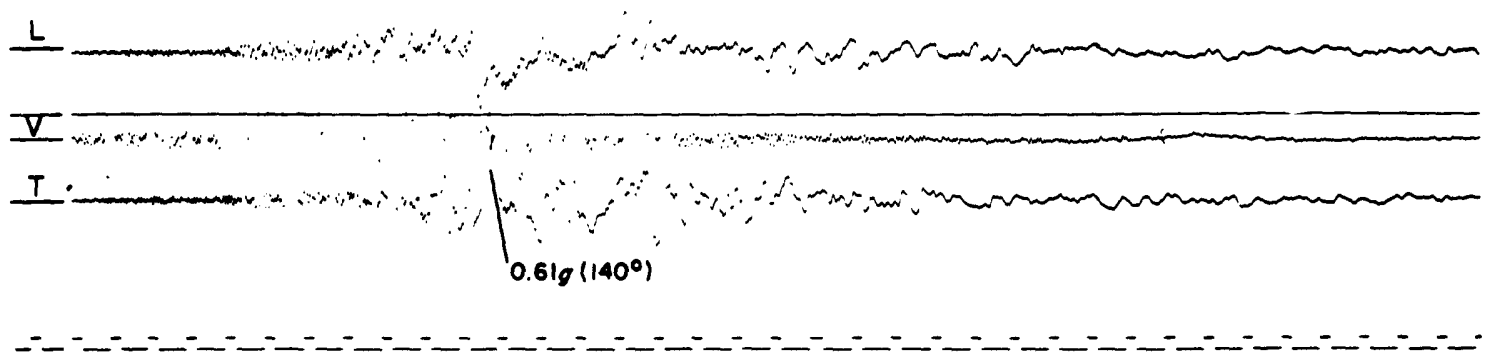

$5 \mathrm{~cm}$

BRAWLEY AIRPORT

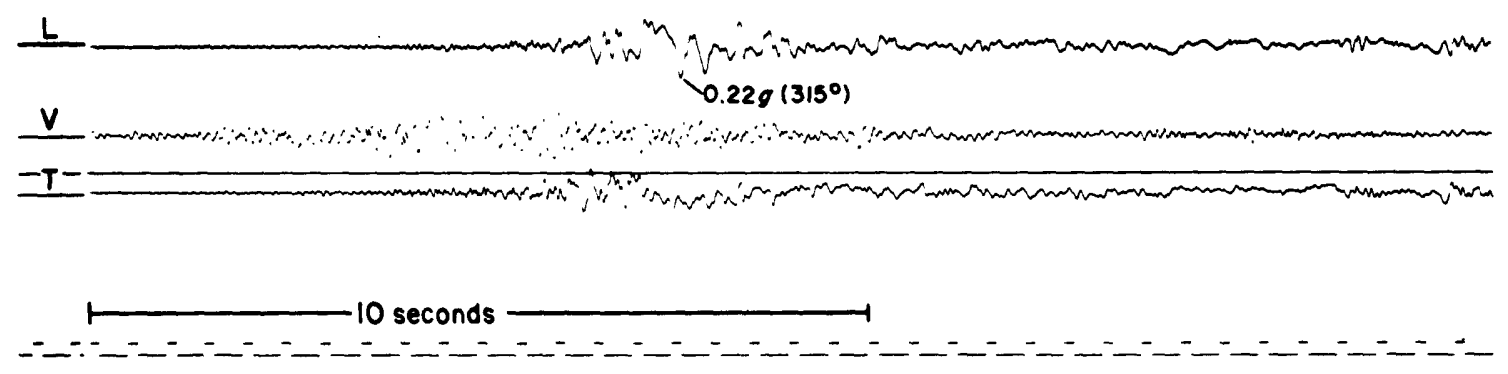

HOLTVILLE POST OFFICE

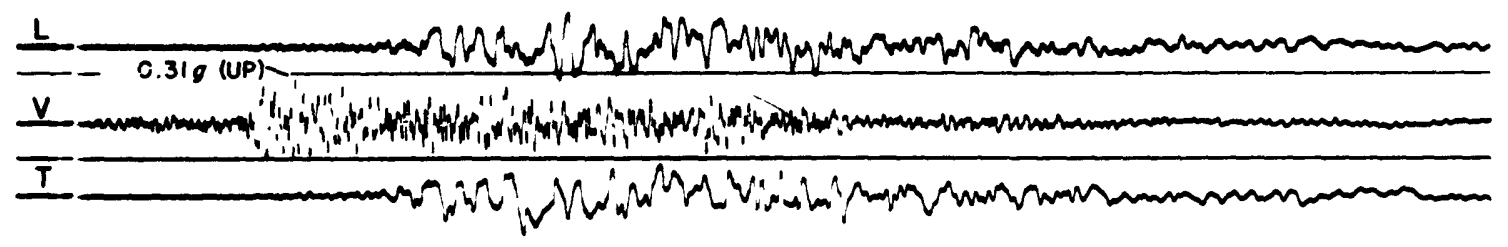

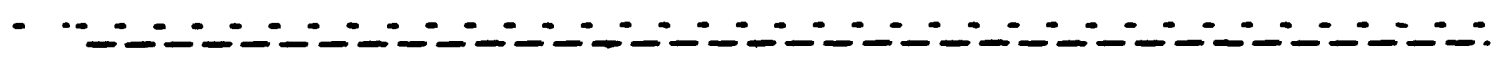

FIGURE 63.--Selection of USGS accelerograms from Imperial Valley -- continued. 
EL CENTRO ARRAY STATION IO

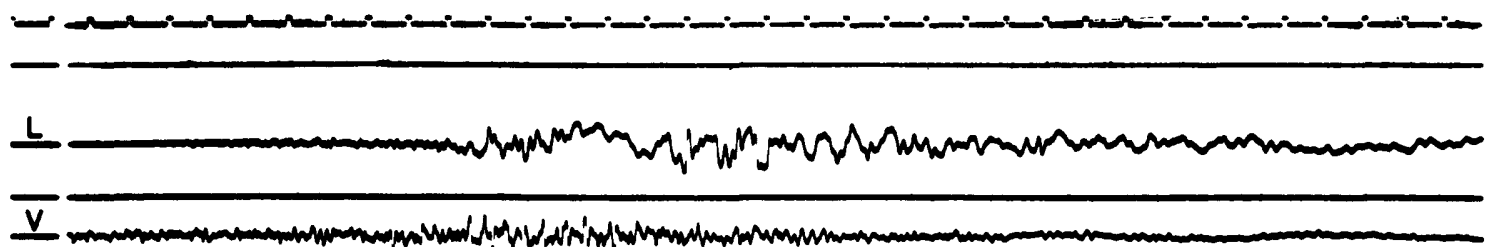
$I$

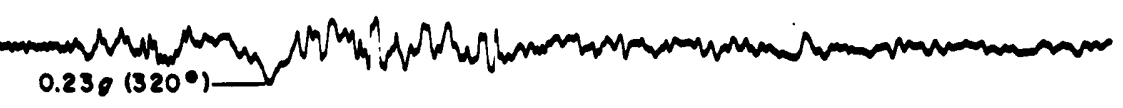

CALEXICO FIRE STATION

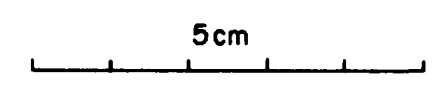

L

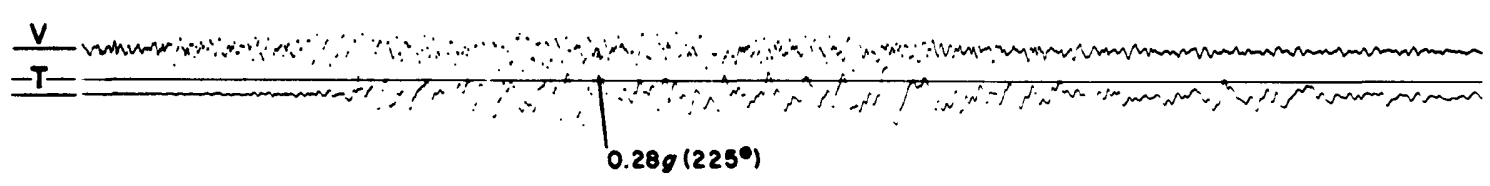
-

EL CENTRO ARRAY STATION II

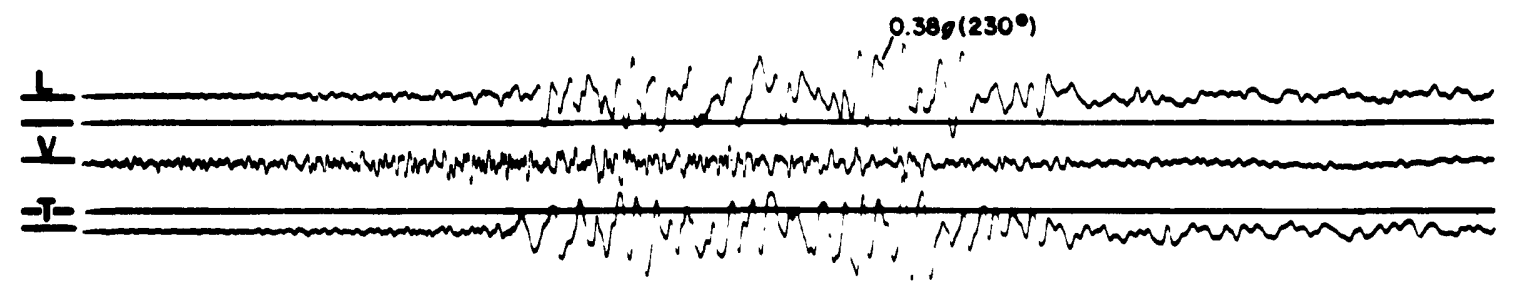

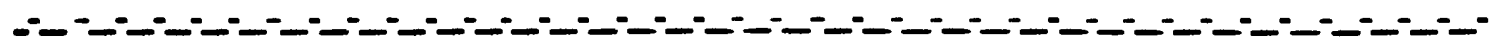

FIGURE 63.--Selection of USGS accelerograms from Imperial Valley -- continued. 
EL CENTRO ARRAY STATION 3

$L$

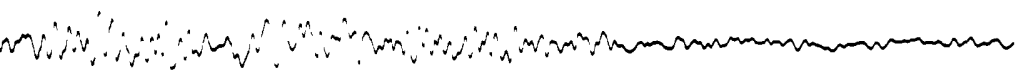

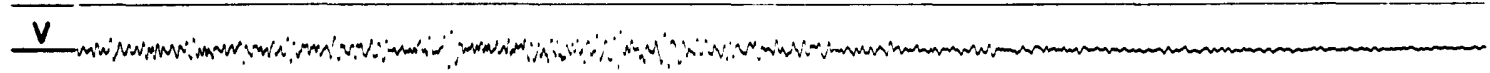

I . . .

$0.279\left(140^{\circ}\right)$

PARACHUTE TEST FACILITY

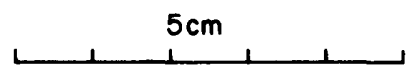

$I E$

$=-[-10$ seconds

EL CENTRO ARRAY STATION 2

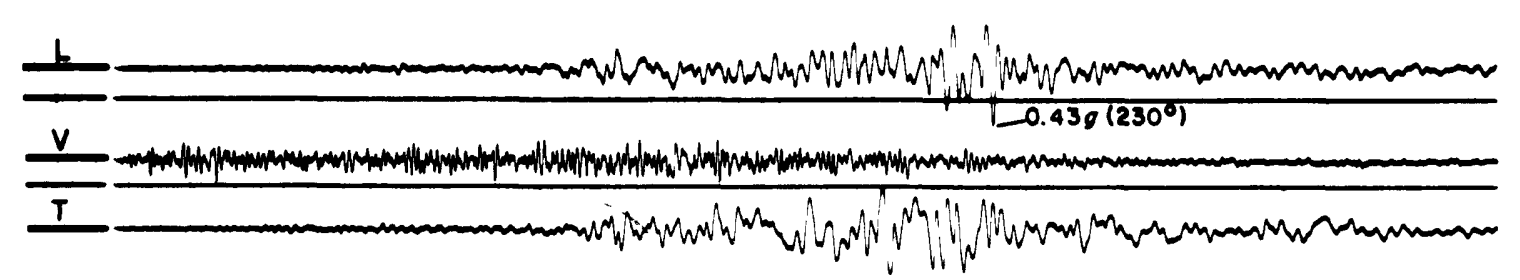

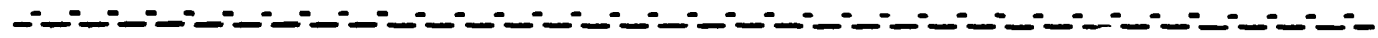

FIGURE 63.--Selection of USGS accelerograms from Imperial valley - continued. 


\section{EL CENTRO ARRAY STATION 12}

L $\underline{v}$ $T$ $-0.15 g\left(140^{\circ}\right)$

(1)

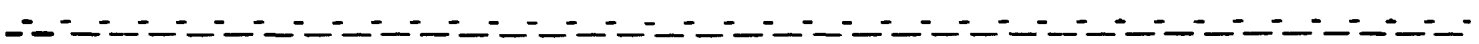
, $5 \mathrm{~cm}, \ldots$

CALIPATRIA FIRE STATION

L

V $T$

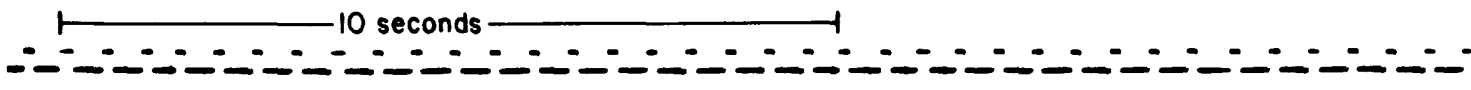

EL CENTRO ARRAY STATION 13

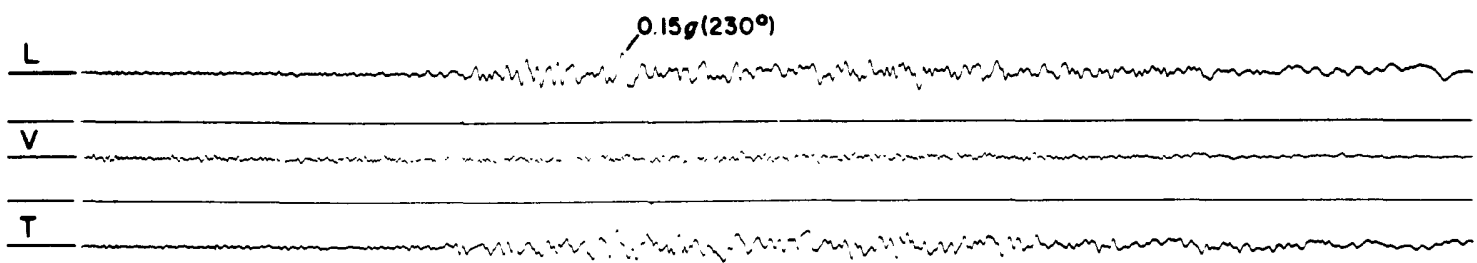

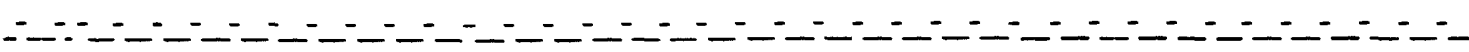

FIGURE 63.--Selection of USGS accelerograms from Imperial Valley - continued. 
EL CENTRO ARRAY STATION I

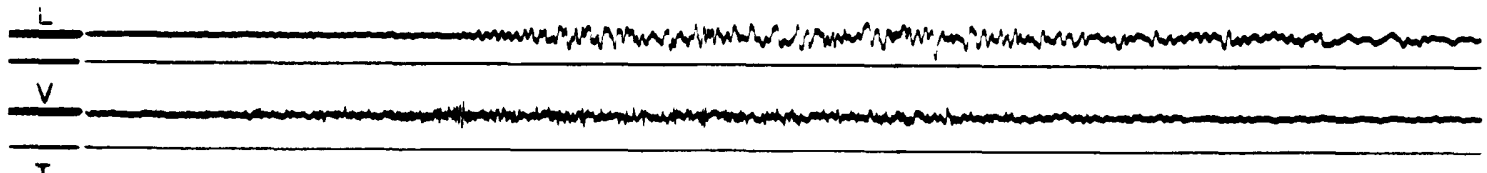

T

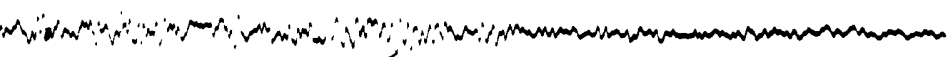
$0.15 g\left(140^{\circ}\right)$

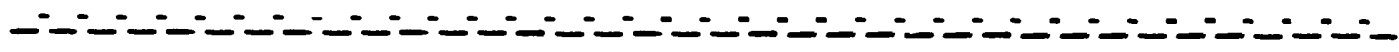

$5 \mathrm{~cm}$

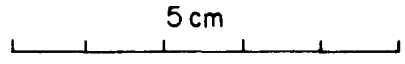

SUPERSTITION MOUNTAIN

$\underline{L}$ $021 g\left(135^{\circ}\right)$

$\underline{\mathrm{V}}$

(1)

I

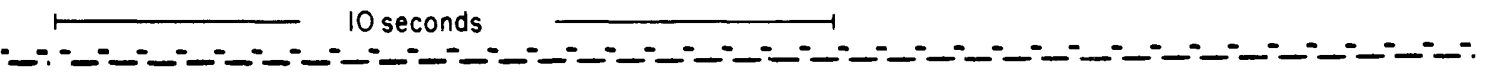

SALTON SEA WILDLIFE REFUGE

$\leq$

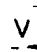

T

$0.139\left(225^{\circ}\right)$ - $h$ hranswion

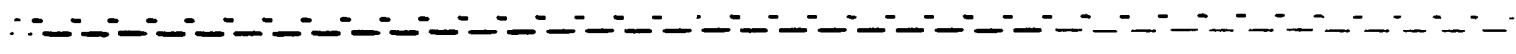

FIGURE 63.--Selection of USGS accelerograms from Imperial Valley -- continued. 
EL CENTRO RECORDINGS OF IMPERIAL VALLEY EARTHQUAKES

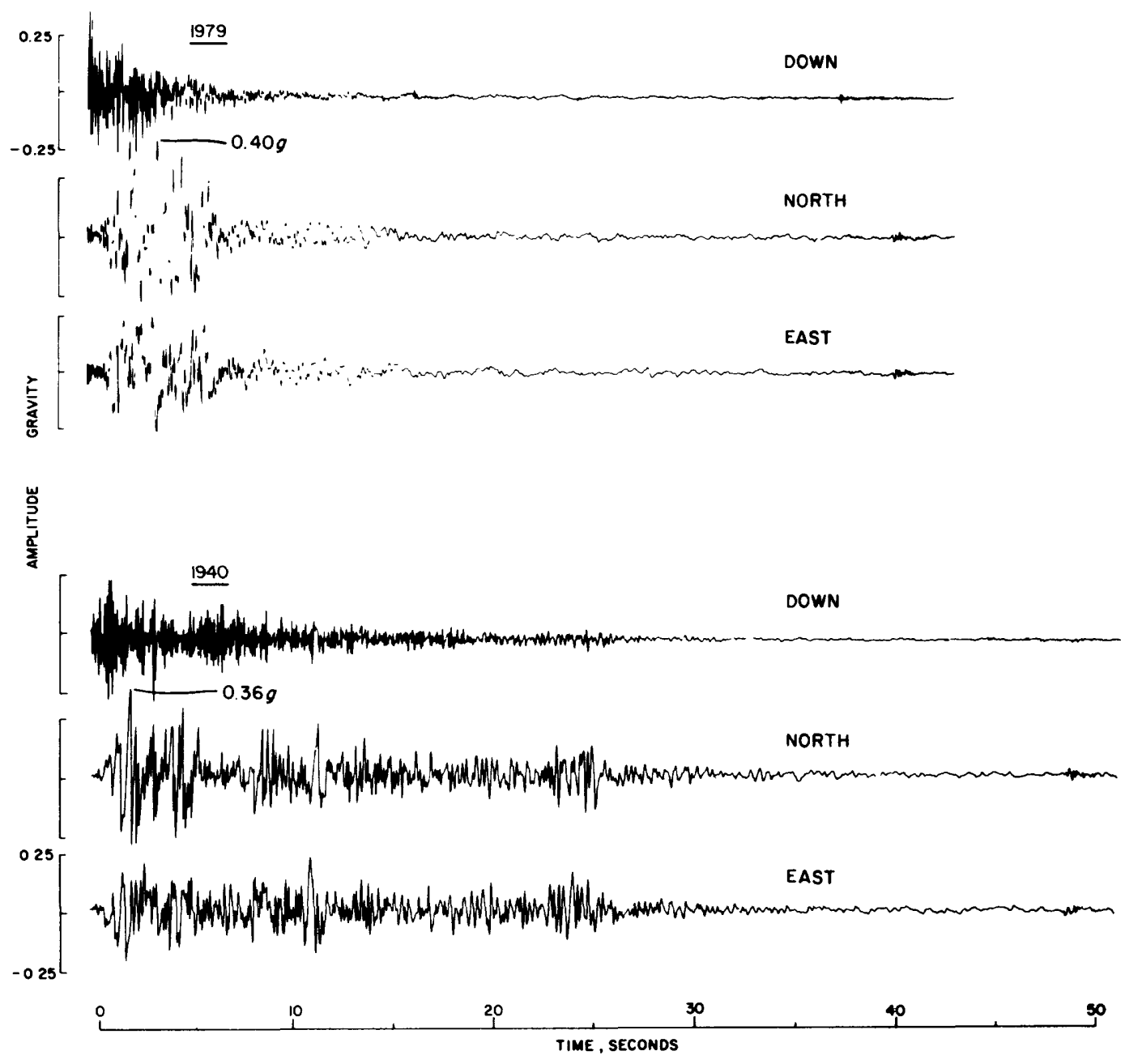

FIGURE 64.--Accelerograms from E1 Centro array station 9 (302 Commerclal Avenue), for the Imperial Valley earthquakes of 15 October 1979 and 18 May 1940 . 
Table 9.--Summary of U.S. accelerograph records recovered during 1979

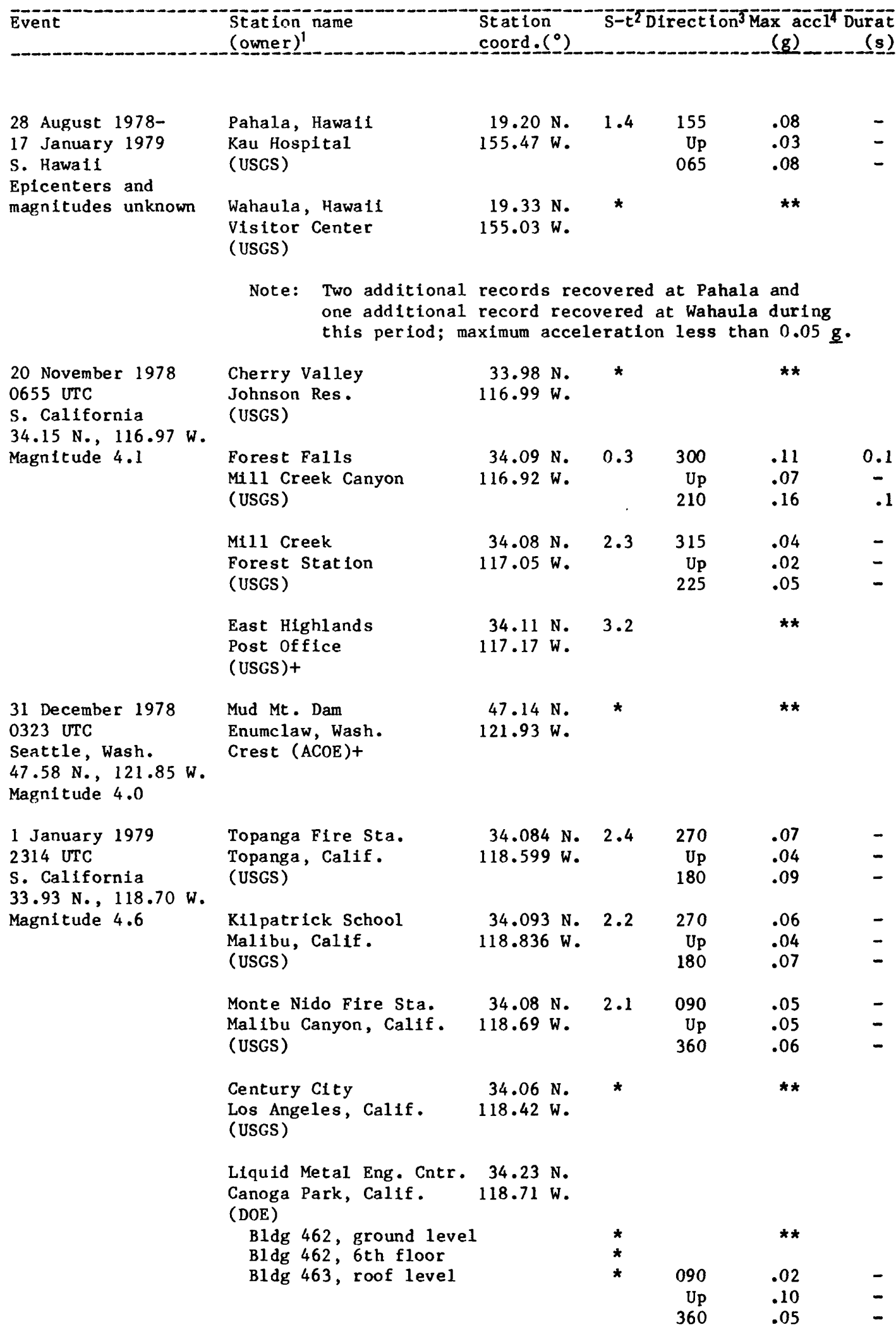


Table 9.--Summary of U.S. accelerograph records recovered during 1979--Continued

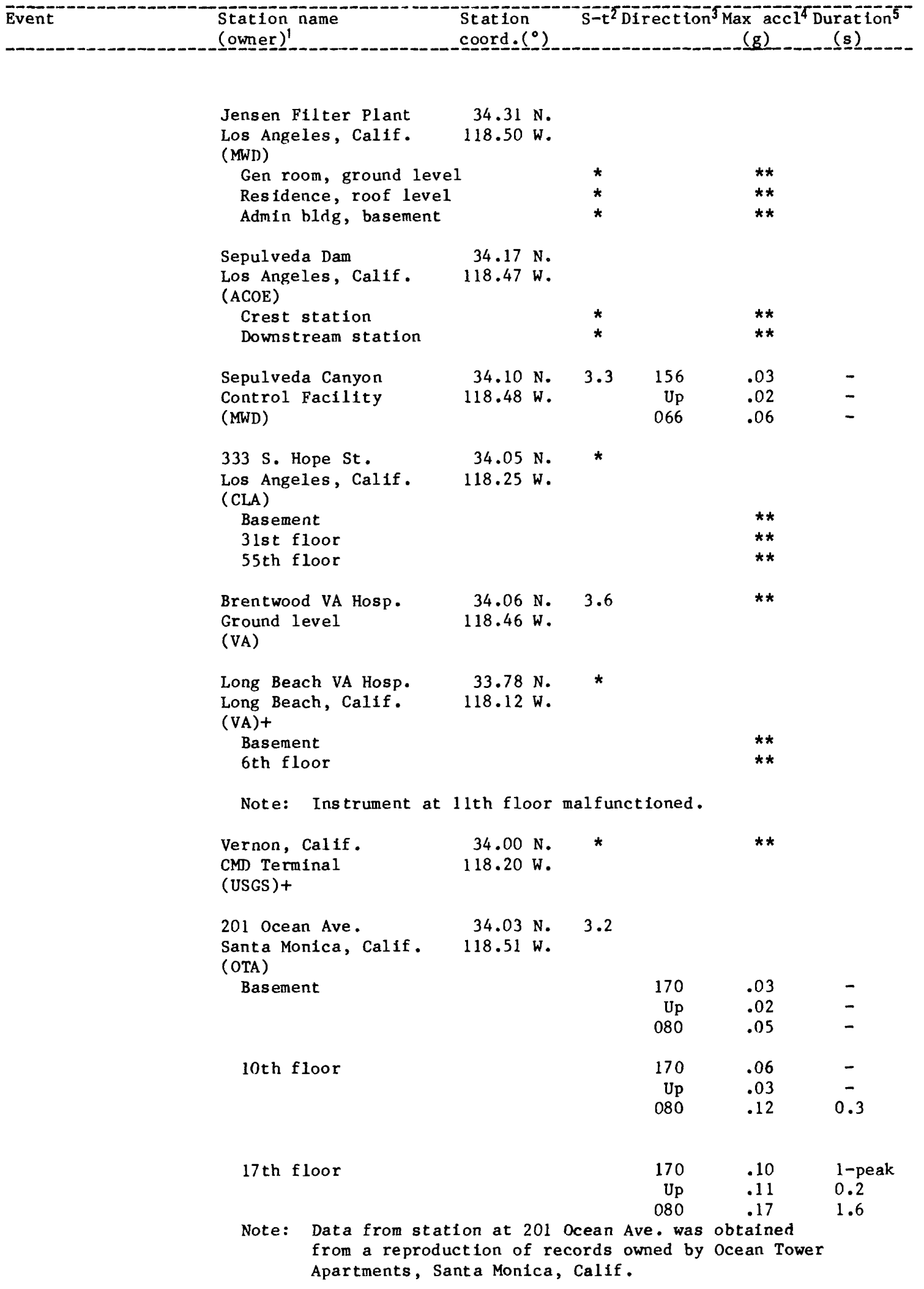


Table 9.--Summary of U.S. accelerograph records recovered during 1979..-Continued

Event
Station name

12 February 1979
0448 UTC
S. California
$33.45 \mathrm{~N} ., 116.42 \mathrm{~W}$.
Magnitude 4.4

22 February 1979

1557 UTC

N. California

40.01 N., $120.07 \mathrm{~W}$.

Magnitude 5.2

Note: Additional accelerograph records were recovered at California Strong-Motion Jnstrumentation Program (CSMIP) sites; stations that were triggered include Sant a Catalina, Culver City, Inglewood, University of California at Los Angeles, Hollywood Storage, Century City, Long Beach (2), Irvine, She rman Oaks, and Ventura (Rich McJunkin, oral commun.).

Pinyon Flt. Observ. $\quad 33.61 \mathrm{~N}$. Underground vault $\quad 116.46 \mathrm{~W}$. (USGS)

Rancho De Anza Anza-Bor rego Park (USGS)

Grizzly Valley Dam $\quad 39.88 \mathrm{~N}$.

Abutment station $120.48 \mathrm{~W}$. (CDWR)+

$$
33.35 \text { N. } 1.8
$$$$
116.40 \mathrm{~W} \text {. }
$$

Yakutat, Alaska

FAA-VOR Bldg. (LDGO)

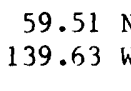

Icy Bay, Alaska Gulf Timber Co. (USGS)

$59.97 \mathrm{~N}$. $141.64 \mathrm{~W}$.

*

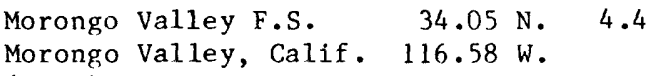
(USGS)+

34.30 N., $116.44 \mathrm{~W}$. Magnitude 5.0

15 March 1979

2107 UTC

S. California 34.32 N., $116.44 \mathrm{~W}$. Magnitude 5.2

15 March 1979

2307 UTC

S. California

$34.33 \mathrm{~N} ., 116.44 \mathrm{~W}$. Magnitude 5.0

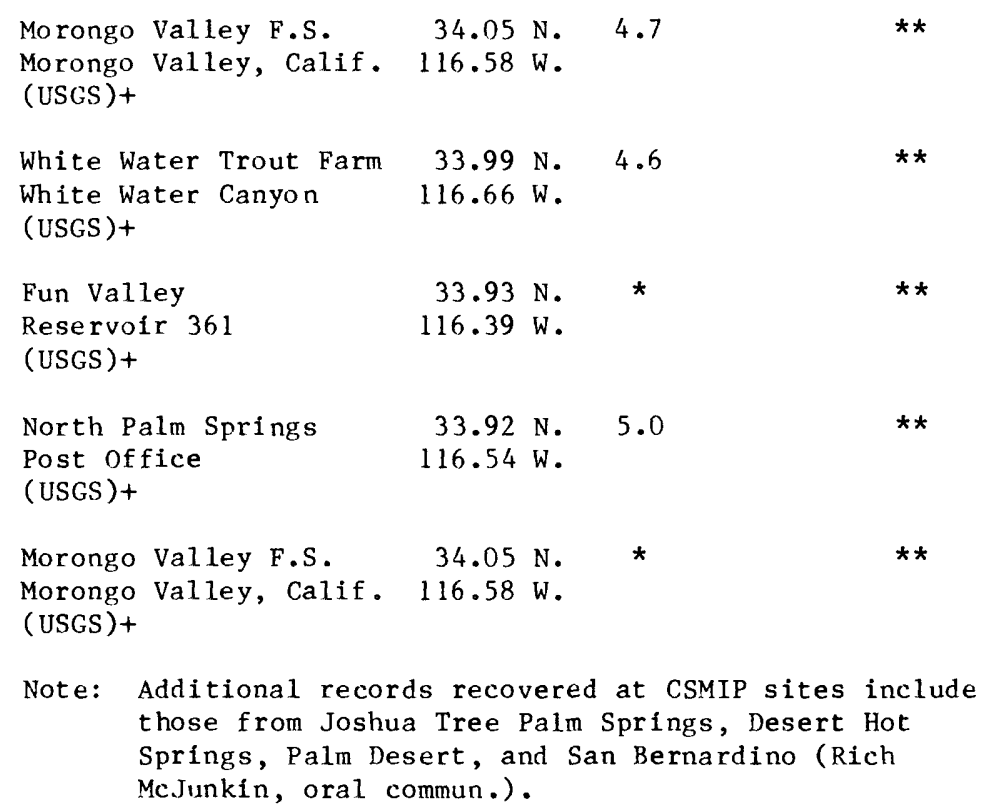

Note: Additional records recovered at CSMIP sites include those from Joshua Tree Palm Springs, Desert Hot Springs, Palm Desert, and San Bernardino (Rich McJunkin, oral commun.). 
Table 9.--Summary of U.S. accelerograph records recovered during 1979--Continued

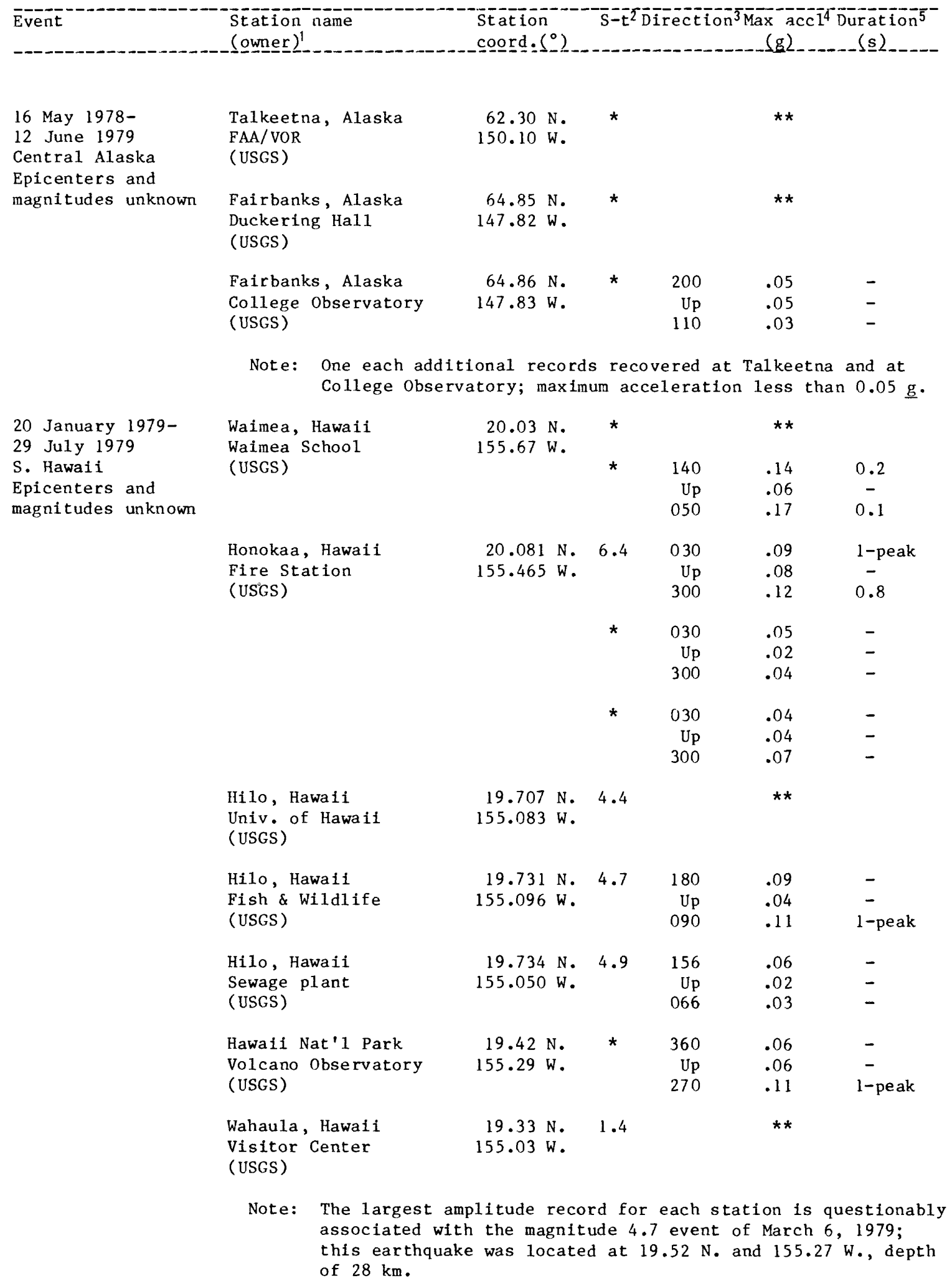


Table 9...Summary of U.S. accelerograph records recovered during 1979--Continued

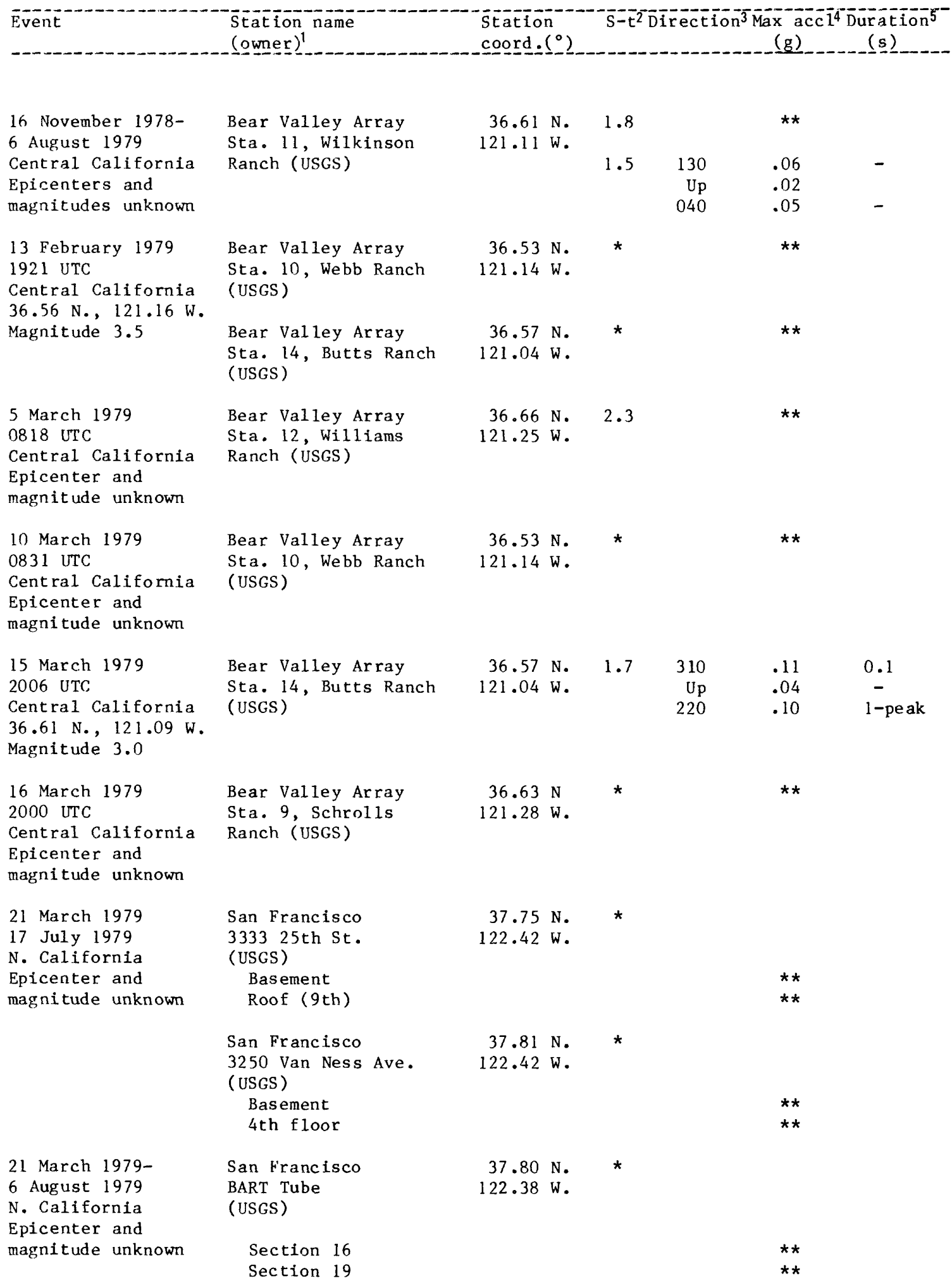


Table 9.--Sum mary of U.S. accelerograph records recovered during 1979..Continued

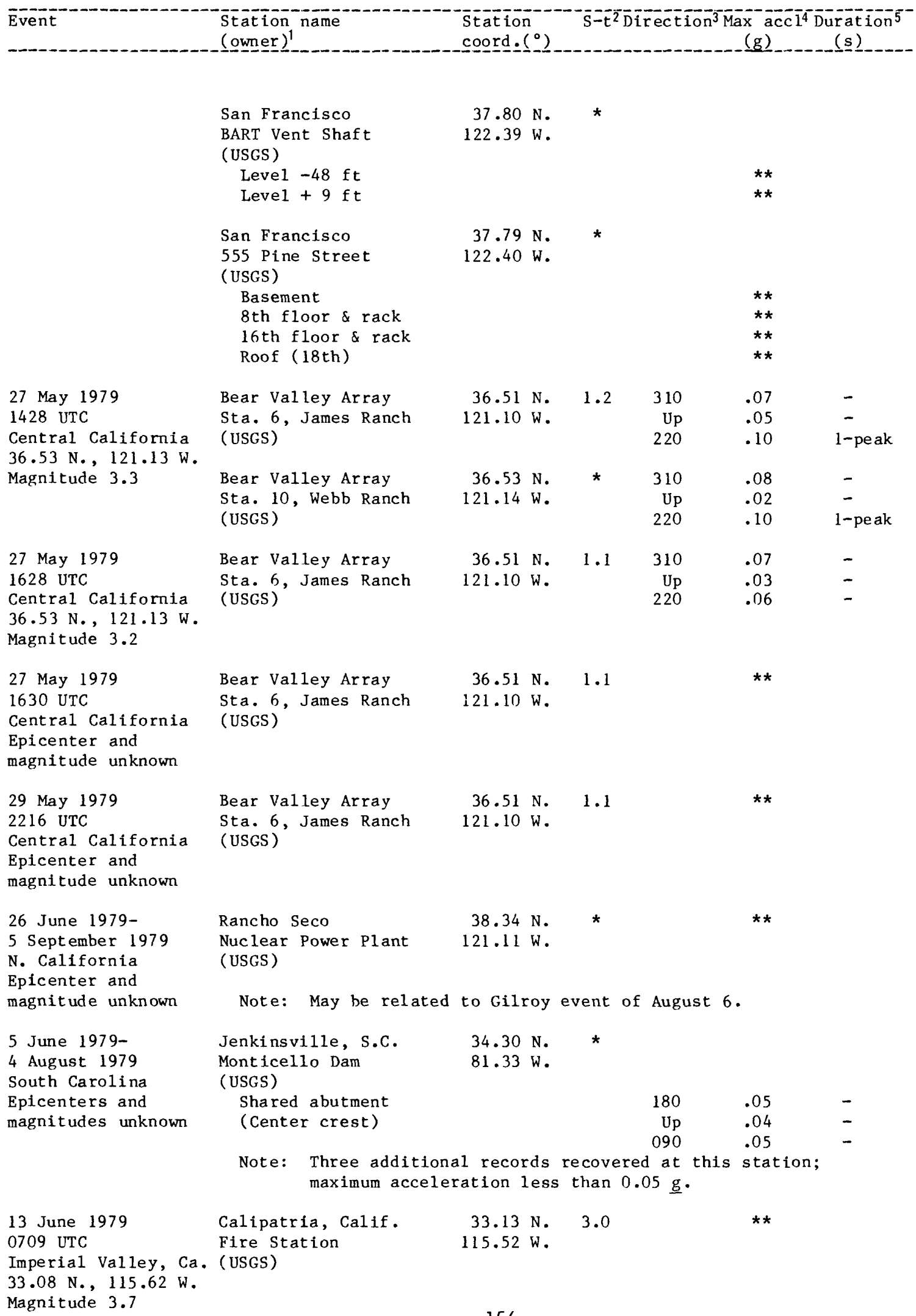


Table 9.--Sum mary of U.S. accelerograph records recovered during 1979--Continued

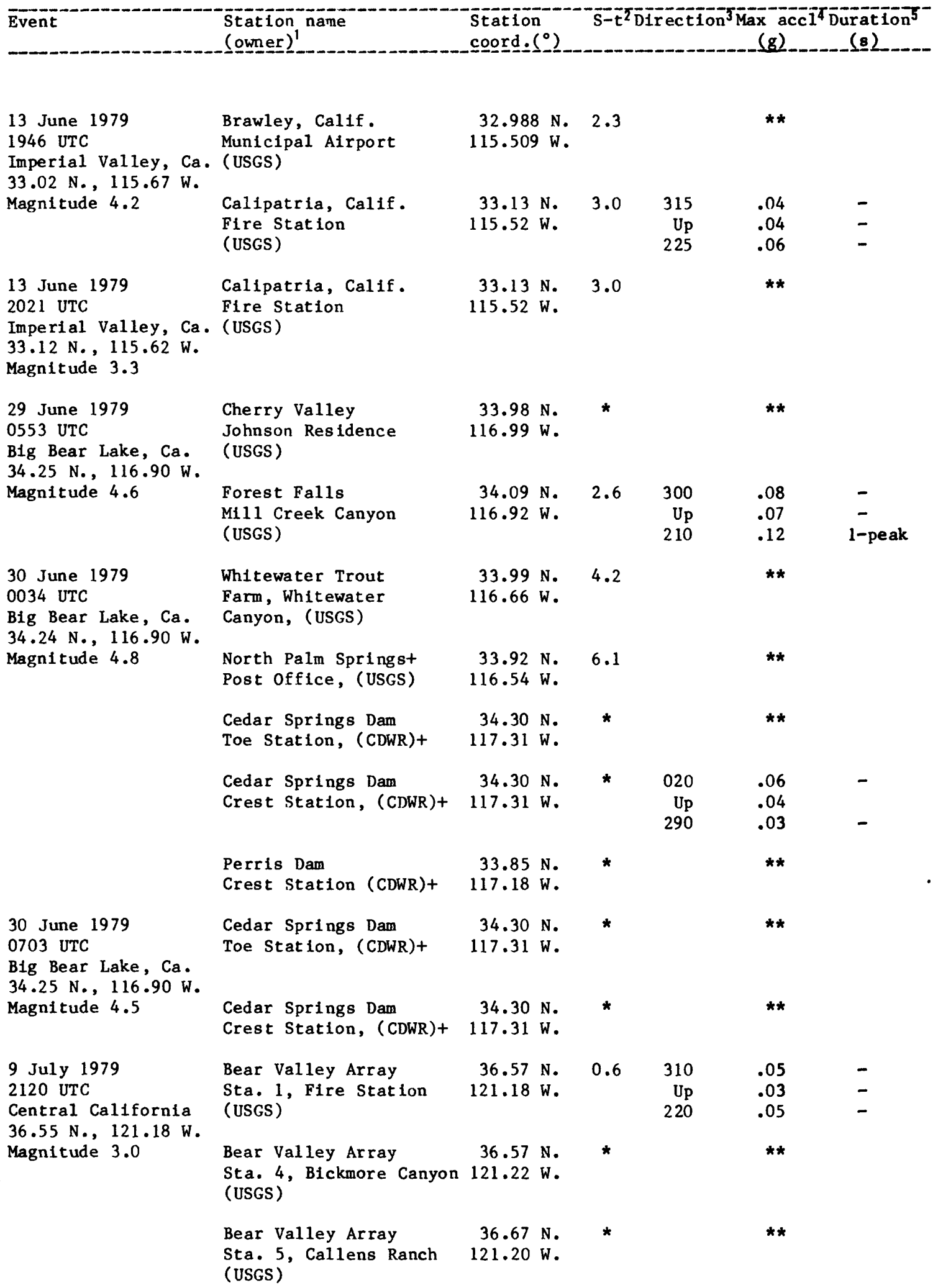


Table 9.--Summary of U.S. accelerograph records recovered during 1979--Continued

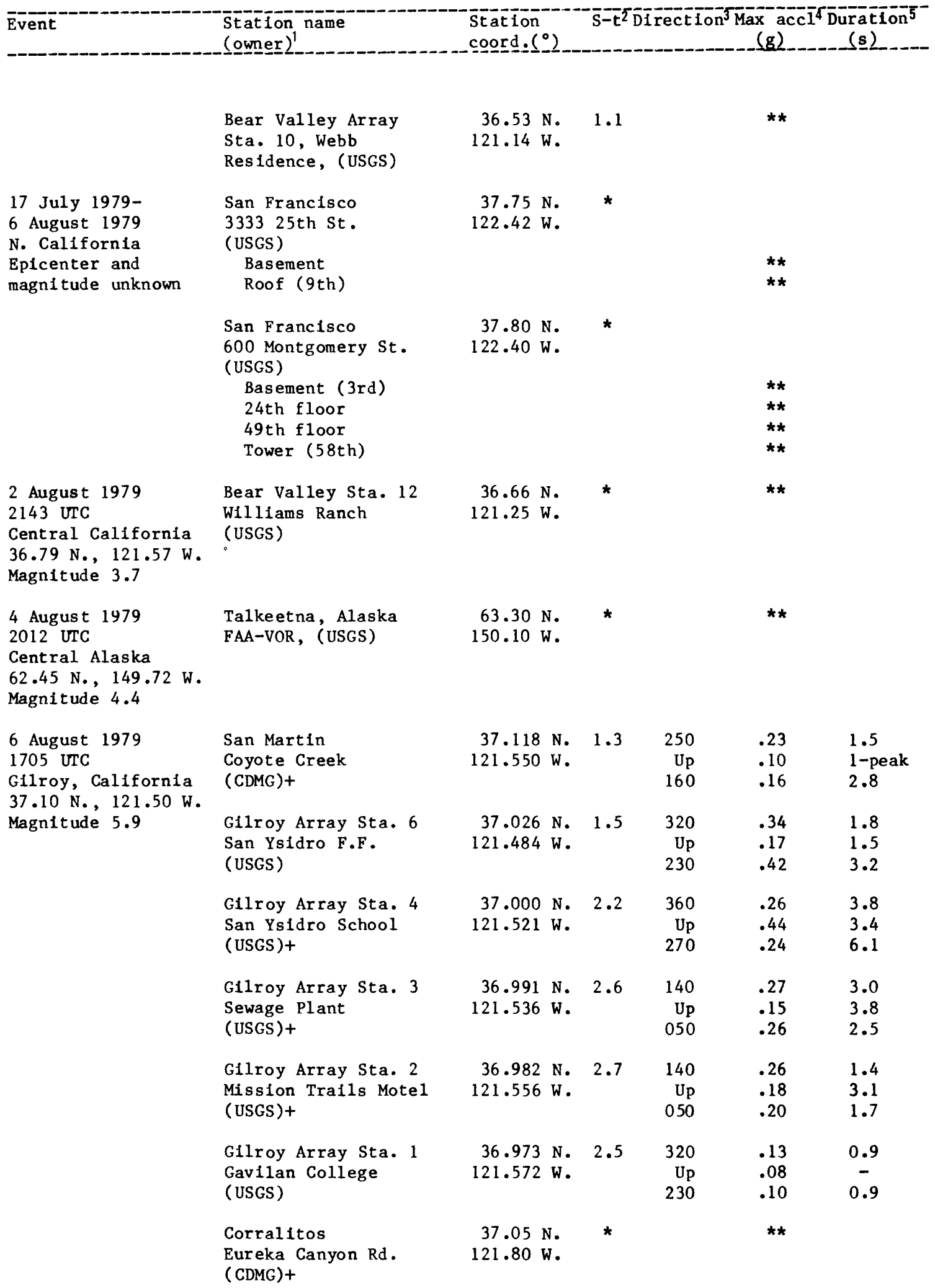


Table 9.--Summary of U.S. accelerograph records recovered during 1979--Continued

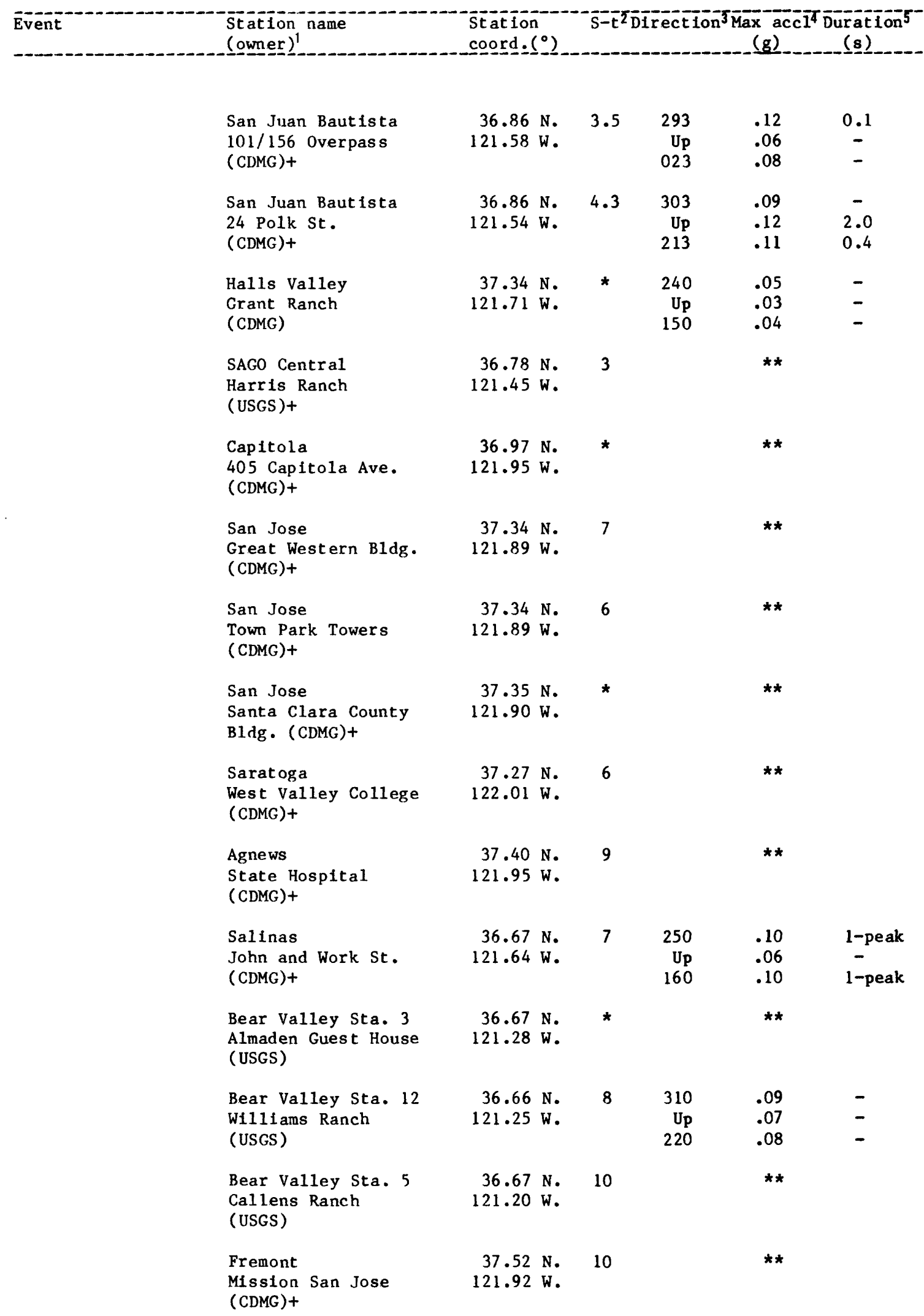


Table 9.--Summary of U.S. accelerograph records recovered during 1979--Continued

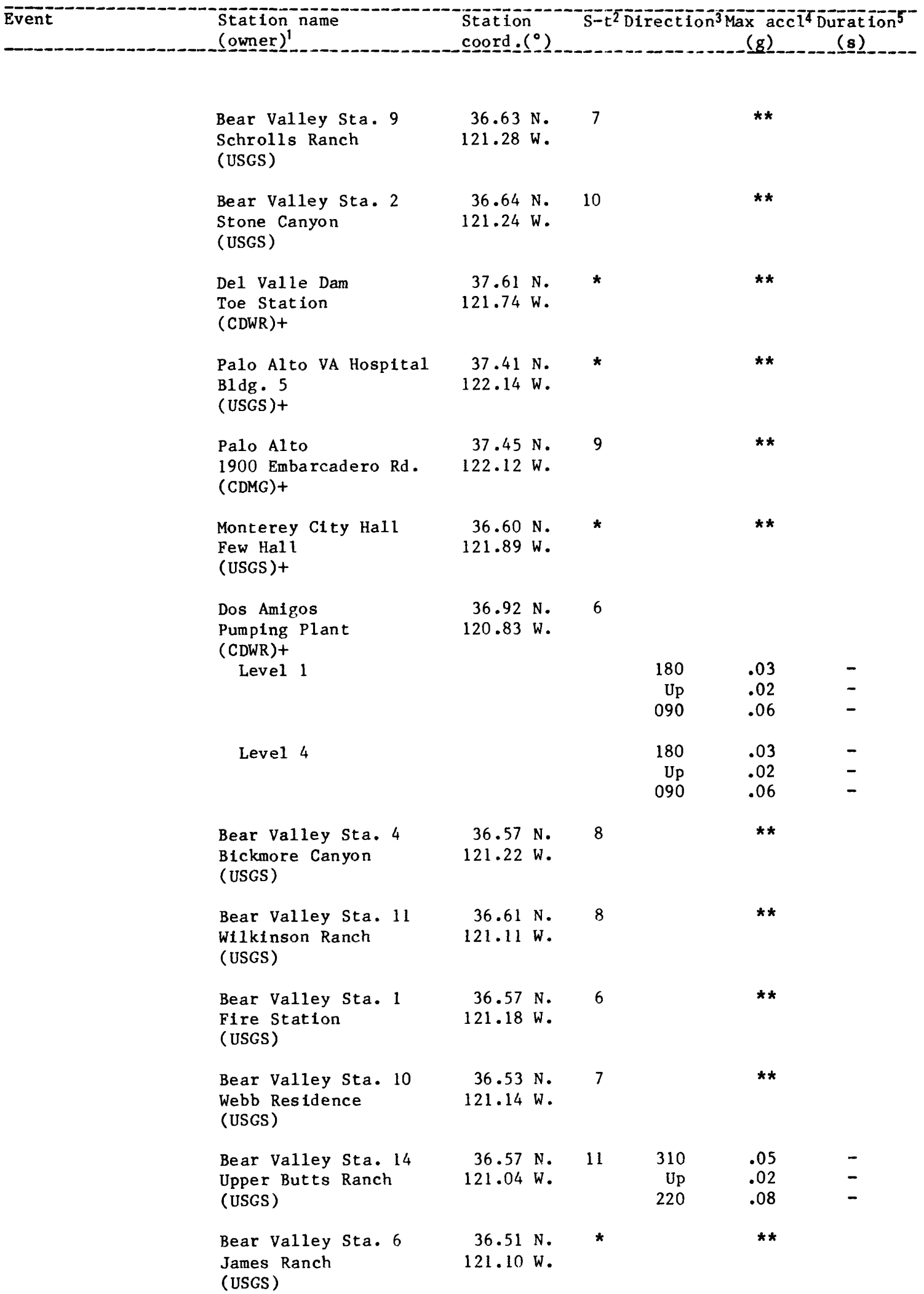


Table 9.--Summary of U.S. accelerograph records recovered during 1979.-Continued

\begin{tabular}{|c|c|c|c|c|}
\hline \multirow[t]{3}{*}{ Event } & $\begin{array}{l}\text { Station name } \\
\text { (owner) }\end{array}$ & coord. & \multicolumn{2}{|c|}{ 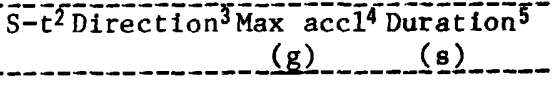 } \\
\hline & $\begin{array}{l}\text { APEEL Array Sta. 2E } \\
\text { Hayward } \\
\text { (USGS)+ }\end{array}$ & $\begin{array}{r}37.66 \mathrm{~N} . \\
122.08 \mathrm{~W} .\end{array}$ & 12 & $\star *$ \\
\hline & $\begin{array}{l}\text { Hayward } \\
\text { C1ty Hall } \\
\text { (USGS)+ }\end{array}$ & $\begin{array}{r}37.68 \mathrm{~N} \\
122.08 \mathrm{~W}\end{array}$ & * & $\star *$ \\
\hline & $\begin{array}{l}\text { APEFL Array Sta. } 7 \\
\text { Crystal Springs } \\
\text { (USGS)+ }\end{array}$ & $\begin{array}{r}37.48 \mathrm{~N} . \\
122.31 \mathrm{~W} .\end{array}$ & $\star$ & $* *$ \\
\hline & $\begin{array}{l}\text { San Ramon } \\
\text { Fire Station } \\
\text { (CDMG) }\end{array}$ & $\begin{array}{r}37.78 \mathrm{~N} . \\
121.98 \mathrm{~W} .\end{array}$ & 13 & $* *$ \\
\hline & $\begin{array}{l}\text { Lower Crystal Springs } \\
\text { Dam, Abutment } \\
(\mathrm{CDMG})+\end{array}$ & $\begin{array}{r}37.53 \mathrm{~N} . \\
122.36 \mathrm{~W}\end{array}$ & $\star$ & $* *$ \\
\hline & $\begin{array}{l}\text { Oakland } \\
\text { Calrus Bldg. } \\
(\text { CDMG)+ }\end{array}$ & $\begin{array}{r}37.74 \mathrm{~N} \\
122.15 \mathrm{~W}\end{array}$ & * & ** \\
\hline & $\begin{array}{l}\text { Greenfie1d } \\
845 \text { 0ak St. } \\
(\text { CDMG })+\end{array}$ & $\begin{array}{r}36.32 \mathrm{~N} \\
121.24 \mathrm{~W}\end{array}$ & * & $\star *$ \\
\hline & $\begin{array}{l}\text { San Francisco } \\
\text { International Airport } \\
\text { (CDMG)+ }\end{array}$ & $\begin{array}{r}37.62 \mathrm{~N} . \\
122.40 \mathrm{~W} .\end{array}$ & 13 & ** \\
\hline & $\begin{array}{l}\text { B1g Sur State Park } \\
\text { Ma1ntenance B1dg. } \\
\text { (CDMG)+ }\end{array}$ & $\begin{array}{r}36.25 \mathrm{~N} . \\
121.78 \mathrm{~W}\end{array}$ & * & ** \\
\hline & $\begin{array}{l}\text { South San Francisco } \\
\text { Kalser Medical Bldg. } \\
(C D M G)+\end{array}$ & $\begin{array}{r}37.66 \mathrm{~N} \\
122.43 \mathrm{~W}\end{array}$ & 17 & $\star \star$ \\
\hline & $\begin{array}{l}\text { Oakland } \\
\text { Title Ins. \& Trust } \\
\text { (CDMG)+ }\end{array}$ & $\begin{array}{r}37.81 \mathrm{~N} . \\
122.27 \mathrm{~W} .\end{array}$ & 16 & $* *$ \\
\hline & $\begin{array}{l}\text { San Francisco } \\
\text { Di amond Heights } \\
\text { (CDMG)+ }\end{array}$ & $\begin{array}{r}37.74 \mathrm{~N} \\
122.43 \mathrm{~W} .\end{array}$ & $*$ & $* *$ \\
\hline & $\begin{array}{l}\text { San Francisco } \\
333325 \mathrm{th} \text { St. } \\
\text { (USGS) }\end{array}$ & $\begin{array}{r}37.75 \mathrm{~N} . \\
122.42 \mathrm{~W} .\end{array}$ & $\star$ & $\star \star *$ \\
\hline & $\begin{array}{l}\text { San Francisco } \\
555 \text { California St. } \\
\text { (USGS)+ }\end{array}$ & $\begin{array}{r}37.79 \mathrm{~N} . \\
122.40 \mathrm{~W}\end{array}$ & $\star$ & $* *$ \\
\hline & $\begin{array}{l}\text { San Francisco } \\
600 \text { Montgomery St. } \\
\text { (USGS)+ }\end{array}$ & $\begin{array}{r}37.80 \mathrm{~N} . \\
122.40 \mathrm{~W} .\end{array}$ & * & $\star *$ \\
\hline
\end{tabular}


Table 9.--Summary of U.S. accelerograph records recovered during 1979--Continued

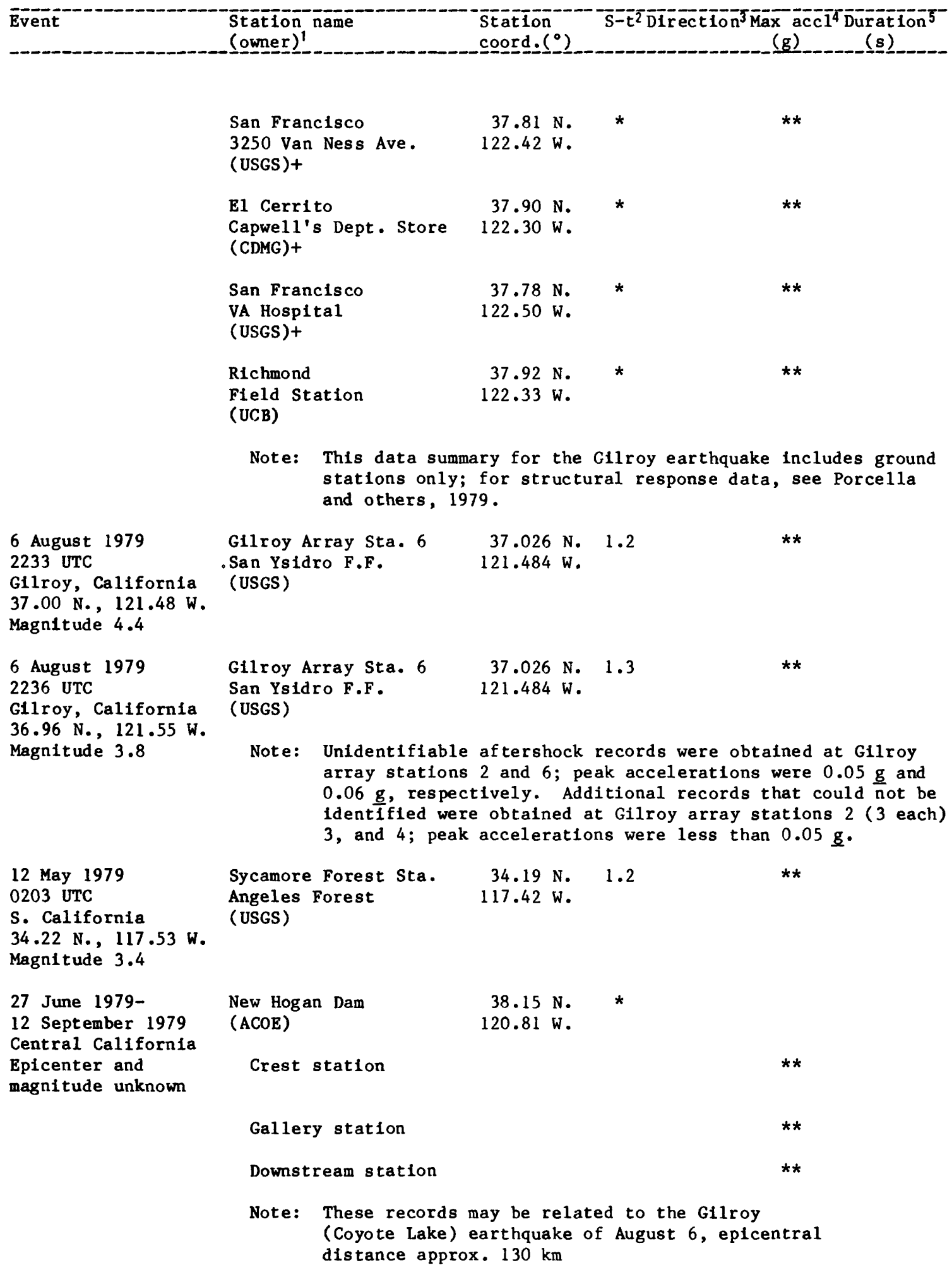


Table 9.--Summary of U.S. accelerograph records recovered during 1979--Continued

\begin{tabular}{|c|c|c|c|c|c|c|}
\hline Event & $\begin{array}{l}\text { Station name } \\
\text { (owner) }\end{array}$ & $\begin{array}{l}\text { Station } \\
\text { coord. }\left({ }^{\circ}\right)\end{array}$ & \multicolumn{4}{|c|}{$\begin{array}{l}\mathrm{S}-\mathrm{t}^{2} \text { Direction } \\
\mathrm{(g})\end{array}$} \\
\hline $\begin{array}{l}22 \text { August } 1979 \\
0201 \text { UTC } \\
\text { S. California } \\
33.72 \text { N., } 116.83 \mathrm{~W} . \\
\text { Magnitude } 4.1\end{array}$ & $\begin{array}{l}\text { Cranston } \\
\text { Forest Station } \\
\text { (USGS) }\end{array}$ & $\begin{array}{r}33.74 \text { N. } \\
116.84 \text { W. }\end{array}$ & 2.2 & & $\star *$ & \\
\hline $\begin{array}{l}3 \text { September } 1979 \\
1144 \text { UTC } \\
\text { S. California } \\
33.38 \text { N., } 116.33 \mathrm{~W} \text {. } \\
\text { Magnitude } 3.8\end{array}$ & $\begin{array}{l}\text { Rancho de Anza } \\
\text { Anza-Borrego Park } \\
\text { (USGS) }\end{array}$ & $\begin{array}{r}33.35 \mathrm{~N} . \\
116.40 \mathrm{~W}\end{array}$ & * & $\begin{array}{r}135 \\
\text { Up } \\
045\end{array}$ & $\begin{array}{l}.08 \\
.02 \\
.04\end{array}$ & $\begin{array}{l}- \\
-\end{array}$ \\
\hline $\begin{array}{l}22 \text { September } 1979 \\
0759 \text { UTC } \\
\text { S. Hawail }\end{array}$ & $\begin{array}{l}\text { Hilo, Hawail } \\
\text { Fish \& Wildlife } \\
\text { (USGS)+ }\end{array}$ & $\begin{array}{r}19.731 \mathrm{~N} \\
155.096 \mathrm{~W}\end{array}$ & 6.2 & $\begin{array}{r}180 \\
\text { Up } \\
090\end{array}$ & $\begin{array}{l}.44 \\
.18 \\
.17\end{array}$ & $\begin{array}{l}4.4 \\
0.6 \\
2.7\end{array}$ \\
\hline Magnitude 5.5 & $\begin{array}{l}\text { Hilo, Hawaii } \\
\text { Univ. of Hawaii } \\
\text { (USGS)+ }\end{array}$ & $\begin{array}{r}19.707 \mathrm{~N} . \\
155.083 \mathrm{~W} .\end{array}$ & * & $\begin{array}{r}265 \\
\mathrm{Up} \\
175\end{array}$ & $\begin{array}{l}.02 \\
.03 \\
.11\end{array}$ & $\begin{array}{l}- \\
\text { 1-peak }\end{array}$ \\
\hline & $\begin{array}{l}\text { Hilo, Hawaii } \\
\text { Sewage Plant } \\
\text { (USGS)+ }\end{array}$ & $\begin{array}{r}19.734 \mathrm{~N} . \\
155.050 \mathrm{~W} .\end{array}$ & * & & $\star \star$ & \\
\hline & $\begin{array}{l}\text { Honokaa, Hawaii } \\
\text { Fire Station } \\
\text { (USGS)+ }\end{array}$ & $\begin{aligned} 20.081 \mathrm{~N} . \\
155.465 \mathrm{~W} .\end{aligned}$ & * & & ** & \\
\hline & $\begin{array}{l}\text { Pahala, Hawaii } \\
\text { Kau Hospital } \\
\text { (USGS)+ }\end{array}$ & $\begin{array}{r}19.20 \mathrm{~N} . \\
155.47 \mathrm{~W} .\end{array}$ & * & & $* *$ & \\
\hline & $\begin{array}{l}\text { Wahaula, Hawaii } \\
\text { Visitor Center } \\
\text { (USGS)+ }\end{array}$ & $\begin{array}{r}19.33 \mathrm{~N} . \\
155.03 \mathrm{~W} .\end{array}$ & * & $\begin{array}{r}145 \\
\text { Up } \\
055\end{array}$ & $\begin{array}{l}.04 \\
.11 \\
.04\end{array}$ & $\underset{\text { 1-peak }}{-}$ \\
\hline & $\begin{array}{l}\text { Note: } \\
\text { additiona1 } \\
\text { maximum acc }\end{array}$ & $\begin{array}{l}\text { records rec } \\
\text { ord recovere } \\
\text { ration less }\end{array}$ & $\begin{array}{l}\text { overe } \\
\text { d at } \\
\text { than }\end{array}$ & $\begin{array}{l}\text { at Wa } \\
\text { lo } \mathrm{Fi} \\
05 \mathrm{~g} .\end{array}$ & $\begin{array}{l}\text { a and } \\
\text { nd wi }\end{array}$ & \\
\hline $\begin{array}{l}15 \text { 0ctober } 1979 \\
2316 \text { UTC } \\
\text { Imperial Valley, Ca }\end{array}$ & $\begin{array}{l}\text { Blythe } \\
\text { CDF Fire Station } \\
\text { (CDMG)+ }\end{array}$ & $\begin{array}{r}33.67 \mathrm{~N} . \\
114.71 \mathrm{~W} .\end{array}$ & * & & $\star *$ & \\
\hline Magnitude 6.6 & $\begin{array}{l}\text { Bonds Corner } \\
\text { Highways } 98 \& 115 \\
\text { (USGS) }\end{array}$ & $\begin{array}{r}32.693 \mathrm{~N} . \\
115.338 \mathrm{~W} .\end{array}$ & 2.4 & $\begin{array}{r}230 \\
\mathrm{UP} \\
140\end{array}$ & $\begin{array}{l}.81 \\
.47 \\
.66\end{array}$ & $\begin{array}{l}13.2 \\
12.0 \\
13.3\end{array}$ \\
\hline & $\begin{array}{l}\text { Borrego Air Ranch } \\
\text { Borrego Springs } \\
\text { (USGS) }\end{array}$ & $\begin{array}{r}33.19 \mathrm{~N} . \\
116.28 \mathrm{~W} .\end{array}$ & 8.2 & & $* *$ & \\
\hline & $\begin{array}{l}\text { Brawley Airport } \\
\text { Brawley } \\
\text { (USGS) }\end{array}$ & $\begin{array}{r}32.988 \mathrm{~N} . \\
115.509 \mathrm{~W} .\end{array}$ & 6.3 & $\begin{array}{r}315 \\
\text { Up } \\
225\end{array}$ & $\begin{array}{l}.22 \\
.18 \\
.17\end{array}$ & $\begin{array}{l}2.2 \\
5.2 \\
1.8\end{array}$ \\
\hline & $\begin{array}{l}\text { Cabazon Post office } \\
\text { Cabazon } \\
\text { (USGS) }\end{array}$ & $\begin{array}{r}33.92 \mathrm{~N} . \\
116.78 \mathrm{~W}\end{array}$ & * & & $\star *$ & \\
\hline
\end{tabular}


Table 9.--Summary of U.S. accelerograph records recovered during 1979--Continued

\begin{tabular}{|c|c|c|c|c|c|c|}
\hline \multirow[t]{5}{*}{ Event } & $\begin{array}{l}\text { (owner) } \\
\text { (owne }\end{array}$ & $\begin{array}{l}\text { Station } \\
\text { coord. }\end{array}$ & \multicolumn{4}{|c|}{ 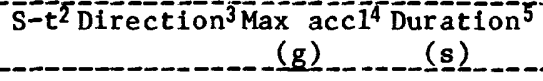 } \\
\hline & $\begin{array}{l}\text { Calexico Fire Sta } \\
\text { Fifth \& Mary } \\
\text { (USGS) }\end{array}$ & $\begin{array}{r}32.669 \mathrm{~N} \\
115.492 \mathrm{~W}\end{array}$ & 3.2 & $\begin{array}{r}315 \\
\text { Up } \\
225\end{array}$ & $\begin{array}{l}.22 \\
.21 \\
.28\end{array}$ & $\begin{array}{l}9.5 \\
8.8 \\
10.8\end{array}$ \\
\hline & $\begin{array}{l}\text { Calipatria Fire Sta } \\
\text { Calipatria } \\
\text { (USGS) }\end{array}$ & $\begin{array}{r}33.13 \mathrm{~N} . \\
115.52 \mathrm{~W} .\end{array}$ & 7.4 & $\begin{array}{r}315 \\
\text { Up } \\
225\end{array}$ & $\begin{array}{l}.09 \\
.07 \\
.13\end{array}$ & $\begin{array}{l}- \\
\text { 1-peak }\end{array}$ \\
\hline & $\begin{array}{l}\text { Coachella Canal } \\
\text { Station } 1 \\
\text { (USGS) }\end{array}$ & $\begin{array}{r}33.64 \mathrm{~N} \\
116.08 \mathrm{~W}\end{array}$ & * & & ** & \\
\hline & $\begin{array}{l}\text { Coachella Canal } \\
\text { Station } 4 \\
\text { (USGS) }\end{array}$ & $\begin{array}{r}33.36 \mathrm{~N} . \\
115.59 \mathrm{~W} .\end{array}$ & 8.5 & $\begin{array}{r}135 \\
\text { Up } \\
045\end{array}$ & $\begin{array}{l}.14 \\
.04 \\
.11\end{array}$ & $\begin{array}{l}0.5 \\
- \\
0.3\end{array}$ \\
\hline
\end{tabular}

Note: Anomalously high accelerations recorded at Coachella Canal Station 4 may be a result of structure response.

\begin{tabular}{|c|c|c|c|c|c|}
\hline $\begin{array}{l}\text { Coronado } \\
1770 \text { Ava de1 Mundo } \\
(\mathrm{CCO})+\end{array}$ & $\begin{array}{r}32.68 \mathrm{~N} . \\
117.17 \mathrm{~W} .\end{array}$ & * & & $\star *$ & \\
\hline $\begin{array}{l}\text { Coronado } \\
1780 \text { Ava del Mundo } \\
(\mathrm{CCO})+\end{array}$ & $\begin{array}{r}32.68 \mathrm{~N} . \\
117.17 \mathrm{~W}\end{array}$ & * & & $\star *$ & \\
\hline $\begin{array}{l}\text { E1 Capitan Dam } \\
\text { Left Abutment } \\
\text { (CDMG) }\end{array}$ & $\begin{array}{r}32.88 \mathrm{~N} \\
116.82 \mathrm{~W}\end{array}$ & * & & ** & \\
\hline $\begin{array}{l}\text { E1 Centro, Imperial } \\
\text { County Services Bldg. } \\
\text { (CDMG) }\end{array}$ & $\begin{array}{r}32.793 \mathrm{~N} . \\
115.564 \mathrm{~W} .\end{array}$ & 5.0 & $\begin{array}{r}360 \\
\text { Up } \\
090\end{array}$ & $\begin{array}{l}.29 \\
.19 \\
.32\end{array}$ & 6 \\
\hline $\begin{array}{l}\text { E1 Centro, Imperial } \\
\text { County Center } \\
\text { (CDMG) }\end{array}$ & $\begin{array}{r}32.79 \mathrm{~N} . \\
115.56 \mathrm{~W}\end{array}$ & 5.0 & $\begin{array}{r}092 \\
\text { Up } \\
002\end{array}$ & $\begin{array}{l}.24 \\
.27 \\
.24\end{array}$ & 5 \\
\hline $\begin{array}{l}\text { E1 Centro array sta. } 1 \\
\text { Borchard Ranches } \\
\text { (USGS) }\end{array}$ & $\begin{array}{r}32.960 \mathrm{~N} . \\
115.319 \mathrm{~W} .\end{array}$ & 6 & $\begin{array}{r}230 \\
\text { Up } \\
140\end{array}$ & $\begin{array}{l}.15 \\
.10 \\
.15\end{array}$ & $\begin{array}{l}3.1 \\
1-\text { peak } \\
4.8\end{array}$ \\
\hline $\begin{array}{l}\text { E1 Centro array sta. } 2 \\
\text { Keystone Road } \\
\text { (USGS) }\end{array}$ & $\begin{array}{r}32.916 \mathrm{~N} . \\
115.366 \mathrm{~W} .\end{array}$ & 6 & $\begin{array}{r}230 \\
\text { Up } \\
140\end{array}$ & $\begin{array}{l}.43 \\
.17 \\
.33\end{array}$ & $\begin{array}{l}5.7 \\
9.3 \\
9.2\end{array}$ \\
\hline $\begin{array}{l}\text { E1 Centro array sta. } 3 \\
\text { Pine Union School } \\
\text { (USGS)+ }\end{array}$ & $\begin{array}{r}32.894 \mathrm{~N} . \\
115.380 \mathrm{~W} .\end{array}$ & 5.4 & $\begin{array}{r}230 \\
\text { Up } \\
140\end{array}$ & $\begin{array}{l}.22 \\
.15 \\
.27\end{array}$ & $\begin{array}{l}6.2 \\
5.6 \\
6.0\end{array}$ \\
\hline $\begin{array}{l}\text { E1 Centro array sta. } 4 \\
2905 \text { Anderson Road } \\
\text { (USGS) }\end{array}$ & $\begin{array}{r}32.864 \mathrm{~N} . \\
115.432 \mathrm{~W} .\end{array}$ & $4.8 *$ & $\begin{array}{r}230 \\
\text { Up } \\
140\end{array}$ & $\begin{array}{l}.38 \\
.32 \\
.61\end{array}$ & $\begin{array}{l}6.5 \\
6.7 \\
6.8\end{array}$ \\
\hline $\begin{array}{l}\text { E1 Centro array sta. } 5 \\
2801 \text { James Road } \\
\text { (USGS) }\end{array}$ & $\begin{array}{r}32.855 \mathrm{~N} . \\
115.466 \mathrm{~W} .\end{array}$ & 5.1 & $\begin{array}{r}230 \\
\text { Up } \\
140\end{array}$ & $\begin{array}{l}.40 \\
.71 \\
.56\end{array}$ & $\begin{array}{l}7.6 \\
5.6 \\
7.4\end{array}$ \\
\hline
\end{tabular}


Table 9.--Summary of U.S. accelerograph records recovered during 1979--Continued

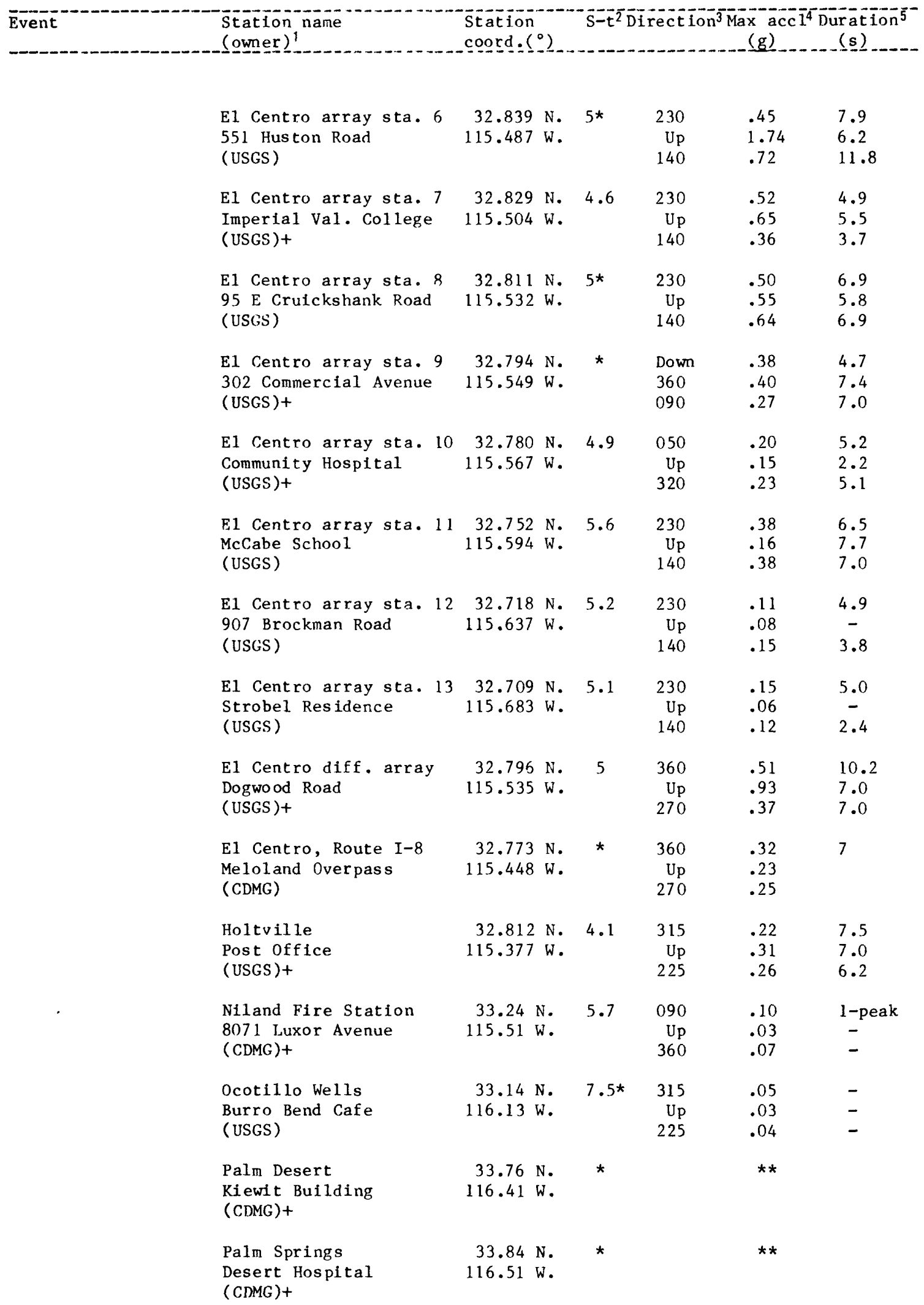


Table 9.--Sum mary of U.S. accelerograph records recovered during 1979--Continued

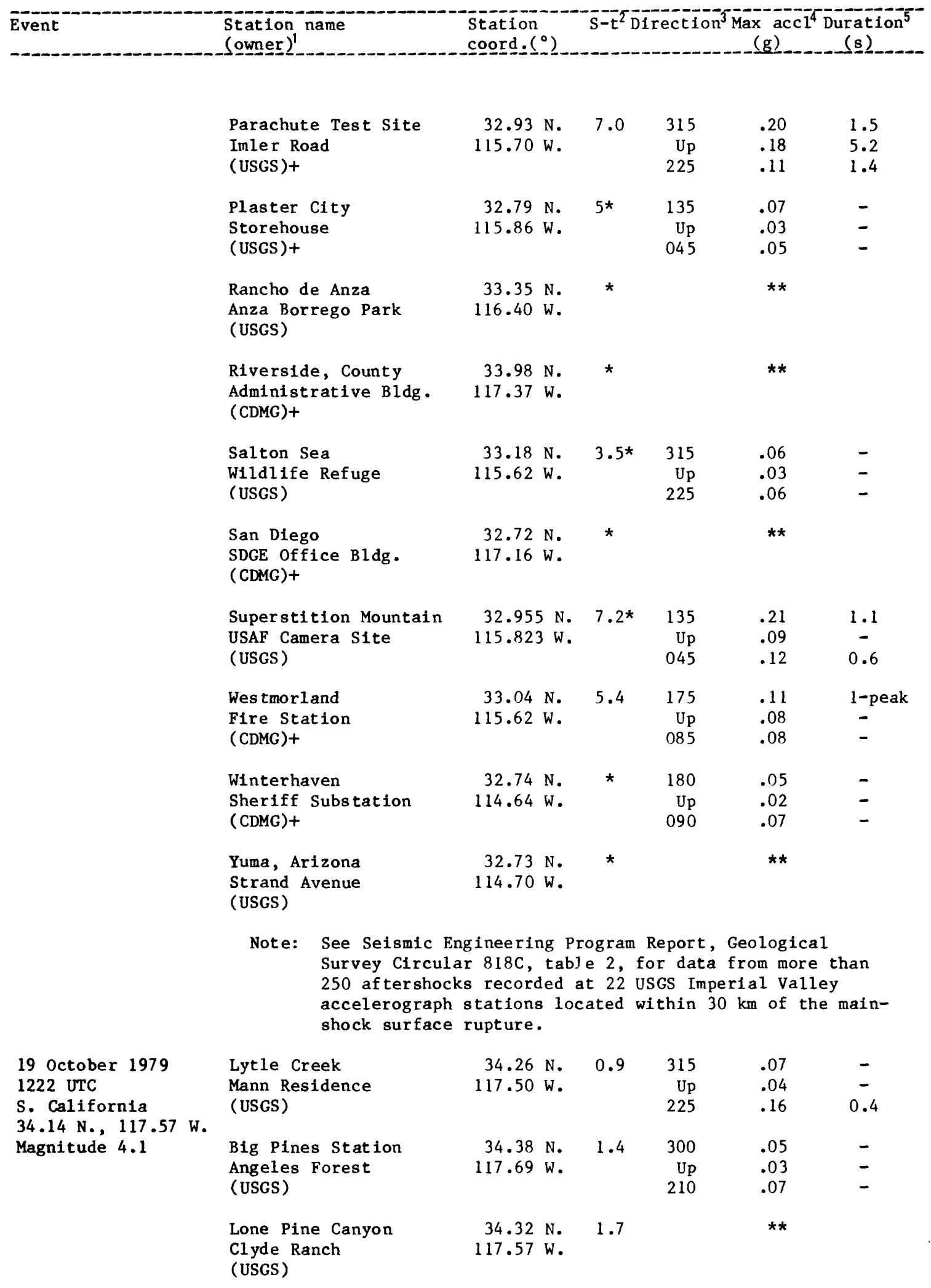


Table 9.--Sum mary of U.S. accelerograph records recovered during 1979--Continued

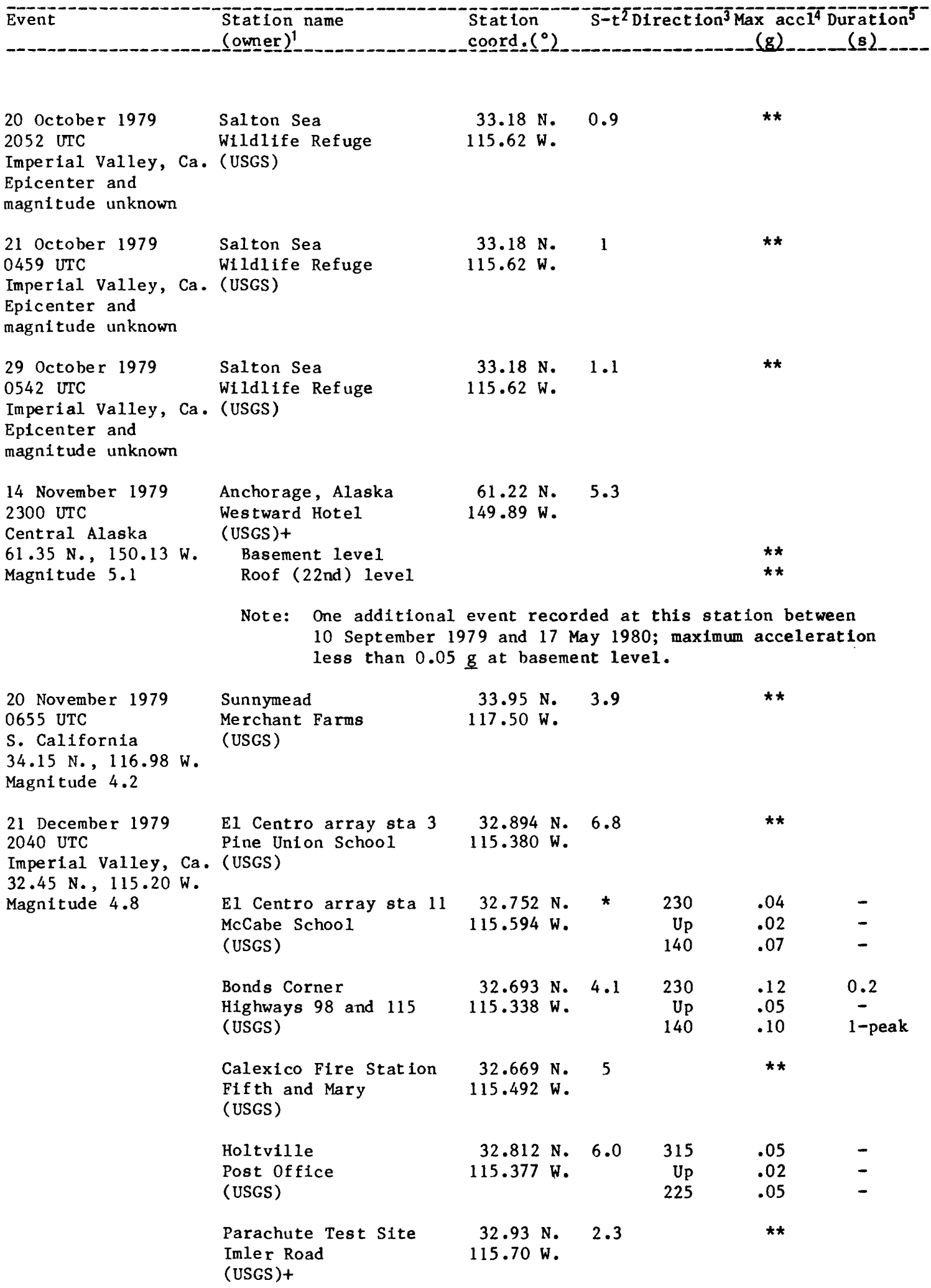


Table 9.--Summary of L'.S. accelerograph records recovered during 1979--Continued

\begin{tabular}{|c|c|c|c|c|c|c|}
\hline \multirow[t]{4}{*}{ Event } & $\begin{array}{l}\text { Station name } \\
\text { (owner) }\end{array}$ & St at ion & \multicolumn{4}{|c|}{$\mathrm{S}=\mathrm{t}^{2}$ Direction ${ }^{3} \mathrm{ax}$ accl $\mathrm{g}^{4}$ Duration } \\
\hline & $\begin{array}{l}\text { E1 Centro diff. array } \\
\text { Dogwood Road } \\
\text { (USGS)+ }\end{array}$ & $\begin{array}{r}32.796 \mathrm{~N} . \\
115.535 \mathrm{~W} .\end{array}$ & * & $\begin{array}{r}360 \\
\text { Up } \\
270\end{array}$ & $\begin{array}{l}.06 \\
.03 \\
.08\end{array}$ & $\begin{array}{l}- \\
-\end{array}$ \\
\hline & $\begin{array}{l}\text { E1 Centro array sta. } 9 \\
302 \text { Commerical Avenue } \\
\text { (USGS)+ }\end{array}$ & $\begin{array}{r}32.794 \mathrm{~N} . \\
115.549 \mathrm{~W} .\end{array}$ & * & $\begin{array}{l}\text { Down } \\
360 \\
090\end{array}$ & $\begin{array}{l}.02 \\
.07 \\
.07\end{array}$ & $\overline{-}$ \\
\hline & 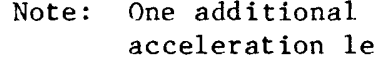 & $\begin{array}{l}\text { ecord recov } \\
\text { than } 0.05\end{array}$ & & array & & ximum \\
\hline
\end{tabular}

\footnotetext{
1 Station owner code:

ACOE - U.S. Army Corps of Engineers

CCO - City of Coronado

CDMG - California Division of Mines and Geology

CDWR - California Dept. of Water Resources

CLA - City of Los Angeles

DOE - U.S. Department of Energy

LDGO - Lamont-Doherty Geological Observatory

MWD - Metropolitan Water District of Southern California

OTA - Ocean Tower Apartments, Santa Monica

UCB - University of California, Berkeley

USGS - U.S. Geological Survey

VA - Veterans Administration

+ - WWVB time code not legible or instrument not equipped with a radio

receiver; correlation of accelerogram with event may be questionable.

${ }^{2} \mathrm{~S}$-wave arrival minus trigger time $(S-t)$ interval.

* $S$ - $t$ interval is questionable or cannot be determined.

${ }^{3}$ Direction of case acceleration for upward trace deflection on accelerogram. Horizontal components are 1 isted as azimuth in degrees clockwise from north; vertical components are listed as "up" or "down."

${ }^{4}$ Peak acceleration recorded at ground level on one vertical and two orthogonal horizontal components.

** Denotes maximum acceleration is less than $0.05 \mathrm{~g}$ at ground level or less than $0.10 \mathrm{~g}$ at upper floors of buildings.

${ }^{5}$ Duration between first and last peaks of acceleration greater than $0.10 \mathrm{~g}$.
} 


\section{References}

Armstrong, C. F., 1979, Coyote Lake earthquake: California Geology, v. 32, no. 11, p. 248251 .

Bath, Markus, 1966, Earthquake energy and magnitude, in Physics and chemistry of the Earth, Volume 7: Oxford and New York, Pergamon Press, p. 115-165.

Bollinger, G. A. and Mathena, E., 1980, Seismicity of the Southeastern United States: Southeastern U.S. Seismic Network, Bulletin No. 5,51 p.

Brady, A. G., Perez, V., and Mork, P. N., 1980, The Imperial Valley earthquake, October 15 , 1979: digitization and processing of accelerograph records: U.S. Geological Survey Open-file Report 80-703, $309 \mathrm{p}$.

Brune, J., Prince, J., Vernon III, F., Mena, E., and Simons, R., 1980, Strong-motion data recorded in Mexico during the main shock of the October 15, 1979 Imperial Valley earthquake: Institute of Geophysics and Planetary Physics, University of California, San Diego, La Jolla, California 92093, unpublished report.

Bryant, W. A., 1979, Earthquakes near Honey Lake, Lassen County, California: California Geology, v. 32, no. 5, p. 106-109.

California Division of Mines and Geology, 1979, Partial records and file data, Imperial Valley earthquake of October 15, 1979: Office of Strong-Motion Studies, Sacramento, California 95816 .

Converse, A., 1978, Strong-motion information retrleval system user's manual: U.S. Geological Survey Open-file Report 79-289, 56 p.

Gut enberg, B. and Richter, C. F., 1956, Magnitude and energy of earthquakes: Annali $\mathrm{d} i$ Geofisica, v. 9, no. 1, p. 1-15.

Hawkins, H. G. and McNey, J. L., 1979, Homestead Valley earthquake swarm, San Bernardino County, California: California Geology, v. 32 , no. 10 , p. 222-224.

Healy, J. H., Rubey, W. W., Grigg, D. T., and Raleigh, C. B., 1968, The Denver earthquakes: Science, v. 161 , no. 3848, p. $1301-1310$.

Hutton, L. K., Pechmann, J. C., Cole, D. M., Johnson, C. E., Ebel, J. E., German, P. T., and Given, J.W., 1980, Epicentral locations for the Homestead Valley Earthquake sequence, March 15, 1979: California Geology, v. 33, p. 110-114.

Lahr, J., Plafker, G., Stephens, C., Fogleman, K., and Blackford, M., 1979, Interim report on the St. Elias, Alaska earthquake of 28 February 1979: U.S. Geological Survey Open-file Report 79-670, 35 p.
Lahr, J. C., Stephens, C. D., Hasegawa, H. S., and Boatwright, J., 1980, Alaskan seismic gap only partially filled by 28 February 1979 earthquake: Science, v. 207, p. $1351-1353$.

Lee, W. and Lahr, J., 1972, HYP071: A computer program for determining hypocenter, magnitude, and first motion pattern of local earthquakes: U.S. Geological Survey Openfile Report, $100 \mathrm{p}$.

Mooney, H. M. and Walton, M., 1980, Selsmicity and tectonic relationships for the Upper Great Lakes Precambrian Shield Province, Nuclear Regulatory Report, NUCREG/CR-1569, U.S. Nuclear Regulatory Commission, Washington, D.C., $85 \mathrm{p}$.

Neal, C. R., Mcjunkin, R. D., and Levias, E., 1979, Effects of Imperial Valley earthquake 15 October 1979, Imperial County, California: California Geology, v. 32, no. 12, p. $259-265$.

Nuttli, 0. W., 1973,' Seismic wave attenuation and magnitude relations for eastern North America: Journal of Geophysical Research, v. 78 , no. 5, p. 876-885.

Porcella, R. L., 1979, Seismic Engineering Program Report, January-April 1979: Geological Survey Circular 818-A, 20 p.

Porcella, R. L., 1980 , Seismic Engineering Program Report, May-August 1979: Geological Survey Circular 818-B, $24 \mathrm{p}$.

Porcella, R. L. and Matthiesen, R. B., 1979, Preliminary summary of the U.S. Geological Survey strong-motion records from the october 15, 1979 Imperial Valley earthquake: U.S. Geological Survey Open-File Report $79-1654,41 \mathrm{p}$.

Porcella, R. L., Matthiesen, R. B., McJunkin, R. D., and Ragsdale, J. T., 1979, Compilation of strong-motion records from the August 6 , 1979 Coyote Lake earthquake: U.S. Geological Survey Open-file Report 79-385 and California Division of Mines and Geology Preliminary Report 25, $71 \mathrm{p}$.

Porter, L. D., 1980, Data processing procedures for the main-shock motions recorded by the California Division of Mines and Geology Strong-Motion Network, Imperial Valley earthquake of October 15, 1979: Office of Strong-Motion Studies, Sacramento, California 95816, unpublished report.

Reagor, B. G., Stover, C. W., Algermissen, S. T., Steinbrugge, K. V., Hubiak, P., Hopper, M. G., and Barnhard, L. M., 1980, Preliminary evaluation of the distribution of intensity, in Selected papers of the Imperial, California earthquake of October 15, 1979, edited by C. Rojan, U.S. Geological Survey Open-File Report 80-1094, p. 1-16. 
Richter, C. F., 1958, Elementary selsmology: San Francisco, Calif., W. H. Freeman and Co., Inc., $768 \mathrm{p}$.

Rogers, A. M. and Malkiel, A., 1979, Earthquakes in the Permian Basin of Texas-New Mexico: Selsmological Society of America Bulletin, v. 69 , no. 3, p. 843-865.

Rojan, C. and Ragsdale, J. T., 1980, Strongmotion records from the Imperial County Services Building, El Centro, California: Earthquake Engineering Research Institute Reconnaissance Report, p. 173-184.

Seismic Englneering Branch, 1977, Western hemisphere strong-motion accelerograph station 11st - 1976: U.S. Geological Survey Openfile Report 77-374, 112 p.

Stephens, C. D., Lahr, J. C., Fogleman, K. A., and Horner, R. B., 1980, The St. Elias, Alaska earthquake of 28 February 1979; Regional recording of aftershocks and short-term, pre-earthquake selsmicity,
Selsmological Society of America Bulletin, v. 70, no. 4 (in press).

Stover, C. W., Reagor, B. G., and Wetmiller, R. J., 1980, Intensities and 1soseismal map for the St. Ellas earthquake of February 28, 1979: Seismological Society of America Bulletin, v. 70, no. 5, p. 1635-1649.

Thatcher, W., 1979, Horizontal crustal deformation from historic geodetic measurements in southern California: Journal of Geophysical Research, v. 84, no. B5, p. 2351-2370.

Uhrhammer, R. A., 1980, Observations of the Coyote Lake, California earthquake sequence of August 6, 1979: Selsmological Society of America Bulletin, v. 70, no. 2, p. 559-570.

Wood, H. D., and Neumann, F., 1931, Modifled Mercalli Intensity Scale of 1931: Seismological Society of America Bulletin, v. 21, no. 4, p. $277-283$.

Yarger, H. L., 1981, Aeromagnetic survey of Kansas, EOS Transactions, American Geophysical Uni on, v. 62, p. 173-178. 
The publications 1 isted below are available from the National Geophysical and Solar-Terrestrial Data Center, NOAA/EDIS, (D61), 325 Broadway, Boulder, C0 80303. please allow 4 weeks for receipt of the reports. Minimum charge per order is $\$ 3$.

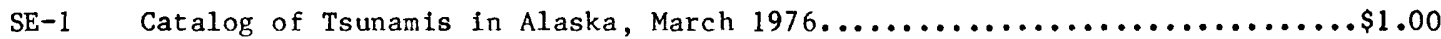

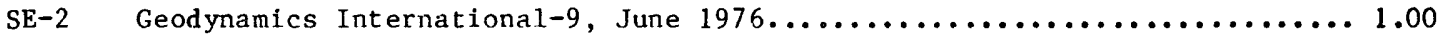

SE-3 Summary of earthquake Focal Mechanisms for the Western Pacific -

Indonesian Region 1929-1973, March 1977, NTIS PB $80207293 \ldots \ldots \ldots \ldots \ldots \ldots \star \ldots$

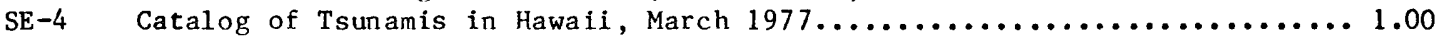

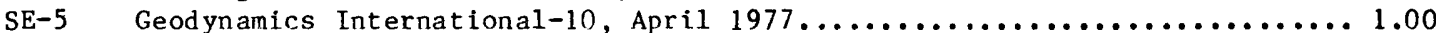

SE-6 Catalog of Seismograms and Strong-Motion Records, May 1977............ 2.00

SE-7 Directory of Seismograph Stations, July 1977, NTIS No. PB 271684/AS...... **

SE-8 Survey of Practice in Determining Magnitudes of Near Farthquakes, Part 2, Eurupe, Asia, Africa, Australasia, the Pacific, August 1977, NTIS No.

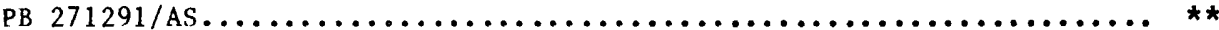

SE-9 Survey of Practice in Determining Magnitudes of Near Earthquakes, Part 1 , North, Central, and South America, January $1978 \ldots \ldots \ldots \ldots \ldots \ldots \ldots \ldots \ldots . \ldots \ldots$

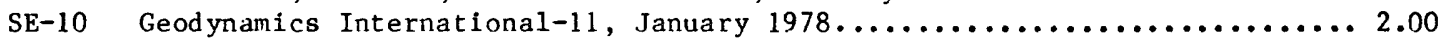

SE-11 The Information Explosion and Its Consequences for Data Acquisition

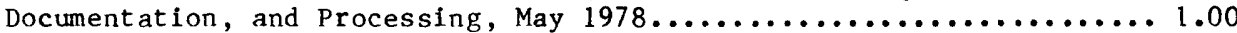

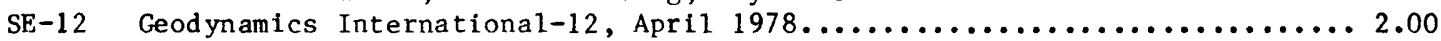

SE-13 Bibliography of Statistical Aspects of Seismicity, August 1978, NTIS

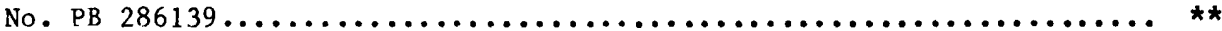

SE-14 Directory of U.S. Data Repositories Supporting the International

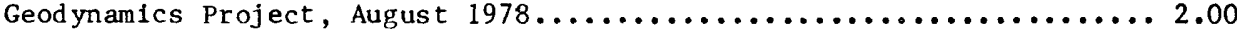

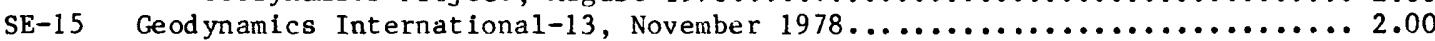

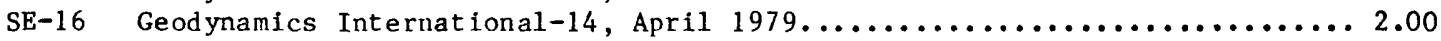

SE-17 Annual Mean Values of Geomagnetic Components for Selected Observatories, 1940-73, June 1979, NTIS No. PB 298716/As......................*

SE-18 Homogeneous Magnitude System of the Eurasion Continent: P Waves, August

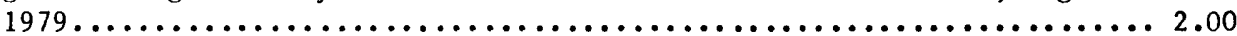

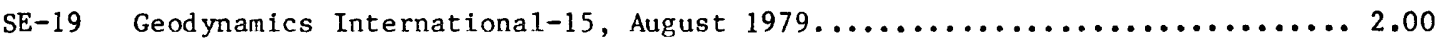
SE-20 Manual of Seismological observatory Practice, September 1979...........7.50

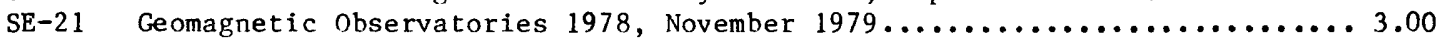

SE-22 Historical Seismogram Filming Project: First Progress Report, November

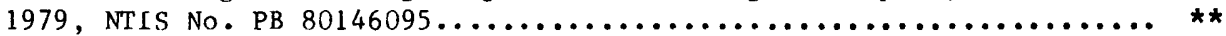

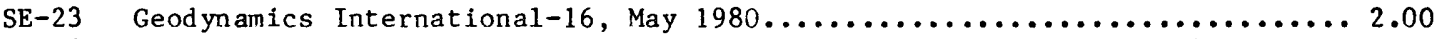

SE-24 Historical Seismogram Filming Project: Second Progress Report, August

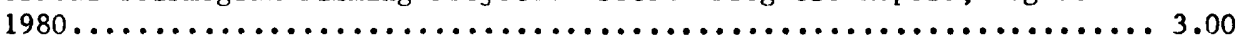

SE-25 Directory of World Seismograph Stations Volume I. The Americas Part 1-

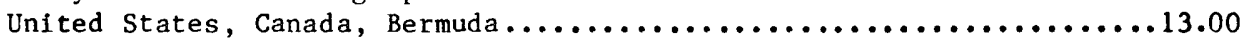

SE-26 Geodynamics International-17, Final Report, December $1980 \ldots \ldots \ldots \ldots \ldots \ldots \ldots 2 . \ldots 0$

SE-27 Catalog of Significant Earthquakes 2000 B.C. - 1979, July 1981 ........ 3.00

SE-28 Historical Selsmogram Filming Project: Third Progress Report, July 1981.. 3.00

,NGSDC-1 A Historical Summary of Earthquake Epicenters In and Near Alaska, April

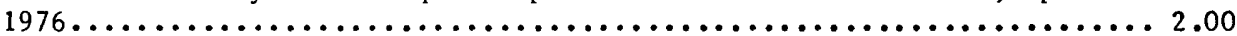

NGSDC-2 Final Report: An Analysis of Earthquake Intensities with Respect to Attenuation, Magnitude and Distance, August 1976 (NUREG/CR-1805).....3.00

NGSDC-3 An Analysis of Earthquake Intensities and Recurrence Rates In and Near

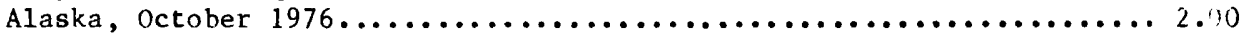

NGSDC-4 Reevaluation of Modified Mercalli Intensity Scale for Earthquakes Using Distance as Determinant, January 1978 (NUREG/CR-1804)............5.50

NGSDC Data Fact Sheet No. 1. Some Summary Geomagnetic Activity Data 1932-1976

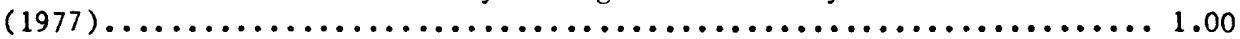

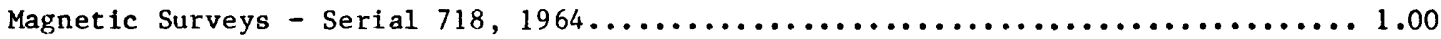

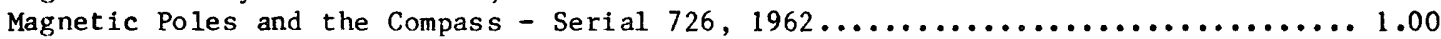
KGRD 2 Bibliography and Index to Literature on Manganese Nodules (1874-1975),

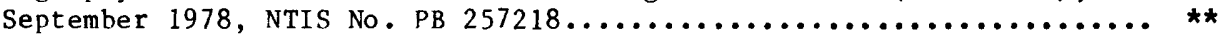

KGRD 5 Earthquake Data File Summary, May 1976, NTIS No. PB $265445 \ldots \ldots \ldots \ldots \ldots \ldots$ KGRD 6 Catalog of Strong-Motion Seismograph Stations and Records, NTIS No.

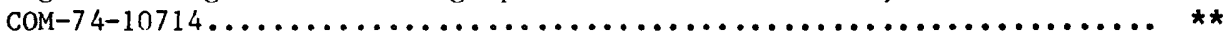

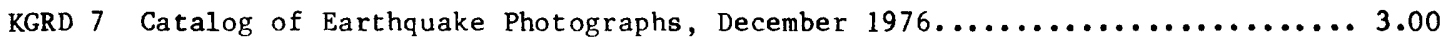

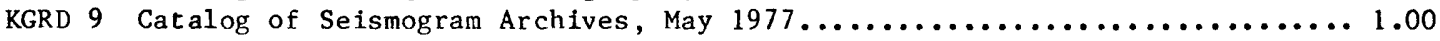


KGRD 10 The Marine Geophysical Data Exchange Format - "MCD77," September 1977.... 1.00 KGRD 11 Summary of Digital Marine Geophysical Data Holdings (Bathymetric,

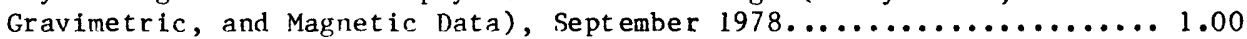

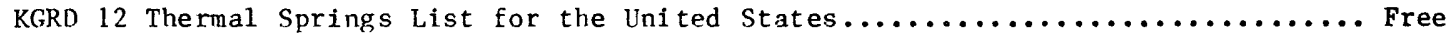

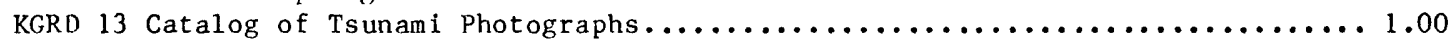
Proceedings of Marine Geology Data Management Workshop, May 22-24, 1978......... Free Proceedings of Marine Geology and Geophysics Data Workshop, Nov. 5-7, 1980....... Free Publication 41-1, Earthquake History of the United States, Revised Edition through

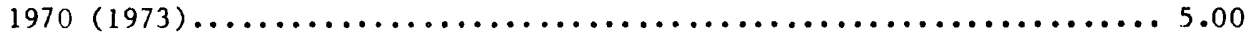
Earthquake History of the United States (1971-76 Supplement) 1979............2.25 Publication 41-2, Earthquake Investigation in the Western United States, 1931-1964

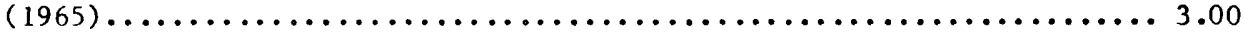

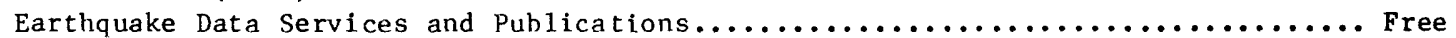

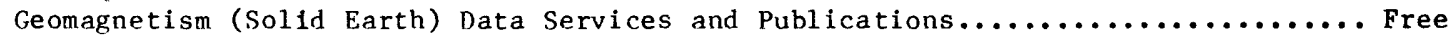

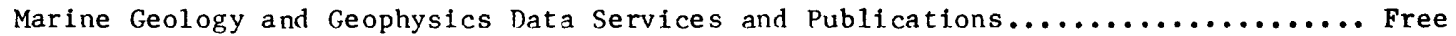
Tetrahedron Globe, 1976 (Q) - Earthquake Epicenters of the World..............** Icosahedron Globe, Earthquake Epicenters of the World.....................*** Icosahedron Globe, $1978(\mathrm{~N}-\mathrm{N})$ - International Geomagnetic Reference Field....... Icosahedron Globe, 1979 (S) - International Geomagnetic Reference Field......... Volcanoes of the World map (L.D. Morris, T. Simkin, and H. Meyers) 1979........ 2.50\#仡

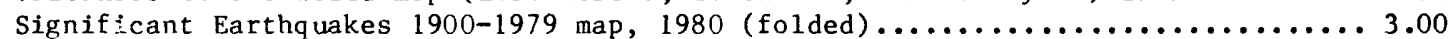

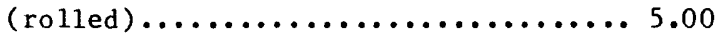
Inventory of Natural Hazards Data Resources in the Federal Government........... Free Terrestrial Heat Flow Data map, $1976 \ldots \ldots \ldots \ldots \ldots \ldots \ldots \ldots \ldots \ldots \ldots \ldots \ldots \ldots \ldots \ldots \ldots \ldots \ldots \ldots \ldots$. . . . . . . . .

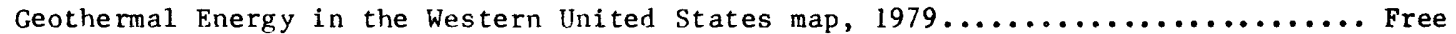

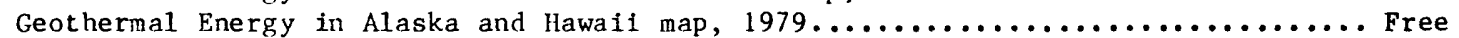
Geopressured-Geothermal Energy in Reservoir Fluids of the Northern Gulf of Mexico Bas in map, $1979 \ldots \ldots \ldots \ldots \ldots \ldots \ldots \ldots \ldots \ldots \ldots \ldots \ldots \ldots \ldots \ldots \ldots \ldots$ Free

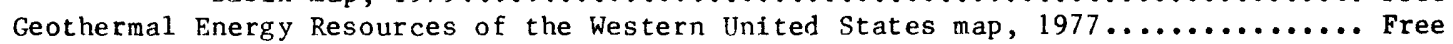
Geothermal Resources of Idaho map, 1980 (referral to state agency).............. Free Geothermal Resources of Utah map, $1980 \ldots \ldots \ldots \ldots \ldots \ldots \ldots \ldots \ldots \ldots \ldots \ldots \ldots \ldots \ldots \ldots \ldots$. . . . . . . . . . . . . . . . . Geothermal Resources of Colorado map, 1980 (referral to state agency)............ Free\#

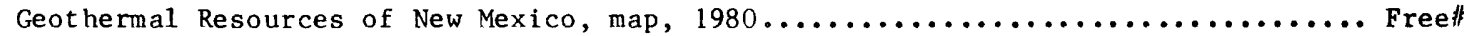

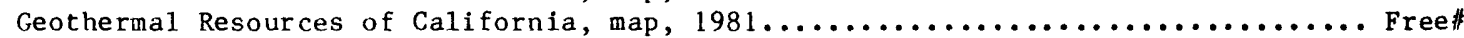

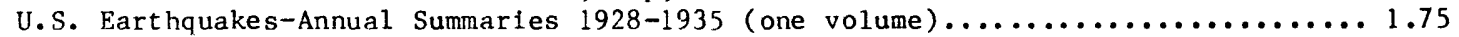

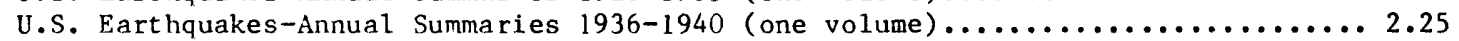

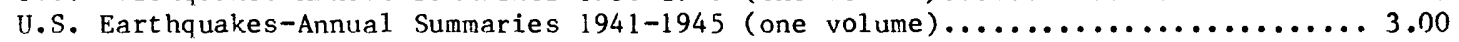

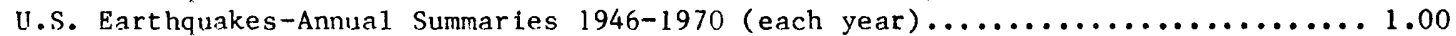

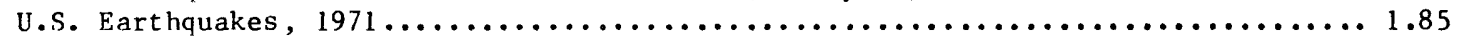

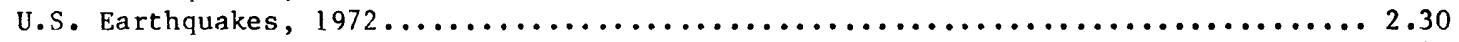

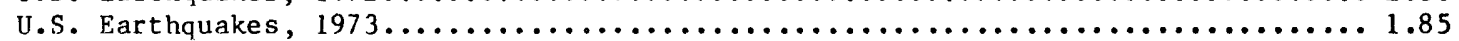

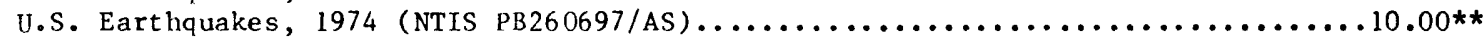

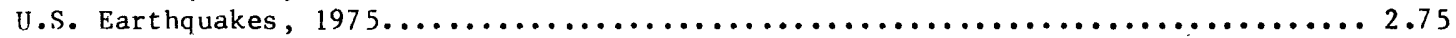

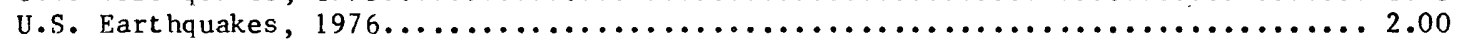

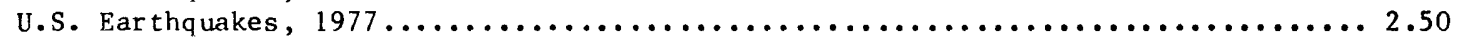

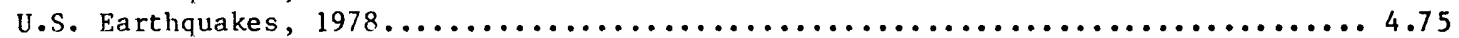
San Fernando, Calif., Earthquake of February 9, 1971

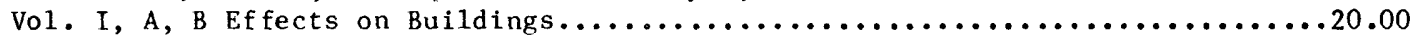

Vol. II Utilities, Transport, Sociological Aspects............................

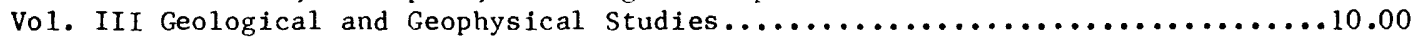

Prince William Sound, Alaska, Earthquakes of 1964 and Aftershocks

Vol. I........nTrs No. COM-75-10962/AS.........................**

Vol. II Part A Engineering Seismology, NTIS No. COM $75-10963 /$ AS............. **

Vol. II Parts B, C Seismology and Marine Geophysics .................... 5.00

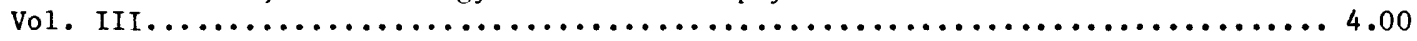

**Available from National Technical Information Service (NTIS), 5285 Port Royal Road, Springfield, VA 22161 .

***Price: 10 or more copies, $\$ 0.10$ each; 2 to 9 copies; $\$ 1$ total; 1 copy free, 2 or more $\$ 0.20$ each.

非Available from NOAA, National Ocean Survey, (C44), 6501 Lafayette Ave., Riverdale, MD 20840 .

\#For availability consult NGSDC. 